

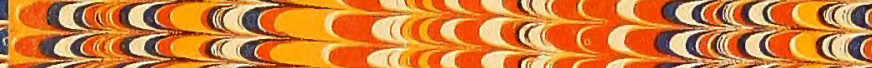

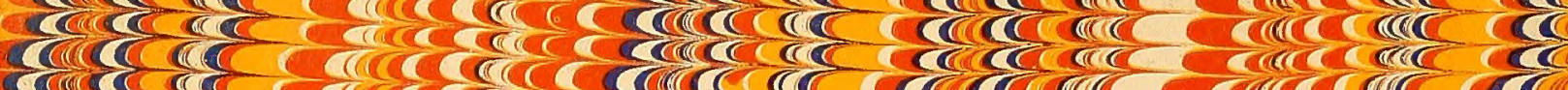

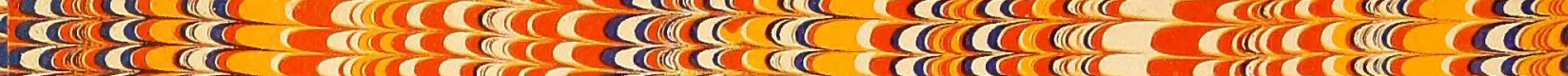

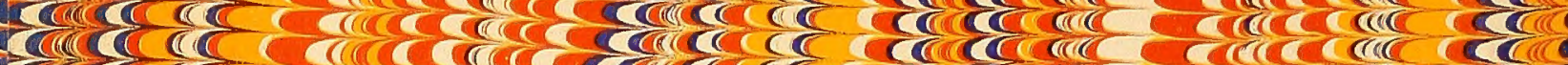

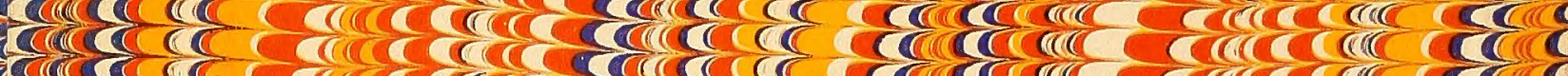

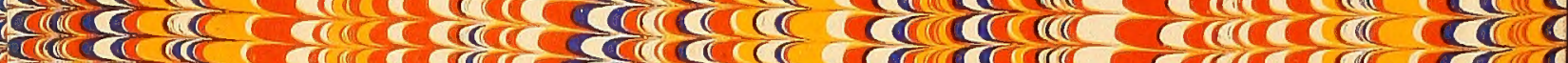

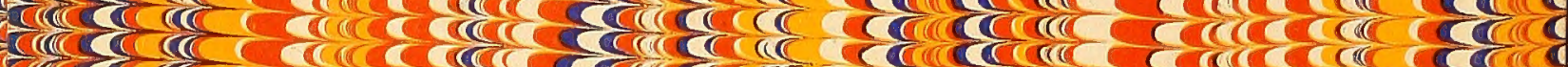

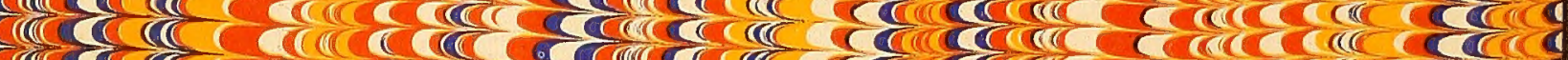

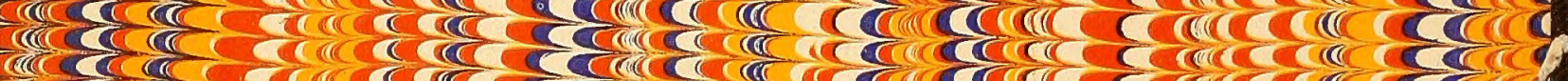

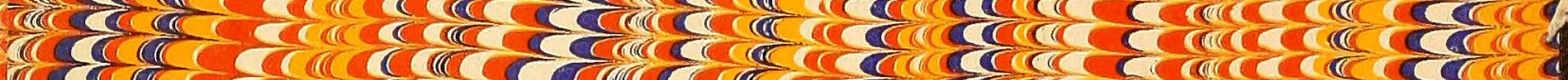

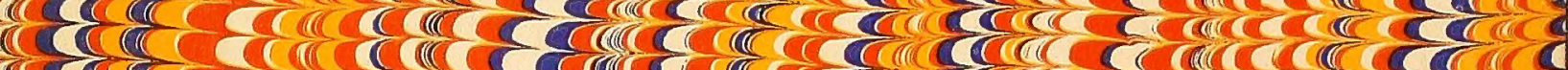

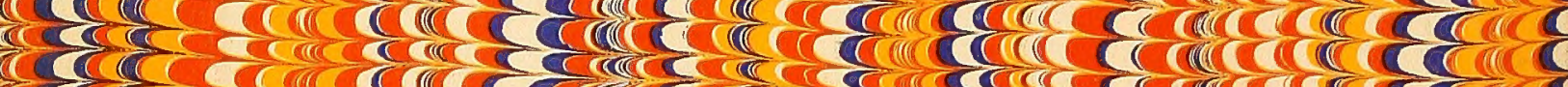

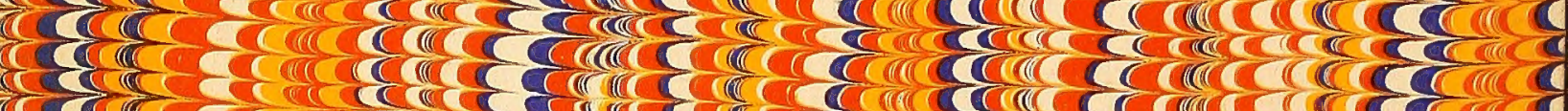

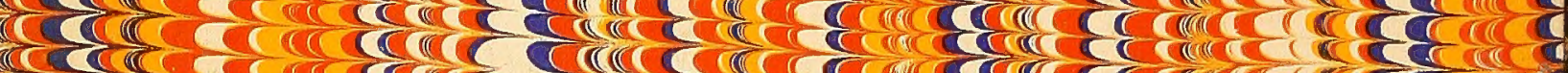

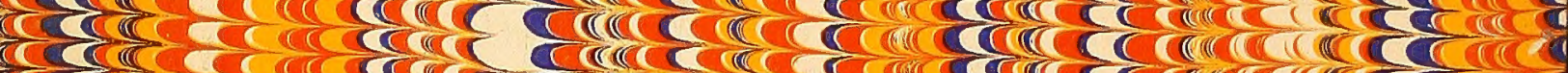

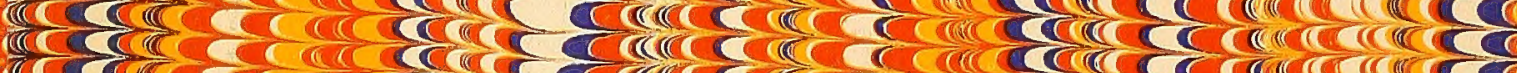

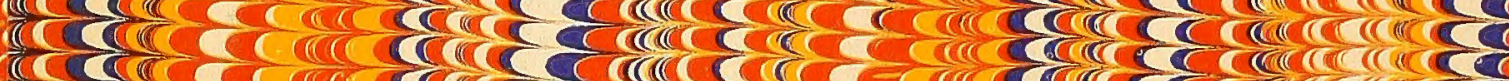

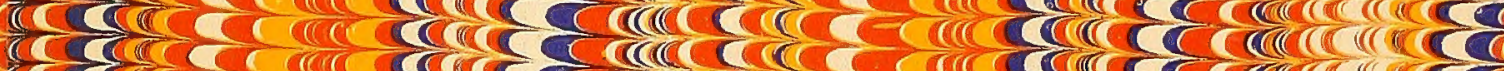

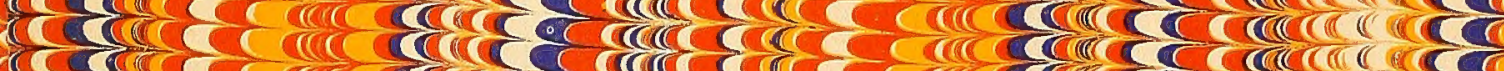

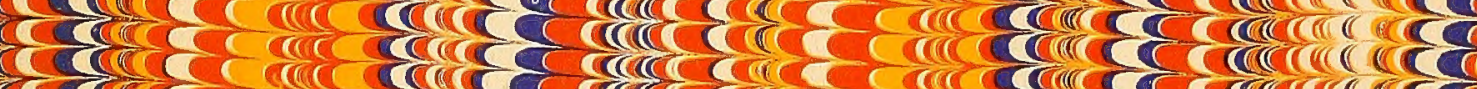

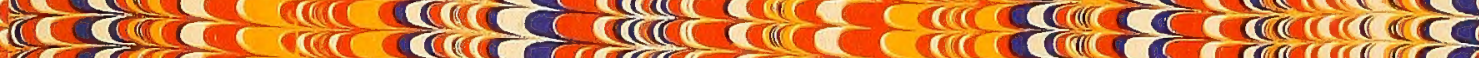
acrere -

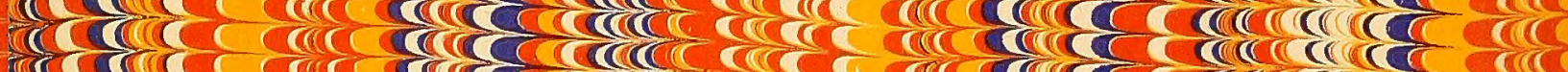

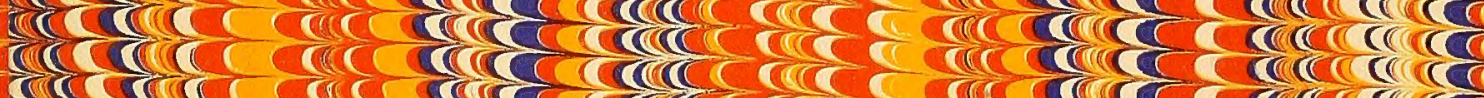

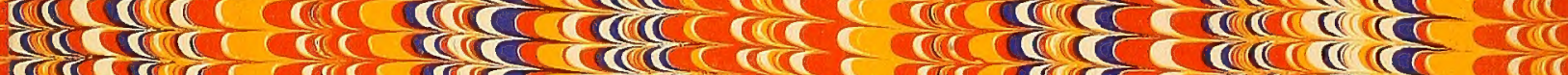

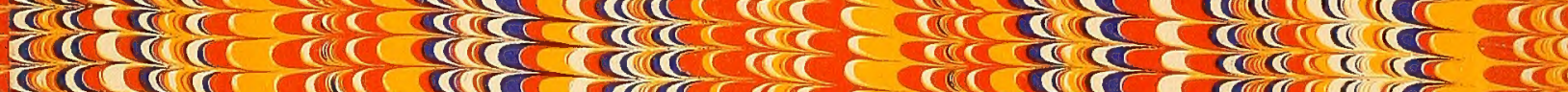
-

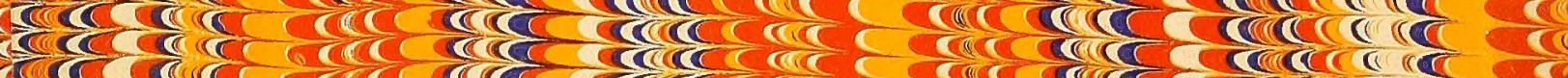

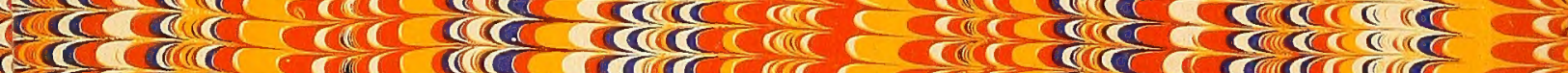

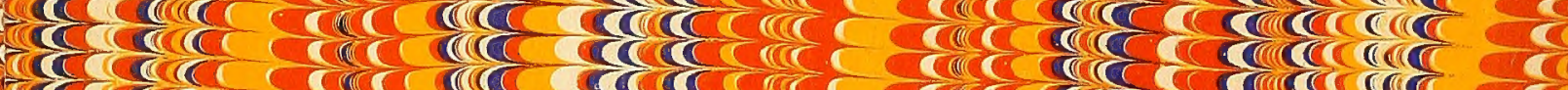

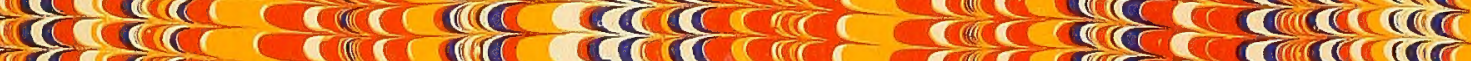

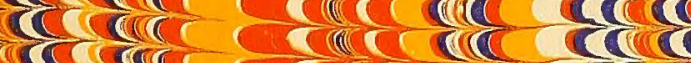

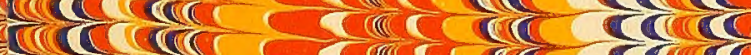

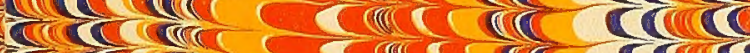

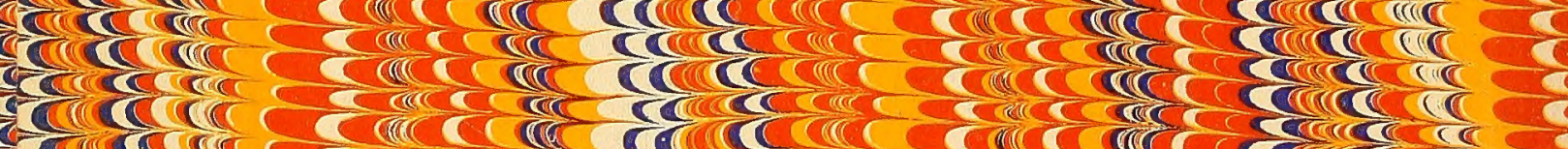

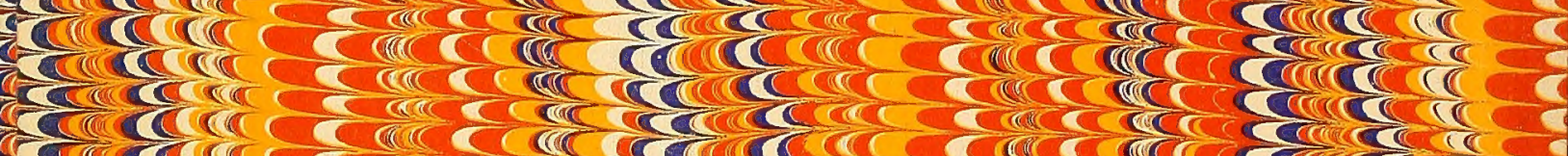

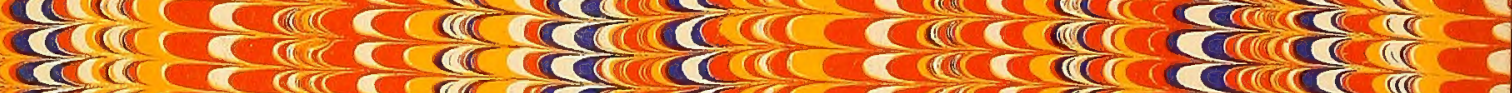

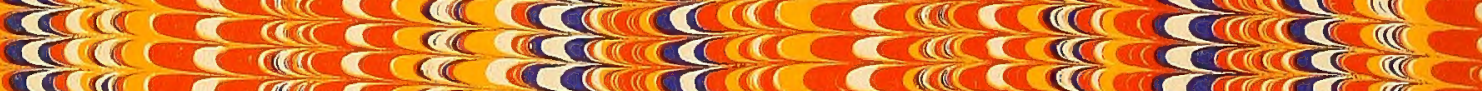
पर

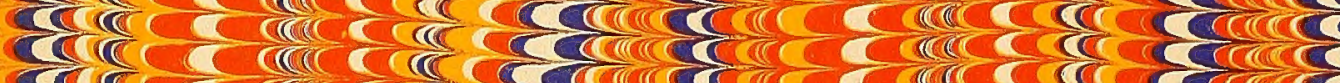

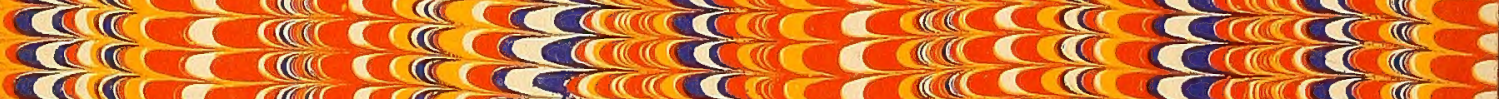
सra

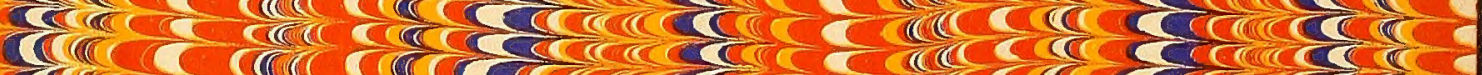

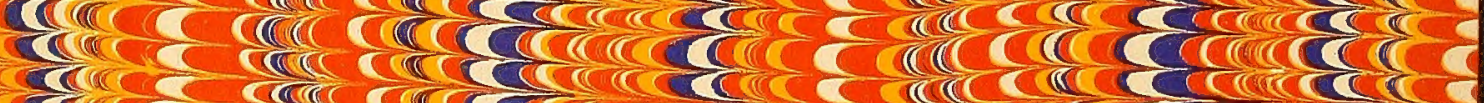

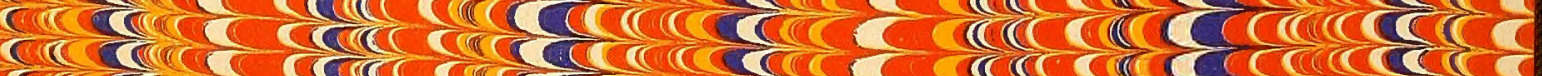

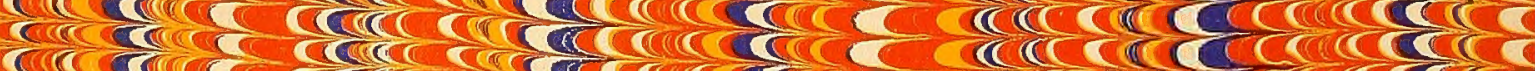

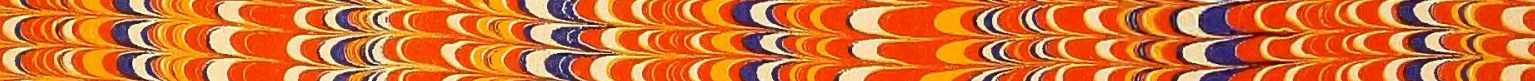

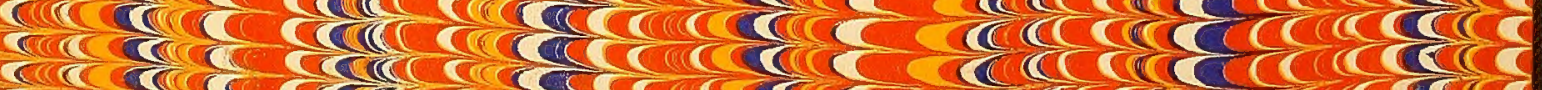

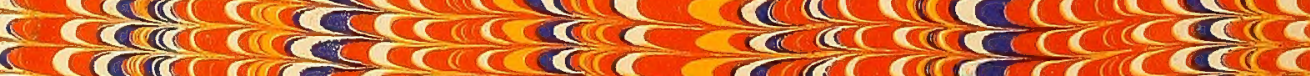

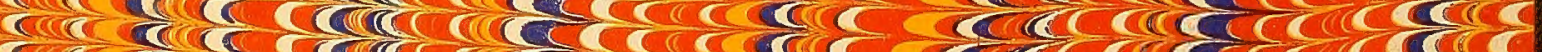




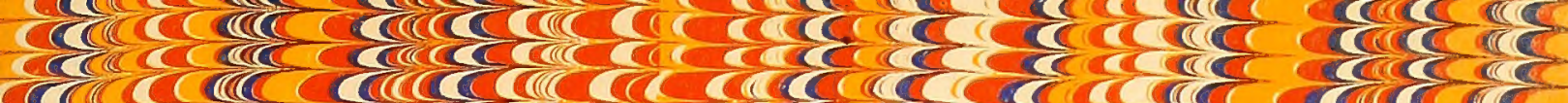

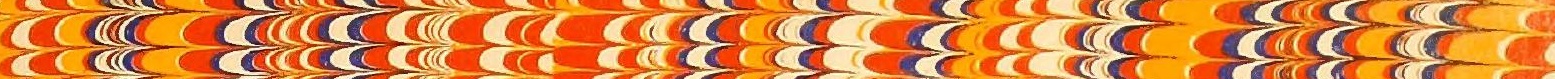

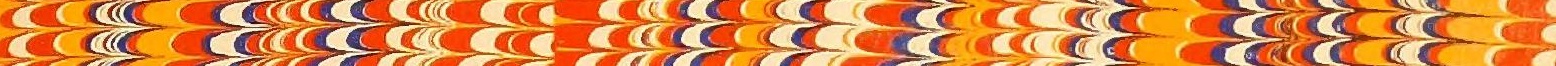

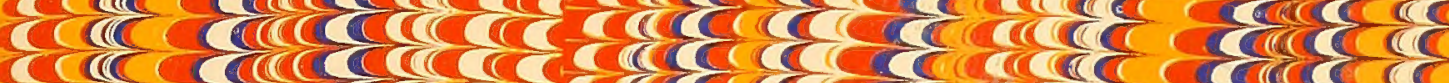
ads

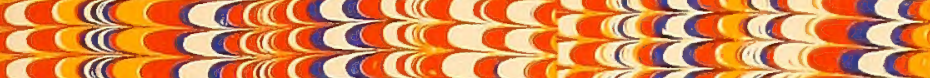

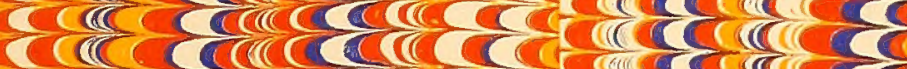

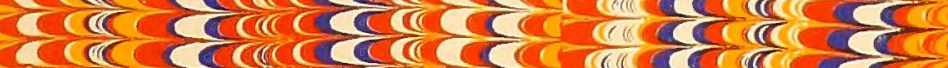

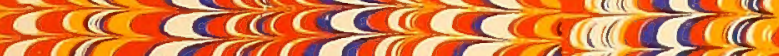
द्व

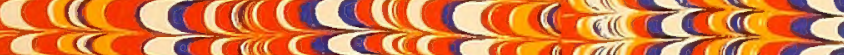
ता

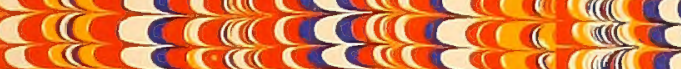

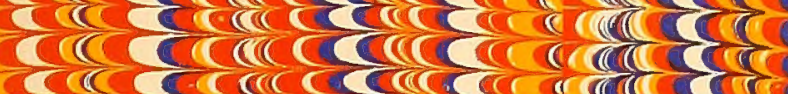

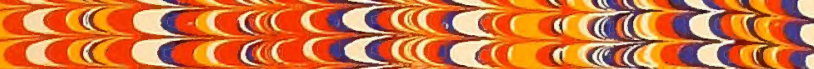
या ब(i)

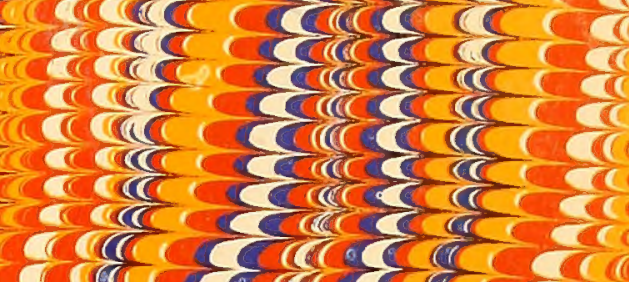

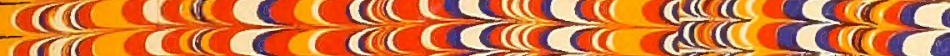

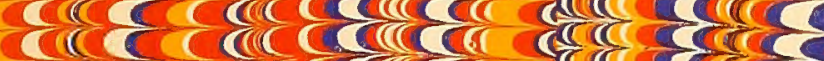

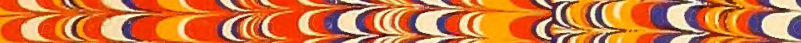

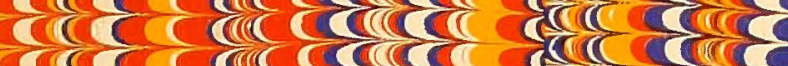

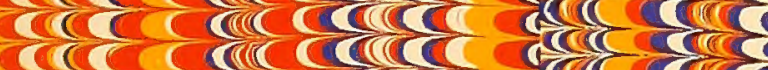

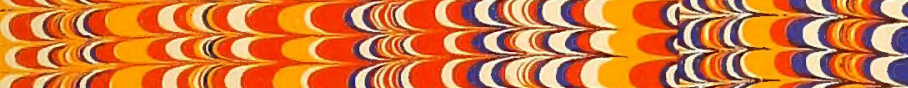

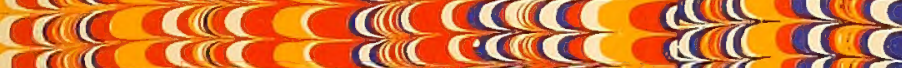

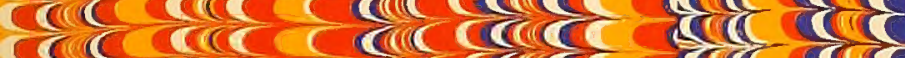

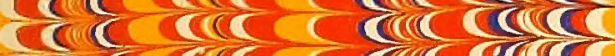
बत्व बत्व

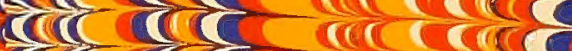

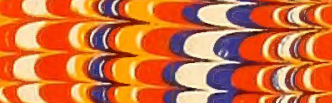
ख़े

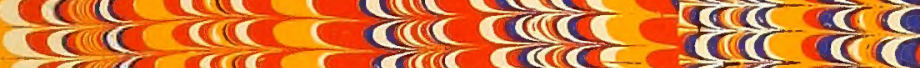

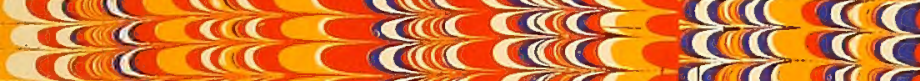

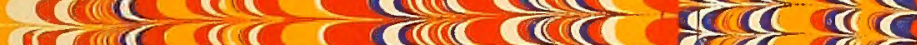

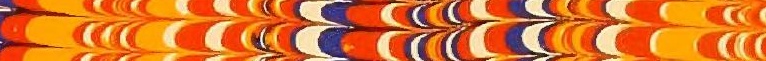

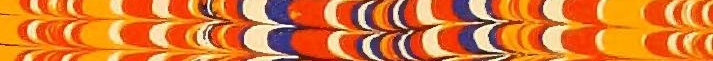

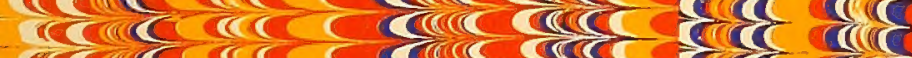

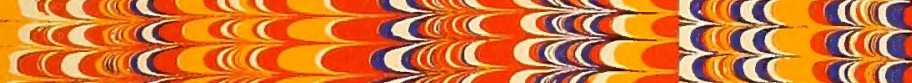

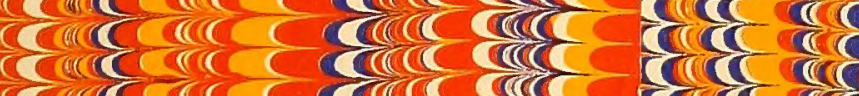
वबis

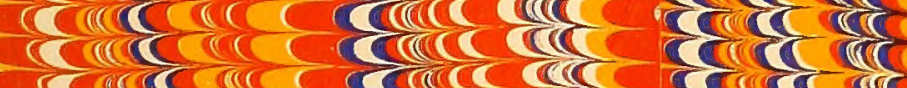

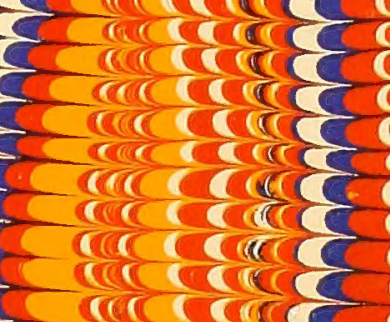
बिलिखिए तe 





DEPARTMENT OF COMMERCE AND LABOR BUREAU OF FISHERIES

ORORGE M. BOWERS, COMmisstoner

\section{THE FISHES OF SAMIOA}

DESCRIPTION OF THE SPECIES FOUND IN THE ARCHIPELAGO, WITH A PROVISIONAL CHECK-LIST OF THE FISHES OF OCEANIA

FROM BULLETIN OF THE BUREAU OF FISHERIES

Volume XXV, 1905, Pages 173 to 455, Plates XXXuI to LIII

ISSUED DECEMBER $15 ; 1906$

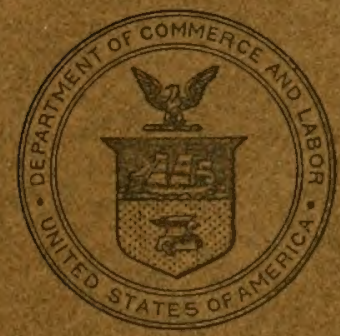

255810

WASHINGTON:

GOVERNMENT PRINTING OFFICE

1906 

DEPARTMENT OF COMMERCE AND LABOR

BUREAU OF FISHERIES

GEORGE M. BOWERS, COMmissioner

\section{THE FISHES OF SAMIOA}

\section{DESCRIPTION OF THE SPECIES FOUND IN THE ARCHI- PELAGO, WITH A PROVISIONAL CHECK-LIST OF THE FISHES OF OCEANIA}

FROM BULLETIN OF THE BUREAU OF FISHERIES

Volume XXV, 1905, Pages 173 to 455, Plates XXXIII to LIII

ISSUED DECEMBER 15, 1906

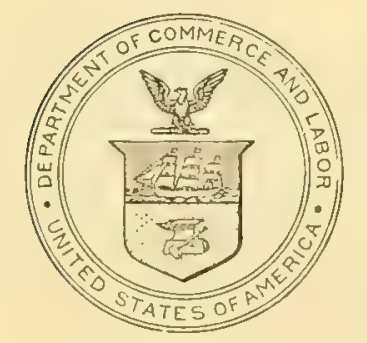

255810

WASHINGTON

GOVERNMENT PRINTING OFFICE 


\section{.}

I 


\section{THE FISHES OF SAMIOA}

DESCRIPTION OF THE SPECIES FOUND IN THE ARCHIPELAGO, WITH A PROVISIONAL CHECK-LIST OF THE FISHES OF OCEANIA

By DAVID STARR JORDAN AND ALVIN SEALE 


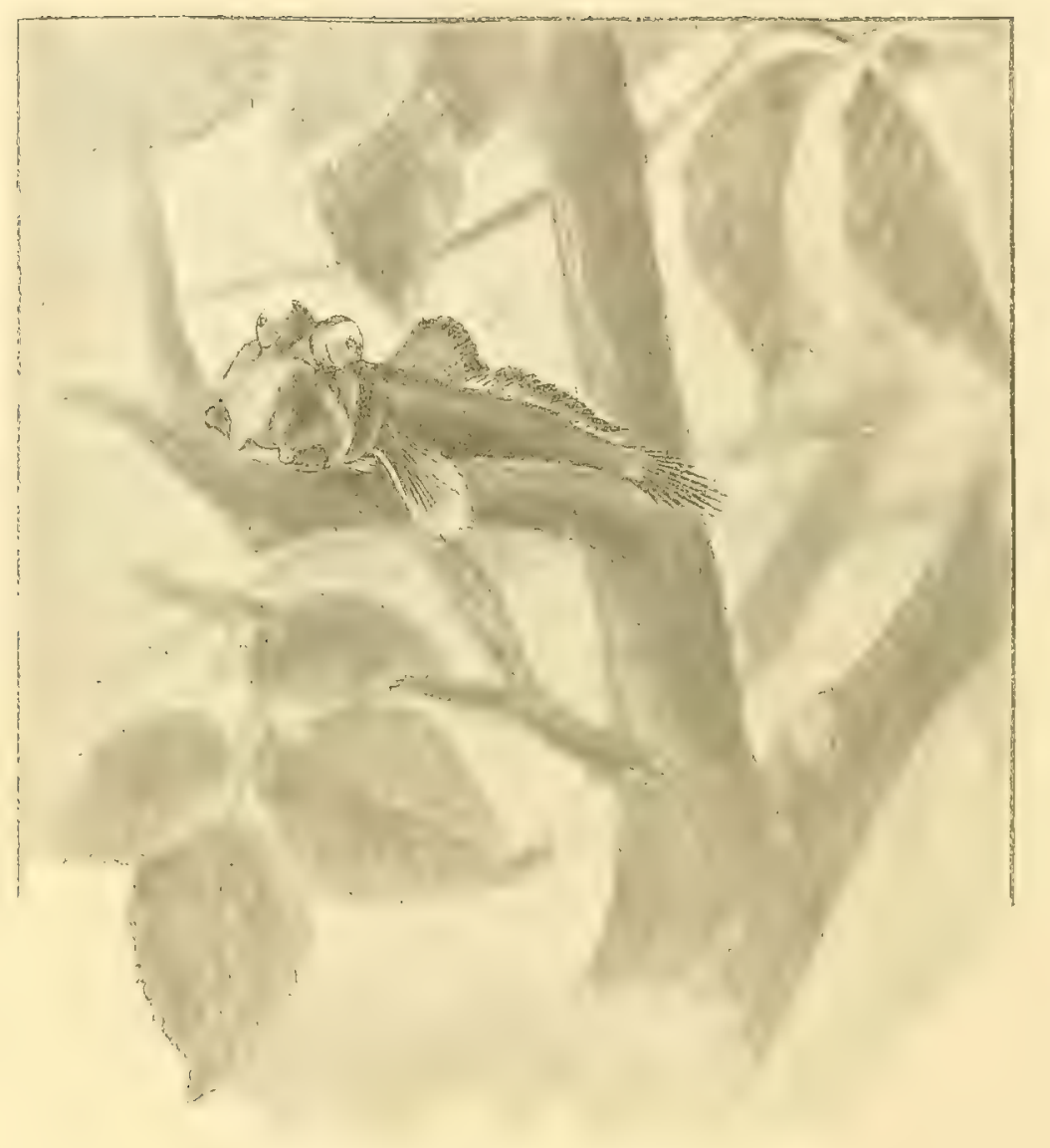

Fig. 1.-Periophthulmus burluarus Linm:1 11- 


\title{
THE FISHES OF SAMOA.
}

\author{
DESCRIPTION OF THE SPECIES FOUND IN THE ARCHIPELAGO, WITH A PROVISIONAL \\ CHECK-LIST OF THE FISHES OF OCEANIA.
}

BY DAVID STARIR JORDAN and ALVIN SEALE.

\section{INTRODUCTION.}

The islands of Samon, known also as the Navigator Islands, or Schiffer Insel, lie in the South Pacific Ocean in latitude $14^{\circ}$ sonth and Iongitude $172^{\circ}$ mest. They are voleanic in character, each of the larger ones rising in a high ridge, with extinct craters, now very heavily mooded. The almost constant rains tend to make these forests very dense, feeding swift, clear streams, which carry a large volume of water considering the slight length of their courses. Each island is surrounded by a broad coral reef, the outer parts bare at low tide, with a narrow, shallow channel between the inner part and the shore. This reef is interrupted in certain regions, known as the "iron-bound" coast, where the lava rocks cease abruptly beside deep water. It is also interrupted at the mouths of certain streams, which by their fresh waters kill the coral and make a channel through the reef.

Of these islands the westernmost, Saraii, about 45 miles long by 30 miles broad, is the largest and the most recent geologically. Upolu, 40 miles by 15 miles, is near it in size and position. On the north side of the latter island is the broad V-shaped Bay of Apia, which can scarcely be called a harbor, as it is filled up by the reef with the exception of a deep and tortuous channel opposite the mouth of the rirer Vaisigano, a considerable stream, perhaps the largest on the islands. Upolu and Saraii are now under the German flag, with the capital at Apia. On the west side of the Bay of Apia is the long, narrow peninsula of coral sand, known as Mulinu'u, the residence of Mataafa, chief of Samoa, and the former residence of the kings of the islands. To the west of Mulinu'u is the shallow Bay of Vaitele, and to the eastrard of A pia is the larger Bay of Vailele. Into Vaitele Bay flows Gasegase River. Into the Bay of Apia Hows the Vailema stream and the Vaisignno River, while to the eastward Vaivasi River runs into the Bay of Vailele.

The next island in size and importance is Tutuila, 20 miles long by about \pm miles broad, which lies about a deep crater, with the two high peaks of Matabas and Peoa adjoining it. The crater has a narrow opening at one side and forms the landlocked harbor of Pago Pago, the best in Polynesia, about 2.5 miles long and 1 mile wide, with everywhere a broad rim of coral reef. 'There is a small stream near the head of the harhor, and there are springs along the side. 
The oldest island is Manua, still farther to the eastward, nearly circular, and about 10 miles across, and there are also about six smaller islets, none of which was examined by us. The islands of Tutuila and Manua are now under the flag of the United States.

In the summer of 1902 investigation of the fish and fisheries of this archipelago was made under the auspices of the U. S. Bureau of Fisheries. ${ }^{a}$ The work was conducted chietly from Apia and Pago Pago; and during the comparatively short time devoted to it, rich collections, numerous as to species and individuals, were obtained, and many species new to science vere discovered.

The coral reefs of the South Seas literally swarm with fishes. The larger species live in the deeper channels, passing in and out with a display of brilliant colors. The smaller species, as Pomacentridæ, Blenniidæ, Chætodontidæ, live on the surface of the reefs and are segregated in pools as the tides recede. Many of these reef fishes show marked protective coloring, having the hues and markings of the reef itself. Still others show what may be termed defiant coloring, their hues of blue, scarlet, yellow, and green being in vivid contrast to the rocks about them. Nowhere are these reef tishes more brilliant than in Polynesia. It is not easy to explain the reason for these vivid hues, nor for the elaborate and striking markings which accompany them. It is clear that protective coloration is needless, for these species are exceedingly active and when disturbed move through the water like animated lightning; but why such a riot of color should exist is not evident. There is apparently no advertising end to be served, and the idea that recognition has a high value to the species has never been received with favor by naturalists. In the record of the voyage of Captain Cook is the following account of the fishes of the atoll called Palmerston Island:

At one part of the reef which bounds the lake within, almost even with the surface, there was a large bed of coral, which afforded a most enchanting prospect. Its base, which was fixed to the shore, extended so far that it could not be seen, so that it appeared to be suspended in the water. The sea was then unruffled, and the refulgence of the sun exposed the rarious sorts of coral in the most beautiful order; some parts luxuriantly branching in the water, others appearing in vast variety of figures, and the whole greatly heightened by spangles of the richest colors, glowing from a number of large clams, interspersed in every part. Even this delightful scene was greatly improved by the multitude of fishes that gently glided along, seemingly with the most perfect security. Their colors were the most beautiful that can be imagined: blue, yellow, black, red, \&c., far excelling anything that can be produced by art. The richness of this submarine grotto was greatly increased by their various forms, and the whole could not possibly be surveyed without a pleasing transport, accompanied, at the same time, with regret that a work so astonishingly elegant should be concealed in a place so seldom explored by the human eye.

The fish fauna of Upolu and Tutuila is entirely the same, nor is there evidence of any divergence from the fauna of Tahiti, Tonga, and other islands of similar character. It is largely identical with that of the East Indies, from which nearly all

a This expedition was under the direction of Dr. Davin Starr Jordan, who was assisted in the work by Prof. Vernon Lyman Kellogg and Mr. Michitaro Sindo, of Stanford University for the Bureau, and the volunteer service of Prof. Robert Edgar Allardice, of Stanford University, and Knight Starr Jordan.

Acknowledgments for assistance of various kinds are due to the governor of Samoa, Dr. Schnee, and to Mr. H. J. Moors, of Apia; to Capt. Uriel Sebree, U.S. Navy, commandant at the station, and his officers and assistants, through whom the U. S. guaboat Whocling and its equipment were placed at the disposal of the investigating party; to Mauga, chief of Tutuila, and to Tuatagaloa in Apia, through whose interest many small reef fishes were obtained; and to various Samoan assistants, chief among whom were Taua, Vaiula, Musila, and Salewale, of Apia, and Afele, of Pago Pago, whose services contributed much to the suecess of the work. 
of its elements are clearly derived. But a number of East Indian species fail to extend their range thus far to the east, very many of them not ranging beyond the island of Papua or New Guinea. A few large species are confined to the islands of Polynesia, and many of the small ones, especially those living in crevices in the coral, seem to have originated in Polynesia. It is a general rule of distribution that with any given species the one nearest related will be found in neighboring waters, but not in the same waters. 'This indicates that in general species hare a basis in geographical separation. But the Samoan species of Eviota, Enneaptemygius, Salarias, and the like scem to form exceptions to this rule. Here closely related species live in the same region. Perhaps these forms originate in saltations or "mutations". More likely the isolation of different coral masses is suflieient to prevent the migration of individuals, and hence to favor the selection of fluctuations under varying conditions, thus producing distinct species in regions not far separated. As most of these little fishes are less than an inch long and local in their habit, this is possible. The conditions illustrate the remark of Dr. Elliott Coues that "migration holds species true; localization lets them slip." In other words, a species splits up into minor groups if its range is divided by barriers preventing free morement of individuals.

The previous collections of fishes from Samoa hare been relatively few. The earliest recorded species, from A pia, was numed Diagramma gibbosum by Hombron \& Jacquinot in their ichthyology of the "Voyage au Pole Sud" by Dumont D'Urville, published in $18 t 1$.

Later, 1868 to 1870 , the gigantic trading house of "Cresar Godeffroy und Solnn" of Hamburg made Apia the center of its operations. Among other workings of this firm was the establishment at Hamburg of the Godeffroy Museum and the publication for a time of a "Journal des Museum Godeffroy," in which the matural history of the South Seas was elaborately treated. Among other" papers on this subject, the "Fische der Südsee" of Dr. Albert Günther (1873) is especially noteworthy. This is based primarily on a series of colored life sketches of the fishes of Hawaii, Tuhiti, Samoa, and other islands, made by $\mathrm{Mr}$. Andrew Garrett in the several years of his residence in Polynesia. In this paper descriptions are given of most of the fishes then known from the South Sens, with excellent colored plates of a large proportion of these. Unfortunately, the Godeffroy firm fell into financial embarrassment, the publication of its journal was suspended, and the "Fische der Südsee" was never completed, ceasing abruptly in the family of Labrida.

From the Godeffroys a considerable number of fishes had been earlier sent to the Nuseum of Vienna, where, about 1868, they had been described by Dr. Rudolph Kner and Dr. Franz Steindachner. Still later, Rer. S. J. Whitmee, a missionny resident on the island of Savaii, sent to the British Museum a large and well chosen collection from Savaii and Upolu. A part of this collection has been used by Dr. George Albert Boulenger in the preparation of the first volume of his Catalogue of Fishes of the British Museum. Outside the percoid group, however, this collection remains unstudied. A small collection also was made about 1876 by Dr. Streets, of the United States Nary. It was described in the Bulletin of the U. S. National Museum, volume vir, in 1877. A ferw species in the Academy of Natural Sciences at Philadelphia, collected by Mr. Caldwell, have been recorded by Mr. Henry W. Fowler. 
At the time of our visit at Samoa the following species, 164 in number, were known from the Samoan Islands; about six were not taken by us; and in regard to a few there is some question of correctness of identification. The nomenclature in this list is that adopted in the present paper.

LIST OF SPECIES KNOWN FROH SAMOA PRIOR TO 1902.

Fistularia petimba.

Macrorhamphosus brevispinis.

Liza ceruleomaculata.

Liza troscheli.

Polydactylus plebeius.

Holotrachys lima.

Holocentrus ruber.

Holocentrus punctatissimus.

Holocentrus diadema.

Holocentrus microstomus.

Holocentrus opercularis.

Holocentrus lævis.

Megalaspis cordyla.

Caranx forsteri.

Scomberoides sanctipetri.

Trachinotus ovatus.

Trachinotus bailloni.

Pempheris oualensis.

Epinephelus merra.

Epinephelus fuscoguttatus.

Epinephelus socialis.

Epinephelus somerati.

Cephalopholis argus.

Cephalopholis miniatus.

Variola louti.

Paracanthistius maculatus.

Kuhlia marginata.

Amia novemfasciata.

Amia sayayensis.

Mionorus græefei.

A pogonichthys variegatus.

Euelatichtbys crassispinus.

Plectorhynchus diagramma.

Plectorhynchus orientalis.

Priacanthus cruentatus.

Scolopsis trilineata.

Scolopsis lineata.

Xystrema gigas.

Gnathodentex aurolineatus.

Terapon jarbua.

Monotaxis grandoculis.

Kyphosus waigiensis.

Lethrinella miniata.

Lethrinus moensi.
Lethrinus ramak.

Pharopteryx melas.

Pharopteryx nigricans.

Upeneus vittatus.

Mulloirles samoensis.

Pseudupeneus barberinus.

Pseudupeneus indicus.

Pseudupeneus moana.

Pomacentrus nigricans.

Pomacentrus lividus.

Chromis ceruleus.

Dascvllus aruanus.

Abudefduf sordidus.

Abudefduf dicki.

Abudefduf uniocellatus.

Abudefduf amabilis.

Abudefduf leucopomus.

Abudefduf zonatus.

Abudefduf bonang.

Labrichthys cyamotæenia.

Labroirles dimidiatus.

Cheilinus digrammus.

Cheilinus trilobatus.

Pseudocheilinus hexatænia.

Hemigymnus melapterus.

Anampses melanurus.

Anampses, diadematus.

Stethojulis casturi.

Stethojulis renardi.

Stethojulis strigiventer.

Thalassoma schwanefeldi.

Monodactylus argenteus.

Platax orbicularis.

Chretodon ulietensis.

Chretodon Iineolatus.

Chretodon citrinellus.

Chretodon semeion.

Chetodon unimaculatus.

Chretodon quadrimaculatus.

Heniochus monoceros.

Holocanthus diacanthus.

Holocanthus bicolor.

Holocanthus nicobariensis.

Siganus marmoratus.
Hepatus matoides.

Hepatus aterrimus.

Hepatus lineatus.

Hepatus nigricans.

Hepatus achilles.

Hepatus guttatus.

Zebrasoma veliferum.

Ostracion punctatum.

Balistapus aculeatus.

Platycephalus variolosus.

Sebastopsis guamensis.

Scorprenopsis gibbosa.

Pterois radiata.

Dendrochirus brachypterus.

Mapo fuscus.

Rhinogobius neophytus.

Awaous genivittatus.

Awaous ocellaris.

Zonogobius semidoliatus.

Paragobiodon echinocephalus.

Amblygobius phalæna.

Valenciennea violifera.

Asterronterix semipunctatus.

Eleotris fusca.

Hypseleotris guntheri.

Pseudogobiodon citrinus.

Gobiodon ceramensis.

Periophthalmus barbarus.

Soleichthys heterorhinos.

Parapercis tetracanthus.

Enneapterygius minutus.

Enneapterygius hemimelas.

Petroscirtes tapeinosomus.

Petroscirtes atrodorsalis.

Petroscirtes longifilis.

Alticus evermanni.

Alticus sebre.

Alticus variolosus.

Alticus alboguttatus.

Alticus perioplathalmus.

Salarias edentulus.

Salarias fasciatus.

Exallias brevis.

Antennarius drombus.

The fish fauna of the Samoan Islands is one of the richest on the globe. In our short stay we obtained 475 species, of which 92 seem to be new to science. The following is a list of these new forms. 
LIST OF 92 SAMOAN SPECIES BELIEVED TO BE NETF.

Himantura fai.

Gymnothorax talofa.

Echidna trossula.

Anarchias allardicei.

Anarchias knighti.

Rhinamurena eritima.

Zenarchopterus vaisiganis.

Anchovia evermanni.

Anchovia apiensis.

My ripristis sanguineus.

Corythroichthys sealei.

Corythroichthys waitei.

Corythroichthys zuataafi.

Microphis torrentius.

Atherina uisila.

Decapterus lundini.

Caranx gilberti.

Amia exostigma.

Amia doryssa.

Foa vaiule.

Foa fo.

Apogonichthys isostigma.

Ambassis vaivasensis.

Ambassis lafa.

Pseudupeneus moana.

Chorististium susumi.

Pomacentrus eclipticus.

Pounacentrus vaiuli.

Abudefduf taupou.

Abudefduf metallicus.
Chromis iomelas.

Halichores dedalma.

Platyglossus Hos-corallis.

Callyodon fumifrons.

Callyodon kellogoi.

Callyodon maoricus.

Callyodon pyrrhurus.

Callyodon ruberrimus.

Callyodon erythacus.

Callyodon upolensis.

Callyodon zonularis.

Callyodon abacurus.

Callyorlon latax.

Callyodon eyanogrammus.

Callyodon ultramarinus.

Callyodon lazulinus.

Iepatus aquilinus.

Dendrochirus sausaulele.

Sebastapistes laotale.

Synchiropus lili.

Eviota afelei.

Eviota smaragdus.

Eviota sebreei.

Eviota pruinosa.

Eviota zonura.

Eviota distigma.

Eviota prasites.

Eviota herrei.

Drombus tutuilae.

Valenciennea violifera.
Trimma cresiura.

Glossogobius vaisiganis.

Vailima sterensoni.

Vaimosa fontinalis.

Mapo crassiceps.

Mars strigilliceps.

Rhinogobius corallinus.

Rhinogobius nuscarum.

Chanogobius erythrops.

Vitreola sauritta.

Kelloggella cariinalis.

IIetereleotris phaenna.

Hetereleotris clara.

Sicyopterus tauie.

Iypleurochilus vaillanti.

Alticus everuanni.

Alticus musile.

Alticus thalassinus.

Salarias atkinsoni.

Salarias garmani.

Salarias sindonis.

Salarias bryani.

Blennjus tonganus.

Petroscirtes azureus.

Petroscirtes xestus.

Enneapterygius luclsoni.

Enneapterygius pardochir.

Enneapterygius tusitale.

Enneapterygius tutuilic.

Enneapterygius cerasinum.

All of the specimens are firom the reef's; we had no means of fishing in the open sea. In general, we had four methods of collecting: First, the use of druamite, by which nearly all our large fish were taken. Second, the use of poison in the pools on the reef at low tide; the poisons nsed were commercial chloride of lime and sulphate of copper, the first much to be preferred, and thus were obtained hundreds of small fishes, notably P'omacentrida, Gobiidx, Blenniidæ, and eels. Third, the use of the seine along the shores, whereby the herring and other shore fishes were taken. Fourth, the employment of divers to bring up coral heads, which when broken yield many specimens of Eviota, Enneapterygins, and the smaller eels. The larger fishes, Callyodon excepted, have been described long since, but most of the little fishes taken from the corals are new. 'This method of collecting bas nerer been practiced by other naturalists in this region.

In the present paper are given the field notes of l'rofessors Jordan and Kellogg, the descriptions of new species, with other notes, and enough of synonymy to complete the references given by Dr. Gunther in his "Catalogne of Fishes of the British Museum" and his "Fische der südsce", and those given by Dr. Boulenger in volume $\mathrm{I}$ of his edition of the British Museum Catalogue; and of those given by Jordan and Evermann and by Dr. Gilbert in their recent reviews of the tishes of Hawaii. Synonymy is given in general only when our studies have added something to the record given by these authorities. Type localities are shown in the syonymy in heury-face type. 
The colored plates are in some cases a revision of field sketches by Dr. Jordan; the others were made from specimens that had not faded. Some of the sketches are not quite accurate in certain details of scales and fin rays, but the shades of coloration are very well shown. ${ }^{a}$

The area represented in this list comprises Hawaii, Polynesia, Melanesia, and Micronesia. It excludes New Zealand, Torres Straits, the Arafura Sea, and the islands to the westward of Waigiu and to the southward of the Louisiades; but the eastern coast of New Guinea is included. All the species we find recorded from these regions are embraced in the list. There are doubtless numerous omissions, and there are many nominal species which will be eliminated when the region is fully explored.

Of these regions, the fauna of Hawaii is much the most distinct from that of Samoa. With most of the same genera, the species of shore fishes in Hawaii are very largely distinct from those of Polynesia. This is due to the long separation of Hawaii, and perhaps to the westward direction of her ocean currents, while those of Samoa and Tahiti trend eastward. The very extensive fauna of Melanesia is essentially that of the East Indies, with the loss of some species, and the incursion of very many others from Australia. The fauna of Micronesia differs little from that of Polynesia.

The islands whose fish fauna is considered may be classified as follows:

\section{IIAWAII.}

$\begin{array}{lll}\text { Hawaii. } & \text { Kauai. } & \text { French Frigate Shoal. } \\ \text { Oahu. } & \text { Nihhau. } & \text { Laysan. } \\ \text { Molokai. } & \text { Bird. } & \text { Nidway. } \\ \text { Maui. } & \text { Necker. } & \text { Johnston. }\end{array}$

Lanai.

Fanning Islands:

Palmyra.

Christmas.

Thornton.

Marquesas Islands:

Nukahiva.

Paumotu Islands:

Gambier Islands (Mangareva).

Makatea.

Pitcairn.

Tahiti, or Society Islands:

Tahiti (Otabeite).

Raiatea (Ulietea).

Huahine.

Billingshausen.

Cook Islands:

Rarotonga.

Austral Islands:

POLYNESIA.

Samoa, or Navigator Islands:

Savaii.

Upolu.

Tutuila.

Manua.

Rose.

Tonga, or Friendly Islands:

Tongatabu.

Vavau.

Fermadec Islands:

Raoul, or Sunday.

Fiji Islands:

Viti Levu.

Tanua Levu.

Ovalau.

Levuka.

Kandavu.

Tubuai.

a The colored drawings for the most part were made by Kako Morita; the uncolored sketches are the work of Chloe Leslie Starks, W. S. Atkinson, R. L. Hudson, and Sekko Shimada.

The authors express their indebtedness to Dr. Charles HI. Gilbert for assistance of various sorts, and to Mr. Albert C. Herre, of Stanford University, for help in sorting and determining various fishes; to MIr. William E. Safford, of the U.S. Department of Agrieulture, for aid in the determination of the native names; and to Dr. Barton. Warren Evermann for assistance of various kinds, especially in proof reading and in seeing these pages through the press. 
New Hebrides:

Banks Group.

Espiritu Santo.

Faté (Vate).

Aneiteum.

Tanna.

Erromango.

Loyalty Islands:

New Caledonia.

Santa Cruz Islands:

Vanicolo (Vanikoro).

Ticopia.

Solomon Islands:

Guadalcanar.

Shortland.

Alu.

Bougainville.

New Georgia.

San Cristohal.

Phoenix Islands:

Howland.

Sydney.

Ellice Islands:

Rotumah.

Nurakita.

Funafuti.

Gilbert Islands:

Makin.

Apamana.

Marshall Islands:

Jaluit.

Bonham.

Radack Islands.

MELANESIA.

Bismarck Archipelago:

Admiralty Islands.

New Hanover.

New Ireland (New Mecklenberg).

Duke of York Group.

New Britain (New Pomerania).

L'Echiquier Islands.

Papua, or New Guinea:

Waigiu.

Misol.

Rawak.

New Guinea.

D'Entrecasteaux Islanils.

D'Urville Islands.

Percy.

Normanby.

Moresby.

Louisiades.

MICRONEMIA.

Caroline Islarıds:

Kusaie (Strong or Oualan).

Yap.

Rug.

Royalist.

Pingelap.

Ulea (Wolea).

Ladrone Islands (Mariana):

Guam.

Bonin Islands:

Marcus.

Palau Islands (Pelew).

\section{SYS'TEMA'TIC LIST OF SPECIES.}

Family BRANCHIOSTOMID E.

\section{AMPHIOXIDES Gill.}

1. Amphioxides pelagicus (Günther). Deep waters of Hawaii.

EPIGONICHTHYS Peters. (Asymmetron Andrews.)

2. Epigonichthys caudatus (Willey). Louisiades.

Asymmetron caudatum Willey, Quart. Jour, Mic. Soc. 1396, 219, Louisiades.

\section{Family SCYLLIORHINIDE.}

CATULUS Smith.

3. Catulus spongiceps Gilbert. Deep seas of Hawaii. 
Family HEMISCYLLIDE.

HEMISCYLLIOM Müller \& Henle.

4. Hemiscyllium ocellatum (Gmelin). New Guinea (Macleay); Australia.

5. Hemiscyllium freycineti (Quoy \& Gaimard). Waigin.

Scyllium freycineti Qnoy \& Gaimard, Voy. Uranie, 192, 1824, Waigiu.

Scyllium malaisianum Lesson, Voy. Coquille, Ir, 94, pl. 6, 1530, Waigiu

oRECTOLOBUS Bonaparte. (Crossorhinus גiüller \& Henle.)

6. Orectolobus barbatus (Gmelin). New Guinea (Macleay); Australia; Japan.

7. Orectolobus dasypogon (Bleeker). Waigiu; Alu.

Crossorhinus dasypogon Bleeker, Archiv Neerl. 1567, 400, with plate, Waigiu.

If this species is really different from the Australian O. bartatus, it is probable that Japanese as well as Melanesian specimens belong to it.

\section{Family GINGLYMOSTONATIDE.}

NEBRIUS Rüppell.

8. Nebrius concolor Rüppell. New Guinea (Macleay); Indian Seas.

GINGLYMOSTOMA Müller \& Henle.

9. Ginglymostoma ferrugineum (Lesson). New Ireland; Waigiu; India.

Scyllium ferrugineum Lesson, Voy. Coquille, Ir, 95, 1824.

Ginglymostonna mulleri Günther, Cat., vin, 40s, 1870.

\section{Family CARCHARIIDE. Halie; Tanifa.}

GALEUS Rafinesque.

10. Galeus japonicus Müller \& Henle. Laysan; Japan.

\section{GALEOCERDo Müller \& Henle.}

11. Galeocerdo tigrinus Müller \& Henle. Hawaii; Australia; Japan.

\section{TRIENODON Müller \& Henle.}

12. Triænodon obesus (Rüppell). Aneiteum; East Indies.

\section{PRIONACE Cantor.}

13. Prionace glauca (Linnæus), Hawaii; warm seas.

\section{CARCHARIAS Rafinesque.}

14. Carcharias melanopterus Quoy \& Gaimard. Mulie alamata. Waigiu; Thornton I.; Christmas I.; Washington I.; Hawaii; Samoa.

This species, known at once by the jet black tips to its fins, is the commonest shark in the channels between the reefs of Samoa.

15. Carcharias phorcys Jordan \& Evermann. Hawaii.

16. Carcharias insularum Snyder. Hawaii.

17. Carcharias nesiotes Snyder. Hawaii; Laysan; French Frigate Shoals.

18. Carcharias sorrah Müller \& Henle. Solomon Is. (Seale); East Indies.

19. Carcharias maou (Lesson). Paumotu Is.

Squalus maou Lesson, Voy. Coquille, II, 91, pl. 1, 1830, Paumotu Is.

20. Carcharias pleurotænia Bleeker. New Guinea (Bleeker); East Indies.

\section{HYPOPRIONODON Gill.}

21. Hypoprionodon macloti (Müller \& Henle). New Guinea (Bleeker); East Indies. 
Family SPHYRNIDE.

SPHYRNA Rafinesque.

22. Sphyrna zygæna (Linnæus). Mata-i-taliga. Samoa; Hawaii; Fiji; New Guinea; warm seas.

The common hammerhead is abundant at the reets of Samoa, as also at Hawaii. Two specimens preserved from Apia.

Family ALOPIDE.

ALOPIAS Rafinesque.

23. Alopias vulpes (Gmelin), Hawaii; warm seas.

Family LAMNIDE.

ISUROPSIS Gill.

24. Isuropsis glauca (Müller \& Henle). Hawaii; tropical Pacific.

CARCHARODON Smith.

25. Carcharodon carcharias (Linnæus). Hawaii; warm seas.

Family SQUALIDE.

SQUALUS Linnæus.

26. Squalus mitsukurii Jordan \& Snyder. Hawaii; Japan.

ETMOPTERUS Rafinesque.

27. Etmopterus villosus Gilbert. Deep waters of Hawaii.

\section{CENTROSCYLLiUM Müller \& Henle.}

28. Centroscyllium ruscosum Gilbert. Deep waters of Hawaii.

\section{ISISTIOS Gill.}

29. Isistius brasiliensis (Quoy \& Gaimard). South Pacifie, off Fiji; Brazil; Guinea.

Family RHINOBATIDE.

RHINOBATUS Bloch \& Schneider.

30. Rhinobatus granulatus Cuvier. New Guinea; Bougainville Is.; East Indies.

31. Rhinobatus thouini Müller \& Henle. Hood Bay, New Guinea (Macleay).

32. Rhinobatus joram Montrouzier. Louisiades. Rhinobatus joram Montrouzier, Ann. Soc. Lyons, 1856, 220, Woodlark I. (Louisiades).

\section{Family DASYATIDE.}

DIscoBatis Macleay \& Macleay.

This genus is near Urotophus, but has no fin on the tail. The skin is smooth, the disk circular, the ventrals entire, and the teeth small. (Not Discobatus Garman 1880, a Japanese genus.)

33. Discobatis marginipinnis Macleay \& Macleay. Admiralty Is.

Discobatis marginipinnis Macleay \& Macleny, Proc. Linn. Soc. N. S. W. 1885, 676, p1. 46.

\section{DASYATIS Rafinesque.}

34. Dasyatis sciera Jenkins. Hawaii.

35. Dasyatis lata Garman. Hawaii.

36. Dasyatis hawaiiensis Jenkins. Hawaii.

37. Dasyatis kuhli (Müller \& Henle). New Ireland; East Indies.

38. Dasyatis trigonoides (Castelnau). New Caledonia.

Raya (Neotrygon) trigonoides. Castelnau, Proc.Zool. Soc. Vict. 1873, 121, New Caledonia; a sting ruy with the spine wanting. 


\section{TENIURA Müller \& Henle.}

Tail long, with a rayless fold of skin below:

39. Tæniura lymma (Forskål). New Guinea (Macleay); East Indies.

40. Tæniura atra Macleay. New Guinea (Macleay).

\section{HIMANTURA Duméril.}

Tail very long, without fold.

41. Himantura fai Jordan \& Seale, new species. Fai. Samoa.

Snout 4.80 to base of tail; eye 2.75 in interorbital space, which is equal to snout; length of nasal opening 2.75 in interorbital.

Body broally pentagonal, the snout very broad but somewhat pointed; disk wider than long ( 14.50 inches wide, $11.50 \mathrm{long}$ ); length of disk 3.30 times in the long whip-like tail; teeth not large, about

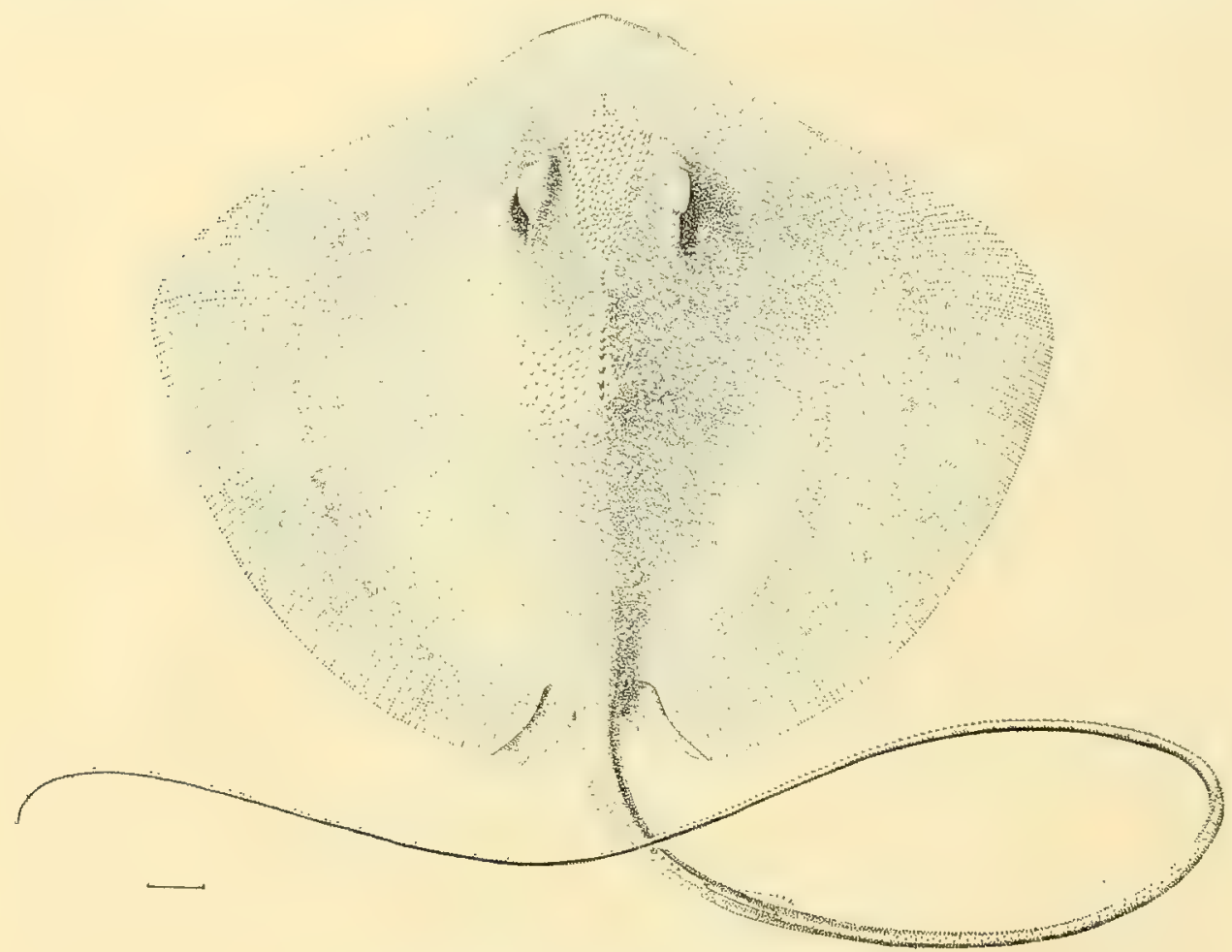

FIg. 2.-Iimantrra fai Jordan \& Seale, new species. Type.

13 oblique series on upper jaw and 23 oblique series in lower; upper buccal flap with fine fringes; width of mouth 1.75 in snout; distance between lower gill-openings equal to distance from first to fifth opening; length of rentral fins slightly less than interorbital space; tail without fold of any kind, its lower surface smooth, the upper surface with scattered small prickles (spine removed by fisherman from type); a row of 10 large spinules in front of spine; seven small spines on median line of disk at its highest joint; a few scattered minute spicules scarcely showing through the skin near these spines and on interorbital region, otherwise disk perfectly smooth.

Color in spirits, back a uniform drab, top of tail dusky, under surface of disk uniform white, under surface of tail light brown. 
One specimen, type no. 51712, U.S. Yational Museum, from Apia, Samoa. Length with tail 47 inches. The color in life was plain brown, not very dark, white below, with no reddish shades and no ocelli. The species is allied to Himantura uanak, but the latter species has the disk considerably narrower.

42. Himantura uarnak (Forskâl). New Ireland; Fast Indies.

43. Himantura granulata (Mtacleay). New Guinea.

Trygon granulatus Macleay, l'roc. Linn. Soc. N. S. W. 1K\$3, 598, S. E. New Guinea.

\title{
HYPOLOPHUS Duméril.
}

44. Hypolophus sephen (Forskal). New Britain; Gast Indies.

\section{Family AETOBATIIE.}

AEтоватUs Blainville. (Myliohatis Müller \& Henle.)

45. Aetobatus punctatus (Macleay \& Macleay). Admiralty Is.

Jyliobatis punctatus Macleay \& Macleny, Proc. Linn. Soc, N. S. W. 1886, 675, pl. 46, fig. 1, Admiralty Is.

STOASODON Cantor. (Aetobatis Müller \& Henle, not of Blainville.)

46. Stoasodon narinari (Luphrasen). Hawaii; Laysan; East Indies; West Indies.

\section{Family HOBULIDE.}

MOBULA Rafinesque.

47. Mobula japonica Müller \& Henle. Hawaii; Japan.

48. Mobula draco (Günther). Misol.

Dicerobatis draco Günther, Voy. Curaçao, 412, 1873.

\section{Family CHIMERIDA.}

CHIMERA Linnæus.

49. Chimæra purpurescens Gilbert. Deep seas of Hawaii; Japan.

Family ELOPIDE.

ELOPS Linnæus.

50. Elops saurus Linnæus. Hawaii; Samoa; New Guinea; warm seas.

MEGALOPS Lacépède.

51. Megalops cyprinoides (Broussonet). Tahiti; Guam; Tubuai; Samoa; Papua; Fiji; New Hebrides (Seale); Last Indies.

Segalops macropterus Bleeker, Ned. Tydschr. Dierk. 1866, 284, East Indies.

This widely diff in the shores. Most of our many specimens from A pia were taken in a pool in the village just east of the month of Vaisigano River, this pool being alternately filled by rain and by the surf in storms. None of these specimens is more than a foot long. They correspond perfectly to the Megalops macropterus of Bleeker, which is plainly the original Clupea cyprinoides of Broussonet. We much doubt the validity of any of the species detached from Megalops cuprinoides by Bleeker. In any case, the true cyprinoides, from Tahiti, is Bleeker's macroplerus.

\section{Family CHIROCEXTRIDE: CHIROCENTRUS Covier.}

52. Chirocentrus dorab (Forskal). New Guinea; Jew Britain; Fast Indies.

\author{
B. B. F. $190,-13$
}




\section{Family CHANID E.}

Chanos Cuvier.

53. Chanos chanos (Forskâl). Hawaii; New Caledonia; Samoa; New Guinea; tropical Pacific. Common along the shores inside the reefs of Samoa.

\section{Family ALBULIDE.}

\section{ALBULA Gronow.}

54. Albula vulpes (Linnæus). Tahiti; Tonga; Hawaii; New Guinea; warm seas.

\section{Family CLUPEIDE. ETRUMEUS Bleeker.}

55. Etrumeus micropus (Schlegel). Hawaii;-Japan.

STOLEPHORUS Lacépède. (Spratelloides Bleeker.)

56. Stolephorus delicatulus (Bennett). Nefu. Samoa; East Indies.

About 20 specimens of this fragile little fish were taken inside the reefs of Apia and Pago Pago. Color in life, deep sky blue, sides silvery.

DUSSUMIERIA Guvier \& Valenciennes.

57. Dussumieria acuta Cuvier \& Valenciennes. New Guinea (Macleay); East Indies.

CoRICA Gray. (Clupeoides Bleeker.)

58. Corica papuensis Ramsay \& Ogilby. New Guinea.

Corica papuensis Ramsay \& Ogilby, Proc. Linn. Soc. N. S. W. 1886, 19, Strickland River (New Guinea).

SARDINELLA Cuvier \& Valenciennes.

(Amblygaster Bleeker; Sartinia Poey.)

59. Sardinella sirm (Forskål). I'a moana; Pelupelu. Samoa; East Indies.

Clupea sirm Rüppell, Neue Wirbelthiere, 77, taf. 21, fig. 1, 1835, Red Sea. Günther, Cat., vII, 425, Zanzibar, Batavia. Sardinclia lcigastroides, Bleeker, Tijds. Ned. Ind., vif, 255, Manado; scales 45.

We have numerous specimens of a large sardine from the shores about Apia. It agrees closely with Günther's account of 'Clupea sirm, and must be the fish thus called by Günther. It has only a single dark spot behind the gill-opening, and the species with a series of such spots along the side (leiogaster and punctata) must he different. It is, of course, an excelient food-fish.

Life colors of a specimen from Pago Pago, deep blue above, somewhat streaky along rows of scales, abruptly silvery below; a small spot behind gill-opening; tips of jaws dusky; fins small, dusky above.

\section{HARENGULA Cuvier \& Valenciennes.}

(Trozuala, Rogenia, and Chupeonia Cuvier \& Valenciennes; Paralosa Bleeker.)

60. Harengula commersoni (Cuvier \& Valenciennes). Pelupelu. Vanicolo; Samoa; East Indies.

(?) Clupea melanura Cuvier, Regne Anim., ed. I, vol. II, p. 318, 1s17; no description; obseure reference to Lacepède. Chupconia commersoni Cuvier \& Valenciennes, IIist. Nat. Poiss., $\mathrm{xx}, 350,1817$, Pondicherry.

Clupeonia vittata Curier \& Valenciennes, op. cit., 352, 1847, Vanicolo.

ITasengula melanurus Bleeker, Nat. Tijds. Ned. Ind, v, 245.

Clupea atricauda Günther, Cat., vir, 426, 1869, Ceram, Amboina.

One the specimen was taken at Apia. Life colors, caudal lobes jet black; back blue, blackish streaks along the rows of scales above, sides silvery white. 
61. Harengula gibbosa (Bleeker). Fiji (Günther); East Indies.

62. Harengula chrysotænia (Bleeker). Tahiti; Last Indies.

63. Harengula vanicoris Jordan \& Seale, new nane. Vanicolo; Papua; East Indies.

Alausa melamura Cuvier \& Valenciennes, op. cit., 411, 1847, Vanicolo, New Guinct, Amboina; not Clupea melumera Cuvier.

\section{lamily DOROSOMATIDE.}

\section{ANODONTOSTOMA Bleeker.}

Last ray of dorsal not produced.

64. Anodontostoma breviceps (I'eters). IBismarek Is.; New Ilanover; Last Indies.

Chatoessus breviceps Peters, Berl. Mon. 1576, 845, New Hanover, Bismarck Is., Amboina.

65. Anodontostoma chacunda (Hamilton-Buchanan). New ('uinea (Macleay); East Indies.

\section{KONOSIRUS Jordan \& Snyder.}

Last ray of dorsal filamentous, as in Dorosoma.

66. Konosirus thrissa (Iinnæus). New Guinea; Fast Indies; China.

Chatoessus nasus (Bloch) Cuvier \& Valenciennes.

Family ENGRAULID E.

\section{ANCHOvIA Jordan \& Evermann.}

67. Anchovia purpurea (Fowler). Hawaii.

68. Anchovia apiensis Jordan \& Seale, new species. Nefu. Samoa.

Head 4.50 in body ( $t$ o base of caudal); depth 5; eye 3.20 in head; snout 4.50; interorbital searcely equal to eye; dorsal I, 13; anal I, 20; scales 34; maxillary elongate, 5 in length of head.

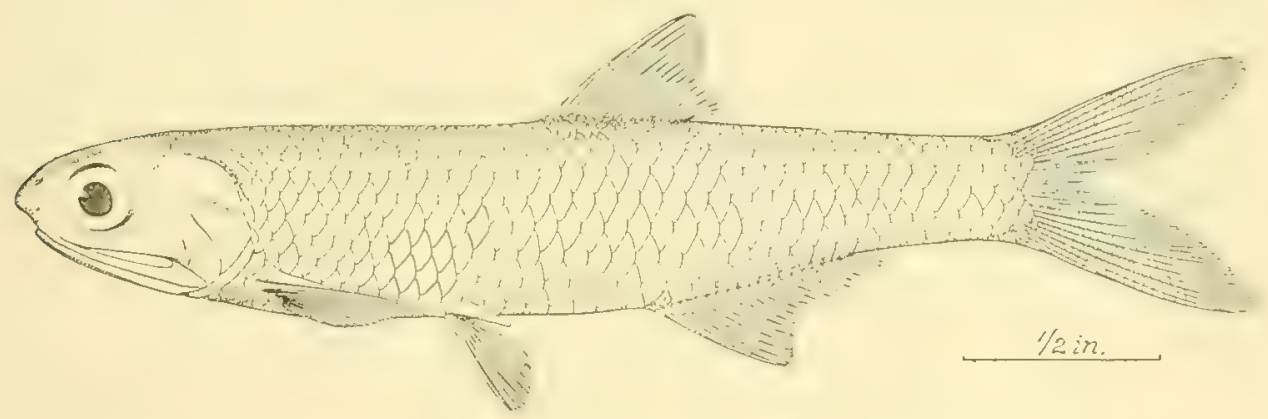

FIG. 3.-Anchavia apicnsis Jordan \& Seale, new species. Type.

Body oblong, compressed; snout produced, conical; mandible 1.45 in head; maxillary extending to posterior angle of preopercle; minute tecth in jaws, palatines, vomer, and pterygoids; gillrakers 1.20 in eye, 30 on lower limb; insertion of dorsal nearer base of caudal than tip of snout by a distance equal to widh of eye, its longest ray 1.20 in head; length of pectoral less than depth of body, $1.75 \mathrm{in} \mathrm{head;} \mathrm{insertion} \mathrm{of} \mathrm{ventrals} \mathrm{equally} \mathrm{distant} \mathrm{between} \mathrm{origin} \mathrm{of} \mathrm{pectorals} \mathrm{and} \mathrm{origin} \mathrm{of} \mathrm{anal;}$ origin of anal under posterior third of clorsal, its luse equal to distance from anterior margin of eye to posterior margin of opercle; candal forked, its lobes equal to length of hear; caudal peduncle rather deep, 2.20 in hearl; scales deciduous, the niddle row of lyelly with spines.

Color in spirits white, the scales with silvery reflections, more or less punctulate with minute black dots on upper surface; cheeks and iris with gilt reflections; a dusky blotch on upper part of orbit, and on auchal region; slight dusky shading along base of dorsal, anal, and upper hase of caulal; caudal with a slight wash of dusky; other fing white. Life colors white, pale olive on hack; a sil very lateral banci.

Type no.51720, U.S. National Museurn, from Apia; length 3 inehes. Of this small species, we have about a dozen fine specimens from the shores inside the reet at Apia. 
69. Anchovia evermanni Jordan \& Seale, new species. Nefu. Samoa.

Head 4 in length; depth 4.50; eye 3.75 in head; snout 1.75; dorsal I, 13; anal 1 , 30; scales 34; interorbital space equal to eye; maxillary equal to depth of fish, $4.50 \mathrm{in}$ length.

Body elongate, compressed; scales large and deciduous; belly trenchant, the scales of middle row each ending in a sharp spine; snout projecting, conical; origin of dorsal midway between tip of snout and base of caudal, its longest ray equal to distance from middle of eye to posterior margin of opercle; pectoral inserted low and extending to base of ventrals, the length 1.50 in head; ventrals 2 in head, their origin nearer pectoral than base of anal; origin of anal posterior to base of dorsal, its length equal to head; caudal deeply forked, the lobes equal to length of head; numerous small teeth on the pterygoids, palatines, vomer and jaws; maxillary extending to posterior angle of preopercle, and bearing a single row of fine teeth; gillrakers scarcely equal to eye, 23 on the lower limb.

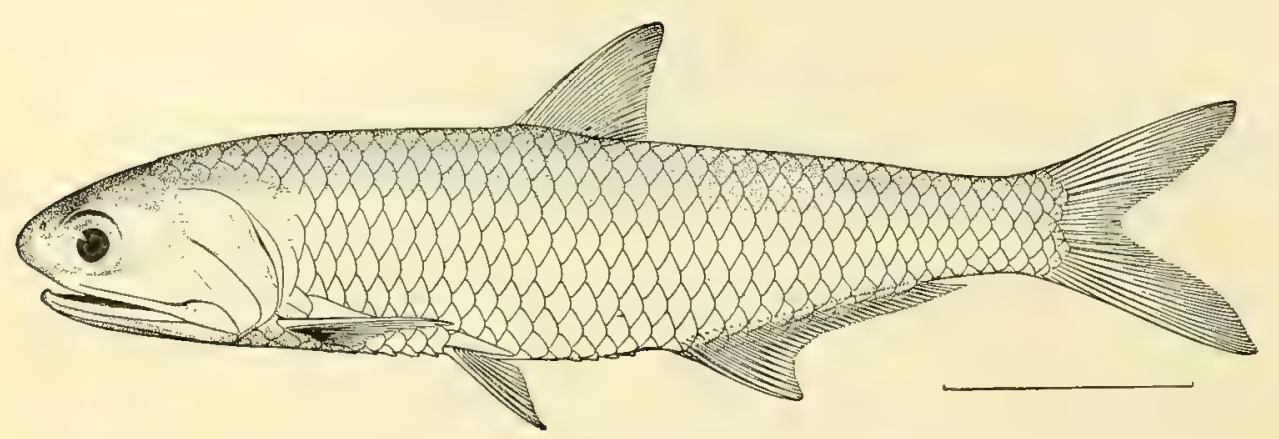

FrG. 4.-Anchovia evermanni Jordan \& Seale, new species. Type.

Color in spirits, silvery, darker above, with a bluish wash; a golden wash on cheek; a dusky blotch on upper margin of orbit; fins all yellowish white, the caudal with an indistinct tip of dusky on end of lobes. In life one specimen had an orange blotch behind gill-opening above, dorsal and caudal chiefly light orange-brown, no silvery Iateral band.

Five specimens, from Apia; type no. 51719, U. S. National Museum, 5 inches long. In all these specimens the depth is 4.66 to 4.75 in the length, instead of 4 times, as stated by Bleeker and Günther of Anchovia brlama, the nearest known species.

This species is named for Dr. Barton Warren Evermann.

70. Anchovia scratchleyi (Ramsay \& Ogilby). New Guinea.

Engrautis scratehteyi Ramsay \& Ogilby, Proc. Linn. Soc. N. S. W. 1886, 18, Strickland River (New Guinea).

71. Anchovia enchrasicoloides (Bleeker). New Guinea (Macleay); East Indies.

\section{Family AULOPIDE.}

\section{CHLOROPHTHALMUS Bonaparte.}

72. Chlorophthalmus proridens Gilbert \& Cramer. Deep waters of Hawaii.

\section{Family SYNODONTIDE.}

SYNODUS Bloch \& Schneider.

73. Synodus varius Lacépède. Hawaii; Samoa; New Guinea; Fiji; Mangareva (Seale); Japan. A few specimens of this widely diffused species were taken at Samoa, on the shore within the reef.

74. Synodus kaianus Günther. Deep seas of Hawaii; Arafura Sea.

\section{TRACHINOCEPHALUS Gill.}

75. Trachinocephalus myops Forster. Hawaii; warm seas. 


\section{SAURIDA Cqvier.}

76. Saurida gracilis (Quoy \& Gaimard). Hawaii; Samoa; New Guinea; Solomon Is. (Seale).

Two specimens were taken in the seine at Apia. They are more deeply colored than Hawailan examples, but are not otherwise different. This species is common about Hawaii.

77. Saurida grandisquamis Günther. Louisiades; Australia.

78. Saurida tumbil (Bloch). Vanicolo; Waigiu; East Indies.

\section{Family BRACHYPTEROIDE.}

\section{BRACHYPTEROIS Günther.}

79. Brachypterois antennatus Gilbert. Deep seas of Hawaii.

\section{Family MYCTOPHIDE. \\ DASYSCOPELUS Günther.}

80. Dasyscopelus asper (Richardson). New Ireland.

81. Dasyscopelus stellatus (Bennett). Open Pacific.

scopehts stellatus Bennett, Whaling Voyage, II, 288, open Pacific.

82. Dasyscopelus pristilepis Gilbert \& Cramer. Deep seas of Hawaii.

83. Dasyscopelus spinosus (Lütken). Deep seas of Hawaii.

\section{NANNOBRACHIUM Günther.}

84. Nannobrachium nigrum Gilbert. Deep seas of Hawaii.

MYCTOPHUM Rafinesque.

85. Myctophum fibulatum Gilbert \& Cramer. Deep seas of Hawaii.

86. Myctophum margaritatum Gilbert. Deep seas of Hawaii.

87. Myctophum lutkeni Gilbert. Deep seas of Hawail.

88. Myctophum evermanni Gilbert. Deep seas of Hawaii.

\section{RHINOSCOPELUS Lütken.}

89. Rhinoscopelus oceanicus Jordan \& Evermann. Deep seas to the southward of Hawaii.

DIAPHUS Eigenmann. (Ethoprora Goode \& Bean.)

90. Diaphus urolampus Gilbert \& Cramer. Deep seas of Hawaii.

91. Diaphus chrysorhynchus Gilbert \& Cramer. Deep seas of Hawaii.

92. Diaphus adenomus Gilbert, Deep seas of Hawaii.

\section{CENTKOBRANCHUS Fowler.}

93. Centrobranchus chøerocephalus Fowler. Deep seas of Hawaii.

94. Centrobranchus gracilicaudus Gilbert. Deep seas of Ilawaii.

NEOSCOPELUS Johnson.

95. Neoscopelus alcocki Jordan \& Starks. Ieep seas of Hawaii; Japan.

Family MAUROLICIOE.

ZALARGES Jordan \& Starks.

96. Zalarges nimbarius Jordan \& Starks. Open sea letween Hawai and Seattle. 


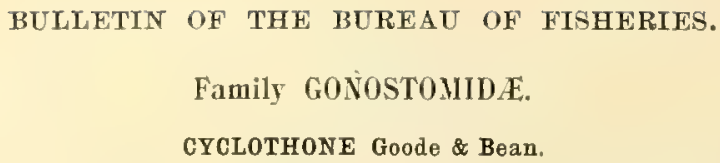

97. Cyclothone rhodadenia Gilbert. Deep seas of Hawaii.

98. Cyclothone canina Gilbert. Deep seas of Hawaii.

\section{GoNostoma Rafinesque.}

99. Gonostoma elongatum Günther. Deep water off New Guinea. Gonostoma ebongatum Günther, Challenger Rept., 186, 1887, New Guinea.

Family STOMIIDE.

STOMIAS Risso.

100. Stomias boa Risso. Mid-Pacific; Mediterranean.

Stomias boa, Peters, Berl. Mon. 1876, 846, $149^{\circ} 26^{\prime}$ W., mid-Pacific.

\section{ASTRONESTHES Richardson.}

101. Astronesthes lucifer Gilbert. Deep seas of the Pacific.

Family IDLACANTHIDE.

IDIACANTHUS Peters.

102. Idiacanthus fasciola Peters. Open Pacific.

Idiacanthus fasciola Peters, Berl. Mon, 1876, 846 , north of New Guinea, $1{ }^{\circ} 45^{\prime \prime} \mathrm{S}$., $136^{\circ} \mathrm{W}$.

\section{Family STERNOPTYCHIDE.}

STERNOPTYX Herrmann.

103. Sternoptyx diaphana Hermann. Deep seas of Hawaii; deep seas.

\section{POLYIPNUS Günther.}

104. Polyipnus nuttingi Gilbert. Deep seas of Hawaii.

\section{ARGYRIPNUS Günther.}

105. Argyripnus ephippiatus Gilbert \& Cramer. Deep seas of Hawaii.

\section{ARGYROPELECUS Cocco.}

106. Argyropelecus heathi Gilbert. Deep seas of Hawaji.

\section{DIPLOPHOS Günther.}

107. Diplophos pacificus Günther. Mid-Pacific.

\section{Family PARALEPIDE.}

LESTIDIUM Gilbert.

108. Lestidium nudum Gilbert. Deep seas of Hawaii.

\section{NEOSUDIS Castelnau.}

109. Neosudis vorax Castelnau. New Caledonia.

Neasudis vorax Castelnau, Proc. Zool. Soc. Viet. 1878, 118, Noumea (New Caledonia). 
Family HALOSAURIDE.

ALDROVANDIA Goode \& Bean. (ITulosanropsis Collett.)

110. Aldrovandia kauaiensis Gilbert. Deep waters of Itawii, Kauai I.

111. Aldrovandia proboscidea Gilbert. Deep seas of II twaii.

112. Aldrovandia verticalis Gilbert. Deep seas of Hawai.

Family PLOTOSIDA.

PLotosus Lacépède.

113. Plotosus anguillaris Bloch. Alpor. Samoa; Waigiu; New Guinea; Solomon Islands (Seale); Asia; East Indies.

Plotosus ikapor Lesson, Voy. Coquille, Zool. Ir, 132, pl. 31, 1ig. 3, 1530, Waigiu.

This little catfish is occasionally taken in shallow water inside the reef at Apia. The yellow stripes on the sides are very faint or wanting in our specimens, which otherwise do not seen to differ at all from specimens from Nagasaki. We therefore place the species of the South Seas (Plotosus ikapor, described first from Waigiu) in the synonymy of I'lotosus anguillaris.

Color dark olive, mottled, white below; sides with scarcely a trace of pale stripes; fins dusky; especially on the edges. Young individuals more distinctly marked, with two white stripes.

\section{CNIDOGLANIS Gänther.}

114. Cnidoglanis macrocephalus (Cuvier \& Valenciennes). New Guinea (Macleay); Timor.

\section{TACHYSURUS Lacépède.}

115. Tachysurus græfi (Kner \& Steindachner).

Arius graffi Kner \& Steindachner, Sitz. $1 \mathrm{k}$. Wiss. Wien, 1867, 28, Samoa.

This species is described from Samoa. Perhaps the specimen is not Samoan, but came from the East Indian region, where catfishes of this type are abundant.

116. Tachysurus armiger (De Vis). New Britain.

Arits armiger De Vis, Proc. Linn. Soc. N. S. W. 1881, 45t, New Britain.

\section{GALEICHTHYS Cuvier \& Valenciennes.}

117. Galeichthys froggatti (Ramsay \& Ogilby). New Guinea.

Arius froggatti Ramsay \& Ogilby, Proc. Linn, Soc. N. S. W. 18\$6, 15, Strickland River (New Guinea).

118. Galeichthys latirostris (Macleay). New Guinea.

Arius latirostris Macleay, Proc. Linn. Soc. N. S. W. 1881, 276.

\section{NETUMA Bleeker.}

119. Netuma spatula (Ramsay \& Ogilby). New Guinea.

Arits spalula Ramsay \& Ogilby, op. cit., 16, Strickland River (New Guinea).

120. Netuma thalassina (Rüppeli). New Guinea (Macleay); East Indies.

\section{HEMIPLMELODUS Bleeker.}

121. Hemipimelodus dayi Ramsay \& Ogilby. Strickland River, New Guinea.

122. Hemipimelodus crassilabris Ramsay \& Ogilby. Strickland River, New Guinea.

\section{LAMBERTIA Perugia.}

123. Lambertia atra Perugia. New Guinea.

Lambertia atra Perugia, Ann. Mus, Genova 1k94, 5.0.0, East New Guinea. 


\section{Family ANGUILLIDE.}

ANGUILLA Thunberg. Tuna.

124. Anguilla mauritiana Bennett. Thna tafa'i-lautalo; Tuna gatala. Waigin; Tahiti; Samoa, in rivers; Johanna I.; Levuka and Ovalau; Fiji (Günther); East Indies.

Anguilla mauritiana Bennett, Proc. Comm. Zool. Soc. 18:1, 128, Mauritius. Günther, Cat., virr 26, Amboina, Ceylon, Philippines, Formosa, Almorah, Johanna I. Günther, Shore Fishes, Challenger, 18s0, 58, Lake Waîheira (Tahiti)

Anguilla marmorata Quoy \& Gaimard, Voy. Uranie, 1824, 241, Waigiu.

Nurana mamorata Kner, Novara Fische, 369, Tahiti, Hongkong.

Anguilla labrosa Richardson, Voy. Erebus and Terror, 113, 1816, South Seas.

Murana maculata Bleeker, Atlas, Murænidæ, 9, tab. I, fig. 2, East Indies; not of Lacépède.

Anguilla johannz Günther, Fish. Zanzibar, 124, Johanna I.

This species is the commonest eel of the Samoan Islands, abounding in quiet waters in all the streams, and reaching a considerable size. We have about 20 specimens, mostly from Vaisigano River. The species raries considerably in the insertion of the dorsal, which is always well forward, however. The body is always finely mottled or marbled, hence the vernacular name of tuga tafailotalo, or "eel colored like [boiled] taro."

Life colors of one specimen from Apia, dark brown, everywhere reticulate with darker. Another was mottled olive and black; doreal and anal edged with pale.

125. Anguilla fidjiensis Giinther. Rivers of Fiji.

Anguilla fidjiensis Günther, Cat., vin, 26, 1870, Kandavu and IVairi (Fiji).

This species, which we have not seen, is very close to Anguilla mauritiana, and seems within the limits of variation of that species.

126. Anguilla obscura Günther. Fiji.

Anguilla obscura Günther, Proc. Zool. Soc- Vict. 1871, 673, Fiji.

127. Anguilla otaheitensis Kaup. Tahiti.

Anguilla otaheitensis Kaup, Aale Hamb. Mus. 17, Tahiti.

128. Anguilla megastoma Kaup. Tuna mea. Mangareva; Aneiteum; Tahiti; Samoa; Rarotonga; Tubuai; Austral Is.; Nukahiva, Marquesas Is. (Seale).

Anguilla megastoma Kaup, Apodes 30, Megareva.

Anguilla aneitensis Günther, Cat., virr, 34, 1870, Aneiteum. Günther, Shore Fishes, Challenger, 1880, 58, Lake Waiheira (Tahiti).

This species is uniformly colored above, pale below, with the dorsal well forward, though less advanced than in Anguilla mouritiana; the teeth in very broad bands, the vomerine band narrower than the maxillary bands. We have two specimens from the Vaisigano River at Apia. Kaup's type is said to come from Megarava, which is evidently a misprint for Mangareva, one of the Gambier Islands.

Life colors of a specimen from Apia, yellow brown, belly and dorsal yellow; fine yellow dots on lateral line. Much paler and more yellow than Anguilla australis. Dorsal fin more advanced.

129. Anguilla sidat Bleeker. Samoa; New Zealand.

The species seems to differ from Anguilla australis in having the maxillary extending beyond the eye, the vomerine teeth also extending backward almost as far as the maxillary teeth. IVe have one large specimen from Samoa answering to the description of this species. Were it not for the much longer maxillary we should think this the adult of Anguilla australis.

Life colors of a specimen from Apia, plain dark brown, yellow below; dorsal grayish dusky. Dorsal posterior.

130. Anguilla australis Richardson. Samoa; New Zealand; East Indies.

Of this species we have half a dozen young from the streans (Vaisigono, Gasegase) about Apia. They seem to agree perfectly with Anguilla australis, having the dorsal inserted a little before vent and the vomerine band of teeth considerably shorter than the maxillary band. 
THE FISHES OF SAMOA.

Family SYNAPHOBRANCHIDE.

SYNAPHOBRANCHUS Johnson.

131. Synaphobranchus brachysomus Gilbert. Deep seas of Hawail.

Family LEPTOCEPHALIDE.

LEPTOCEPHALUS Gmelin.

132. Leptocephalus marginatus Valenciennes. I'usi solasulu. Hawaii; Samoa; Jew Guinea; East Indies.

This conger eel, common throughout the Pacific, is abundant both at Samoa and HIonolulu. It is easily known by the black blotch on the pectoral fin. We have 8 examples from Samoa.

CONGRELLUS Ogilby.

133. Congrellus bowersi Jenking. Hawaii.

134. Congrellus neo-guinaicus (Bleeker). New Givinea.

135. Congrellus fijiensis Ogilby. Fiji.

Congrcllus fijiensis Ogilby, Iro2. Lin. Soc. N.S. W. 1898, 288, Fiji.

136. Congrellus guttulatus (Günther). Samoa; Fiji.

One specimen from Apia. Life colors, light olive, with dark cross-shades; pectoral plain; vertical ins with broad dark edge; an oblique olive shade before eye.

137. Congrellus æquoreus Gilbert \& Cramer. Deep seas of Hawaii.

\section{PROMYLLANTOR Alcock.}

138. Promyllantor alcocki Gilbert \& Cramer. Deep seas of Ilawail.

\section{METOPOMYCTER Gilbert.}

139. Metopomycter denticulatus Gilhert. Deep seas of Hawaii.

VETERNIO snyder.

140. Veternio verrens Snyder. Hawaii.

\section{Family MURENESOCIDE.}

MURENESOX McClelland.

141. Murænesox cinereus (Forskal). Hood Bay; New Guinea; East Indies.

Family UVRII) F.

MOR正ICHTHYS Bleeker.

142. Murænichthys macropterus Bleeker. New Caledonia; East Indies.

MYROPTERERA Ogilby.

143. Myropterura laticaudata Ogilby. Jiji.

Iyropten ura laticaudata Ogilby, Proc. Linn. Soc. N. S. W., 1897, 247, Fiji.

Family NEMCHTHYIDA.

NEMICHTHYS Richardson.

144. Nemichthys scolopaceus Richardson. North of Papua in deep water; open seas. Nemichthys scolopaceus, Peters, Beri. Mon. 1876, 849, north of I'apun in deep whter. 


\section{SERRIVOMER Gill \& Ryder.}

145. Serrivomer beani Gilbert. Deep seas of Hawaii.

STEMONIDIUM Gilbert.

146. Stemonidium hypomelas Gilbert. Deep seas of Hawaii.

NEMATOPRORA Gilbert.

147. Nematoprora polygonifera Gilbert. Deep seas of Hawaii.

Family OPHICHTHYIDA.

SPHAGEBRANCHUS Bloch.

148. Sphagebranchus flavicaudus Snyder. Maui, Hawaii.

\section{DALOPHIS Rafinesque.}

149. Dalophis longipinnis (Kner \& Steindachner). Samua.

This snall species, very slender in form and having the dorsal inserted in advance of the gillopening, is known to us from a very young example taken at Apia.

150. Dalophis misolensis (Günther). Misol.

Ophichthys misolensis Günther, Ann. Mag. Nat. Hist., x, 1872, 426, Misol.

\section{MICRODONOPHIS Kaup.}

151. Microdonophis fowleri Jordan \& Evermann. Hawaii.

152. Microdonophis macgregori Jenkins. Hawaii.

153. Microdonophis polyophthalmus Bleeker. Hawaii; East Indies.

This species differs from the type of Wicrodonophis in having the dorsal inserted over the middle of the head. The body is uniformly colored.

\section{BASCANICHTHYS Jordan \& Davis.}

154. Bascanichthys pinguis Günther. Solomon Islands.

Ophichthys pinguis Guinther, Ann. Mag. Nat. Hist., $x, 1872,425$, Solomon Islands.

\section{CALLECHELYS Guichenot.}

155. Callechelys luteus Snyder. Molokai, Hawaỉan Islands.

156. Callechelys filaris (Günther). Misol.

Ophichthys filaris Günther, Ann. Mag. Nat. Hist., x, 1872, 425, Misol.

LEIURANUS Bleeker.

157. Leiuranus semicinctus (Lay \& Bennett). 'Ata'ata uli. Hawaii; Japan; East Indies.

Of this species we have one large specimen from Apia. Its coloration is wonderfully close to that of Chlevastes colubrinus, but the black bands are broader than in the latter, and most of them do not meet the fellow on the belly. This species is widely diffused, occurring in company with the two species of Chlecastes, both of which are colored remarkably like it.

158. Leiuranus cobra (De Vis). South Seas.

Ophichthys cobra De Vis, Proe. Linn. Soc. N. S. W., 1884, 455, South Seas.

This species is said to have the head one-tenth of the length of the trunk. In other respects it agrees with Leiuranus semicinctus, with which it is probably identical. 


\section{BRACHYSOMOPHIS KaUp.}

159. Brachysomophis henshawi Jordan \& Snyder. Honolulu.

160. Brachysomophis crocodolinus (Bennett). Tahiti; Mauritius.

\section{MYRICHTHYS Girard.}

161. Myrichthys stypurus Smith \& Swain. Johnston I.

162. Myrichthys magnificus (Abbott). Hawaii,

CHLEVASTES Jordan \& Snyder.

163. Chlevastes colubrinus (Boddaert). Samoa; Guan; Fast Indies.

A few specimens from Samoa.

164. Chlevastes fasciatus ( 1 hl). Samoa; Last Indies.

Muræna fasciata Ahl, De Muræna et Ophichtho, 1759, 9, East Indies.

Ophichthys colubrinus fasciatus Günther, Cat., vII, 81, 15i0, Borneo.

Ophichthys naja De Vis, Proc. Linn. Soc. N. S. W. 1884, 45., South Seas.

This species seems to us distinct from Chlevastes colubrinus. The head is shorter, 9 to 11 times in the length of the trunk (7 to 8 in Chlevastes colubrinus). The black cross-bands are less regularly"

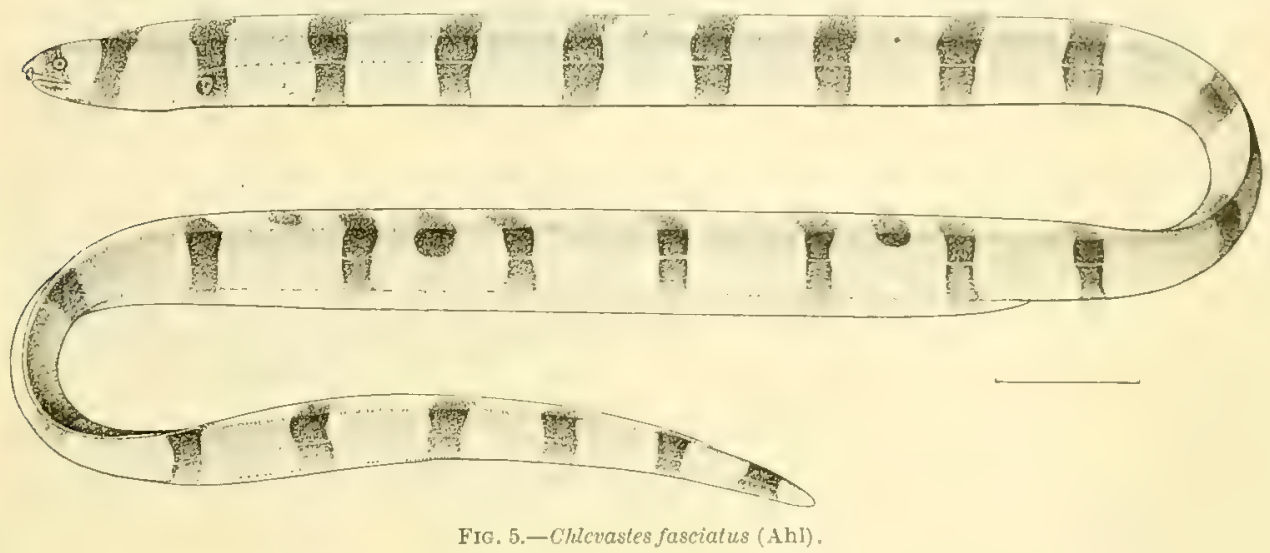

formed, having backward projections, and there is in the pale interspace usually a large rounder black spot or ocellus.

We have two large examples from the coral reef at Apic.

\section{Family MORINGUIDE.}

MORINGUA Gray. (Including I plthalmichthys Kaup.)

165. Moringua hawaiiensis Snyder. Honolulu.

166. Moringua macrocephala Bleeker. Samoa; East Indies.

Of this rare species, distinguished by its long head, we have one fine specimen from the harbor of Pago Pago. Depth 4 in head; head 9 in total length; pectoral minute, scale-like; gill-openings separate. Life colors light pinkish brown, nearly uniform; head very clear translucent rosy red; caudal nore orange.

This specimen was taken in salt water at the mouth of a little brook and was very tenacions of life.

167. Moringua javanica (Kaup). Fiji; Mloluccas. 


\section{Family HURENIDE.}

\section{RHINAMURENA Garman.}

This genus differs from Eurymycterc in having the anterior nostrils slit and dilated at the ends, which are produced into long flaps.

168. Rhinamuræna quæsita Garman. Marshall Is.

Rhinamurrena quxsita Garman, Bull. Essex Inst. 1859, 114, Marshall Is,

169. Rhinamuræna eritima Jordan \& Seale, new species. Samoa.

Head 7.20 in total length, 2.65 in body anterior to vent; depth 2 in head; vent exactly midway between tip of snout and tip of tail; length of snout, from posterior nostril, 5.20 in head; eye 2 in snont; angle of jaws 2.20 in head; jaws curved and can not be completely closed; dorsal high 4.60 in head; anal abont one-half as high as dorsal; origin of anal immediately posterior to vent; origin of dorsal about midway between gill-openings and angle of jaws; gill-openings size of eye; anterior nostrils on end of snout long, about equal to eye, terminating in an expanded disk two-thirds as wide as eye; posterior nostrils consisting of slightly elevated tubes situated on upper side of snout directly

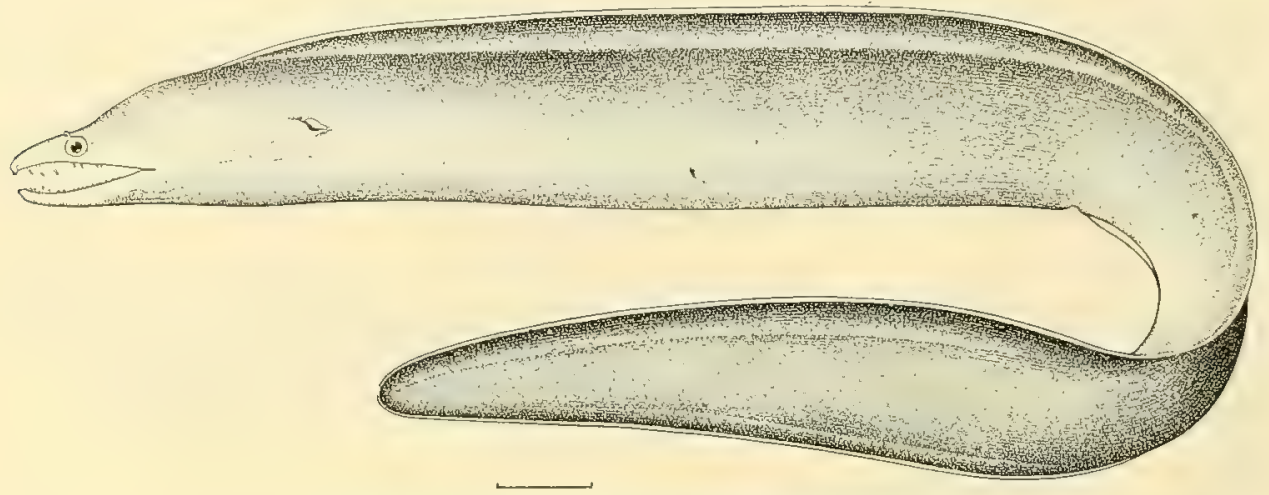

FiG. 6.-Rhinamuraena eritima Jordan \& Seale, new species. Type.

above anterior margin of eye; top of snout flat with a narrow concave groove; depth of snout at anterior margin of eye slightly less than width; forehead evenly rounded from posterior of eyes; teeth in lower jaw in a single row of 25 sharp, concave teeth on each side, the anterior five being enlarged; posterior teeth of upper jaw small and uniserial, the anterior teeth large biserial canines, three of which are on the median line of vomer; a single row of blunt palatine teeth; throat with numerous longitudinal wrinkles.

Life colors, light-grayish brown, paler below; dorsal dusky with a sharply defined bluish white edge; anal with a faint pale edge. Color in spirits earth-brown, yellowish on belly and under part of head, dorsal and anal with distinct white margins, that of the dorsal broader, the posterior third of dorsal shading into an intermarginal black area, a yellowish wash on head posterior to eye.

This very handsome eel is known to us from a single specimen 20.15 inches long, taken at Pago Pago. Type no. 51717, U. S. National Museum.

\section{MUR瓜A Linnæus.}

\section{Muræna kailuæ Jordan \& Evermann. Hawaii.}

Muræna parlalis Bleeker, Atlas, Murænidæ, 86, pl. 25, figs, 1 and 2, Java, Cocos; probably not Muræna pardalis of Schlegel, a Japanese species.

Muræna hailua Jordan \& Evermann, Bull, U. S. Fish Comm., Xxir, 1902 (1903), 165, Kailua (Hawaii).

Jurzena lampra Jenkins, Bull. U. S. Fish Comm., xxII, 1902 (1903), 423, fig. 3, Honolulu.

Jurana kauila Jenkins, Bull. U. S. Fish Comm., Xxir, 1902 (1903), 424, fig. 4, Honolulu.

This species is rather common about the Hawailan reefs, but was not seen at Samoa. The receipt of additional specimens from Honolulu forces us to believe that the variation in the arrangement of 
spots in this species is very great. If $I$. kavila and $M$. lampra are distinct species, we must add still two more to the list. The species is very close to the Japanese Irurana pardalis Schlegel, and may prove to be a variation of the latter, as Bleeker has supposed. In Vurana kailure the white spots on the belly are larger than in the Japanese species.

The life coloration of this species is very bright and attractive.

171. Muræena pavonina Richardson. South Seas.

Irurana pavonina Richardson, Voyage Sulphur, 110, pl. 53, figs. 1-6, South Seas.

\section{ENCHELYNASSA Kaup.}

172. Enchelynassa canina (Quoy \& Gaimard). Hawaii; Samoa; Rawak; Waigiu.

Murena caninaa Quoy \& Gaimard, Voy. Vrunie, 217, 1524, Rawak, Waigiu.

Enchelynassa bleckeri Kaup, Apodes, 72, fig. 55, 1851; lorality unknown. Jordan \& Snyder, Proe. U. S. Nat. Mus., Xxที, 1904, 941, Hawaỉ.

Gymnothorax vinolentus Jordan \& Evermann, Bull. U. S. Fish Comm., Xxir, 1902 (1903), 165, Kailua (Hawaii).

Of this species 3 specimens are known besiles the original type. These are the type of $G$. vinolentus from Hawaii, a very similar specimen now before us, from Samoa, and a very large example similar to Kaup's type, from Hawaii. It is one of the largest of the morays, and the most formidably armed.

\section{EURYMYCTERA RaUp.}

173. Eurymyctera acutirostris (Abbott). Hawail.

Murænc acutirostris Abbott, Proc. Ac. Nat. Sci. Phila. 1860, 476, Hawaii.

Gymnothorax acutirostris Fowler, Proc. Ac. Nat. Sci. Phila. 1900, 494, plate 18, Hawaii, same specimen.

GYMNOTHORAX Bloch. Pusi.

\section{Gymnothorax eupterus (Günther). Raoul I.}

Muræna euptera Günther, Cat., virI, 122, 1870, Raoul I.

175. Gymnothorax waialuæ Snyder. Hawaii.

Gymnothorax wräalux Snyder, Bull. U. S. Fish Co.mm., XxII, 1902 (1901), 520, pl. 6, Waialua (near Honolulu).

This species is known from a young example taken by Professor Snyder. It is very close to the Japanese-East Indian species, Gymnothorax reticuleris, but the arrangement of the sharply defined black cross-bands is different, and the interspaces between the bands are pale, as in Chlevastes colubrinus.

176. Gymnothorax petelli (Bleeker). Hawaii; Samoa; East Indies.

Muræna petelli Bleeker, Nat. Tijds, XI, 8t. Java. Günther, Cat., viry, 105, Jara, Mauritius.

Gymnothora petelli, Bleeker, Atlas, Murænidæ, 99, tab. xxxur, fig. 1.

Murena interrupta Kaup, Apodes, 67, fig. 51, 1854, Red Sea.

Gymnothorax leucacme Jenkins, Bull, U. S. Fish Comm, xxir, 1902 (1903), 427, fig. 7, Honolulu.

Of this handsome species we have 7 large specimens from Pago Pago and Apia. They agree entirely with the accounts both of petelli and leucacme.

Life colors of a specimen from A pia, dark brown, with 19 to 22 broad black cross-bars about as wide as the interspaces; fins barred like body; iuterspaces on anal whitish, some of the dark bands reaching the fin, others not; interspaces on dorsal pale, whitish on edge, each interspace with a large marginal black spot; tip of the tail white (sometimes black); angle of mouth black; belly light brown, the bands anteriorly not meeting across it (a dark spot sometimes between each pair of bands).

177. Gymnothorax meleagris (Shaw). Samoa; Fiji; East Indies.

Murxna meleagris Shaw, Nat. Misc., pl. 220, about 1802, Pacific. Günther, Cat., vir, 100, Zanzibar, Java, Mauri. tius, Fiji, Seychelles.

9. Murxnophis hauy Lacépẻde, Hist. Nat. Poiss., V, 646, pl, vit, fig. 2, 1803; no locality.

Thyrsoidca chlorostigma Kaup, Apodes, 89, 1854, Seychelles.

Gymnothorax chlorostigma Bleeker, Atlas, 97 , tnb. xxxiv, fig. 2, Enst Indies.

a This spccies, Enchelynassa canina, is said to be black, with very long ncedle-like teeth, and tubular nostrils. The type was only 7.5 inches long, and from the description is probably the young of Enchelynassableckeri. 
Of this strongly marked species, known by its many small yellow spots, black gill-opening and white-tipped tail, we have one large specimen from Apia. Color in life bright brown, with everywhere stellate spots of yellowish white, the spots round and much. smaller than eye, smaller on the head and slightly larger and much farther apart on tail; belly, chin, snout, and throat spotted like the body; fins dusky-edged, spotted; tail broadly tipped with white; gill-opening black.

178. Gymnothorax xanthostomus Snyder. Hawaii.

179. Gymnothorax leucostictus Jenkins. Hawaii.

180. Gymnothorax goldsboroughi Jordan \& Evermann. Hawaii.

181. Gymnothorax nuttingi Snyder. Hawaii.

182. Gymnothorax eurostus (Abbott). Hawaii.

183. Gymnothorax thyrsoideus (Richardson). Samoa; Tonga; Guam; Faté and Tubuai (Seale); East Indies.

Mrurxena thyrsoidea Richardson, Voyage Sulphur, 111, 1815, not fig., China. Günther, Cat., viı, 113, China, Pinang. Steindachner, Sitz. Ak. Wiss. Wien 1900, 514, French Pass.

Wurana griseobadia Richardson, Voygge krebus and Terror, 89, Tonga.

Mutana prosopeion Bleeker, Nat. Tijd. Ned. Ind., Iv, 300, East Indies.

Gymnothorax prosopeion, Bleeker, Atlas, Murcnida, 88, tab. xxxix, fig. 3.

Wurana tile, Seale, Bishop Museum, 1901, 62, Guam; not of Hamilton.

This widely diffused species may be known by its pale color and small whitish spots, with the anterior part of the head abruptly blackish. It is probably the species called Murana tile by Seale.

A small specimen from Pago Pago. Color in life light gray, mottled with light purple, leaving the ground-color as pale spots; head distinctly dark purplish or blackish; iris white; gill-opening and angle of mouth pale; dorsal colored like the body, with a broad pale edge; anal pale.

184. Gymnothorax pictus (Ahl). Pusi gatala. Hawaii; Samoa; New Guinea; Tahiti; Rarotonga; Mangareva; Makatea; Shortland I. (Seale); East Indies.

This species, readily known by its pale color and purplish specklings which gradually gather together with age to form dark spots, is very common throughout the South Seas. We liave about 10 specimens of various sizes from Samoa, the largest representing the form called Gymmothorax sidereus, which is the adult. Gymnothorax litus, a closely allied form, seems to us a distinct species.

Color in life of a specimen from Apia, light gray, very finely dotted and marbled with purplish gray, which is purplish brown in larger examples; adult with numerous irregular diffuse transverse bars made up of dark spots, streaks and reticulations, these being a little denser in the bars; these bars composed of three lengthwise series of denser areas, which gradually with age form series of dark spots, the uppermost on the dorsal; top of head and snout densely speckled like the body; chin and throat with scattered purplish specks, which disappear on the belly, which is white; angle of mouth and gill-opening uncolored; anal speckled like the body, the edge less spotted.

In the young there are neither spots nor bars, but the ground-color is covered with reticulations of different degrees of intensity, the fish always pale purplish with white belly.

185. Gymnothorax litus (Richardson). Tahiti; Marquesas Is; Samoa; Fast Indies.

Ifurana lita Richardson, Voyage Erebus and Terror, 84, IS\$6, Moluccas.

Gymnothorar pictus Blceker, Atlas, Murenide, in part, tab. XxIx, fig. 1, but not description.

Mrumen nigrolineata Liaup, A podes, 66, 1854, Marquesas Is.

Durcena chrysops Tíaup, Apodes, 70, 1854, Tahiti.

Of this species we have several specimens from Apia. It is close to Gymnothorax pictus, but is apparently distinct, having the color darker, and the lower jaw and throat profusely marked with blackish lines. This region is faintly speckled in $G$. pictus. $G$. chrysops seems to be the same species and $G$. nigrolineatus also may be the same.

Color in life of a specimen from Apia, ground-color yellowish olive, darker above, thickly covered with reticulations and specklings of dark purplish brown, darker than in G. pictus; some trace of irregular dark reticulated cross-streaks on tail; fins colorer like the body, as are head, throat and belly; lower jaw and throat closely spotted; no black at angle of mouth nor on gill-opening; no pale erlges to fins. 
186. Gymnothorax tænioides (Günther). Samoa.

Muræna trnioides Günther, Proc. Zool. Soc. 1871, 674, Savaii (Samoa).

This species is quite unlike any taken by us in Samoa. We have not seen it.

187. Gymnothorax favagineus Bloch \& Schneider. Samoa; Faté, New IIebrides (Seale); Last Indies.

Gymnothorax favagineus Bloch \& Schneider, Syst. Ichth., 525, taf. 105, Tranquebar.

Murxna tessellata Richard on, Ichth. Sulphur, 109, pl. 55, tigs, 5-8, 1845. Gtinther, Cat., Vur, 106, Zunzibar, Jast Indies. Gymnothorax tessellatus Bleeker, Atlas, 93, tub. xxvir, fig. 3; pl. 2s, fig. 1.

Murana python Kaup, Apodes, 68, fig. 53, Africa.

Of this East Indian species we have one small example from Samoa. It much resembles Bleeker's figure of Gymnothorax tessellatus. Apparently $G$. isingleenu, with the spots separated by broad interspaces of the ground color, is a different species.

Color in life of a specimen from Pago Pago, pale yellowish olive, with four rows of blackish olive spots along the side, larger than eye on body, smaller on head, very regular, a similar row on dorsal and anal; belly also spotted; the ground color reduced to a broad net-work around the spots.

188. Gymnothorax polyophthalmus (Bleeker). Samoa; Caroline Is.; East Indies.

Hurana polyowhthalma Bleeker, Act. Soc. Ned. Ind., IIr, Celebes, x, 15, Celebes.

Of this species, hitherto known from one small example, we have two examples equally small, from. Apia, and a larger one, 8.75 inches long, from Kusai Islani, Caroline Group. All of them resemble Bleeker's figure very closely. The body is covered with many black spots on a light ground, the largest of them being rings with a yellow center.

Color in spirits, light olive, almost white below, with about three rows of dark olive spots as large as eye, each spot being ring-like with a yellowish center of the ground-color; besides these many small dark spots and specks; a row of ring-like spots on dorsal with many smaller specks; a row of blackish spots along base of anal; posterior half of dorsal and whole of anal with a broad unspotted edge; spots anteriorly very small; scattering spots on chin and belly; gill-opening pale; no spot at angle of mouth.

189. Gymnothorax stellatus (Lacépède). Pusi yulepule. Samoa; New Britain; East Indies.

Murnophis stellatu Lacépède, Hist. Nat. I'oiss, v, pp, 62\%,629,64, 1803, New Britair.

Iurana fimbriata Bennett, Proc. Comam. Zool. Soc., 1, 1531, 168. Günther, Cat., viI, 10s, Borneo, Amboina, Port Essington.

Hurana bullatc Richardson, Voy, Erebus and Terror, 56, 1816, Borneo,

Wurna isingleenoiles Bleeker, Verh. Brt. Gen., xxr, Mur., 4५, East Indies.

Gymothorax isingleenoides Bleeker, Aths, Murkenirle, 91, tab. xxxr, fig. 1, East Indies.

Of this strongly marked species we lave eight specimens from Apia. Lacépède's stellatus, with two rows of black spots, is probably the same as the fimbriatus of Bennett.

Color in life of one specimen, body pale redish olive with many purplish black spots, irregvlar in form, about as large as eye; the oblong spots longer, the spots all narrower than the interspaces; spots arranged in about 3 rows, with a row also on clorsal fin and the lower row extending on anal; belly pale, unspotted; clorsal and anal with a yellowish margin, broader on anal, which is mostly pale; head with much smallex spots; sparsely placed; folds on neck dark, conspicuous; rill-opening pale; angle of mouth with a small black spot, a whitish spot before it on the lower jaw only; chin and snont dark.

190. Gymnothorax buroensis (Bleeker). Caroline Is.; Samoa; Last Indies.

Murcna buroensis Bleeker, Nat. Tijds. Ned. Ind., vir, 79, Buro.

Gumnothorat burocnsis, Blecker, Atlas, Aluranide, 9), tab. xi, lig. 1, Eust Indies.

Of this species we have 10 specimens from Samoa and three from the island of Kusai, in the Carolines, collection of Mr. A. P. Lundin. The species is alwas very dark, with darker spots and markings, which vary considerably with age and shade of color. The tip of the tail is always white. We identify our specimens with burocnsis with a little doubt, but there is no other species with which we can place them.

Color in life of a specimen from Apia, clark brown, a little paler below; lorsal fin high, with very obscure black bars, and behind edged with light ortuge; the body also fatintly harred with darker. This coloration was seen in three young examples olotaincl from a crackert coral heal. 
Color in spirits (adult specimens) very dark purplish brown, with longitudinal rows of small, diffuse, irregular black spots, smaller than eye, arranged in about four irregular rows; these spots rather larger on the tail, smaller towards the head, which is not spotted; top of head and snout dark; angle of mouth not colored; gill-opening not colored; fins colored like the body, the caudal with a narrow pale edge; throat pale, unspotted; belly darker and spotted posteriorly.

191. Gymnothorax mucifer Snyder. Honolulu.

Gymnotharax macifer Snyder, Bull. U. S. Fish Comm., xxIr, 1903 (1904), 519, pl. 5, fig. 9, Honolulu.

This species is known from a single example from Hawaii. It strongly resembles Gymnothorax buroensis, but in the latter the upper teeth are in two rows.

192. Gymnothorax laysanus (Steindachner). Hawaii; Laysan.

Juræna laysana Steindachner, Denks, Ak. Wiss. Wien, xvı, June 27, 1900, 177, Laysan.

Gymnothorax loysamus, Jenkins, Bull, U. S. Fish Comm., XXII, 1902 (1903), 425, Honolulu. Snyder, Bull, U. S. Fish Comm., XxII, 1902 (1901), 518, Honolulu, Hilo.

Lycodontis partibranchialis Fowler, Proc. Ac. Nat. Sei. Phila. 1900, 404, Hawaii.

This species is occasionally taken about the Hawaiian Islands. Dr. Steindachner's second figure representing a species finely speckled with white only may represent some other species. Fowler's parvibranchialis with white spots in about four rows seems to be identical with our smaller specimens.

193. Gymnothorax polyuranodon (Bleeker). New Guinea (Bleeker); East Indies.

194. Gymnothorax hilonis Jordan \& Evermann. Hawaii.

195. Gymnothorax tenebrosus (Richardson). Tahiti (Seale). Muræna tenebrosa Richardson, Voy. Erebus and Terror, 84, 1846; locality unknown, probably Tahiti.

196. Gymnothorax variegatus (Quoy \& Gaimard). Guam.

197. Gymnothorax chalazius Waite. Tubuai; Austral Is. (Seale); Australia. Gymnothorax chalazius Waite, Rec. Austr. MUs., v, 145, 1904, Lord Howe I.

An ally of Gymnothorax laysanus, recently taken by Mr. Seale at Tubuai.

198. Gymnothorax javanicus (Bleeker). Pusi maoa'e. Samoa; East Indies.

Muræna platbernon Richardson, Voy. Erebus and Terror, 84, 1846, Darnley I,; not of Quoy \& Gaimard.

Mrurena javanica Bleeker, Nat. Tijds. Ned. Ind., XIx, 241, Java.

Gymnothorax javanicus, Bleeker, Atlas, Murænidæ, 95, tab.Xxxv, fig. 2.

Of this species we have five examples from Samoa from $1 \frac{1}{2}$ to 4 feet in length. It is one of the largest eels of the South Seas, and the coloration is the same at all ages. The species is well separated from $G$. batuensis, with which and with several other species Dr. Günther has confounded it under the name $G$. flavomarginatus. Murænophis griseus Lacépède seems to be G. pictus. Mursena geometrica= Muræna bilineata Rüppell is a species of Echidna.

Color in life of a very large specimen from Apia, brownish with blacker spots, larger behind; a large black spot around gill-opening. Another specimen from Apia in life was reddish brown with jet black spots and blotches, irregular in size but much larger than eye; about three rows on body, reducing ground-color to broad reticulations; about 40 to 50 spots in a row, those of the upper row extending on the dorsal, the spots rather larger than those in the second row; those of the third row still smaller; belly paler, with smaller black spots; head similar, the spots small, much smaller than eye; angle of mouth black; gill-opening in a large black spot; wrinkles on head dark; fins spotted and colored like the body; tip of tail with a pale edge; obscure pale edging to fins behind.

199. Gymnothorax flavomarginatus (Rüppell). Pusi gatala (spotted moray). Samoa; Hawaii; New Guinea; Norfolk I.; East Indies.

Muræna favomarginata Ruppell, Atlas, 119, tab. xxx, tig. 3, 1828, Red Sea. Günther, Cat., viI, 119, Zanzibar, Seychelles, Batu, Norfolk Island.

Gymnothorax flavomarginatus, Bleeker, Atlas, Murænidæ, 95, tab. xxxiı, fig. 2, tab. xxxrv, fig. 3, East Indies.

Murana batuensis Bleeker, Nat. Tijds. Ned. Ind., XII, 241, Batu.

This dull-colored moray is, with Gymnothorax undulatus, the most common species at Samoa, and it is occasionally taken at Hawaii. It is readily known by the small dusky spots which cover the whole body, obscuring the pale ground color. The gill-opening is black, and there is a mere trace of 
a yellow edge to the vertical fins posteriorly, but hardly a yellow margin. The fore part of the head

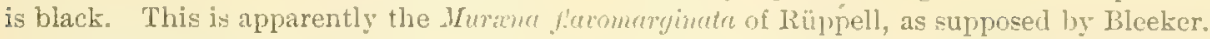

Color in life of a specimen from Apia, yellow-olive, larker ahove, witls some yellow spots; luody. and fins with black spots; fins narrowly edged with yellow; front of head black.

Color of same specimen in alcohol, dusky olive, paler below; everywhere with confluent marblings or spots of purplish brown, the olive grouncl-color appearing as small, irregular, yellow sunts or vague streals; head a little darker; snout and tip of chin black; gill-opening in a conspicuous black spot; angle of mouth black; tip of caudal narrowly eifgel with yellowish white, the color extending as a very narrow edge on vertical fins; dorsal nearly black, mottlel like the body; anal similar.

\section{Gymnothorax thalassopterus Jenki}

Gymnothorax thalassopterus Jenkins, Bull. C. S. Fish Comm., xxir, 1902 (1903), 427, pl, 11, Honolulu; not cotypes,

This species is known from one specimen from IIonolulu. In this type, as shown in Jenkins' figure, the dark spots on the bolly are almost all separate, not confluent as in G. fluromarginalus. In all other regards the two forms seem to agree, and G. thalasopterus is probably only a variant individual of the latter species. The smaller cotypes from IIonolulu mentioned by Dr. Jenkins are the ordinary flawmarginatus, the dark spots every where confluent as usual.

201. Gymnothorax talofa Jordan \& Starks, new species. Samoa.

Head 7 in entire length; depth $2.3: 3$ in head; snout rather sharp, 5 in hearl; eye 1.80 in snout: length of mouth 1.50 in head; gill-opening smaller than pupil; lower jaw strongly hoolied upwart toward its tip; in the upper jaw an irregular broken series of sharp canines on cach sicle, slightly

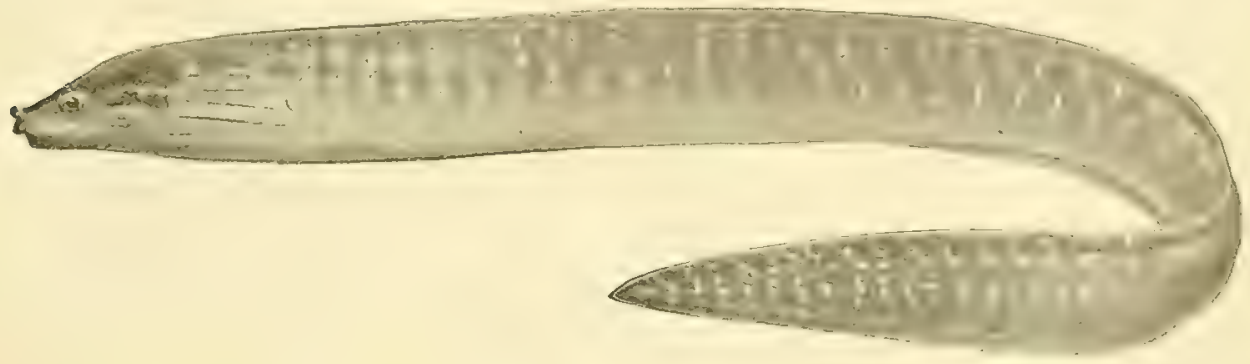

FIG. 7.-Gymnothorax talofu Jordan d. Starks, new specics. Type.

hooked backward; posteriorly an outer series of much more regular, closer-set, and smaller series somewhat directed backward; anteriorly and medially two vertical vomerine teeth longer and sharper than the others. On the lower jaw a series of teeth similar to the outer series of upper jaw, while anteriorly are $t$ or 5 sharp canines irregular in length; trunk 1.33 in caudal.

Color in alcohol dark reddish brown, with whitish streaks and blotches arranged in one or two rows with a vague third row below, the ground-color forming dark cross-shades between the whitish streaks. The white markings are in fact short vertical streaks, which on the tail become narrow white wavy cross-bands, relatively conspicuous. Head and anterior part of trunk with a row of diffuse dark blotches on the cross-shades, these distinct near head, where the first one is a long werlge on the temporal region, but fading behind; angle of mouth black; a white streak from snout to vent along the median line; gill-opening pale; fins colored like body; caudal with a narrow yellowish edge; belly and throat plain brown.

Two specimens, from A pia. The type, no. 51713, U. S. National Museum, is 10 inches in length. Talofa is the common Samoan salutation, equivalent to the Hawaiian aloha.

202. Gymnothorax detactus Bryan \& Iterre. Marcus I. ; Samoa; Nukahira (Seale). Gymnotharax detactus Bryan \& Herre, Bishop Museum, II, 1903, 120, Marcus I.

Two specimens from Apia seem to be identical with this species, although Bryan and Herre do not mention the markings at the angle of the mouth. 
Color in alcohol pale gray, much mottled and spotted with purplish brown, the brown forming vague branching cross-bars or streaks, much anastomosed, covering belly also, these most bar-like behind; throat and chin paler; no pale edge to fins; angle of mouth brown, with a yellow spot before it on each jaw; pores on jaws white; fins colored like the body.

\section{Gymnothorax rhodocephalus Bleeker. Rarotonga (Seale); East Indies.}

(Gymnothorax formosus Bleeker.)

204. Gymnothorax lineatus (Lesson). Tahiti; Oualan; Samoa; East Indies.

Muræenophis lincatus Lesson, Voy. Coquille, 127, pl. 11, fig. 1, 1830, Oualan; poor figure.

Murena flaveolus Lesson, Voy. Coquille, 128, pl. 11, fig. 2, 1830, Oualan; smaller specimen, with a, better figure. Murzna grisea Blecker, Verh. Bat. Gen., xxı, Bali, 11, Bali; not of Lacépède.

Murkena vichardsoni Bleeker, Nat. Tijds, III, 226. Bleeker, Atlas, Murænidæ, 100, tab. XLII, fig. 2. Kner, Novara Fische, 385, Tahiti. Günther, Cat., VıI , 118, Zanzibar, Amboina, Ceram, East Indies.

Irurcuca ceramensis Bleeker, Nat. Tijds, III, 297, Ceram.

Gymothorax ceramensis Bleeker, Atlas, Murænidæ, 101, tab. xxxir, fig. 3.

Murana scoliodon Bleeker, Verh. Bat. Gen., $x x v$,-Murenidæ, 43 , Sumatra.

Muræna troscheli Bleeker, Verh. Bat. Gen., xxy, Murænidæ, 45.

Nurzna renosa Kanp, Apodes, 68, 1854, Timor.

Thyrsoidea multifasciata Iraup, Apodes, 87, 1854, Moluccas.

Murena vermicularis Peters, Wiegmann's Archiv, 1855, 271

Muræna diplodon Peters, Wiegmann's Archiv, 1855, 271

Murma floresiana Bleeker, Nat. Tijds., vi, 334, Flores.

We refer tiree examples of a small moray from Apia to Lesson's lineatus and fareolus. In this species the dorsal fin is very high, the body brown crossed by irregular darker lines, and there is, as in $G$. rhodocephalus and $G$. detactus, a dark spot between two yellow spots at the angle of the mouth. The individual specimens differ somewhat in color, enough to allow for the discrepancies in the poor figures I ablished by Lesson. The common Gymnothorax richardsoni of the East Indies seems to be the same species.

Color in alcohol light reddish brown, darker above, with dark vertical broken streaks or bands, very irregular in form and more or less reticulating; at intervals broadening into dark spots; markings a little more irregular on the tail; belly pale, unspotted or else marked like the body; head unspotted; angle of mouth black, with a white spot before it on both jaws; fins very high, paler than body, the cross-streaks on body extending on dorsal and anal; no white edgings on fins; gill-opening pale.

Close to $G$. stellatus, but with the spots replaced by cross-streaks and reticulations. Also near $G$. detactus but the dorsal much higher, and the markings darker and more band-like. G. rhodocephalus is also related, but in that species the cross-streaks behind are pale.

205. Gymnothorax ercodes Jenkins. Hawaii.

206. Gymnothorax steindachneri Jordan \& Evermann. Hawaii; Laysan.

Gymnothorax steindachneri Jordan \& Evermann, Bull. U. S. Fish Comm., xxII, 1902 (1903), 166, Honolulu.

Afurna favomarginatc var., Steindachner, Denks. Ak. Wiss. Wien, Lxx, 1900, 514, pl. vi, fig. 3, Laysan; not of Rüppell.

Of this species we have several specimens from Hawail. It bears little resembiance to Gymnothorax flavomarginatus, under which name Dr. Steindachner figures it.

207. Gymnothorax gracilicauda Jenkins, Hawaii.

This species, with a long and slender tail, is recognized in the original type only, a small specimen, perhaps the young of Gymnothorax steindachneri.

208. Gymnothorax undulatus (Lacépède). Pusi pulepule. New Guinea; Hawaii; Samoa; Tubuai; Raiatea (Seale); East Indies.

? Muræena marmorata a Quoy \& Gaimard, Voy. Uranie, 247, 1824, Waigiu, Rawak.

This species is very abundant throughout the South Seas. We have about 8 examples, large and small, from Apia, and many from Hawaii.

Color in alcohol of a large specimen from Apia, dark brown with pale yellow or yellowish-white reticulated and undulated cross-streaks, very numerous and much narrower than the masses of ground

a The scanty description of Quoy \& Gaimard is insufficient to identify this species. It is said to be reddish yellow with a ring-like arrangement of markings. The teeth are said to serrated. It is probably identical with Gymnothorax undulatus, but it might be any other of several species. 


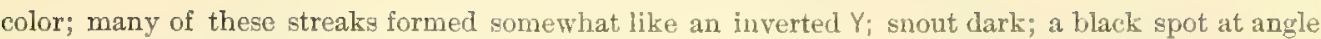
of mouth; gill-opening not black; markings on head more diffuse; black folds along side of neck; belly yellowish, marbled with brownish; fins colored like body, the anal with a narrow yellowish margin; tip of tail with a narrow pale edge.

209. Gymnothorax berndti Snyder. Hawaii.

\section{STROPHIDON Mcclelland.}

210. Strophidon brummeri (Bleeker). East Indies.

Recorded by De Vis, Proc. Linn, Soc. X. S. W. 1894, 157 , New Hebrides.

\section{ECHIDNA Forster.}

211. Echidna nebulosa (Ahl). Pusi. Tahiti; Wahia; Tonga; Borabora; Hawai; Samoa; New Guinea; Shortland I.; Nukahiva (Seale); Fast Indies.

This widely diffused species is very common about Samoa, where about 40 specimens were taken. It is relatively scarce about Hawaii.

212. Echidna zebra (Shaw). Samoa; Hawaii; East Indies.

This species, of a rich brown color, with narrow golden rings, is common at Samoa, where about 30 specimens were taken. It is rather scarce about Hawaii.

213. Echidna polyzona (Richardson). Tahiti; Nukahiva (Seale); East Indies.

214. Echidna zonophæa Jordan \& Evermann. Hawaii.

This species is close to Echidna polyzona, but with the other nominal species from Hawail it seems to differ in having the ground-color broken by mottlings. It may prove identical with Echidnu zonata. In Echidna polyzona, as figured by Bleeker, the ground-color is plain dark brown as in Echidna zebra, covered by rings of clear yellow.

215. Echidna zonata Fowler. Hawaii.

Echidna zonata Fowler, Proc. Ac. Nat. Sci. Phila, 1960, 496, Hawaii.

Echidna vincta Jenkins, Bull. U. S. Fish Comm., XXII, 1902 (1904), 429, Hawaii.

Echidna polyzona Fowler, Proc. Ac. Nat. Sci. Phila., 1900, 496, Hawaii; not of Richarison.

Dr. Jenkins found this species rather common at Honolulu. We see no difference between the species called zonata and vinctu.

216. Echidna psalion Jenkins. Hawaii.

This species is known from a single example, evidently very close to $E$. vincta, if indeed vincta and zonophea and possibly obscura and tritor be not all color variations of the same species, Echidna tritor.

217. Echidna tritor Vaillant \& Sauvage. Hawaii.

218. Echidna obscura Jenkins. Hawaii.

219. Echidna leihala Jenkins. Pusi'ai'aiugu. Hawaii.

Numerons specimens taken recently at Hawaii leave little room for doubt as to the identity of the nominal species, Echidna zonnta, vincta, psation, zonophxa, leihala, olscura with Echidna tritor. The variations in the bands are very great, scarcely any two specimens being alike.

220. Echidna trossula Jordan \& Starks, new species. Samoa.

Hurana nigra, Scale, Bishop Museum, 1901, 62, Guam; not of Day.

Head 7.5 in entire length; depth 2 in head; snout blunt, 6.5 in head; eye 1.5 in saout; tubes of anterior nostrils scarcely as long as diameter of pupil; cleft of mouth from tip of snout to ancle 3.33 in head; teeth slightly movable except those. in roof of mouth behind vomerine teeth; teeth in upper jaw in a single row on each side, anteriorly rather blunt and conical, posteriorly sharper and smaller; the one sort giving place to the other abruptly; a median row of two teeth anteriorly similar to those of anterior outer row; behind these and remote from them, extending back in the roof of the mouth 
to opposite the last teeth of the outer row, a patch of blunt teeth usually in two rows, but sometimes in one, or irregularly in two; teeth in lower jaw anteriorly biserial, posterioriy uniserial, resembling in size and shape the outer series of upper jaw; gill-opening as long as eye; nuchal hnmp well developed; preanal portion of body equal in length to postanal.

Color dark with irregular dark brown spots, each conforming to the shape of its adjoining spots, thickly placed over a light gray ground, leaving a fine network of the latter everywhere.

Life colors in a specimen from Pago Pago, dark brown, fins and tail paler; surface finely dotted with dark points. A specimen from Apia, with head very short, had iris golden red; body brownish, very finely but sharply dotted with darker brown; no markings.

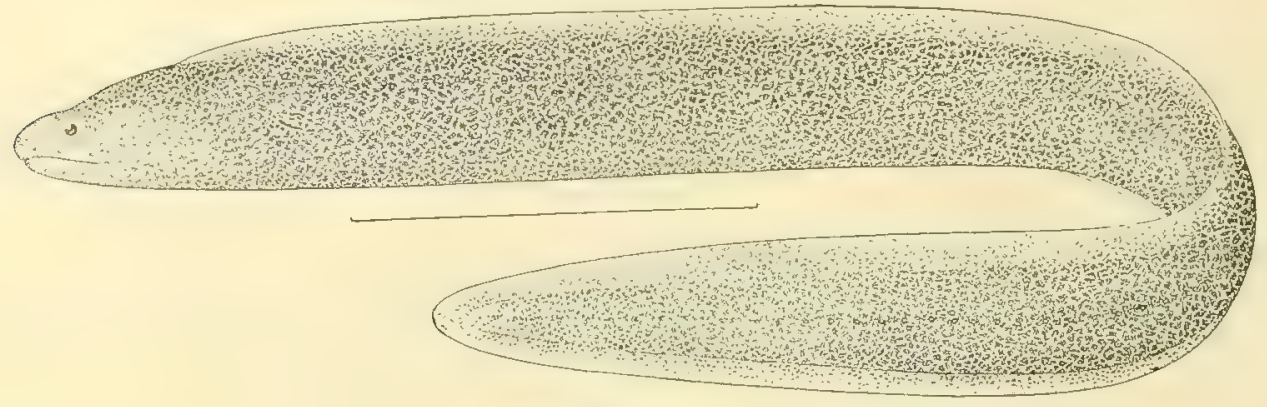

FIG. 8.-Echidna trossula Jordan \& Starks, new apecies. Type.

Type 10.51714, U. S. Tational IIuseum, a specimen 6.5 inches long, from Apia.

This species, known by the presence of fine black specks all over the body, is rather common about Samoa, where a dozen specimens were taken, at Apia and Pago Pago. A small eel with a small month.

221. Echidna uniformis Seale. Guam.

Echidna umiformis Seale, Bishop MLśeum, 1901, 62, Guam.

222. Echidna delicatula Bleeker. Samoa; Faśt Indies.

Echidnc kishinouyci Jordan \& Snyder, Proc. U. S. Nat. Mus, 1901, 890, with plate, Riukiu Is.

Of this species, known by the mottled purplish coloration and the anterior insertion of the dorsal, we have 7 examples from Pago Pago. The largest of these is about 18 inches long. This species is well distinguished from E. amblyodon of the East Indies, in having the insertion of the dorsal well in front of that of the pectoral.

Life colors of a specimen from Pago Pago, dark olivaceons green, fins paler greenish, body covered all over with brown reticulations around black spots.

223. Echidna amblyodon Bleeker. Marquesas Is. (Seale); East Indies.

\section{ANARCHIAS Jordan \& Starks, new genus.}

Anarchias Jordan \& Starks, new genus of Murænidæe (A. allerdicei).

This genus contains suall morays resembling Gymmothorcx, but entirely lacking the anal fin; the dorsal is dereloped as usual.

224. Anarchias allardicei Jordan \& Starks, new species. Samoa.

Head 8.5 in length; depth 2.3 to 2.7 ; snout slightly blunter than in $A$. knighti, 5.5 in head; eye 1.5 in snout; length of mouth 2.7 to 3 in head. Teeth similar to those of A. knighti except that there is only a single vounerine tooth; tube of anterior nostril less than half diameter of eye; large pores rather widely separated follow along the edge of mandible and border nouth above; three of them on each side of upper part of snout, the most posterior one at upper edge of eye; trunk 1.2 to $1.7 \mathrm{in}$ tail. No anal fin; no distinet caudal; no pectoral. 
Four specimens, two from Apia, two from Pago Pago.

Life colors of a Pago Pago specimen dark clear brown, the dorsal blackish; tip of tail bright yellow Specimen caught in the coral by cracking the large growing heads.

An Apia specimen was brown, lighter beneath; tip of tail bright vellow.

Color in spirits, everywhere a uniform dark reddish brown darker above; tip of caudal and under part of mandible pale.

Type no. 51715, U. S. National Museum, $160 \mathrm{~mm}$. in length, from Pago Pago.

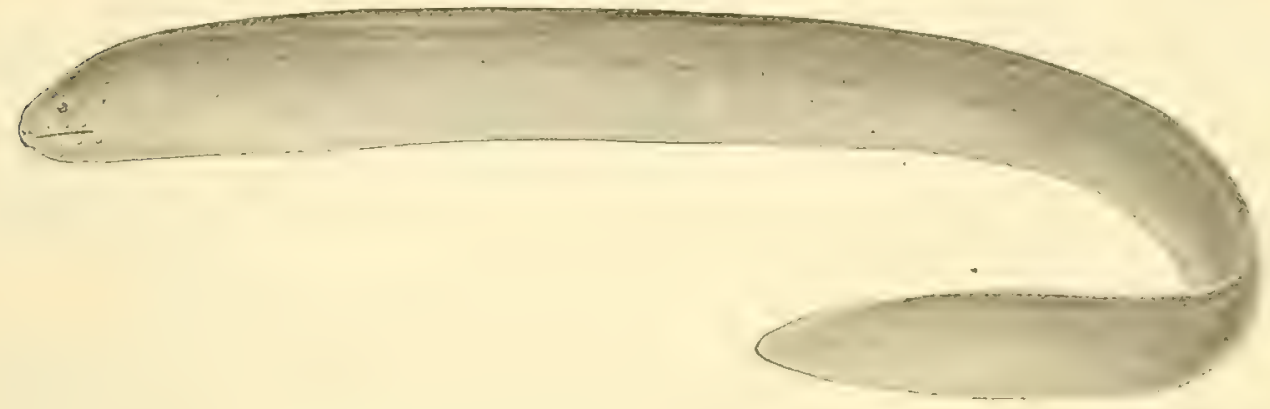

FIG. 9.-Inarchias allardicei Jordan \& Starks, new species. '1ye.

225. Anarchias knighti Jordan \& Starks, new species. Samon.

Head 9.5 in full length; (lepth 2.13 in head; snout short and moderately 1)lunt, 7.25 in heal; eye 1.2 to 1.5 in snout; length of mouth, 3 in hear. Teeth in two series in the upper jaw, the outer series more close-set, smaller and more regular than the inner, the inner series rather large, sharp, and of unequal length; anteriorly a pair of median vomerine teeth similar to those on the inner row; teeth of mandible in two rows and resembling those of upper jaw; tube of anterior nostril half diameter of eye; gill-openung very small, smaller than pupil. Length of trunk contained 1.17 in tail.

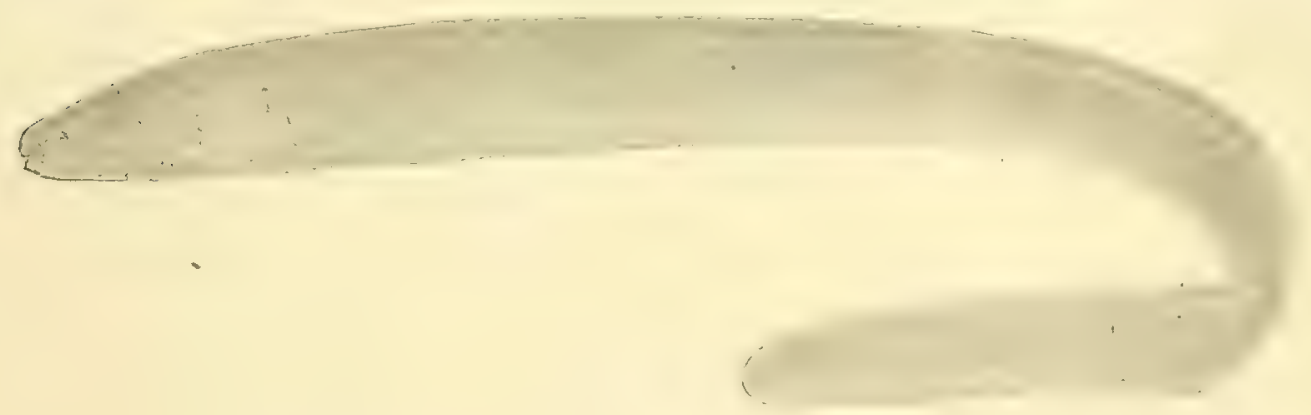

FiG. 10.-Anarchias knighti Jordan es starks, new species. Iy"let.

In spixits a network of dark lines covers the head and body over a ground colur oi slaty brown. These in the type corer the body everywhere except under the mandible, which is white. In the cotype the underparts are only slightly mottled, leaving them a soiled white.

This species differs from A. allardici particularly in having the body mottlen, and in having a - slightly longer snout and mouth and a slightly larger eye. It is known from two examples taken at Apia by Prof. Robert Elgar Allardice and Master Knight Starr Jorlan. Type, no. 51716 U.S. Sational Museum, $115 \mathrm{~mm}$. in length, and the cotype, Ith mm., loth from A pia. 


\section{SCUTICARIA Jordan \& Snyder.}

226. Scuticaria tigrina (Lesson). Pusi solasulu. Hawaii; Samoa; Borabora; Tonga; Johnston I.; Tahiti; Nukahiva (Seale).

This species is occasionally taken at Samoa and at Hawaii. It is common in the East Indies. We have 10 examples from Apia and Pago Pago.

Life colors of an example from Pago Pago, livid pale-pinkish brown with black spots.

UROPTERYGIUS Rüppell.

227. Uropterygius marmoratus (Lacépède). New Britain; Hawaii; Samoa; Oualan; Nukahiva (Seale).

This large eel, known by its finely mottled coloration and the paler color of its vertical fins, is occasionally taken in Samoa, whence we obtained about 10 examples. It is also sometimes taken in Hawaii.

Life colors of a specimen from Apia, dark brown, all freckled with white above and below, the white tending to form reticulations around brown confluent spots.

228. Uropterygius macrocephalus (Bleeker). Pusi, Sulalulu. Samoa; East Indies.

Of this species we have about a dozen specimens from $A$ pia, the longest about 8 inches in length. The body in all is mottled, the caudal pale. These may be the young of Uropterygins marmorata, as Günther suggests, but it is not likely. We find no tube on the posterior nostrils, and so place it in a different species. It is nossible that this species is not distinct from Uropterygius micropterus Bleeker, which differs in the shorter head.

Life colors in a specimen from Apia, livid bluish white, with fine brown reticulations.

229. Uropterygius concolor Rüppell. Samoa; Nukahiva (Seale); Red Sea.

Gymnomurzena jusca Peters, Berl. Mon. 1866, 524, Amboina.

In this species the color is uniform purplish red witbout spots, the fins scarcely paler. It agrees fairly with the accounts of $U$. concolor, and still better with that of $G$. fusca.

230. Uropterygius leucurus Snyder. Lanai, Hawaiian Is.

231. Uropterygius xanthopterus (Bleeker). Nukahiva (Seale); East Indies.

\section{Family NOTACANTHIDE.}

NOTACANTHUS Bloch. (Gigliolia Goode \& Bean.)

232. Notacanthus moseleyi (Goode \& Bean). South Pacific.

\section{Family BELONIDE.}

\section{BELONE Guvier.}

233. Belone platyura Bennett. Ise. Hawaii; Samoa;

Of this species, rather common about Hawaii, one specimen was taken at Apia. It is readily recognized by the presence of gillrakers and by the large caudal keel. Anal 20; dorsal 15; tail very much depressed, flat-keeled; axil dusky.

Life colors, deep green, with blue Iuster above, abruptly white on sides; luster everywhere clear blue; fins pale; tip of dorsal and upper cauclal lobe dusky; anal and ventral somewhat dusky.

\section{TYLOSURUS Cocco.}

234. Tylosurus leiuroides (Bleeker). A'u. Samoa; New Guinea (Macleay); East Indies.

Four specimens of this species were taken at Apia. Life colors of one of these, gray, side silvery with silvery blue lateral line; jaws bluish edged; luster bluish, no green; fins translucent bluish; dorsal a little purplish on lobe, not black; last dorsal rays low; head deeply sculptured. 
235. Tylosurus coromandelicus (Van Hasselt). New Britain; East Indies.

(Belone melanotus Bleeker.)

236. Tylosurus urvillei (Cuvier \& Valenciennes). Vanicolo.

237. Tylosurus cancila (Hamilton-Buchanan). New Guinea (Macleay); East Indies.

238. Tylosurus giganteus (Schlegel). L'u. Samoa; Hawaii; Levuka; Oualan; Kandavu; Fiji; New Guinea (Macleay); Tubuai 1s. (Seale); East Indies; Japan.

This huge species is rather common about Samoa, as also at Hawaii and throughout the tropical Pacific. We obtained three moderate-sized and a few rery large specimens from Samoa. One specimen leaped from the water to seize a charge of dynamite in the air.

ATHLENNES Jordan \& Fordice.

239. Athlennes hians (Cuvier \& Valenciennes). Hawaii; West Indies; Acapulco.

\section{Family EXOCETIDE.}

\section{HEMIRAMPHUS CuVier.}

240. Hemiramphus pacificus Steindachner. Hawaii; Samoa.

Of this species about 20 specimens were taken with the seine near the mouth of the harbor of Pago Pago. The fish is not rare about Hawaii.

Life colors, light olive, silvery below; a clear blue line bounding silvery stripe above; all dark parts of body with bright blue luster; base of anal with blue stripe; tip of lower jaw deep orange.

241. Hemiramphus depauperatus Lay \& Bennett. Hawaii; Marcus I.

242. Hemiramphus affinis Günther. Jse lai. Samoa; New Hebrides (Seale).

This species is the common ise or halfbeak, found everywhere in shallow water along the shore at Samoa. It is distinguished from related species by the insertion of the ventrals nearer base of caudal than gill-opening. We have about 50 specimens. None of our specimens have the head quite as long as indicated in Günther's description. The head with lower jaw is 2.75 to 3 in length to base of caudal.

Life colors of a specimen from Pago Pago, dorsal with blackish-edged blotch; a dusky spot in pectoral axil; lateral line and a lateral streak bright clear green; membranes of lower jaw dusky, with some red. A specimen from A pia had the lower jaw very red below; two blue streaks on cach side of body;.

243. Hemiramphus laticeps Günther. Fiji.

244. Hemiramphus limbatus Cuvier \& Valenciennes. Guam; East Indies.

245. Hemiramphus argenteus Bennett. Open sea, near equator.

246. Hemiramphus eclancheri Cuvier \& Valenciennes. Marquesas (Cuvier \& Valenciennes, Seale),

247. Hemiramphus quoyi Cuvier \& Talenciennes. New Guinea (Jacleay); Last Indies.

248. Hemiramphus gaimardi Cuvier \& Valenciennes. Papua; East Indies.

249. Hemiramphus commersoni Cuvier. Fiji (Günther); New Guinea; Shortland I. (Seale); East Indies.

250. Hemiramphus australiensis Seale. Tubuai (Seale).

251. Hemiramphus cantori Bleeker. New Guinea (Macleay); Iast Indies.

252. Hemiramphus acutus Giinther., Rarotonga.

IIemiramphus aculus Ginther, I'roc. Linn. Soc. X. S. W. 1811, 671, Rarotonga (Cook Is.).

253. Hemiramphus melanurus Cuvier \& Valenciennes. Solomon Is. (Seale); liat Indies. 


\section{EULEPTORHAMPHUS GIll.}

254. Euleptorhamphus longirostris (Cuvier \& Valenciennes). Hawaii; open Pacific; warm seas generally.

\section{ZENARCHOPTERUS Gill.}

255. Zenarchopterus dispar (Cuvier \& Valenciennes), New Guinea (Macleay); East Indies.

256. Zenarchopterus maculosus Garman. Fiji.

257. Zenarchopterus vaisiganis Jordan \& Seale, new species. Taoto.

Head, without lower jaw, 4.30 in length, with lower jaw, 2.30; lower jaw from tip of upper 3.90; eye 3.60 in head; upper jaw slightly broader than long, about equal to eye; interorbital slightly greater than eye; dorsal 12; anal 12; modified with a clasping organ, with a fleshy intromittent organ just anterior to base; scales $2-13-3$; snout 3.10 .

Body elongate, the depth 1.75 in head, the width 2.75; scales deciduous, the lateral line running very low on body; depth of caudal peduncle equal to interorbital space; width of preorbital in front of eye equal to pupil; opercle and preopercle entire; suborbital with more or less adipose membrane; villiform teeth in jaws, none on vomer, maxillary or tongue; gill-rakers thick, rather blunt, the longest about 2 in pupil, 12 developed on lower limb; base of dorsal fin 1.30 in head, fully one-half being on caudal peduncle, fourth and fifth rays are elongate, being about equal to base of fin; longest ray of anal, which is widened and elongate, forming one of the wings of the claspers, is about equal to length of

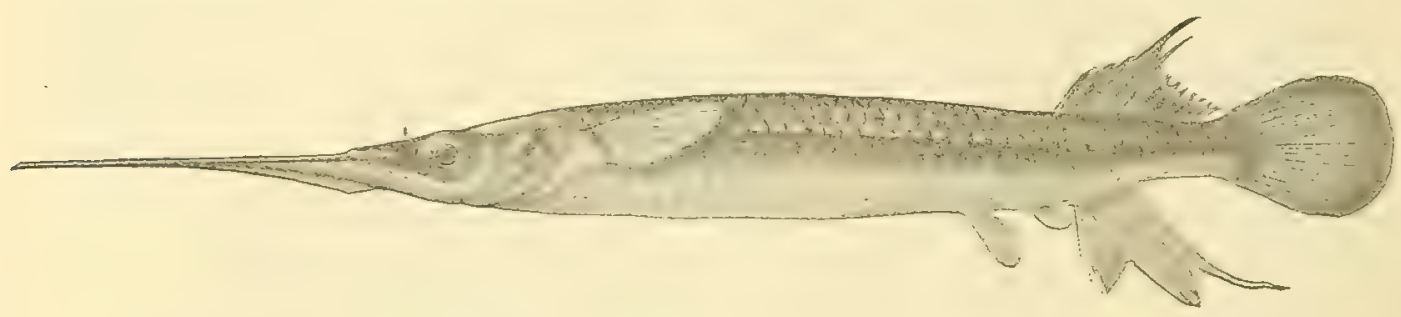

FIG. 11.-Zcnarchoptemes raisiganis Jordan \& Seale, new species. Type.

hèad; fleshly base of anal equal to eye; ventral small, 2.95 in head, its origin far back at beginning of posterior third of body; pectoral 1.20 in head; intromittent organ very prominent, situated between tip of ventrals and base of anal, its width 2 in length; caudal rounded, 1.20 in head.

Color in spirits, silvery below, darker above, with wash of greenish blue, a distinct dark-blue line from opercles to base of caudal; lower jaw deep blue; orbit with rim of blue; anterior of anal with dusky wash; a black spot on anterior dorsal, the tin more or less washed with dusky; caudal with dusky wash; other fins with very slight trace of dusky.

Color in life, pale olivaceous; a silvery streak along side; fins dirty-yellowish olive.

Fourteen specimens from Vaisigano River, at Apia. The type is no. 51718, U. S. National Museum, length 6 inches.

EVOLANTIA Snodgrass \& Heller.

258. Evolantia microptera (Cuvier \& Valenciennes). Hawaii; New Ireland; East Indies; Galapagos Is.

PAREXOCETUS Bleeker.

259. Parexocotus brachypterus (Solander). Tahiti; Hawaii; Laysan; West Indies.

260. Parexocœtus brevipinnis (Cuvier \& Valenciennes). New Ireland.

261. Parexocctus rostratus (Günther). Hawaii.

EXOCGETUS Linnæus.

262. Exocœtus volitans Linnæus. Hawaii; East Indies; Atlantic Ocean. 
CYPSILURUS Swainson. Malolo.

263. Cypsilurus unicolor (Cuvier \& Valenciennes). Tanicolo; sea between Auckland and Samoa: Tasman Sea.

Exacalus unicolar Cuvier \& Yalenciennes, Hist. Nat. Poiss, xrx, 97, 1846, Vanicolo.

Evonautes unicolor', Jordan, Guide to the Study of Fishes, Ir, 213, 1905.

Of this species we have $t$ examples taken in the sea south of Samoa, and one from the Tasman Sea between Sydney and Auckland. All were obtained by Mr. A. P. Lundin, then navigator of the

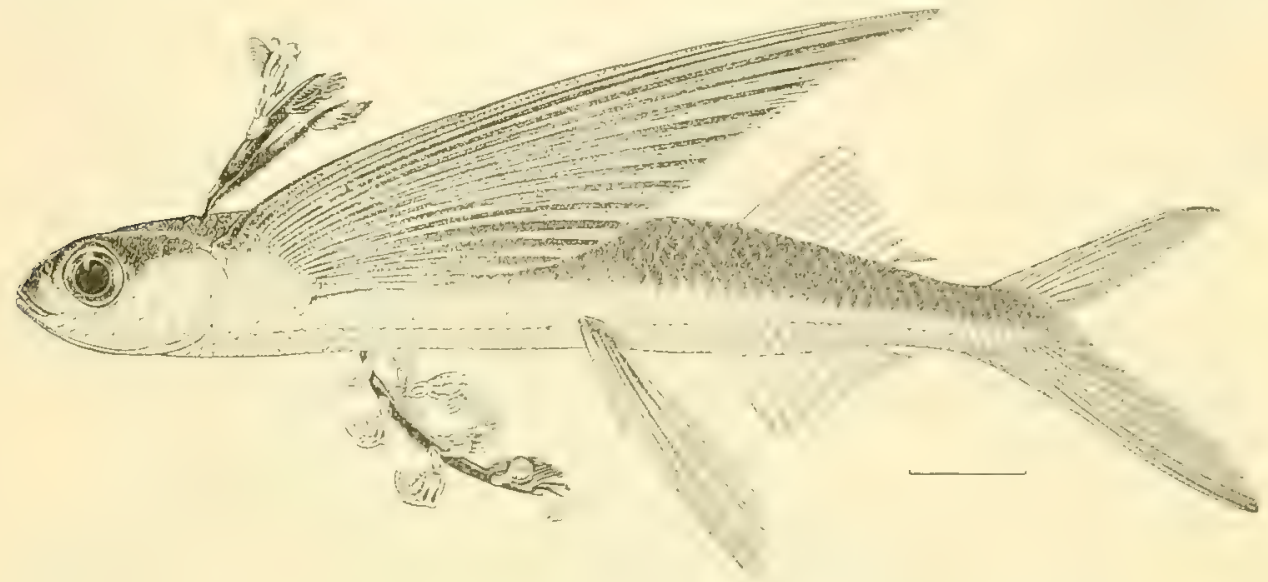

Fig, 12,-Cunsilurus uniculo. (Cuvier d talenciennes).

steamer Sicru. The species reaches a lenth of about 18 inches. On the specimen figured 4 parasitic copepoc crustaceans (Pcnella) were attachel, and on ench of these were attached parasitic barnacles, Conchoderma cirgatum, looking like a cluster of strange orchids.

264. Cypsilurus gilberti Snyder. Hawaii.

265. Cypsilurus speculiger (Cuvier \& Valenciennes). Tasman Sea, between Auckland and Syduey:

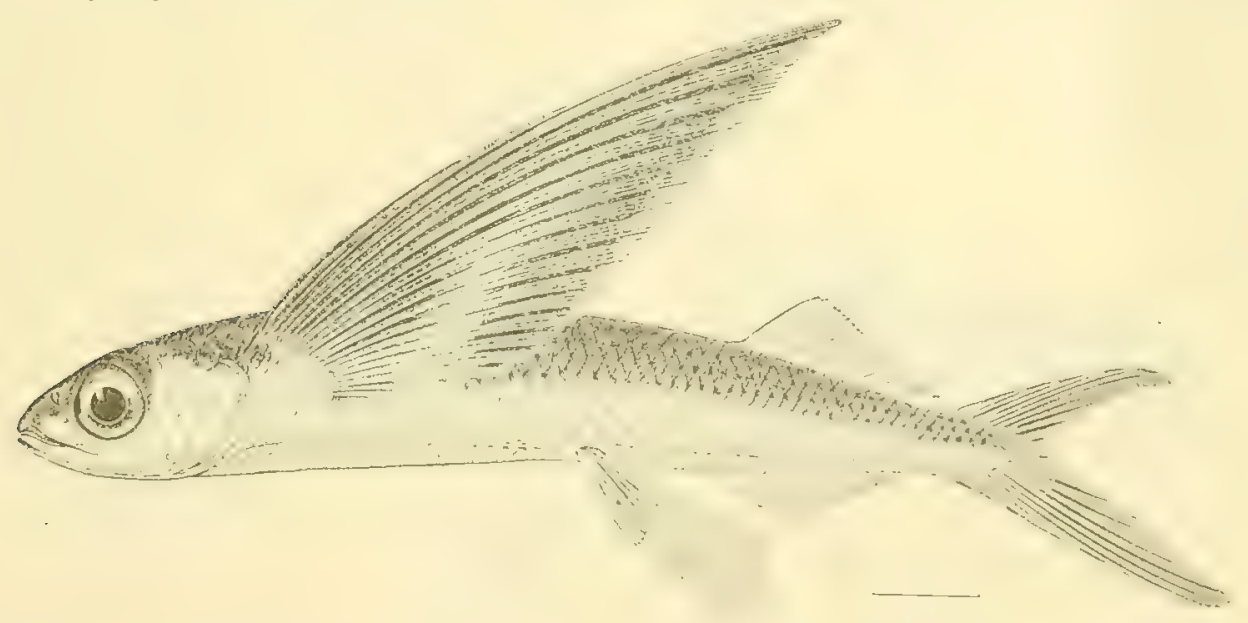

FIG. 13.-C'y)siturus spectliger (Cuvier \& Valenciennes).

Of this species we have 5 examples taken by Mr. A. I'. Lundin, in the Tasman Sea, between Srodney and Auckland. According to Dr. Lütken, this species oceurs in the Athantic also. The Atlantic species, called Exoculus rubescens, roberti, and apinis, and wrongly called Hoculus colitans, is, however, probably different, having the band on the pectoral less marked. 
266. Cypsilurus lamellifer (Kner \& Steindachner). Open Pacific:

Exocoetus lamellifer Kner \& Steindachner, Sitz. Ak. Wiss. Wien 1867, 384, Pacific.

267. Cy_silurus atrisignis Jenkins. Hawaii; Kusai, or Strong I., Caroline Group.

Of this species, besides Dr. Jenkins's type from Hawaii, we have a second, taken at Kusai, or Strong Island, of the Caroline group, by Mr. A. I. Lundin, then navigator of the missionary vessel Morning Star.

268. Cypsilurus pœcilopterus (Cuvier \& Valenciennes). New Britain;. Tahiti; Caroline Is.; Samoa; Fast Indies.

Exocatus spilopterus Günther, Cat., vi, 202, Caroline Is.

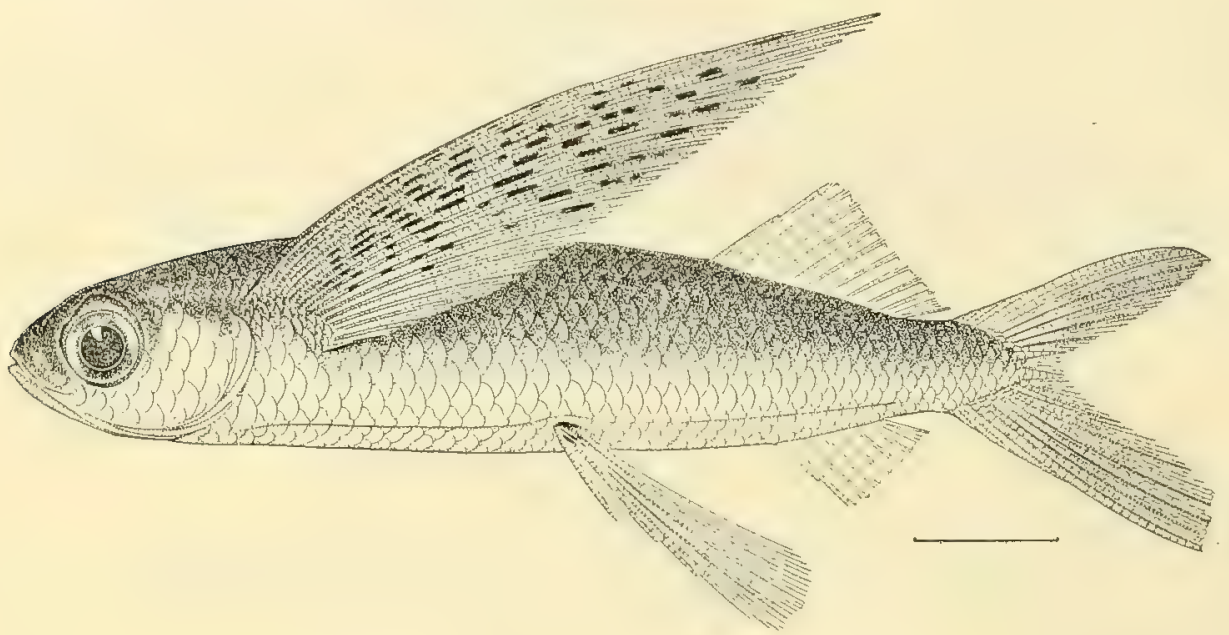

FIG. 14,-Cypsilurus pxcilopterus (cuvier \& Valeneiennes).

This species is easily recognized by its plump body and spotted pectorals. Its maximum size is smaller than that of Cypsilurus simus and C. quindecimradintus, the length being about 9 inches. Life colors of one specimen blue above, pectoral with large spots, ventrals plain, basally dnsky, no red on pectoral.

One fine example flew on board the steamer Kauan off the western end of Tutuila, in the night.

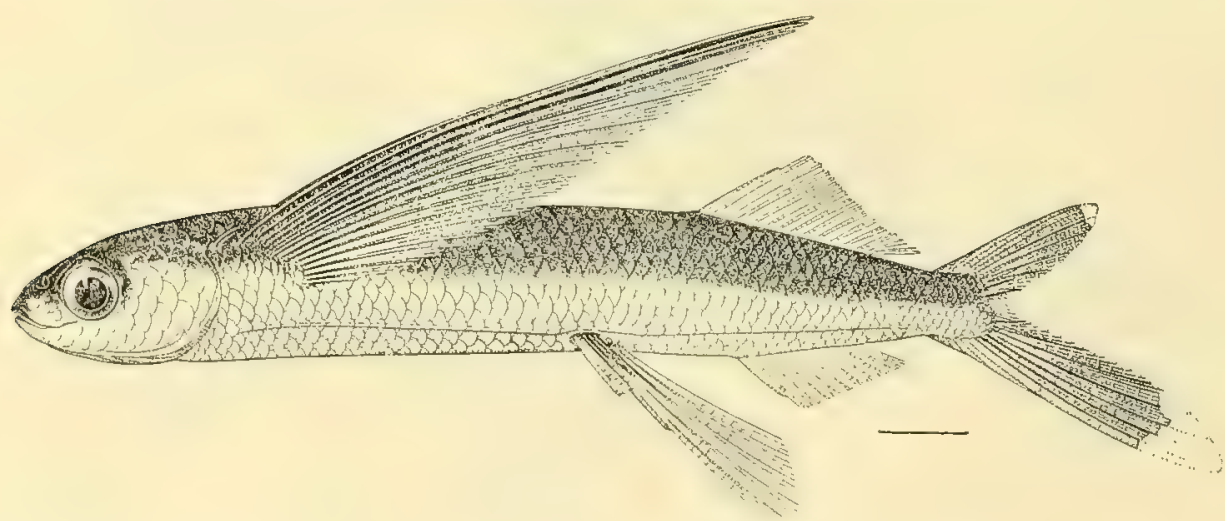

FIG. 15,-Cypsilurus quindecimradiatus Fowler.

269. Cypsilurus quindecimradiatus Fowler. Thornton I.; north of Samoa.

Of this well-marked species, distinguished by its long dorsal of 14 or 15 rays, its large size and the absence of pectoral markings, we have two large examples taken by Mr. A. P. Lundin in the sea to the southward of Samoa. 
270. Cypsilurus oligolepis Bleeker. Shortland I. (Seale); East Indies.

271. Cypsilurus simus (Cuvier \& Valenciennes). Hawai. Very abundant.

272. Cypsilurus bahiensis (Ranzani). Hawail, abundant; Atlantic; Panama region.

273. Cypsilurus naresi (Günther). Fiji; Niew Hebrides.

274. Cypsilurus solandri (Cuvier \& Valenciennes). Tahiti; Seychelles.

275. Cypsilurus longibarba (De Vis). New Britain.

Exaccetus longibarba De Vis, I'roc. Linn. Soc. N. S. W. 1884, 454, New Britain; very young.

276. Cypsilurus katoptron (Bleeker). Seas south of Samoa; Australia; East Indies. Exocoelus robustus Günther, Cat, vr, 289, 1866, Australia.

A specimen of this species agreeing well with Bleeker's figure was taken by Mr. Lundin, then mate of the steamship Sierra, in the open sea sonth of Samoa. The species has black, white-banded pectorals, much as in Cypsilurus speculiger, but the dorsal rays are more numerous (14).

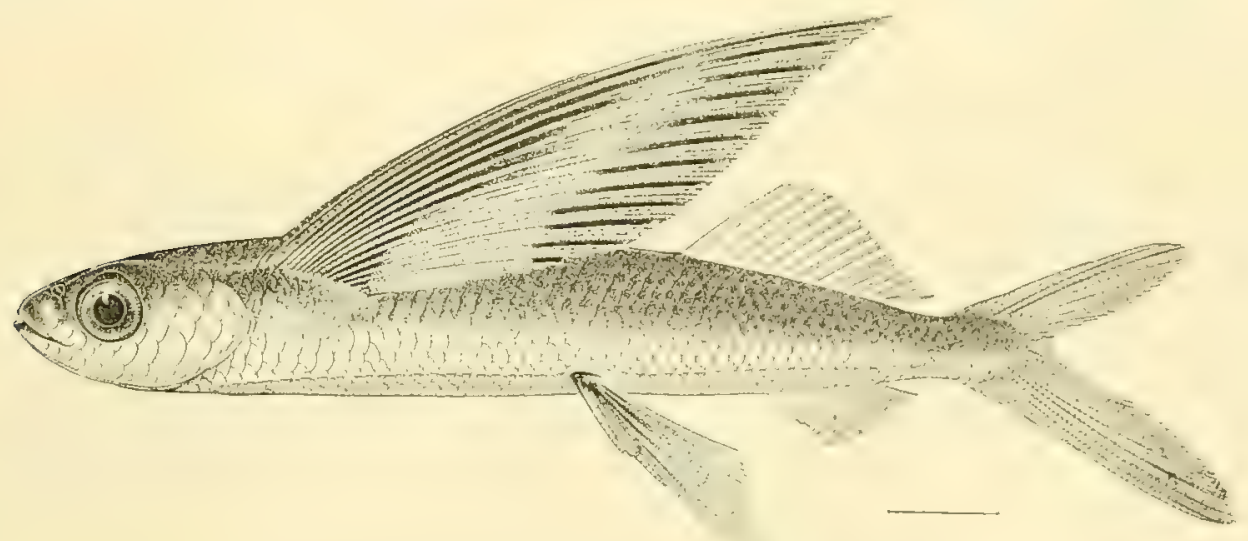

FIG. 16.-Cypsilurus katoptron (Bleeker).

277. Cypsilurus arcticeps (Günther). New Guinea (Macleay); China.

\section{Family AULOSTOMIDE.}

\section{Aulostomos Cavier.}

278. Aulostomus valentini (Bleeker). Taolito. Hawaii; Samoa; Tahita; Paumotu Is.; Johnston I. ; Aneiteum; East Indies; Japan.

This common tast Indian speciey is occasionally taken in Samoa as in Hawaii. We lrave one example from Apia.

\section{Family FISTULARIIOE.}

\section{FISTULARIA Linnæus.}

279. Fistularia petimba Iacépède. Fiji; Guam; Hawaii; Samoa; New Guinen; New. Britain; Necker I.; Mangarera; New Hebrides; Solomon Is.; Makatea; Rarotonga; Raiatea; Last Indies. Samoa.

This species is common throughout the South Seas. We have a few exampley from the shores at

280. Fistularia serrata Cuvier. Hawaii; New Guinea; Last Indies; Japan. 
Family MACRORHAMPHOSIDE: MACRORHAMPHOSUS Lacépède.

281. Macrorhamphosus brevispinis (Kner \& Steindachner). Samoa.

This species, recorded from Samoa, was not seen by us.

282. Macrorhamphosus finschi (Hilgendorf). New Britain. Centriscus finschi Hilgendorf, Nat. Freunde, 1884, 52, New Britain.

283. Macrorhamphosus hawaiiensis Gilbert. Hawaii.

\section{Family CENTRISCIDE. \\ CENTRISCUS Linnæus.}

284. Centriscus komis (Macleay). Palau Is.

Amphisite homis Macleay, Proc. Linn. Soc. N. S. W. IrI, 1878, 166, Komis (Palau Is.).

\section{IEOLISCUS Jordan \& Starks.}

285. ÆEoliscus strigatus (Günther). New Guinea (Macleay); East Indies.

\section{Family SOLENOSTONIDE.}

SOLENOSTOMUS Lacépède.

286. Solenostomus cyanopterus Bleeker. Hawaii; New Guinea; East Indies.

\section{Family SINGNATHIDE. \\ CORYTHROICHTHYS Kaup.}

287. Corythroichthys waitei Jordan \& Seale, new species. Samoa.

Rings $17+35$; dorsal 29 or 30 , situated on the first 6 candal rings; snout slender, as viewed from above its edges parallel to the eyes, where the hear is abruptly much widened; length of snout 1.2 in

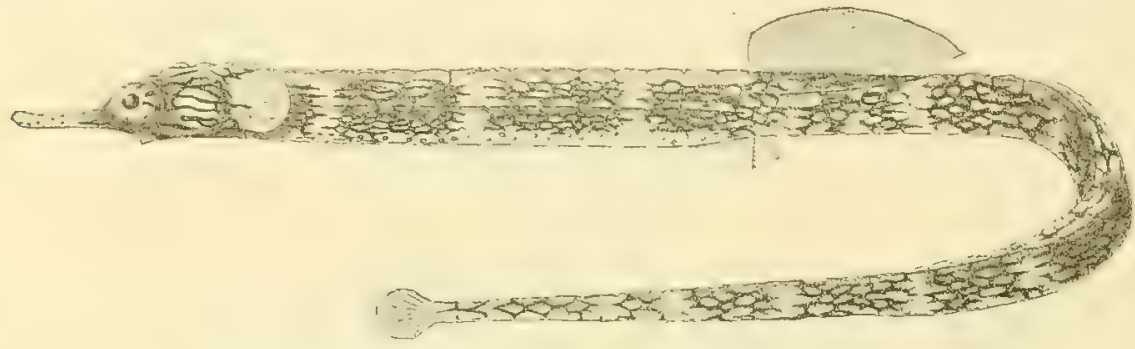

Frg. 17.-Corythroichthys waitci Jordan \& Seale, new species. Type.

head; eyes large, produced above profile, 4.5 in head; a sharp semiconnected ridge extending from behind eyes to just behind pectoral base, three lobed, the first lobe on occiput, the other two on body plates; a sharp ridge extending back from supraorbital crest across parietal region; top of snout with a thin, low ridge; superior thoracic ridge not continuous with superior caudal ridge, but the former extending above the beginning of the latter for 3 or 4 rings; trunk contained 1.5 in caudal portion of the body; color very light, made slightly dusky by a network of fine lines along the sides, these interrupted by diffused light cross-bars on every fifth ring, just anterior to which the network of dark lines is more conspicuous and extends across the back; dark lines irregularly connected with each other, extending more or less horizontally back from the eye. In life snont rose-red, head with black stripe; general color pale yellowish; caudal bright rose-red, its upper and lower margins pale.

The type is no. 51723, U. S. National Museum, $3 \pm$ inches in length. This species is named for Mr. Edgar R. Waite, the accomplished curator of the Australian Museum, now of the Canterbury Museum of Christchurch, New Zealand. 
288. Corythroichthys sealei Jordan \& Starks, new specice. Samoa.

Head 7.50; snout erpual to distance from middle of eye to posterior margin of opercle, the snout narrow, being scarcely one-half of eye; foreheal rather abrupt; rings $16-+32$; dorsal 32 high, the rays being equal to or greater than depth of fish, the base of the fin not elevated; no crest on head or snout; only a trace of a single raised line across opercle; rings of body with six faces, those of the tail with four; distance in front of anal fin 1.75 in posterior lart of borly; depth 2.75 in head, slightly greater than the width; the egg sac: in the male occupies the ventral portion of the sixteenth to twenty-eighth ring; length of dorsal slichtly less than wistl of eye; caudal yin-shaperl, 3 in hearl, anal minute, slirectly below third ray of drorsal.

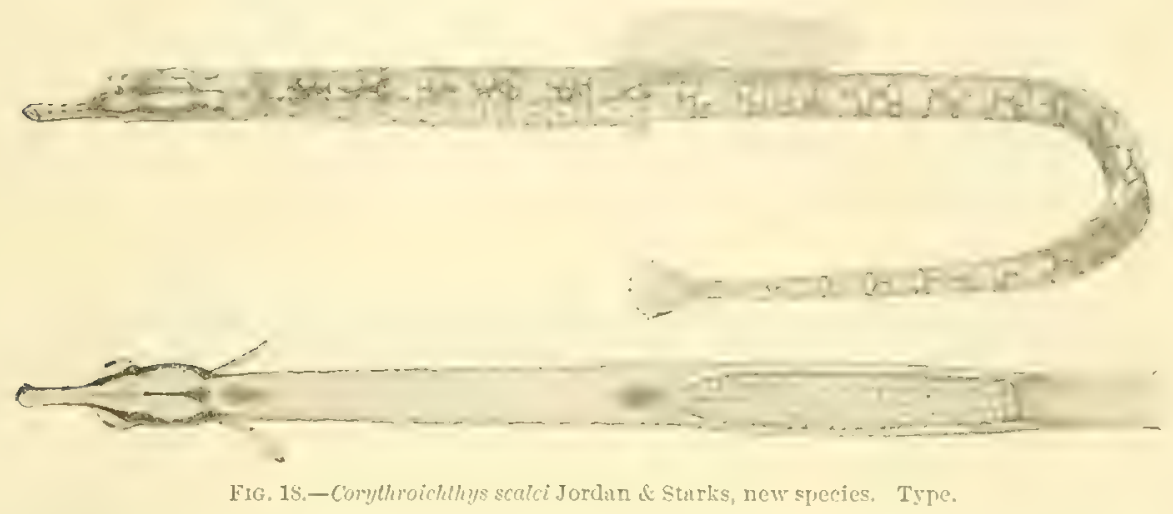

Color in life light gray spotted with redulish brown and lighter gray; snout and caudal whitish: hearl barred below. Colow in spirits whitsk, each ring with a branched greenish spangle on sicle and top, under surface white; two distinct greenish lines along side of head across opercle to base of pectoral, the lower one of these lines extending slightly out on the snout; top of head marked into a number (10) of irregular squares by narrow dark lines; four rings of minute dots around snont; a dark elongate black area on throat, more or less separated from a black ventral spot on first borly ring; three rows of small round dots on side of body below the branched greenish spots; dorsal fin with scattered dots.

Three specimens from Apia, the type no. 51722, U. S. Yational IIuseum, 3.25 inches long.

289. Corythroichthys matafa Jordan \& Seale, new species.

Head 11.75; snout 3 in head, narrow, width about 2 in eye; eye 3.75 in head; interorbital very narrow, less than one-half width of eye; rings $15+34$, the minute anal fin being on the 15 th ring, in the male the egg sac occupying the ventral surface of rings 15 to 26 ; body seren-sided, the tail but four; dor:al

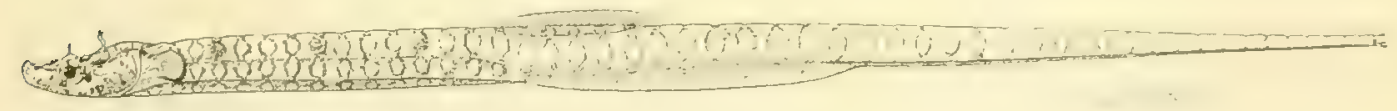

Frg. 19.-Corythwichthys matcafa Jordan \& Senle, new species, Tỹu.

21 , its base not elevated; opercle without a bony ridge extending across it but with numerous ruliating rows of pits, the widest point of opercle with a short dermal flap; medial line of snout with a distinct crest with six teeth, the height of crest leing slightly less than width of pupil on anterior hali of smout, the crest not toothed; no interorbital crest, a short, fringed, dermal tentacle oser cach eyc, its length less than wilth of interorbital; a single fringed tentacle on midlle of nuchal region; a pair of short tentacles just below and a little posterior to eye, another pair below middle of snout; a rin-like projection over upper margin of opercle; snont rather pug-like in shape; rectoral less in length than width of opercle; caudal short, about erual to eye; anal minute.

Color whitish, each ring on each of its faces with an oval, brown-rimuch spot of silvery; under surface of tail whitish; snout with 2 rings of dusky; about 5 dusky cross lines under thront; abont it radiating dusky lines in eye and over heat. 
One specimen, the type, no. 5172t, U. S. National Iluseum, 4.20 inches long, from the coral reefs off Mulinu'u, the residence of Mataafa, chief of Upolu, a distinguished and able statesman, once king of Samoa.

290. Corythroichthys trachypoma (Günther). Thursday I.; Prince of Wales I.

Symgnathus trachypoma Günther, Zool. Alert, 18s4, 30.

TRACHYRHAMPHUS Kaup.

291. Trachyrhamphus sp. Marquesas Is.

A specimen badly mutilated and therefore not in fit condition for description, was taken by Mr. Seale at Nukahiva in the Marquesas Islands. It represents probably an undescribed species.

\section{MICROPHIS Kaup.}

292. Microphis brachyurus (Bleeker). Tcotao. Tahiti; Samoa; Aneiteum; East Indies.

About a dozen examples were taken in the Vaisigano River and in other streams about Apia. All the species of this genus in Samoa are confined strictly to fresh waters.
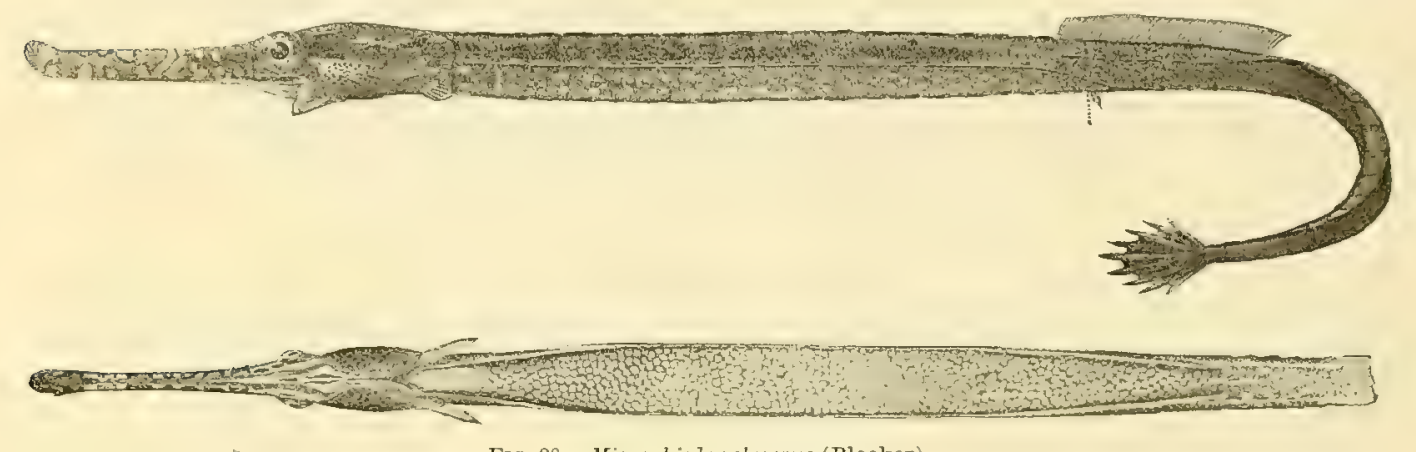

FIG. 20.-Microphis trachyurus (Bleeker).

Life colors of one specimen from Apia, light olive, darker on back; a bright red stripe along side from below pectoral backward to middle of trunk; head darker olive, barred with paler olive; caudal dusky olive. Another specimen was dark, speckled with whitish, a vertical orange dash behind opercle the only bright color, and seen in males only.

293. Microphis pleurotænia (Günther). Hawaii.

294. Microphis sculptus (Günther). Fiji.

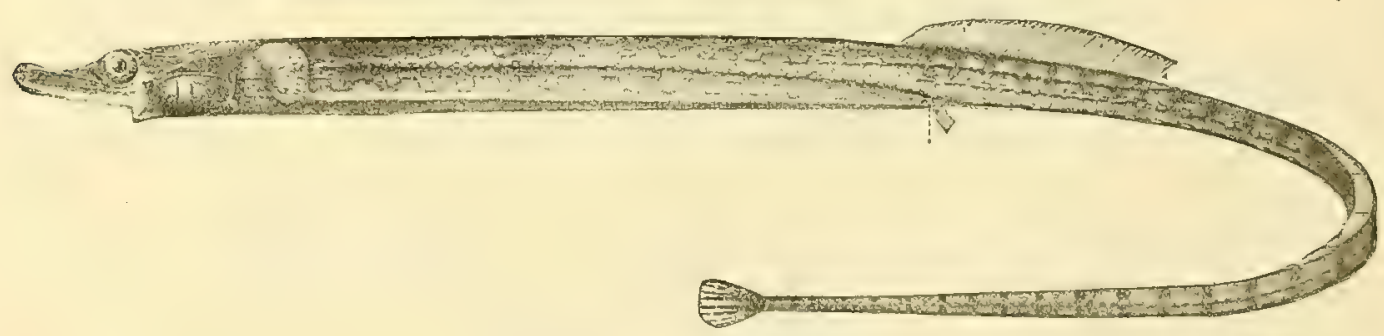

FIG. 21.-Microphiv cudatus Peters.

295. Microphis caudatus Peters. Samar; Java.

Microphis candatus Peters, Berl. Mon. 1868, 276, Samar (in fresh water), Java.

Doryichthys caudatus Günther, Cat, virI, 182, Java.

Six specimens of this species were taken in the Gasegase River at Vaimosa, near Apia. 
296. Microphis torrentius Jordan \& Seale, new species. Samoa.

Head 9.30 to base of caudal, 4.10 in distance anterior to and; snout 2.20 in head; width of snout: in its length; eye about equal to width of snout; interor)ital narrow, 2 in eye; dorsal 32 ; anal 3 ; rings $16+33$, no spines; the rings of posterior half square; abdominal rings wider, containing the egg sac; a

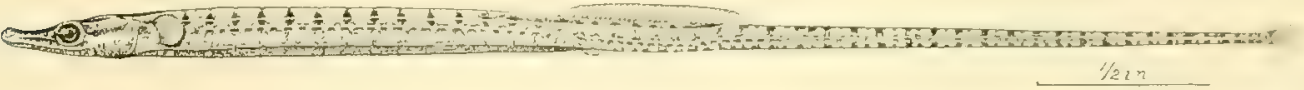

FIG. 22.-Wicrophis torrentius Jordan \& Seale, new species. Type,

single unbranched stay across.opercle; a low medium ridge on snout and 2 in interorbital; slope of forehead not abrupt; length of pectoral equal to opercle; caudal equal to snout; insertion of the minute anal almost a third nearer tip of snout than tip of caudal; anterior base of dorsal directly over anal.

Color in spirits, greenish with a slightly darker band on each ring; a distinct black line along side of snout through eye, across opercle to bise of pectoral; anal with four narrow cross-bands of white.

Three specimens, taken high up in the Vaivase River, near Vailele, to the eastward of $\Lambda$ pia, in a swift brook running through pasture land. The type is no. 51725, U. S. National Museum, from near Apia, length 3.25 inches.

\section{GASTEROTOKEUS Heckel.}

297. Gasterotokeus biaculeatus (Bloch). Samoa; I’apua; East Indies.

Five specimens were taken at Apia and Pago Pago. They were caught in the scine on shallow shores inside the reefs.

Life colors of a specimen from Pago I'ago, clear olive brown, finely mottled above; six round jet black spots like ink-dots on lower part of side of body; lower side of head sulphur-yellow, mottled with brown; faint brown bars at tip of tail, which is red; belly yellowish brown, with brown cross. streaks.

\section{ICHTHYOCAMPUS Kaup.}

298. Ichthyocampus erythræus Gilbert. Deep seas of Hawaii.

299. Ichthyocampus papuensis Sauvage. Yew Guinea (Saurage, Rull. Sci. and Philom. 1850, 228).

\section{HIPPOCAMPUS Rafinesque.}

300. Hippocampus fisheri, Jordan \& Evermann. IIawaii.

301. Hippocampus hilonis Jordan \& Erermann. Hilo, Hawaii.

302. Hippocampus kuda Bleeker. New Guinea (Macleay, as $H$. guthlatus); East Indies.

Family PEGASID E:

PEGASUS « Linnæus, 1758 (volitans).

Cataphractus Gronow, 1763 (araco=rolitans).

Eurypegasus Bleeker, $186 \pm$ (draco= colitans).

Zulises Jordan \& Snyder (umitengu, near draco).

303. Pegasus volitans Linnæus. New Britain (Puter; Berl. Mon. 1876, 843); East Indies.

304. Pegasus papilio Gilbert. Deep seas of Hawaii.

\section{PARAPEgasUS Duméril.}

305. Parapegasus natans (Linnreus). New Guinea; Australia; China.

a The genus Pegasus was based, by Linneus in 1758, on a single species, I'ogasus rolitans. In 1763 the anme cirlaphrums of Gronow was based on the same species, which in 1766 binnaus renamed I'tgasus draconis. The same genus was called Eurypegasus by Bleeker in 1864 and Zalises by Jortan of Snyder in 190:. 


\section{Family ATHERINIDE.}

\section{ATHERINA Linnæus.}

306. Atherina lacunosa Forster. New Caledonia; New Hebrides; Fiji (Günther); Solomon Is. and New Hebrides (Seale); East Indies.

(Atherina pinguis Lacépède.)

307. Atherina forskali Rüppell. New Guinea (Macleay); East Indies.

308. Atherina endrachtensis Cuvier \& Valenciennes. New Guinea; Australia.

309. Atherina waigiensis Quoy \& Gaimard. Waigiu. Atherina cylindrica Cuvier \& Valenciennes.

310. Atherina uisila Jordan and Seale, new species. Visila.

Head 4.35 in length; depth 7 ; greatest width 7.40 ; eye 2.75 in head; snout 4 ; interorbital equal to eye; dorsal VII-I, 10; anal I, 12; scales 2-42-3; maxillary extending to below anterior margin of eye.

Boly somewhat conical; head as wicle as deep; interorbital space flat with two narrow grooves. gillrakers equal in length to pupil, about 25 on lower limb; a single row of minute teeth in jaws, patches of minute teeth on yomer and palatines; origin of dorsal nearer tip of snout than base of caudal, its longest spine equal to eye; origin of soft dorsal slightly posterior to origin of anal; base

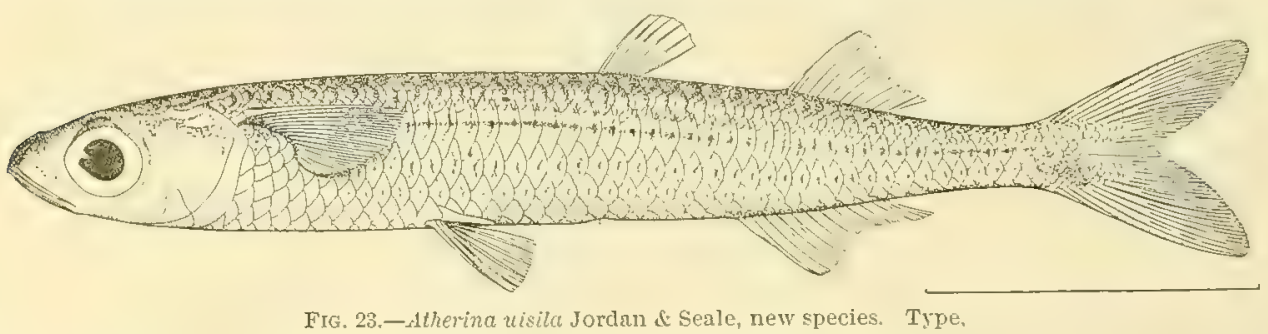

of soft dorsal 2.50 in head; base of anal 1.75 in head; the longest rays of soft dorsal and anal equal to eye; pectoral 1.50 in head; ventral 2; caudal 1.20, deeply emarginate; 18 rows of scales in front of spinous dorsal; pectoral reaching sixth scale of lateral line; origin of spinous dorsal over the sixteenth scale of lateral line; opercle and preopercle entire.

Color in life, olive; a lateral band with a brighter streak above; lower jaw blue; a black band across pectoral, fins otherwise plain. Color in spirits, below the lateral stripe white with slight wash of pale green; margin of scales with or without fine black dots; a wide stripe of bright silver from opercle to base of caudal, at its widest point this stripe equal in width to the pupil; scales of lateral line in some specimens with darker centers, which give the appearance of a slightly darker line in the upper third of the silvery line; above the stripe the scales have darker margins and are punctulate with minute blue dots, the ground color being pale green; pectoral with a slight wash of dusky; other fins white; opercle silvery.

This species is near therina lamosa, but seems to be different.

Forty specimens from Apia. The type is no. 51726, U. S. National Uuseum, length 3.75 inches.

311. Atherina insularum Jordan \& Evermann. Hawaii.

Family MELANOTENIIDE.

RHOMBATRACTUS Gill.* (Aristeus Castelnau; preoccupied.)

312. Rhombatractus novæguineæ (Ramsay \& Ogilby). Strickland River, New Guinea. Nematocentris nowe-guinere Ramsay \& Ogilb5, Proc. Linn. Soc. N. S. Wales 1856, 13; Strickland River.

313. Rhombatractus rubrostriatus (Ramsay \& Ogilby). Strickland River, New Guinea.

314. Rhombatractus goldiei (Macleay).

Aristers goldiei Macleay, Proc. Linn. Soc. N. S. W. 1883, 259, Goldie River (New Guinca). 


\section{Family IUGILIDE.}

\section{MUGIL Linnæus.}

315. Mugil cephalus Linnæens. Hawaii; Raiatea; Tahiti; New Guinea (Macleay); Nukahira and Solomon Is. (Seale); Mediterranean; Atlantic coasts of United States; Panama; southern California; Japan; Red Sea.

(Mugil aur Forskål; Mugil cephatotus Cuvier of Talenciennes.)

316. Mugil caldwelli Fowler. Samoa.

Mugil caldrelli Fowler, I’roc. Ac. Nat. Sci, Philれ. 1900, 52t, Samoa.

This species, not recognized by us in Samoa, is probably based on the young of some other species, perhaps the common mullet of Oceania, which we have been unable to separate from the European Wugil. cephalus or the Asiatic Mugil ceur.

317. Mugil broussoneti Cuvier \& Valenciennes. Cook Is.

318. Mugil tongæ Günther. Tonga.

319. Mugil planiceps Cuvier \& Valenciennes. Guam; Fast Indies.

320. Mugil kelaarti Günther. Tahiti; Raiatea (Seale); Last Indies.

321. Mugil kandavensis Günther. Kandayn; Fiji.

322. Mugil perusi Cuvier \& Valenciennes. Tanicolo.

323. Mugil argenteus Quoy \& Gaimard. Samoa (Günther); Australia.

This species, recorded from Samoa, was not seen by us.

324. Mugil sundanensis Bleeker. New Ginea (Macleay); Wast Indieg.

\section{LIZA Jordan \& Swain:}

325. Liza melinoptera (Cuvier \& Talenciennes). Afa; Fue' $f(t$. Tanicolo; Tonga; Samoa.

This mullet, known by the honey-colored ( $\mu \varepsilon \dot{\lambda}$ s) caudal fin and by the black pectoral, is very abundant about Samoa, and reaches a large size. About 20 specimens were taken. The name melinoptera (not melanoptera) refers to the yellow vertical fins, not to the black pectoral.

Life colors of a specimen from Apia 15 inches long: Very pale olive, silvery below; faint narrow lines along series of scales; lips pale; first dorsal pale gray, the spines dark; soit dorsal dusky, yellowish at tip; caudai pale soiled yellow; anal blackish, yellowish at tip, the last rays colorless; ventral pure whitish; pectoral mostly deep sooty black, the lower rays grayish.

Another specimen from Apia, young, with scales 26-10, anal IIx, 9, had first dorsal, second dorsal, and most of pectoral jet black; ventral blackish at base, edge yellowish; caudal and anal blackish washed with deep yellow, edge blackish; iris dark brown. Life colors of young specimen: (scales 26) from Pago Pago, back with two or three yellowish cross blotches; pectoral black; caudal bright yellow; even in very young examples; anaI yellow; rentral tipped with pale yellow.

326. Liza cæruleomaculata Lacépède. Lnae; 'Ana'analagi. Guam; New (ruinea; Samoa; East Indies.

Nugil crouleomaculatus Lacepède, Hjst. Nat. Poiss, V, 3\$5̄, 1\$03, Mauritius.

Jugil axillaris Cuvier \& Vulenciennes, Hist. Nat. Poiss, XI, 131, 1S30, Mauritius, New Guinea. Ginther, Cat. III, 44. Senle, Bishop Mus. 1901, 66, Guam. Günther, Fische der Sïrlsee, 216, taf. cxx, fig. B, Snmon, Red Sen, Seychelles. Igonostomus dorsalis Streets, Bull. U. S. Nat. Mus, vir, 102, 187,. Samoa; Fery young.

Life colors of a specimen from Apia, silvery; darker above; no stripes; fins pale; caudal dark at tip; a dark axillary spot; pe toral dull yellowish; iris silvery brownish. Scales 39; anal III, 9.

This is a large mullet, recognizable by the blue spot at the base of the pectoral. It is common about Samoa, where about 25 specimens were preserved.

327. Liza troscheli (Bleeker). Aur. Samoa; New Guinea; Last Indies.

Mugil troschelii Blceker, Nat. Tijd., Xv, 277, Java. Günther, Cat., In, 418, Ceylon, Horneo.

Mugil borneensis Blecker, Nat. Tijd., Ir, 1851, 201, Last Indies, Kner, Novara Fische, 22, Tahiti. Ginther, Cat. III, 448. Günther, Fische der Stidsec, 218, Tuhiti.

Jugil compressus, Günther, Fische rler sidsee, 217, taf, cxxin, fig. A, samon; not tyge.

B. B. F. $190 \%=15$ 
Life colors of a specimen from Pago Pago, olivaceous, dull and pale, very faint streaks along the rows of scales; anal dusky; caudal dull, colorless, with a dark streak along its whole margin above, below and behind. Anal III, 9; scales 32; maxillary uncovered; eye 3.5 to 4 in head, hence smaller than in the descriptions of $L$. troscheli.

One specimen from Apia had a slight brassy luster in life, and faint olive lateral stripes. Another was brownish above, the sides silvery, with the barest trace of striations; fins all plain, the caudal dusky at tip.

This species is very common about Samoa, entering the river mouths and brackish waters. About 30 specimens were taken.

328. Liza compressa (Günther). Normanby I., New Guinea (Macleay).

329. Liza neocaledonica (Castelnau). New Caledonia. Mrugil neocaledonicus Castelnau, 1873, 116, New Caledonia.

330. Liza waigiensis (Quoy \& Gaimard). Waigiu; New Guinea; Bougainville Is. (Peters); Tahiti; Guam; Mangareva; New Hebrides; Solomon Is.; Raiatea and Rarotonga (Seale); East Indies.

331. Liza papillosa (Macleay). Normanby I.

Mrugil papillosus Macleay, Proc. Linn. Soc. N. S. W. 1883, 270.

\section{MYXUS Günther.}

332. Myxus leuciscus Günther. Rarotonga, Cook Is̄.; Makatea (Seale).

\section{CH正NOMOGIL Gill}

333. Chænomugil chaptali (Eydoux \& Souleyet). Hawaii; Kingsmill; Laysan.

(Myxus pacificus Steindachner.)

334. Chænomugil nauticus Bryan \& Herre. Mareus I.

Chænomugit nauticus Bryan \& Herre, Bishop Museum 1903, 127, Marcús I.

QUERIMANA Jordan \& Swain.

335. Querimana crenilabis (Forster). Tahiti; Tanna; Paumotu; Kingsmill; Ponape; New Ireland; Christmas I.; Red Sea.

ESCHRICHTHYS Macleay.

336. Aschrichthys goldiei Macleay. Goldie River, New Guinea. Eschrichthys goldiei Macleay, Proc. Linn. Soc. N. S. W. 1583, 5, Goldie River.

\section{AGonostomus Bennett.}

337. Agonostomus plicatilis (Cuvier \& Valenciennes). Rivers of New Hebrides; New Caledonia.

338. Agonostomus loaloa (Macdonald). Fiji.

Gonotomyrcus loaloa Macdonald, Proc, Zool. Soc. N. S. W. 1869, 3s, with plate, rivers of Viti Levu (Fiji).

\section{Family SPHYRENIDE.}

\section{SPHYR瓜NA LinnæUS.}

339. Sphyræna obtusata Cuvier \& Valenciennes. Sapatu. Samoa; Fiji; Guam; New Guinea (Macleay); Faté in the New Hebrides (Seale); East Indies.

One specimen of this species was taken at Apia. It is apparently the species figured by Günther in the Fische der Südsee.

Life colors, olive green, below white with bright reflections; sides with two lateral stripes of dark olive, the lower continnous, the upper along lateral line of rounded, confluent blotches; caudal rather bright olive yellow, dusky edged; lower fins white; upper pale olive; snout green. Scales very large, 76 . 
340. Sphyræna forsteri Cuvier \& Valenciennes. Samoa; Tahiti; Vavau; New Guinea.

Of this species, we have one specimen from $\Lambda$ pia. It agrees fairly with Dr. Günther's figure in the Fische der Südsee. The Sphyrana forsteri of Steindachner from Mexico is a very distinct species, sphyrana ensis Jordan \& Gilbert.

Life colors of the specimen from Apia: Obliqne blotch on opercle and base of pectoral; black blotch on dorsal and anal; caudal largely blackish; ventral and pectoral pale; obscure dark, short bars along sides. Scales 91; pectoral not reaching quite to dorsal; ventral farther.

341. Sphyræna helleri Jenkins. Hawaii.

This is the offshore small-scaled species, known in Hawaii as kaualea.

342. Sphyræna snodgrassi Jenkins. Hawaii.

This is the large-scaled species, known as kaku in Honolulu.

343. Sphyræna grandisquamis Steindachner. Pacific Ocean, exact locality unknown. Sphyrana grandisquamis Steindachner, Sitz. $\mathrm{Ak}$, Wiss. Wien 1866, 416

344. Sphyræena megalolepis Peters. New Ireland.

Sphyrarka megalotepis Peters, Berl. Mon. 1876, 812, New Ireland.

345. Sphyræna kenie Klunzinger. Bougainville Is.; Red Sea.

Sphyrzena kenie Klunzinger, Syropsis, 1, 823, 1870, Red Sea. Klunzinger, Roth. Areer, 129. Peters, Berl. Mon. 1876. \$42, Bougainville Is.

Family POLYNEMIDE.

POLYDACTYLUS Rafinesque.

346. Polydactylus plebeius (Broussonet). Umiumia. Tahiti; Samoa; Solomon Is.; New Britain; Tahiti and Nukahiva (Seale); East Indies.

Polynemus plebeius Broussonet, Ich. Decas., fig. 309, 1788, Tahiti.

Polynemus lineatus Lacépède, Hist. Nat. Poiss., V, pl, 13, fig. 2, 1803, Ile de France. Günther, Cat., II, 227, Samor, Solomon Is., Amboyna.

Polynemas plebeius Peters, Berl. Mon. 1876, 835, New Britain.

Polynemus plcbeius Günther, Fische der Sijdsee, 103, pl. Lxxvi, fig. A, Amboina; not of Günther, Cat., Ir, 329.

Polynemus treniatus Günther, Cat., II, 526, 1860, Amboina and Guadalcanar, Solomon Is.

This is evidently the original Polynemus pleteius of Broussonet, which has been much confused by subsequent authors. It was well described by Günther under the name of Polynemus lineatus, and earlier cescribed by Lacépide under the sane name. It is common at Ajia, where 6 specimens were taken with the hook in the ship channel, and is ralued as a food fish. Scales 55 ; 5 pectoral filaments.

The adults are very sharply striped, the dark lines along the rows of scales being conspicuous. Young examples do not show these lines clearly, and these accord better with the figure given by Broussonet. An adult example from Apia in life was white with streaks of olive brown. A young example from Pago Pago in life was entirely silvery, the fins pale with dark dots, pectoral a little more yellowish, no dark spot on base of lateral line.

347. Polydactylus sexfilis (Cuvier \& Valenciennes). Hawaii; Johnston I.; East Indies.

Family BERYCIOE.

MELAMPHAES Günther.

348. Melamphaes unicornis Gilbert. Deep seas of Hawail.

CAOLOLEPIS Gill.

349. Caulolepis longidens Gilbert. Deep seas of Hawaii.

\section{Family POLYMIXIIUE. \\ POLYMIXIA Lowe.}

350. Polymixia berndti Gilbert. Deep seas of Ilawii. 


\section{Family HOLOCENTRIDE.}

MYRIPRISTIS Cuvier. Malau.

351. Myripristis murdjan(Forskål). Iranifinif. Hawaii; Samoa; Harvey Is.; Tahiti; Fiji; Paumotu Is.; Guam; Laysan; New Hebrides, Raiatea, and Irarotonga (Seale); East Indies.

This species is common throughout the South Seas. It is the most abundant of the genus about Hawaii, and is fairly plentiful at Samoa. It is distinguished by its large scales (30), by the presence of white edges on the soft vertical fins and the ahsence of black tips on dorsal and anal. There is always a dark bar across the gill-opening.

352. Myripristis intermedius (Günther). Malau: Samoa; Kingsmill; Harvey Is.; Tahiti; Galapagos Is.

Myripristis murdjan, var, intermedia Günther, Fische der Südsee, 92, Samóa, Harvey, Kingsmill, Tahiti.

This form is common at Samoa, where about 20 examples were taken. It differs from $H$. murdjon chiefly or entirely in the presence of a black blotch on the tip of the soft dorsal and anal. Dr. Günther regards it as a mere color variation of $M$. murdjan. We should take a similar view were it not for the fact noted by Dr. Flunzinger, that in the Red Sea, and in Hawaii, where $W_{0}$ murdjon is abundant, no specimens of this type have been taken.

A specimen from the Galapagos Islands, collected by Snodgrass and Heller and recorded as M. murdjan, has black tips to the dorsal and anal, and would be referable to M. intermedius.

Color deep red, dusky on dorsal and anal, fins all bright red, pale-edgerl in front.

353. IIyripristis adustus Bleeker. ILalau no. Samoa; Tahiti; Paumctu Is.; Harvey Is.; Kingsmill; New Guinea; Marcus I.; Shortland I. (Seale); East Indies.

Ifyipristis adustus Bleeker, Amboina, 1Ir, 18, East Indies. Günther, Cat., I, 22, Amboina. Günther, Fische der Südsee, 92, taf. 62, Tahiti, as variety of $M$. murdjan, Samoa, Pamotu, Harvey $I_{.,}$Kingsmill I. Bryan \& Herre, Bishop Museum, vol. II, no. 1, 128, Marcus I.

Myripristis botche, Day, Fishes of India, 169; not of Cuvier \& Valenciennes.

This well-marked and handsome species is rather common about Samoa, where about 12 specimens were taken. It may be at once knowa from M. murdjan by the steel blue (not red) color, and especially by the broad black edging of both dorsals, and of the caudal and anal fins. In $M$. intermedius there is no black on the spinous dorsal or caudal.

Life colors of a specimen from Apia, gray tinged with reddish; edge of scales brown; a darkbrown blotch across opercle and axil; dorsal, anal and caudal pale pinkish gray at base, the edge broadly black, washed antelıorly with blood-red; spinous dorsal also mostly black; pectoral pale pinkish; ventral whitish.

354. Myripristis microphthalmus Bleeker. Malau tea; Malau mataputa. Samoa; New Guinea (Macleay); Faté, New Hebrides (Seale); Last Indies.

This species is rery abundant at Samoa, where about 40 specimens were taken. It has the silvery luster and dark scale-edgings of Myripristis adustus without the deep red shades of M. murdjan. Life colors were noted in various specimens as follows:

(1) Specimen from Apia. Silvery red brown, lighter than in $M$. murdjan, each scale silvery with dark edges; opercular spot blood red, not black; same color on base of pectoral; fins paler; dorsal and anal with silvery base; dorsal, anal, caudal, and ventral with pale edge; spinous dorsal orange red, its base pale grayish, blotched with orange.

(2) Specimen from Pago Pago, very deep, scalcs 30, maxillary entire. Brownish, sides pinlish silvery, not very red; a blackish red cross-band on opercle, shoulder, and axil; first dorsal whitish at base, scarlet above; second dorsal, anal, and caudal pink, scarlet or orange at tips, and with a dictinct white edge; pectoral pale; ventral dull orange, whitish-edged.

(3) Specimen called malau mataputa, or swelled-face; very deep; very large-scaled. Purplish black above, very silvery on side; a blood-red band from nape to axil; preopercle and opercle nearly white; spinous dorsal pinkish below, scarlet above; soft dorsal and anal pinkish behind, scarlet on lobes, with white edge; caudal red, orange behind, the edges slightly pale; ventral and pectoral reddish, ventral white-edged.

Larger examples more red, with dusky behind pale edges of dorsal and anal; fins all bright red except white edgings.

(4) Red, dusky on dorsal and anal; fins all bright red, pale-edged in front.

(5) Larger specimen. Dorsal clear deep red. 
(6) Bright clear red, the scales a little paler on centers; first dorsal bright red, the tips scarlet; other vertical fins clear red with distinct pale erlges and no blackish; no stripes along anterior edge; ventral deep red with pale edge; pectoral clear red; a blackish opercular axil bar.

355. Myripristis hexagonus (Lacépède). Samoa; Mauritius.

Lutjanus hexayonus Lacépède, Hist. Nat. Poiss., IY, 213, 1802, Mauritius.

Nyripristis herayonus, Cuvier \& Valenciennes, II ist. Nat. Poiss., Ir, 171. Quoy d Gaimard, Voy. Astrolabe, 5, pl. 14. Günther, Cat., r, 27.

We refer to this species, with some doubt, two specimens, large-scaled, with little black on the opercle which ends in about fire points, the one larger than the others. It is near. Wyripristis murdjan, and still nearer to Myripristis berndli of Hawaii.

Life colors of a specimen from $\Lambda$ pia, light brick-red, the sides rather silvery, and no dark lines; a darker red patch on opercle and axil; a silvery crescent on iris behind; fins all red, the spinous dorsal paler at base, the others darker on lobes; anal and caudal with very inconspicuous pale edging.

356. Myripristis berndti Jorlan \& Evermann. Ifawaii.

357. Myripristis chryseres Jordan \& Evermann. Hawaii.

358. Myripristis symmetricus Jordan \& Evermann. Hawai.

359. Myripristis argyromus Jordan \& Evermann. Hawaii.

360. Myripristis sanguineus Jordan \& Seale, new species. IIrlau ula; Segasega. Tahiti; Samoa.

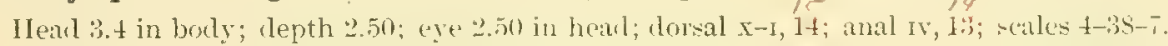

Body elongate, deep and compressed; hear blunt, its length less than its lepth; snout short, its length from the upper nostril equal to pupil; premaxillary slightly protractile; maxillary reaching to a

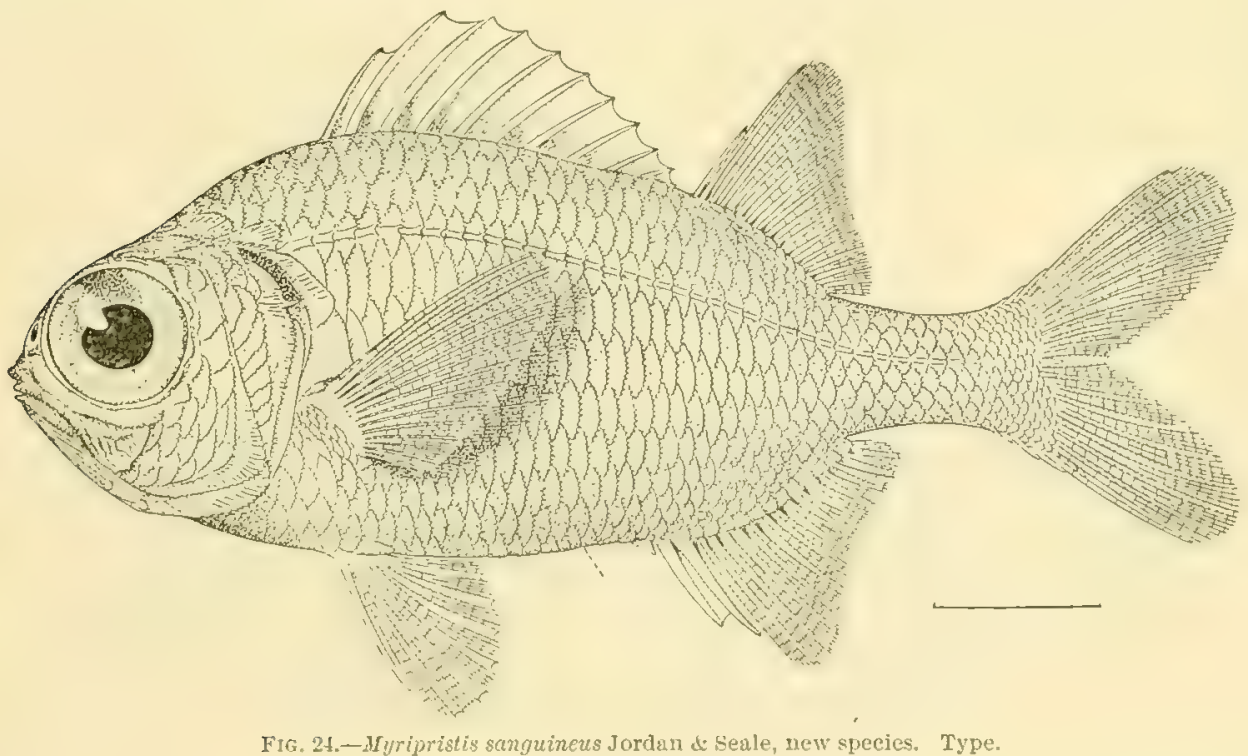

line below the posterior erlge of pupil, its distal end broad, 4.50 in head, its lower posterior margin arned with blunt teeth; lower mandible 1.50 in head; bands of small teeth in jaws, vomer, and palatines; a patch of enlarged blunt outer teeth on each side of upper and lower jaw; gillrakers numerous, long and strong; interorbital space 3.85 in head; opercle striate and denticulate, with. one small spine at angle; scales all striate and toothed; a row of modified scales over the nuchal region; origin of dorsal about even with lower base of ventrals and on line with the third scale of the lateral line; clorsal spines slender, the first 2.75 in head, the third longest, 2 in head; anterior dorsal and anal rays somewhat prodnced, their length 1.50 in head; third anal spine strongest, the fourth longest, equal to orbit; caudal emarginate; pectoral reaching to eleventh scale of the lateral line. 
Color in life deep red, a black opercular spot; fins all red, the dorsal pale red with the margin deep crimson; outer margin of soft dorsal and the anal also a dark red.

Color in spirits pale yellowish, the fins a brighter yellowish; a dusky blotch at posterior margin of operele, and a dusky wash in axil of pectoral.

One specimen, the type (no. 51721, U. S. National Museum), from Apia. Two other specimens, from Tahiti, Society Islands, are in the Bishop Huseum, Honolulu. This species is distinguished by the much enlarged front teeth. It is close to Myripristis argyromus and $M$. symmetricus.

361. Myripristis pralinius Cuvier \& Valenciennes. Mamo; Malau mamo. Port Praslin, New Ireland; Samoa; East Indies.

This species is very abundant at Samoa, where about 50 examples were taken. Our specimens agree well with the account of Günther and Sauvage. The small scales, the serrated maxillary, and the dark bar at the gill-opening are characteristic.

Life colors of a specimen from Apia crimson red, the centers of the scales not much lighter, the lower parts rosy; opercular spot deep red, almost black, base of pectoral deep red; fins bright rose, dorsal, caudal, and ventral all edged with white; shade of lins same as body; first dorsal deep red, paler at base.

362. Myripristis carneus Ramsay \& Ogilby. Admiralty Is.

Myripristis carneus Pamsay \& Ogilby, Proc. Limn. Soc. N. S. W. 1886, 474.

363. Myripristis parvidens Bleeker. New Ireland (Sauvage); East Indies.

364. Myripristis multiradiatus Günther. Vavau; Tonga; Hawaii; Samoa.

A species identical with the Hawaiian species called by us Myripristis multiradiatus, which is abundant at Honolulu, is very common at Samoa. It is probably the true multiradiatus, though we find no specimen with more than 16 dorsal rays. In the type from Vavau Dr. Günther found 18. The species is extremely close to $M$. pratinius.

Life colors of a specimen from Pago Pago light bright red; darker green across opercle, shoulder and axil; spinous dorsal scarlet, deepest on edges; other fins red like the body; pectoral, dorsal, anal and caudal with an anterior pale edge; eye very large, maxillary entire.

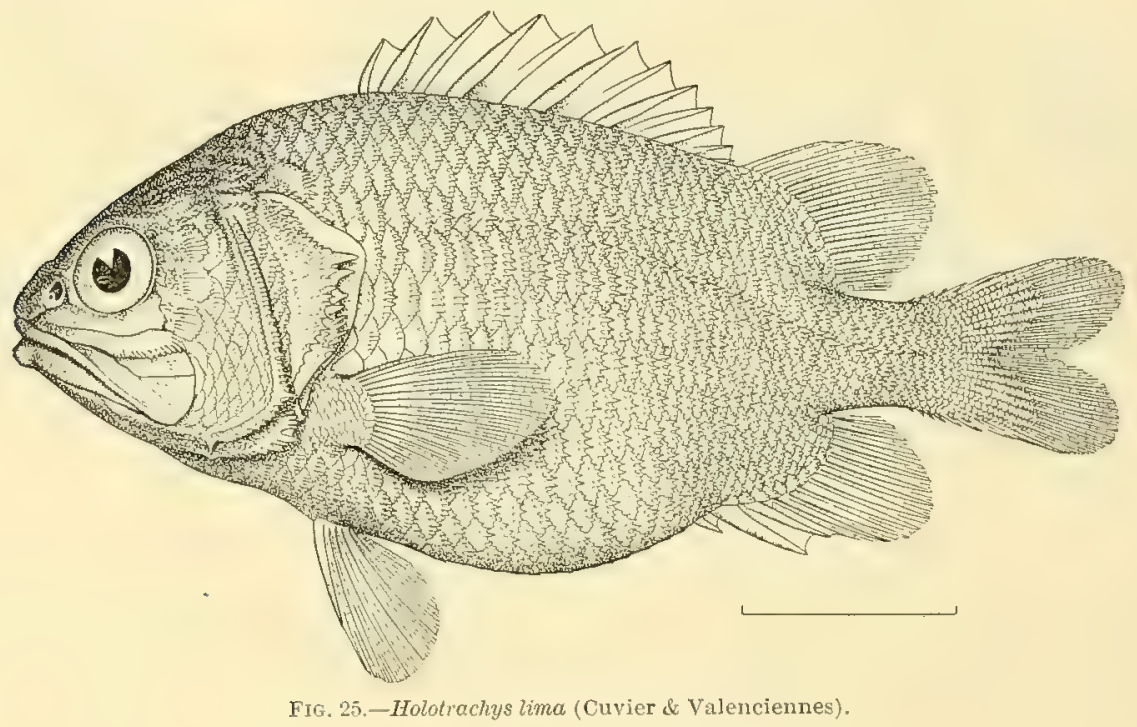

HoLOTRACHys Günther. (ITarpage De Vis.)

365. Holotrachys lima (Cuvier \& Valenciennes). Halau mutu; Mutu. Hawaii; Samoa; Tahiti; Laysan; lle de France.

This species is very common at Samoa, as also about Hawaii. It is of small size and is uniform brick-red in color. 
366. Holotrachys roseus (De Vis). South Seas.

IIarpage rosca De Vis, Proc. Linn. Soc. N. S. W. 18s4, 4.18 , South Seas.

This species is unknown to us. It is very close to $I I$. lima, and is probably the same.

OSTICHTHYS Langsdorf.

367. Ostichthys pillwaxi Steindachner. Hawaii.

HOLOCENTRUS (Artedi) Gronow, Malou.

368. Holocentrus spinifer Forskảl. Yalau toa. Samoa; Hawaii; Borabora; Waigiu; Papua; Johnston I.; Thornton I.; Vanicolo; Tonga; Vavau; New Hebrides; Solomon Is.; Raiatea (Seale); East Indies.

IIolocentmis leo Cuvier \& Valenciennes, Hist. Nat. Poiss., III, 201, 1829, Borabora and New Guinea; not Ilolocentrum spiniferum Cuvier \& Valenciennes and Sauvage.

This large species is common at Samoa, and ranges from Hawai, where it is not rare, to the Red Sea and Madagascar. It is known by its deep body and narrow, convex profile. It much resembles II. caudimaculatus, and the name spinifer is adopted for the latter species by Valenciennes and Sauvage; but as Forskal speaks of the dark spots behind the eye, which is characteristic of the species called Holocentrus leo, we agree with Kippell, Bleeker, Günther, and Klunzinger in $r$-ding the present species as the true spinifer, leo being a synonym.

Forskal and Klunzinger state that the dorsal spines of this species are envenomed. Both this species and $H$. caudimaculatus are common in the Red sea.

Life colors of a specimen from Apia, deep red, scales with golden edges; no lengthwise stripes or violet streaks; preopercle and opercle blood-red above; axil blood-red; first dorsal same color, unmarked; dorsal, anal, and caudal scarlet, the upper and lower part of caudal redder; third and fourth spines red; ventrals scarlet, the spine pink; pectoral scarlet; cheek pale brassy red, no white stripes, except a faint streak below eye along upper edge of cheek, and a paler edge behind opercular spot. One specimen with a sharp white stripe above opereular spine.

Life colors of another specimen from Apia, deep red, scales with narrow pale edges; deep reddish black spot on opercle and across to axil; dorsal red, edged with deeper red; fins all red without pale edging; membrane of third anal spine deep red.

369. Holocentrus caudimaculatus Rüppell. Tamalur mumu; Tameno mumu. Samoa; Tahiti (Seale); Palau Is.; Gilbert Is.; New Guinea; East Indies.

Holocentrum spiniferum Cuvier \& Valenciennes, and of Sauvage; Itolocentrum lconoides Bleeker.

This species is abundant about Samoa, and westward to the Red sea. It is near $I I$. spinifer but the rofile is broaler and not concave, and there are other differences well expressed by Klunzinger and by Sauvage. The color is deeper than in $H$. spinifer, and the white spot on the back of the tail is rarely wanting in $H$. caudimaculatus. In $H$. spinifer this is not found, but is represented by a trace of paler color.

- Life colors of a specimen from Apia, all deep red; faint violet streaks on lower parts; a faint line down and backward from eye; axil deep red; fins all deep red; anal spine and front edge of ventral only whitish; a large whitish black blotch on the back of the tail behind dorsal.

370. Holocentrus violaceus Bleeker. Lulau lifi; Malau uli. Samoa; New Guinea (Macleay); Amboina.

This very strongly marked species is common at Samoa, where about a dozen specimens were taken. It is deep violet-brown, not red, with a vertical pale streak on each scale, and a white blotch on the back of each scale. It is not known from Hawaii.

Life colors of a specimen from Apia called malau tifa and malau uli, blackish red, a vertical bar of violet silvery at base of each scale; head mostly clear dark red; a blackish spot on opercular membrane; a blood-red axillary spot; a darker red spot on upper part of opercle; first dorsal dark red with a whitish edge and a deep red line below it; second dorsal, anal, and caudal dark red with a darker anterior edge; a pink spot on back of tail; ventral red, the spine bluish; first spine and first ray of anal moderately deeper red; pectoral red; mouth small.

Life colors of a specimen from Pago Pago called malau tifa (pearl shell), violet pearly reflections; the color very dark, the violet pearly bars on cach scale bejow conspicuous; a bright pink spot on hack of tail. 
371. Holocentrus binotatus Quoy \& Gaimard. Samoa; Guara; Papua; Tonga; Solomon Is.

This species is rather common about Samoa, where about 30 specimens were taken. Usually one or two small dark spots are present on the membranes of the front of the spinous dorsal. There is little doubt that the original $H$. binotatum is the species called unipunctatum by Günther.

Life colors of a specimen from Apia, very deep red all over, with faint blue-black streaks, abont 7 in number; head almost plain red, with two faint cheek stripes; fins all deep red, the dorsal with a row of dark spots and dark edges.

Life colors of a specimen from Pago Pago, very bright red, with streaks of shining golden; fins all deep red, unmarked, the vertical fins a little darker on front edge; a slightly darker spot on membranes of first two dorsal spines.

372. Holocentrus erythræus Günther. Hawaii; Samoa; New Hebrides; Tahiti; Harvey Is.; Kingsmill; Tahiti; Paumotu Is.; Johnston I. Solomon Is.

Of this large and handsome species one small specimen was taken by us at Samoa. The fish is rather rare in deeper waters about Hawaii.

373. Holocentrus furcatus Günther. South Seas, probably New Hebrides.

374. Holocentrus xantherythrus Jordan \& Evermann. Hawaii.

375. Holocentrus tiere Lesson: Samoa; Tahita; Thornton I.

Iolocentrum tiere (Lesson), Cuvier \& Valenciennes, Hist. Jat. Poiss., IrI, 202, 1829. Tahiti. Lesson, Voy. Coquille, II, 221, 1830, Tahiti. Günther, Cat., I, 45.

Ioloccntrm pocilopterum Bleeker, Kokos-Eilanden, 356 . Bleeker, Atlas, Cocos Island. Günther, Cat., I, 35.

Holocentrus polynesia Fowler, Proc. Ac. Nat. Sci. Phila. 1904, 229, Thornton I.

This species is known when adult and in good condition by the two rows of pale spots on the dorsal fin. It is rather common at Samoa, where about 12 specimens were taken. $I$. polynesix seems to be based on a specimen in which the dorsal color has faded. Holocentrum tiere must be the same species. The elongate, faintly striped body, the rather large mouth, the ragged suborbital, the low weak dorsal spines, the subequal and strong opercular spines, as shown in Lesson's figure, are all traits of the species called $H$. pecilopteris.

Life colors of a specimen from Apia, deep crimson red; lower half with bright violet streaks; axil deeper red; dorsal deep red with a row of white spots and tips white; other tins deep red; ventral with paler edge and darker streak, fourth anal spine in a dark streak; pectoral red; head with deeper red blotches, but no white. Another specimen from Apia in life was red, rather bright, the sides silvery; cheek silvery with a red streak; no streaks along scales; dorsal edged with dark red with white spots; red at base; vertical fins red, the edges scarcely darker; ventral pink, axil red; pectoral pink.

376. Holocentrus tiereoides Bleeker. Marcus I.; New Hebrides; Solomon Is.; Tahiti (Seale); Anboina.

This species is known to us from the example taken by Bryan and Herre, which agrees well with Bleeker's account. The species is evidently very close to $H$. tiere, but the scales are much larger (40) instead of 50 ).

377. Holocentrus punctatissimus Cuvier \& Valen iennes. Malaufaimu. Tahiti; Sanoa; Hawaii; Strong I.; Guanı; Marshall Is.; Paumotu Is.; Laysan; Aneiteum; Tabuai; Mangareva;, Rarotonga; Faté; Makatea and Shortland I. (Seale).

Holocentrum punctatissimum Cuvier \& Valenciennes, Hist, Nat. Poiss, II, 215, 1829, Caroline Is.

IIoloccntmu stercus-muscarum Cuvier \& Valenciennes, op. cit., YI, 503, 1831.

Holocentum diploxiphus Gunther, Proc. Zool. Soc. 1871, 660. Gunther, Fische der Südsec, 97, Samoa, Marshall Is., Tahiti, Paumotu, Aneiteum.

Holocentivs gracilispinis Fowler, Proc. Ac. Nat. Sei. Phi]a, 190t, 228, Honolulu.

Holocentrus gladispinis Fowler, Proc. Ac. Nat. Sci. Phila. 1904, 225, Tahiti.

This species is common about Samoa, where about 50 specimens were taken. It is also abundant about Honolulu. The form of the body is characteristic, and the silvery color is usually, but not always, obscured by dark points irregularly scattered, giving the fish a soiled appearance.

H. grecilispinis, based on our own collections from Honolulu, we can not separate from Samoan specimens. H. gladispinis is based on an examnle from Tahiti with the preopercular spine a little 
longer. The color of the dorsal is usually characteristic, but the marks often fade in spirits. This species is not recorded from the East Indies, where the closely related $H$. lacteoguttatus seems to take its place

Life colors of a specimen from Apia called malau fuium, freckled red, dark across gill-opening; iris golden; first dorsal deep red on edge, other fins brick red, scarcely edged with paler; ventrals brick red. A specimen from Pago Pago was pinkish, soiled lyy dark dots; dorsal deep red on edge, pale at base; faint dark streaks on. rows of scales; a red dash across cheek; fins light red; a dark streak along anal.

378. Holocentrus lacteoguttatus Cuvier \& Valenciennes. New Guinea; East Indieg.

IIolocentrus lacteo-guttatum Cuvier \& Valenciennes, Hist. Nut. I'oin.. III, 214, East Indies.

Holocentrus argenteum Quoy \& Gaimard, Voy. Astrolabe, 677, 143., Papua. Cuvier \& Valeneiennes, op. cit., III, 21:.

This species is not known to us. It has not been recorded to the eastward of New Guinea. According to Klunzinger, the type of $I$. argenteus, examined by him belongs to the species, for which we adopt the name lacteoguttatus.

379. Holocentrus diadema (Lacépède). Yalau tusilusi; Yalau pāuli; Malau tui. Hawaii; Samoa;

Tonga; Tahiti; Borabora; Laysan; Guam; Marcus I.; New Hebrides (Seale); East Indies.

This small species, always known by its black spinous dorsal and the alternate stripes of white and red on the body, is very common at Samoa, and equally so at Hawaii. It is in general the most abundant species of Folocentrus in the Pacific Ocean.

Life colors of a specimen from Pago Pago called malau pauli, red, with white stripes; dorsal dusky, a continuous stripe, same as from Honolulu.

380. Holocentrus ruber (Forskål). Louisiades; East Indies; China; not certainly known from the South Seas.

381. Holocentrus praslin Lacépède. Samoa; Ruikiu Is.

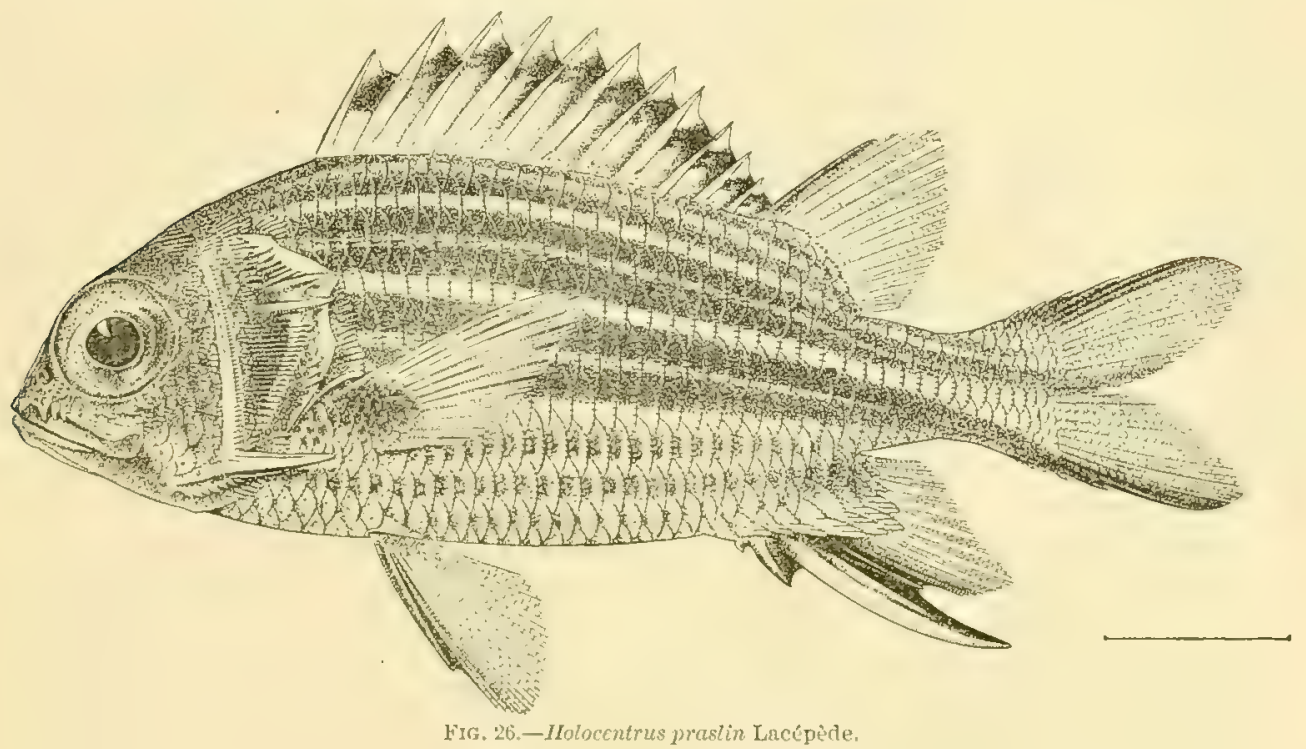

This species, known By its rery dark lateral stripes, which seem black in spirits, is common at Samoa, but is not known from Hawai. Life colors were noted as follows in rarions specimens:

(1) From Apia. Deep red, very bright, paler below; 10 longitudinal streaks, narrow and sharply defined, the four uppermost light crimson, the rest almost pure white, with bromnish edere; a white stripe downward and backward from eye, a rel one and a white one above it; spinous dorsal 
blood red with an interrupted row of whitish spots and a whitish tip; other fins clear red, caudal with a blood red edge, as also a stripe along fourth anal spine; ventral similarly striped; pectoral pinkish.

(2) From Apia. Whitish, olive shaded; 9 stripes of brownish black, unequal in width and depth of color, separated by white and grayish and pinkish stripes, the stripe on level of eye broad and white, the two black stripes above it confluent behind as also the two below it; the white stripe from axil of anal to axil of pectoral also broad; opercle reddish black; lower part of head and breast soiled gray with blackish stripes; dorsal grayish white with blackish median band; soft dorsal light yellow, edged before with dark maroon; caudal light clear yellow, edged above and below with maroon black; anal lighter yellow, with darker anterior stripe and a black maroon blotch at base; a maroon black bar below soft dorsal made of two coalescent black stripes; ventral yellow, edged with maroon and white; pectoral reddish, the axil blackish.

(3) From Pago Pago. Very dark blood red, with whitish pink stripes; dorsal white, with median black stripe; second dorsal yellowish, with red anterıor margin and blackish blotch at base; caudal yellow with maroon stripes; anal yellowish with a black stripe and a spot at base; ventral yellowish, with white and black stripe.

(4) From Apia. Deep lustrous coppery red, paler below, the dark alternating with pale stripes, the red very deep and bronze shaded above, growing paler and more diffuse below; about 7 streaks distinet; head blackish freckled bronze; dorsal dark blood red, mesially pale and pale at tips; soft dorsal, anal, and caudal golden, with maroon stripe anteriorly narrow on soft dorsal; ventral similar golden and maroon; breast soiled mottled brown and whitish; pectoral pale reddish brown.

Holocentmus ruber differs from this specjes chiefly in the plain colors, red striped with deeper red. Probably Holocentrus prastin is an "ontogenetic species" representing $H$. mber on the coral reefs, and differing mainly in the much heightened coloration.

382. Holocentrus ensifer Jordan \& Evermann. Hawaii; Mangareva (Seale).

383. Holocentrus bowiei Jordan \& Snyder. Tahiti.

384. Holocentrus microstomus Günther. Samoa; Guam; Tonga; Hawaii; Kingsmill I.; Paumotu Is. ; Harvey Is.; Tahiti; Tubuai; Raiatea and Rarotonga (Seale).

This species, well distinguished by its silvery body striped with dark, and by the dark area on the front of its spinous dorsal, is rather common about Samoa, where about 12 examples were taken. It is not rare about Honolulu. From Holocentrus sammara, which has somewhat the same coloration, it is known by the deeper body and smaller mouth. This species and the next, intermediate between Holocentrus and Flammeo, render the latter genus difficult of definition. We therefore place all the Pacific species in Holocentrus.

385. Holocentrus scythrops Jordan \& Evermann. Hawaii; Laysan; East Indies.

(Holocentrum argenteam Bleeker \& Steindachner, not of Quoy \& Gaimard.)

This species is rather rare about Hawaii. It was not seen at Samoa. It has been once or twice described as Holocentrum argenteum, but the true argenteum, as Klunzinger has shown, is a different species (lacteoguttatus)

386. Holocentrus lævis Günther. Samoa; Louisiades; Solomon Is.; New Britain; New Guinea; Amboina.

IIolocentrum goldiei Macleny, Proc. Linn. Soc. A. S. W. 1883, 352, New Guinea.

Holocentrun lave Günther, Cat., I, 47, Louisiades, Guadalcanar, Amboyna. Günther, Fische der Südsee, 101, taf. 65 , fig. B.

IIolocentrum noux-brittania De Vis, Proc. Linn, Soc. N. S. W. 1S84, 447, New Britain; young.

Ilolocentrus achromopterus Fowler, Proc. Ac. Nat. Sci. Phila. 1904, 236, Samoa.

Holocentrum goldiei Macleay, Proc. Linn. Soc. N. S. W., VII, 1883, 352, New Guinea.

This species is ratber common about the reefs of Samoa, where about 20 examples were taken. It resembles $H$. sammara, but the body is deeper and there is never any black on the spinons dorsal.

Life colors of a specimen from Pago Pago, the stripes less regular and fewer than in $H$. sammara, distinctly shown, the pale stripe on lateral line being dull red, dorsal paler, deep red between first and second spines, the white band much broader and more diffuse; caudal almost plain; darker red on edge of second dorsal and caudal, much deeper on anal; ventral paler red than in other; ventral and anal spines red. 
387. Holocentrus sammara (Forskal). Malau peapea. Hawaii; Tahiti; Samoa; Borabora; Paumotu Is.; Solomon Is.; Guam; New Guinea; Thornton I.; Marquesas Is. (Seale); East Indies.

Labrus angulosus Lacepede, Hist. Nat. Poiss., III, 430, pl, 22, 1ig. 1, 1803.

Irolocentrun christianum Cuvier \& Valenciennes, Hist. Nut. 1'oiss., III, 219, 1823, Red Sea.

Holocentrum tahiticum Kner, Novara Fische, II, 1860, f. 2, pl. 16, Tahiti. Kner, Sitz. Ak. Wiss. Wien, 1864, 182, Tahiti.

IIolocentrus fuscostrialus Seale, Bishop Mus., 1901, 69, Guam.

Holocentrus thorntonensis Fowler, Proc. Ac. Nat. Sc1. Ihila. 1304, 231, Thornton I. (Young).

This handsome fish is very common on the reefs at Samoa, where about 100 examples were taken. It is rare abont Hawaii.

The species varies considerably in the distinctness of the dark maroon lateral stripes, but the black on the first dorsal is never absent. In the young it takes, the form of an ocellus. Such a young example is the type of Holocentme thorntonensis. Life colors were noted as follows in various specimens:

(1) Specimen from Apia. Silvery, with golden, red, and greenish reflections; back with four stripes of dark maroon red, the second and third brightest; head dark red above, mostly silvery, with red wash below; lips thesh color; opercle dark red above; fins pale red, the spinous dorsal broadly eriged with blood red; caudal with a maroon stripe in each lobe, anal and ventral also; no pale edging.

(2) From Apia. Olive, lustrous purplish above, coppery silvery below; each scale with a large distinct coppery black spot, these forming about ten stripes; cheek whitish with black spots; head wine-shaded on lips, snout, and opercle; preoperele white; dorsal maroon, whitish spots at base, tips white; front of dorsal with large black, red-washed blotch; soft dorsal, anal, and caudal golden yellow; with a long maroon stripe on anterior rays, covering most of caudal lobes; pectoral coppery reddish; ventral white.

(3) Young specimen from Apia. Red, with a large black blotch on front of spinous dorsal, a dark red stripe in each caudal lobe and on front of soft anal; a dark band across opercle.

(4) From Apia. Silvery rose; brownish above with stripes of rosy maroon, all but one indistinct, the bright one following course of lateral line; opercle dark maroon; dark band across base of pectoral; front of dorsal with very large blotch of maroon black, fin otherwise flesh-color, tips whitish; soft dorsal yellow, transparent behind, with maroon stripe in front; anal whitish with maroon stripe; pectoral and ventral nearly white; caudal pale orange, the lobes rosy maroon.

388. Holocentrus opercularis (Cuvier \& Valenciennes). Tahiti; New Ireland; Samoa; Palau Is.; Paumotu Is.; Guam.

This strongly marked species is well figured by Dr. Günther. Two specimens were taken at Samoa.

Life colors of one from Pago Pago, light red, each scale with a darker center and a silvery edige; dark streaks along rows of scales; head red; opercle blood red; iris very red; first dorsal jet black, with a row of white spots at base and tip; second dorsal, anal, and caudal red, with a darker bar in front and a shade of orange bebind; pectoral and ventral pink; pectoral red at base; a red shade down and back from eye. Mouth large; chin prominent; anal spine long; body slender.

\section{Family LAMPRIDE.}

\section{LAMPRIS Retzius.}

389. Lampris regia (Bonnaterre). Hawaii; all warm seas.

The name Zeus regius of Bonnaterre and that of Zeus guttatus of Brinnich, both 1788, antedate Zeus luna of Gmelin (1789). We do not know which of these first has actual priority, but regius is a name preferable to the commonplace and overworked specific name guttalus. It is true, however, that the name guttatus has been more generally used than that of regius, and the account given by Brünnich is the best found in any early author. Following the arbitrary rule which we have adopted, the name regius on page 72 in Bonnaterre's work antedates gullatus on page 398 in that of Brünich.

Famils ZEIDE.

\section{STETHOPRISTIS Gilbert.}

390. Stethopristis eos Gilbert. Deep seas of Hawaii.

CYTTOMIMUS Gill.

391. Cyttomimus stelgis Gilbert. Decp seas of Hawaii. 


\section{Family SCOMBRIDE. \\ SCOMBER (Artedi) Linnæus.}

392. Scomber japonicus Houttuyn. Hawaii; California; Japan; Atlantic.

scomber colias Gmelin.

393. Scomber microlepidotus Rüppell. Solomon Is. and New Hebrides (Seale); coasts of Asia.

394. Scomber chrysozonus Rüppell. Bougainville Is. (Peters, Berl. Mon. 1876, 836); Red Sea.

395. Scomber loo (Cuvier \& Valenciennes). Ga. Samoa; Waigiu; Fiji; I’alau Is.; New Guinea (Macleay); East Indies.

This well-marked mackerel is abundant in the open channels about the reefs of Samoa, and is an excellent food fish. The species is quite distinct from Scomber kanagurta, with which Günther has confounded it.

Life colors of a specimen from Apia, lustrous green, silvery below; round blackish green spots on sides of back.

\section{AUXIs Cuvier.}

396. Auxis thazard (Lacépède). Hawaii; New Guinea; warm seas.

\section{GYMNOSARDA Gill.}

397. Gymnosarda pelamis (Linnæus). Hawaii; warm seas.

398. Gymnosarda alleterata (Rafinesque). Hawaii; warm seas.

\section{GERMO Jordan.}

399. Germo germo (Lacépède). South-Seas; Japan.

(Thynn us sibi Schlegel.)

400. Germo macropterus (Schlegel). Hawaii; southern California; Japan.

This species is known by its elevated dorsal and anal, and especially by the citron-yellow finlets.

SARDA Cuvier.

401. Sarda chilensis (Cuvier \& Valenciennes). Hawaii; Califoraia; Chile; Japan.

SCOMBEROMORUS Lacépède.

402. Scomberomorus commersoni Lacépède. New Guinea (Macleay); East Indies.

\section{ACANTHOCYBIUM Gill}

403. Acanthocybium solandri (Cuvier \& Valenciennes). Hawaii; warm seas.

\section{Family LEPIDOPIDE. \\ RUVETTUS Cocco.}

404. Ruvettus protiosus Cocco. Hawaii; Japan; West Indies.

PROMETHICHTHYS Gill.

405. Promethichthys prometheus (Cuvier \& Valenciennes). Hawaii; Tahiti; Australia; Japan.

$$
\text { LEMNISOMA Lesson. (Gempylus Cuvier \& Valeneiennes.) }
$$

406. Lemnisoma thyrsitoides Lesson. Hawaii; Tahiti; West Indies. 


\section{Family XIPHIIDE.}

407. Xiphias gladius Linnæus. Hawaii; warm seas.

\section{Family CARAYGIDE.}

\section{SCOMBEROIDES Lacépède.}

408. Scomberoides sanctipetri (Cuvier \& Valenciennes). Lai. Hawaii; Samoa; Kingsmill I.; Tahiti; Johnston I.

This widely diffused species is rather common about Samoa and Hawaii. A few specimens were taken in the channels of Apia.

409. Scomberoides tolooparah (Rüppell). Hawaii; New Ireland; Vanicolo; New Guinea (Nacleay); East Indies.

410. Scomberoides lysan (Forskảl). New Guinea (Macleay).

SERIOLA Cuvier.

411. Seriola purpurescens Schlegel. Hawaii; Japan.

412. Seriola sparna Jenkins. Hawaii.

\section{NAUCRATES Rafinesque.}

413. Naucrates ductor (Linnæus). Hawaii; Japan; warm seas.

\section{ELAGATIS Bennett.}

414. Elagatis bipinnulatus Quoy \& Gaimard. Hawaii; Iles des Papous; New Britain (Peters); Solomon Is. (Seale); East Indies; West Indies.

\section{MEGALASPIS $\because$ Bleeker.}

415. Megalaspis cordyla (Linnæus). Atualo. Samoa; East Indies.

Common in the open channels in the reef.

\section{DECAPTERUS Bleeker.}

416. Decapterus pinnulatus (Eydoux \& Souleyet). Hawaii; Raiatea; Tahiti; Bonin Is.; Panmotu Is.

(Decapterus canonoides Jenkins.)

This species is different from Decapterus muro-adsi of Japan, and apparently also distinet from Decaptemes sunctichelene of the Atlantic.

417. Decapterus lundini Jortan \& Seale, new species. Samoa.

Hear 3.75 in length; depth 3.20 ; eye 4 in head, 1.20 in snout; dorsal YT-T, 21-1; anal II, 21-1; scales small, 95 in lateral line, of which $₫ 5$ are modified with plates; interorbital, 4 in head; maxillary, 3 , reaching to below the anterior margin of eye, all but its posterior third hidden under the preorbital.

Body elongate, compressed, fusiform; scales covering entire body and head; adipose erelid well developed, covering entire eye except width of pupil; small teeth in single series on jaws and palatines, slightly enlarged teeth on vomer; very minute teeth on tongue: gillrakers shorter than width of eye, 24 on lower limb; preopercle entire, opercle with small rounded nick on upper margin; base of dorsal slightly greater than anal, its longest ray 1.85 in head; first ray of anal 2 in head;

a The name Mcyalaspis Blecker dates from 1851. At about the same time Angelin gave the same name to a genus of Trilobites. As to this Dr. Stejneger observes (in lit. Dec. 16, 1901): "Two struws point to the Trilobite's being the younger name. Bleeker's Jegalaspis is mentioned in the 'Leistungen' for 1S51. Angelin's name is not mentioned in the 'Leistungen' 'until 185:-3.'" There is also doubt for other reasons whether Angelin's paper appenred before $185 \%$. We therefore retain Megalaspis for the genus of fishes. 
pectoral 3.10 in length, extending to below the 8 th dorsal ray; ventral 2 in head; caudal slightly less than head, 4.50 in length; depth of caudal peduncle, 2 in its width (with keels).

Color in spirits, silvery with wash of yellowish below, darker above, with about nine indistinct vertical brown bands as wide as eye and slightly greater than the interspaces on sides of body, fading out below lateral line; a distinct black opercular spot; a dusky wash on inner axil of pectoral; a dusky blotch on tip of snout and tip of lower jaw; a golden wash on preopercle; dorsal and anal yellowishwhite with narrow dusky margin; pectoral, ventral, and caudal yellowish-white.

One specimen, type no. 51727, U. S. National Museum, from Pago Pago, length 7.25 inches, taken in a school of the common "atule" (Trachurops).

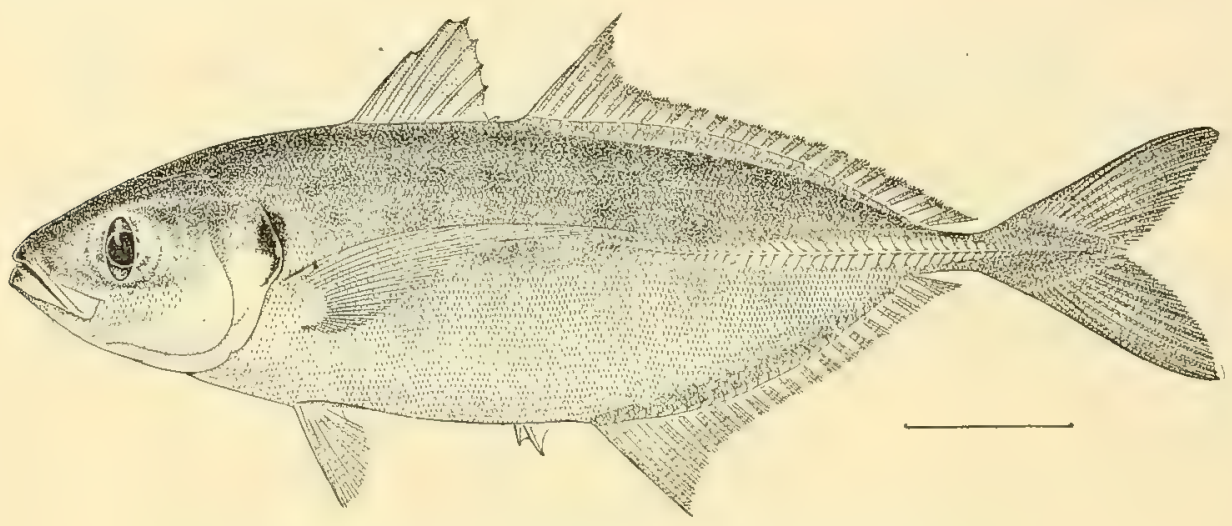

Frg. 27.-Decapterus Lundini Jordan \& Seale, new species, Type.

TRACHUROPS Gill.

In this genus there is much variation in the size of the eye. In mauritiana (=torva) the eye is smaller than in crumenophthalma. In the Japanese form it is still smaller. We can not yet clearly define these forms as different species.

418. Trachurops crumenophthalma(Bloch). Atule. Samoa; Hawaii; Tahiti; Solomon Is.; New Hebrides; Marquesas Is. ; and Rarotonga (Seale); all warm seas.

This species is the commonest food-fish of Samoa, entering the harbors in great schools. The flesh is excellent. There is apparently no difference between Trachurops torva and the common $T$. crumenophthalma of the Atlantic.

CARANX (Commerson) Lacépède. (Including Carangus Griffith = Tricopterus Rafinesque, 1810.")

419. Caranx lugubris Poey. Kingsmill Is.; Rarotonga; Marquesas Is.; Tahiti and Solomon Is. (Seale); West Indies; Clarion Island; St. Helena.

420. Caranx melampygus Cuvier \& Valenciennes. Malanli. Hawaii; Samoa; Marcus I.; New Guinea; Waigiu; Rawak; Austral Is.; Solomon Is. and New Hebrides (Seale); Clarion Is.; East Indies.

This species is the finest of the commoner food-fishes of Samoa, being especially excellent as chowder. It is abundant in the channels between the reefs, reaching a large size. Several scores of specimens were taken, a few being preserved.

Life colors of a specimen from Pago Pago, body light olive with darker olive spots; fins deep clear blue.

421. Caranx thompsoni Seale. Hawaii.

422. Caranx forsteri Cuvier \& Valenciennes. Ulua. Samoa; Hawaii; Papua; Vanicolo; New Ireland; New Guinea; Tanna; Tahiti (Seale); East Indies.

The earliest name for the ulua seems to be that of Curanx forsteri. According to Sauvage (Poiss. Madagascar) the types of Caranx sem and Caranx lessoni have the breast naked. These must then go 
into the synonymy of Carangus ignobilis. Caranx kleini (Bloch), as Dr. Klunzinger has pointed out, is not the ulua, but some one of the species found in Hindustan. Caranx sexfasciatus is the banded species of the river mouths called Carangus rhabdotus by Jenkins. The name Caranx hippos has no pertinence to this species, having been based on a specimen of "Caranx carangus" from South Carolina. Saurage recognizes Carangus forsteri as a species distinct from the ulua, but his figure of the type shows no differential characters. Caranx perani and Caranx belengeri of Cuvier and Valenciennes are also based on the uluci.

In life the ulua is easily recognized by its yellow pectoral, the anal lobe being dusky, and the dorsal not edged with black. The breast is fully scaled. Carangus marginatus is similar, but has the dorsal edged with blackish. Carangus ignobilis, like Carangus hippos of the Atlantic, has the breast naked except for a small central patch. The anal lobe is bright yellow, the pectoral pale. As a foodfish Carangus forsteri, the ulua, and Carangus melampygus, the malauli, are far stoperior to all others of this genus in the Pacific. Caranx latus (fallax) of the Atlantic is a closely related but distinct species. We adopt for the ulua, provisionally, the name of Caranx forsteri, as it seems to be the oldest properly applied to the species.

The ulua is the food fish par excellence of the mid-Pacific, both in Samoa and Hawaii. It reaches a large size, similar to that of the malauli, and it is scarcely less common than the atule. Hundreds of specimens were taken in Samoa, and a few preserved.

A specimen from Pago Pago in life had the anal dark, pectoral yellow in the young, growing dull with age; body green, with biue specks, the fins with blue-black luster. Dorsal rays 23 or 24; body deep; preorbital deep; breast scaly; fins high; no opercular spot.

One specimen from Apia in life had the pectoral bright yellow, anal dark; another was pale bluish silvery, the vertical fins all dusky, the pectoral bright yellow, ventral slightly dusky. Eye small; plates small.

423. Caranx marginatus (Gill). Hawaii; Samoa; west coast of Mexico and Panama.

Two species from Samoa seem to be referable to this species. Possibly Caranx heberi Bennett, from Ceylon, is the same species.

424. Caranx ignobilis (Forskål). Lupo. Samoa; Hawaii; New Guinea (Macleay); East Indies. (Carangus hippoides Jenkins; Caranx sem, ckala, lessoni, atanthopygus, etc., Cuvier \& Valenciennes.)

Frequently taken about Samoa.

425. Caranx sexfasciatus (Quoy \& Gaimard). Lupo. Hawaii; Samoa; Vanicolo; Waigiu; Java.

This species, recently described as C. rhabdotus Jenkins from Hawaii, is common in the mouths of the streams of Upolu, especially the sluggish stream called Gasegase River, ascending even into the smaller brooks. One specimen was taken by us in salt water, and this has lost the cross bands and some part of the peculiar dusky shade of the others, although even in this the caudal plates are of a watery blackish color. About a dozen specimens were taken. The cross bands, rery distinct in the young, grow faint with age.

This species seems to be the one figured by Quoy and Gaimard under the name of Caranx sexfasciatus. Jenkins's figure of Caranx rhabdotus represents it very fairly, and we are forced to believe that the two are the same species. From Caranxignobitis, which has also the anal fin yellow, Caran $x$ sexfasciatus differs in having the breast entirely scaled. In Caranx ignobilis the breast is naked, with a small central patch of seales as in Caranx hippos of the West Indies. Caranx forsteri has more anal rays and more ( 30 to 33 ) lateral plates. The mouth is larger in Caranx sexfasciatus than in Caranx forsteri or any other of the related species. Caranx forsteri shows no cross bands at the size $(4$ to 8 inches) of our specimens of Caranx sexfasciatus.

Life colors of a specimen from Gasegase River, at Apia, dark brassy with a transparent blackish wash, as usual in fishes from muddy water; 6 broad darker cross bands; a black opercular spot; no pectoral spot; anal dull yellow, the lobe not sharp; upper fins dark. Another specimen from Apia had the pectoral pale, anal yellow. A specimen from fresh water near Vailele, Upolu, in life had the body barred, an opercular spot, upper fins dusky, lower dull yellow. In a specimen from the swamp at Pago Pago the anal fin was bright yellow, caudal not so.

426. Caranx dasson Jordan \& Snyder. Hawaii.

427. Caranx elacate (Jordan \& Lvermann). Hawaii. 
428. Caranx regularis Garman. Fiji.

Caranx regularis Garman, Bull, Mus. Comp. Zool., rol. xxxıx, no. 8, 1903, 232, Fiji.

429. Caranx parasitus Garman. Fiji. Caranx parasitus Garman, Bull. Mus. Comp. Zool. vol. $\operatorname{xxxxx,~no.~8,~1903,~232,~Fiji.~}$

430. Caranx boops Cuvier \& Valenciennes. New Guinea; Vanicolo; East Indies.

431. Caranx novæ-guineæ Cuvier \& Valenciennes. New Guinea.

432. Caranx affinis Rüppell. Hawaii; East Indies.

433. Caranx hasselti (Bleeker). New Guinea (Macleay); Hawaii; East Indies. (Carangus politus Jenkins.)

A specimen of Carangus hasselti from Negros in the Philippines agrees in every respect with Jenkins's account of Carangus politus.

434. Caranx helvolus (Forster). Tahiti(?); Hawaii.

This species, obtained by Forster on the second cruise of Captain Cook, was rediscovered by Professor Snyder in 1901.

435. Caranx cheilio (Snyder). Hawaii.

436. Caranx papuensis Alleyne \& Macleay. New Guinea. Caranx papuensis Alleyne \& Macleay, Proc. Linn. Soc. N. S. W. 1876, 325.

437. Caranx platessa Cuvier \& Valenciennes. New Guinea (Alleyne \& Macleay); Australia. (Caranx georgianus Cuvier \& Valenciennes, )

438. Caranx bucculentus Alleyne \& Macleay. New Guinea.

439. Caranx moresbyensis Macleay. New Guinea. Caranx moresbyensis Mracleay, Prcc. Limn. Soc. N. S. W. 1883, 3ñs, Port Moresby (New Guinea).

440. Caranx obtusiceps (Macleay). New Guinea.

441. Caranx cheverti Alleyne \& Macleay. New Guinea.

442. Caranx laticaudus Alleyne \& Macleay. New Guinea.

143. Caranx cæruleopinnatus Cuvier \& Valenciennes. New Gninea.

444. Caranx ferdau (Forskål). Lupo. Samoa; Haraii; Tahiti; Bonin Is. ; East Indies.

This species is not rare about Hawaii and was frequently taken at Samoa, where it is valued as a food fish.

445. Caranx ajax (Snyder). Hawaii.

446. Caranx gymnostethoides Bleeker. Johnston I., south of Hawaii; East Indies.

447. Caranx speciosus ${ }^{a}$ (Forskảl). Hawaii; Samoa; New Guinea; Fiji; East Indies; Panama.

Not rare about Hawaii, and occasionally taken at Pago Pago. Life colors of a specimen from Pago Pago, green-golden with green iridescence; black transverse bars on head (through eye), next one blackish; others simply dark, fading posteriorly; candal with blackish tips and margin.

448. Caranx edentulus Alleyne \& Macleay. Perey I., New Guinea.

449. Caranx armatus (Forskål). New Britain; New Guinea (Peters, Alleyne \& MIacleay); East Indies.

450. Caranx oblongus (Cuvier \& Valenciennes). Vanicolo; Oualan; New Britain; Solomon Is.; Sumatra.

This species, as jriginally described, has the anal rather low, the opercular spot wanting, the plates on the tail about 40 . It is not clear that all the above references belong to it, although specimens from Sumatra, recorded by Mr. Fowler as Citula oblonga, agree fairly with the original account.

a The genus Caran $x$ was originally based on C. speciosus, a species without teeth in the adult stage. Carangus has small even teeth; Tricopterus, larger, unequal teeth, and Citzla, the dorsal rays produced, the teeth being very small. For the present we place all these spccies in asingle genus, caranx, as the subdivisions need better definition. 
451. Caranx plumbeus (Quoy \& Gaimard). Lupo; Lupo ta; Lalafutu; Alälafutu. Ile de France; Samoa.

Head 3.25 in length; depth 2.18; dorsal VI-I, 22; anal II-I, 18; eye 3 in head; snout 2.75; maxillary 2.18, extending to below anterior margin of eye; 43 plates along straight portion of lateral line, the curved portion a third longer than the straight.

Body oblong, compressed; profile of head gibbous aud keeled; anterior dorsal and anal rays elongate (male fishes have 9 and 10 dorsal rays and 7 and 8 anal rays elongate), the first dorsal ray being greater than depth of fish, 2 in length. The first anal ray is 2.75 in length; base of anal about equal to pectoral, which is 2.75 in length of fish; base of dorsal 2.20 in length; candal deeply forkerl, the lobes slightly longer than head; ventrals 2 in head; operele with small rounded nick on upper margin; scales of body small, about 100 in curved portion of lateral line; thorax naked; cheek scaled and upper part of opercle scaled; bands of minute teeth in jaws, vomer, palatines and middle of tongue; a narrow adipose eyelid; preorbital less than width of eye; mouth large, lower jaw slightly the longer; gillrakers strong, two-thirds length of eye, 16 on lower limb.

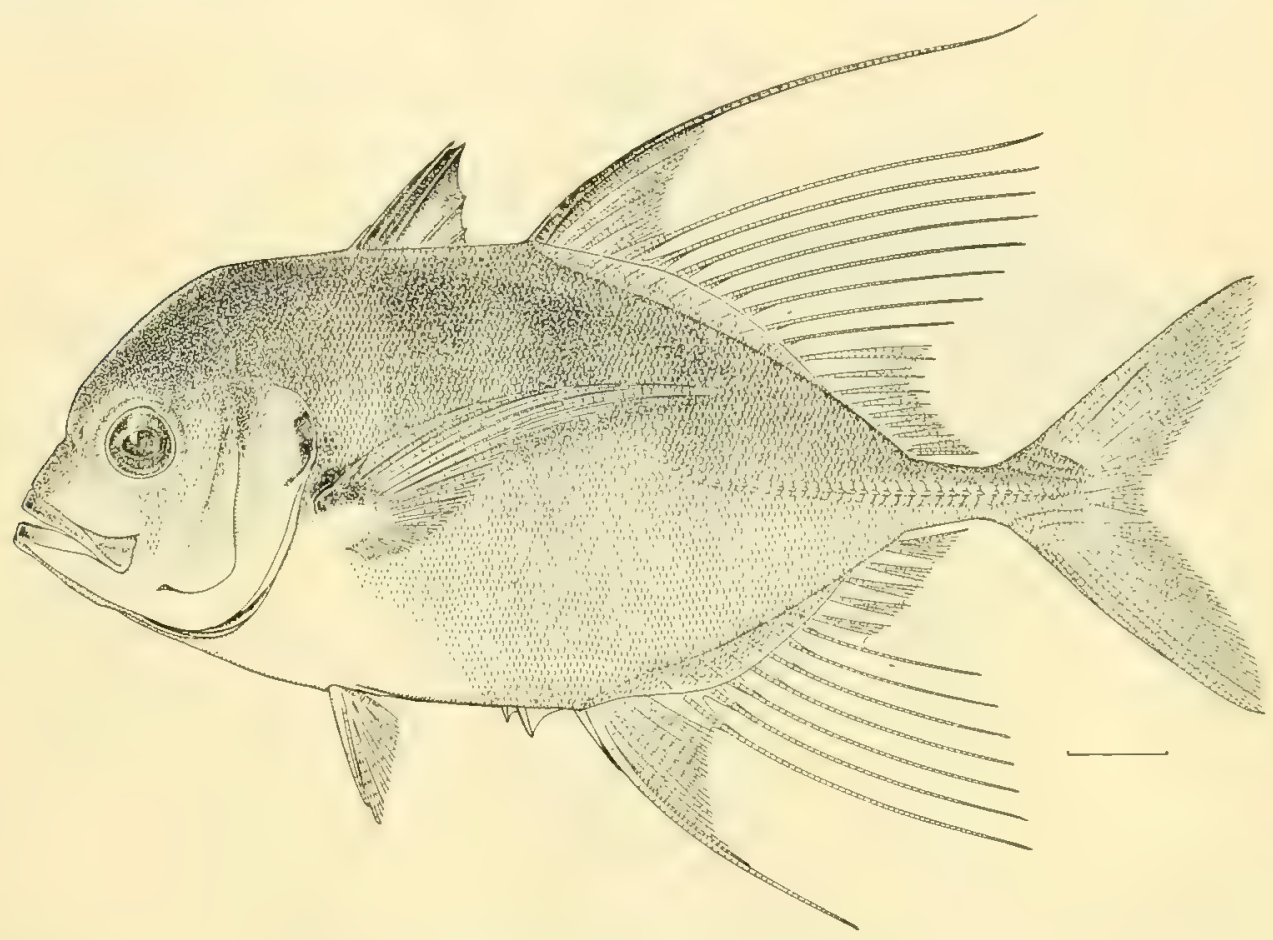

FIG, 28.-Caranx plumbeus (Quoy \& Gaimerd).

Color in spirits silvery bronze, the scales with beautiful iridescence, slightly darker above, some specimens showing slight indications of five or six wide vertical brown bands on upper half of hody; a black opercular spot; a large black spot in axil of pectoral, extending on its upper base; cheek more or less blotched with golden; an indistinct dusky blotch on upper part of preopercle between the black opercular spot and eye; spines of dorsal dusky; margin of dorsal and its elongate filaments dusky; caudal with indistinct dusky margin; pectoral, ventral, and anal yellowish white, the anal showing a slight dusky wash on webs.

A specimen from Apia in life was silver-green, bluish below; axil black; opercular spot faint olive; caudal dull yellow; anal and ventral whitish, slightly olive-tinged. Dorsal and anal with one filament only. In others of the same species, males, there are numerous filamentous rays on the clorsal and anal fins.

This species belongs to the subgenus Cilula. We have 5 specimens, $t$ male and 1 female, takcn in the seine at Apia and Pago Pago. The description is that of a male 12.50 inches long. 
Citula plumbea Quoy \& Gaimard from Ile de France, with the fin-rays as in our specimens and the depth nearly 3 in total length, is apparently identical with the species in hand. Caranx armatus (Forskâl) may be the same, but the body is deeper in some specimens called. Caranx armatus than in our specimens from Samoa, which we record provisionally as Caranx plumbeus. In Caranx armatus the depth is 2 to 2.5 in total length.

452. Caranx mandibularis Macleay. New Guinea.

Caranx mandibularis Macleay, Proc. Linn. Soe. N. S. W. 1883, 356, New Guinea.

This species belongs to Citule, having the first dorsal ray very long.

453. Caranx gilberti Jordan \& Seale, new species. Samoa.

Head 3.60 in length; depth 2.20; eye 4 in head, 1.10 in snout; interorbital 2.95 in head; dorsal VI-I, 33; anal II-I, 29; scales minute, 143 on lateral line, 25 of which are modified into plates of moderate size; maxillary 2.50 in head, extending to below anterior margin of eye.

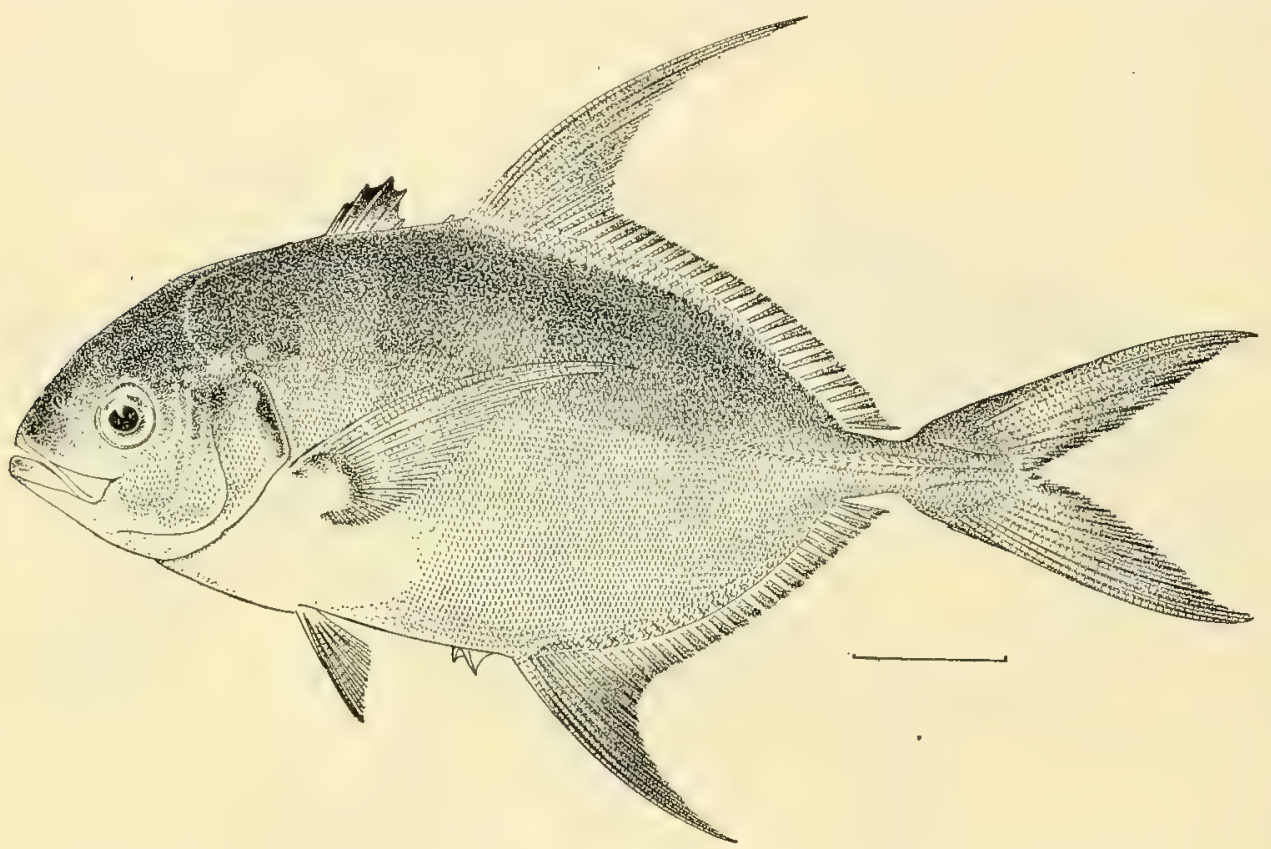

Fig. 29-Caranx giberti Jordan \& Seale, new species. Type.

Body ovate, strongly compressed, shaped as usual in Caranx, the upper profile more ovate than lower; anterior lobes of dorsal and anal falcate, elongate and graduated, the anterior ray of dorsal longer than head, 3 in length (without caudal), anterior ray of anal equal to head; base of dorsal slightly greater than anal; pectoral reaching to below straight portion of lateral line, its length equal to base of anal, 2.75 in length of fish without caudal; length of caudal slightly less than pectoral; ventrals 2 in head; teeth in villiform bands on vomer, palatine, and tongue; jaws with patches of minute teeth in front and a single series on side, no enlarged outer teeth; gillrakers less than width of eye, 14 on lower limb; preopercle entire; opercle with slight rounded nick above; eye with adipose membrane slightly developed; head and body scaled, except thorax, which is naked; dorsal and anal enveloped in rather high shields.

Color in spirits, silvery with slight brassy tint, darker above; dorsal, anal, and caudal with slight dusky wash. There is a narrow black margin to caudal and a black line on margin of dorsal; pectoral and ventral yellowish white.

One specimen, type no. 51729, U. S. National Iuseum, from Pago Pago, island of Tutuila, length 8.50 inches. 


\section{ALECTIS Rafinesque.}

454. Alectis ciliaris (Bloch). Hawaii; Samoa; New Ireland (Peters); Tahiti; Palau Is.; Kingsmill I. New Guinea; Solomon Is.

Of this widely distributed species, we have several small specimens from Apia.

\section{TRACHINOTUS Lacépède.}

455. Trachinotus ovatus (Linnæus). Mlälafutu. Samoa; New Hebrides; New Guinea (Macleay).

Of this widely diffused species, we have three examples from Apia, one very large, nearly 2 feet in length. Life colors of one of these specimens gray, back tinged with creamy bronze; dorsal dark, the lobe largely covered with creamy bronze; ventral, anal, belly, and lips still more orange; tail black. Specimen from Pago Pago; lobes of dorsal, anal, and caudal black, washed with creany orange; ventral and anal lobe largely orange.

456. Trachinotus bailloni Lacépède. Samoa (Günther); New Hebrides; Tahiti; New Britain (Peters); New Guinea (Macleay).

This species, recorded from Samoa with the preceding, was not taken by us.

457. Trachinotus russelli Cuvier \& Valenciennes. New Guinea; East Indies. Trachynotus coppingeri Günther, Zool. Alert, 1884, 29, Percy I. (New Guinea), in Cloudy Bay.

\section{Family CORYPHÆNIDE.}

\section{CORYPHæNA Linnæus.}

458. Coryphæna hippurus Linnæus. Hawaii; warm seas.

459. Coryphæna equisetis Linnæus. Between Tahiti and Hawaii; warm seas.

$$
\text { Family BRAMIDE. }
$$

TARACTES Lowe.

460. Taractes orcini (Cuvier \& Valenciennes). South seas; Indian Ocean.

COLLYBUS snyder.

461. Collybus drachme Snyder. Off Hawaii.

\section{Family PSENIDA}

\section{PSENES Cuvier.}

462. Psenes javanicus Cuvier \& Valenciennes. Guam; East Indies.

(Psenes guamensis Günther.)

\section{CUBICEPS LOWO.}

463. Cubiceps pauciradiatus Günther. Misol.

Cubicepr pauciradiatus Günther, Ann. Mag. Nat. Hist, 1872, 423, Misol. Regan, Ann. Mag. Nat. Hist. 1902, 123.

\section{ARIOMMA Jordan \& Evermann.}

464. Ariomma lurida Jordan \& Evermann. Hawaii.

465. Ariomma evermanni Jordan \& Snyder. IIawaii. 
Family ICOSTEIDA.

SCHEDOPHULUS Cuvier.

466. Schedophilus medusophagus Cocco. Off Samoa (Günther).

Family STROMATEIDA.

LEIRUS Lowe.

467. Leirus maculatus (Günther). South Seas.

468. Leirus paucidens Günther. Between New Guinea and Japan. Lirus paucidens Günther, Pelagic Fishes Challenger, 1888, 11, open sea north of New Guinea.

\section{Family RACHYCENTRIDE.}

RACHYCENTRON Kaup. (Elacate Cuvier.)

469. Fachycentron pondicerrianum Cuvier \& Valenciennes. Vanicolo; East Indies.

Family ANOMALOPIDE.

ANOMALOPS Knex. (Heterophthalmus Bleeker.)

470. Anomalops palpebratus Kner. Fiji; Paumotu Is.;. Celebes.

Family PEMPHERIDA:

PEMPHERIS Cuvier.

471. Fempheris oualensis Cuvier \& Valenciennes. Manifi; Fo a'ao. Oualan, or Strong Island; Tahiti; Guam; Vanicolo; Samoa; Kingsmill I. ; Caroline Is.; New Guinea (Macleay).

Pempheris oualensis Cuvier \& Valenciennes, Hist. Nat. Poiss, vit, 299, 1881, Oualan.

Pempheris otaitensis Cuvier \& Valenciennes, op cit., VII, 304, 1831, Tahiti. Günther, Cat., II, 568, China, Amboyna. Kner, Novara Fische, 171, Java. Günther, Fische der Siidsee, 102. Seale, Bishop Museum 1901, 74, Guam. Saurage, Poiss. Madagascar, 286, Tahiti.

Pempheris mangula Günther, Fische der südsee, 102, taf. 59, fig. B, Samoa, Vanicolo, Kingsmill I., Caroline Is, Tahiti; not of Cuvier \& Valenciennes.

Of this species, sharply distinguished by the presence of a large black spot on the base of the pectoral, we have about a dozen fine specimens from Samoa. Life colors of a specimen from Apia, dirty olive, sides silvery; dorsal dirty olive, its anterior rays black; caudal pale within, the outer rays dirty dull red; anal gray, its base blackish; pectoral reddish, the anterior rays quite red, its base jet black; ventral gray; axil jet black; body with some violet luster.

472. Pempheris vanicolensis Cuvier \& Valenciennes. Pula. Vanicolo; Samoa; Ile de France.

pempheris vanicolensis Cuvier \& Valenciennes, Hist. Nat. Yoiss., viI, 305, 1831, Vanicolo.

Pempheris nesogallica Cuvier \& Valenciennes, op. cit., viI, 306, 1831, lle de France.

Three specimens taken in the seine at Apia. This species is well distinguished by the entire absence of black on the base of the pectoral. Depth 2.2 in length. We see no reason for aupposing this species to be identical with the Indian species Pempheris mangula.

Life colors of a specimen from Apia, coppery black; dorsal and anal pale, the lobes tipped with jet black; pectoral golden; ventral orange, blackish at base; no spot at base of pectoral.

\section{Family SCORPIDE. \\ MONODACTYLUS Lacépède.}

Monodactylus Lacépède, Hist. Nat. Poiss., III, 131, 1802 (falciformis).

Centropodus Lacépède, op. cit., IIx, 303, 1802 (rhombeus=argenteus).

Acanthopodus Lacépède, op. cit., Iv, 558, 1803 (argenteus).

Psethus Cuvier (argenteus).

This genus is distinguished from Psettias Jordan, new genus (sebx) by the rounded outline of the body, which is not deeper than long. In Psettias it is very much deeper than long. 
473. Monodactylus argenteus (Linnæus). Toto. Samoa; New Guinea; Vanicolo; Fiji; East Indies; Australia.

Chxtodon argenteus Linnæus, Syst. Nat., ed. X, 1758, China; after Lagerstrom. Günther, Cat., II, 488, Moluccas, Amboina, Ceylon, Australia.

Psettus argenteus, Günther, Fische der Südsee, 140, Samoa. Klunzinger, Fische Roth. Meeres, 794, Red Sea.

Scomber rhombeus, Forskîl. Descrip. Anim., 58, 1775, Red sea.

Monodactylus falciformis Lacépède, Hist. Nat. Folss., IIr, 131, 1802.

Psettus commersoni Chvicr \& Valenciennes, Hist. Nat. Poiss, Vr, 250, 1831, Vanicolo; after Lacepède.

This species, common in the East Inlies, was found rather abundant in the harbor of $A$ pia in the deeper water between the reefs. Eight specimens were taken. It is a valued food-fish.

Life colors of a specimen from Apia, silvery white with some dusky; a faint orbital bar. Young with three curved blark cross tars on the head.

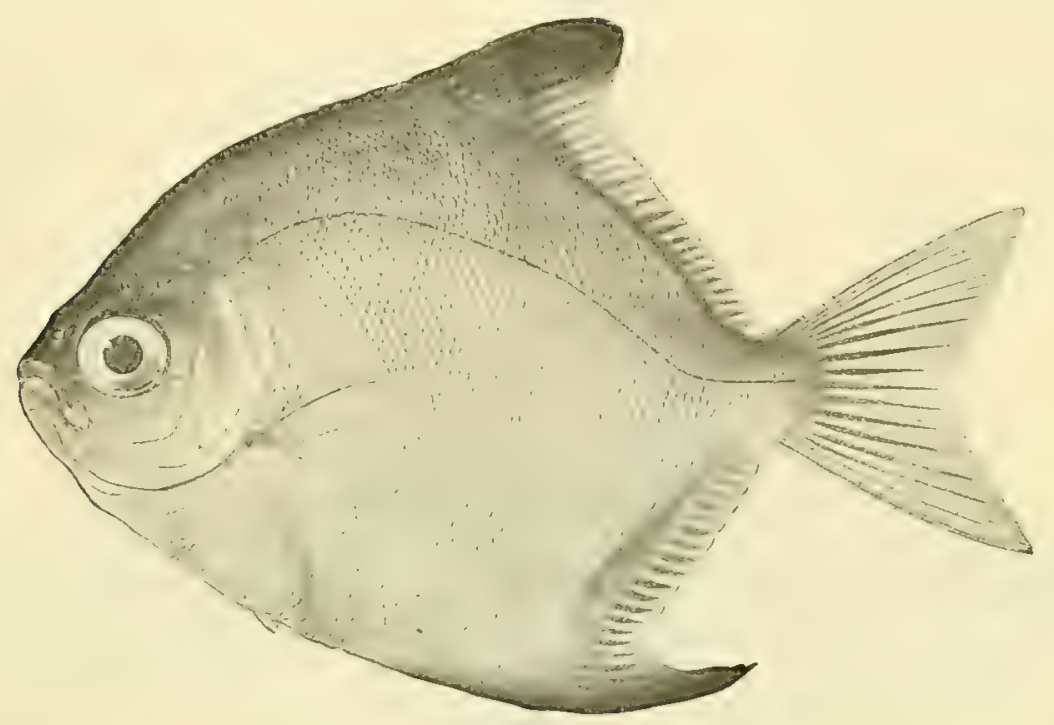

FIG. 30.-Monodactylus argentcus (Linnæus).

ATYPICHTHYS Günther.

474. Atypichthys strigatus (Günther). Erromango, New Hebrides; Palacky; Australia.

\section{Family KURTID \&.}

\section{KURTUS Bloch.}

475. Kurtus gulliveri Castelnau. New Guinea.

K̈urtus gulliveri C'astelnau, I'roc, Nat, Hist, Soc, Victoria, New Guinea.

Cyrtus gulliveri, Ramsay \& Ogilby, Proc. Linn. Soc. N. S. W., 18ะ6, 10, Strickland River (New Guinea).

\section{Family APOGONICHTHYIDE.}

AMIA Gronow ( 1763$)$, (Apogon Lacépède, 1802.) Fo.

476. Amia snyderi (Jordan \& Evermann). Hawaii; Samoa; Tahiti; I'aumotu Is.; Tubuai; Faté, Shortland I., and Raiatea (Seale).

Apogon snyderi Jordan \& Evermann, Bull. U. S. Fish Comm., xxIr, 1902 (1903), 180, Honolulu.

Aporon ficnalus Günther, Fische der Sudsce, I, 19, taf, 19, fig. A, 1873, Hawaian, Suciety, and Paumotu Is, Steindachner, Denks. Ak. Wis. Wien, Lxx, 1900, 48t, Honolulu. Not Apogon frenatus Valenciennes, Nouv. Ana. Mus. Nat. Ifist., 1832, 57 , pl. 4, fig. 4, nor of Klunzinger.

"Under the rules of nomenclature adopted by us the name Amia Gronow (1763) becomes tenable Ior this genus, having priority over Apogon (1802) and over Amia Linmeus (1766), for which genus Rafinesque's name, Amiatus (1815), must be used. 
This large species is very common about the Samoan Islands, as also about Hawaii. We have about 40 specimens from Apia and Pago Pago. The dark spot at base of caudal above is usually distinct, though varying much in degree of definition. There is a more or less evident lateral shade, but never sharply defined.

Life colors of a specimen from Apia, brownish red; sides washed with clear light green, the edges of scales brownish red; a diffuse black bar at base of caudal, forming a pretty distinct rounded spot above lateral line and extending backward on edges of both caudal lobes; a faint dark shade from snout across eye, with a darker bloteh on opercle and a rounded spot behind eye; a dusky shade on siff from eye to tail on larger specimens; axil dull reddish hrown; fins all dull reddish brown; first foral black on anterior spines; second dorsal and ventral dusky shaded.

477. Amia frenata (Valenciennes). New Guinea; Guam.

Apogon frenatus Valenciennes, Nouv. Ann. Hist. Nat, I, 57, 1832, with plate, New Guinea, Guam.

This species we have failed to recognize. It is close to our Amia exostigma, differing in the narro lateral band, and in the more diffuse caudal spot, which is at the end of the lateral band. It is more remote from Amia snycleri, which has the lateral stripe fainter, broader, and more diffuse.

478. Amia exostigma Jordan \& Starks, new srecies. Samoa.

Head 2.75 in length; depth 3.3; eye 3 in head; interorbital width 5; snout 3.75; maxillary 2.25; audal peduncle 2.67 ; dorsal vII-x, 9 ; anal II, 9; scales 2-25-5.5.

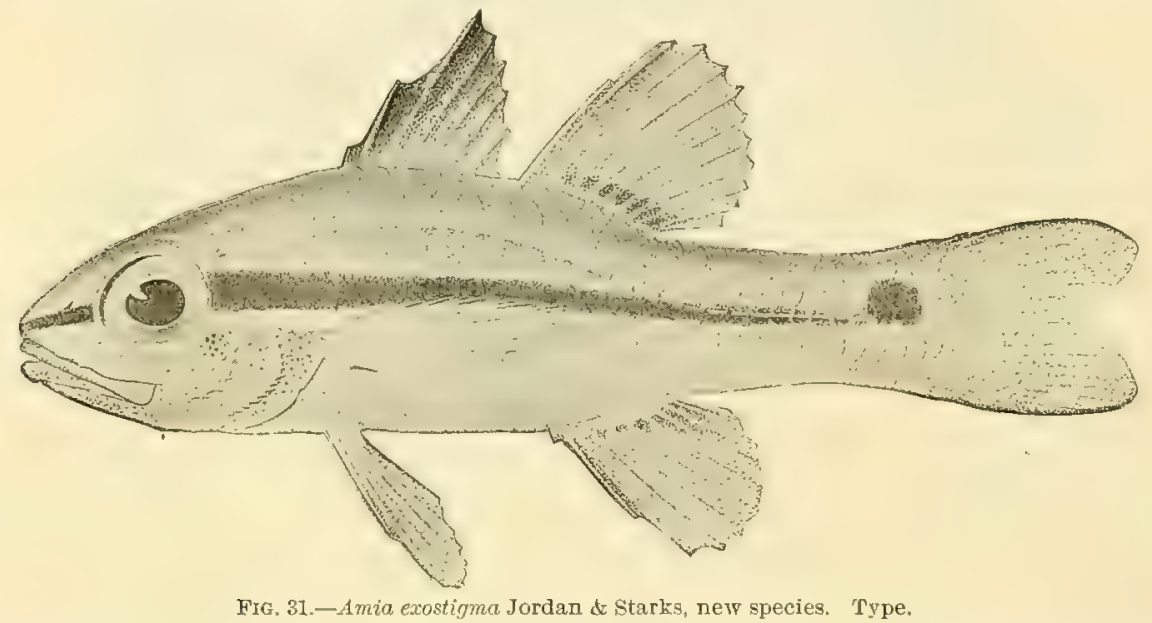

Body slender; upper anterior profile a slight, even, unbroken curve from tip of snout to first dorsal spine; snout blunt, and projecting very slightly beyond the maxillary; maxillary extending to below middle of eye, its anterior end projecting a very little beyond tip of lower jaw; teeth in moderately wide bands on jaws, in a narrower $V$-shaped patch on vomer; rather large spines on both posterior edges of preopercle, those near the angle larger, all of them directed backward; gillrakers rather slender, the longest one-third the diameter of the eye, $4+1 \pm$ in number, about 4 of which are represented by tubercles on the anterior end of the lower limb.

Scales every where ctenoid, the marginal denticulations fine and close-set, preceded by many short spinules regularly placed, forming a moderately wide band around the posterior border of each scale. Third dorsal spine longest, its length equal to distance between tip of snout and posterior margin of pupil; when fin is depressed its tip reaches a little past front of soft dorsal; first spine very short, 5 in eye; the second spine midway between these two spines in length; second dorsal with a long spine equal in length to the second dorsal base; second dorsal ray the longer, equal to length of head anterior to anterior preopercle margin; second anal spine a little longer than diameter of eve; anal placed a little posterior to soft dorsal; ventrals scarcely reaching to front of anal; pectoral reashing to above base of second anal spine.

Color in life of a specimen from Pago Pago, light olive; jet black band from snout through eye, fading behind; just above this stripe at base of caudal a round, jet black spot as large as pupil; fins 
dull reddish; first dorsal spine black; a dark streak on base of dorsal and anal and upper and lower caudal lobes; cheek and breast soiled silver.

Color in alcohol, slightly dusky with fine dots; scarcely darker on back; a black lateral band from tip of snout across eye, but not involving eye, tapering backward to base of middle caudal rays; widest just behind eye; a conspicuous round black spot on caudal peduncle at base of caudal rays, just above lateral line; a short light stripe with violet reflections on opercle bordering black lateral stripe, below which opercle is silvery with violet reflections; upper and lower margins of caudal bordered with black; dusky shades at base of soft dorsal and anal.

Eight specimens from Apia and Pago Pago. This species is very close to Amic frenata and $A$. melunorhynchus, differing in having the very distinct caudal spot above the termination of the jet black lateral band and entirely separated from it, the band growing very faint before reaching the base of the caudal.

The lateral band is in this specie; very broad anteriorly, almost as broad as the eye, while in Amic frenata this band is narrow. In Imia snyderi, also a closely related species, the lateral band and its terminal spot are broad and diffuse.

The type is from Apia; it is 3 inches in length, and is no. 51732, U. S. National Museum.

479. Amia menesema (Jenkins). Hawaii.

480. Amia crassiceps (Garman). Fiji; Samoa.

Apogon crassiccps Garman, Bull, Mus, Comp. Zool., 19c3, Suva (Fiji).

One large specimen taken at Apia.

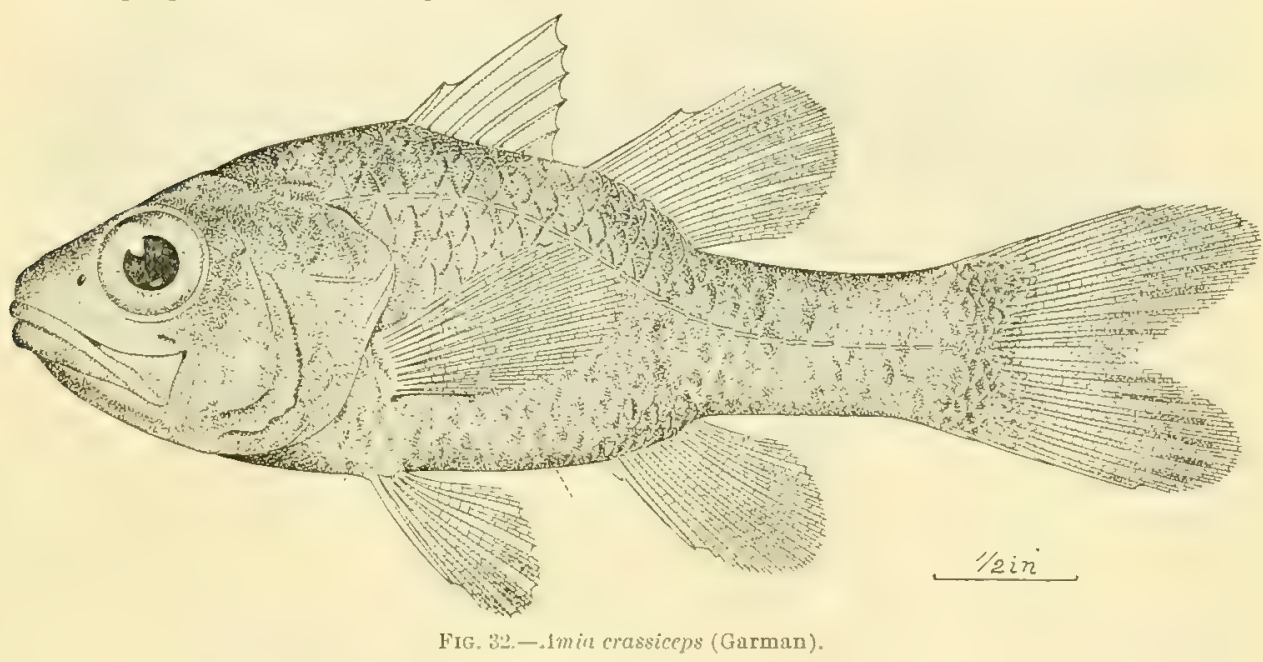

481. Amia evermanni (Jordan \& Snycler). Hawaii.

482. Amia orbicularis (Cuvier \& Valenciennes). Radack I.; East Indies.

483. Amia guamensis (Valenciennes). Guam. Apogon guamensis Valenciennes, Ann. Mrus, Nat. IIist., I, 55, 1831, Guam.

A deep-bodied, plain-colorer species with large head and one limb only of the opercle serrate; candal notehed. This species may be the same as A. crassiceps.

484. Amia savayensis (Günther). Savaii, Samoa; Tonga; Yap; Tahiti; Fiji; Faté; Shortland I. and Raiatea (Seale); East Indies.

Apngon ravayensis Günther, Proc. Zool. Soc. 1871, 656, Savaii (Samoa). Günther, Fische der Südsee, 21, taf, 19, 'fig. 3, Samoa, Tonga, Jap, Tahiti, Celebes. Seale, Bishop Mus, 1901, Fishes Guam, 76, Guam

Aprogon bandancmsis Steindachner; not of Bleeker, who has wrongly identified savayensis with bandancnsis,

Apogon fuscus Güntber, Fische der Süsee, 22, Fiji.

Apoyon nubilus Garman, Bull. Mus. Comp. Zool, 1903, Suva (Fiji).

This species is very common about the Samoan Islands. We have about 100 specimens from Apia and Pago Pago. Ordinarily the color markings are very distinct. There is an oblicue black streak 
backward and downward from eye; about eight vertical silvery stripes on the side between pectoral and region above middle of anal; a blackish saddle on caudal peduncle, and a black and white stripe on each edge of caudal. In some specimens, however, any or all of these marks may be reduced to mere traces. The silvery cross-streaks, the most characteristic of these traits, were wanting in Gïnther's types. Apparently the specimen called by Günther Apogon fuscus was one in which all the marks were obliterated. It is certain that this is not the fuscus of Quoy and Gaimard, which has the caudal rounded and blotched with black. Bleeker is certainly wrong in regarding saxayensis as the same as Amia bandanensis. Garman's Apogon nubilus is apparently the young of this species with the markings faded, although more distinct than in Günther's type.

Color in life of a specimen from Pago Pago, dusky olive, with seven narrow dull silvery crossstreaks, each dark-edged on each side; other fainter streaks curved behind; a dusky saddle on caudal perluncle, another under soft dorsal; fins dull red, first dorsal anteriorly black; a dark streak along each caudal lobe; a dusky streak behind eye.

A specimen from Apia in life was brownish olive; side with seven pinkish-white cross-streaks, each edged with brown; an oblique brownish olive bar below eye; a jet black saddle on back of tail; first dorsal blackish; other fins light brownish red; a black streak edged with orange down each lobe of the caudal; tips of soft dorsal and anal light orange-red.

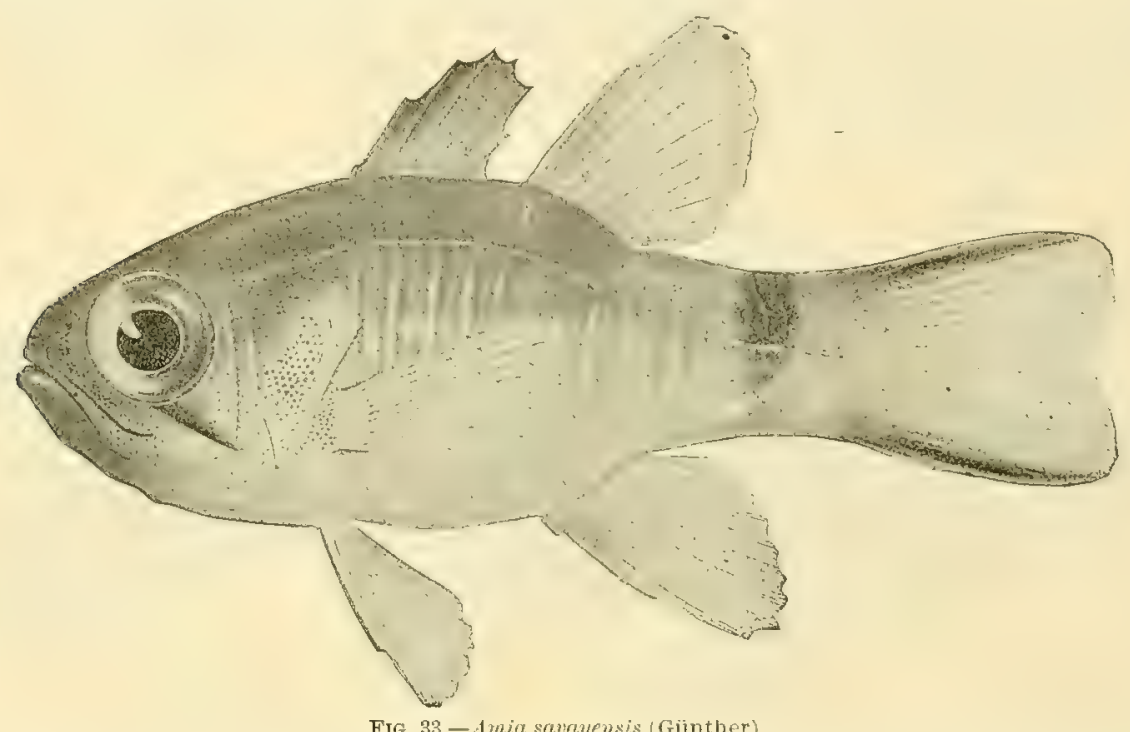

FIG. 33.-Amia savayensis (Günther).

The life colors of a young example from Apia were dull olive, faintly barred with paler, a large black spot before base of caudal; no other markings; first dorsal biack; other fins pale grayish. Called fo by the Samoans.

Another specimen from Pago Pago in life was dull olive, slightly reddish, with some silvery on sides, arranged in cross-bands along muscles; a dark streak like a pencil mark across opercle, another downward and backward from eye; a faint diffuse dark blotch above lateral line from base of caudal, then joined saddlewise over back; first dorsal dusky; other fins purplish olive, the spine of second dorsal dusky. Caudal lunate; dorsal vir; preoperele serrate.

485. Amia koilomatodon (Bleeker). Samoa; Shortland I. ; Solomon Is. (Seale); East Indies.

Hear 2.60 in length; depth equal to head; eye 3.10 in head; dorsal vi-r, 10 ; anal II, 8; scales 228-6; interorbital 1.50 in eye; snout 1.20 in eye.

Body oblong, compressed, slightly elevated; caudal peduncle rather thick and strong, its depth $1.50 \mathrm{in} \mathrm{length,} \mathrm{which} \mathrm{is} \mathrm{equal} \mathrm{to} \mathrm{distance} \mathrm{from} \mathrm{anterior} \mathrm{margin} \mathrm{of} \mathrm{eye} \mathrm{to} \mathrm{posterior} \mathrm{margin} \mathrm{of} \mathrm{opercle;}$ mouth large; maxillary equal to post-ocular portion of head; its distal end under posterior margin of pupil, the width of distal end slightly greater than pupil; villiform teeth on jaws, vomer, and palatine; 
the two limbs of preopercle distinctly denticulate; the lower posterior limb of preorbital denticulate; gillrakers rather sharp pointed, the longest scarcely equal to pupil, 17 on lower limb; second dorsal spine much the strongest, its length 2 in head; base of soft dorsal 3 in head, its longest ray 1.80 in head; anal rounded, its base 2 in its length, the second spine 2.25 in head, its longest ray 1.75 in head; pectoral 1.45 in head, its distal end below middle of soft dorsal; ventrals reaching base of anal, their origin directly below origin of pectoral; caudal bilobed, 1.50 in head.

Color in spirits, light brownish; a black half-band at origin of spinous dorsal extending to beneath anterior third of pectoral; a second black band at origin of soft dorsal, extending down to lateral line; a third black band at posterior axil of soft dorsal, longer than second band, extending to below lateral line, in young examples extending to middle of anal base; a third very indistinct dark band over middle of caudal peduncle (in an old example this is broken up into three or four round spots); a distinct round spot on lateral line just anterior to base of caudal; a round black spot on opercle; a distinct black line from eye to angle of preopercle; anterior dorsal spine black, upper and lower margin of caudal dusky; tip of ventral and anal with dusky wash; pectoral vellow.

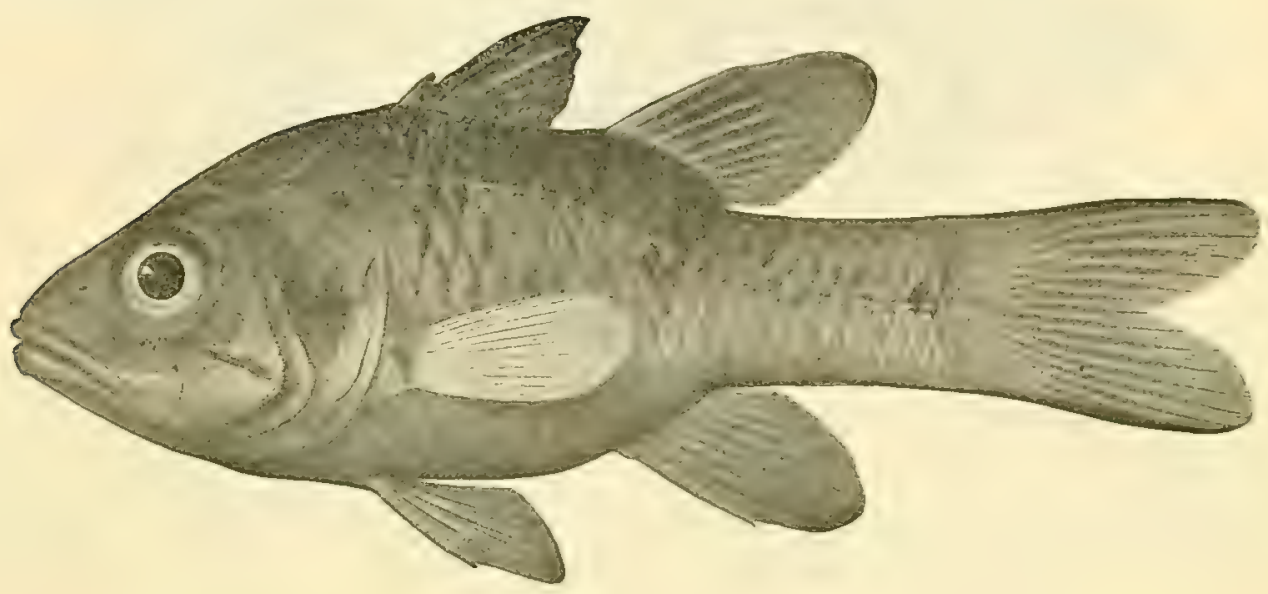

Fig. 34.-Amia koilomatodon (Blecker).

Color in life of a very large specimen from. Pago Pago, dark reddish olive brown; a faint darker bar under first dorsal, one under second dorsal; a small round blackish spot at base of caudal, and one on opercle before its edge; iris golden. Fins all dusky brownisl red, the first dorsal darker; dorsal rather dark; dark dots confluent along base of soft dorsal. Caudal lunate; dorsal vi.

Another large specimen from Pago Pago was dark olive brown in life, much nottled, with three vague dark cross-bands; a large black spot on opercle and another at base of caudal; fins mottled brown.

We have eight specimens from Apia and Pago Pago, of a large and robust species of 1 min, evidently allied to Amia koilomatodon. It has a distinct caudal spot, which is said to be wanting in the latter, but as no other differences appear, we refer our specimens provisionally to imiu koilomatodon. The specimen described is no. 51733 , U. S. National Museum, 5.63 inches long.

486. Amia nigripinnis (Cuvier \& Valenciennes). Bonham I, East Indies.

487. Amia maculifera (Garrett). Hawaii.

488. Amia novæ-guineæ (Valenciennes). Papua; East Indies.

489. Amia aroubiensis (Hombron \& Jacquinot). Samoa; Tahiti; Tubuai; Shortland I.; Nukahiva (Seale).

Apogon aroubicnsis Hombron \& Jacquinot, Voy. au Pole Sud, Poiss., 31, nl. 1, fig. 1, Aroub in Malaysia. Apogon fasciatus Günther, Fische der Südsee, 19, taf, 20, fig. A.

This species very closely resembles dimia novemfasciala, but the colors are deeper, and the black bands, broader and continuous, do not extend on the caudal fin. There is no black spot on base of 
pectoral. It is certainly a distinct species, and it is fairly represented by Dr. Günther's figure A, as well as apparently in the poor plate of Hombron and Jacquinot.

About 10 specimens from Apia and Pago Pago. Color in life of a specimen from Apia, reddish gray, with five stripes of very deep red-black, the interspaces gray; iris gray with yellowish tinge; fins all pale red; an oblique streak on each dorsal and on anal; none on caudal, the bands not converging on the fin.

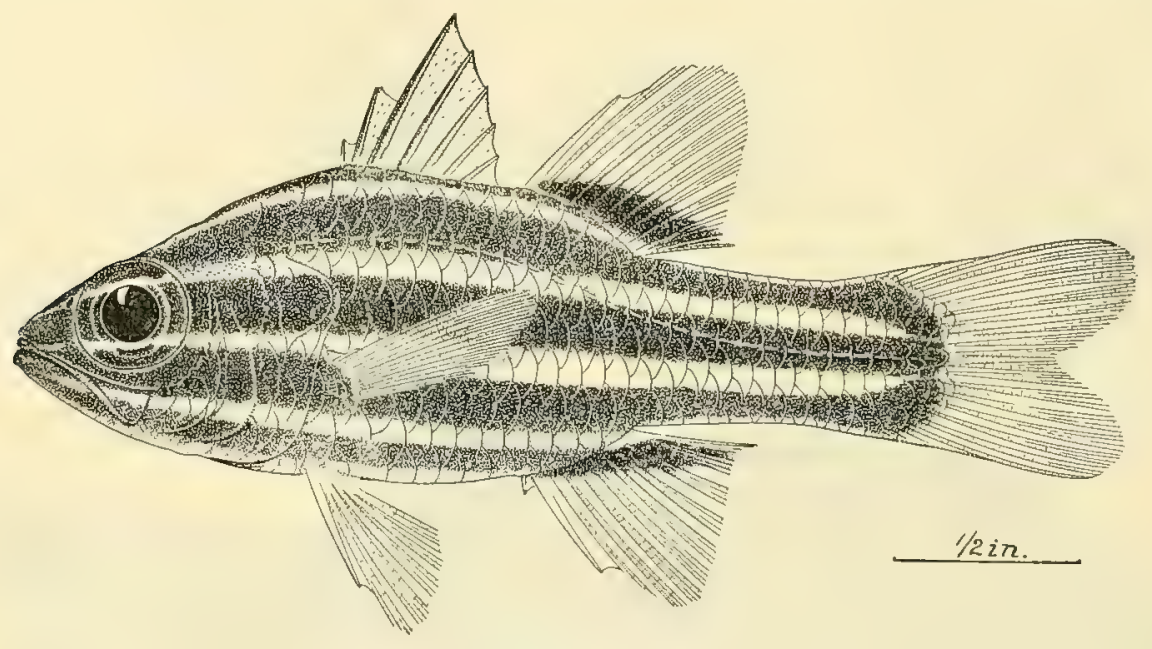

FIG. 35.-Amia aroubiensis (Hombron \& Jacquinot).

490. Amia novemfasciata (Cuvier \& Valenciennes). Samoa; Guam; Tahiti; Kingsmill I.; Faté (Seale); East Indies.

Apogon novemfasciatus Cuvier \& Valeneiennes, Hist. Nat, Poiss., Ir, 151, Timor and Guam.

Apogon fasciatus Quoy \& Gaimard, Voy. Uranie, 314, Guam, Günther, Fische der Südsee, 19, taf, 20, fig, B, Society, Samoan, and Kingsmill islands, etc.; not fig. A. Bleeker, Atlas, tab. Xuvir, fig. 4, East Indies. Streets, Bull. U. S. Nat. Mus., viI, 100, 1877, Samoa. Seale, Bishop Mus. 1901, 76, Guam; not of White.

Head 2.50 in length; depth 2.85; eye 3.20 in head; snout 4 in head; dorsal vII-I, 9; anal II, 8; scales 2-28-6; interorbital 2 in orbit.

Body oblong, compressed; caudal peduncle strong, its depth 1.50 in its length, which is 1.35 in head; mouth large, jaws equal, maxillary 2 in head, its distal end under posterior third of eye; bands of small teeth on jaws, vomer, and palatines; gillrakers not very sharp, the longest equal to width of pupil, 14 on lower limb (12 developed); opercle entire; onter limb only of preopercle denticulate; base of spinous dorsal 1:40 in the third spine, which is the longest and strongest; base of soft dorsal 2.75 in head, its longest ray equal to distance from middle of eye to posterior tip of opercle; base of anal equal to orbit, its longest ray 1.75 in head; pectoral 1.50 in head, its distal end reaching to base of soft dorsal; rentrals 1.40 in head, their insertion directly below base of pectoral, their tips scarcely reaching base of anal fin; caudal emarginate, 1.30 in head.

Color in spirits, yellowish white, with four brown longitudinal bands about as wide as interspaces, the first extending from middle of interorbital, dividing in front of dorsal fin into two which continue along base of dorsal, uniting behind in a single line along top of caudal peduncle; the 2nd band extending from upper margin of orbit to caudal, where it runs obliquely out on fin to join the end of the third line, which extends from tip of snout through eye to tip of caudal fin; the fourth line extending from side of snout along lower part of orbit, over base of pectoral to caudal, where it extends obliquely out on the fin to join the third line at tip-three of the bands thus converging on the caudal fin, each of these bands more or less distinctly widened at about three intervals. There is also an indistinet dusky line from angle of month to base of ventrals; a narrow white line along side of snout; two larger dark blotches are apparent on the third body band; base and axil of pectoral dusky; a black line with a narrow light one above it through lower base of soft dorsal; a slight wash of dusky in anterior membrane of spinous dorsal, usually a narrow black line through lower part of anal, lisappearing with age. 
Color in life of a specimen from Apia, olivacems, the bands black, converging on caudal; spaces anteriorly before pectoral silvery white, with bright luster; the streaks on head above very white; fins all brick-red.

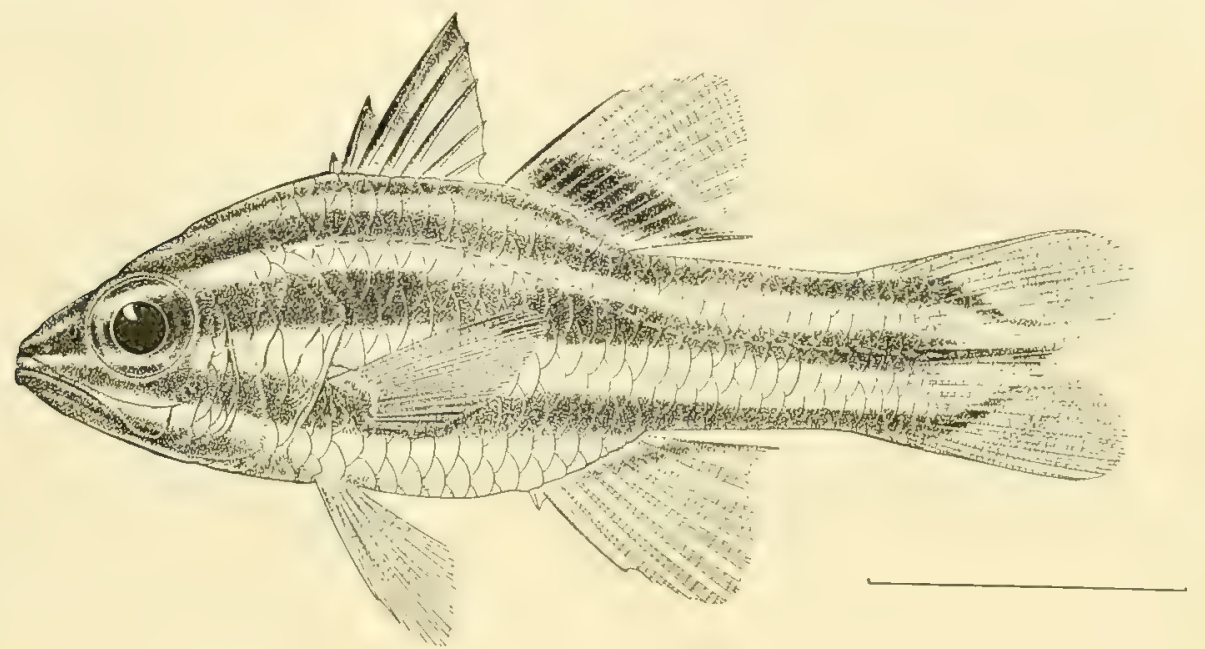

FIG. 36.-Amia novemfasciata (Cuvier \& Valenciennes).

Another specimen has the stripes darker oljve, almost black, on whiter ground; a black bar across axil, and a black spot in front of it; a stripe from angle of mouth to ventrals; fins all pale red, in younger individuals orange yellow; no black marks, except dusky streak at base of second dorsal and anal, which runs obliquely up and back; black bands convergent on caudal, the outer inargin pale; first dorsal all pale.

A third specimen from the same locality has a deeper body, the black stripes more olive, none helow level of pectoral; no black bar across axil; a blackish spot on lower part of opercle; fins dull

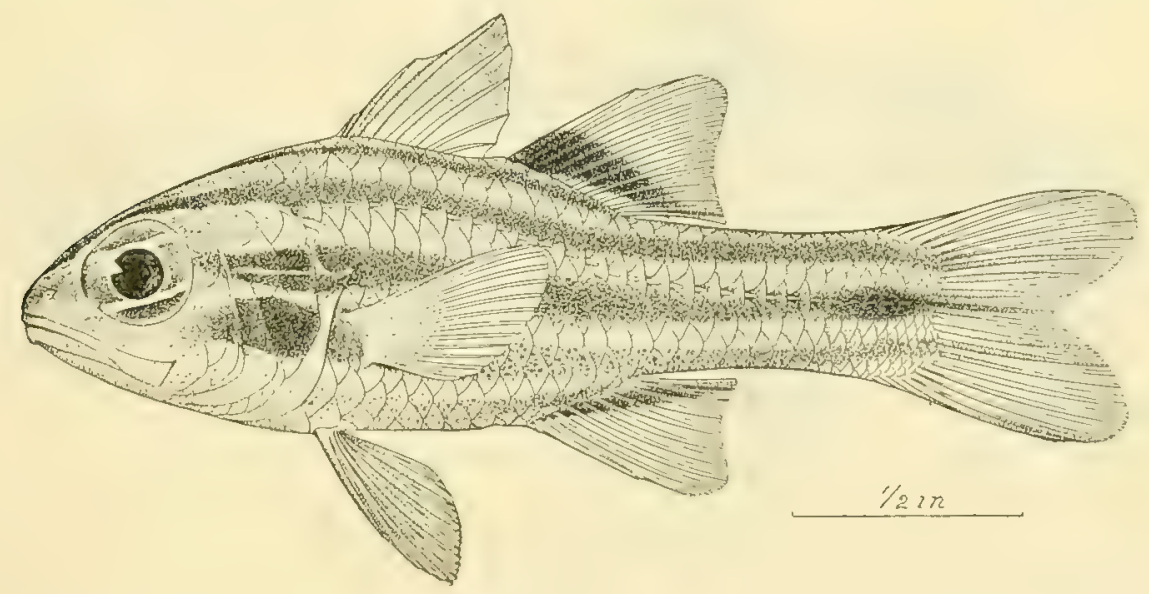

F1G. 37.-1 mia norenfasciala (Cuvier \& Valenciennes). A color vnriation.

red; both dorsals and anal with an oblique black cross-band; stripes on caudal less distinctly converging, the onter margin black; first dorsal all black. These specimens differ rather markedly from the ordinary ones and may represent a distinct species, but, except in color, we find no tangible characters. 
This species is very abundant at Pago Pago and Apia, and we have about 100 specimens. Length 3.25 inches. We have not seen the plate of Mullus fasciatus, published by John White. From the account of Cuvier and Valenciennes this species, like quadrifaciata, has but two black stripes on each side. The present species, Apogon fasciatus of most authors, has five (or four) stripes on each side, two of them converging to meet the middle stripe on the caudal fin. These stripes are relatively narrow, and are again narrowed in two or three places. A black spot at the base of the pectoral is also very constant.

Concerning the types of Apogon novemfasciatus, Dr. Léon. Vaillant writes:

Je viens d' examiner les deux specimens qu'on peut regarder comme types primitifs de Cuvier et Valenciennes; Ce sont deux individus isolés, l' un rapparté de Timor par Péron, $l^{\prime}$ autre de Guam par Quoy et Gaimard.

Le premier est un patit exemplaire, long de $60+12=52 \mathrm{~mm}$. en mediocre etat, en grand partie decolore; tout ce qu' on peut dire, c'est que les bandes laterales se voient sur la partie basilaire de la caudale (No. 56-16)

$L$ etat du second est plus satisfaisant. La longueur est de $40+12=52 \mathrm{~mm}$. Les trois lignes sombres laterales, se prolongent visiblement sur la caudale, la superieure, et l' inferieur convergeant nettement, l' une vers l' autre $\in \mathrm{n}$ arriere (o. 853).

The second of these specimens evidently corresponds to the Amia novemfasciata of the present paper, and the other, which is properly the type of novemfasciatus, is almost certainly a discolored example of the same species, as the black spots are seen on the base of the candal fin. In Apogon aroubiensis of Hombron and Jacquinot the black spots do not encroach on the caudal fin at all.

491. Amia amboinensis (Bleeker). New Guinea' (Macleay); Shortland I. (Seale); East Indies.

492. Amia sangiensis (Bleeker). Fiji (Günther); New Guinea (Macleay); Yap (Günther); East Indies.

493. Amia fleurieu (Lacépède). New Guinea (Macleay); East Indies

(Ostorhinchus flentieu Lacépède; Centropomus aureus Lacépède; Apogon annidaris Rüppell; Apogon roseipinnis Cuvier \& Valenciennes.)

494. Amia tænioptera (Bennett). New Guinea (Macleay); East Indies.

495. Amia buruensis (Bleeker). Normanby I.; New Guinea (Macleay).

496. Amia trimaculata (Cuvier \& Valenciennes). New Guinea; East Indies.

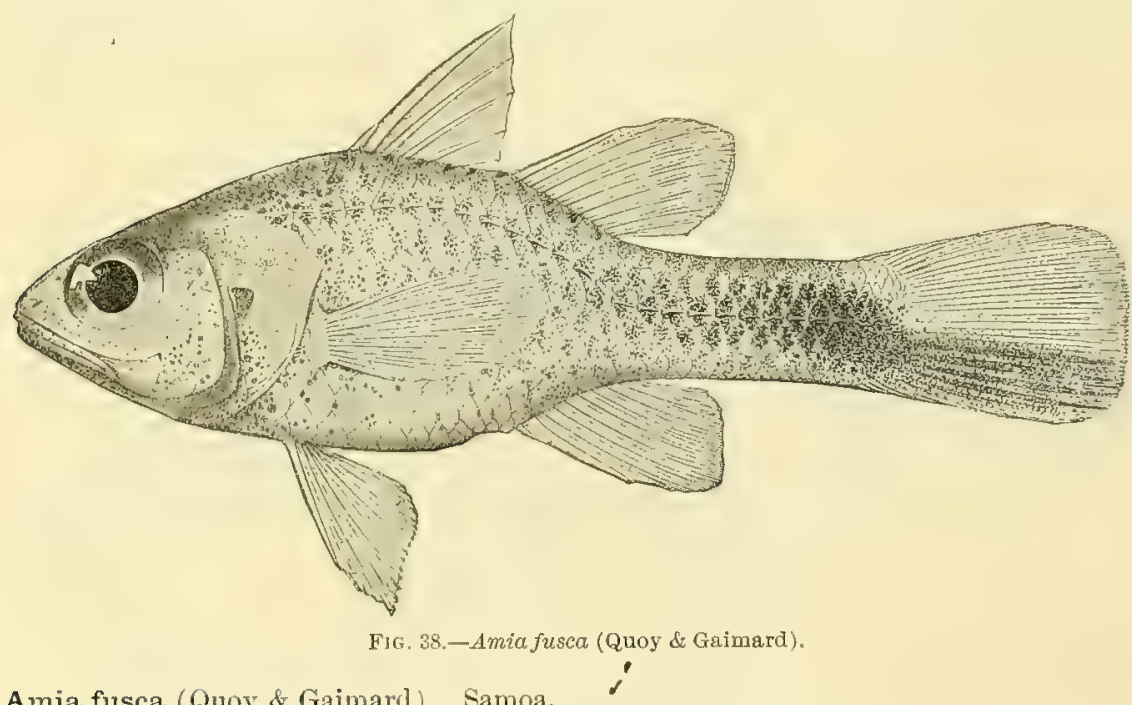

497. Amia fusca (Quoy \& Gaimard). Samoa.

Aponon fuscus Quoy \& Gaimard, Voy. Uranie, Zool., 345, 1824, Guam.

Head 2.85 in length; depth 3 ; eye 2.75 in head; snout 4.80 ; dorsal VI-I, 8; anal $\mathrm{x}$, 8; seales 2-23-6; interorhital equal to snout.

Body oblong, compressed, head and body scaled; caudal peduncle long, 3.10 in length of fish, its depth 2.55 in head; jaws even; maxillary 1.95 in head, its distal end under posterior margin of pupil; 
bands of villiform teeth on jaws, vomer, and palatines; gill-rakers sharp pointed, the longest less than width of pupil, 14 on lower limb; posterior margin of opercle ending in a spine-like point which extends as a small bony stay across opercle; the posterior limb of preopercle only is serrated; lateral line evenly curved from its origin to a line with posterior axil of dorsal, the straight portion 1.50 incurved. Base of spinous dorsal 1.50 in its height, the second (upright) spine being the longest and strongest; base of soft dorsal 1.95 in its length, the soft dorsal spine being equal to base of tin, 2.90 in head; base of anal equal to depth of caudal peduncle, its longest ray 1.95 in head; ventrals scarcely reaching base of anal, equal in length to distance from middle of eye to posterior tip of opercle, their insertion being slightly in advance of pectoral; pectoral 1.50 in head, the tip on a line with middle of soit dorsal; caudal rounded, $1.20 \mathrm{in}$ head.

Color in spirits yellowish white, thickly covered with minute dots; a broad black area covering most of the caudal peduncle, except its upper and lower sides, this black marking extending out and covering the lower half of the caudal fin; anteriorly this color fades out under the posterior axil of soft dorsal; there is a dusky wash on upper half of eye and on dorsal surface of head; cheek punctulate with brown dots rather larger than those of body, a small brown spot on opercle near base of the bony stay; sides of thorax rather strongly shaded with brown dots; fins yellowish white. The black color of the lower half of the caudal, which fin is not forked, is very distinctive.

One specimen from Apia, length 1.75 inches.

498. Amia zosterophora (Bleeker). New Guinea (Macleay); East Indies.

499. Amia leptacantha (Bleeker). New Guinea (Macleay); East Indies.

500. Amia nematophora (Bleeker). New Guinea (Macleay); East Indies.

501. Amia cookii (Macleay). New Guinea. Apogon cookit Mracleay, Proc. Linu. Sac. N. S. W., v, 188t, 324, New Guinea.

502. Amia hyalosoma (Bleeker). Puinepet I.; East Indies.

503. Amia erythrina (Snyder). Hawaii; Samoa.

Of this small species we have seven examples from Apia and Pago Pago. It is clear red in life, often with scattered paler spots, and some dark shading. Our specimens agree well with those from Hawaii.

A specimen from Pago Pago in life was all deep vermilion red. One from Apia was all bright red, a dusky blotch on opercle, dusky shades along base of first dorsal and on top of head; no markings.

504. Amia doryssa Jordan \& Seale, new species. Samoa.

Apogon hypselonotus, Günther, Fische der Südsee, 20, South Seas; not of Bleeker.

Head 2.60 in length; depth 2.95; eye 2.85; dorsal vI-I, 9; anal II, 8; scales 2-26-6; interorbital equal to snout.

Body oblong, compresssed, its greatest depth at origin of dorsal; body and head scaled; caudal peduncle long, 1.20 in head, its depth 2.95; jaws about even, the under one scarcely as Iong as upper; maxillary 1.95 in head, its distal end under posterior margin of pupil; bands of minute villiform teeth on jaws, vomer and palatines; gillirakers sharp pointed, 12 on lower limb, the longest less than pupil; opercle with three small spine-like projections on posterior margin; both limbs of preopercle with small denticulations; anterior part of lateral line with strong oblique curve under base of soft dorsal; second (upright) spine of dorsal very strong, flat, and sabre-like, its length equal to distance from anterior margin of eye to posterior margin of operele; shape of the spinous dorsal that of an acute triangle, the base of which is 1.75 in its length; base of soft dorsal equal to orbit; the spine of soft dorsal slightly longer than base of fin, the fin rounded, its longest ray equal to distance from miadle of eye to posterior margin of opercle; base of anal 1.50 in length of longest ray; ventrals below base of pectoral, their length 1.50 in head, their tips reaching to base of anal; pectoral 1.40 in head, extending to a line with sixth anal ray; caudal bilobed, the longest ray equal to distance from anterior margin of orbit to posterior edge of opercle.

Color in life, light brick-red, fins a little darker; no trace of markings. Color in spirits, yellowish white, some black shading at base of spinous dorsal; a few small dusky blotches on upper part of opercle; fins without markings. 
Three specimens from Apia. The type is no. 51812, U. S. National Museum; length 1.87 inches.

Dr. Günther identifies his specimens, apparently similar, with Apogon hypselonotus, but Dr. Bleeker is apparently correct in regarding the species of the South Seas as distinct. The species resembles Amia erythrina, but the dorsal spines are stronger and longer than in the latter, and the physiognomy is different.

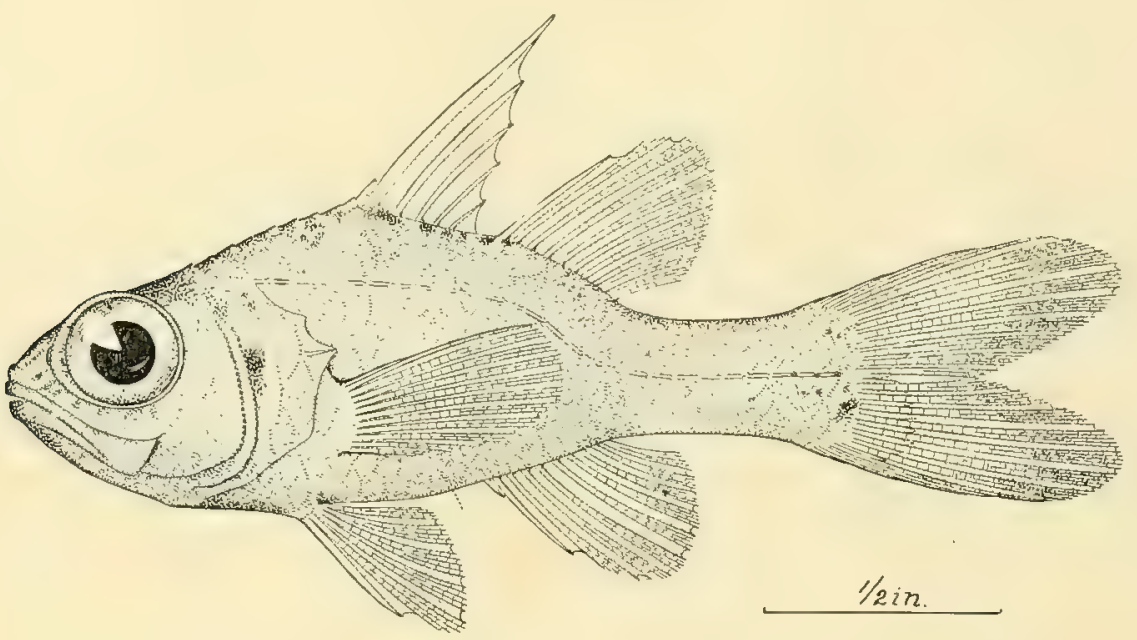

Fig. 39.-Amia doryssa Jordan \& Seale, new species. Type.

505. Amia lateralis (Valenciennes). Samoa; Vanicolo.

Apogon lateralis Valenciennes, Nouv. Ann. Hist. Nat, 1, 58, 1832, Vanicolo.

Head $a$ 2.40 in length; depth 2.75; eye 3.75 in head; snout 4; dorsal vi-I, 9; anal II, 8; scales, 1.5-26-5; interorbital scarcely equal to eye.

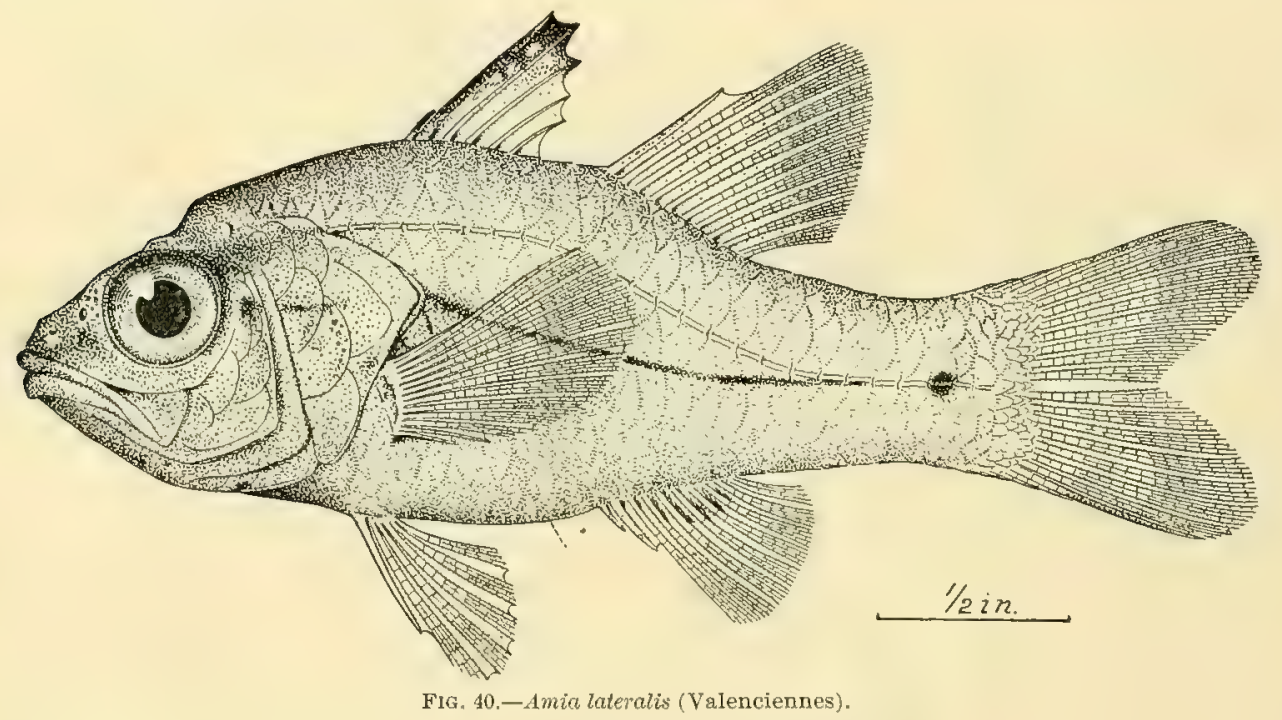

Body oblong, comprassed, and somewhat elevated; mouth large; maxillary 2.15 in head, its distal end under posterior margin of pupil; teeth in villiform bands on jaws; vomer and palatines; cheek scaled; preopercle with the onter limb very slightly denticulate, the teeth finer above, the inner limb 
entire; gill-rakers strong, blunt, and finely denticulate, the longest two-thirds as long as pupil, 17 on lower limb; second dorsal spine longest, 2.20 in head; longest ray of soft dorsal, 2 in head, its base 3 ; caudal emarginate, the lobes rounded; base of anal, 3 in head, its longest ray, 2.50, the spines small; pectoral extending to a line with sixth dorsal ray, 1.75 in head; insertion of ventrals slightly in advance of base of pectoral, their tip extending to anal opening, their length equal to postocular part of head.

Color in spirits, dull yellowish white with a slight wash of brown; everywhere punctulate with indistinct minute dark dots the size of pin pricks; a narrow and distinct line of brown from posterior margin of opercle to base of caudal, where it terminates in a small round black dot about half the size of pupil; a short black line from posterior margin of eye to near posterior margin of opercle, a dusky blotch above this at upper end of preopercle and including the upper portion of orbit and eye; a more or less distinct dusky line from anterior of orbit down side of snout; dorsal fin with anterior spine, dusky black at tip; other fins white; opercle gilt.

Twenty-six specimens from Apia. The specimen described is 3 inches long.

This species is rather common in the sluggish waters at the mouths of the streams of Apia. From the other Samoan species it may be known by ity strong likeness to the species of $A$ mbassis, among which it is often found. It has always a small black spot at base of caudal and a low spinous dorsal, the long spine barely reaching base of second dorsal when compressed.

MIONORUS Krefft. $F$.

This genus has the lateral line complete, the palatine provided with teeth, and the two limbs of the preopercle both strictly entire. In $M$. graffei the body is short and greatly compressed, and the dorsals high. Other species provisionally referred to the same genus (waikiki, carinatus, glaga, etc.) have the general form of Amia.

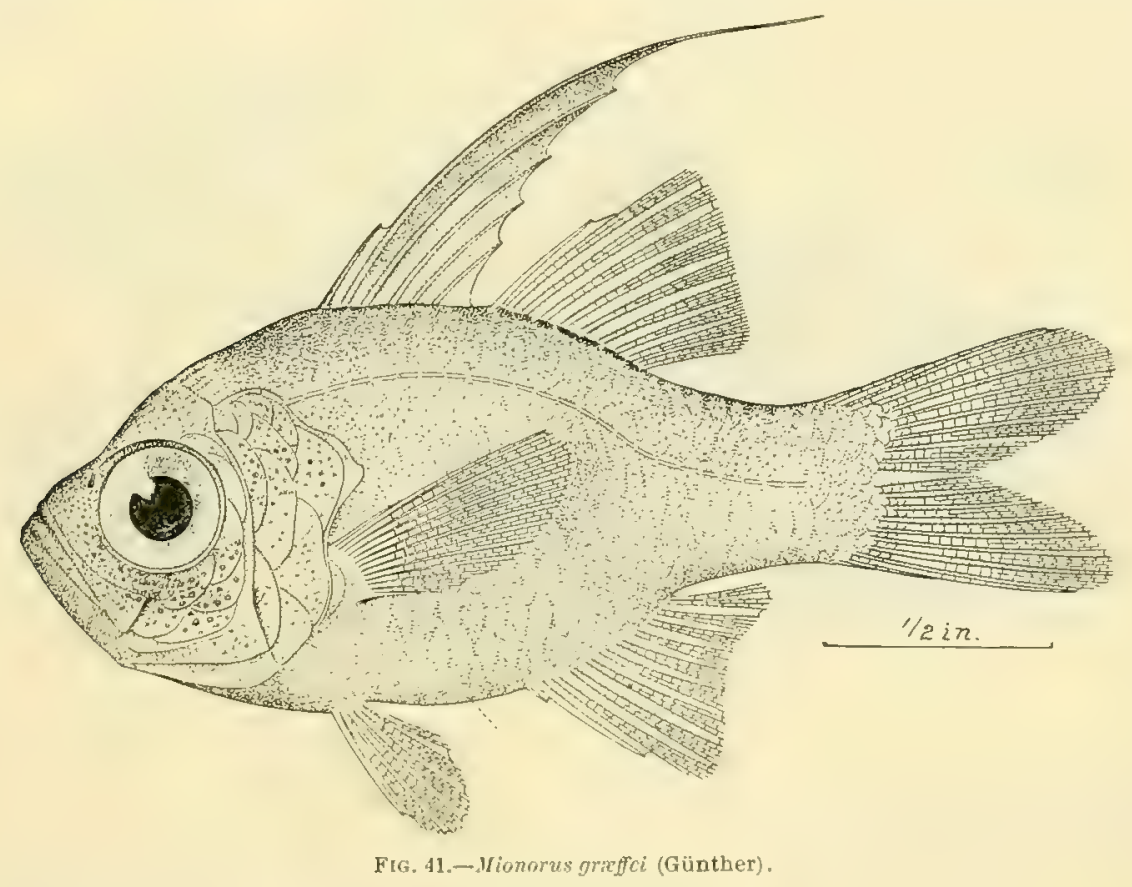

506. Mionorus græffei (Günther). Samoa; Marshall Is.

Apogon graffei Günther, Fische der Siidsee, 22, taf, 20, fig, $\mathbb{\mathrm { F }}_{\mathrm{q}}$ 1873, Boston I. (Marshall Is.). Streets, Bull, U. S. Nat. Mus., vir, 101, 1877, Samoa.

Of this pretty species we have two specimens from Apia, and ten from Pago Pago. The greatly compressed body and elongate whip-like spine are characteristic. 
Color in life of a specimen from Apia, translucent, with orange shades on head; fins plain pink, the spinous dorsal dark-edged; no stripes or spots; very deep and much compressed; second dorsal spine filamentous, reaching past middle of soft dorsal.

A specimen from Pago Pago in life was light pinkish olive; no spot or bar of black; two golden bronze cross-streaks behind head; two on opercle and two or three similar streaks radiating from eye; a streak of dark points along middle line of back; first dorsal dusky, the long whip-like produced spine black; other fins plain pink, the caudal faintly dark-edged. Caudal well forked; preopercle serrate.

The other specimen from Apia, with body very deep, was transtucent olive, paler below, silvery on side; a dark streak along base of dorsal; four vertical bars of bright golden bronze behind eye on opercle and front of body, these not much above or below level of large eye; upper fins pale orange; lower pale red; pectoral colorless. Scales very large; dorsal filamentous; anal Ir, 10.

507. Mionorus waikiki (Jordan \& Evermann). Mawaii.

FOA Jordan \& Evermann. Fo.

Foa Jordan \& Evermann, Bull. U. S. Fish Comm., xxır, 1903 (July 29, 1905), 210 (type Fowleria brachygramma).

This genus is characterized by the entire preopercle, incomplete lateral line and by the presence of teeth on the palatines. The species are all very small in size, and they live in crevices of coral reefs.

a. Opercle without black spot.

$$
\text { Analysis of species of Foa. }
$$

$b$. Body and fins plain, pale

$b b$. Body much mottled; fins mottled.

c. Head very large; back with broad difiuse dark cross-sharies . . . . . . . . . . . . . . . . . . . . . . . . . . . . . . . . fo

ce. Head moderate; no broad blackish cross-bands . ...................................................

\section{Foa brachygramma (Jenkins). Hawaii.}

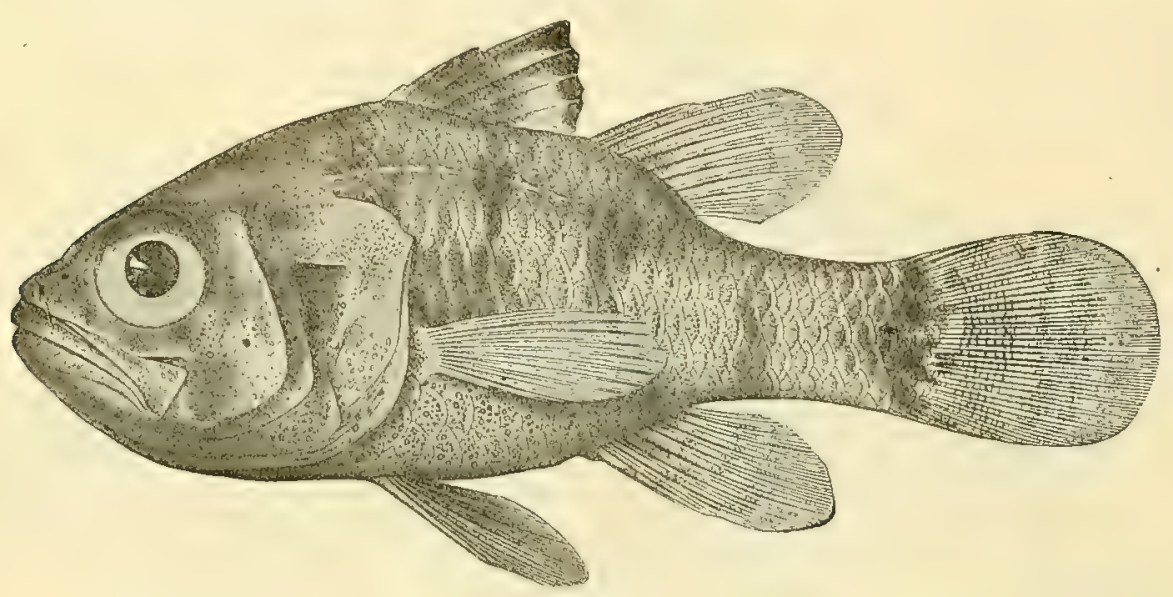

FIG. 42.-Foa fo Jordan \& Seale, new species. Type.

509. Foa fo Jordan \& Seale, new species. Samoa.

Head 2.20 in length; depth 2.50; eye 3.75 in head; snout 4.75. in head; dorsal viI-I, 9; anal Ir, 8; scales 1-21-6; lateral line discontinued at the ninth scale from head; interobital equal to snout.

Body oblong, compressed, rather deep; body, cheeks and opercles scaled; caudal peduncle rather short and strong, its depth 1.50 in its length, which is $1.70 \mathrm{in}$ head; mouth large, the jaws equal; premaxillary equal to postocular part of head; bands of minute teeth in jaws, vomer and palatine; opercle entire; preopercle with both limbs very minutely denticulate, the denticulations being hidden under the scales; gillrakers not very sharp, rather strong, 12 on lower limb, the longest less than length of pupil; base of spinous dorsal slightly greater than its height, which is 2 in head; base of soft dorsal 
3 in head, its height 1.90 in head; anal base about equal to eye, its longest ray 3 in head; pectorals 1.75 in head, extending to below middle of soft dorsal; ventral inserted directly below base of pectoral, its length 1.75 in head; caudal rounded, 1.50 in head.

Color in spirits, yellowish white, the scales shaded more or less with light brown; five diffuse, irregular vertical cross-bands of dusky, the first in front of dorsal, the second from middle of spinous dorsal, the third from base of soft dorsal, the two posterior ones encircling caudal peduncle; there is also a more or less distinct dusky area on nuchal region; dusky cross-shades under chin; the fins, except pectorals, all more or less indistinctly blotched with dusky, the spinous dorsal being black at tip with a lighter area in middle and dusky at base; anal shows indications of three or four darker cross-shades; ventral dusky; a dark spot on opercle, just posterior to eye; upper portion of orbital and snout shaded with dusky.

Of this species, well distinguisher by its large head, blackish cross-bands, and by the absence of opercular spot, we have one specimen from Apia, the type, no. 51735, U. S. National IIuseum, 1.50 inches long. We have also 2 specimens from the Philippines. Fo is the Samoan name of all species of $A$ mir and related genera.

510. Foa vaiula Jordan \& Seale, new species. Samoa.

Head 2.50 in length; depth 3 ; eye 3 in head; snout equal to interorbital; dorsal vil-I, 9; anal Ir, 7 ; scales 2-21-6; lateral line continued only to tenth scale from head.

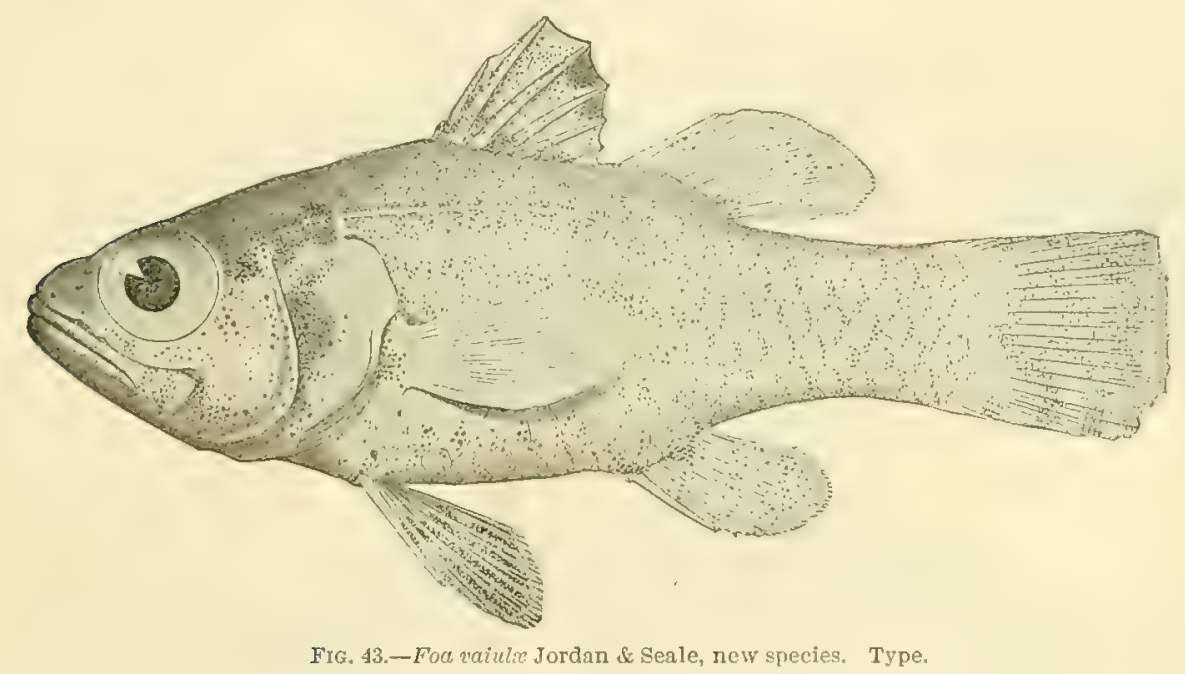

Body oblong, compressed; body, cheeks, and opercles scalerl; caudal peduncle rather strong, its depth 1.75 in its length, which is 1.50 in head; mouth large; jaws equal; maxillary 1.85 in head, its distal end under posterior third of eye; bands of minute teeth on jaws, vomer, and palatines; opercle entire; preopercle with very minute denticulations on each limb; gillrakers rather strong at base, sharp-pointed, the longest about two-thirds width of pupil, 7 developed on lower limb; spinous dorsal rounded, its base equal to its height; base of soft dorsal 3 in head, rounded, its lonirest ray 2.20 ; base of anal 3.50 , its longest ray 2.18 ; pectoral 1.75 , reaching anterior base of soft dorsal; ventral 1.80 , its tip not reaching base of anal, their insertion below base of pectoral; caudal square, its length 1.95 in head.

Color in spirits, yellowish white, each scale shaded by numerous fine brown dots like pin pricks, darker on nuchal region, with a small but distinct black spot above opercle at origin of lateral line; some dark shadings on opercle and cheek behind and below eye; pectoral yellow, all the other fins shaded more or less with small brown dots, darkest on spinous dursal, which also has black blotches between third and fifth spines at tip of fin and at the base; on caudal fin the dots form three irregular bands. This species is mottled somewhat as in Ipogonichthys marmoralus, but is without opercular spot.

One specimen, type, no. 51734, U. S. National Museum, from Apia, length 1.20 inches. Named for the fisherman Vaiula, of Apia.

$$
\text { B. 13. 1. 1905-17 }
$$


APOGONICHTHXS Bleeker. Fo.

Fowleria Jordan \& Evermann, Bull. U. S. Fish Comm., xxir, 1902 (Apr. 11, 1903), 180 (auritus).

This genus is based on a species, Apogon auritus Cuvier \& Valenciennes, which we have not seen. It is, however, very closely related to three Samoan species, with which it is doubtless congeneric. These species differ from the group called Foa in having no teeth on the palatines. In all of them there is a large black ocellus on the operele, and the lateral line, although interrupted, shows rudimentary pores on the caudal peduncle.

a. Opercle with a large ocellated black spot.

b. Body mottled with dusky; fins all closely chequered; lower side of head chequered ........................

66. Body deep red in life, with many pale cross-bands; fins faintly mottled; caudal hlackish at tip........... marmoratus

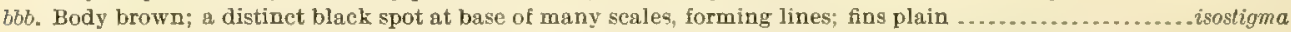

511. Apogonichthys variegatus (Valenciennes). Samoa; Tahiti; Yap; Ile de France.

?Apogon auritus Cuvier \& Valenciennes, Hist. Nat. Poiss., VIr, 443, 1831, IJe de France; color plain, fins plain, an opercular spot.

Apogon variegatus Valenciennes, Ann. Sci. Nat., I, 1832, 55, Ile de France; body and fins mottled; an opercular spot. Apogon auritus, Günther, Fische der Südsee, 23, Tahiti, Yap. Day, Fishes of India, Streets, Bull. U. B. Nat. Mus, VII, 1877, 100, Samor. Sauvage, Fish. Madagasear, 141 , not plate.

This species is common on the reefs about Samoa. We have fen examples from Apia and twenty from Pago Pago. It is well figured by Day as Apogon auritus, but the original auritus is said to have the fins plain. There is a black opercular spot, and the body and fins are everywhere closely mottled with light and blackish. The vertical fins especially are finely marked, the pattern suggesting that of the fins of some gobies.

This species may be the original Apogon auritus, but it can not be identified as that without comparison with the original type. Apogon punctulatus of Rüppell and A. polystigma of Bleeker may be the true auritus. At any rate, the figures diverge widely from our fish. The description of 1. auritus of Sauvage approaches it, but his figure looks much like Foa brachygramma.

Life colors of a specimen from Apia, body everywhere much mottled, blackish, and gray; all the fins save the ventrals elaborately spotted and barred; jaws barred and mottled; a black ocellus on the opercle.

Another specimen from Apia was dirty olive-brown; opercle with a black pale-edged ocellus, very large and conspicuous; fins all much like the body, brown and mottled; caudal rounded.

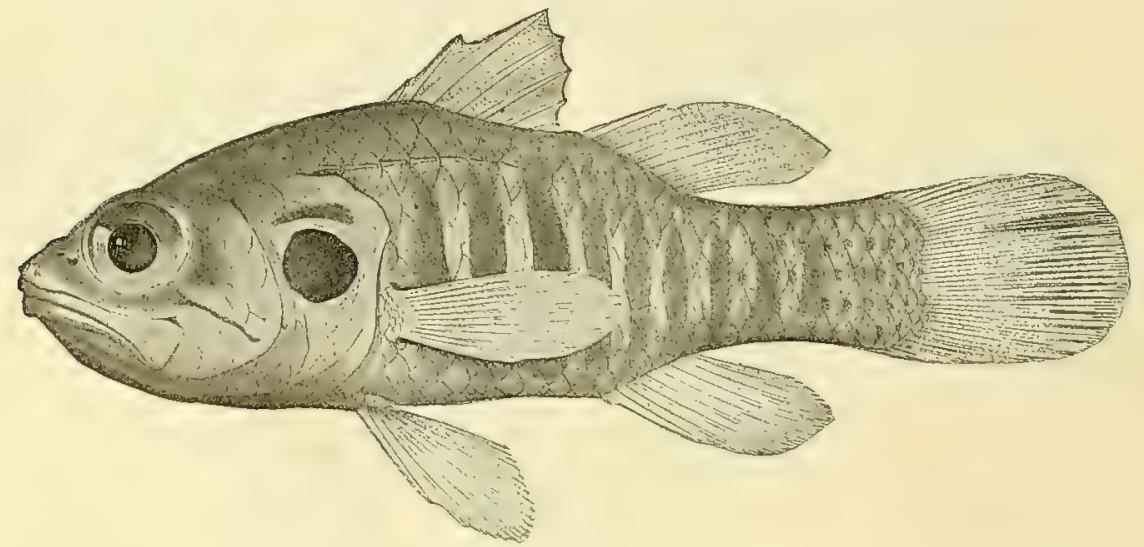

Fig. 44.-Apogonichthys marmoratus (Alleyne \& Macleay).

512. Apogonichthys marmoratus (Alleyne \& Macleay). Fo mumu (red). Samoa; North Australia.

Apogonichthys marmoratus Alleyne \& Macleay, "Proc. Linn. Soc. N. S. W., 1876, 268, pl. r, fig. 2, Cape Grenville (North Australia).

Of this species, distinguished by its clear red color, black opercular spot, and the body covered with pale crossbands, we have three specimens from Pago Pago, and ten from Apia. It is well separated from Apogonichthys variegatus. The little figure given by Alleyne and Macleay is characteristic. 
Life colors of one specimen rom Pago Pago, light clear brownish red, the ground-color forming about nine distinct crossbars on the body, about twice as broad as the pale olive interspaces; head mottled; a large black spot on opercle, washed with golden and surrounded by a golden ring, this spot two-thirds diameter of eye and covering most of the bone; fins all very bright cardinal red, the caudal with an irregular black shade at tip. Caudal rounded. Length 21 inches.

513. Apogonichthys isostigma Jordan \& Seale, new species. Samoa.

Head 2.55 in length; depth 3; eye 4 in head; snout equal to eye; dorsal vII-I, 9; anal II, 8; scales $2-22-6$, the lateral line interrupted; interorbital less than snout, 1.75 in orbit.

Body oblong, compressed, scaled, the scales covering cheeks and opercles; depth of caudal peduncle 1.30 in its length; mouth large, the lower jaw slightly the shorter; maxillary 2 in head, its distal end under posterior margin of orbit, the distal width being greater than pupil; teeth in villiform bands on jaws and vomer, no teeth on palatines; opercle entire; preopercle apparently entire, but with a few slight serrations at angle hidden under the skin; gillrakers short, the longest 2 in pupil, blunt, ending in a prickly knob, 7 developed on lower limb; base of spinous dorsal equal to its height; which is 2.10 in length of hear; base of soft dorsal 1.50 in its longest ray, which is 2 in head; ventrals do not reach to the anal, their length 1.75 in head, their insertion directly below base of pectoral; pectoral 1.50 in head, terminating at the seventh round black spot on side; caudal rounded, 1.40 in head.

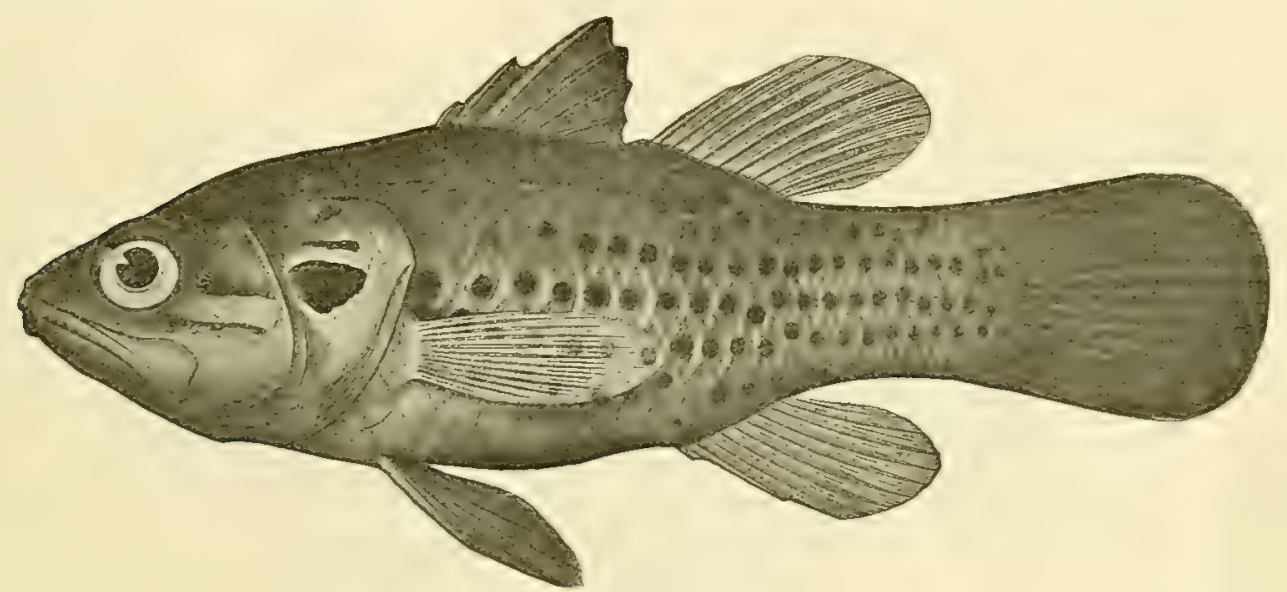

FIG. 45.-Apognnichthys isostigma ,ordan \& Seale, new species: Type.

Color in spirits, light brown, with about five rows of distinct round dots forming the center of scales along the sides, two of these lines with their origin at axil of pectoral and extending to caudal, one with its origin at posterior tip of opercle and extending to caudal, the other two usually extending from near middle of fish to caudal (very old examples show a few other scattered dots over the body); a large, black, white-edged spot on opercle, a more or less distinct dusky area extending from eye back to this spot; a narrow black line from lower part of orbit across cheek; top of head and snout dusky, a narrow dark line across opercle just above the black spot; all the fins except pectorals have a wash of dusky, the caudal being almost black; pectoral yellowish white.

Life colors of one specimen plain dark hrown, each scale with a darker spot, these forming dark streaks along scales, but no marblings; large opercular ocellus with a golden edge; fins dark brown, unspotted.

This species has the large opercular ocellus found in Apogonichthys auritus, polystigma, variegatus and marmoratus. The body is, however, markerl with large distinct spots, about one on each scale, arranged in regular lines; the fins are dusky but unspotted, and there is an oblique dark line below: and behind the eye.

The species is nearest $\mathbf{A}$ pogonichthys polystigma Bleeker, but it does not seem to agree with Bleeker's account. It is not unlikely that Bleeker's fish is the original spogon aurius. It is certainly different from Aprogonichthys variegahus. Ipogon auritus Seale (Bishop IIus. 1901, 76) from Guam, must be the present species.

Nine specimens from Apia. The type is no. 51736, U. S. National Museum, and is 2.67 inches long. 


\section{ARCHAMIA Gill.}

514. Archamia lineolata (Ehrenberg). Fo. Samoa; Vanicolo; East Indies. (Pl. xxxvrr, fig. 1.)

Apogon lineolatus Ehrenberg in Cuvier \& Valenciennes, Hist. Nat. Poiss., II, 160, 1828, Red Sea. (Anal $\pi I_{\text {, 14.) }}$ Apogon macropterus Kuhl \& Van Hasselt in Cuvier \& Valenciennes, Hist. Nat. Poiss., 15, 160, Java. (Anal II, 13.) Apogon ceylonicus Cuvier \& Valenciennes, op. cit., III, 491, Ceylon. (Anal II, 13.) Apogon argenteus Valeneiennes, Ann. Mus. Nat. Hist. 1832, 60. Vanicolo. (Anal II, 14.) Apogon fucatus Cantor, Cat, Malay, 4, 1850, Penang. (Anal Ir, 16.) Apogon notatus Day, Proc. Zool. Soc. 1870, 936, Madras. (Anal ir, 16.)

This species is very abundant about the reefs of Samoa. We have about twenty specimens from Pago Pago and forty from Apia. We find no specimens with fewer than 16 soft rays in the anal fin. Possibly two species (fucatus and lineolatus) have been confounded, the latter with fewer rays.

The species is subject to considerable variation. The delicate orange cross-streaks characteristic in life mostly fade in spirits. Only in the very largest specimens is a large black scapular spot distinct; usually there is no trace of it. In some specimens there is a round black spot at base of caudal; in most there is only a diffuse black blotch or cluster of black points. In some the sides of the head are profusely speckled, in others clear silvery. All show a faint silvery horizontal streak just before and just behind eye. In all the body is deep, but there is considerable variation. The variations in color are somewhat parallel with those in Amia savayensis.

Life colors of a specimen from Apia, light soiled pinkish olive, with many dark specks; sides silvery; body with 18 narrow curved cross-streaks of bronze orange. A large black blotch covering whole side of tail; scapular spot ohsolete; fins all light rosy. Depth 2.25 to 2.50 in length.

Another specimen from A pia was light clear pink; about 15 narrow curved cross-streaks of bright rosy, some golden on cheek; a blackish stripe across eye and cheek; a round black spot on scapular region, and a larger and blacker one on tail at middle of base of caudal; fins all rosy, the caudal dusky shaded; iris golden, before and behind.

\section{PARAMIA Bleeker.}

\section{(('heilodipterus Cuvier \& Valenciennes; not of Lacépède.)}

515. Paramia quinquelineata (Cuvier \& Valenciennes). Mata uliuli. Samoa; New Guinea; Raiatea and Nukahiva (Seale)

This species is abundant about Samoa. We have about 40 examples from Apia and Pago Pago. The species is known at once by the black streaks, about 5 in number, which do not quite reach a black caudal spot which is in the center of a golden area.

Life colors of a specimen from Pago Pago, brownish, with about 5 stripes of black; a yellow ocellus around a black spot at the base of caudal.

A specimen from Apia was translucent olive; a round jet black spot at base of caudal with a broad golden yellow border; six black stripes along side; fins dirty translucent, the dorsal darker in front; ventral pinkish; no other red.

516. Paramia macrodon (Lacépède). Tuganini. New Guinea (Macleay); Samoa; East Indies.

(Cheitodipterus octovittatus Cuvier \& Valenciennes.)

This large species, reaching a length of eight inches, is rather common at Samoa. We have about twenty specimens from Apia and Samoa. It is known by the diffuse black caudal blotch and by -the presence of about eight dark stripes on each side.

Life colors of a specimen from Apia, pale translucent olive; with 7 to 9 streaks of soiled bronze, as wide as interspaces, the middle stripes plainer; one on middle line before dorsal; 7 on head besides a black band through eye; a broad diffuse black bar at base of caudal; fins all reddish, dusky shaded.

A larger example shows the streaks but faintly; first dorsal and ventrals tipped with black; candal irregularly black-edged.

517. Paramia truncata (Günther). Misol.

Cheilodipterus truncatus Günther, Cruise Curaçao, 1872, 418, Misol.

\section{SYNAGROPS Günther.}

518. Synagrops argyrea (Gilbert). Deep seas of Hawaii. 


\section{Family AMBASSIDE.}

\section{AMBASSIS Lacépède.}

Ambassis Cuvier \& Valenciennes, Hist. Nat. Poiss., II, 1829 (ambassis).

The generic name Chanda has priority over 1 mbassis, as Cantor and IVaite have recognized, but Fowler, the first reviser of Chanda, has made its type identical with the type of Bleeker's genus Pseudambassis. Pending a final agreement on the rule of nomenclature governing this case, we may follow Fowler's arrangement.

Ambassis, or Chanda, is characterized among related genera by the serrated preorbital, small teeth, large scales, complete laterai line, and the presence of about ten rays in the dorsal fin. A procumbent dorsal spine is always present, but in the Samoan species it is very small and concealed in the flesh. The weakness of this spine defines the genus Pseudoambassis of Castelnau, a group which we think inseparable from Ambassis. Pseudambassis of Bleeker is apparently a valid genus, with long anal fin and small scales. Priopis Kuhl \& Van Hasselt differs from Aspro in the interrupted lateral line.

Hamilton-Buchanan's Chanda (orala=noma), which is the same as Bogoda Bleeker, is characterized by the uninterrupted lateral line, small scales, and strong curved canines. Parambassis Bleeker, with canine teeth and a short anal fin, is apparently a valid genus.

519. Ambassis lafa Jordan \& Seale, new opecies. Lafo. Samoa.

Head 2.60 in length; depth equal to head; eye 3.45 in head; snout 5 ; dorsal vir, I, 10; anal IIx, 11, scales $3-31-6$; interorbital 4 .

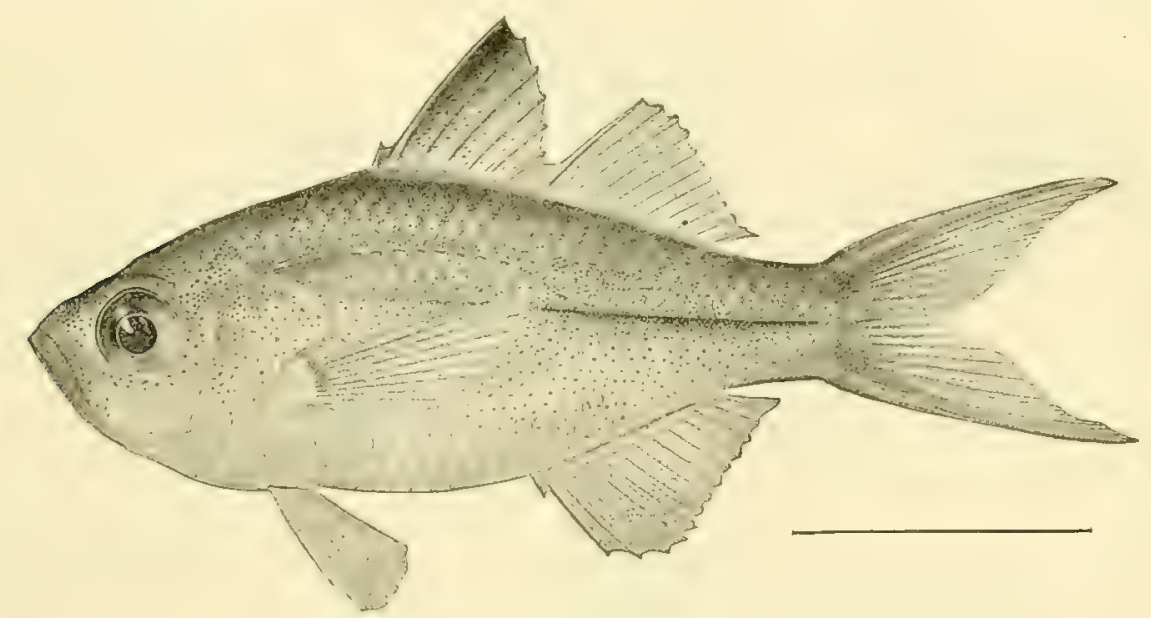

FIG. 46.-Ambassis lafa Jordan \& Seale, new species. Type.

Body oblong, compressed, slightly elevated; profile of head slightly concave over eye; body, opercles, and cheeks scaled; mouth rather large; maxillary 2.75 in heal, its distal end under anterior margin of pupil; lower jaw slightly the longer, minute villiform teeth in jaw, vomer and palatines, the inner row in jaws depressible, tongue smooth; gillrakers pointed, equal to width of pupil, 20 on lower limb; opercle entice; preopercle with flat spine at angle and the lower limb only serrated, the outer limb strongly denticulate below; depth of caudal peduncle greater than length of maxillary, 2.25 in head; second upright dorsal spine the longest and strongest, 1.50 in head; connection of soft with spinous dorsal very narrow, less than width of pupil; spine of solit dorsal 2.25 in head, the longest ray 2 in head; base of anal equal to distance from middle of eye to posterior tip of opercle, its longest ray equal to longest ray of dorsal; pectoral equal to distance from anterior of eye to posterior tip of opercle; ventral equal to base of anal; length of third anal spine $2.30 \mathrm{in}$ head, the second but little shorter, the first very small; caudal deeply forked, its lobes about equal to head; the ventrals are slightly in advance of base of pectorals. Lateral line continuous.

Color in life yellowish white, darker above, the margins of each scale being shaded with minute brown dots; a dark line from base of caulal along median line of body, fading out near the opercle; tip of snout, upper part of snout, interorbital, and upper half of eye dusky; dusky shading 
on first web of spinous dorsal; all the fins more or less punctulate with minute brown dots like pin points; opercle gilt; lower half of eye golden yellow; darker shadings along base of dorsal and anal, and a dusky line on under side of caudal peduncle, more distinct in the young, in which the line extends along the belly.

Color in life of a specimen from fresh water at mouth of Vaisigano River, A pia, olive, sides silvery, with a silvery lateral stripe; scales all dark-edged; fins dirty olive, with no trace of red markings, except that front of spinous dorsal is marked with dull orange.

This species is very abundant in the lower waters of the Vaisigano River and other streams of Upolu. We have upwards of a hundred specimens. The spinous dorsal is high, the spine reaching middle of second dorsal.

Type no. 51818, U. S. Nationol Museum, a specimen 3.69 inches long, from near mouth of Vaisigano River, Apia.

520. Ambassis vaivasensis Jordan \& Seale, new species. Lafa. Samoa.

Head 2.75 in length; depth equal to head; eye 3.10 in head; dorsal vII-I, 9; anal III, 9; scales $2-27-5$; interorbital 4 ; snout 1.50 in eye.

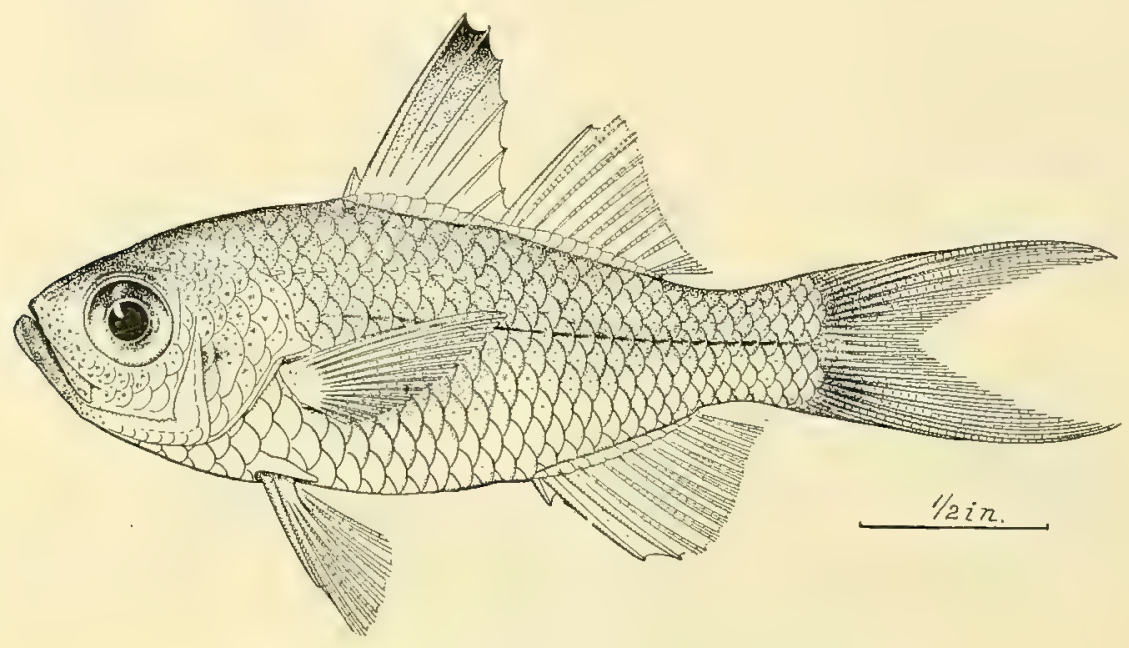

FrG. 47-Ambassis raivasensis Jordan \& Seale, new species. Type.

Body oblong, compressed, scarcely elevated, the scales of moderate size, covering opercles and cheeks; mouth large; profile of head slightly concave over middle of eye; maxillary 2.75 in head, its distal end under anterior margin of pupil; lower jaw slightly the longer; bands of villiform teeth in jaws, vomer and palatines, the inner series in jaws depressible; gillrakers rather slim, sharp-pointed, longest equal to pupil, 24 on lower limb; opercle entire, ending in a sharp-pointed flap; preopercle with flat spine at angle and denticulated on its lower limb; lower margin of outer limb of preopercle toothed; depth of caudal peduncle equal to length of maxillary; second (upright) spine of dorsal the longest and very strong, 1.40 in head; connection of soft with spinous dorsal very narrow, about onehalf width of pupil; spine of second dorsal 2 in head, the longest ray 1.75; caudal deeply forked, the lobes pointed, the longest ray 2.50 in length; base of anal equal to distance from middle of eye to posterior tip of opercle, its longest ray equal to longest ray of dorsal; of the three anal spines the first is very short, the second is long, 2 in head, the third is the longest, 1.80; pectoral reaching to a line with second dorsal ray, 3 in total length; base of ventrals directly over base of pectorals, length 1.50 in head; lateral line continuous.

Color in spirits, yellowish white, the back and upper part of sides slightly shaded with minute punctulations of brown; a silvery band along the median line of side from posterior margin of opercle to caudal, the band becoming more distinct posteriorly with a slight shading of brown; tip and first membrane of spinous dorsal shaded with dusky; base of caudal with slight shading of dusky, other fins white without markings; opercles gilt; upper part of orbit and eye dusky, lower part golden. The side is marked by a silvery streak with no caudal spot or crossbar. 
This species is rather common in the Vaisigano, Vaivase, and other streams of Upolu.

Thirty-one specimens from Apia, Samoa. The type is no.-51819, U. S. National Iuseum, from Vaivase River, Apia; length 2.50 inches.

521. Ambassis miops Günther. Rarotonga.

Ambassis miops Günther, Proc. Zool. Soc. Lond. 1871, 655, streams of Rarotonga.

522. Ambassis grigas (Ramsay \& Ogilby). Streams of New Guinea.

Ambassis gigas Ramsey \& Ogilby, Proc. Linn. Soc. N. S. W. 1886, 9, New Guinea.

523. Ambassis macracanthus (Bleeker). Streams of New Guinea (Macleay); Java.

PRIOPIS Kuhl \& Van Hasselt.

524. Priopis papuensis (Alleyne \& Macleay). Streams of New Guinea. Ambassis papuensis Alleyne de Mreleay, Proc. Linn. Soc, N. S. W. 1876, 267.

525. Priopis agrammus (Günther). New Guinea (Ramsay \& Ogilby); North Australia. Ambassis agrammus Günther, Ann. Mag. Nat. Hist. 1867, 57, Cape York.

\section{TETRACENTRUM Macleay.}

Dorsal fin continuous; anal spines four. Otherwise resembling Amia (Apogon).

526. Tetracentrum apogonoides Macleay. Streams of New Guinea. Tetracentrum apogonoides Macleay, Proc. Linn. Soc. N. S. W. 1883, 256, Goldie R. (New Guinea).

\section{Family KUHLIIDE.}

KUHLIA Gill.

527. Kuhlia rupestris (Lacépède). Sesele. Samoa; Guam; Vanicolo; Fiji; Tonga; Rodriguex; Futuna; New Mebrides; Molicolo; New Guinea; Solomon Is.; Caroline Is.; Palau Is.; New Caledonia; East Indies.

This species, which closely resembles the American black bass in form and habits, is very common in all the rivers of Samoa, where it reaches a weight of 5 or 6 pounds. Many specimens were taken, most of them from the deep swimming-pool in the Vaisigano River above Apia.

528. Kuhlia marginata (Cuvier \& Valenciennes). Salele. Fiji; Tahiti; Samoa; Gilbert Is.; Papua; Bonham I.; Misol; East Indies.

This species is found in the river mouths of Samoa, about a dozen specimens, mostly small, being taken in the Vaisigano River at Apia.

529. Kuhlia urvillii Boulenger. South Pacific; locality unknown.

530. Kuhlia malo (Cuvier \& Valenciennes). Hawaii; Tahiti; Tubuai; Paumotu Is. (Seale); Fiji; Rodriguez; Laysan.

531. Kuhlia tæniura (Cuvier \& Valenciennes). Safole. Samoa; Johnston I.; Marcus I.; Tubuai; Paumotu Is.; and Tahiti (Seale); East Indies; Galapagos Is.

This species, unlike the others of the genus, never enters fresh water, nor is it found about the reefs. It frequents the "iron-bound," or lava, coast in rather deep water. Our specimens, about a dozen in number, were taken on the northwest shore of Tutuila, opposite Pago Pago.

532. Kuhlia caudovittata (Lacépède). Tahiti.

\section{Family SERRANIDE.}

PLECTROPOMUS (Cuvier) oken, (Lates Cuvier \& Valenciennes.)

533. Plectropomus calcarifer (Bloch). New Guinea (Macleay); Australia.

\section{PIKEA Steindachner.}

534. Pikea aurora Jordan \& Evermann. Hawan. 


\section{CHORIstistiuM Poey.}

This genus has been hitherto known from a single species taken by Poey in Cuba, and named Chorististium rubrum. The discovery of a second species is most interesting.

535. Chorististium susumi Jordan \& Seale, new species. Susu umi. Samoa.

Head 2.55 in length; depth 3.40 ; eye 4.50 in head; dorsal $V_{I-I}, 10$; anal III, 8; scales 3-49-11; interorbital equal to eye.

Body elongate, compressed; scales of moderate size, striated and ciliated, entirely covering head and body; lateral line strongly curved, the straight portion 2 in curved; snout rather wide but acute; the lower jaw slightly the longer; maxillary 2.40 in head, extending to posterior third of eye; a distinct supplemental bone; mouth large, with broad bands of villiform teeth in jaws, vomer and palatines, the inner row in jaws slightly longer and depressible; no teeth on tongue; gillrakers equal to one-half eye, 13 on lower linb; longest spine of dorsal 2.75 in head; distance between last dorsal spine and origin of soft dorsal 4.50 in head; base of soft dorsal equal to depth of caudal peduncle, its margin somewhat rounded, its longest ray 2 in head; caudal bilobed, its longest ray 2 in head; base of anal equal to

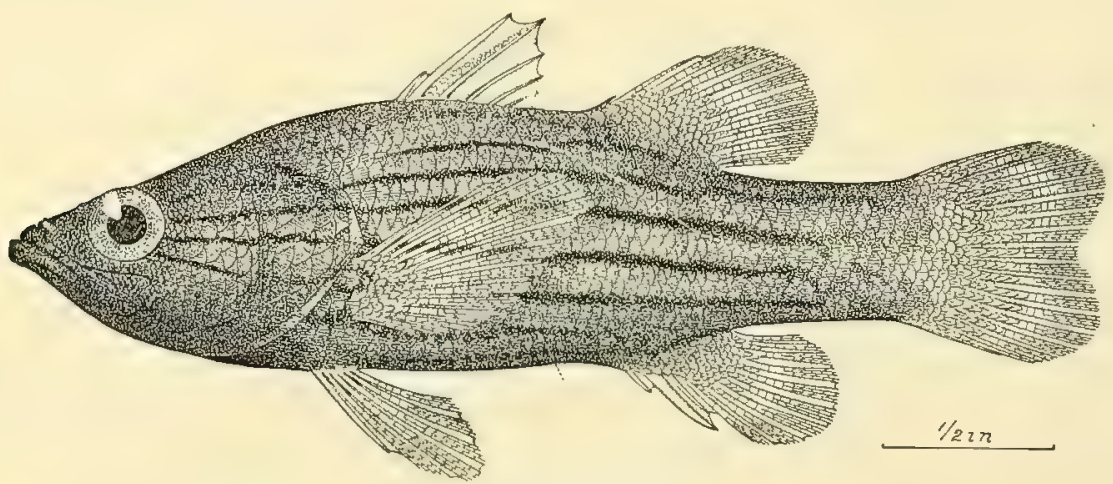

FIG. 48.-Chorististium susum Jordan \& Seale, new species. Type.

iongest (2nd) anal spine; its longest ray 2.10 in head; pectoral equal to distance from middle of eye to posterior margin of opercle; ventrals inserted directly below the base of pectorals, their length 1.55 in head; opercle armed with three flat spines, the two lower ones closest together; preopercle slightly serrate.

Color in spirits, light brown, with seven longitudinal lines of deeper brown on sides; four of these lines arise from posterior margin of orbit and extend to or near base of candal; the remaining three seem to arise at margin of opercles and extend about to a line with axis of soft dorsal; fins all uniform. yellowish white.

Life colors of one specimen trom Apia, dark brown suffused with red, redder below and behind; about seven olive-red stripes, very dark on body, these not extending much on head; fins all plain bright cherry red.

Two specimens from the reel at Apia. The type is no. 51738, U. S. National Museum, 3.10 inches long.

\section{CENTROGENYS Richardson.}

536. Centrogenys waigiensis (Quoy \& Gammard). New Guinea; Australia; East Indies.

\section{PARACANTHISTIUS Bleeker.}

\section{(Plectropoma Boulenger, not les Plectropomes of Cuvier = Plectropomus Oken.)}

537. Paracanthistius maculatus (Bloch). Samoa; Lousiades; Fiji; Palau Is.; New Guinea (Macleay); Faté (Seale).

One large example taken at Apia. It belongs to the form called leopardus, the body covered with round blue dark-edged spots, none of them elongate. This is apparently not specifically distinct from the true maculatus, in which these spots are larger, some of them oblong or elongate.

538. Paracanthistius oligacanthus (Bleeker). Carolıne Is.; East Indies. 
ANYPERODON Günther.

539. Anyperodon leucogrammicus (Cuvier \& Valenciennes). Gatala alevc. Samoa; Ponape; Caroline Is; New Hebrides; New Guinea (Macleay); East Indies.

Of this handsome species, 7 adult specimens were taken at Apia. Life colors of one of these, clear olive-green, with 4 faint interrupted stripes of white, the second and third widened and distinct at intervals, forming 2 white spots on side; lowest stripe very distinct across cheek; side with about 8 rows of bright orange-brown spots, not ocellated or reticulated; head with smaller spots; lower parts of head coppery red; spinous dorsal olive with 3 rows of larye orange spots; second dorsal, anal, and caudal green, dorsal and anal with a spot at base of each ray; pectoral pale olive; ventral dusky olive, both unspotted. Body elongate; caudal rounded; teeth in 2 rows below.

\section{VARIOLA Swainson.}

540. Variola louti (Forskâl). I'a manaia. Tahiti; Samoa; Paumotu Is.; New Hebrides; Solomon Is.; Marshall Is.; Faté (Seale).

Of this beautiful and widely diffused species, 10 specimens of different sizes were taken at Apia and Pago Pago.

Life colors of a specimen from Pago Pago, greenish above, rosy below; upper spots clear violet; lower lateral spots cherry-red; crimson on tail, the edges of spots dark, the spots largely lake; dorsal deep red, with spots of violet and lake; caudal similar, similarly golden behind; pectoral purplish, pale golden behind, violet spotted at base; ventral clear red, red spotted at base, tinged with golden at tip; spots arranged in lines, the lateral spots oblong.

541. Variola flavimarginata (Rüppell). Samoa; East Indies.

Serranus flavimarginalus Ruppell, Atlas Rothen Meeres, 109, 1828, Red Sea.

Variola flavimarginata, Bleeker, Verh. Ak. Amst., IV, 9, 1873, East Indies. Bleeker, Atlas Ichth., vir, 23, tab. CCs XXXLX, fig. 1.

Serranus melanotinic Bleeker, Act. Soc. Sci. Ind. Ned., II, 1857, Amboina.

Of this rare species, overlooked by Dr. Bulenger, we have one fine specimen from Apia. It has the general form of Taviola louti, but a very different coloration, there being a broad black band along the upper part of the side.

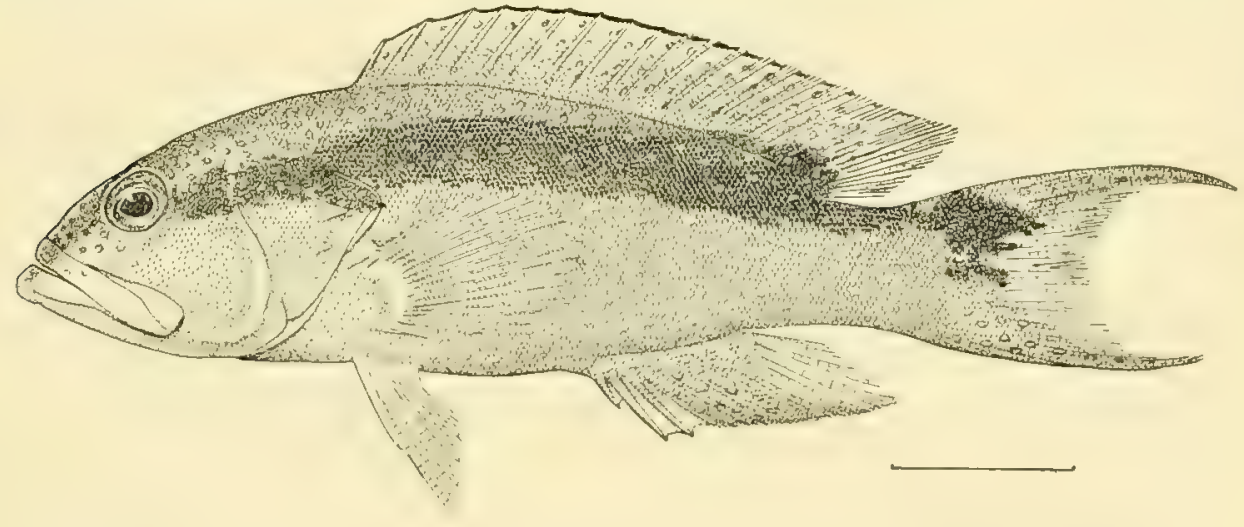

FIr. 49.- Variola flarimarginata (Rüppell).

Life colors, ground-color pinkish salmon, whiter region behind pectoral; a velvet blackish longitudinal band, side above brownish salmon; spots whitish below and posteriorly; elsewhere purple-pink with lake border.

\section{CEPHALOPHOLIS Bloch \& Schnoider.}

This genus, as here understood, differs from Epinephelus in having but 9 dorsal spines. There is considerable difference among the species in the form of the skull, but in this regard few of the l'acific species have been examined. It here includes Enneacentrus and Petrometopon of Gill, Menephorus of Poey, and Bodianus Cuvier (not of Bloch). 
542. Cephalopholis argus (Bloch). Gatala moana (blue spotted); Gatala uli; Vaiania. Samoa; Hawaii; Borabora; New Guinea; Marquesas Is.; Papua; New Britain; Tahiti; Tubuai and Rarotonga (Seale); East Indies.

Common about the reefs of Samoa. Life colors of a specimen from Pago Pago, dark gray all over, with evenly disposed rather pale-blue spots with blackish edge; caudal with narrow white margin; dorsal with very narrow white margin on posterior half; pectoral paler than body.

543. Cephalopholis miniatus (Forskâl). Samoa (Boulenger); Apamana; New Guinea (Macleay); New Britain (Peters); Shortland Is. (Seale).

544. Cephalopholis boenack (Bloch). New Guinea (Macleay).

545. Cephalopholis urodelus (Forster). Mata' ili. Tahiti; IKingsmill Is.; Harvey Is.; Paumotu Is.; Samoa; Solomon Is.; New Guinea; Uene, Society Is.; Misol; New Hebrides; Micronesia; Fanning Is.; Funafuti, Ellice Is.; Mangareva (Seale); East Indies.

Of this handsome species, $t$ specimens were taken at Apia. Life colors of one, deep brick-red, darker olivaceous on back, the posterior parts almost black, the belly and sides paler and brighter red; head closely covered on sides with vermilion spots, the ground-color forming reticulations around them; body spotted with small vermilion spots which are sparse and show faintly on the groundcolor; opercular flap olivaceous; dorsal dark red, the edge bright red, the narrow margin dusky; anal similar but brighter, with broader margins; traces of vermilion spots; caudal red-black, very dark, with two white cross-bands, converging behind, cutting off the dusky red corners; ventral vermilion with a dark edge; pectoral vermilion at base, then blackish, the edge broadly dull orange.

Another specimen was brown, with yellow-greenish tinge; dorsal with two yellow-white spaces interrupting brown, and with posterior third with yellow white edge; caudal with angulated transverse yellow white bar, also narrower terminal bar yellow white; anal with one yellow white blotch; ventral blackish brown; pectoral yellow white with brown blotch at base and two weakly indicated brownish cross-bands; sides of body and head with creamy white blotches.

546. Cephalopholis leopardus (Lacépède). Gatala uli. Samoa; Tahiti; Louisiades.

Of this species, 8 specimens were taken at Apia. Life colors of one of these, dark olive, with round scarlet spots on side; a black opercular spot; a black spot on tail below axil of dorsal, a smaller one behind it; dorsal reddish olive, with a scarlet margin; caudal with deep red convergent bands, a yellow stripe within each, the outer margin whitish; anal mottled red and bluish with a broad scarlet band and grayish edge; pectoral orange; ventral red; lips cream and olive mottled, reddish within.

547. Cephalopholis aurantius (Cuvier \& Valenciennes). New Ireland; Louisiades; East Indies.

548. Cephalopholis sexmaculatus (Rüppell). Tahiti; Paumotu Is.

549. Cephalopholis sonnerati (Cuvier \& Valenciennes). Kingsmill I.; Palau Is.; East Indies.

\section{EPINEPHELUS Bloch.}

550. Epinephelus merra Bloch. Gatala; 'Ata'ata pulepule. Samoa; Marcus I.; New Ireland (Peters); Tahiti; Guam (Seale); Fiji; New Hebrides; Solomon Is.; New Guinea (Macleay).

This species is excessively common about the reefs of Samoa, the young living in every crevice, by far outnumbering all other species of this family. About 50 specimens were preserved.

Life colors of a specimen from Apia, very dark olive-brown, the ground-color reduced to hexagonal spots surrounded by whitish olive reticulations, which are broader and clearer below; spots on head smaller; fins all similarly marked; edge of dorsal dusky, with a paler streak below. Gillrakers 12 .

Another specimen from Apia was olivaceous, dark above, the spots dull orange with darker centers; those on dorsal more orange, the interspaces grayish olive; maxillary, branchiostegals, and belly also spotted. Gill-rakers 12.

551. Epinephelus stellans (Richardson). Samoa; East Indies.

Of this species, apparently distinguished from Epinephelus merra by the presence of small white spots scattered over the body, among the larger dark ones, we have 3 examples from Samoa. 
552. Epinephelus dæmeli (Günther). 'Uo'uo. Guam; Samoa; Norfolk I.; New Guinea; Solomon Is. (Seale); Australia.

Of this species we have two large specimens from Apia. Life colors of one, rery dark olive with many fine brown spots, gray reticulations around them on cheeks and jaws; five black irregular blotches on back, and two below it; one blotch on back of tail; fins all mottled and barred obscurely, reddish brown, olive and black. Ten gill-rakers.

The other specimen was olive-gray, closely covered with small dark brown spots which are larger below; a large black blotch on back of tail; fins all dusky, all spotted like the body, pectoral paler.

553. Epinephelus fuscoguttatus (Forskảl). Samoa; Marshall Is.; Tonga; Greenwich Is.; New Guinea (Macleay, as Serronus microdon); East Indies.

Of this species, we have 6 specimens, large and small, from Apia. They agree fairly with Bleeker's plate.

Life colors of one specimen, olive, rather pale, with round brown spots which are narrower than the interspaces; a dark brown moustache behind the maxillary; upper jaw spotted; a black saddle on caudal peduncle; dorsal, caudal, and head spotted like body; caudal dusky behind with whitish edge; anal similar, less spotted; ventral similar; caudal with smaller spots. Gill-rakers 12; preopercle rounded, feebly notched and spined.

554. Epinephelus corallicola (Cuvier \& Valenciennes). Samoa; Mortlock Is.; Caroline Is.; Greenwich I.; Howland I.; New Guinea (Macleay).

Of this species, we have one example from Apia. It agrees fairly with Günther's figure of Serranus howlandi.

Life colors, margin of caudal bright golden yellow, pectoral with margin weakly orange yellow, body with flesh-brown polygonal blotches.

555. Epinephelus macrocephalus (Lacépède). Kingsmill I.; Mortlock Is.; Ponape: Rodriguez; East Indies; New Guinea (Macleay).

556. Epinephelus maculatus (Bloch). Samoa; Papua; Marshall Is.; Caroline Is.; Shortland I.; Paumotu Is. (Seale).

Of this well-marked species, we have one young example from $A$ pia.

557. Epinephelus fasciatus (Forskål). Louisiades; Tahiti; Paumotu Is.; New Britain; Bonham I. ; New Guinea; Mangareva (Seale); Japan; East Indies.

558. Epinephelus chlorocephalus (Cuvier \& Valenciennes). Tonga; East Indies.

559. Epinephelus australis (Castelnau). New Britain (Boulenger); Australia.

560. Epinephelus pachycentron (Cuvier \& Valenciennes). Louisiades; East Indies.

561. Epinephelus summana (Forkål). Caroline Is.; New Guinea; Shortland I. (Seale); East Indies.

562. Epinephelus megachir (Richardson). Louisiades; New Guinea (Alleyne \& Macleay as Serranus alatus); East Indies.

563. Epinephelus sexfasciatus (Cuvier \& Valenciennes). Louisiades; East Indies.

564. Epinephelus tauvina (Forskâl). Louisiades; Ponape; Palau Is.; Fast Indies.

565. Epinephelus quernus Seale. Hawaii.

566. Epinephelus undulosus (Quoy \& Gaimard). Misol; Shortland 1. (Seale); East Indies.

567. Epinephelus spiniger (Günther). Marcus I. (Bryan \& Herre, Bishop Mus., Ir, 1903, 129).

568. Epinephelus cæruleopunctatus (Bloch). New Britain (Peters); East Indie*.

569. Epinephelus socialis (Günther). Tahiti; Kingsmill I.; Paumotu Is.; Samoa (Boulenger).

We did not find this species, recorded from Samoa by Dr. Boulenger. 
570. Epinephelus magnificus (Macleay). New Guinea. Serranus magnificus Macleay, Proc. Ling, Soc. N. S. W. 1\&83, 229, New Guinea.

571. Epinephelus albopunctatus (Boulenger). Marquesas Is.

572. Epinephelus goldiei (Macleay). New Guinea; New Caledonia. Serranus goldiei Macleay, Proc. Linn. Soc. N. S. W. 1883, 226, New Guinea.

\section{ODONTANTHIAS Bleeker.}

573. Odontanthias fuscipinnis (Jenkins). Hawaii.

\section{PSEUDANTHIAS Bleeker.}

574. Pseudanthias kelloggi (Jordan \& Evermann). Hawaii.

575. Pseudanthias hypselosomus (Bleeker). New Guinea.

576. Pseudanthias mortoni (Macleay). New Guinea.

Anthias mortoni Macleay, Proc. Linn. Soc. N. S. W. 1883, 253, Moresby I. (New Guinea).

\section{ANTHIAS Bloch.}

577. Anthias manadensis Bleeker. New Guinea (Macleay); East Indies.

578. Anthias cheirospilos Bleeker. New Guinea (Macleay); East Indies.

\section{CAPRODON Schlegel.}

579. Caprodon schlegeli Günther. Hawaii; Japan.

\section{GRAMMISTES Bloch \& Schneider.}

580. Grammistes sexlineatus (Thunberg). Samoa; Tabiti; Solomon Is.; New Guinea; New Hebrides; Kingsmill I.; Marquesas Is. (Seale). (Pl. xxxviI, fig. 2.)

Two specimens from Apia. Life colors of one of these, black with 7 irregular stripes of pale golden yellow; fins all dull reddish, the first dorsal dusky, the rest pale.

\section{POGONOPERCA Günther.}

581. Pogonoperca ocellata Günther. Tahiti; Misol; East Indies.

\section{PHAROPTERYX Rüppell.}

Plesiops Cuvier, Règne Animal, II, 266, 1817, repeated in 2d ed., 1828. (No type; no species known at that time.)

Plesiops Oken, Isis, 1182, 1817; name only, after Cuvier.

Pharopteryx Rüppell, Atlas, 15, 1828 (nigricuns).

Plesiops Günther, Cat., Ir, 363, 1861 (nigricans).

The name Plesiops, without specified type or reference to any species, no species of the genus having been described at the time, should apparently give place to Pharopteryx.

582. Pharopteryx nigricans Rüppell. Samoa; Tahiti; Tonga; Palau Is.; Gilbert Is.; Fiji; Solomon Is. (Seale.)

Pharopteryx nigricans Rüppell, Atlas, 15, pl. IV, fig. 2, 1828, Red Sea.

Plesiops nigricans Rüppell, N. W. Fische, 5, 1835. Bleeker, Atlas Ich., IX, tab. cccxc, fig. 3. Günther, Cat, 1II, 363, Red Sea.

Plesiops caruleolinealus Rüppell, N. W. Fische, 5, 1835, Red Sea.

Plesiops corallicola Bleekẻr, Nat. Tijds. Ned. Ind., Iv, 1853, 280. Günther, Fische der Südsee, 87, taf, 58, fig. B, Tahiti, Tonga, Palau, Gilbert Is.

Plesiops nigricans Boulenger, Cat., I, 340, Zanzibar, Ceylon, China, Andamans, Sumatra, Fiji, Tonga, Samoa Micronesia.

This species is very abundant in the reefs of Apia and Pago Pago. About 100 specimens were taken in the tide pools. Life colors of a specimen from Apia, black; head with sky-blue spots; a 
black ocellus on opercle, with orange below it; fins all black; dorsal and caudal edged with white; pectoral broadly edged with scarlet. Some (male) with sky blue spots in center of opercular ocellus, and a sky-blue stripe along middle of dorsal and anal. Some with blue spots along whole of body.

583. Pharopteryx melas (Bleeker). Samoa; Savay; Kandavu; East Indies. (Pl. xxxviI, fig. 3.)

Plesiops melas Bleeker, Bali, 1819, 9, Bali.

Plesiops nigricans var, apoda Kner, Sitz. Ak. Wiss. Wien 1868, 5ł, Savay, Kandavu.

This species is very common in the tide pools on the reefs of Upolu and Tutuila. It is almost as common as Phuropteryx nigricans, but it never reaches as large a size as that species. About 60 specimens were taken. In life it is well distinguished by the broad scarlet edge of the spinous dorsal fin. The body is without blue spots or lines and there are always 11 dorsal spines, while 12 are present in all our specimens of $P$. nigricans. This leaves no doubt that $P$. apoda of Kiner, based on a specimen which had lost the ventral fins, is our species, but fortunately the well-chosen name given by Bleeker is earlier.

Bleeker's description of Plesiops melas evidently belongs to this species, and not to Pharopteryx nigricans. He finds $x i, 8$ dorsal rays, and the color is diagnostic: "Corpore pinnisque omnibus nigerrimo maculis vel vittis nulla; membrana pinne dorsalis spinose partie superiore tantum pellucida." This clear margin to the dorsal is, however, in life flane red.

Life colors of a specimen from Pago Pago, dark, blackish brown to black; the whitish sides finely spotted with black; dorsal with bright brick-red margin, then clear white, then broad dark-brown base, with blue line and posteriorly several short blue linear spots; caudal with orange-yellow submarginal band; blue lines in anal; ventral and pectoral pale smoky. In some specimens the caudal is black, or has a dull orange intramarginal band.

Another specimen from the same locality was black, first dorsal scarlet, edged with blue stripes on black below.

A specimen from Apia was black, iris and edge of dorsal spines scarlet; no opercular spot.

A third specimen from Pago Pago was all black, no ocellus; first dorsal edged with scarlet, a white line below it; second dorsal and caudal not pale-edged; pectoral all black.

GRAMMATONOTUS Gilbert.

584. Grammatonotus laysanus Gilbert. Laysan.

\section{Family PRIACANTHIDA.}

\section{PRIACANTHUS Cuvier. (Abuhammir Forskål.)}

585. Priacanthus cruentatus (Lacépède). Mata-pula. Hawaii; Samoa; Tahiti; Caroline Is.; Japan; West Indies; Clarion Is.

This species is common throughout the Pacific. It is rather common at A pia, where about a dozen specimens were taken. It is also found at Hawaii.

Life colors of a specimen from Apia, bright light red, silvery on sides; fins much the same; dorsal, anal, and caudal with small round spots of deep red.

586. Priacanthus alalaua Jordan \& Evermann. Hawaii.

587. Priacanthus hamruhr (Forskảl). New Guinea (Macleay); Solomon Is. (Seale); Japan; East Indies.

588. Priacanthus meeki Jenkins. Hawaii.

Family I,UTIANIDA.

LUTIANUS Bloch. (Hobar Forskål.)

589. Lutianus kasmira (Forskâl). Tahiti; Samoa; Fiji; Louisiades; New Ireland; Guam; MIarcus I.; New Hebrides (Seale); East Indies.

(Iolocentrus bengalensis Bloch.)

Two small specimens of this very widely distributed species were taken at Pago Pago. Life colors of one of these, bright light golden olive with four bright blue stripes, darker edge; fins like the body, paler at base; edge of spinous dorsal deep golden. 
590. Lutianus cæruleolineatus (Rüppell). Marcus I. (Bryan \& Herre); New Guinea (Macleay); East Indies.

Mesoprion quinquelineatus Cuvier \& Valenciennes, Hist. Nat. Poiss., II, 445; not of Bloch.

591. Lutianus gibbus (Forskål). Th'ava; Mala'i; Mala'i pa'pue. Samoa; New Britain; Tahiti; New Ireland; Waigiu; Papua; Borabora (as Mesoprion boreneis Cuvier \& Valenciennes); Solomon Is. and New Hebrides (Seale); East Indies.

(IIolocentrus boutton Lacépède; Diacope bottonensis Cuvier \& Valenciennes.)

Ten large examples were taken at Apia and Pago Pago. * The species is easily known by the deep notch on the preopercle.

Life colors of a specimen from Pago Pago, dark olive green, the belly bright coppery red; each scale with a fine pale blue-green spot, these forming continuous lines; head mostly coppery red; caudal peduncle abruptly (obliquely) black behind dorsal; dorsal dark brown, the soft fin with white edge, the soft rays black at base; caudal black at base, golden at tip, with a maroon stripe in each lobe; anal coppery red with a black submarginal shade and a white edge; ventral coppery red, with blackish shade; pectoral pale orange, the axil black.

A specimen from Apia was olive ahove, very bright coppery red below; faint pale streaks along rows of scales; dorsal coppery red, dusky shaded at base, the edge yellow; anal dusky red, edged with whitish; ventral similar to anal; pectoral light orange-red.

592. Lutianus bohar (Forskål). Mumea. Samoa; Tahiti; Paumotus; Solomon Is. (Seale); New Guinea (Macleay); Marcus I. (Bryan \& Herre); Thornton I. (Fowler); East Indies.

Two large examples were obtained at Pago Pago. This fish has the reputation of being always poisonous, the only species not Plectognath of which this statement is made. The two round pale spots below the dorsal fin are diagnostic.

Life colors, deep brick red everywhere, blackish on back, each scale with a whitish vertical spot, these forming lines along the rows of scales which are very oblique above lateral line, horizontal below; a dark dash along maxillary and behind it (in one specimen only); two rounded pale blotches along base of soft dorsal; dorsal blackish maroon, a narrow pale edge; caudal dark maroon, a narrow dark edge (the lower lobe longest, the fin deeply forked); anal darker red in front, with pale edge; pectoral deep red above and in axil, pale below; ventral mesially blackish red, pale edge. Dorsal $x$, 13; anal III, 8; scales 8-64; canines large.

593. Lutianus bidens (Macleay). New Grinea.

Genyoroge bidens Macleay, Proc. Linn. Soc. N. S. W. 1883, 230, New Guinea.

594. Lutianus argentimaculatus (Forskål). $A^{\prime} \alpha ;$ Nanue. Samoa; Kingsmill I.; New Britain; New Guinea (Macleay).

Mesoprion garretti Günther, Fische der Südsee, 1873, 15, taf, 13, fig. B, Kingsmill I.

Of this species four fine specimens were taken at A pia. The largest, known as $a^{\prime} a$, is nearly 2 feet in length. Two others still much larger were seen but not taken. The species bears a strong superficial resemblance to Lutianus griseus of the Atlantic.

Life colors of a specimen from Apia, olive, flushed with very dark coppery red; belly dark coppery red; a narrow blue streak below eye; fins all deep coppery red; ventral and anal black towards edge with pale anterior margin; caudal with a narrow black margin.

Another specimen from Apia, called ganue, had the colors of Lutianus griseus, the Atlantic speciesdull green, scales darker in center; lower parts, with all fins, more or less coppery red; anal pale-edged; a blue streak below eye.

595. Lutianus olivaceus (Cuvier \& Valenciennes). Waigiu. Perhaps same as preceding.

596. Lutianus roseus (Cuvier \& Valenciennes). Ulea, Caroline Is.

Based on a drawing, a very doubtful species. Red; dorsal xIII, 12, with blue spots. It also is probably identical with Lutianus argentimaculatus.

597. Lutianus rivulatus (Cuvier \& Valenciennes). Uiui; Nanue. Samoa; East Indies.

Of this well-marked species two fine specimens were taken at Apia. Life colors of one called lanue, dark olive, each scale with a blue spot; belly coppery with blue stripes; head closely covered 
with wavy streaks of bright blue; dorsal greenish yellow; caudal same, dusky toward tip, with dusky edge; pectoral dusky, with pale edge; anal golden, the first soft rays dusky with narrow pale edge.

A specimen called vi'ui was clear olive green, bronze-orange on belly; each scale above with a small round pale-blue spot; head brassy yellow, entirely covered with light clear-blue streaks and vermiculations; maxillary yellow; fins all soiled yellow, brightest on edge.

598. Lutianus marginatus Cuvier \& Valenciennes. Taira; Tagau; Tamala; Lanue; Nanue. Samoa; Tahiti; Louisiades; Vanicolo; Oualan; Thornton I.; New Hebrides and Shortland I. (Seale).

Of this species, by far the most abundant of the genus, about 40 specimens were preserved-from Apia and Pago Pago. Life colors were noted in various specimens as follows:

(1) Specimen from Apia called taiva. Olive above, each scale edged with brassy, the belly gradually shaded to brassy orange; lower parts of head bright coppery; front of head dusky purplish, brassy about eye; dorsal blood-red, paler at base, a narrow pale edge; caudal deep wine-color with a pale edge; anal bright golden, the first soft rays darker; ventral pure golden, the first rays paler, the last duller; pectoral golden, the lower rays paler.

(2) Specimen called tagau, from Apia. Golden olive; yellow below; lower side of head marbled bluish gray and coppery red; dorsal scarlet, darker above, with a blackish stripe lengthwise and a whitish edge; caudal deep wine-red with whitish edge; pectoral and ventral golden; anal yellow with blackish and whitish edges.

(3) Specimen called tamala, from Apia. Brassy orange, bright on belly, coppery on lower part of head, dusky greenish shaded on back; head bright scarlet below with blue streaks about sub-and interopercle; dorsal scarlet with a broad black band and white edge; caudal dark wine-color, paleedged; anal golden, darker anteriorly, and pale edged; ventral deep golden; pectoral light yellow.

(4) Also called tamala, from Apia. Coppery red, rather pale, greenish above; each scale edged with coppery; head deep coppery red, paler creamy red below with grayish shades; lower jaw gray; no black spot; belly yellow; dorsal blackish red, very deep paler below; soft dorsal with pale edging; caudal blackish red, edge paler; anal golden, deeper yellow anteriorly; ventral golden; pectoral transparent olivaceous.

(5) Young specimen from Apia. Very pale olive, the sides silvery gray, unmarked, the lower parts golden shaded; lower parts of head with blue and golden markings; dorsal fin pale at base, with broad edging of maroon black, and a narrow white margin; caudal grayish; dark maroon distally, with a white margin; lower fins all clear golden.

(6) From Apia. Olive green, belly orange, no spot; lower part of head scarlet over whitish; dorsal red, first with pale middle; soft dorsal dark-edged; caudal deep wine color, with white edge; ventral and anal golden; pectoral yellowish.

599. Lutianus unicolor (Alleyne \& Macleay). Percy I.; New Guinea.

Genyoroge unicolor Alleyne \& Macleay, Proc. Linn. Soc. N. S. W. 1876, 266.

600. Lutianus semicinctus (Quoy \& Gaimard). Waigiu; Rawak; New Guinea (Macleay); Kingsmill I.; Fiji; East Indies.

601. Lutianus fulvus Forster. Tahiti; Guam.

602. Lutianus rufolineatus (Cuvier \& Valenciennes). Fiji; Waigiu; Papua; East Indies.

Diacope rufolineata Cuvier \& Valenciennes, Hist. Nat. Poiss, vr, 531, 1830, Papua.

Diacope vitianus Hombron d Jacquinot, Voy. Pole Sud, 37; taf. 2, fig. 2, Fiji.

Mesoprion amboinensis Blecker, Nat. Tijds. Ned. Ind., III, 259, Amboina.

Jesoprion melanospilos Bleeker, op. cit., 750, Celebes.

603. Lutianus goldiei (Macleay). New Guinea.

Mesoprion goldiei Macleay, Proc. Linn. Soc. N. S. W. 1883, 233, New Guinea.

604. Lutianus parvidens (Macleay). New Guinea. (Macleay, op. cit., 234.)

605. Lutianus caudalis Cuvier \& Valenciennes. Vanicolo.

606. Lutianus waigiensis (Cuvier \& Valenciennes). Waigiu; North Australia.

607. Lutianus marginipinnis (Macleay). New Guinea.

IYesoprion marginipinnis Macleay, Proc. Linn. Snc. N. S. W. 1883, 254, Normanby I. (New Guinea). 
608. Lutianus sexfasciatus (Macleay). New Guinea.

609. Lutianus rubens (Macleay). New Guinea.

Nesoprion rubens Macleay, Proc. Linn. Soc. N. S. W. 1883, 232, New Guinea.

610. Lutianus flavipes (Cuvier \& Valenciennes). Vanicolo; East Indies.

Diacope analis Cuvier \& Valenciennes, Hist. Nat. Poiss., vr, 534, 1830, Ile de France.

Diacope aurantiaca Cuvier \& Valenciennes, op. cit., VI, 535, 1830, Vanicolo.

611. Iutianus lineatus (Quoy \& Gaimard). Samoa; Waigiu; Guam; Christmas I. East Indies. Serranus limbatus Cuvier \& Valenciennes, Hist. Nat. Poiss, II, 307, 1828, Guam.

Of this species we have 3 young specimens from the reef at Apia. They are reddish olive in spirits, with about 6 yellowish stripes from the snout to base of caudal; dorsal dark-edged; caudal dusky behind; notch on preopercle slight; tongue with teeth.

612. Lutianus vitta (Quoy \& Gaimard). Waigiu; Louisiades; East Indies.

613. Lutianus chrysotænia (Bleeker). New Guinea (Macleay); East Indies.

614. Lutianus johni (Bloch). Tahiti (Günther); East Indies.

615. Lutianus fulviflamma (Forskâl). Fiji; New Guinea (Macleay); Faté (Seale); East Indies.

616. Lutianus monostigma (Cuvier \& Valenciennes). Tuiva uliuli; Vava sui; Feloïtega; Samoa; Tahiti; Kingsmill I.; Paumotu Is.; New Guinea (Macleay); Tubuai; Marquesas Is. and Faté (Seale).

Mesoprion monostigma Cuvier \& Valenciennes, Hist. Nat. Poiss., II, 446, 1828.

Lutianus lioglossus Bleeker, Atlas, vIII, 70, tab. XLVI, fig. 4, 187\%.

Of this well-marked species 12 fine specimens were taken at Apia. Life colors were noted in various specimens as follows:

(1) Specimen from Apia called vava sui. Olive-green, scales on sides brassy; belly whitish tinged with golden yellow; a small, well-defined black lateral spot; fins all golden-yellow; lips orange-red; no stripe on head; axil dark.

(2) Specimen called feloitega, from Apia. Color the same as in no. 1, with black axil spot, except that lower parts are shaded with coppery red; jaws bright red; fins all deep yellow; seems same except for red color.

(3) From Apia. Coppery red, the belly paler red, the back olive; a small jet-black lateral spot; fins all bright orange yellow, the dorsal dark on edge, the soft dorsal paler; a pale streak below eye.

(4) Specimen called tava uli'uli, from Pago Pago. Dull olive-green, without red shades; lateral spot distinct; fins above yellow olive; below more yellow, verging on orange; soft dorsal, anal, and ventral with pale edge; traces of bronze streaks along scales.

This species, often poisonous, is well distinguished by its small, well-defined lateral spot and the absence of teeth on the tongue. It is well represented in Günther's plate (Fische der Südsee, pl. 16), except that in that plate the first soft ray of the dorsal is represented as a spine. In our judgment, Günther and Sauvage are right in identifying the monostigma of Cuvier \& Valenciennes with Bleeker's lioglossus.

617. Lutianus erythropterus (Bloch). Guam; East Indies.

(Diacope lineolata Rüppell.)

618. Lutianus russelli (Bleeker). Solomon Is. (Seale); East Indies.

619. Lutianus flaviroseus (De Vis). New Britain.

This species is unknown to us. It bears some resemblance to Lutianus monostigma, but has a faint dark spot at base of caudal.

620. Lutianus ehrenbergi (Peters). New Ireland; New Britain; East Indies. Mesoprion ehrenbergi Peters, Berl. Mon. 1869, 704, New Ireland, New Britain.

621. Ioutianus aureovittatus (Macleay). Solomon Is.

This species is unknown to us. There is a large black blotch on the lateral line, and three golden stripes along the lower part of the side. 
622. Lutianus adeti (Castelnau). New Caledonia.

Diacopus adeti Castelnau, Proc. Zool. Soc. Victoria, IIr, 1873, New Caledonia.

623. Lutianus fuscescens (Cuvier \& Valenciennes). Tahiti (Seale); East Indies; China.

624. Lutianus niger (Forskål). Samoa (Günther); Papua; East Indies.

(Mesoprion macolor Cuvier \& Valenciennes.)

This strongly marked species, the type of Bleeker's genus Macolor, recorded from Samoa by Dr. Günther (Fische der Südsee, p. 11) was not taken by us.

\section{APRION Cuvier.}

625. Aprion virescens (Cuvier \& Valenciennes). Hawaii; Fiji; Tahiti; East Indies.

626. Aprion microdon Steindachner.

627. Aprion latifrons Kner. Fiji.

Sparopsis latifrons Kner, Sitz. Ak. Wiss, Wien 1868, 27, Fiji.

\section{ETELIS Cuvier.}

628. Etelis evurus Jordan \& Evermann. Hawaii.

629. Etelis marshi Jenkins. Hawaii.

\section{CHETOPTERUS Schlegel.}

630. Chæetopterus dubius Günther. Hawaỉ; Japan.

(Bowersia ulaula Jordan \& Evermann.)

ROOSEVELTIA Jordan \& Evermann, new genus.

Rooseveltia Jordan \& Evermann, new genus of Serranidee (Serranus brighami Seale).

631. Rooseveltia brighami (Seale). Hawaii.

632. Rooseveltia aloha (Jordan \& Snyder). Hawaii.

\section{BOWERSIA Jordan \& Evermann.}

633. Bowersia violescens Jordan \& Evermann. Hawaii.

(Apsilus microdon Jordan \& Evermann; not Apron microdon Steindachner.)

\section{APHAREUS Cavier.}

634. Aphareus furcatus (Lacépède). Tahiti; East Indies; Japan.

635. Aphareus flavivultus Jenkins. Hawaii.

\section{SYMPHORUS Günther.}

636. Symphorus spilurus Gïnther. Palau Is. Symphorus spilurus Gunther, Fische der Südsee, 61, taf. 47, 1873, Palau Is.

\section{NEMIPTERUS Swainson. (Synagris Günther.)}

637. Nemipterus ruber (Cuvier \& Valenciennes). New Guinea; Last Indies.

638. Nemipterus tolu (Cuvier \& Valenciennes). New Guinea (Bleeker); Java.

639. Nemipterus waigiensis (Quoy \& Gaimard). Waigiu; Rawak.

640. Nemipterus marginatus (Cuvier \& Valenciennes). New Guinea; East Indies.

641. Nemipterus tæniopterus (Cuvier \& Valenciennes). New Guinea (Ogilby); Australia; India. Dentex toniopterus Cuvier \& Valenciennes, H, st. Nas. Poiss., VI, 216, 1830, no locality. Synagris notalus Day, l'roc. Zool. Soc, 1870,684 , India.

642. Nemipterus furcosus (Cuvier \& Valenciennes). New Guinea (Macleay); East Indies.

$$
\text { B. B. F. 190, -1: }
$$


CESIO Cavier.

643. ' Crsio cærulaureus (Lacépède). Samoa; New Guinea; Solomon Is. (Seale); East Indies.

This beautiful little fish is rather common in the coral reefs, about a dozen specimens being taken at Apia. Life colors of one of these, clear light blue, very bright; a golden streak above eye and above lateral line to base of caudal; dorsal dusky gray; caudal pink, with a black stripe along each lobe; anal pinkish; ventral white; pectoral colorless, a black bar at base; a brownish mark behind eye.

644. Cæesio erythrogaster Cuvier \& Valenciennes. New Guinea (Macleay).

645. Cæsio lunaris Ehrenberg. New Ireland; New Guinea (Macleay); Solomon Is. (Seale).

646. Cæsio chrysozonus Kuhl \& Van Hasselt. New Guinea (Macleay); East Indies.

647. Cæsio argenteus (Bloch). Gilbert Is. (Günther); East Indies.

648. Cæsio pisang Bleeker. New Guinea (Macleay).

PTEROCESIO Bleeker.

649. Pterocæsio tile (Cuvier \& Valenciennes). Caroline Is.; Gilbert Is.; Tahiti; Tonga.

Family MENIDE.

ERYTHRICHTHYS Schlegel.

650. Erythrichthys schlegeli (Günther). Hawaii; Japan.

TERAPON Cuvier.

(Djabub Forskål; Therapon Cuvier \& Valenciennes.)

651. Terapon jarbua (Forskål). 'Ava'ava. Samoa; Fiji; New Britain; New Guinea; Solomon Is. (Seale).

(Holocentrus servus Bloch.)

This species is exceedingly common in tide waters at the river mouths in Samoa. We haveabout 40 specimens from the mouth of the Vaisigono River. It takes the hook readily.

Life colors of a specimen from Apia, greenish gray, bands olive brown, those in caudal browner; first dorsal gray and olive; second dorsal, ventral, and anal creamy orange. Adults have the markings more faint.

652. Terapon nasutus Macleay. New Guinea.

Therapon nasutus Macleay, Proc. Linn. Soc. N. S. W. 1884, 258, Normanby I. (New Guinea).

653. Terapon interruptus Macleay. New Guinea.

654. Terapon chalybœus Macleay. New Guinea.

655. Terapon trimaculatus Macleay. Goldie River, New Guinea.

656. Terapon caudavittatus (Richardson). New Guinea (Macleay); Australia.

657. Terapon sexlineatus (Quoy \& Gaimard). New Guinea; Australia; Timor.

658. Terapon oxyrhynchus Schlegel. Fiji (Günther); Japan.

659. Terapon puta Cuvier \& Valenciennes. New Britain; East Indies. Therapon trivittatus De Vis, Proc. Linn. Soc. N. S. W., VIII, 457, New Britain,

660. Terapon argenteus (Cuvier \& Valenciennes): Kandavu, Fiji (Kner). Therapon argenteus Kner, Sitz. Ak, Wiss, Wien, 1868, 7, Kandavu.

661. Terapon unicolor Günther. Kandavu, Fiji (Kner); Australia.

662. Terapon theraps Cuvier \& Valenciennes. Caroline Is. (Günther); East Indies. 


\section{Family HEMULIDE.}

\section{PLECTORHYNCHUS Lacépède. (Gaterin Forskål.)}

Fowler separates from Plectorhynchus the species with large scales and 14 dorsal spines as Euelctichthys, and those with small scales and 10 dorsal spines as Spilotichthys. In I'leclorhynchus (=Diagramma) the scales are small and the dorsal spines mostly 12 (11 to 13). Further structural differences have been noted by Waite and Ogilby ( $\mathrm{ms}$. .).

663. Plectorhynchus diagramma (Lacépède): 'Ava'ava moana. Samoa; Waigiu; Tahiti; New Guinea (Macleay).

(Dingramma lessont Cuvier \& Valenciennes; Diagramma linealum Cuvier \& Valenciennes; T'lectorhynchus cuvieri Bleeker.)

Of this strongly marked species we have two specimens from Apia and Pago Pago. In one, about nine inches long, the pale color is yellowish, the two median bands on the side coalescing over the pectoral, and the dorsal and caudal fin being marked with black stripes and no spots; the pectoral fin has a large black median spot. This specimen corresponds closely with the original figure of $P$, cuvierias given by Bennett.

The other specimen is nearly two feet long. The pale markings are bluish gray, the stripes on the side are all distinct, and the stripes on the dorsal and caudal are broken up into large round spots, those on the caudal forming two cross-series. The pectoral fin is unspotted. This corresponds to the figures of Plectorhynchus lessoni as given by Lesson, Günther, and Bleeker. Bleeker's figure of Plectorhynchus cuvieri represents an intermediate stage. We have no doubt that these specimens belong to one species, for which the tenable name is Plectorhynchus diagramma.

Life colors, young specimen from Apia, dark brown, belly white, side with five pure whitestripes of varying width with deep brown interspaces; head anteriorly washed with golden, the stripes becoming yellow; dorsal striped, dark brown and light yellow; caudal redder brown and deep yellow in elaborate stripes; anal yellow with two brown red stripes; ventral golden with dark spots, its axil deep red; pectoral with a brown-red axil and basal bar, the fin yellow with a large black spot.

The Pago Pago specimen, adult, had eight dark brown longitudinal stripes on side (the eighth weak); caudal bright yellow with about 30 subcircular brown blotches and margin dark brown; dorsal yellowish like tail, with black brown margin and blotches; anal same; pectoral yellow with red axil; ventrals yellow with red axil and brown markings on posterior aspect; ground-color of body white with slight bluish tinge; the white interspaces on back strongly tinged with yellow.

664. Plectorhynchus orientalis (Bloch). Samoa (Günther); East Indies.

Not found by us; perhaps representing a stage in growth of $P$. diagramma.

665. Plectorhynchus pica (Cuvier \& Valenciennes). Tahiti; Fiji.

666. Plectorhynchus radja Bleeker. New Guinea (Macleay).

667. Plectorhynchus polytænia Bleeker. New Guinea (Macleay).

668. Plectorhynchus punctatissimus (Playfair). Tahiti; Seychelles.

Diagramma punctatissimum Playfair, Proc. Zool. Soc. 1867, 851, Seychelles. Günther, Fische der Südsee, 27, taf. 21, Society Is, on a figure of Garrett.

669. Plectorhynchus giganteus (Günther). Ponape; Caroline Is.

Diagramma giganteum Günther, Ann. Mag. Nat, Hist. 1879, 6, Ponape.

670. Plectorhynchus chætodonoides Lacépède. I'a mai-moana. Samoa; Fiji (Günther); Last Indies.

(Diagramma pardalis Kuh1 \& Van Hasselt; adult.)

One very large example, closely resembling the figure of the adult given by Dr. Bleeker, was taken at Apia. Life colors, olive, closely covered above with hexagonal spots of dark brown, restricting the pale olive-green ground color to reticulations; belly slate-color; all the fins spotted like the body, the spots smaller, the pectoral spotted only on the inside; caudal with a gray and then a black margin; membrane of jaws, inside of mouth, and the naker skin at opercular joints all bright blood-red. 
671. Plectorhynchus papuensis (Macleay). New Guinea. Diagramma papuensis Macleay, Proc, Linn. Soc. N. S. W. 1883, 237.

672. Plectorhynchus hæmatochir (Bleeker). New Guinea (Macleay); East Indies. (Plectorhynehrs goldmanni Bleeker.)

\section{SPILOTICHTHYS Fowler.}

673. Spilotichthys centurio (Cuvier \& Valenciennes). New Guinea (Macleay); Seychelles.

674. Spilotichthys pictus (Thunberg). New Guinea (Bleeker); Fiji (Günther); East Indies; Japan.

\section{EUELATICHTHYS Fowler.}

675. Euelatichthys crassispinus (Rüppell). Misimisi. Samoa; East Indies.

Diagramma crassispinum Rüppell, Neue Wirbelthiere, Físche, 125, taf, 30, fig. 4, 1835, Red Sea. Günther, Cat., 1,319 .

Diagramma gibbosus Hombron \& Jacquinot, Voy, Sud Pole, 46, pl. 5, fig. 5, 1854. Günther, Cat., I, 319. Günther, Fische der Südsee, 26

Diagramma affine Günther, Cat., I, 319, Australia, Moluccas, Amboina, Madras, China.

Of this species we have three large examples and one small one from Apia. The small specimen has the caudal fin gray. In the others this fin is black. The small specimen and two of the large ones have the soft dorsal covered with small blackish spots, Some of these spots are seen on the caudal fin. In one specimen there are no distinct spots on the dorsal, and one faint one only at base of caudal. These specimens certainly belong to the same species, and we see no reason for separating the nominal species affine and gibbosus from it, although $P$. gibbosus, originally described from Samoa, is said to have 13 spines. This may be an individual variation or an error in counting.

Life colors of a specimen from river mouth at Apia, blackish; caudal abruptly pale gray; round black spots on dorsal, anal, and base of caudal; body unspotted; fins else blackish.

Another specimen from Apia, called misi misi, was dark olive, each scale with darker edge; preopercle and opercle black-edged; fins all plain dusky, the edges blacker; a few small black spots on second doreal; no red or yellow.

676. Euelatichthys crassilabris (Alleyne \& Macleay). New Guinea. Diagramma crassilabris Alleyne \& Macleay, Proc. Linn. Soc. N. S. W. 1876, 271, Hall Sound (New Guinea),

This species must be very close to $P$. crassispinus.

677. Euelatichthys obscurus (Günther). Fiji.

Diagramma obscumum Günther, Proc. Zool. Soc. 1871, 657, Fiji.

This species is not known to us. It resembles $P$. crassispinus, but the second anal spine is much smaller than in the latter.

678. Euelatichthys unicolor (Macleay). New Guinea.

Diagramma unicolor Macleay, Proc. Linn. Soc. N. S. W. 1876, 261, China Straits, New Guinea.

\section{POMADASIS Lacépède 1804.}

679. Pomadasis hasta (Bloch). New Britain (Peters); East Indies; New Guinea (Macleay).

\section{SYMPHYSANODON Bleeker.}

680. Symphysanodon typus Bleeker. New Guinea.

Symphysanodon typus Bleeker, Arch. Neerl. Ind. 1878,61.

\section{scoLoPsis Cuvier. (Ghanan Forskål.)}

681. Scolopsis trilineata Kuer. Taiva tusi. Samoa; Fiji; New Guinea; New Hebrides (Seale). Scolopsis trilineata Kner, Sitz. Ak. Wiss. Wien 1868, 301, Samoa. Glinther, Fische der Südsee, 31, taf. 25, fig. A, Samoa, Fiji.

This species is one of the most tastefully colored of the coral-reef fishes of Samoa. About 20 specimens were obtained at Apia and Pago Pago. 
Life colors of a specimen from Apia called taiva tusi, pearl-gray, darker on back; forehead very dark brown, crossed by two bright blue stripes, both of which become golden yellow on eye, which is crossed by a dark brown stripe; three pearly white stripes behind eye, the middle one fainter, uniting near middle of body and proceeding to last ray of dorsal; fins pinkish gray; dorsal narrowly edged with orange; anal with pale blue; anal and soft dorsal with some orange shading; lower half of belly and head pure white.

682. Scolopsis bilineata (Bloch). New Guinea (Macleay); Kandavu, Fiji (Kner); Shortland I. (Seale); East Indies; Ovalau and Levuka (Günther).

683. Scolopsis lineata (Quoy \& Gaimard). Guam; Samoa (Günther); Faté (Seale).

684. Scolopsis ciliata (Lacépède). Vanicolo; New Guinea (Macleay); East Indies.

685. Scolopsis monogramma Kuhl \& Van Hasselt. New Guinea (Macleay); Faté and New Hebrides (Seale); East Indies.

686. Scolopsis temporalis Cuvier \& Valenciennes. New Guinea (Macleay); Fiji (Günther); Vanicolo; Waigiu; Louisiades; Solomon Is. (Seale).

687. Scolopsis xenochrous Günther. Misol.

Scolopsis xenochrous Günther, Cruise of the Curaçoa, 1873, 20.

688. Scolopsis cancellata Cuvier \& Valenciennes. Polynesia; New Hanover (Peters); East Indies.

689. Scolopsis margaritifera Cuvier \& Valenciennes. New Guinea (Macleay); East Indies.

690. Scolopsis affinis Peters. New Ireland; New Britain.

Scolopsis affinis Peters, Berl. Mon-, 1876, 832, New Britain, New Ireland.

691. Scolopsis macrophthalmus Ramsay \& Ogilby. New Guinea,

\section{PENTAPUS Cuvier \& Valenciennes.}

692. Pentapus caninus Cuvier \& Valenciennes. New Guinea (Macleay); Louisiades; Apamana; Gilbert Is. (Günther).

693. Pentapus vittatus (Bloch). New Guinea (Günther); Solomon Is. (Seale); East Indies.

\section{GNATHODENTEX Bleeker.}

694. Gnathodontex aurolineatus (Lacépède). Tolai. Samoa; Hervey Islands; Tonga; Gilbert Is.; Tahiti- Paumotu Is.; Marcus I.; New Guinea (Macleay); Tubuai and Mangareva (Seale); East Indies.

This species is common about Samoa, where about 15 specimens were taken.

Color of a specimen from Apia called tolai, light olive-gray; 6 to 8 very faint longitudinal stripes of brownish bronze above lateral line, all of them disappearing behind micldle of body; still fainter streaks below lateral line; larger specimens with 5 broad, faint stripes of gold-bronze below lateral line; arı oblong spot of light yellow below soft dorsal; fins all plain light reddish, the edges a little darker; opercular flap dark; inside of mouth orange.

\section{Family SPARIDE,}

LETHRINUS Cuvier. (Schoür Forskål, 1775.)

695. Lethrinus ramak (Forskil). Mailafo'u; Magauli. Samoa; Palau Is.; Kingsmill I.; Fiji, East Indies.

Sciana ramak Forskul, Deser. Anim., 53, 1775, Red Sea.

Lethinusehrenbergi Cuvier \& Valenciennes, II ist. Nat. Poiss., 11, 31, 1830, Red Sea.

Lethrinus flavescens Cuvier \& Valenciennes, Hist. Nat. Poiss., VI, 299, 1836, Tonga.

Lethrmus ramah, Gunther, Cat., I. 459, Red Sea, Ceylon. Güntber, Fische der Sidsce, 69, taf, 46, fig. B, Samon, Palau Is., Kingsmill, Celebes.

This species is common at Samoa. Five large specimens were secured. 
Life colors of a specimen from Apia called mailafo' $u$, a faint pinkish band from pectoral back; head olive; lips flesh color; dorsal dull orange mottled with gray; caudal dull orange; anal reddish; ventral pale-yellowish tinged; pectoral faintly orange; no lateral spot.

Another specimen from Apia, called magaul, was light green, no spot; axil black; head dark; lips and gums scarlet; dorsal light bright red; caudal dirty yellow; pectoral bright yellow, orange above; anal dull orange; ventral gray, black at tip.

696. Lethrinus harak (Forskål). Mata'ele'ele. Samoa; New Britain; New Hanover (Peters); Faté in the New Hebrides (Seale).

Of this species 2 large specimens were taken at Apia. Life colors of one called mata 'ele'ele, dull olive green; fins all brick red; inside of mouth scarlet. A black lateral spot on molar teeth.

697. Lethrinus bonhamensis Günther. Samoa; Bonham I.; Philippines.

Lcthrinus bonhamensis Günther, Fische der Südsee, 65, taf. 46, Bonham X.

A single large specimen corresponding to Günther's figure was taken at Apia. It is near Lethrinus harak, but is apparently distinct. We have also examined specimens of the same species in the U.S. National Museum, collected on Negros Island in the Philippines by Prof. Bashford Dean.

698. Lethrinus papuensis Alleyne \& Macleay. New Guinea.

699. Lethrinus amboinensis Bleeker. Samoa; Palau Is. (Günther); East Indies.

Of this species we have 1 specimen from Apia.

700. Lethrinus erythropterus Cuvier \& Valenciennes. Ulea.

701. Lethrinus chrysostomus Richardson. New Guinea (Alleyne \& Macleay); Australia.

702. Lethrinus nebulosus (Forskål). Fiji (Günther); East Indies.

703. Lethrinus mahsena (Forskål). Samoa; Fiji; Palau Is.; Paumotu Is.; Waigiu; Mangareva (Seale).

(Lethrinus hypselopterous Bleeker.)

Of this species we have 1 large example from Apia, corresponding to Günther's tigure, and almost equally well to Bleeker's plate of Lethrinus hypseloplerus.

704. Lethrinus mahsenoides Bleeker. New Guinea (Ramsay \& Ogilby); East Indies.

705. Lethrinus alboguttatus Cuvier \& Valenciennes. Bonin Is.

706. Lethrinus laticaudus Alleyne \& Macleay. New Guinea. Lethrinus laticaudus Alleyne \& Macleay, Proc. Linn. Soc. N. S. W. 1876, 276, Percy I. (New Guinea).

707. Lethrinus moensi Bleeker. Tahiti; Tonga; Fiji; Paumotu Is.; Harvey Is.; New Guinea; Palau Is.; Louisiades; Marquesas Is. (Seale); East Indies.

708. Lethrinus ornatus Bleeker. New Guinea (Macleay); East Indies.

709. Lethrinus leutjanus Lacépède. New Guinea (Macleay); Faté (Seale); East Indies.

710. Lethrinus hæmatopterus Bleeker. Fiji (Günther); New Guinea (Macleay); East Indies.

711. Lethrinus erythracanthus Cuvier \& Valenciennes. Luganor; Mortlock Is.; Carolines.

712. Lethrinus sordidus Cuvier \& Valenciennes. New Guinea.

713. Lethrinus waigiensis Cuvier \& Valenciennes. Waigiu.

714. Lethrinus xanthopterus Cuvier \& Valenciennes. Ulea, Caroline Islands.

715. Lethrinus aurolineatus Macleay. New Guinea.

Lethrinus aurolineatus Macleay, Proc. Linn. Soc. N. S. W. 1883, 247, New Guinea.

LETHRINELLA Fowler.

This genus is distinguished from Lethrinus by the elongate pike-like snout and jaws.

716. Lethrinella miniata (Forster). Filoa 'ava. Samoa; Tahiti; Louisiades; Mareus I.; New Britain; East Indies. 
Of this remarkable species, distinguished by the pike-like prolongation of the snout, we have 3 large examples from Apia, one of them $2 \frac{1}{2}$ feet long. The long snout and comparative slenderness of the teeth define the well-marked genus Lethrinella of Fowler.

Life colors of a specimen called filoa va, from Apia, pale grayish olive unmarked; mouth scarlet within; membrances of upper jaw red; dorsal, anal, and caudal grayish, mottled olive, edged with dull red; pectoral dull light olive, ventral dusky gray.

\section{MONOTAXIS Bennett.}

717. Monotaxis grandoculis (Forskal). Mumu moaga; Loalia (a Rarotongan word). Hawaii; Samoa; Papua; Fiji; East Indies.

This species is rather common about Samoa, as also at Hawaii. It is valued as a food fish.

Life colors of a specimen from Apia, olive green, with 2 whitish cross-bars; a black crescent at base of pectoral; dorsal brownish, reddish at tip; caudal orange, yellow at base; anal like dorsal; pectoral and ventral reddish.

718. Monotaxis euanus (Günther). Tonga Is.

Sphrerodon euanus Günther, Ann. Mag. Nat. Hist., IV, 1879, 137̄, Eua (Tonga Is.).

SPARUS (Artedi) Linnæus. (Chrysophrys Cuvier \& Valenciennes.)

719. Sparus australis (Günther). New Hebrides; Australia.

Chrysophrys australis Günther, Cat., I, 491, rivers of Australia. De Vis, Proc. Linn. Soc. N. S. W. 1881, 457, Api (New Hebrides).

720. Sparus novæ-caledoniæ (Castelnau). New Caledonia.

Chrysophrys novæ-caledonix Castelnau, Proc. Zool. Soc. Vict. 1873, 110, New Caledonia.

721. Sparus berda Forskảl. New Guinea (Nacleay); East Indies.

(Spamı hasta, Bloch \& Schneider.)

\section{Family KYPHOSIDE. \\ PACHYMETOPON Günther.}

722. Pachymetopon squamosum Alleyne \& Macleay. New Guinea.

Pachymetopon squamosum Alleyne \& Macleay, Proc. Linn. Soc. N. S. W. 1876, 225, Hall Sound (New Guinea).

KYPHOSUS Lacépède. (Tahmel Forskâl, 1775.)

723. Kyphosus fuscus (Lacépède). Hawaii; New Hebrides (Seale); East Indies.

724. Kyphosus lembus (Cuvier \& Valenciennes). Vanicolo; East Indies.

725. Kyphosus sandvicensis (Sauvage). Hawaii; Laysan; Marcus I. (Bryan \& Herre).

This species seems to be almost identical with Kyphosus elegans. Peters, a species from the west coast of Mexico.

726. Kyphosus waigiensis (Quoy \& Gainard). Umue; Matu mutu. Waigiu; Papua; Caroline Is.; Samoa; Palau Is.; New Guinea.

Three large specimens of this species were taken at Apia. Life color of one called umue, bronze. brownish, with a gray spot on each scale, these forming pale bluish streaks, alternating with darker bronze streaks; no other colors; fins all dusky; pale below eye, a dark streak about it; opercle darkedged.

727. Kyphosus tahmel (Forskål). New Guinea(Bleeker); East Indies.

SECTATOR Jordan \& Fesler.

728. Sectator azureus Jordan \& Evermann. Hawaii. 


\section{Family GERRIDAE.}

\section{XYSTEMA Jordan \& Evermann.}

729. Xystæma gigas (Günther). Matu loa. Samoa; Fiji; Tonga.

Gerres gigas Günther, Cat., Iv, 262, Tonga. Günther, Fische der Südsee, 30, taf xxıv, fig. A, Tonga, Fiji, Samon

Life colors of a specimen from Apia called matu loa, silvery with faint dark shades; no bright colors; caudal pale edged; first dorsal elevated, its edge dusky.

One large specimen and one very small one taken at Apia. Apparently this species is distinct from $\boldsymbol{X}$. oblongum (Cuvier \& Valenciennes) of India, with which. Day unites it. $\boldsymbol{X}$. oblongum is still more elongate.

730. Xystæma argyreum (Forster). Matu. Samoa; Tahiti; Waigiu; Strong I.; Tanna; Australia; East Indies.

(Gerres waigiensis Quoy \& Gaimard.)

Compared with $\boldsymbol{X}$. argyreum, $\boldsymbol{X}$. gigas is less silvery, and has more distinct streaks along the rows of scales. In $\mathrm{X}$. gigas the snout is longer than eye; the body is more elongate, and the head proportionately longer.

This species is more common at Samoa than $X$. gigas, but seems to reach a rather smaller size. We have 8 examples of different sizes from Apia and Pago Pago. Life colors of an example from Apia, silvery, without dark streaks; ventral and anal light yellow; other fins scarcely yellowish; edge of spinous dorsal dusky.

731. Xystæma abbreviatum (Bleeker). New Guinea (Ramsay \& Ogilby); East Indies.

This can not be Sparus erythroums of Bloch, which is a species of Tystæma, said to be from Japan. Bloch's type is more elongate, the depth being $3 \frac{1}{5}$ inches, the total length $10 \frac{1}{2}$ inches in the type in the Iuseum of Berlin.

732. Xystæma macrosoma (Bleeker). Samoa (Kner, Sitz. Ak. Wiss. Wien 1868, 9, Savaii); Admiralty Is. (Gunther); East Indies.

This species, recorded by Kner from Samoa, was not seen by us.

733. Xystæma punctatum (Cuvier \& Valenciennes). Vanicolo; New Britain and New Hanover

(Peters); East Indies.

(Gerres filamentosus Cuvier \& Valenciennes, adult.)

Valenciennes describes Gerres punctatus as having the depth $3_{2}^{1}$ in the total length with caudal. This is true of the very young only ( 22 inches long). In the adult it is 3 or a little less. Gerres punctatus is, however, evidently the same as G. filamentosus, and the name occurs on an earlier page of the same work.

734. Xystæma acinaces (Bleeker). New Guinea (Macleay); East Indies.

735. Xystæma poeti (Cuvier \& Valenciennes). Milne Bay, New Guinea (Macleay); East Indies.

736. Xystæma macracanthum (Bleeker). New Guinea (Macleay); East Indies.

ULEMA Jordan \& Evermann.

737. Ulæma bispinosum (Alleyne \& Macleay). New Guinea. Gerres bispinosus Alleyne \& Macleay, Proc. Linn. Soc. N. S. W. 1876, 273, Hall Sound. Anal rays Ir, S.

\section{Family EQUULIDE.}

\section{EQUULA Cuvier.}

Equula Cuvier, Règne Anim., ed. 1, vol. II, 323, 1817 (insidiator). Deveximentum Fowler, Journ. Ac. Nat. Sci. Phila. 1904, 517 (insidiator).

738. Equula insidiator (Bloch). Tahitı (Kner); East Indies.

This species is separated by Fowler from Leiognathus as the type of a distinct genus Deveximentum, characterized by the vertical mouth. But the same species is the original type of the genus Equzia, which has been regarded as a synonym of Leiognathus. 
LEIOGNATHUS Lacépède.

739. Leiognathus fasciatus (Lacépède). Samoa; Fiji (Günther); New Britain (Peters); East Indies.

This species is common at Samoa, numerous specimens being taken about Apia and Pago Pago in the seine.

Life colors of a specimen from Apia, spots on sides and dorsal bars dull brassy; axil brassy and brassy shades on dorsal and anal fins.

Another specimen from Apia was silvery, faintly streaked and barred above. Dorsal spine not reaching tip of last spine in specimen 3 inches long. Young.

740. Leiognathus obscurus (Seale). Guam.

Lciognathus obscurus Seale, Bishop Mus. 1901, 74, Guam.

741. Leiognathus equula (Forskål). New Caledonia; East Indies.

Equala caballa (Cuvier \& Valenciennes). Castelnau, Proc. Zool. Soc. Victoria, 1873, 114, New Caledonia.

742. Leiognathus dussumieri (Cuvier \& Valenciennes). Tahiti (Kner, Novara Fische, 167); East Indies.

743. Leiognathus edentulus Lacépède. New Guinea (Macleay); East Indies.

744. Leiognathus smithursti (Ramsay \& Ogilby). New Guinea. Equula smithursti Ramsay \& Ogilby, Proe, Linn. Soc. N. S. W. 1886, 11.

GAZZA Cavier.

745. Gazza minuta (Bloch). New Guinea; New Britain (Peters); Tahiti (Kner); East Indies.

746. Gazza equulæeformis (Rüppell). Solomon Is.; East Indies.

747. Gazza argentaria (Forster). Tanna; New Hebrides; East Indies.

Family MULLIDA.

UPENEUS Crvier: (Upeneoides Bleeker.)

748. Upeneus vittatus (Forskål). Vete. Tahiti; Samoa; Papua; Borabora; Fiji; Marquesas Is. (Seale); East Indies.

This species is rather common about Samoa, where about a'dozen specimens were taken. In life the belly is a bright sulphur-yellow. The number of bands on the caudal fin is fewer than in Upeneus arge, one of those on the lower lobe being very broad and black.

Life colors of a specimen called ucte, olive, sides silvery, no red except on iris and sides of snout, side with 5 golden bands, fourth the brightest and broadest; belly bright sulphur yellow, in a broad stripe; barbels white; frst dorsal black at tip, with 2 white and 2 brassy bands, one of the latter at base; second dorsal with 4 'white and 4 olive oblique bands; fourth and fifth lateral bands converging on tail; upper lobe also with 3 dark oblique bands and 4 white bands; lower with 3 white and 2 dark bands, the outer one very broad, nearly as broad as eye, and black with yellow edge, twice the width of upper outer band.

749. Upeneus arge Jordan \& Evermann. Hawaii.

This large species is common about Hawaii, but has not been seen elsewhere. It has the belly silvery white in life and the caudal bands are more numerous and more even than in Upeneus viltatus.

750. Upeneus tæniopterus (Cuvier \& Valenciennes). Hawaii (Steindachner); Ceylon.

751. Upeneus tragula Richardson. New Guinea (Macleay); East Indies; China.

\section{PSEUDUPENEUS Bleeker.}

(Upeneus, Pseudupeneus, and Parupeners, all of Bleeker.)

752. Pseudupeneus multifasciatus (Quoy \& Gaimarl). Hawaii.

This species is very common about Hawaii, where it replaces the $P$. moana of the islands of Polynesia. In the former species the bright red area among the bands on the side is behind the pectoral. In Pseudupeneus mouna the bright yellow area is under the soft dorsal. 
753. Pseudupeneus moana Jordan \& Seale, new species.: Moana; Moaga; Maga (juv.); Moana faiara. Samoa.

Upencus trifasciatus Günther, Fische der Südsee, 59, taf. xlIV, fig. B, Vavau, Samoa, Amboina; not of Lacépède. Upeneus multifasciatus Seale, Bishop Musetum, I, 71, 1901, Guam; not of Quoy \& Gaimard.

Parupenens multifasciatus Bleeker, Mulloides, 20, 1874; Atlas, Mulloides, tab. Iv, fig. 4.

Head 3 in length to base of caudal; depth 3.25 ; eye 6.10 in head; interorbital 3.75 ; maxillary 3 in head, its distal width greater than eye, its posterior end not reaching below anterior margin of eye by at least two-thirds width of eye; dorsal vir-9; anal 7; scales 2-32-6; barbels long, reaching to second row of scales in front of ventrals.

Body oblong, compressed, deepest at origin of spinous dorsal; depth of caudal peduncle 2 in its length; body and head scaled; lips wide; teeth in a single row in each jaw, no teeth on vomer or palatines; preopercle entire; a short flat opercular spine; gill-rakers slim and sharp, 25 on lower limb, the longest slightly more than one-half width of eye; only two complete rows of scales between the dorsal fins; height of spinous dorsal 1.35 in head, its base 1.90 ; base of soft dorsal 1.95 in head; its last ray usually elongate, reaching to base of caudal; pectoral 1.35 in head; ventral 1.20 in head; base of anal 2.50 in head; its posterior ray somewhat prolonged, 1.95 in head; caudal 1.35 in head.

Color in spirits, upper half of body brownish with wash of purple, yellowish white below; a broad saddle of black on caudal peduncle; another broad black band from anterior half of soft dorsal; between these two is a bright yellow area, about as wide as the posterior black band; a narrow black band between the two dorsals, the yellow lines bordering on its posterior and anterior margins being narrow, about one scale in width; a broad, black band from anterior two-thirds of spinous dorsal; another black band in front of spinous dorsal, making in all five black vertical bands on the sides; all of these bands fade out a little below the axis of the body; there is a dusky blotch posterior to eye extending more or less distinctly upon nuchal region; a dusky line through eye and along sides of snout; spinous dorsal dusky; soft dorsal dusky at base with yellow margin, and some 4-5 narrow intermarginal lines of alternating light and dusky; the last ray of dorsal is entirely deep black; caudal dusky, with black upper and lower margins; anal yellowish with 4 intermarginal longitudinal lines of dusky; pectoral yellow; ventral yellow, the outer rays bluish.

Life colors of a specimen from Apia, dirty purplish red mottled with black and yellow, with \pm darker cross-bands; lower side of head wine red; barbels purplish; dorsal clouded dusky; second dorsal with blue and yellow streaks at tip; caudal dirty brown, edged with black above and below; anal pale violet, and with 4 violet and 4 light yellow streaks; ventral red with a purple-black edge; pectoral bright golden orange. Adult.

Another specimen from A pia, called moana, was olive, with golden edges and bluish base to seales; five blackish cross-bands; a black blotch behind eye; first dorsal dusky, second golden blackish at base, streaked above with bluish; caudal golden, covered with fine bluish streaks; anal dusky; ventral dusky; pertoral yellowish; barbels golden.

This species, common in the East Indies and in the South Seas, seems never to have received a distinctive specific name. The name trifasciatus certainly belongs to Pseudupeneus bifasciatus, while that of multifasciatus was given to the common moana of the Hawiian Islands.

Twenty-five specimens from Apia. The type is no. 51737, U. S. National Museum, length 8.55 inches.

The species is known from Samoa, Guam, Tahiti, Vavau, New Guinea (Macleay), Mangareva, Rarotonga, New Hebrides, Tubuai, and Nukahiva (Seale); also from East Indies.

754. Pseudupeneus atrocingulatus (Kner). Moana; Moaga. Samoa(Günther); Vavau; Amboina. Upeneus atrocingulatus Kner, XxI, 443. Günther, Fische der Südsee, 59, as var. C of U. trifasciatus, Samoa, Vavau, Amboina.

This species is close to Pseudupeneus moana, but the coloration is different from any specimen seen by us. We therefore regard it as a different species.

755. Pseudupeneus bifasciatus (Lacépède). Matalau uliuli; Maga (young). Hawaii; Samoa;

Rarotonga; Caroline Is.; Solomon Is; Marcus I.

(Mullus bifasciatus and Mrullus trifasciatus Lacépède.)

This species is common both at Hawaii and Samoa, where it reaches a large size, and is highly valued as food. It is easily distinguished from related species by the two or three broad cross-shades, one under each dorsal. 
Life colors of a specimen from Apia, called matalau uliuli, dusky violet-brown, no red; traces of faint diffuse dusky crossbars, one under first dorsal, one under second, the third on caudal peduncle; head with faint violet and golden specks and edgings; barbels black, yellow at tip; two faint paler cross-rings, one before and one behind dark bar on caudal peduncle; fins dusky; first dorsal dull bronze with pinkish rays; second dorsal and anal dull violet, with dull yellowish cross-streaks; caudal violet-black mottled with yellowish; ventral dull violet-bronze; pectoral paler, similar; a dusky bar across its base. A younger example was a little more reddish.

Another specimen from Apia was dark brownish gray, no red; three broad blackish cross-bands, the first at front of first dorsal, second under second dorsal, third on caudal peduncle; first dorsal blackish, tinged with dark red, olive at base, the rays pale violet; soft dorsal light olive with blue lines, and a broad black edge; caudal and anal similar; ventral dull red, shaded with black, a dusky bar across base of pectoral; pectoral pale reddish; barbels yellow.

A specimen called maga (young), from Apia, was dirty green, much marbled; a black bar below front of first dorsal and one below front of second dorsal; second dorsal and anal blackish, edged with jale; caudal dusky olive brown, pale-edged; ventral black, pale-edged; first dorsal brown; barbels yellow; head soiled and mottled olive.

756. Pseudupeneus semifasciatus (Macleay). New Guinea.

Upeneus semifasciatus Macleay, Proc. Linn. Soc. N. S. W. 1884, 263, Hood Gay.

757. Pseudupeneus porphyreus Jenkins. Hawaii.

758. Pseudupeneus chryserydros (Lacépède). Matulau. Samoa; Hawaii; Tahiti; Faté (Seale); East Indies.

Parupeneus xanthospilurus Bleeker, Mulloides, 57, 1874, Amboina.

This species is common about Samoa, as also about Hawaii. It is well distinguished by its peculiar violaceous coloration, like the lees of wine, according to Commerson, and by the golden or pale area on the back of the tail. The barbels, as in Upencus cyclostomus, are elongate. There seems to be no question that Lacépède's glowing description of the "Mullus rougeor" belongs to this species.

Life colors of a specimen from Apia, very pale violet, pinkish and greenish, not nearly so dark as in Hawaii.

759. Pseudupeneus cyclostomus (Lacépède). Samoa; Fast Indies.

Of this species we have three large specimens from Pago Pago. The species resembles Pseudupeneus chryserydros, but lacks the pale saddle on the tail, while the general color is clear rerl without markings. The barbels, as in Pseudupeneus chryserydros, are long, reaching past base of ventrals. The species is well represented in Sauvage's figure of Upeneus cyclostomus.

760. Pseudupeneus saffordi (Seale). Guam; East Indies.

Upeneus cyclostomus Günther, Fische der Südsee, 60, 1873, Mascarene I.; not of Lacépède. Upeneus chryserythrus Sauvage, Poiss. Madagascar, 228; not of Lacépède. Upeneus saffordi Seale, Bishop Museum 1901, 72, Guam.

This species was not seen by us. It is apparently the Upeneus cyclostomus of Günther, with short barbels, reaching preopercular margin, and with a pale area on the back of the tail.

761. Pseudupeneus crassilabris (Cuvier \& Valenciennes). Johnston I.; Papua. Openeus luteus Cuvier \& Valenciennes, Hist. Nar. Poiss, V1r, 521, 1531, Isle de France. Upeneus crassilabris cuvier \& Valenciennes, op. cit, 523, Papua.

762. Pseudupeneus chrysonemus Jordan \& Evermann. Hawaii.

763. Pseudupeneus fraterculus (Cuvier \& Valenciennes). Hawaii (Steindachner); Seychelles; Zanzibar.

764. Pseudupeneus tæniatus (Kner). Fiji; China?.

Upeneus barbcrinoides Kner, Novara Fische, pl. IV, 81, China; not of Bleeker.

Upeneus treniatus Kner, Sitz. Ak. Wiss. Wien 1808, 13, Kanathia (Fiji).

Parupeneus kneri Bleeker, Ned. Dierk., IV, 142, China; after Kner.

This species was not taken by us, unless it should prove to be the young of Prendupencus cluysonemus, which shows two pale lengthwise stripes on the upper anterior portion of the body in life. 
765. Pseudupeneus barberinus (Lacépède). Ta'uleia. Samoa; Palau Is.; Paumotu Is.; Harvey

I.; Kingsmill I.; Solomon Is.; East Indies.

This widely diffused species is rather common about Samoa, where three large examples were taken.

Life colors of a specimen from Apia, reddish gray, with bluish and yellowish streaks on head, the scales edged with bronze; a blackish brown stripe from snout through eye to last dorsal rays; a large dark brown spot at base of caudal; dorsal reddish, brown-edged in front; second dorsal and aual with obscure yellowish cross-streaks; caudal reddish, the rays yellowish; ventral and pectoral pale, tinged with yellowish; barbels white.

A larger example redder, with marks fainter.

766. Pseudupeneus barberinoides (Bleeker). New Guinea (Macleay); East Indies.

767. Pseudupeneus indicus (Shaw). Ta'uleia; Lailai. Samoa; Tonga; Fiji; Waigiu (as U. waigiensis Cuvier \& Valenciennes); East Indies.

Of this species we have two large specimens from Apia. The golden spot on the side of the back and the black spot on the back of the tail are characteristic.

Life colors of a specimen from Apia, olive-green, each scale darker olive at edge; a large oblong golden yellow blotch under soft dorsal; a large black blotch before base of caudal; cheek olive, with blue streaks; dorsal olive, second dorsal faintly barred with brassy; anal pinkish, similarly barred; ventral pink; pectoral pinkish; caudal pale yellowish olive, the outer rays pink; ventral bright pink; barbels pinkish.

768. Pseudupeneus pleurostigma (Bennett). Hawaii; Tahiti; Gilbert Is.; East Indies.

769. Pseudupeneus pleurospilos (Bleeker). Shortland I.; Solomon Is. (Seale); Japan; East Indies.

770. Pseudupeneus preorbitalis (Smith \& Swain). Johnston I.; southwest of Hawaii.

771. Pseudupeneus filamentosus (Macleay). New Guinea.

Upeneus filamentosus Macleay, Proc. Linn. Soc. N. S. W. 1884, 266; Hood Bay.

\section{MULLOIDES Bleeker.}

772. Mulloides auriflamma (Forskål). Ula'oa; I'ete. Samoa; Hawaii; New Guinea; Guam; Borabora; Tubuai; Tahiti and Nukuhiva (Seale); East Indies.

Upeneus atherinoides Cuvier \& Valenciennes, Hist. Nat. Poiss., vir, 526, Guam.

This species is abundant throughout the Pacific. Wre took several specimens in Pago Pago and about a dozen in Apia.

Life colors of a specimen from Apia called ula'oa, olive, belly silvery, flushed with red; a golden stripe, very bright, with yellow shades above and below; a black bar across base of pectoral; ventral and anal blackish yellow; caudal and both dorsals plain golden; pectoral colorless; no bars or spots.

Another specimen from Apia, light gray olive; back pinkish; opercles pink; a brownish yellow lateral band with yellow shades below; upper fins yellow; lower gray; yellow on sides of head; caudal dull yellow; barbels white.

773. Mulloides vanicolensis (Cuvier \& Valenciennes). Vanicolo; Johnston I. (Smith \& Swain).

774. Mulloides samoensis Günther. Afolu; $I$ 'a sina (white or lady fish-the young). Hawaii; Samoa.

This species is very abundant about Samoa, and scarcely less so in Hawaii. The small black spot on the side near the tip of the pectoral fin is very constant.

In one specimen from Apia there was a golden orange lateral band somewhat interrupted. Another specimen from this locality was pale, a broad deep dull,yellow lateral stripe with yellow shades above and below; yellow dashes on sides of hear, besides coppery; a small dark brown spot above end of pectoral in lateral shade; first dorsal anteriorly deep yellow, fading behind; second dorsal pale yellow, caudal bright yellow; lower parts, barbels and fins pure white.

The $i^{\prime} a$ sina is plainly the young of the afolu.

775. Mulloides erythrinus Klunzinger. Hawaii; Laysan; Tahiti; East Indies. 
776. Mulloides flammeus Jordan \& Evermann. Hawaii; Raiatea and Tahiti (Seale; perhaps the young of $M$. pflugeri).

777. Mulloides pflugeri Steindachner. Mawaii.

778. Mulloides zeylonicus (Cuvier \& Valenciennes). New Guinea (Bleeker); Ceylon.

Family TOXOTID E.

TOXOTES Cavier.

779. Toxotes jaculatrix (Pallas). New Guinea (Macleay); Faté, New Hebrides (Seale); East Indies.

Family SILLAGINIDE.

SILLAGO Cavier.

780. Sillago sihama (Forskål). Admiralty Is. (Günther); Bougainville Is. (Peters, Berl. Mon. 1876, 836); East Indies.

781. Sillago ciliata Cuvier \& Valenciennes. Percy I.; New Guinea (Macleay); Australia.

782. Sillago insularis Castelnau. New Caledonia. Sillago ciliata or insularis Cástelnau, Proc. Zool. Soc. Vict. 1873, 113, New Caledonia.

783. Sillago gracilis Macleay. New Guinea.

Sillago gracilis Mracleay, Proc. Linn. Soc. N. S. W. 1851, 279, Hall Sound.

Family MALACANTHIDE.

Malacanthus Cuvier.

784. Malacanthus parvipinnis (Vaillant \& Sauvage). Hawail.

OCEANOPS Jordan \& Seale, new genus.

Oceanops Jordan \& Seale, new genus of Malacanthidre (M. Latorittatus Lacépède).

785. Oceanops latovittata (Lacépède). Gatasami. Samoa; Palau Is.; Papua; East Indies. (Pl. xxxIx.)

This singularly beautiful fish is rather rare at Samoa. Two large specimens were taken at Pago Pago. The large size and brilliant blue coloration distinguish this species, in a very marked manner, from its dull gray-colored congeners. It has also a much longer, pike-like snout, thus unlike I/alacanthus plumieriand parvipinnis. It may be held as the type of a distinct subgenus or genus-Oceanopsthis appellation being a translation of the native name.

Life colors of a specimen from Pago Pago called gatasami (eye of the sea), intense violet blue; back black, with the blue reduced to streaks; jet black lateral band; belly abruptly white; dusky across base of pectoral; dorsal dusky at base, abruptly grayish above; caudal black, with a white square, bluish white stripe above, upper angle brown; anal whitish; ventral whitish; pectoral blue.

\section{Family PSEUDOCHROMIDE.}

PSEUDOCHROMIS Mäller \& Troschel.

786. Pseudochromis fuscus Müller \& Troschel. Solomon Is.; Yap I.; Palau Is.; East Indies.

\section{PSEUDOGRAMMA Bleeker}

787. Pseudogramma polyacanthus (Bleeker). Tahiti; Fiji; Marcus I. Raiatea, East Indies. l'seudochromis polyacanthus Bleeker, Ternate, vir, 375, 1856, Ternate. Kner, S1tz, Ak, Wiss, Wien 1867, 717, Fiji Gunther, Fische der Sudsee, 159, Laf, 95, fig. A, Tahiti, Rasatea. Fowler, Proc. Ac. Nat. Sci. Phila. 1900, 523 Tahiti.

Pseudogramma polyacanthu, Bryan \& Herre, Bishop Museum, vol, 1I, no. 1, 1903, 139, Marcus 1. 


\section{Family CIRRHITIDA}

\section{CHEILODACTYLUS Cuvier.}

788. Cheilodactylus vittatus Garrett. Hawaii.

\section{CIRRHITUS Lacépède.}

789. Cirrhitus marmoratus Lacépède. Potati. Hawaii; Rarotonga; Samoa.

This species, very common at Hawaii, is not rare about the reefs of Samoa. Six specimens were taken at Apia.

790. Cirrhitus oxycephalus Bennett. Bonham I.; Marshall group; East Indies.

\section{PARACIRRHITES Bleeker.}

791. Paracirrhites forsteri (Cuvier \& Valenciennes). Hawaii; Marquesas Is. (Seale).

792. Paracirrhites arcatus (Cuvier \& Valenciennes). Hawaii; New Guinea.

793. Paracirrhites cinctus (Günther). Hawaii.

794. Paracirrhites hemistictus (Günther). Kingswill I.; Tahiti. Cirrhites hemistictus Günther, Fische der Südsee, 69, taf. 50, fig. B, Kingsmill, Tahiti.

795. Paracirrhites polystictus (Günther). Tahiti; Kingsmill I. Cirrhules polystictus Günther, Fische der Sudsee, 70, taf. 50, fig. A, Kingsmill, Tahiti.

796. Paracirrhites melanotus (Günther). Tahiti; Raiatea. Cirrhites melanotus Günther, Fische der Sudsee, 72 , taf. 52, fig. C, 1873, Tahiti, Raiatea.

797. Paracirrhites punctatus (Cuvier \& Valenciennes). Savaii (Kner, Sitz. Ak. Wiss. Wien 1868, 16).

This species, obtained at Samoa by Kner, was not seen by us.

CIRRHITOIDEA Jenkins.

798. Cirrhitoidea bimacula Jenkins. Hawaii.

\section{Family POMACENTRIDA.} PREMNAS Cuvier.

799. Premnas biaculeatus (Bloch). New Guinea (Macleay); East Indies.

\section{AMPHIPRION Bloch \& Schneider.}

800. Amphiprion melanopus Bleeker. Samoa; Tonga; Ponape; Solomon Is.; Guam; Woodlark I. ; New GLinea; East Indies; D'Entrecasteaux Is. (Macleay.)

Amphipron melanopus B.eeker, Amboina, Nat. T1jds. Ind., 1II, 561, Amboina. Gunther, Cat, IV, 8.

Prochilus melanopus Bleeker, Atlas, Pomacentridæ, 26, tab. ccccI, fig. 7, 1877, Singapore, Ceram, Ternate, Amboint Solor, New Guınea.

Amphiprion ephippızm Gunther, Fische der Sudsee, 225, Tonga, Samoa, Ponape, Solomon Is. Seale, Bishop Nuseum 1901, 82, Guam, not of Bloch.

Amphipran monojasciatus Thiollière, Fauna Woodlark, 198, 1857, Woodlark I.

Of this species four specimens were taken by us at Apia, and one at Pago Pago. The specimens agree well with Bleeker's plate and with each other, and the species is no doubt a valid one.

Life colors of a specimen from Apia, deep reddish brown, the caudal peduncle bright brownish, the anterior region deep orange brown or cinnamon; a pale violet stripe across head edged before and behind with indigo-blue; ventral and anal black; dorsal reddish brown; paler behind; pectoral deep cinnamon brown; caudal pale brownish yellow.

801. Amphiprion arion De Vis. South Seas.

Amphimmon arion De Vis, Proc. Linn. Soc. N. S. W. 1884, 450, South Seas.

802. Amphiprion polymnus (Bloch). Palau Is. ; Ponape; Last Indies; Japan.

According to Günther this species, with melanopus, tricolon, chrysopterus, and xanthurus, is based on variants of Amphiprion ephippium. This view is open to question. 
803. Amphiprion tricolor Günther. Palau Is.; New Guinea; East Indies.

804. Amphiprion xanthurus Cuvier \& Valenciennes. Samoa (Günther); Ponape.

805. Amphiprion chrysopterus Cuvier \& Valenciennes. Kingsmill I. (Günther); Bourbon I.

806. Amphiprion bicinctus Rüppell. Solomon Is.; Guam; East Indies.

807. Amphiprion percula (Lacépède). Borabora; Vanicolo; New Guinea; New Ireland; New Britain; Solomon Is.

808. Amphiprion papuensis Macleay. New Guinea.

Amphiprion papuensis Macleay, Proc. Linn. Soc. N. S. W. 1883, 271.

809. Amphiprion perideraion Bleeker. Palau Is.; East Indies.

810. Amphiprion bifasciatus (Bloch). New Guinea; East Indies.

811. Amphiprion rosenbergi Bleeker. New Guinea.

\section{POMACENTRUS Lacépède.}

812. Pomacentrus pavo (Bloch). Toupou. Samoa; Tahiti; Ponape; Bonham I.; Woodlark I.; New Britain (as Pomacentrus notatus De Vis, Proc. Linn. Soc. N. S. W. 1884, 451); East Indies. (Pl. $\mathrm{xL}$, fig. 1.)

This beautiful little fish is very abundant about the coral reefs of Samoa, and is the handsomest of all blue fishes called taupou, or damsel. We have about 100 specimens. In the smaller examples the back and sides are nearly uniform sky-blue. In the adult the blue becomes differentiated as streaks and lines on each scale, the orange ground color nearly hidden by the blue markings.

Pomacentrus nolatus De Vis seems to agree fully with Pomacentrus pavo. It is doubtless the same species.

Life colors were noted as follows in various specimens of $P$. pavo:

(1) Specimen from Apia, called taupou. Brilliant sky-blue, grayer below and on caudal peduncle; a dark steely edge on each scale; head profusely spotted with blue, the spots small and darker-edged; a large black ocellus on opercular angle; dorsal blue, deep blue on distal half, the tips of first soft rays almost black, posterior rays mostly golden; caudal golden, pale blue mesially at base; anal pale blue, distally pale olive; pectoral and ventral slightly yellowish.

(2) From Apia. Deep violet-blue, clear, the dorsal, anal and caudal, with caudal peduncle, shading into bright golden; base of dorsal and anal deep blue; a small opercular spot, none on body or axil; pectoral pale yellowish; ventral blackish.

(3) From Pago Pago. Deepest violet-blue, intensely dark blue on back; head with many pale sky-blue dots and curved lines; two from eye to mouth; a blue line around chin; caudal peduncle and posterior part of soft dorsal and anal with whole caudal deep orange yellow; a deep black spot on opercular angle; axil with a blue dot rather faint; no spot in axil of dorsal and anal; spinous dorsal and front of soft dorsal deep blue, edged with sky-blue; ventral and pectoral pale bluish; anal and dorsal pointed; caudal pointed with unequal lobes; breast blue, with dark streaks.

(4) From Apia. Bright blue, with indigo markings on head; a black opercular spot with a white one before it; spinous dorsal deep blue; solt dorsal golden; caudal pure yellow; anal pale yellow; no fin spots; ventral blue; belly pale blue; pectoral colorless.

(5) From Pago Pago. Vivid blue head, shoulders and back, with numerous spots of light blne, also violet; small black opercular spot; axil unspotted; first dorsal blue, with blackish edge; second dorsal golden, black-edged; no black spot; caudal and caudal peduncle bright yellow; anal blue; ventral dusky, pectoral bluish.

813. Pomacentrus cyanomus Bleeker. New Guinea (Macleay).

814. Pomacentrus prosopotænia Bleeker. New Guinea (Macleay); East Indies.

815. Pomacentrus tæniurus Bleeker. Tahiti and Faté (Seale); East Indies.

816. Pomacentrus bifasciatus Bleeker. Boston I.; East Indies. 
817. Pomacentrus trimaculatus Cuvier \& Valenciennes. Palau Is.; Guam; Marcus I.; New Guinea (Macleay); East Indies.

This species is easily recognizable by the black spots on the side of the back. It was not taken by us. Bleeker identifies $P$. perspicillatus with $P$. trimaculatus, but the description of the former is too scanty to permit of certainty.

818. Pomacentrus notophthalmus Bleeker. Woodlark I.; Faté; New Hebrides (Seale); East. Indies.

This species, not taken by us, is very well marked by its coloration, the anterior dorsal region being violet-brown, the rest of the body largely yellow.

819. Pomacentrus vaiuli Jordan \& Seale, new species. Taiul. Samoa. (Pl. xL, fig. 2.)

Head 3.50 in length; depth 2; eye 2.85 in head; dorsal XIII, 14; anal II, 16; scales 3-30-9, twenty scales in lateral line proper, which ends under posterior third of soft dorsal fin; interorbital equal to eye; snout 3.40 in head.

Body compressed, elevated, the upper and lower outlines evenly rounded; depth of caudal peduncle 2 in head, its length 2.75; mouth small; maxillary reaching to below anterior margin of eye, a single series of rather flat cutting teeth in each jaw; no teeth on vomer or palatines; preorbital rather wide, 2 in maxillary, its lower posterior margin strongly toothed; suborbital very narrow, about one-half as wide as preobital, its lower margin toothed; opercle entire; preopercle denticulate; gillrakers rather blunt, the longest less than width of pupil; base of dorsal 1.75 in length of fish without caudal, its longest ray 1.20 in head; posterior extremities of dorsal and anal pointed; base of anal equal to head; pectoral equal to head; first rays of ventral somewhat prolonged and filiform, reaching to base of anal; caudal forked, its lobes slightly longer than head.

Color in spirits, purplish, lighter with yellowish wash on upper third of body, the colors thus being reversed from the usual coloring in fishes; scales with blue dots in the center which form numerous blue longitudinal lines on body, about 17 on each side, some more or lessirregular, the upper one of the lines extending from tip of snout over interorbital space along base of dorsal; the second has its origin on nuchal region; the third has its origin at posterior of orbit; two narrow blue lines from orbit to mouth; a distinct black opercular spot; a black blue-edged ocellus on the base of the 7 posterior soft dorsal rays; dorsal yellowish with dark margin; caudal bright yellow; pectoral bright yellow; ventral and anal dark blue; the anus has 3 bands of blue dots.

Life colors were noted in various specimens as follows:

(1) Specimen from Apia called vaiuli (blue water). Brilliant deep blue, darkest helow: the back abruptly orange-yellow with two blue stripes on each side, breaking up behind into rows of dots; no median stripe; dorsal orange with blue edge and blue dots; soft dorsal with a large, black, blue-edged oceilus; caudal and pectoral golden; ventral and anal blue-black.

(2) From Apia. Deep purplish; dull golden about gill-openings and on tail; sides of head and region of gill-opening with numerous sky-blue spots; a small round black spot on angle of opercle above black speck in axil; dorsal brownish, dull golden behind with a black, bluish-edged ocellus on base of soft dorsal; obseure blackish band along middle of spinous dorsal; anal brownish, with four or five oblique irregular blackish bands; pectoral and caudal golden; ventral blue-black.

(3) From Pago Pago. Iridescent purple-blue on sides in post-pectoral region, fading behind into brown-blue; above rich umber with blue in longitudinal series of dots; dorsal light umber with a very narrow marginal bright blue line; anal purplish brown; pectoral thin clear yellow, purple-violet below; dorsal with black ocellus with narrow blue margin on posterior end.

(4) From Apia. Back golden brown, grayish on tail; sides and belly deep blue; a row of dark blue spots along each row of scales; two dark blue stripes from snout to dorsal; dorsal golden brown, blue-shaded; a large, black ocellus, blue-edged, on the base of last soft rays; catidal pure golden; anal blue-black, with two oblique shades across it; pectoral golden; ventral blue-black.

The young of this species is remarkable for the reversal of the coloration, the back being golden, the lower parts violet black. With age, the dark coloration extends upward on the back. The black opercular spot and the black ocellus at the end of the soft clorsal remain the same at all ages. The violet spots on the side grow fainter with age but do not disappear.

Fifteen specimens from Apia and one from Pago Pago. The type, no. 51740, U. S. National Museum, is 2.75 inches long. 
820. Pomacentrus tripunctatus Cuvier \& Valenciennes. Vanicolo; Fiji; East Indies.

Pomacentrus tripunctatus Cuvier \& Valenciennes, Hist. Nat. Pois.s, V, 42I, 1s30, Vanicolo.

? Pomacentrus trilineatus Ehrenberg in Cuvier \& Valenciennes, op. cit., V, 428, 1830, Red Sea. Sauvage, Poiss. Madagasear, 423.

Pomacentrus taniometopon Kner, Sitz. Ak. Wis. Wien 18.38, 56, Kandavu.

This species was not taken by us. The black ocellus on the back of the tail seems to be a distinctive character. It is doubttul whether Pomacentrus dorsalis of Japan is the same species.

821. Pomacentrus amboinensis Bleeker. New Guinea (Macleay).

822. Pomacentrus bankanensis Bleeker. Guam; East Indies.

823. Pomacentrus semifasciatus Gïnther, Boston I., Harshall Group.

Pomacentrus semijascialus Günther, Fische der Südsee, 226, with plate, 1873, Boston I.

This species was not seen by us.

824. Pomacentrus jenkinsi Jordan \& Evermann. Hawaii.

825. Pomacentrus analis Macleay. New Guinea.

Pomacentrus analis Macleay, Proc. Linn. Soc. N. S. W. 1853, 361.

826. Pomacentrus melanopterus Bleeker. I' $u \sin a ; T u^{\prime} u^{\prime} u$. Samoa; East Indies.

Pomacentrus megalops Sauvage, Poiss. MIndagascar, 426; after Liénard.

Ten specimens from Apia. This species is easily separated from $P$. nigricans and other black species by the large black spot covering the whole base of the pectoral. From most of the black species it may be known by the presence of 13 dorsal spines, there being but 12 in $I$. nigricans and $P$. lividus.

Life colors of a specimen from Apia, called $t u^{\prime} u^{\prime} u$, all black, a large jet black spot or cross bar on base of pectoral; belly with coppery shade; gray spots on scales.

827. Pomacentrus littoralis Kuhl \& Van Hasselt. Tahiti; Caroline Is.; IVaigiu; Guam; Shortland I.; Raiatea and Makatea (Seale); East Indies.

This species is distinguished by the presence of 13 dorsal spines, a plain dusky coloration with a black spot on the tip of the opercle only, and a strongly serrate suborbital. In $P$. inomatus, which is similarly colored, this bone is nearly entire. In $P$. nigricans, $P$. lividus, and its allies or variations there are 12 dorsal spines.

This species was not taken by us. The species called $P$. emarginatus and $P$. chrysums are almost certainly identical. They would be certainly placed in $P$. littoralis were it not stated that the caudal is yellow, and there is no mention of an opercular spot. According to Sauvage, the Lltoralis of Bleeker is a different species, properly called Pomacentrus pristiger Cuvier \& Valenciennes.

828. Pomacentrus inornatus De Vis. Samoa.

Pomacentrus inornatus (misprinted niomatus) De Vis, Proc. Linn. Soc. N. S. W. 1884, 451, South Seas.

Three specimens from Apia. This fish is plain blackish, without spot. The nose is distinctly blacker than the rest of the body. There are 13 dorsal spines, largely enveloped in the scaly sheath, and the suborbital is almost entire, without the strong retrorse serrations seen in most of the other black species. The species is certainly identical with $P$. inornatus of De Vis. Pomacentrus emargmatus seems to differ in the strongly serrated preorbital.

829. Pomacentrus nigricans Lacépède. T'i'u'u. Samoa; Fiji; Tonga; Palau; Ponape; Tahiti; Raiatea; Marquesas I. and Faté (Seale); East Indies.

(Pomacentrus scolopscus Quoy \& Gaimard; Pomacentrus taniops Lesson.)

This species is very abundant in all the pools on all the coral reefs of Upolu and Tutuila. It may be known from its intimate associate, $I$. lividus, with which Bleeker has confounded it, by the narrow preorbital, more extensively scaled forward. In both species there are 12 dorsal spines, and the preorbital is strongly serrated. Usually the color of the body 18 plain dusky olive, without blue spots. The dusky spot or shade on soft dorsal and on axil of pectoral is variously developed, sometimes very distinct, sometimes obscure. The blue stripe on the suborbital is usually but not always distinct. 
Either this species or $P$. albofasciatus must be the original $P$. nigricans of Lacépède. In view of the fact that albofasciatus is perhaps a color variation, or else the female of scolopseus, we may adopt the name nigricans for the latter or for both.

Life colors of a specimen from Apia, greenish black; a sharp pale streak below eye; base of pectoral black; spinous dorsal, anal and base of soft dorsal and caudal blackish; pectoral bright yellow; rest of soft dorsal and caudal bright yellow, brightest behind.

A specimen called $t u^{\prime} u^{\prime} u$, from Apia, was sooty; middle of body paler olivaceous, darker above, livid bluish below; two blackish cross shades under front of dorsal; posterior parts and head black; opercle, iris, space below eye violet; axil black; fins all black, paler behind; axils of dorsal and anal very black.

A young individual from the same locality was olive; brownish anteriorly, yellowish behind middle; dorsal dull orange, with a large jet-black spot in the axil; caudal golden; anal black, with orange shade; pectoral golden with a black spot in the axil; ventral black.

The original Pomacentrus nigricans is described from an unknown locality in the Pacific. It is plain blue-black, the depth half the length, the preorbital serrate; dorsal xIr, 17, anal II, 15. It can be no other species, as the other black ones have 13 dorsal spines. Pomacentrus nigricans of Quoy \& Gaimard and of later writers is Pomacentrus jenkinsi, a species with 13 dorsal spines.

830. Pomacentrus albofasciatus Schlegel. Ulavāpua. Samoa; Palau I.; East Indies.

This species or form is abundant about Samoa, swarming in the crevices of the reefs. We have over a hundred specimens from Apia and Pago Pago. It is dull-colored, usually blue-black, with a broad whitish cross-band on the posterior part of the body. This hand is never wholly absent. There is also a black pectoral spot and a black blotch, not ocellated on the last rays of the dorsal. This species is regarded by Günther as a variety of $P$. scolopseus. We find no difference except in the presence of the broad pale cross-band in albofusciatus. This is wanting in S. nigricans. It is usually but not always present in the form or species called eclipticus, which has in addition a short very white bar before the black dorsal spot. The three forms agree in all other regards, and are probably, as Dr. Günther has indicated, variations of Pomacentrus scolopseus, or Pomacentmes nigricans, to adopt the earliest name given to any of these dusky species with 12 dorsal spines. All the dusky species of Pomacentrus have 13 dorsal spines, excepting Pomacentrus nigricans and its allies or variations. Eight of our specimens of Pomacentrus albofasciatus are females. Two are apparently male, but may possibly be spent females. Both males and females are found among the specimens of nigricans and eclipticus.

Life colors of a specimen from Pago Pago, brown with vertical pale blue streaks on many of the scales; a broad, yellowish-white cross-band under last dorsal spines; a violet-pink streak below eye; violet scale above axil; axil black, as also base of pectoral; dorsal colored like body; first three spines black, rest pale; soft dorsal with large black blotch in axil; caudal dull olive-gray; anal similar, with violet dots on scales at base, and with violet edge; ventral dusky with thin violet edge; pectoral dull.

A specimen from Apia, called ularäpua, was dirty olive; a yellowish cross-band under soft dorsal.

831. Pomacentrus eclipticus Jordan \& Seale, new species. Samoa.

Head 3.20 in length; depth 2.20; eye 3 in head, equal to interorbital space; dorsal xir, 15; anal Ir, 12; scales $3-29-9,19$ in lateral line.

Body oblong, compressed, elevated, scales covering head and body; caudal peduncle 2 in head, its depth equal to its length; mouth small, its angle under anterior margin of eye; a single row of rather flat cutting teeth in each jaw, no teeth on vomer or palatines; opercle with a single flat spine on margin; preopercle strongly denticulate also, its width at angle of mouth equal to pupil, directly below median line of eye, preorbital width two-thirds of pupil; gillrakers not very sharp, the longest twothirds width of pupil, 9 on lower limb; spines of dorsal graduated posteriorly, the last being the longest, 2 in head; first dorsal spine less than eye; middle ray of soft dorsal the longest, 1.45 in head; base of anal 1.25 in head, its longest spine about equal to base; pectoral 1.10 in head, its tip on line with 11 th scale of lateral line; first rays of ventral slightly elongate, extending to anal opening, the length slightly greater than head; caudal forked, the lobes rounded, the upper one slightly the longer, about equal to head.

Color in spirits ranges from light yellowish brown to dark brown, almost black; the type specimen is light yellowish brown, with slight shading of dusky on head and upper surface of body; all specimens show a distinctive black spot in axil of soft dorsal with a white spot of equal size and shape just anterior to the dark spot; in size this dark spot is equal to the orbit in height and two-thirds of orbit 
in width; a very distinct black spot on the upper base of pectorals which extends into the axil of the fins; a more or less distinct blue line on preorbitals, and there may be 3 or 4 indistinct pearl-colored spots on the opercles or cheeks; dorsal fin with a black blotch near margin of $3-4$ spines, with a yellowish white line below; in general, the fins follow the shading of color shown on the body, the dorsal with a narrow margin of dusky, the anal with a dusky blotch; ventral with a dusky wash; iris blue.

Life colors of a specimen from Apia, dull brownish, paler behind middle of body; fins plain; a large black spot on last rays of soft dorsal; a large golden one before it; a black spot in anal axil, one in pectoral axil, and one on opercle.

A specimen from Pago Pago was black, blacker on base of last dorsal and anal rays; a short, vertical whitish bar just before the spot on dorsal; a black bloteh on base of pectoral, covering axil; fins all black, the caudai and soft dorsal a little paler at tip; iris brownish; preopercle serrate, a faint rather broad blue streak below eye to tip of snout.

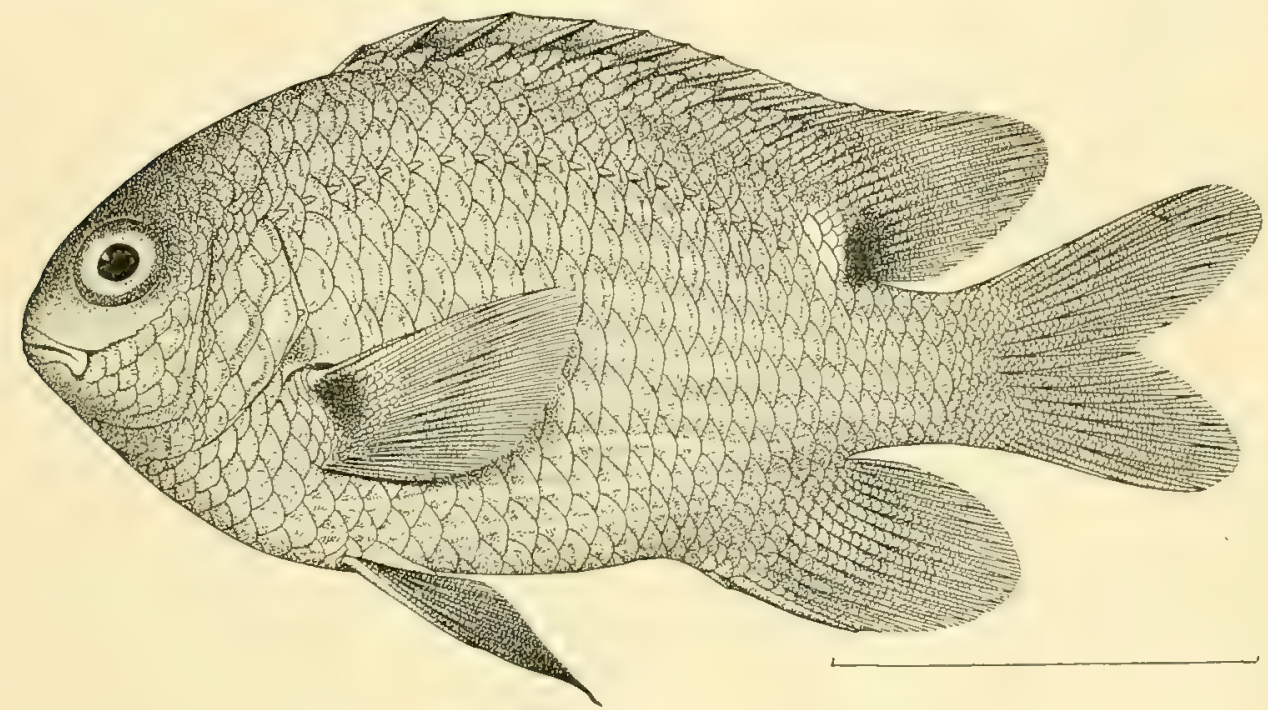

FIG. 50.-Pomacentrus ecliplicus Jordan \& Seale, new species. Tyre.

Of this abundant species or form, we have about 30 examples from Apia and 10 from Pago Pago. The species may be known by its plain coloration, the pectoral spot boing distinct and the dorsal spot still more so, preceded by a short vertical bar, which is typically pure white. Among our specimens are both males and females, a fact which shows that this is not the male of Pomacentrus albofasciatus. For the present we may regard it as a distinct species.

The type is no. 51735, U. S. National Museum, from Apia; length 3 inches.

832. Pomacentrus lividus (Forster). Tu'u'u sue uli; I'u sina. Samoa; Vavau; Ponape; Boston I.; Borabora; Huahine; Santa Cristina; Fiji; Mareus I.; Tahiti; Guam; Fah; Nukahiva and Raiatea (Seale).

Chatodon lividus (Forster), Bloch \& Schneider, Syst. Ichth., 235, 1501, Bolabola.

Eupomacentrus lividus, Bleeker, Pomac., 73, 1877, East Indies generally.

Pomaccntrus lividus, Sauvage, Poiss. Madagascar, 426.

Pomacentrus punctatus, Quoy \& Gaimard, Voy. Uranie, 395, taf. 64, fig. 1, 1824, Ile de France. Günther, Cat., Ir, 29. Kner, Novara Fische, 243, Tahiti, Nicobnr Is. Senle, Bishop Museum, 1901, 80, Guam, Bryan \& IIerre, Bishop Museum, 1903, Marcus I.

Pomacentrus prosopotanoides Bleeker, Amboina and Ceram, 246.

Pomacentrus cyanospilos Bleeker, Ceram, It, 709, Ceram. Gunther, Cat., Iv, 30, East Indies, Günther, Fisehe der Sudsee, 229, taf., Boston I., Upolu, Vavau, Ponape, IIuahine, Borabora, Santa Cristina.

Pomacentrus zitianus Sauvage, Bull. Phil. Soc., Ju, 1879, 206, Viti Levu (Fiji).

This large species is very abundant in the rock pools of the coral reets of Samoa. It is found in company with Pomacentrus nigricars, which it much resembles. It is, however, easily distinguished 
by the broad naked preorbital, a character well shown in Günther's plate. The blue or whitish spots are generally conspicuous, especially on the sides of the head.

We can not see that P'omacentrus vitianus Sauvage differs in any respect from P'omacentrus lividus.

Life colors of various specimens were noted as follows:

(1) From Pago Pago. Violet-black, with three obscure black cross-bands; eye bluish; a violet stripe below eye to snout; a violet shade on opercle; a faint dark blotch at base of pectoral; no spot, either black or white, in axil of dorsal; fins all black.

(2) Same locality. Black body and fins; axil with a black spot extending on base of pectoral; anal edged with violet-blue; fins all black.

(3) From same locality; specimen called 'u sina (white tail). All black, unspotted; axil and broad bar across base of pectoral black; edge of dorsal, anal, and caudal dull whitish.

(4) From Apia. Grayish black mottled with sooty gray; a round black opercular spot; no other markings; ventral black.

(5) From Apia. Dull olive brown, each scale posteriorly with a black spot; dorsal dusky, the soft dorsal dull yellow at base, with a curved black bar behind it; anal similarly marked; caudal dull yellow at base; pectoral dull orange; ventral brownish.

(6) From Apia; fins low. All grayish black; base of dorsal, anal, and caudal golden washed; axil dark.

833. Pomacentrus devisi Jordan \& Seale, new name. South Seas.

Pomacentrustrifasciatus De Vis, Proc. Linn. Soc. N. S. W. 1884, 452, South Seas; name preoceupied.

834. Pomacentrus onyx De Vis. South Seas.

Pomacentrus onyx De Vis, Proc. Linn. Soc. N. S. W. 1854, 4511, South Seas.

\section{ABUDEFDUF $a$ Forskål.}

(Glyphisodon Lacépède; Stegastes Jenyns; Chrysiptera Swainson; Euschistodus Gill; Paraglyphidodon, Glyphidodontops, Hemiglyphidodon, and Amblyglyphidodon Bleeker.)

835. Abudefduf sordidus (Forskål). Ǔlarāpua. Samoa; Hawaii; Tahiti; Raiatea; Bonham-I.; Faté and Makatea (Seale); East Indies.

This species, recognizable by its large size, by faint dark cross-bands, and the black spot below the axil of the dorsal, is common throughout the tropical Pacific. It is abundant both at Hawaii and Samoa, but is found among lava rocks only, not about the coral reefs. A specimen from Apia in life had six dark cross-bands and the usual spot at base of last dorsal ray.

a We have referred the question of the propriety of the use of Abudefduf instead of Glyphisodon, and of the rejection of Abuhammr, Farer, and other quasi subgeneric names of Forskil, to our friend Dr. Leonard Stejneger. From a letter dated November 23 , 1904, we quote his view of the matter, with which we fully concur:

"Forskal, we are informed, based his nomenclature and systematic arrangement principally on Linnæus, 10th ed., probably the only systematic work he had with him. It is therefore of importance to examine into the "subdivisiones" of genera which Linnæus employed. He has four kinds, for instance:

$$
\text { 1. Perca, p. } 289 .
$$

$\mathrm{X}$. Pinnis dorsalibus 2 distinetis.

xx. Dorso monopterygio, ete., ete.

2. Cimex, p. 441.

a. Apteri.

b. Seutellati.

c. Coleoptrati, etc.

\section{Salmo, p. 308.}

X. Trutte.

XX. Osmeri.

XXX. Coregoni.

X. Mantis.

4. Gryllus, p. 425.

$\mathbf{X}$, Acridia.

XXX. Bulla, etc.

Only the fourth kind of subdivision corresponds exactly to our subgenus, but the names of subdivision 3 are by common consent treated as subgenera and used as such in the singular (thus by yourself and Dr. Evermann in Fishes of North and Mid. America). Of course the names of the second division have never been used in this sense, and in No. 1 there are no names.

The question as to Forskal's names then resolves itself to which of these categories they are to be referred. If they are used as subgenera, or in a subgeneric sense like category 3 , we must accept them.

It seems then to me that Abudefduf comes withincategory 4. Both Chatodon and Acanthurus are in the singular, and Abudefduf is in no manner distinguishable from them.

On the other hand, Perca dentibus Louti, Daba, Scanis dentibus Sidjan, Abu djubbe, Iarid, fall under category 1.

The subdivisions of Sciana (p. 44) seem to me to be very much of a similar character, or, rather, they correspond almost exactly to the modern way of subdividing "commode" such large genera accordung to groups of species, which we 
836. Abudefduf septemfasciatus (Cuvier \& Valenciennes). Mutu; Alala sayc. Samoa; Guam; Faté; Shortland I.; Rarotonga; Raiatea and IIakatea (Seale); East Indies.

Of this well-marked species we have four large examples from Apia. Life colors of one of these, called mutu, dull olive, with black bars, six wider than interspaces; silvery streaks faint along rows of scales; pale whitish streak along spinous dorsal; everything else pale.

837. Abudefduf saxatilis (Linneus). Samoa; Waigiu; Tubuai (Seale); Marcus I.; East Indies; Japan.

This species, common from Japan to the Red Sea, is occasionally taken in the South Seas. Wre have one large example, corresponding to Abudefuf waigiensis from Apia. In Hawaii it is replaced by Abudefduf abdominalis, and in America by the equally closely related Abudefof marginalus.

838. Abudefduf abdominalis (Cuvier \& Talenciennes). IIwaii; Laysan.

839. Abudefduf colestinus (Cuvier \& Valenciennes). Fili muna. Samoa; Ulietea; New Guinea; Waigiu; Tahiti; Raiatea; Faté and Shortland Is. (Seale). (Pl. xu, fig. 1.)

This species is very common about Samoa, nearly a hundred specimens being taken at Apia and Pago P'ago. It is perfectly well distinguished from Abudefduf saxalilis, and rarely inhabits the same waters. Its life color is pale sky-blue, not olive-green, and the black stripe on each lobe of the caudal is constant.

A specimen from Apia in life was vivid sky-blue with paler streaks along scales; cross-bands jet black, a black stripe on each caudal lobe.

840. Abudefduf curacao (Bloch). New Guinea (Macleay); Shortland I. (Seale); Eact Indies; Japan.

841. Abudefduf dicki (Liénard). Tu'u'u. Samoa; Poną̣e; Guam; East Indies. (Pl, Xl, fig. 2..) Glyphisodon unifasciatus kner \& Steindachner, Sitz. Ak. Wiss. Wien 1867, 375, Samoa.

Of this handsome and well-marked species half a dozen specimens were taken at Apia. Lift colors of one of these, called tu'u'u, golden brown, dark, each scale with a vertical bar of dark blue; a large jet-black crescent from front of soft dorsal across body and covering most of anal; behind this abruptly pale orange-red, the color covering caudal peduncle, caudal and last rays of dorsal and anal; older examples have color deeper, clear orange-red behind black crescent; pectoral bright golden yellow, dusky behind; ventral blackish; head plain.

842. Abudefduf lacrymatus (Quvy \& Gaimard). I'u samasama (yellow tail). Samoa; Guam; Yap; Howland I.; East Indies.

Of this well-marked species, black, with bluish white well differentiated spots, we lhave three specimens from A pia.

Life colors of a specimen called i'u samasama, black, with scattered round spots of deep violet-blue, on head, nose, back and sides, also on dorsal; caudal peduncle, caudal and posterior part of soft dorsal abruptly pale -rayish yellow, the color of the ginger flower; fins otherwise black, the anal washed with orange; dorsal and spinous anal with violet spots; ventral black, edged with blue; axil a little dusky.

Another specimen was black (brownish) with bright violet shade on opercle and preorbital and numerous violet-blue spots on spinous dorsal, which has a narrow blue edging; axil black, dorsal black, its last rays abruptiy bright orange; caudal dusky orange-brown; anal black with pale blue anterior edge; peetoral dusky; ventral blackish.

843. Abudefduf behni (Bleeker). Samoa; Rarotonga (Seale).

Of this species, pale brownish black, with a black axillary spot, we have one fine specimen from Apia.

do not wish to split up nomenelatorially. It is as if I should say the enormous genus of Rana cun be subdivided for the sake of convenience into (1) the temporaria group; (2) the esculenta group, etc. That Forskul (or his editor) uses capituls and an upper casc capital initial means nothing, for he also has "(C) Immaculati" exactly like Abu hammir.

The case of the Scirnas, i. e., Abu hamrur, ete., is not exactiy like that of Abudejduf, and I believe there is iust difference enough to draw the line just between them. I do not believe they fulfill the conditious for being subgenern, while Abudcriluf dnes." 
844. Abudefduf melas (Bleeker). Laysan (Steindachner); East Indies.

845. Abudefduf nigrifrons (Macleay). New Guinea (Proc. Linn. Soc. N. S. W. 1884, 271).

846. Abudefduf bimaculatus (Macleay). New Guinea.

847. Abudefduf leucogaster (Bleeker). Shortland I. (Seale); East Indies.

848. Abudefduf pallidus (De Vis). New Guinea. Abudefduf pallidus De Vis, Proc. Linn. Soc. N. S. W. 1884, 452.

849. Abudefduf imparipennis (Vaillant \& Sauvage). Hawaii.

850. Abudefduf filamentosus (Macleay). New Guinea.

Abudefduf filamentosus Macleay, Proc. Linn. Soc. N. S. W. 1883, 365 .

851. Abudefduf plagiometopon (Bleeker). New Guinea (Macleay).

852. Abudefduf emamo (Lesson). Borabora.

Glyphisodon emamo Lesson, Voy. Coquille, 190, 1830, Borabora.

853. Abudefduf sindonis (Jordan \& Evertaann).- Hawaii.

854. Abudefduf bankieri (Richardson). New Guinea (Macleay); East Indies.

855. Abudefduf anabatoides (Bleeker). New Guinea (Macleay); East Indies.

856. Abudefduf glaucus (Cuvier \& Valenciennes). Samoa; Guam; East Indies.

Glyphisodon glaucus Cuvier \& Valenelennes, Hist. Nat. Poiss., V. 475, 1830, Guam.

Glyphisodon modestus Schlegel, Amphipr., 23, tab, 6, fig. 2, East Iadies. Bleeker, Pomacentridæ, 131. Bleeker, Atlas Ichth., tab. Iv, fig. 9, Sumatra, Java, Borneo, Amboina. Günther, Cat., Iv, 55, Java.

Glyphisodon phaiosoma Bleeker, Verh. Bat. Gen., xxII, Ichth. Bali, 9, Bali.

This species is common about Samoa, where about 100 specimens were taken. It resembles Abudefduf zonatus, but is of a washed-out blue color in life without white bar or black ocellus.

Life colors of a specimen from Apia, pale sooty olive, yellowish on belly; fins all grayish; preopercle and preorbital with pale edge; a dull orange tint on soft dorsal and caudal; pectoral deep yellow, soiled with dusky; anal dark-edged anteriorly.

Another specimen from Apia was violet-blackish with green luster; fins all pale bluish with yellowish tinge; ventral bright yellow; no fin spots; three whitish spots violet-tinged on sides on level of pectoral, O-shaped; more of these on other side and irregular.

857. Abudefduf zonatus (Cuvier \& Valenciennes). Tu'u' $u$. Samoa; Fiji; New Guinea; East Indies.

Glyphisodon zonatus Cuvier \& Valenciennes, Hist. Nat. Poiss, v, 483, 1830, New Guinea. Bleeker, Pomacentridæ, 138, and Atlas, 407, fig. 3, Cocos, Java, Bornen, Celebes, Ceram, Amboina, New Guinea.

Glyphisodon brownriggii Günther, Fische der Südsee, 232, taf. 127, figs, C, E, A; not of Bennett.

Glyphisodon rossii Bleeker, Kokos, 48, Cocos I.

Glyphisodon albocinctus Kner, Sitz, Ak. Wiss. Wien, 351, Fiji.

Gluphisodon levevzona Kner, Sitz. Ak. Wiss. Wien, 350, Savay; not of Bleeker.

Glyphisodon cingulatus Kner, Sitz. Ak, Wiss. Wien, LVI, 1867, 725, Fiji.

This little species is very common about Samoa, 150 specimens, of all sizes, being taksn. None shows blue stripes or lines, and nearly all have a single white bar on each side. This is lost in the very oldest. In the largest of all is a distinct whitish blotch on the soft dorsal near its last rays.

Life colors of various specimens were noted as follows:

(1) Specimen called $t u^{\prime} u^{\prime} u$, from Apia. All blackish, with pale centers to scales; head reticulated gray and blackish; a black speck at end of opercle; caudal with yellowish shade at base; fins otherwise black; caudal and soft dorsal paler behind; pectoral dusky and black.

(2) From Apia. Dusky olive; a white cross-bar under middle of body; a black ocellus edged with white on last dorsal spines; dorsal pinkish dusky; other fins all dusky.

(3) From Pago Pago. Blue-blackish; a broad whitish gray cross-band; an obscure black spot under last dorsal spines; a jet-black spot in axil of last dorsal ray; dorsal dull orange, blackish at base; caudal dull orange; pectoral yellow, axil black; ventral and anal blackish.

(4) From Apia. Deep steel-blue, each scale with a paler center along side; a distinct white band under middle of soft dorsal; dorsal black at base, the upper two-fifths orange, not very bright; belly dusky; no opercular spot or ocellus; caudal dull orange, the edge dark; anal all blue-black, as is also ventral; pectoral golden, a hlack bar across its base, the axil dark. 
(5) From Apia. Blackish; large white stripes along rows of scales; a whitish bar below middle of spinous dorsal; dorsal and anal dusky; soft dorsal half dusky, the tip dull orange; anal almost all dusky; caudal dull orange; pectoral bright golden, no ocelli; ventral black.

(6) From Apia. Blue-black; each seale on front part of sides with a pale gray spot; a vertica? whitish bar below middle of spinous dorsal; dorsal dusky bluish below, the upper half dull orange with a pale lateral streak; anal blue-black; caudal sooty; pectoral yellow; ventral blackish.

858. Abudefduf hemimelas (Kner). Fiji.

Glyphisodon hemimelas Kner, Sitz. Ak. Wiss. Wien 1868, pl. vill, fig. 25, 351, Fiji.

Glyphidodon brownriggii var. hemimelas, Günther, Fische der Südsee, 233.

This species is not known to us. From the figures of Kner and Günther, it would seem to be a species distinct from A. zonatus. Dr. Günther regards it as a "variety" of "Glyphidodon brounriggii", that is, of Abudefduf zonatus.

859. Abudefduf amabilis (De Vis). Samoa; Tahiti; Oualan; Faituna; Fiji; Ponape. (Pl. xLII, fig. 1.)

Glyphisodon amabitis De Vis, Proc. Linn. Soc. N. S. W., 1881, 452, South Seas.

Glyphidodon brownriggii var. xanthozona Günther, Fische der Südset, 234, taf. 127, fig. D, Oualan, Futung, Samoa, Tahiti, Ponape; not Glyphisodon xonthozona Bleeker.

This species is very abundant about Samoa. Dr. Günther regards it as a "variety" of Abudefduf zonatus ("brownriggii") from which it differs wholly in color, though in little else. It is near xanthozona of Bleeker, but that species has yellow fins and a black ocellus on the dorsal, which is largely yellow.

Life colors of a specimen from Apia, blue-black; two yellowish white cross-bands; opercles orange; an orange streak across axil; base of pectoral dusky; dorsal dusky with a light brown tip; caudal dusky at base, then creamy with a dusky median blotch; pectoral pale yellowish.

860. Abudefduf antjerius (Kuhl \& Van Hasselt). Tu'u'u. Samoa; Guam; New Ireland; Strong I.; New Guinea; East Indies. (Pl. Xlı, fig. 2.)

Glyphisodon antjerius Kuhl \& Van Hasselt, Anjer (Java). Cuvier \& Valenciennes, Hist, Nat. Poiss., V, 481, 1830, Java. Günther, Cat., IV, 50 (in part). Günther, Fische der Suidsee, 233. Seale, Bishop Museum, 1901, 83, Guam.

Glyphisodon biocellatus Cuvier \& Valenciennes, Hist. Nat. Poiss., v, 482, 1830, Guam, Strong I., Java, New Guinen, Peters, Berl. Mon., 1876, 813, New Ireland.

Glyphisodon punclulatus Cupier \& Valenciennes, Hist. Nat. Poiss., v, 484, 1830, Guam.

This species is known to us from about 40 small specimens. It is near Abudefduf zonatus, but it never has a white lateral cross-band, and it always has a vivid blue stripe from snout to dorsal. Other blue dots and lines are usually present as well as a black ocellus near middle of dorsal fin. As our specimens differ widely from Aludefduf leucopomus, and from zonatus of the same size, we must regard antjerius as a species distinct from zonatus, brononiggii, and leucopomus.

Life colors of a specimen from A pia, called tu' $u$ ' $u$, blue-black above, a bright sky-blue stripe from eye to front of dorsal; a blue-black ocellus surrounded by sky-blue on last rays of spinous dorsal; a much smaller one on last ray at base; a blue dot in axil; body becoming more orange-yellow backward and downward; pectoral, soft dorsal and caudal brilliant yellow; anal orange-red, edged with dark; pectoral orange, with anal dark-edged.

Another specimen from Apia was steel-blue, not brilliant, each scale with a vertical pale dash; a pale shade under front of spinous dorsal; a large black spot under spinous dorsal, a smaller one in axil of soft dorsal; dorsal orange, edged with dark; caudal yellowish orange with a black edging; caudal peduncle and anal orange, edged with black; ventral black; pectoral golden.

861. Abudefduf leucopomus (Cuvier \& Valenciennes). Tu'u'u. Samoa; Oualan; Guam; Nukahiva; Rarotonga (Seale). (Pl. xuri, fig. 1.)

Glyphisodon leucopomus Cuvier and Valenciennes, Hist. Nat. Poiss, V, 480, Oualan (Caroline Is.).

Glyphidodon brownriggii, "Bastarde zwischen G. brownriggii und G. uniocellatus," Günther, Fische der Südsee, 210, 235, taf. 128, fig. B, Apia, Oualan.

? Glyphisodon antjerius Bleeker; not of Cuvier \& Valenciennes.

This species, one of the prettiest of the taupos, or damsel fishes, is common about the reefs of Samoa, where about 50 specimens were taken. All these, young or old, have a broad blue stripe along side of back. Some are otherwise nearly plain golden, others show traces of dark cross-bands. The clear-colored ones are in general the largest and brightest examples. 
1. brownriggii, of Ceylon and the East Indies, has a similar blue dorsal stripe, but according to the figures of Bennett, Bleeker and Day it lacks the large black spot at upper base of caudal. All our specimens in spirits have the opercle white, with a black spot at tip. The species may, however, prove inseparable from $A$. brownriggii.

Life colors were noted in various specimens as follows:

(1) From Apia. Bluish-black with blue and golden dots; a vivid blue stripe on each side of back; a black ocellus below soft dorsal; a larger one at base of caudal above; opercle golden with a black spot; axil not black; caudal peduncle before spot pale; dorsal orange and dusky bluish in alternate stripes; caudal orange-yellow; anal yellowish with oblique bluish stripes, very faint, the outer rays dusky; belly yellow, the breast and throat dark blue; ventral dusky orange; pectoral golden.

(2) From Apia. Blue-olive, with many blue dots; belly and tail golden; a broad vivid blue stripe along back; two black spots above it, the second in axil of last ray largest; a black band nearly across base of caudal; opercle golden with a black spot; a golden bar behind pectoral; fins all golden, the soft dorsal and anal orange at tip; first dorsal soiled with bluish; anal with a blue anterior edge.

(3) From Apia. Olive, a broad stripe of intense blue from snout above to base of caudal above, the two meeting around snout and around dorsal; a broad black median band on top of head to nape; two deep blue-black spots under soft dorsal, in front and in axil, the second the larger; a small spot at upper base of dorsal; belly gradually yellow; dorsal, anal, caudal, and ventral deep orange; pectoral a little paler; a blue streak along lower side of eye.

(4) From Pago Pago. Golden; blue back; two ocelli.

862. Abudefduf uniocellatus (Quoy \& Gaimard). Taupou. Samoa; Fiji; Tonga; Marquesas Is.; Futuna; Vanicolo; New Hanover; East Indies. (Pl. xLII, fig. 2.)

(?Glyphisodon assimilis Günther.)

This beautiful species is very common about Samoa, where about 100 specimens were taken on the reefs. There is some difference in the color of the sexes, the females having the dorsal more or less yellow, the fin in the males being blue.

Life colors of a specimen from A pia, called tanpo, most vivid blue with violet cross-streaks on back; scales on side with yellow dots; belly and lower part of side abruptly yellow; dorsal deep blue, the edge almost black, with a pale violet-blue median band; soft dorsal with an indigo-black blotch at base of last rays, anterior edge indigo-black, the median part blue-violet; caudal deep orange, bluish at base and above, the upper edge indigo-black; anal deep orange, its axil blue; pectoral and ventral blue, the ventral with some orange shade.

A specimen from Pago Pago was of deepest clear blue, sides with many small round golden spots; sides of head with violet specks; a black-violet streak from snout to eye, and upward and backward; three dark spots forming this streak; belly clear orange-yellow; dorsal deep blue; a large black blotch at base of last rays; soft dorsal pale orange, deep blue at base, the margin deep blue black; caudal orange-red, blue at base, the upper margin deep blue black; ventral orange-red, blue-edged; pectoral colorless.

863. Abudefduf taupou Jordan \& Seale, new species. Vaiuli sama, Taupou. (Pl. xurII, fig. 3.)

Head 3.75 in length; depth 2.75; eye 3 in head, equal to interorbital space; dorsal xiIr, 11; anal II, 11; scales 2-16-9.

Body, oblong, compressed; snout rounded; a single row of fine compressed teeth in each jaw; preorbital narrow, about one-half as wide as pupil, its marginsmooth and rounded; margin of preopercle smooth; head, excepting snout, scaled; depth and length of caudal peduncle equal, and equal to postocular part of head; fourth dorsal spine 1.50 in head; the soft rays of dorsal much longer, about equal to head; pectoral equal to head; ventral prolonged into a filament which reaches beyond origin of anal; caudal more or less rounded.

Color in spirits a deep slaty blue black; the belly abruptly yellowish white; a distinct black spot on posterior base of soft dorsal at axil; an indistinct black line extending back from the posterior of orbit; dorsal fin washed with yellowish white and having a distinct hlack margin which extends out to tip of fin; the lower half of fin blue; caudal yellowish white; the upper ray black; anal yellowish; ventral yellowish. Some specimens have a wash of dusky on base of anal and base of caudal.

The female fish is without the dark margin to dorsal and caudal, the fins being uniform yellowish white in spirits: 
Life colors of various specimens were noted as follows:

(1) From Apia. Deep sapphire-blue or ultramarine; no spots; belly abruptly golden; dorsal brilliant scarlet, the last rays bluish with a small dark spot in axil; caudal dull bluish; anal orange; ventral orange; pectoral blue; a dark stripe through eye and a median one on top of bead; these and the dorsal ocellus more distinct in the young.

(2) From Apia. Deep sky-blue; belly abruptly greenish yellow; a black stripe from snout to dorsal above; a black stripe from snout through eye to begiuning of lateral line; spinous dorsal brilliant scarlet; soft dorsal pale brownish, with a large black spot at its base; caudal brownish; anal orange-red, deeper before; ventral orange; pectoral purplish, rather dark.

(3) From Pago P’ago. Violet-blue, almost uniform above; belly abruptly orange-yellow; a black median streak above head; black streak through eye and snout; black streaks and dots on side of head and shoulder; first dorsal uniform scarlet; second dorsal duller, with large jet-black spot at base; caudal bluish, slightly tinged with orange; ventral and anal orange-red; pectoral dusky; no axillary or opercular spot; side with numerous fine yellow spots visible under lens.

(4) From Pago Pago. Vivid deep blue, the belly and throat from chin abruptly yellow; a narrow black streak through snout and eye up and back to shoulder; a large black spot at base of soft dorsal; spinous dorsal deep scarlet, the solt dorsal and caudal pale bluish; anal and ventrals scarlet; pectoral plain; no spots on axil or opercle.

(5) From Apia. Deepest azure blue, finely dotted with golden on sides; belly whitish; spinous dorsal light vivid scarlet, dusky at base; soft dorsal pale blue, with a large black non-ocellated spot on base, the anterior edge scarlet; caudal pale blue; pectoral same; ventral and anal scarlet.

The specimen of Abudefduf azureus figured by Quoy \& Gaimard, from Guam, probably belongs to Abudefduf taupo. The original type of Aludefiluf azurets, earlier called Aluulefduf cyancus by the same writers, is from Timor. This species, Abudefuluf cyaneus, is not yet known irom the South Seas.

This most beautiful little fish differs from A. uniocellatus in the scarlet spinous dorsal fin. About eight specimens were taken at Apia and Pago I'ago.

In company with Pomacentrus paro, Abuclefduf uniocellatus, and other dainty blue species, this fish is known as taupo (damsel, village belle) at Samoa.

The type specimen is no. 51741 , U. S. National Museum, from Apia, length 2.50 inches.

864. Abudefduf filholi (Sauvage). Fiji.

Glyphisodon filholi Sauvage, Bull, Soc. Philoll., 1879, III, 207, Fiji.

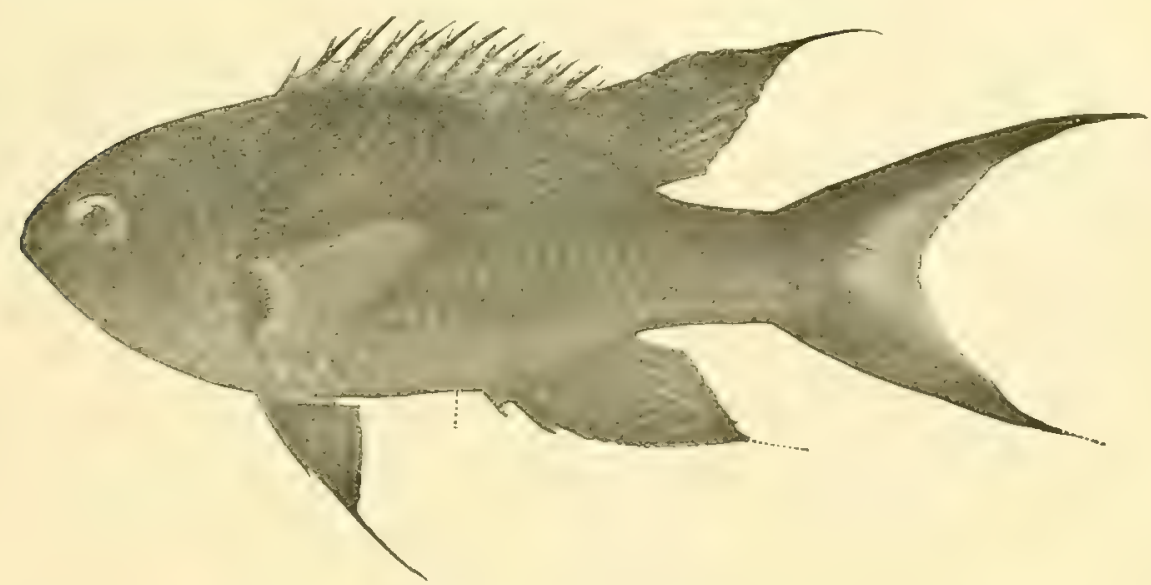

FIG. 51.-Abudefduf mclallicus Jordan \& Senle, new species. Type.

865. Abudefduf metallicus Jordan \& Seale, new species. Pipi. Samoa.

Head 3.50 in length; depth 2.50; eye 3.25 in head; interorl)ital 2.80 in head; snout equaling two. thirds of eye; dorsal xII, 10 ; anal II, 11; scale 2-17-7.

Body elongate, compressed, the profiles evenly curved; head rounded; preorbital narrow, about one-half the width of pupil, and very short, ending under anterior third of eye; preoperele not. 
toothed; opercle without spines; head entirely scaled except in front of nostrils; mouth small; a single row of small compressed teeth in each jaw; tips of all the fins except pectorals prolonged more or less into filaments; length of fifth dorsal spine 1.75 in head; pectoral equal to head; filament of ventrals reaching to base of anal, the length of the ordinary rays being much less, 1.20 in head; midcaudal ray 1.20 in head, the outer caudal rays greatly prolonged.

Life colors of a specimen from Apia (elongate, with all fins produced), blue-black, paler below; a black bar across base of pectoral; no other marks; fins all dusky-edged in a larger specimen apparently the same.

Color in spirits, violet black, lighter below; a distinct black base to pectorals; fins blackish, the pectoral and inner part of caudal lighter; the ventrals with slight wash of bluish.

Of this beautiful species, allied to Abudefduf cochinchinensis of Day, we have about ten examples from Apia. The type is no. 51742, U. S. National Museum, length 3.30 inches.

\section{DASCYLLUS Cuvier.}

Dascyllus Cuvier, Règne Animal, ed. II, 1829a (aruanus).

Tetradrachmum Cantor, Malayan Fishes, 240, 1851; substitute for Dascyllus on account of the prior Dascillus Latreille, 1796, a genus of Coleoptera.

866. Dascyllus aruanus (Linnæus). Namo. Samoa; Tonga; Tahiti; Fiji; Guam; New Guinea; Woodlark I.; Marquesas Is. ; Shortland I. and Raiatea (Seale); East Indies.

This beautiful little fish is excessively common in the crevices of the coral reefs about Samoa. About 200 examples were taken by us. It is generally diffused from Polynesia to the Red Sea, but it does not occur about Hawaii. In life it is grayish dove-color with jet-black cross-bands.

867. Dascyllus melanurus Bleeker. Ponape; Shortland I. (Seale); East Indies.

868. Dascyllus trimaculatus (Rüppell). Samoa; Louisiades; Aneiteum; New Guinea; East Indies.

Of this widely diffused species we obtained three specimens in Samoa. Life colors of a specimen from Pago Pago, dusky purplish, the scales dark edged; ventral outline and caudal peduncle brassy; dorsal black, with a row of golden spots; soft dorsal rather pale; caudal and anal bleached and golden; ventral black, some golden; pectoral yellowish, a black axillary spot; a round white spot on each side of back, distinct in our specimens, but very faint in others examined, from the Philippines.

869. Dascyllus albisella Gill. Hawaii.

This species is rather rare about the Hawailan Islands, and has never been seen elsewhere. It is very close to Dascyllus trimaculatus, but it has a white vertical bar where the latter species has a white spot.

870. Dascyllus reticulatus (Richardson). Kandaru; New Britain; Ponape; New Guinea (Macleay).

Heliases reticulatus Richardson, Ich. Chin., 254, 1838, Canton.

Tetradrachmum reticulatum, Bleeker, Pomacentridæ, 145, 167\%, East Indies, generally common.

Dascyllus xanthosomus Bleeker, Banda, 1, 247, Banda. Günther, Cat., Iv, 14, Borneo, Günther, Fische der Südsee, 237, Kandavu, New Britain, Ponape.

Pomacentrus unifasciatus Kner, Denk. Ak. Wiss. Wien 1869, 348, taf. 8, fig. 24, Kandavu.

This species of the East Indies was not taken by us.

871. Dascyllus unifasciatus (Kner).

Pomacentrus unifasciatus Kner, Sitz. Ak. Wiss. Wien 1868, 318, taf. 8, fig. 24, Kandavu.

This species is unknown to us. It is evidently very close to Dascyllus reticulatus, perhaps the same species.

\section{CHROMIS Cavier.}

872. Chromis cæruleus (Cuvier \& Valenciennes). I'a lanu-moana; Teatea; Mamo. Samoa; New Guinea; Ulea; Palau I.; Paumotu I.; Yap; Kingsmill I. ; East Indies. (Pl. xLIv, fig. 1.)

IItiases caruleus Cuvier \& Valenciennes, Hist. Nat. Poiss, v, 497, 1830, New Guinea, Ulea; said to have 13 dorsal spines.

Iletiases frenatus Cuvier \& Valenciennes, op. cit., 498, Guam; said to have 13 dorsal spines.

Heliases lepisurus Cuvier \& Valenciennes, op. cit., 498, New Guinea. 
Chromis lepisurus, Bleeker, Pomacentridæ, 164; Atlas, 403, fig. 7, Cocos, Java, Celebes, Sumbawa, Flores, Aru, New Guiner.

Glyphisodon bandanensis Bleeker, Ichth. Bijdr. Banda, Nat. T. Ned. Ind., 1r, 248, Banda.

Ileliases frenatus, Bleeker, N. Bijdr. Ich. Ceram., ibid., 710; perhaps not of Cuvier \& Valenciennes.

Cantharus cxruleus, Cuvier \& Valenciennes, op. cit., V, 342.

Ileliases caruleus Bleeker, Vierde Bijdr. Ichth. Kokos-eil; Nat. T. Ned. Ind., vir, 455.

ILliases lepidurus, Güther, Cat., IV, 63. Günther, Fische der Südsee, 238, taf. 128, figs, C and D, Pulau, Purmotu I. Yap, Kingsmill I.

Glyphisodon anabatoides Day, Proc. Zool. Soc, 1870, 696, Andaman Is.

Glyphisadon amboinensis Seale, Bishop Museum, 1901, St, Guam; perhaps not II, amboinensis of Bleeker.

This beautiful species is very common about Samoa, where about 100 specimens were taken in pools on the reefs. With a general.blue-green coloration usually with small yellow dots, there is considerable minor variation in the markngs in this species. The pale blue frenum is probably nevel wholly wanting, although much more conspicuous in some specimens than others.

Life colors were noted in various specimens as follows:

(1) From Pago Pago. Vivid steel-green, becoming violet-blue in spirits, silvery below; faint bluish lines along sides of belly; fins all bluish; a large black spot on base of pectoral; a narrow clear blue streak before eye; ventral sometimes pale, sometimes dusky; no other marks.

(2) From Apia; called mamo. Clear sky-blue with a strong greenish tinge, whitish below; no yellow, orange or brown; side with 5 or 6 dark blue streaks like pencil marks along rows of scales; axil with a blue-black spot; first dorsal deep bluish; caudal gray, with a bright blue stripe along each lobe; other fins bluish.

(3) From Apia; called i’a lanu-moana or blue-fish, scales 25 . Vivid sky-blue with bright reflections; finely dotted with black and with fine golden yellow spots, about one for each scale; belly white; fins plain, like body; ventral darker; chin blue.

(4) From Apia. Vivid sky-blue, growing paler below; usually with small yellow dots anteriorly; axil black; spinous dorsal blue black; soft dorsal and caudal mostly bright orange; anal vivid blue; axil black; ventral pale; pectoral dusky.

(5) From Pago Pago. Clear blue-green, silvery below; some specimens rather green, others blue; three pale blue streaks on side of body; base of pectoral dusky; back of caudal peduncle deep green; fins dusky, without blue.

(6) From Pago Pago. Light blue; darker violet-blue on shoulder; whitish blue below golden on caudal peduncle and below base of second dorsal; a black axil spot; fins all dusky blue, some yellow on second dorsal; pectoral almost colorless; ventral posteriorly blackish

The nominal species crmuleus and frenatus are doubtless identical with Chromis lepisums, in which case the name cxruleus has precedence. The type of cxruleus is said to have 13 dorsal spines, while Chromis lepisurus has 12. No other difference appears in the description. Chromis frenatus has a more distinct blue stripe from the snout to the eye, and the caudal lobes less produced. Both these characters are seen in young specimens. In some of our specimens especially, but not always the smaller ones, there is a sharply defined narrow blue streak from eye to snout, as in frenatus. In others there is a faint pale streak, and in some a dark streak a little lower down, or on the lower edge of the pale streak.

In response to a request to reexamine the original types of these species, Dr. Léon Vaillant writes (October 12, 1904):

Les types de IICliases (ou Chromis) cxruleus, frenalus et $I$. lepisurus sont dans un etat de conservation qui en permet facilement l'etude. Il y'a quatre exemplaires du Chromis lepisurus venant de la Nouvelle Guince (No. 875t) deux du Chromis crevilus de la meme localite (No. 5644) sept du Chromis frenatus de Guam. (574t et A 253.) Tous les animaux ont ete rapportes par Quoy \& Gaimard. Ce sont les types de l'Histoire des Poissons.

"Les earactires donnes par les autores de ce travaíl étant du caractère de coloration ne se retrouvent guire sauf par le trait argentée qui va de l'veil au museau, quon voit tres distinctement, et sur toutes les exemplaires du Chromis frcnalus mais en ce que tous les excmplaires sont sensiblement plus petit que ceux des deux autres espèces, ce pouvait etre un caractìre de jeune age, une sorte de livrée neoterique.

"A premiere vue, ce Chromis frenatus m'avait paru assez different des Chromis lepisurus et Chromis cu'vulcus pour lesquelles l'identification ne sauriat pas faire de doute, mais en prenant les dimensions exactes et les reduisunt proportionellement a les longueurs donnés, j'ai pume convaincre que les differences de proportions n'etaient que appurent et dues a les difficultég qu'on epreuve de comparer des exemplaires.

"En résumé, je partage tout a fait votre avis et pense comme vous que ces trois espèces $\Omega^{\prime} e n$ font qu'une, a peine serait on autorise n regarder le Chromis frenatus compo une varicté." 
Dr. Vaillant notes that the caudal angles are more prolonged in the specimens called Chromis lepisurus, but a table of measurements sent by him shows no important difference in proportions.

873. Chromis analis (Cuvier \& Valenciennes). I'a lamu-moanc. New Guinea (Macleay); Samoa; East Indies.

This well-marked species is common at Samoa, where about 25 specimens were taken. Life colors of a very deep specimen from Apia, pale blue, light golden behind and on soft dorsal, anal, and caudal; sides with a few narrow bronze lines; ventral white, dusky-edged, very long; caudal, dorsal, and especially anal dark-margined; a little dusky shade at base of soft dorsal and anal behind; iris blue; a dark speck in pectoral axil.

874. Chromis ovalis (Steindachner). Hawaii.

875. Chromis elaphrus Jenkins. Hawaii.

S76. Chromis dimidiatus (Klunzinger). Tahiti; Raiatea; East Indies.

Ileliastcs dimidiatus Klunzinger, Fische Rothen Meeres, 529, Red Sea.

Heliastes dimidiatus, Günther, Fische der Südsce, 237, taf. 125, fig. B, Tahiti, Raialea.

This species was not seen by us. It is very close to our Chromis iomelas, but according to the figure of Dr. Günther, and the description of Dr. Klunzinger, the posterior boundary of the black area is at the front of the anal fin.

877. Chromis iomelas Jordan \& Seale, new species. Samoa.

Head 3.30 in length; depth 2; eye 2.10 into head, equal to interorbital; dorsal xII, 11; anal II, 12; scales $2 \frac{1}{2}-16-8$.

Body rather deep and stout; head scaled, except between and in front of nostrils; teeth small, in several rows on each jaw; caudal peduncle short, its length equal to its depth; preorbital narrow, equal to about one-half of pupil; fourth dorsal spine about equal to postocular part of head; lobes of caudal prolonged into filaments; pectoral fin slightly longer than head; filames.ts of ventral reaching to base of anal.

Lifé colors, specimen from Pago Pago, anteriorly deep brownish black, abruptly pale lavender behind, the color deepest anteriorly; a large black ocellus on base of pectoral; fins colored like rest of body, the elongate caudal very pale lavender, the elongate ventral black.

In preserved specimens anterior from a line with base of fifth dorsal spine vertically down, the color is brown; all posterior to this line is yellowish white; base of pectorals black; ventrals black; four anterior dorsal spines black, the remainder of dorsal yellowish white; caudal and anal yellowish white.

This species is very close to Chromis dimidiatus, but the lavender-colored caudal region begins much in front of the anal fin. Three specimens were taken at Pago Pago. The type is no. 51743, U. S. National Museum, from Pago Pago; length 2.25 inches.

878. Chromis axillaris (Bennett). Raiatea (Seale); East Indies.

\section{ACANTHOCHROMIS Gill.}

Heptadecacanthus Alleyne \& Macleay, Proc. Linn. Soc. N. S. W. 1876, 343 (longicaudus).

879. Acanthochromis polyacanthus (Bleeker). Faté and New Hebrides (Seale); East Indies.

\section{Family LABRIDE.}

\section{CHCEROPS Rüppell.}

880. Chœrops anchorago (Bloch). Palau; Yap; New Hanorer (Peters); New Guinea (Macleay). (Chorops macrodontes Lacépède.)

Chorops meander Cartier, from the Philippines, is doubtless the young of this species.

881. Chœrops brenchlyi Günther. Misol.

Charops brenchlyi Günther, Ann. Mng. Nat. Hist., 1872, 274.

882. Chœrops cyanostolus (Richardson). New Guinea (Macleay); Australia; Wast Indies.

Cossyphus ommopterus Richardson, probably not Chorops schoenleini of Bleeker; certainly not Cossyphus schoenleini Agassiz. 
According to Günther, the stuffed skin which is type of C. cyanostolus Richardson belongs to the species called $C$. ommopterus by Richardson, on the next page. This species is characterized by the black dorsal spot, which seems to be wanting in the true Cherops schoenleini. Choorops schoenteini of Bleeker has this spot, but also a pale spot beyond it, wanting in C.cyanostolus. This seems to be the same as Chorops unimaculata of Cartier.

883. Chœrops cyanodus (Richardson). Tahiti; Anstralia.

VERRE0 Jordan \& Snyder.

884. Verreo oxycephalus Bleeker. Hawaii; New Guinea; Anstralia; Japan.

VERRICULUS Jordan \& Evermann.

885. Verriculus sanguineus Jordan \& Evermann. IJawaii.

LEPIDAPLOIS Gill.

886. Lepidaplois axillaris (Bennett). New Hebrides; Ulea; Tahiti; Paumotu Is.; Guam; East Indies.

887. Lepidaplois hirsutus (Lacépède). Varau (Günther); East Indies.

888. Lepidaplois albotæniatus (Cuvier \& Valenciennes). Hawaii; Johnston I.

This species, very abundant about Hawaii, was not taken by us at Samoa. It reaches a considerable size, and is subject to some changes in color with growth.

We can not identify the Hawaiian species with Lepridaplois bilunulatus of the East Indies. The latter species, according to Bleeker's figure, has two broad, black curved stripes on the head, instead of the narrow maroon streaks seen in our species. The incomplete account given by Cuvier bears out this probable difference.

889. Lepidaplois strophodes Jordan \& Evermann. Hawaii.

This species, thus far known from small specimens only, is occasionally taken about Hawaii. The black blotch at base of soft dorsal behind extends across the body, forming a broad black bar. This species is probably not the young of Lepidaplois alboteniatus, as supposed by Günther, as we have specimens of the latter of about the same size as the types of strophodes which have the characteristic markings of the adult. Still it is possible that these are acquired by some examples at an earlier stage than by others.

890. Lepidaplois modestus (Garrett). Hawaii.

891. Lepidaplois perditio. (Quoy \& Gaimard). Tonga; Saumarez Reefs; Aneiteum; Japan; Mauritius.

NESIOTES De Vis.

892. Nesiotes purpurescens De Vis. South Seas.

Nesiotes purpurescens De V1s, Proc. Linn. Soc. N. S. W. 1851, 453, South Seas.

\section{LABROIDES Bleeker.}

893. Labroides dimidiatus Cuvier \& Valenciennes. Samoa and Hawaii (Günther); Palau; Yap; New Hebrides; East Indies.

This species was not taken by us.

894. Labroides paradisæus (Bloch). New Guinea (Macleay); East Indies.

\section{DUYMERIA Bleeker.}

895. Duymæria cæruleomaculata Günther. Aneiteum; New Hebrides.

896. Duymæria nematoptera Bleeker. New Guinea (Macleay); Last Indies. 


\section{PSEUDOLABRUS Bleeker.}

897. Pseudolabrus unilineatus Guichenot. Guam.

This species is perhaps the type of a distinct genus.

\section{LABRICHTHYS Bleeker.}

Labrichthys Bleeker, Flores, 331, 1854 (cyanotinia).

Thysanochilus Kner, Denks. Ak. Wiss. Wien, Xxıv, 1865, 5 (ornatus).

Chœrojulis Kner \& Steindachner, Sitz. Ak. Wiss. Wien, LIv, 1867, 393 (castaneus); not of Gill.

898. Labrichthys cyanotænia (Bleeker). Sugale uliuli. Samoa; East Indies.

Labrichthys cyanotænia Bleeker, Bijdr. Ichth. Flores, Nat. T. Ned. Ind., vi, 331, 1854, Flores.

Thysanochilus cyanotznia Günther, Fische der Südsee, 24'2.

Thysanochilus ornatus Kँner, Denks. Ak. Wiss. Wien, xxrv, 1865, 5, taf. 3, fig. 1, Samoa

Platyglossus ocellatus (or Platyglossus chrysotænia var.) Kner \& Steindachner, Sitz. Ak. Wiss. Wien, irv, 1867, 377, Upolu.

Chœrojulis castaneus Kner \& Steindachner, op. cit.. 393, fig., young, Upolu, same specimen as Platyglossus ocellatus.

We have 8 specimens of this dainty fish from Apia. It is notable for its small mouth and very wide lips. There is a posterior canine tooth and 9 dorsal spines.

Life colors of a specimen called sugale uliuli, dark brown, almost black, with obscure stripes of bronze and blue, very dark, and therefore faint; a black spot at base of pectoral; head with wavy blue stripes, lips yellow; dorsal colored like body, with blue edge; anal with blue edge and blue median stripe, elsewhere dark bronze; caudal like body at base, with blue curved streak, posterior part black, the edge pale; ventral blue, with black stripe; pectoral dusky greenish yellow at base.

Another specimen from Apia was jet black, with two white longitudinal, streaks, the upper from end of snout to base of caudal, the other from throat alongside of belly to middle of anal; mouth golden; fins black, the caudal white edged.

899. Labrichthys australis Steindachner. South Seas.

Labrichthys australis Steindachner, Ichth. Mitth., viII, 1866, 476, South Seas.

\section{EPIBULDS Cuvier.}

900. Epibulus insidiator (Pallas). Lapega; Gutu-ume. Samoa; Tahiti; New Guinea; Raiatea and Faté (Seale); East Indies.

This singular fish, which early attracted attention, is common about Samoa. We have 49 examples from Apia and 10 from Pago Pago, and these well illustrate the wide variation in color exhibited by this fish, it being dichromatic, some individuals bright yellow, others dark olive-brown.

Life colors of a specimen from A pia called lapega, dark lemon-yellow, brown on top of head, with vertical bar of blackish on each scale; anal yellow and lower part of head yellow; spinous dorsal brownish, yellow at base, then greenish yellow, then brownish red, then green, then orange-brown; a deep blue spot on front of dorsal, with orange below it.

Young very dark brown; a blue spot followed by yellow on front of dorsal.

\section{HEMIGYMNUS Günther.}

901. Hemigymnus melapterus (Bloch). Alati moana; Paumutu; Afataimi, Tagitagi; Sugale uli; Sugale aloa. Samoa; Palau Is.; Ponape; New Guinea (Macleay); Shortland I. (Seale); East Indies.

This is a very common fish about Samoa. We have 14 examples from Pago Pago and 24 from Apia. The coloration changes with age in a marked degree. In the young the anterior half of the body is largely white.

Life colors of a specimen from Apia, called afataimi, or tagitagi, dark brownish olive; most scales brown at base, with violet blue spot mostly obscure; head dark, the cheek bright yellow, the space behind eye coppery; head everywhere with vermicular streaks, green above, blue below; lips and chin dirty grayish, unmarked; dorsal brownish red, with blue spots and two blue marginal streaks, the lower violet blue and broader; caudal dirty blue, the rays blue, the margin dirty brown; anal dull blue, with many round blue spots and a blue stripe, the edge brownish; ventral whitish, with dull 
orange on first soft ray, and yellow and orange dashes behind; pectoral pale, the axil golden, the upper ray and a bar across base blue, the latter with golden and bluish edge behind; lips very thick; some scales on cheek. A smaller example has the ventrals brighter, orange and blue; otherwise it is the same.

Another specimen from Apia, a large one, was uniform blackish green, the scales showing traces of green and violet markings when examined closely; belly bronze brownish, with a violet spot on each scale, these violet shades scattered over the sides; cheek and interopercle clear olive green; lips dusky olive; a bright grass-green ring about eye; a dull dark blue blotch behind eye; preorbital, suborbital, lower and upper part of cheek and opercle dull bronze-orange with sharp vermiculations; throat reddish gray; dorsal blackish, orange, very dark, with a dark blue edge and a dark blue stripe below; many deep violet spots on membranes; caudal violet blackish, sharled with green on rays and edged with dull orange; violet spots and vermiculations; anal dusky orange, a deep violet blue intramarginal band, and with deep violet spots; ventral orange, with large blue spots; pectoral dusky bluish, paler below.

A specimen called alati moana, from Apia, was deep blue black with olive shades behind front of first dorsal and vent; shoulder light green with dull orange spots, the shade becoming golden olive behind gill-opening and on opercle and cheek; the breast, throat, and belly gray; pink shades on opercle; a pink stripe below eye; a large violet-coppery blotch behind eye, with deep violet spots within, these having paler centers; forehead coppery violet, mottled with green; bright blue close behind eye; dorsal violet black, with green on basal scales, then bright blue marblings anteriorly; violet-blue spots on membranes, with marginal stripes of deep violet-blue, light pinkish brown and black; caudal olive-black, with a median narrorv stripe of violet-blue from base to tip; anal brown suffused with blue, with violet-blue spots, and blue, pinkish, and black edgings; ventral colorless, olive-shaded, the anterior rays pink, margined before and behind by dusky blue; pectoral colorless, the upper edge blue. Canines 2-2; no posterior canines; a few scales on cheek; lateral line continuous.

Life colors of a specimen called panmul, from Apia, posterior parts, behind middle of pectoral, deep brownish black; anterior parts abruptly soiled gray;-dark brown on top of head, with bluish reticulations; upper lip gray, lower whitish; a whitish undulate streak below eye; axil black; dark brown spots about eye; dorsal dark brown, lighter above with streaks of bluish; anal similar, with a blue stripe and an orange margin; caudal with peduncle light brown, spotted with blue; pectoral colorless; ventral tinged with orange.

902. Hemigymnus fuliginosus (Lacépède). Samoa; Carolines; New Guinen (Macleay); East Indies.

Jullus, fasciatus Thunberg, Reise nach Japan, IN, 1791, 351, pI. 314, City of "Meaco" (doubtless Miyakoshima, Temple I., one of the Riukiu group); not of White, 1790, which is a species of $A$ mia.

Sparus fuliginosus Lacépède, Hist. Nat. Poiss., 111, 437, 1802, Ile de France.

Sparus malapteronolus Lacépède, op. cit. 450, Ile de France.

Sparus zonephorus Lacépède, Hist. Nat. P'oiss., IV, 155, 1503; after Bloch.

Sparus meaco Lacépede, op. cit., 161; after Thunberg.

Sparus quinquefasciatus Bennett, Fishes Ceylon, 1839, pl. 23, Ceylon.

iTautoga merlensi Cuvier \& Valenciennes, Hist. Nat. Poiss., XIII, 308, 1839; Carolines.

Cheilinus blochi Cupier \& Valencienne, Hist. Nat. Poiss., XIV, 1839, 108; after Labmis fasciatus Bloch.

Tautoga lencomus Bleeker, Biliton, IV, 239, Biliton; young.

IIemigymnus leucomus Günther, Cat., IV, 139, $180^{\circ}$.

Of this species we have one large specimen from Apia. The name fasciatus is not tenable for it, having been preoccupied.

\section{ANAMPSES Cavier. Sugale.}

903. Anampses cuvieri Quoy \& Gaimard. Hawaii.

904. Anampses cæruleopunctatus Rüppell. Sugale lupe. Samoa; Tahiti; Guam; New Guinea (Macleay); Rarotonga (Seale); East Indies.

This species is not uncommon in the South Seas. We have 9 specimens from Apia.

Life colors of a specimen called sugale lupe, olive, the belly gradually scarlet; each scale with a violet-blue spot, edged with blackish blue, these confluent into streaks behind and below eye; dorsal orange-brown, spotted with blue and blue-edged; caudal like body, the spots smaller, the edge dusky and then whitish; anal bright orange-brown, spotted with blue and with blue edge, the lowest (basal) row of blue spots oblong; ventral orange streaked with blue; pectoral yellowish; dark brown at base. 
905. Anampses evermanni Jenkins. Hawaii.

906. Anampses godeffroyi Günther. Hawaii. Anampses godeffroyi Günther, Fische der Südsee, 252, taf. 140, 1873, Sandwich Is.

This species.is described from a drawing made by Garrett at Hilo. We have specimens from Hawaii corresponding to this drawing, but they seem to us only highly colored examples of the species called Anampses evermanni. Doubtless the two are identical.

907. Anampses diadematus Rüppell. Samoa (Günther); Paumotu Is.; Kingsmill Is.; Huahine; Misol; East Indies.

908. Anampses neoguinaicus Bleeker. New Guinea. Anampses neoguinaicus Bleeber, Arehiv. Neerl. 1878, 57.

909. Anampses melanurus Bleeker. Savaii. Anampses melanurus Günther, Fische der Südsee, 252, Amboina.

910. Anampses pterophthalmus Blekker. New Guinea (Macleay); Oualan (Günther); East Indies.

911. Anampses fidjiensis Sauvage. Fiji.

Anampses fidjiensis Sauvage, Bull. Soc. Philom. 1850, 224, Fiji.

\section{AMPHECES Jordan \& Evermann.}

912. Ampheces geographicus (Cuvier \& Valenciennes). New Guinea (Macleay); East Indies.

\section{STETHOJULIS Günther.}

913. Stethojulis strigiventer Bennett. Samoa (Günther); Palau; Fiji; Vavau; Ponape; New Guinea; East Indies.

914. Stethojulis fulvoventris Seale. Guam.

915. Stethojulis renardi Günther. Samoa (Günther); Guam; Ponape; East Indies.

916. Stethojulis albovittata (Kölreuter). Hawaii.

This species is common about the Hawailan Islands. It is not certainly known from elsewhere, though Günther lists it from Zanzibar and Madagascar. It is well separated from Stethojulis casturi, its representative in Polynesia and the East Indies.

917. Stethojulis casturi Günther. Samoa; Palau Is.; Futuna; New Guinea; Rarotonga (Seale); East Indies. (Pl. xLV, fig. 1.)

Stethojulis albovittata, Bleeker, Atlas, 132, tab. XLIV, fig. 5, East Indies; not of Bonnaterre.

Stethojulis casturi Günther, Fische der Südsee, 255, 1573, Palau, Futuna, Yap.

We have 10 specimens of this fish from the coral reef at Apia. It is readily distinguished from Stethojutis alborittata, with which it has been confounded, by the presence of but one stripe extending the whole length of the side. In Stethojulis albovittata, which is known from about Hawaii only, there are two bluish stripes from pectoral to caudal, and the interspace between them is red.

Life colors of a specimen of $S$. casturi from Apia, violet-black; abruptly livid bluish white below; a sharp boundary stripe bright sky-blue, widened behind and bordered below by pale golden; head olive green, clear on sides; four curved unequal stripes on head, sky-blue with darker edgings, (1) one above eye, including its upper edge, extending along back to last ray of dorsal, (2) a violet line behind eye to above gill-openings, (3) from angle of mouth to lower part of eye, curving above axil and becoming the blue lateral stripe on body; lowest stripe curving across cheek to join its fellow on the chin. A long crescent of vivid scarlet, including the axil. Edge of shoulder-girdle below it deep blue; dorsal dull brownish gray; caudal grayish, the median blue streak extending on it; ventral and anal colorless, pectoral also.

918. Stethojulis trilineata (Bloch \& Schneider). New Guinea (Macleay); New Hanover (Peters); Palau Island (Günther); Last Indies. 
019. Stethojulis phekadopleura Bleeker. Samoa; Solomon Is.; Ponape; New Guinea (Macleay); East Indies.

This is a common species in the East Indies; it also occurs a undantly in the South Seas. TVe obtained 14 examples at Pago Pago and 54 at Apia. We have also examined specimens from Negros in the Philippines.

Life colors of Samoan specimens were noted as follows:

(1) From Apia. Back clear olive-brown with rows of bluish white dots; belly abruptly white, a golden brown boundary stripe widening into a grayish stripe below eye, edged above with a fine white line; the boundary stripe faint with age; belly with 3 or 4 rows of blackish brown spots, one in each scale; base of anal livid blue; a large black spot at base of caudal, surrounded by orange-brown (fainter and more diffuse in old examples, in which the gray stripe below eye is lost, the pale line above it remaining distinct); dorsal orange, dull with bluish and orange spots; caudal dull orange and livid bluish; ventral same, as is also the anal; pectoral colorless; iris reddish; axil unmarked. The lack of axil markings, the white dots above and dark below are characteristic.

(2) From Pago Pago. Green olive above; livid silvery below, brownish above posteriorly; head and all upper parts finely dotted with pale bluish; lower parts with larger dark brown spots in 4 rows; a pinkish white stripe before eye; a black spot on base of caudal above, faint in adult; fins all pale brownish red, the dorsal very finely checked; a pinkish streak below eye, breaking into spots behind; anal livid bluish.

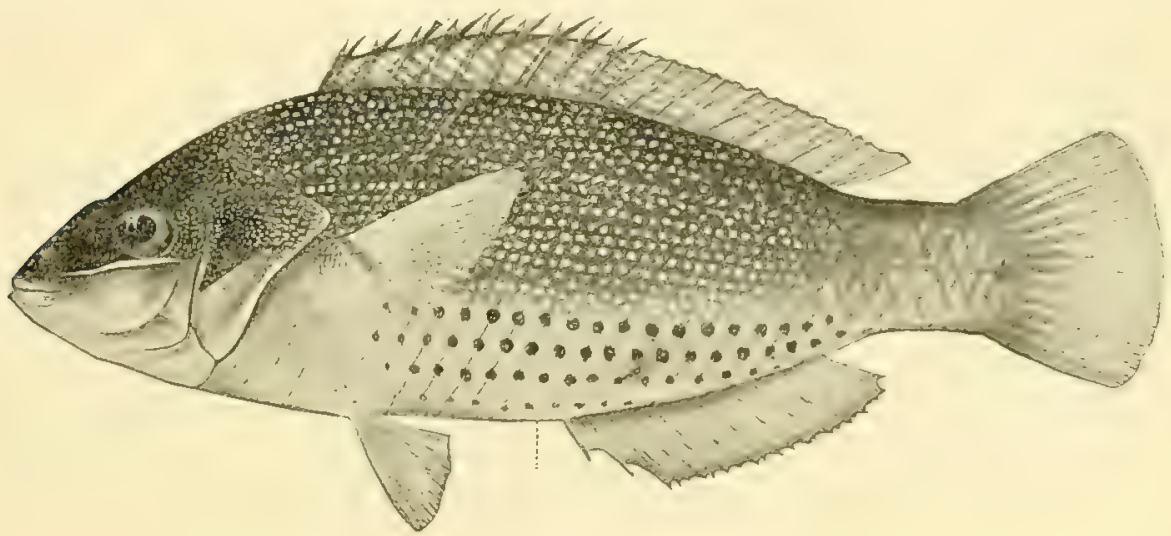

FIG. 52,-Stethojulis phekadopleura Bleeker.

(3) From Pago Pago. Very finely dotted above, coarsely spotted below; no axil or caudal spot; a silvery streak below eye; fins reddish; dorsal much speckled.

(4) Very young; from Pago Pago. Bright reddish brown with a pale streak below eye and another from snout above eye along side of back; bluish spots on scales and some black ones on side of belly; a black spot at base of caudal and another on upper fin rays; caudal colorless; other fins orange.

920. Stethojulis axillaris Quoy \& Gaimard. Hawaii.

This species, as understood by us, is found only about the Hawaiian Islands, where it is rather common. Farther south it is represented by a marked subspecies or closely related species, with slenderer body and paler lower parts, Stethojulis bandanensis of Bleeker. It is barely possible that larger series may show the two to be identical, as supposed by Bleeker and Günther.

921. Stethojulis bandanensis (Bleeker). Samoa; Ialan Is.; Solomon Is.; Fiji; Tahiti; New Hebrides; Ponape; New Guinea. (Pl. xLv, fig. 2.)

Julis bandanensis Bleeker, Banda, I, 254; Banda.

Stethojulas axillarz Bleeker, Atlas, Labr., 136, tab. XLıv, fig. 3, 1862, East Indies; not of Quoy \& Gaimard. Günther, Fische der Sudsee, 25t, taf. 136, fig. c, Palau, Solomon, Fiji, Samoa, Society Is., New Ifebrides, Ponape.

This species has been confused with Stelhojulis axillaris (Quoy \& Gaimard), of Hawaii, to which it is closely related. The only tangible differences are these: Stethojulis axillaris has the body deeper, 
and the belly is not very pale, its coloration not sharply separated from that of the sides. Stethojulis bandanensis is a slenderer fish, and the belly is abruptly whitish, with a dark shade on each scale.

This species is very common about the coral reef at Apia, where we obtained 55 specimens. We also collected 9 at Pago Pago. Life colors of a specimen from Apia, gray, silvery on lower half; everywhere with fine lengthwise streaks of white, these broader and more conspicuous below, especially the one below eye, which has a dark streak above it; a small jet-black spot in axil of dorsal and one on upper part of caudal peduncle just before base of caudal; fins all pale (in young of 2 inches).

A specimen from Pago Pago was olive-green, posteriorly pürplish; cheek abruptly golden; anterior region with fine pale dots; whitish pink spots along side; a white spot across base of pectoral; a black ocellus on last rays of dorsal, anal and base of caudal; fins otherwise light orange. Another specimen has three caudal ocelli.

Another specimen from Apia has its upper half grayish dusky with very fine bluish-white dots; a grayish lateral band, edged with dark above, a broad metallic purplish gray band below it, the belly silvery, each scale with a dark purplish-gray basal spot, two black pale-blue-edged ocelli on caudal peduncle, a black bar across base of pectoral, a bright scarlet dash in axil, with blue on each side of it; side of head below eye abruptly golden; chin and throat white; dorsal golden brown, finely dotted; caudal dull yellowish; ventral, pectoral, and anal colorless, belly livid blue at base of anal.

922. Stethojulis filholi Sauvage.

Stethojulis filholi Sauvage, Bull. Sci. Phil. 1880, 15 (reprint), Fiji.

923. Stethojulis kalosoma (Bleeker). New Guinea (Macleay); East Indies.

\section{LEPTOJULIS Bleeker.}

924. Leptojulis pardalis Kner. Fiji; Guam; Samoa. (Pl. Xlv, fig. 3.)

Leptojulis pardalis Kner, Sitz. Akad. Wiss. Wien 1867, 727, taf, III, fig. 2 (fig. 9 in text), Viti Levu (Fiji Is.). Plaiyglossus nigromaculatus Günther, Proc. Zool. Soc. 1871, 666, pl. 60, Samoa. Halichores nigropunctatus Seale, Bishop Museum, 1901, 89, Guam.

We have 4 specimens of this handsome species, taken at Apia. Life colors of one of these, clear olive-green, yellow below; everywhere with reticulations of ground-color, yellow with blue margins around the black; these marks orange-brown instead of black on forehead, lower part of head, and belly; oblique dark stripes from eye around jaws, edged with light blue; dorsal, caudal and anal similarly marked, the brown becoming distally very bright clear orange-brown; ventral yellow, orange banded; pectoral plain; dorsal edge of body clear olive brown; greenish cross-bars on head.

A canine tooth; scales rather large; lateral line continuous; a low dorsal sheath; body compressed.

\section{MACROPHARYNGODON Bleeker.}

This well-marked genus consists of small species, deep bodied and beautifully colored, the lower pharyngeals very small, with large teeth.

925. Macropharyngodon geoffroy (Quoy \& Gaimard). Hawaii.

926. Macropharyngodon meleagris (Cuvier \& Valenciennes). New Guinea; Samoa; Ulea; Shortland I. (Seale); East Indies.

Julis meleagris Cuvier \& Valenciennes, Hist. Nat. Poiss, XIII, 481, Ulea.

Macropharyngodon geoffroyi Bleeker, Atlas, Labr., 129, tab. Xxxvir, fig. 5, Celebes; not of Quoy \& Gaimard. Platyglossus geoffroyi, Gunther, Cat., IV, 145 (copied).

This species is scarce about Samoa, one fine example being taken at Apia. Life colors, violetbrown; a large, bright-green spot edged with blue on each scale, these confluent into short stripes on the head; belly mostly light blue; a violet-black spot on breast; dorsal orange, shaded with bluish at base, edged with gray, two rows of clear green blue-edged spots; caudal dull orange, brighter on upper and lower margins and covered mesially with large greenish-blue spots; anal dull orange with three rows of greenish, blue-edged spots; the middle series confluent in a band; ventral dull orange, spotted with green; pectoral colorless, dusky at base, the axil green; a jet-black spot edged with yellow on side above and a little behind base of pectoral. 


\section{PLATYGLOSSUS (Klein) Bleeker.}

This genus in very closely allied to Halichcres. The body is deeper and more compressed, and the scales along the base of the dorsal more elevated, forming a low sheath.

\section{Platyglossus marginatus (Rüppell). Samoa; Raiatea (Seale). (II. XLY, fig. 1.)}

Two specimens of this handsome fish were collected by us at Apia. It has not heretofore been found in the South Seas.

Life colors of one specimen, olive-black, region covered by pectoral bright cherry-red; a reddish streak along the edge of each row of scales, these clear brown on back, faint posteriorly and pinkish brown on belly; head golden-brown, much striped with dark blue; belly also blue, striped with brown: dorsal dark orange-brown spotted with dark blue, and edged with sky-blue with a dark blue bounding line; caudal deep orange-brown with dark blue spots and sky-blue edgings; a dark blue bounding line, the angles olive-gray; anal like dorsal but further edged with bright yellowish grecn; ventral and pectoral dark bluish; axil cherry-red.

\section{Platyglossus notopsis (Kuhl \& Van Hasselt). Samoa; East Indies.}

The young of this fish differs markedly from the adult in having four conspicuous white lines along the side and two or three similarly colored spots below the dorsal. The dorsal, in both young and old, has a small ocellus between the first and second spines, and a very large one between the first and sixth rays.

- This is a common fish at Samoa. We have 40 specimens from Apia, and 49 from Pago Pago. Color in life of a specimen from Apia, almost jet-black, with very obscure whitish spots on scales; caudal paler sooty; iris red; pectoral dull olive, a black bar across base; breast and chin purplish black; dorsal, anal and ventral black, the dorsal usually with a large bluish, white-edged ocellus; caudal abruptly pale olive (side with about a dozen greenish pale streaks in younger ones); teeth small, a posterior canine; head naked; body deep, head sharp above; scales large; dorsal uniform.

Another specimen from the same locality was jet-black, with six irregular interrupted whitish lines, plainest on head; dorsal black; with a large white-edged ocellus on first soft rays; caudal abruptly bright white, a whiter stripe along anterior edge; anal and ventrals black.

Life colors of a specimen from Pago Pago, black, with very faint streaks of bluish, scarcely evident and distinct only on head; caudal abruptly muddy white; a large, black, whitish-edged ocellus on first soft dorsal rays, and a little one on first and second spines; dorsal striped throughout with dull orange; anal, ventral, and pectoral plain blackish. This is very close to another that has golden stripes, very distinct. The latter is apparently the young.

929. Platyglossus flos-corallis Jordan \& Seale, new species. Samoa. (Pl. XLVI, fig. 2.)

Head 3.20 in length; depth 3.50 ; eye 4.50 in head; dorsal $I x, 12$; anal 111,12 ; scales $2-30-8$, interorbital equal to eye; snout 3 in head.

Body oblong, compressed; caudal rather deep, 2.30 in head; head unscaled; mouth somewhat protractile, jaws equal, lips thick; teeth in a single series of sharp, somewhat projecting conical teeth in each jaw, the front ones the largest; a sharp canine tooth at angle of jaws; opercle and preopercle entire; gillrakers very short, sharp, about 13 on lower limb; longest dorsal ray 2.75 in head; longest anal spine 2.80 in head; base of anal equal to length of head; pectoral 1.50 in head; anal rounded, 1.50 in head; ventral equal to length of pectoral, its tips not reaching base of anal.

Color in spirits, a dull yellowish brown with ten longitudinal blue lines on the side from head to caudal; these lines are slightly wider than their interspaces and are most distinct on anterior half of body; the caudal peduncle has a median line of yellowish white on its gides extending in from caudal fin; a bright yellow spot on base and in axil of pectoral with a smaller distinct black spot on upper part of base; head yellowish with two blue lines from interorbital to tip of snout, a blue line from anterior margin of eye to tip of snout, a curved blue line around chin over cheek across opercles to base of pectoral, below which are two indistinct blue lines; just back of orbit is a black spot forming the termination of the $4-5$ lines of body; the three upper body lines extend on nuchal region, the second joining the line above, the other terminating at upper posterior margin of orbit; a blue crescent on opercular flap; dorsal with seven longitudinal bands of color, the mid one of greenish white, occupying the middle of the fin, being the widest; a broad, dark green, black-edged stripe just 
below with light green at base of fin; anal similarly colored, except that the mid-band of light green is wider and there is no lighter coloring at base of fin; caudal yellowish white with the outer half covered with reticulated dark markings, tip of upper and lower margin yellowish white; pectoral and ventral yellowish white.

Life colors of three specimens from Pago Pago were as follows:

(1) Green anteriorly, becoming deep vitriol-blue behind pectorals; anterior parts with stripes of orange-red, which are very bright anteriorly and fade out behind; cheeks golden-green; head stripes very plain; axillary region very bright golden, with a black spot above; dorsal with dull, orange and greenish streaks; caudal blue with pale corners and three orange-red stripes converging and reticulating behind, crossed hy horizontal streaks of black; anal with basal and terminal stripes of orange; ventral green with purple stripe; pectoral pale, its base bright golden.

(2) Greenish ground, paler and yellowish anteriorly; ten pinkish salmon longitudinal lines on sides, most pronounced anteriorly. Pectoral with yellowish axil and orange-yellow blotch just behind axil; small but distinet black blotch just in shoulder of pectoral; caudal blue-green at base and mesially with complex linear lines of pinkish salmon, these lines darker in middle portion of fin; dorsal yellowish grass-green with pinkish salmon lines and narrow blue lines; anal similar; ventral bright green with bluish tinge, pinkish salmon on anterior margins; bright blue median longitudinal line on under side of head.

(3) Bronze, with nine sharply-defined lengthwise stripes of greenish blue, as wide as interspaces; a stripe also on median line above and below; head green, yellowish below, the stripes continued on it becoming orange, those below cherry-brown; dorsal brownish orange, with grass-green stripes below and blue lines above and on edge; caudal deep black tinged with red, with blue cross-lines and three green blotches at base; anal orange with one green stripe and four blue streaks; ventral grass-green, blackish-edged; pectoral pale dusky; axil golden; a jet-black spot at base of pectoral.

This beautiful fish is rare ahout Samoa. We obtained but three specimens, all at Pago Pago. It is apparently close to Platyglossus kallochromus, of the East Indies, but there are several notable differences in color.

The type, no. 51744, U. S. National Museum, is 2.75 inches long.

\section{Platyglossus hœveni (Bleeker). Samoa; New Guinea (Macleay); East Indies.}

1- We have two examples of this East Indian fish, both from Pago Pago. Life colors of one of these, bright greenish blue, with about a dozen golden stripes, distinct from snout to base of caudal, the interspaces blue, with darker edgings; sncut grass-green; iris blue, centrally red; base of caudal reddish brown; a blue-edged black ocellus at base of caudal above, and a larger one on front of soft dorsal; a small one on first dorsal spine; caudal abruptly pale, with a reddish, curved cross-band at base and a whitish bluish one behind it; fins (in young) plain; dorsal striped orange and blue; a dark spot before and one behind eye; snout yellow.

\section{HALICHERES Rüppell.}

(Halichores Rüppell, type caruleovittata-scapularis; Guntheria Bleeker; Hemitautoga Bleeker; Ichthycallus Swainson; Cherojulis Gill; Iridio Jordan \& Evermann; Parajulis Bleeker; Octocynodon Fowler.)

The proper type of the genus Halichores is a species (scapularis) belonging to the group called Guntheria. If these sections are regarded as genera, the one commonly called Halichores should rather stand as Ichthycallus, or as Chorojulis, if the American species be separated from the others. But it is probably better to leave all the species with large scales, complete lateral line, and a posterior canine, Platyglossus and Macropharyngodon excepted, together in one large genus.

931. Halichœres scapularis (Bennett). Shortland I. (Seale); East Indies.

? Halichores cxruleoviltalus Rúppell.

932. Halichœres centiquadrus (Lacépède). Ifigi. Samoa; Guam; New Guinea; Tahiti; Shortland I. and Raiatea (Seale); East Indies. (I'. xLrı, fig. 3.) 
This beautiful fish occurs from the Red Sea throughout Polynesia. We have 3 specimens from Pago Pago and 7 from Apia. Life colors of a specimen from Pago Pago, head grass-green, the stripes creamy pink, edged with blue; jaws yellow; stripes on throat of paler pink.

933. Halichœres notophthalmus (Bleeker). Samoa; Tew (iuinea; Rarotonga (Seale); East Indies.

We have 4 specimens of this East Indian fish taken at Apia. Life colors of one specimen, body gray with transverse blotches of black, very irregular; lips orange; iris red; caudal bright yellow with two confluent white blotches at base, with black between; a white blotch across spinous dorsal; a black ocellus, golden-edged, on soft dorsal; anal and pectoral pale; ventral white; a brown red stripe throngh eye; whitish stripe below; a brown red spot below; breast mostly black. (Young).

Another specimen was very pale olive, almost white, with three broad black irregular crossbars, the second broadest and blackest, some black spots on the pale bars along line of back; head pale; cheek with two deep blue horizontal stripes, the upper through eye to gill-opening; darker behind eye; two black spots on each side of breast, two on base of pectoral with white between; dorsal colored like body; a large white-edged black ocellus in black part; soft dorsal mottled, pale gray; caudal deep yellow with two whitish yellow spots at base, dusky between; ventral whitish; pectoral colorless; anal pale.

934. Halichœres trimaculatus (Quoy \& Gaimard). Samoa; Vanicolo; New Guinea; Fiji; Tahiti; Tubuai; Faté and Shortland Is. (Seale); East Indies. (Pl. xuvr, fig. 1.)

This is a common and most beautiful fish about Samoa, where it swarms in the coral reefs. We have 58 specimens from Pago Pago and 80 from Apia.

Life colors were noted in various specimens as follows:

(1) From Apia. Green, each scale with a dark grayish bronze crescent; scales of nape with orange spots; head green, with bright red stripes and spots; cheek golden, the color bounded by a green band above; creamy red marks on chin and throat, bordered by green; a large jet black spot behind shoulder, with two blue ones within it, the color extending as a bar to ventrals, green, with red spots; an indigo-black spot above lateral line before caudal; dorsal light green with three stripes of creamy scarlet; caudal orange, fading lehind, a greenish edge above; anal greenish with two red stripes, the basal one narrower and deeper in color; pectoral colorless; ventral flesh color.

(2) From Apia. Bright green; each scale with a dark olive spot; head green, yellow below, with coppery red streaks and spots about eye; a small black ocellus at base of pectoral, a pink crossbar behind it; a large black spot on caudal peduncle; dorsal greenish, finely covered with coppery red lines; caudal, anal, and rentral similarly barred; belly whitish; pectoral pale.

(3) From Pago Pago. Pale bluish gray, the sides of head sometimes but not always brassy; pale blue stripes before and behind eye, below eye horizontal; tip of snout with plain oblong black spot above; side of body with six blackish cross shades, the second and third widest and more or less confluent; a large blue-black spot on side before caudal; a small black ocellus at upper base of pectoral; fins plain olivaceous; a violet-blue vertical spot on each scale of body.

(4) 1 larger example. Head green, golden below, the marks crimson not blue; bands more reduced; second and third still plainer; spots on scales orange brown; black pectoral spot at base above, with a green, red-edged bar below it, and a red bar across axil to ventral; throat with two red cross-bands; precaudal spot large and distinct, black rose spot obscure; fins all pale reddish, the dorsal streaked with red on green ground; nape with close-set red spots.

935. Halichœres dædalma Jordan \& Seale, new species. Fataga loa. Samoa. (Pl. xLvir, fig. 2.)

Iead 3 in length; depth 3.20 ; eye 5.50 in head; dorsal Ix, 11; anal 111, 11; scales 25; snout 3.10 in head; interorbital equal to orbit.

Body elongate, compressed, the anterior profile of head evenly pointed; depth of caudal peduncle 2.20 in head; teeth in a single series in each jaw, the anterior ones projecting canines, a single posterior canıne at angle of jaw; lips rather thick, with folds; angle of jaws scarcely reaching to anterior margin of eye; opercle and preopercle entire, no scales on cheek; the last spine of spinous dorsal the longest, 3 in head; the longest soft ray 2.75 ; pectoral 1.50 in head; rentral 1.25 ; base of anal 1.85 in base of dorsal, its longest ray about 3 in head; caudal slightly rounded, 1.75 in head. 
In spirits the ground color is yellowish, the upper two-thirds of body with bluish coloring forming more or less distinct bands; nine short silvery white lines over back, separating the bluish bands; belly and under surface with slight tint of pale blue; four rather distinct bands of blue extending from median line of side toward base of anal fin; head with a straight blue line from angle of jaw to midway of opercle; another blue line from distal end of upper lip through lower part of orbit, dividing first back of eye, where it is deep blue, one branch curving back and down on to lower posterior margin of operele; may or may not unite with the dark opercular spot; the other branch extending up and ending on shoulder just above opercle; another blue line from tip of snout to upper part of orbit and extending a short distance back from orbit; two blue blotches on interorbital space one on each side of nuchal region; a black dot between 1st and 2nd dorsal spines; another, much larger, between the 2nd and 3rd dorsal rays; the outer third of dorsal fin has a number of round white spots; the inner portion is similarly colored but the spots are larger and some are paired, forming short thick bands; anal fin with a blue band through the middle which may be more or less broken up into round spots posteriorly; a row of round spots at base of fin; caudal with three rows of dusky bands and some white spots with wash of dusky at tip; pectoral and ventral yellow, unmarked.

In life a specimen from Pago Pago was much mottled, shaded with pink; a black dorsal ocellus, a black opercular blotch; a large black blotch on side; a pink silvery area below eye.

A specimen from Apia, called fatagaloa, was green with red-brown scallops above, the markings brighter below; a blackish blue blotch on caudal peduncle; head with red stripes and green, the edgings of the red stripes bright blue; a horizontal red stripe below the eye; opercle with a dark creamy red spot at tip, golden olive before it; dorsal green and brownish red, the green in rounded blue-edged spots; a black spot on first soft rays; caudal banded green and brownish red; anal paler green and red; ventral green and red.

This species is very common about Samoa, where we obtained 48 specimens from the reef at Apia. A dozen small immature fish, collected at Pago Pago, have been referred by us to this species. The species is very close to IIalichweres pocilus, but the markings are different, notably those on the cheek which form a straight stripe, not a ring or horseshoe.

The type, no. 51845, U. S. National Museum, is from Apia and is 4 inches long.

936. Halichœeres pœcilus (Lay \& Bennett). New Guinea (Macleay); East Indies.

(Halichœres harloffi Bleeker; Ifalichœres annulatus Fowler.)

937. Halichœeres guttulatus (Macleay). New Guinea.

Platyglossus guttulatus Macleay, Proc. Linn. Soc. N.S. W. $1883,587$.

338. Halichœres opercularis (Günther). Fiji; Samoa. (Pl. XLvII, fig. 3.)

This species is very close to Halichores pseudominiatus of the East Indies. Comparing. our specimens with some from Negros, we are inclined to think that Halichores opercularis is a distinct species. The chief difference lies in the a rrangement of the colored stripes on the head.

This species is very abundant about Samoa and about 170 specimens were taken.

Life colors of a specimen from Apia, light olive, with a net-work of dark brown lines above; side golden with two white vertical streaks anteriorly behind rectoral, a broad, bright, purple-pink band at vent, then golden with incursions of purple from the dark bands above; dorsal with vertical streaks of brownish red on yellow; a large and conspicuous black ocellus on front of soft dorsal; a smaller black spot on front of spinous dorsal; caudal yellowish, cross-banded with brownish red; anal similar, ventral pink; pectoral colorless; head brownish and streaked above, with a bright orange streak before and behind eye; a horizontal curved stripe below eye creamy yellow, bordered by light blue and rimmed with dark blue, this bending around forward on subopercle and cheeks; a black ocellus on opercle; about eight whitish spots along base of dorsal, one of them in axis of soft dorsal.

A young specimen from Pago Pago was whitish with scattered reddish spots and incomplete broad blackish transverse band; dorsal with conspicuous semi-ocellus; green, yellow and black-brown on anal; caudal clear; snout red; iris rose-red.

939. Halichœres margaritaceus (Cuvier \& Valenciennes). Vanicolo.

This species, imperfectly described, is very similar to Halichores opercularis, but no mention is made of ocelli on the dorsal fin. 
940. Halichceres macleayi Jordan \& Seale, new name. New Guinea.

Platyglossus margaritaceus Macleay, Proc. Liun. Soc. N. S. W. 1834, 274, Hood Bay; not of Cuvier \& Valenciennes.

941. Halichceres auritus (Cuvier \& Valenciennes). Ulea.

This species, scantily described, is an ally of Halichoeres opercularis, but nothing is said as to ocelli on the dorsal fin.

942. Halichœres nebulosus (Cuvier \& Valenciennes). Guam (Seale); East Indies.

943. Halichœres gymnocephalus (Bloch \& Schneider). New Guinea (Iacleay); Faté (Seale); East Indies.

Labmis gymnocephalus Bloch \& Schneider, Syst. Ichth., 180, 351; fide Peters.

Julis modestus Bleeker, Verh. Bat. Gen., XxI, Labr. Cycl, 26.

Halichores modestus Bleeker, A tlas, Labr., 126, tab. xxxv, fig. 2, East Indies.

Platyglossus modestus Günther, Cat., IV, 157, Singapore.

944. Halichoeres leparensis (Bleeker). Guam (Seale); East Indies.

945. Halichœres papilionaceus (Cuvier \& Valenciennes). Vanicolo.

946. Halichœres chloropterus (Bloch). New Guinea (Macleay); East Indies.

947. Halichoeres ornatissimus (Garrett). Hawaii.

(Halichores iridescens Jenkıns.)

948. Halichœeres lao Jenkins. Hawaii.

949. Halichcres guttatus (Bloch). New Guinea (Macleay).

950. Halichœres solorensis Bleeker. Marquesas Islands (Seale); East Indies.

951. Halichœres melanurus (Bleeker). New Guinea (Macleay).

\section{PSEUDOJULIS Bleeker.}

952. Pseudojulis cerasina Snyder. Hawaii.

\section{CORIS Lacépède. (Hemicoris Bleeker.)}

The genus Hemicoris, of Bleeker, having scales 50 to 60 , differs from Coris only in the absence of posterior canine teeth. These are not well developed even in Coris, and are said to be occasionally absent. For that reason the genus probably can not be maintained.

The genus Julis Cuvier (not of Bleeker or Günther), having the scales 70 to 80 , is better defined and is possibly worthy of retention.

953. Coris aygula Lacépède. Guam; Tahiti; Faté and Tubuai (Seale); Hawaii (Fowler-a doubtful record); Japan; East Indies.

954. Coris cyanea Macleay. New Guinea.

955. Coris papuensis Macleay. New Guinea.

956. Coris variegata (Rüppell). New Guinea (Macleay); New Hebrides; East Indies. (Ramsuy \& Ogilby, Proc. Linn. Soc. N. S. W. 1856, 131.)

957. Coris venusta Sauvage. Hawaii.

(Hemicoris remedius Jenkins.)

958. Coris multicolor Rüppell. Aneiteum (Günther); Red Sea.

959. Coris ballieui Vaillant \& Sauvage. Hawaii. (Coris schauinslandi Steiudachner.)

960. Coris rosea Vaillant \& Sauvage. Hawaii.

(Coris argenteostriatus Steindachner; Hemicoris keleipionis Jenkins. Not Julis rosea Quoy \& Gaimard.)

961. Coris cingulum (Lacépède). New Guinea (Macleay); Aneiteum (Günther); East Indies.

962. Coris caudimacula (Quoy \& Gaimard). Rarotonga (Seale); Mauritius. 


\section{JULIS Cuvier.}

963. Julis greenovii Bennett. Samoa; Hawaii; Manado.

This striking fish is rare about the Samoan Islands. We have three specimens from Apia. It was originally described from Hawaii, but we did not find it there. The colored plate in the report on the fishes of Hawaii is from a Samoan specimen. The coloration shown in that plate is much less bright than that in nature.

Life colors of a specimen from Apia, deep scarlet-red, each scale with an olive speck, below pure cherry-red, 5 blotches on back pure white edged with black, a black blotch on tail filled with bright blue spots; a bar on caudal black, whitish in middle; anal red with a blue edge; ventral, also pectoral, light orange-red; a row of blue spots at base of anal; dorsal clear red with a blue-black edge.

964. Julis pulcherrima (Günther). Hawaii; Samoa; Tahiti; Aneiteum; New Hebrides; Guam; New Guinea; East Indies.

This beautiful fish seems to be rare about Samoa, though rather common at Honolulu. We have one adult specimen from Apia, which agrees very well with Bleeker's figure.

Life colors, head coppery red with green stripes edged with violet; throat with a blackish green stripe; body reddish brown, becoming blackish behind; almost everywhere covered with small deep violet spots; crowded behind, sparse in front, none on head; dorsal bright orange, brown at base with violet-blue spots; soft dorsal cherry red; caudal plain golden yellow running on to orange on edges; anal drab orange-brown with violet markings; pectoral orange, the axil blue-black, edged with grassgreen; ventral olive, with a wide maroon stripe, then a violet edge.

965. Julis gaimardi Quoy \& Gaimard. Hawaii; East Indies?

This species is rather common about Hawaii. It is possible that the East Indian specimens called Coris gaimardi belong to some other species.

966. Julis cuvieri Bennett. New Hebrides; Ile de France.

967. Julis flavovittata Bennett. Hawaii; Laysan.

968. Julis eydouxi (Cuvier \& Valenciennes). Hawaii.

969. Julis lepomis Jenkins. Hawaii.

\section{HOLOGYMNOSUS Lacépède.}

970. Hologymnosus longipes (Günther). Aneiteum.

971. Hologymnosus elongatus (Günther). Aneiteum.

972. Hologymnosus semidiscus (Lacépède). New Guinea (Macleay); Tahiti and Rarotonga (Seale); East Indies.

(Labrus annulatus Lacépède.)

\section{CHEILIO Lacépède.}

This genus, close to Thalassoma, differs in the elongate body and smaller scales. There seems to be but one species, widely distributed and varying considerably in shade of color.

973. Cheilio inermis (Forskål). Masamie; Moai. Hawaii; Samoa; Guam; Vanicolo; Tahiti; Aneiteum; New Guinea; East Indies.

This common and widely spread species is rather scarce at Samoa, though very abundant at Honolulu. We have one specimen from Apia.

THALAssoma Swainson. (Julis Günther, not of Cuvier.) Sugale (choice).

This genus is distinguished by the presence of 8 dorsal spines, large scales, and no posterior canine teeth. The species are all beautifully colored.

974. Thalassoma duperreyi (Quoy \& Gaimard). Hawaii; Johnston I.; Laysan; Mangareva, Gambier Is. (Seale); Acapulco (as Thalassoma steindachneri Jordan \& Evermann).

(Thalassoma clepsydralis Smith \& Swain.) 
975. Thalassoma ballieui (Vaillant \& Sauvage). Hawaii; Johnston I.

(Julis obscurus Günther; Thalassoma verlicalis Smith \& Swgin.)

976. Thalassoma lunare (Linnæus). New Guinea (Macleay); East Indie日.

Apparently all the East Indian references to lunaris belong to T. lunare and the Polynesian references to $T$. lutescens. The species from the Riukiu Islands figured by Bloch as Labrus viridis, by Bennett and by Brevoort as Julis lutescens and described in detail by Jordan \& Snyder (Proc. U. S. Nat. Mus., XxIV), as $T$. lutescens, is the true lutescens, being different from $T$. lunare.

977. Thalassoma guntheri (Bleeker). Samoa; Fanning I. (Streets, Bull. U. S. Nat. Mus., viI, 1877,83 ); New Guinea (Macleay); East Indies.

We have one fine specimen from Apia, apparently referrable to this species. Life colors, bright olive green, much mottled and varied; a bright crimson lateral stripe; another above it, broader, duller, more diffuse, and connected with the first by cross streaks; two oblique crimson stripes from pectoral across belly anteriorly, separated by blue-green; belly livid violet gray; head dark; a red area on preorbital; a deep blue stripe through eye from snout to opercle; a curved blue stripe bounding dark bluish brown of lower part of head; lower jaw orange with a blue stripe; dorsal bluish at base, then crimson in a broad band, then bluish, then broadly edged with green; caudal very pale reddish, this color surrounded by whitish and blue, the upper and lower rays and lobes crimson, the upper a continuation of the dorsal stripe, the lower line extending forward on caudal peduncle; anal pale livicl grayish; pectoral colorless, the axil red and green, the outer half jet black; ventral colorless grayish.

978. Thalassoma lutescens (Solander). Hawaii; Tahiti; Fanning Is. (Streets); Marcus I. (Bryan); Riukiu Is.

979. Thalassoma purpureum (Forskâl). Hawaii; Samoa; Tahiti; Guam; Caroline Is.; Aneiteum; Laysan; Thornton I.; East Indies.

Scarus purpureus Forskal, Descr. Anim., 27, 1775, Red Sea; not Julis vurpurea Rüppell, and of Güuther, which is Thalassoma ruppelli (Klunzinger).

Thalassoma purpureum Seale, Bishop Museum, 1901, 91, Guam.

Julis quadricolor Lesson, Voy. Coquille, II, 139, pl. 35, fig. I, 1826-1830, Tahiti. Cuvier \& Valenciennes, Hist. Nat. Poiss., XIII, 443, 1839, Tabiti. Bleeker, Atlas, Labr., 93, 1862, not the plate which is Thalassoma fuscum.

Thalassoma quadricolor, Jenkins, Bull. U.S. Fish Comm., xxir, 1902 (1903), 462, Hawaii.

Scarus semicxruleus Rüppell, Neue Wirbeltbiere 10, pl. 3, fig. 1, 1835, Red Sea.

Scarus georgii Bennett, Fish. Ceylon, pl. 24, Ceylon.

Julis erythrogaster Cuvier \& Valenciennes, Hist. Nat. Poiss, XII, 4\$7, 1839; may be Thalassoma cyanogaster.

Scarus quinquevutatus Richardson, Voy. Blossom, 66, pl. 19, fig. 3.

Julis ruppelli Steindacbner, Dellks. Ak. Wiss. Wien 1900, 506, Laysan; not of Klunzinger.

Thalassoma immanis Fowler, Proc. Ac. Nat. Sci. Phila. 1899, 4\$8, pl. 18, fig. 2, Caroline Is.

Thalassoma berndti (misprinted berendti) Seale, Bishop Museum 1901, 115, fig. 7. Honolulu.

This species is confused by Günther with Thalassoma fuscum under the name of Julis trilobata. T. purpureum may be known by the variegated head, with three broad scarlet wedges radiating from the eye, and by the presence of three red stripes on a blue-green ground. The fins are colored differently frum those of $T$. cyanogaster. (For color notes see Fishes of Hawaii.) In T. fuscum the head is plain red, and there are two rows of quadrate blotches, compared by Lacépède to Chinese characters, on each side. These are blue on a red background.

T. purpureum is widely diffused in the South Seas. We have one fine specimen from Apia, and several from Honolulu.

980. Thalassoma cyanogaster (Cuvier \& Valenciennes). Tahiti; Samoa.

Julis cyanogaster Cuvier \& Valenciennes, Hist. Nat. Poiss., XII, 4H, 1839, Tahiti; on a drawing of Solander.

Of this species, well distinguished from Thalassorna purpureum by its coloration, we have one fine example from A pia and one from Pago Pago.

Life colors of the specimen from Apia, bright grasg-green, yellowish below with three longitudinal stripes of clear coppery red, cross-hatched; head green with many red stripes and spots; two green stripes forward from eye; a scarlet irregular streak downward and backward across preopercle and subopercle, with numerous jrregular red spots and blotches behind it and above it; dorsal green at base, then orange red, then a narrower grass green stripe, then a red one, the soft rays each tipped with 
grayish blue; caudal with rays pale red, the membranes bright green, the middle rays tipped with yellow, the outer with blue; anal striped, green, bright red, blue, narrow green, lighter red, finally blue; ventral greenish at base, reddish behind; pectoral dusky above without distinct spot, a green bar toward base, a scarlet one below it, then a large green patch behind opercle, with a wavy red stripe surrounding the green, pectoral black at tip; livid blue shades at throat.

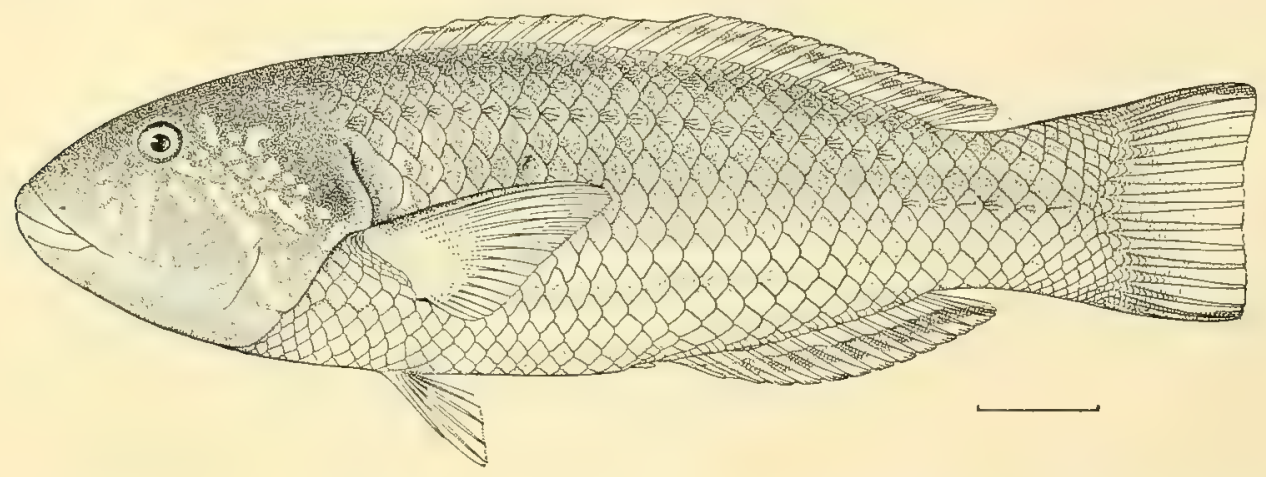

FIG. 53.-Thalassoma cyanogaster (Cuvier \& Valenciennes).

981.: Thalassoma fuscum (Lacépède). Hawaii; Samoa; Laysan; New Hanover; Aneiteum; Tubuai; Rarotonga and Makatea (Seale); East Indies.

Labrus fuscuis Lacépède, Hist. Nat. Yoiss, III, 437, 1802, Ne de France.

Labrus trilobatus Lacépède, Hist. Nat. Poiss., III, 454, 526, 1802, Bourbon, Madagascar.

Julis trilobatus, Cuvier \& Valenciennes, Hist. Nat. Poiss., XIII, 437, 1839, Ile de France. Günther, Cat., IV, 187, var. A. South Africa, Mauritius, Aneitum. Peters, Berl. Mon. 1876, 843, New Hanover.

Julis jormosus Cuvier \& Valenciennes, op. cit, XıI, 439, 1839, Ile de France.

Jutis xruginosus Cuvier \& Valenciennes, op. cit, 441, 1839, Ile de France.

Julis quadricolor Bleeker, Atlas, Labr., 93, tab. XxxIv, fig. 3, Java; not of Bernett.

Julis purpureus Steindachner, Denks. Ak. Wiss, Wien 1900, 506, Honolulu, Laysan.

Thalassoma purpureum, Jenkins, Bull. U. S. Fish Comm., xxir, 1902 (1903), 462, Hawaii; not of Forskă.

This species, known by its green, jews-harp markings on a red ground, compared by Lacépède to Chinese seript, is occasionally taken in the South Seas. We have two specimens from A pia and several from Hawaii.

Life colors of a specimen from Apia, deep red brick color, paler below, the squares deep-bluish green; head coppery olive; first dorsal creamy scarlet, the base green, the edge sky-blue; soft dorsal similar with a red intermarginal band; caudal with rays sky-blue, the membrane bronze-orange; anal orange on basal half, the rest sky-blue, a dark line separating a greenish shade at base; ventrals blue, green at tip; pectoral dusky, darker above with diffuse blackish blotch at tip; axil deep blue, a blue spot rather faint at upper angle of gill opening.

982. Thalassoma punctatum Seale. Guam; Rarotonga (Seale).

Julis punctata Seale, Bishop Museum 1901, 91, Guam.

This species seems to be close to Thalassoma fuscum, but it has a black ocellus on the back of the tail.

983. Thalassoma umbrostigma (Rüppell). Hawaii; Samoa; Laysan; Makatea (Seale); East Indies.

This is an abundant species at Honolulu, but seems to be scarce at Samoa. We have one adult specimen from Apia, and 6 young ones from Pago Pago. Life colors of four young specimens from the latter place were as follows:

(1) Green, bluish white below; three longitudinal bands of dark brown and rose pink; a brick red spot at tail end of each of these bands; anal bluish white with rose suffusion; caudal clear with rose suffusion; dorsal with rose-pink shading.

(2) Yellow-green above, blue green below; two longitudinal series of brick-red spots with blackish centers.

(3) Bright green; 3 lengthwise series of quadrate spots, the median largest and joined by a reddish brown shade; a spot behind eye, the median band extending through eye; upper band also 
distinct, forming 8 spots, the last a speck at upper base of caudal, above sixth on body in the second band; dorsal green with a black spot behind first spine and three in a triangle at first soft ray; fins otherwise all pale green; no axil spot and no dark shade on pectoral.

(4) Bluish below, green on sides and dorsum, with pronounced rose-pink blotches and bars, darker above; pectoral with rose-pink axil; greenish yellow outside at base of pectoral and a small greenish yellow blotch on pectoral itself near base; dorsal green with dark rose-pink median line; anal with rose-pink line along base; caudal blue green with narrow pink blotches and greenish yellow margin.

984. Thalassoma genivittatum (Cuvier \& Valenciennes). Marcus Island (Bryan \& Herre, Bishop Museum, 1903, II, 131); Last Indies.

985. Thalassoma dorsale (Quoy \& Gaimard). Sugale sei; Sugale pulepule; Sugale fu'a'ele'ele. Samoa; Fiji; Aneiteum; New Ireland; New Guinea; Marcus I.; Shortland I. (Seale); East Indies.

This species is common in the East Indies, Indian Ocean, and South Seas. We have 12 specimens from Pago Pago, and 16 from A pia.

Life colors of specimens called sugale sei, from Apia, dark green: 5 indigo blue black crossbars: a bright red lateral streak posteriorly, a fainter one above it, blue below this; 5 broad greenish coppery red bands radiating from eye, the broader anteriorly blue; a black spot before and across base of pectoral; a blue-black spot on base of tail in larger one; chin and lower part of head dark blue (males with a large black green-edged spot above pectoral); sides mottled with red; dorsal blue black; the soft dorsal broadly golden at tip, a bluish streak below the golden; a pale streak across base of spinous dorsal and pale tips; caudal translucent yellowish green, a red streak on each lobe, and a light green edge above and below; anal pale yellow with a black spot anteriorly; ventrals yellowish; pectoral yelłowish; a deep blue-black stripe the whole length of dorsal, pale below, yellowish above.

986. Thalassoma schwanefeldi (Bleeker). Tubuai; Austral I. (Seale); East Indies.

987. Thalassoma janseni (Bleeker). New Guinea (Macleay); Aneiteum (Günther); East Indies.

988. Thalassoma aneitense Günther. Hawaii; Aneiteum; Guam; Nukahiva (Seale).

989. Thalassoma mertensi (Cuvier \& Valenciennes). Ulea.

This species, very imperfectly described from a drawing, we do not recognize. It may be the young of Thallassoma lunare.

\section{G0MPHOSUS Lacépède.}

990. Gomphosus varius (Lacépède). Hawaii; Samoa; Guam; Fanning Is. (Streets); New Guinea (Macleay); East Indies.

This species is rather common about the Hawaiian Islands, as also about Samoa. We have 5 examples from Apia.

We are not altogether certain that the Hawaiian species, Gomphosus pectoralis, is fully irlentical with the East Indian Gomphosus varius, but the evidence points in that direction. Apparently Gomphosis undulatus and Gomphosus pacificus are color variations of this species.

991. Gomphosus undulatus Streets. Fanning Is.

Gomphosus undulutus Streets, Bull. U. S. Xat. Mus., VI, 85, 187t, Fanning Is.

This species, doubtfully separable from Gomphosus varius, is unknown to us.

992. Gomphosus pacificus Seale. Guam.

Gomphosus pacificus Seale, Bishop Museum 1901, 9\&, Guam.

This species is probably a color variant of Gomphosus vurize.

993. Gomphosus tricolor Quoy \& Gaimard. Sugale. Hawaii; Samoa; Tahiti; Caroline Is.; New Guinea (Macleay); Rarotonga; Makatea and Mangareva (Seale); East Indies.

This singular and beautifully colored fish is common about the Hawailan Islands and occurs througheut the South Seas. We have two specimens from A pia and one from l'ago Pago.

Life colors of a specimen from Apia called sugale, deep greenish black, indigo blue on head, each scale of body with a violet bar and an olive wash; a bright yellowish green bar above axil, which is black; dorsal and anal light clear green, bluish at tip; caudal blue black on edges, pale behind, mesially 
light vitriol blue; pectoral with a yellowish green crossbar at base, then dusky green, black on posterior edge with a vertical median band of vivid clear blue; ventral blue black. Another was, in life, green, rather than blue; dorsal and anal yellowish green.

Life colors of a specimen from Pago Pago, dorsal blue-green growing yellowish green at margin; anal and caudal similar; body purplish green with dark pinkish maroon and light olivaceous scale markings.

994. Gomphosus sandwichensis Günther. Hawaii.

\section{CIRRHILABRUS Schlegel.}

995. Cirrhilabrus jordani Snyder. Hawaii.

996. Cirrhilabrus solorensis Bleeker. New Guinea (Macleay).

\section{CHEILINUS Lacépède.}

997. Cheilinus trilobatus Lacépède. Sugale matamumu; Lalaf. Samoa; Tahiti; New Guinea; Ladrones; Guam; Fiji; New Hebrides; Kingsmill I.; Howland I.; Ponape; Futuna; Hawaii (Quoy \& Gaimard-as Cheilinus sinuosus, Cheilinus polygrammıs Cuvier \& Valenciennes, and Cheilinus maculosus Cuvier \& Valenciennes); East Indies.

This wide-spread species is very abundant about Samoa. We have 26 specimens from Apia, and 9 from Pago Pago. Quoy \& Gaimard record it from Hawaii, but no subsequent collector has seen it there. Life colors were noted in various specimens as follows:

(1) From Apia. Olive-gray; a series of greenish blue cross-streaks, very numerous and welldefined; pale cherry-red cross-shades between them; head with radiating streaks and spots of crimson; chin dull, blunt; dorsal light olive with cherry-red edge and intramarginal streak; soft rays mostly colorless; a little dusky spot at base; caudal dusky, edged all around with pale, the tip and edge mostly red; anal olive with green rays, and two red marginal; ventral with blue rays, an olive blotch, and a pink erlge; pectoral yellow olive; dark olive at base.

(2) From Apia. Blackish green; a bright orange-red vertical stripe on each scale, these faint or obsolete posteriorly; head with many bright scarlet stripes and dashes; spinous dorsal olive-green with two scarlet stripes and about four diffuse cross-shades; soft dorsal clear pinkish orange, the rays yellow; no bars or spots; anal dark olive and pinkish orange in streaks, paler behind; no spots; caudal dark olive-green washed with scarlet at tip, yellow-olive between; ventrals pink orange, the rays dark olive-green; pectoral light yellowish olive; throat livid dusky blue; breast coppery green; caudal rounded.

(3) From Apia. Marbled olive-green with four diffuse blackish bars; each scale with a brown vertical streak; head with curved and vertical streaks and bars; spinous dorsal mottled orange, green and brown, soft translucent pink; anal similar, its edge broadly translucent pink; pectoral fleshy red; ventral olive and reddish barred.

(4) From Pago Pago. Dark olive-greenish with pinkish and greenish vertical linear scale spots; head richer dark green with pink linear and spotty markings; pectorals thin, yellowish; ventral with green rays and pink interspaces; anal with pink submarginal line and anterior half with second pink line; general color greenish and bluish; caudal dark bluish; green at base, paler at tip; small round jet-black spot before base of caudal.

998. Cheilinus hexagonatus Günther. Hawaii; Johnston I.

(Cheilinus zonurus Jenkins.)

999. Cheilinus pulchellus Sauvage. Fiji.

Cheilinus pulchellus Sauvage, Bull. Sci. Philom., 1880, 14 (reprint), Fiji.

1000. Cheilinus fasciatus (Bloch). Lalafi pulepule. Samoa; Guam; Solomon I.; Palau I.; New Guinea; Kingsmill I.; Vavau; Ponape; Faté; Shortland I. and Rarotonga (Seale); East Indies.

This species has a wide range extending from the Red Sea to the islands of the Pacific. It is very common about Samoa; we have 50 specimens from Pago Pago and 7 from Apia. Life colors were noted in various specimens as follows:

(1) From Pago Pago. Below eye thin brick-red extending, somewhat smoky, over dorsum just in front of dorsal fin; breast region vermilion; upper head very smoky greenish with short reddish lines 
radiating from eye; under jaw pale smoky; body grayish black with irregular pale narrow cross-bars; small black circular spots on sides, red ones ventrally; caudal black and whitish banded with scarlet; ocellar spots coalescing in vertical series in outer (submarginal) white band; dorsal with two narrow crimson lines-crimson pink spots-markings toward posterior end; pectoral thin brick-red; ventral crimson with blackish blotch.

(2) From Apia. Olive; body with 6 dark bars, irregular and broader than interspaces; posterior half of hear and first band and breast clear cinnamon-brown, the head anteriorly olive; iris scarlet; scarlet and green dashes radiating from eye; lower jaw olive-brown; 22 darker shades across nape; some scales on body darker than others; dorsal gray, red-edged; soft dorsal brown, the last rays transparent orange; a broar pale yellow bar acrosg luse of caudal, the fin with 2 black bars and finely crussed by orange lines; caudal truncate; anal barred at base like body, the edge mottled scarlet, the last rays translucent, tinged green and orange; ventral bright orange red washed with black; pectoral brownish, scarlet at base; lower part of sides with some round brown spots.

(3) From-Apia. Greenish above, reddish below, with dark shade on each scale; 5 whitish olive cross-bands, much narrower thin interspaces, the one at base of caudal broadest; snout paler olive; dorsal and anal colored like hody, not dotted; caudal with 2 dark cross-bands; last rays of dorsal and anal pinkish translucent; sides of breast and belly with dark brown spots. Caudal truncate.

(4) Specimen called lalafi pulepule. Apparently much in common with the preceding, but with additional colors. Whole shoulder region from base of dorsal across opercle and hase of pectoral to breast and including ventrals deep ferrugineous red, the ventrals very deep red; dorsal colored like body, but with scarlet edge and two rows of scarlet spots on interior soft rays; anal spotted with scarlet, yellowish translucent behind, as is soft dorsal; some scarlet spots on yellowish band of anal, between two dark spots; scarlet streaks radiating from eye; dark greenish olive, with five narrow pale olive cross bands; the widest at base of caudal; caudal with two dark bands.

1001. Cheilinus digrammus (Lacépède). Sugale; Lalafi. New Guinea; Louisiades; Fiji; Samoa; Palau Is. ; Shortland I. (Seale); East Indies.

We have eight specimens of this species from the coral reef at Pago Pago, where it is common. Life colors of one specimen, greenish gray with weak salmon-brown scale-blotches; weak salmon diffusion below; pink copper lines on upper head; on lower head purple-brown lines; lips olive-green, also upper head; dorsal with pinkish margins; anal with almost crimson splashes; ventral with crimson coloration at base; pectoral unmarked, thin saffron rays; caudal with blue-green rays, paling and faintly reddish yellow at tips.

1002. Cheilinus undulatus Rüppell. Samoa; Tahiti; Fanning Is.; New Guinea; Vavau; Paumotu Is.; Caroline Is.; Palau Js.: Oualan (as Cheilinus festivcs); Tonga (as Cheilinus godeffroyi Günther, Proc. Zool. Soc. London 1871, 666, pl. 66, young).

This handsome and widely distributed fish was found only at Pago Pago, where we obtained two large specimens. Life colors of one of these, olive-gray, a black area on each scale, these becoming brownish reticulations on breast; streaks before and behind eye black; orange streaks on head below eye, bluish streaks above. Vertical fins all checkered with black bars; tip of caudal bright pale yellow; ventral pale gray.

The other specimen was livid white under head, with salmon-yellow spots and curving linear blotches; salmon-yellow spots on lips; head above light umber with slaty blue-gray lines; sides greenish olive (grayish green?), with vertical blackish brown spots tapering to point above and below; region below pectorals light-yellow greenish with fine purplish red lines; pectoral clear, with greenish yellow tinge at base; ventral thin greenish; dorsal coarsely mottled brownish, with greenish yellowish white spots; caudal similar with yellow margin; from eye two brown-black lines running forward and back with small spot between hinder two near eve.

1003. Cheilinus unifasciatus streets. Fanning Is.

Cheilinus unifasciatus streets, Bull, L'. \&. Niat. Mus, vri, 1877, 82, Fanning Is.

This species is unknown to us. Dr. Streets regards it as very close to Cheilinus rhodochrous of Ginther.

1004. Cheilinus ceramensis Bleeker. Aneiteum; liast Indies. 
1005. Cheilinus nigropinnatus Seale. Guam.

Cheilinus nigropinnatus Seale, Bishop Museum 1901, 86, Guam.

1006. Cheilinus oxycephalus Bleeker. New Guinea (Macleay).

1007. Cheilinus oxyrhynchus Bleeker. Palau Is. (Günther); East Indies.

1008. Cheilinus kittlitzi Cuvier \& Valenciennes. Ulea.

Cheilinus kittlitzi Cuvier \& Valenciennes, Hist. Nat. Poiss., XIv, 105, 1839, Ulea; on a drawing.

Cheilinus sanguineus Cuvier \& Valenciennes, 1. c., Ulea; on a drawing.

1009. Cheilinus roseus Cuvier \& Valenciennes. Ulea.

Cheilinus roseus Cuvier \& Valenciennes, 1. c., Ulea; on a drawing by Mertens.

1010. Cheilinus bimaculatus Cuvier \& Valenciennes. Hawaii.

\section{THALLIURUS Swainson.}

Dorsal spines 10, otherwise essentially as in Cheilinus.

1011. Thalliurus chlorurus (Bloch). Sugale gasufi. Samoa; Yap; Ponape; Tahiti; Tonga; Fiji; Palau Is.; New Hebrides; Paumotu Is.; East Indies.

This common and widely distributed species is abundant at Samoa. We have 4 examples from Pago Pago and 25 from Apia. Life colors were noted in various specimens as follows:

(1) From Pago Pago. Dark olive, scales anteriorly and below each with a round blackish-brown spot; those posteriorly and on back each with a median grayish shade, each forming streaks along rows of scales; a round dusky blotch behind tip of pectoral; another on same line behind it, with traces of two others, the last at base of caudal; dorsal mottled like back, the edge scarlet; soft dorsal translucent orange, deep scarlet at base, with a row of white dots; caudal dark orange, with rows of white dots, and angular white vermiculations at base; anal dark brown, paler behind, with many rows of white dots; ventral dark orange, profusely dotted with white; head with scarlet streaks and dashes; jaws barred with brown.

(2) From Apia. Mottled brown,very dark, not pale below; some dark spots on scales deep brown; head with scarlet spots and dashes, its lower parts blackish green; pale parts of dorsal, anal, and caudal cherry-red with spots of whitish green or grayish blue; ventral very dark-brown red with gray spots, small; pectoral plain reddish.

(3) From Apia. Dark olive, with blackish brown streaks on head; blackish brown spots on scales anteriorly and grayish spots on back and posterior parts; fins much mottled; anal and ventral with small round whitish dots; dorsal edged with dull orange, the posterior rays translucent, tinged with orange-red at base; caudal much mottled, olivaceous washed with orange-red at tip; anal dark olive, dull orange at tip with many white spots; ventral similar, darker; pectoral colorless, yellow at base; caudal truncate.

(4) From Pago Pago. Complexly and irregularly mottled with greenish, brownish, and reddish indications, most marked on dorsal, of three transverse bars; eye with green iris and red circumorbital ring; under side in front of ventrals with bluish-white spots and cross-bars. Spines of dorsal blue green; at base of tail a small but distinct ocellus, with sky-blue pupil, then narrow black line, then yellow going off unevenly into reddish; caudal greenish-blue web, whitish spines; small red cross spots on web and longitudinal spots on rays.

(5) From Apia. Olive with many darker spots and mottlings, a vague row of 4 small blackish spots between pectoral and caudal, the first largest; head with brown streaks; dorsal yellowish and brownish and olive, the last rays clear; caudal with 4 or 5 dark-brown bars; anal and ventral like spinous dorsal, many spots but none stellate.

(6) From Apia. Everywhere excessively mottled, olive, black, and reddish; radiating dark-brown streaks about eye; last soft rays of dorsal translucent pink.

\section{PSEUDOCHEILINUS Bleeker.}

This genus is well defined, as shown by Professor Snyder, by the peculiar structure of its partly divided cornea. The species are small and the deep-blue pigment in the fins persists in alcohol.

1012. Pseudocheilinus octotænia Jenkins. Hawaii. 
1013. Psuedocheilinus hexatænia Bleeker, I'a tusitusi. Samoa; Tahiti; Phoenix I.; East Indies.

(Pl. XLrv, fig. 2.)

Cheilinus psittaculus Steindachner, Sitz. Ak. Wiss. Wien, LIV, 1866, 376, fig. 1, Samoa.

We have 18 examples of this pretty little fish taken at Apia.

Life colors of a specimen called i" a tusitusi, deep purplish blue with six orange stripes which fade on tail; tail rather abruptly grass-green, paler and yellowish behind; black at upper part of peduncle; head rosy, bluish above; chin with two black dots; breast blue; ventrals deep blue; anal purplish, anteriorly deep blue; dorsal orange anteriorly, becoming brownish behind; pectoral colorless; a black dot behind dorsal.

1014. Pseudocheilinus evanidus Jordan \& Evermann. Hawaii.

\section{NOVACULICHTHYS Bleoker.}

1015. Novaculichthys woodi Jenkins. Hawaii.

1016. Novaculichthys tæeniurus (Lacépède). Molemole. Hawaii; Samoa; Vanicolo; New Guinea; East Indies.

This species varies considerably with age. Our smallest specimens have nine black streaks radiating from the eye. As the individual grows older these are reduced to four, two upward and backward and two downward and backward. Still later, only those running downward and backward remain. These finally also disappear leaving the head in the adult quite plain. The other markings, the cream-colored band at base of caudal, the black bar across base of pectoral, the black spot on front of spinous dorsal, and the cross streaks on dorsal and anal change but little with age. In the young the first two dorsal spines are much elevated, as in Novaculichthys kallosomus, which differs mainly in the brighter coloration, with white markings on head and body.

Very common in the crevices of the reefs about Samoa, as also about Hawai. We have one specimen from Pago Pago and 13 from Apia.

Life colors of an Apia specimen, olive-slate, with yellow olive shading on the scales; axil black; a golden spot on first pectoral ray at base; dorsal pale olive, with inky blotch on first rays, the fin obliquely barred with grayish; caudal dusky, a grayish bar across base; pectoral, anal, and ventral olive gray.

Other specimens from Apia, male and female, the former with banded head, were light brown; seven cross bands of dark brown; dorsal and pectoral shaded with dull orange; soft dorsal, anal, and caudal paler, shaded with yellowish; ventral dusky, dull orange washed, with white spots toward tip; a pure white spot in axil; head pale-orange washed below.

1017. Novaculichthys macrolepidotus (Bloch). New Guinea; Waigiu; East Indies.

1018. Novaculichthys kallosomus Bleeker. Hawaii; Samoa; East Indies.

We have one small specimen of this handsome East Indian fish, taken at Pago Pago. Two others, larger in size, were obtained by Snyder and Berndt at Honolulu. All are bright green in life.

Life color of a specimen from Pago Pago, brilliant grass-green with pencil-like streaks of black and bands of dark olive, these bands becoming bronze olive on the fins, markings on body of creamy white, those above greenish white; fins greenish gray, except for markings; ventral dark green.

A colored drawing made in Pago Pago from this specimen is published in Jordan \& Evermann's report on the Fishes of Hawaii.

\section{HEMIPTERONOTUS Lacépède.}

1019. Hemipteronotus pentadactylus (Linnæus). New Guinea (Mracleay); East Indies.

1020. Hemipteronotus umbrilatus Jenkins. Hawaii.

1021. Hemipteronotus copei Fowler. Hawaii.

IIemipteronotus copei Fowler, Proc. Ac. Nat. Sci. I'hila. 1900, 508, Hawaii.

1022. Hemipteronotus baldwini Jordan \& Evermann. Hawaii.

(IIemipteronolus jenkinsi snyder, young female.) 


\section{XYRICHTHYS Cuvier.}

1023. Xyrichthys niveilatus Jordan \& Evermann. Hawaii.

\section{INIISTIUS Gill.}

1024. Iniistius pavoninus (Cuvier \& Valenciennes). Hawaii.

1025. Iniistius aneitensis (Günther). Aneiteum.

1026. Iniistius carneotlavus (Peters). Dana Island.

Tynichthys carneoflave Peters, Berl. Mon. 1876, 843, Dana 1.

We have not seen this species, and we do not find Dana Island on any map. There is a Dana peak in Fiji, and part of the collection described (H. M. S. Gazelle) by Peters, came from Fiji. Most of it was from the New Hebrides.

1027. Iniistius niger (Steindachner). Hawaii.

\section{CYMOLUTES Günther}

1028. Cymolutes leclusei (Quoy \& Gaimard). Hawaii.

\section{Family SCARICHTHYIDE.}

\section{SCARICHTHYS Bleeker.}

1029. Scarichthys auritus (Kuhl \& Van Hasselt). New Guinea (Macleay); Aneiteum (Günther); Rarotonga (Seale); East Indies.

1030. Scarichthys cæruleopunctatus (Rüppell). New Guinea (Iracleay); Rarotonga (Seale); East Indies.

Depth 3.50 in length; eye 3.75 in head, 1 in preorbital portion of head, and 1 in interorbital space; dorsal $x, 10$; anal III, 9; scales of Jateral line 24 .

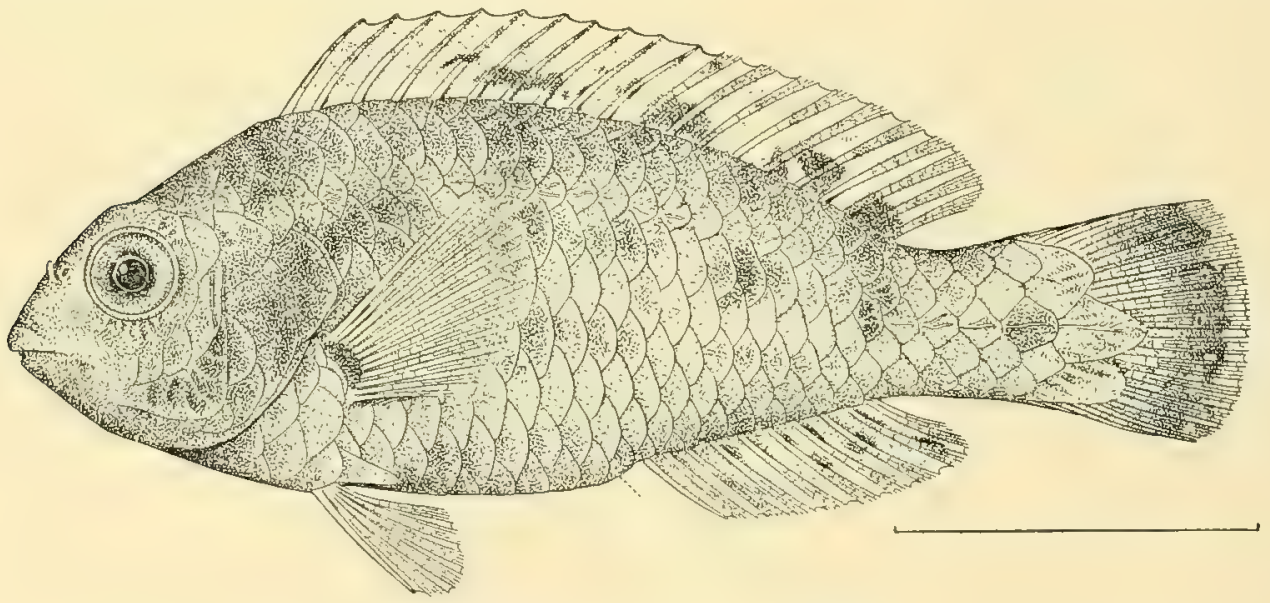

FIG. 54.-Scarichthys crruleopunctatus (Rüppel1).

Body oblong, compressed; lateral line interrupted, the tubules two-branched; teeth and nostrils generic; profile of head slightly different from other species of Scarichthys, being slightly concave above the posterior margin of the eye, and the snout with a slope slightly greater than $45^{\circ}$; caudal peduncle $2.30 \mathrm{in} \mathrm{head;} \mathrm{the} \mathrm{tubules} \mathrm{on} \mathrm{orbitals} \mathrm{and} \mathrm{preopercle} \mathrm{quite} \mathrm{prominent;} \mathrm{base} \mathrm{of} \mathrm{anal} \mathrm{fin} 2.75$ in base of dorsal; length of pectoral 1.40 in head; ventral 2.

Color in spirits, dull coppery green without white dots; about five zones of darker greenish on the body, the first above base of pectoral and over shoulder, the second below the seventh and eighth 
dorsal spines, the third below the first to third dorsal rays, the fourth below the fifth to seventh dorsal rays, and the fifth below the axil of the dorsal; a dark blotch on base of pectoral, and another in the posterior axil of the dorsal, this dark spot occupying the base of the last four dorsal rays; the dark zones of color on the body, with the exception of the anterior one, invade the basal half of the dorsal fin; pectoral white, without marks; ventral with indistinct darker unarkings; anal with five bands of dusky; caudal greenish, the tip white, and a white cross-band near the tip. Related to $S$. auritus, but the markings different.

\section{SCARIDEA Jenkins.}

1031. Scaridea balia Jenkins. Hawaii.

1032. Scaridea zonarcha Jenkins. Hawaii.

1033. Scaridea aerosa Jordan \& Snyder. Hawaii.

\section{CALOTOMJS Gilbert}

\section{Calotomus irradians Jenkins. Hawaii.}

1035. Calotomus sandwichensis (Cuvier \& Valenciennes). Hawaii.

1036. Calotomus moluccensis (Cuvier \& Valenciennes). New Guinea (Macleay); Aneiteum; East Indies.

1037. Calotomus waigiensis (Quoy \& Gaimard). New Guinea; Waigiu; East Indies.

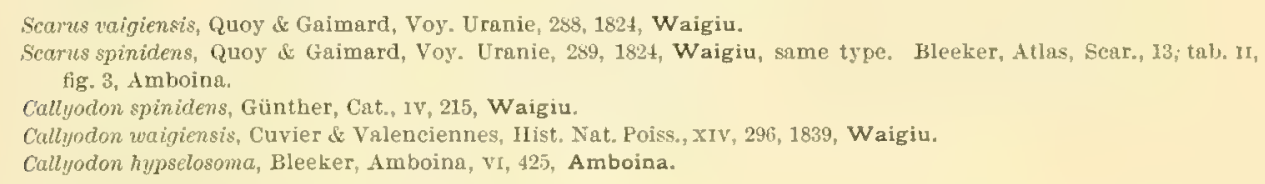

1038. Calotomus snyderi Jenkins. Hawaii.

1039. Calotomus cyclurus Jenkins. Hawaii.

1040. Calotomus carolinus (Cuviel \& Valenciennes). Caroline Is.

1041. Calotomus brachysomus (Bleeker). New Guinea (Macleay); East Indies.

\section{CALLYODON Gronow (1763),}

(Scarus Forskả, 1775; not of Gronow, 1763.)

We regret that the exigencies of the law of priority require the suppression of the time-honored name of Scames; it was first used in 1763 , for a species of latims.

ANALYSIS OF POLYNESIAT SPECIES OF CALLYODON.

a. CAlifonox, Jaws whitish or rosy.

b. Species with the coloration in life chiefy dark red or brown, sometimes golden or clouded, never largely deep blue or green.

c. Lip narrow, not covering more than half of upper jaw.

r. Scales on cheek in two rows.

e. Color blackish-red; caudal fin largely scarlet

ce. Color not as above.

$f$. Sides with pale spots, more or less regularly arranged; young with lengthwise pale streak.............bennctti

$f f$. Olive; scales with darker centers; tins black . ................................................. platodon

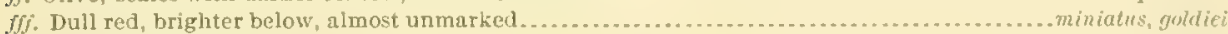

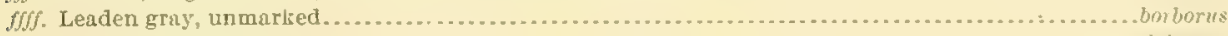

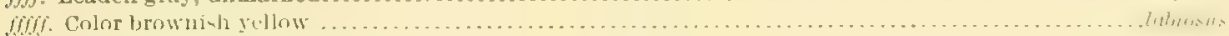

dd. Scales on cheek in three rows; dark red-brown, egch seale on side with three dnrk streaks............ruberrimus

cc. Lip brond, covering more than half of upper jณw.

g. Scales on cheek in two rows.

h. Color dark red-brown, neurly uniform.

$i$. Side of tail with $n$ dusky shade 


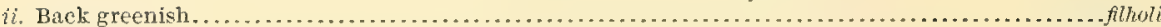

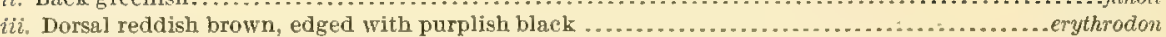

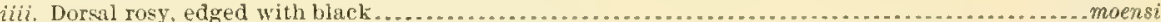

iiii. Caudal lunate, not edged behind with gray ....................................

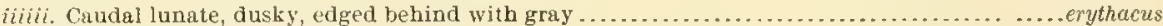

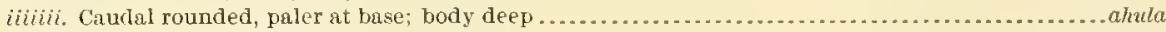

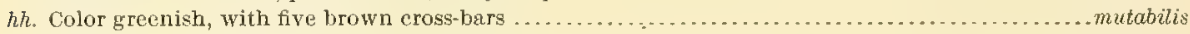
gg. Scales on cheek in three rows.

j. General color dark red or dark brown, without cross shades of blackish or golden (caudal tipped with gray); lacerta (belly with pale streaks); lepidus; paluca; upolensis...........................dubius

jj. General color violet, posteriorly chiefly yellow...................................... macrocheilus

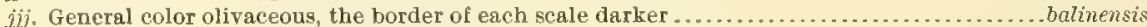

ijij. General color olivaceous; a golden wash or oblique cross-band bebind pectoral ................oviceps

jijij. General color golden brown; the back with five dark cross-bands .......................20nularis

ccc. Lips and scales on eheek undescribed.

$k$. Color mostly red ......................................................... roseiceps, cruentatus

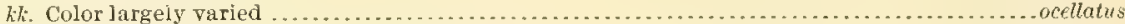

bb. Species largely deep blue or deep green, the color scarcely fading in spirits; head usually more or less variegated; the fins often with red, and usually edged with blue.

l. Lip narrow, not covering more than half of upper jaw.

$m$. Cheek with two rows of scaies.

$n$. Forehead with variegated markings............................ perspicillatus, brighami

$n n$. Forehead plain or with a narrow eross-streak . . . . . . . . . . . . . . . . . . . quoyi, lupus, jonesi

$m m$. Cheek with three rows of scales.................................. papuensis, moresbyensis

ll. Lip broad, covering more than half of upper jaw.

o. Scales on cheek in two rows........................ gilberti, bataviensis, abacurus, formosus o. Scales on cheek in three rows.

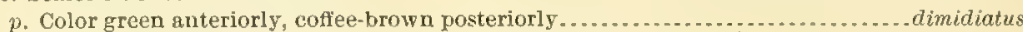

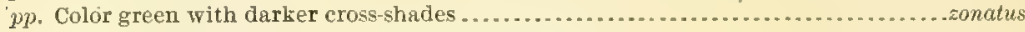
ppp. Color nearly uniform anterior $y$ and posteriorly.

q. Back golden, much spotted anteriorly with clear blue ...................... spilonotus,

pulchellus, blochi, frenatus

gq. Back without spots as above .............................globiceps, spinus, pronus, jenkinsi, fumifrons, kelloggi, tricolor, dussumieri, pyrrhostethus, pepo, fuscialus

III. Lips and scales on cheeks undescribed .......................... festivus, frontalis, forsteri ac. Pseudoscarus. Jaws green or blue.

$r$. Coloration largely dark red, the jaws deep blue; lip largely covering upper jaw: scales on cheek in three rows.

s. Head without green markings ............................. prasiognathas

ss. Head with dark green streaks and markings ........................... maoricus

$r r$. Coloration brown, the fins black-edged ........................................ rrr. Coloration largely deep green or blue.

t. Lip covering less than half of upper jaw.

$u$. Scales on cheek in two series ................................latax, celebicus,

cypho, troscheli, macleayi, gymnognathos uu. Scales on cheek in three rows ........... jordani, strongylocephalus, microrhinos

$t$. Lip covering more than half of upper jaw.

v. Scales on cheeks in two rows; belly with blue streaks............ cyanogrammus

$v v$. Scales on cheeks in three rows...........ultramarinus, lazulinus, cyanognathus

tt. Lips and seales undescribed ... ......................mertensi, spilumus, waitei

1042. Callyodon pyrrhurus Jordan \& Seale, new species. Fuga mumu. Samoa.

Head 2.75 in length; depth 3.75 ; eye 7.50 in head; dorsal $I x, 10$; anal Im, 9; scales 2-24-6; two rows of scales on cheek; lower limb of preopercle bare; snont 2.13 in head; interorbital 3.10.

Body oblong, compressed; anterior part of head bluntly rounded, the snout slightly gibbous; depth of caudal peduncle 2.70 in head; a pair of strong posterior canines on upper jaw, none on lower; lips rather narrow, the upper scarcely covering one-half and the lower about one-third of teeth; base of dorsal fin 1.78 in length without caudal, its longest ray 3 in head; base of anal 1.45 in head, 2.16 in base of dorsal; pectoral 1.45 in head; ventral 1.98; caudal 2, truncate or slightly lunate.

Color in spirits olive-brown, the base of scales slightly darker; chin and thorax with slight wash of yellowish; tip of lips yellowish; indistinctly yellowish from eye to angle of mouth; dorsal fin blackish, with some yellowish mottlings on posterior third of soft dorsal; anal fin dusky, unmarked; pectoral dusky, more or less blotched with bluish wash; ventral similar to pectoral; caudal bright yellow, its 3 margins with a narrow line of black; iris yellow; teeth greenish. 
Color in life of a specimen from Apia, clear olivaceous sooty, a little paler on tail; axil olive-black; dorsal, anal, pectoral and ventral like body, dorsal and pectoral with black edge; caudal deep brownish red, with a blackish edge.

Another specimen from Apia was dark purplish gray; almost black; throat and belly about the same; a little olive on throat; first dorsal, pectoral and ventral like body; axil blackish; soft dorsal washed with red; caudal clear dark red, edged with black, the upper and lower rays dusky.

Life colors of a specimen from Pago Pago, dark purplish gray, centers of scales blackish; axil dark; dorsal, anal, ventral and pectoral black; soft dorsal dull orange with a black edge (some relvety green-black); caudal brilliant scarlet, its edge dark.

Eight specimens from Apia and Pago Pago. The type is no. 51748, U. S. National Museum, from Pago Pago, length 9.75 inches.

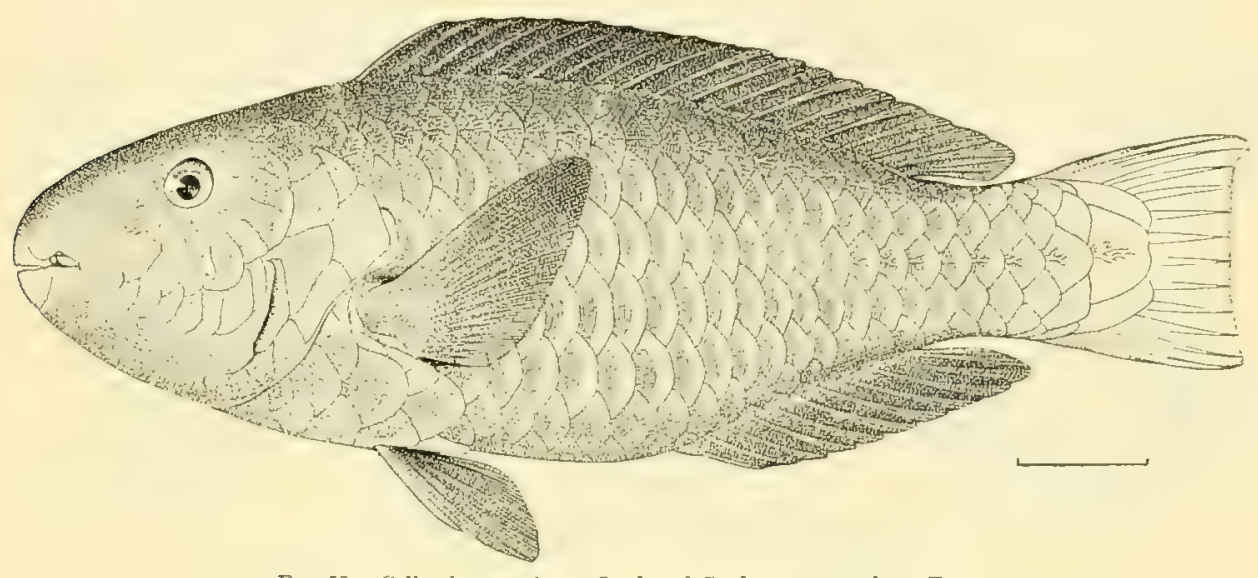

Fig. 55.-Callyodon yyrhurus Jordan \& Seale, new species. Type.

1043. Callyodon bennetti (Cuvier \& Valenciennes). Imasapupema. Hawaii; Samoa.

Scants bennetti Cuvier \& Valenciennes, Hist. Nat. I'oiss, xIv, 270, Sandwich Is. Jenkins, Bull, U. S. Fish Comm. xxiri, 1903, 470, Honolulu.

We have 6 examples of this fis", from Apia. Teeth rosy, dusky at base, uncovered; no canines; two rows of scales on cheek; caudal truncate.

Life colors of a specimen from Apia, blackish brown, a bronze-black area on each scale; snout, lips, and below bright dark cinnamon; belly dark red-brown; dorsal cinnamon, mottled and dark edged; caudal truncate, soiled red-brown; anal similar, almost black; ventral similar to anal; pectoral dark brown, fading below; axil dark.

Another specimen from Apia was violet brown, clear on belly, darker on back; sides olive shaded, the scales mottled; forehead, chin and throat vinous red brown; dorsal deep vinous brown, blackish on edge; caudal similar, paler, a broad dusky shade at tip; axil with a dark cross-shade; anal and ventral like dorsal; pectoral a little paler.

1044. Callyodon platodon (Seale). Gitam.

Pseudoscarus platodoni (misprint) Seale, Bishop Museum 1901, 96, Guam.

1045. Callyodon miniatus (Jenkins), Hawaii.

Scrtus miniatus Jenkins, Bull. U. S. Fish Comm. xix, 1599 (Aug. 30, 1900), 62, fig. 20, Honolulu.

1046. Callyodon goldiei (Macleay). New Guinea.

Pscudoscarus gnldici Macleay, Proc. Linn. Soc. N. S. W. 1883, 590.

1047. Callyodon borborus (Jordan \& Evermann). Hawaii.

Scarus barborus (misprint for borborus) Jordun \& Evermann, Bull. U. S. Fish Comm., Xxir, 1902 (1903), 197, Honolulu. 
1048. Callyodon labiosus (Macleay). New Guinea.

1049. Callyodon ruberrimus Jordan \& Seale, new species. Fuga ulapo. Samoa.

Head 2.75 in length; depth 3.20 ; eye 8.25 in head; dorsal IX, 10; anal III, 9; scales 2-24-6; three rows of scales on cheek, the lower row of only 2 scales, almost covering lower limb of preopercle.

Body elongate, compressed, the anterior of head bluntly rounded, the snout somewhat gibbous; depth of caudal peduncle 2.85 in head; six rows of scales in front of dorsal; a single posterior canine of small size in upper jaw; lips narrow, covering only one-half, or less than one-half, of teeth, the upper lip narrower than lower; base of dorsal 1.85 in head, its longest ray 3 in head; base of anal 1.85, 2.75 in base of spinous dorsal, its longest ray 3.10 in head; pectoral 1.50 ; ventrals 2 ; caudal deeply lunate, exposed outer ray 1.80 ; exposed midray 4.

Color in life of a specimen from Apia, clear reddish brown; coppery red on throat, breast and belly; each scale with three radiating marks of dark brown; lips red. Dorsal reddish brown, dusky edged; caudal dark brownish red; other fins brownish red, a little paler; ventral bright red; teeth pale.

Color in spirits, dull olive-brown, lighter below, being yellowish white on under part of head and body; lips without color bands, the tips being yellowish; there is a wide dark bar of color descending

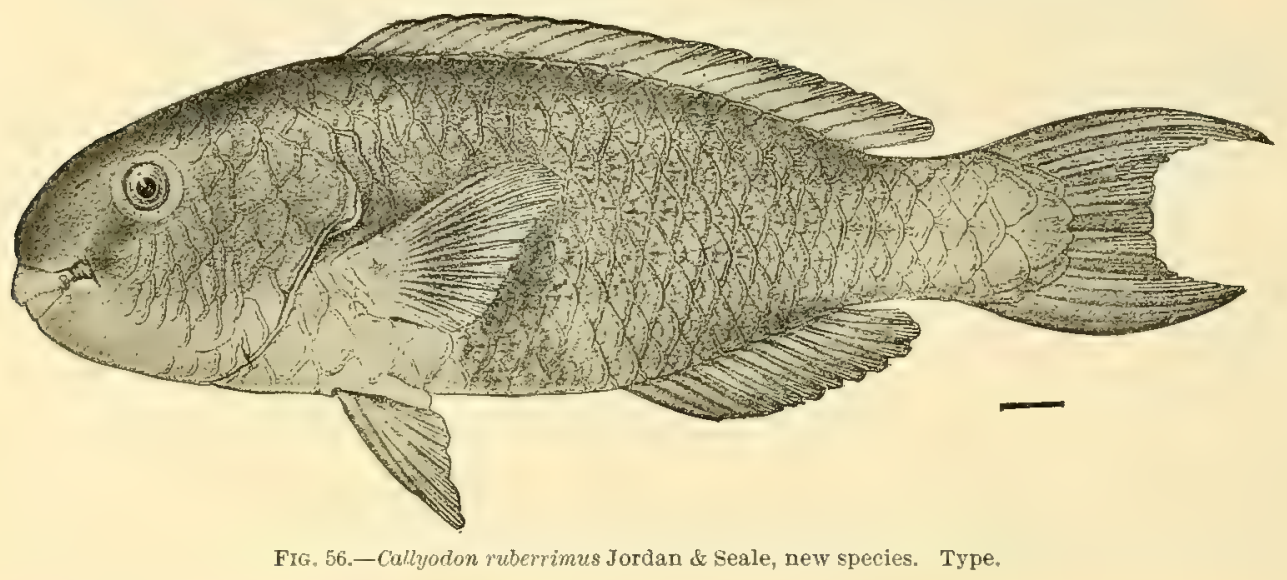

vertically from fourth to seventh dorsal spines to belly; in most of its length the bar is indistinct and made up of black spots, but beneath the posterior part of pectorals it is very distinct; a blackish spot at angle of mouth; a slight trace of a dusky line from lower part of orbit to axis of mouth; a whitish blotch on gill-membranes at isthmus; three dark olive radiating marks on each scale; dorsal fin dull pale green, darker posteriorly, the margin dusky; anal dull grayish green; pectoral brownish, the posterior portion becoming yellowish; ventral dull yellowish; caudal olive-brown; iris golden; teeth pale.

One specimen from Pago Pago, Samoa. Type, no. 51749, U. S. National Museum, length 20.25 inches.

1050. Callyodon purpureus (Cuvier \& Valenciennes). Samoa; Ulea.

Scarus purpureus Cuvier \&.Valenciennes, Hist. Nat. Poiss., XIV, 277, 1839, Ulea.

Head 2.75 in length; depth 2.75; eye 7.25 in head; dorsal Ix, 10; anal III, 9; scales 2-24-6; two rows of scales on cheek, the lower limb of preopercle bare; snout 2.25; interorbital 3.10 .

Body oblong, compressed; anterior profile bluntly rounded, upper jaw prominent; depth of caudal peduncle 2.25 in head; a very small posterior canine in upper jaw; lips narrow, scarcely covering onehalf of upper jaw and less than one-half of lower; five rows of seales in front of dorsal; base of dorsal 1.75 in length without caudal, its longest ray 2.95 in head; base of anal 1.50 in head, 2.30 in base of dorsal; pectoral 1. 40 ; ventral 2.10 ; caudal slightly rounded.

Color in spirits, dull olive brown; a purplish wash on top of head and snout, lighter on under part of head, thorax and belly; 3 or 4 indistinct darker lines on side of belly; caudal peduncle with a 
large roundish black blotch at base of caudal; tip of lips yellowish; caudal and anal dark brown, without markings; pectoral yellowish; ventral yellowish, splashed with brown; caudal yellowish, shaded with irregular blotches of brown; a fine line of gray at the tip with darker intermargin; iris golden; teeth white.

In life dark purplish brown, almost unmarked, but with a large rounded blackish blotch at base of caudal.

Three specimens from Apia. The specimen described is 9.35 inches long.

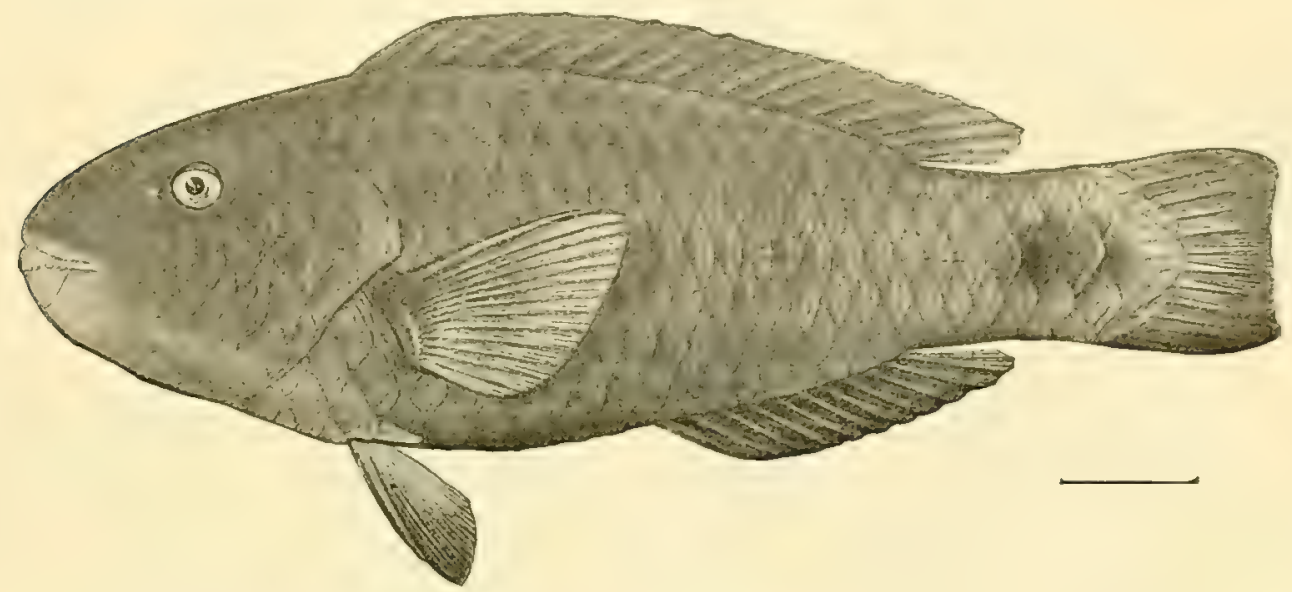

FIG. 57. - Cullyodon purpureus (Curier \& Valenciennes).

1051. Callyodon filholi (Sauvage). Fiji.

Pseudoscarus filholi Sauvage, Bult. Sci. Philom. 1880, 15 (reprint), Fiji.

1052. Callyodon erythrodon (Cuvier \& Valenciennes). Fuga' 'urasai. Samoa; Laysan; Tahiti and Faté (Seale).

Scarus erythrodon Cuvier \& Valenciennes, Hist. Nat. Yoiss., Xıv, 255, 1839, Ile de France.

Scarus cumbawensis Bleeker, Banda, $V$, 104, Sumbawa. Seale, Bishop Museum 1901, 97, Guam. Steindachner, Denk. Ak. Wiss. Wien 1900, Laysan.

Head 2.75 in length; depth 3; eye 7 in head; snout 2.35; interorbital 3; dorsal Ix, 10; anal III, 9; scales 2-21-6; two rows of scales on the cheek, the lower opercular limb naked.

Body oblong, compressed, the anterior profile of head bluntly rounder; depth of caudal peduncle 2.75 in head; no posterior canines; upper lip broad, covering more than two-thirds of teeth, lower lip covering one half of teeth, in the young the teeth are fully covered; four rows of scales in front of dorsal; base of dorsal 1.75 in length without caudal, its longest ray 3.75 in head; base of anal 1.50 , 2.25 in base of dorsal; pectoral 1.50; ventral 2.10; caudal slightly rounded.

Life colors of a specimen from Pago Pago, dark purplish brown, the scales lighter edged, the belly tinged with bright red; dorsal reddish brown, clear behind, finely mottled with dark olive, edged with blackish; caudal dull violet brown, with some darker mottlings and a pale edge; anal dusky wine color, with a dark and a pale edge; ventral vermilion, rather bright; pectoral dull brownish, translucent behind.

Color in spirits, violet-olive, dorsal and anal fins darker, without distinctive markings; pectoral yellowish gray; ventrals grayish, darker at tips, caudal grayish with dusky blotches more or less in form of bands, a very narrow line of gray at margin with submarginal dusky area; usually a dusky blotch posterior to eye; iris golden; lips yellowish; teeth white.

Numerous specimens from Pago Pago. The specimen described is 8.30 inches long.

1053. Callyodon moensi (Bleeker). Tahiti and Faté (Seale); Celebes.

Scarus moensi Bleeker, Celebes, XII, 54 . 
1054. Callyodon brunneus (Jenkins). Hawaii; Samoa.

Scarus brunneus Jenkins, Bull. U. S. Fish Comm., xrx, 1899 (1900), 59, fig. 16, Honolulu.

We have 2 specimens from Apia which agree with cotypes of this species from Honolulu.

1055. Callyodon erythacus Jordan \& Seale, new species.

Head 3 in length; depth 3.10 ; eye 7 in head; snout 2.65; interorbital 3.25; dorsal IX, 10; anal III, 9; scales 2-24-6, two rows on cheek; lower limb of preopercle bare.

Body oblong, compressed; anterior of head evenly rounded and rather blunt; depth of caudal peduncle 2.01 in head; a pair of large posterior canines in upper jaw, none on lower jaw; lips wide, almost covering teeth; three scales in front of dorsal; base of dorsal 1.25 in head, its longest ray 2.35; base of anal $120,2.14$ in base of dorsal; pectoral 1.20 in head; ventral 1.75; caudal lunate, outer exposed ray 1.95 , exposed middle ray 3.95 .

Color in life, dirty purplish brown; belly coppery red; head plain; dorsal brown, blackish at margin anteriorly, pale posteriorly; a white streak along base of dorsal spines; caudal purplish brown, with pale edge; anal mottled brown with dark and pale edge; ventral mottled coppery brown-red; pectoral pale; dark in axil; caudal lunate.

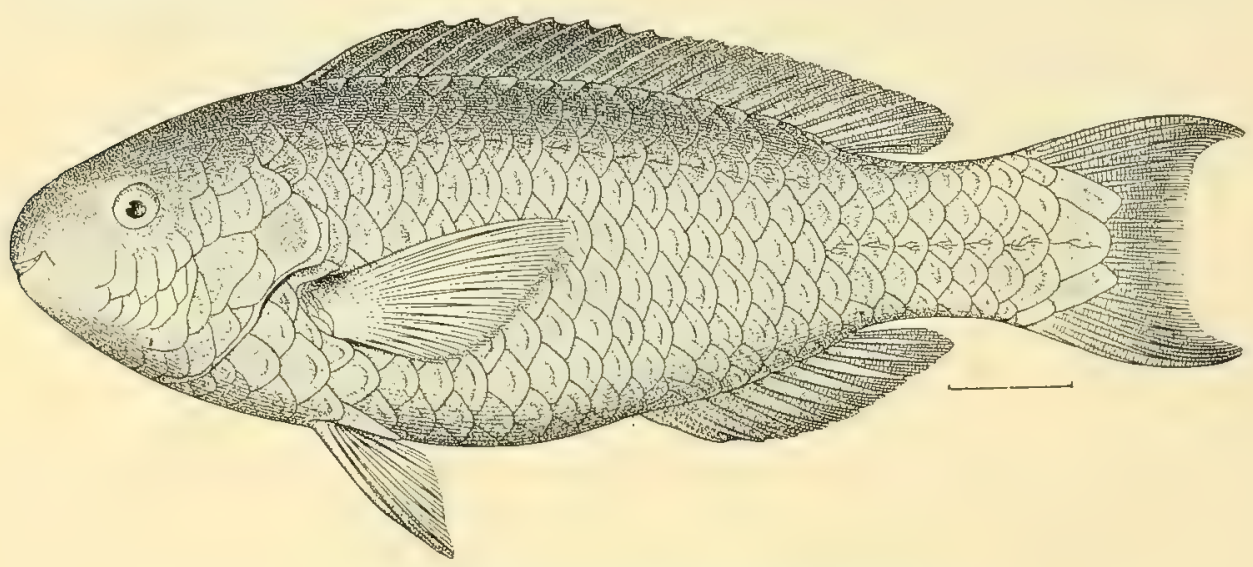

Fig. 58.-Callyodon crythacus Jordan \& Seale, new species, Type.

Color in spirits, dull olive-brown, the base of scales darker, under part of head and belly lighter; three more or less distinct whitish lines along side of belly; a dusky blotch on axil and on posterior part of opercle; a dusky blotch on upper part of eye; top of head duil greenish; lips without distinct bands except two slight traces of greenish around lower lip; dorsals dusky, the membranes around the spines gray; some gray blotches ketween the bases of the rays, a slight wash of gray on posterior tip of fin; anal dusky, some grayish blotches at base; pectoral grayish; ventral grayish; caudal mottled dusky with grayish posterior tip.

This species is clcse to Callyodon lacerta, differing in the pale or red breast, in purplish, not orange, edge to fins, and in having but two rows of scales on cheek. The jaws are well covered, and posterior canines present.

One specimen, the type no. 51750, U. S. National Museum, from Apia, length 10.50 inches.

1056. Callyodon ahula (Jenkins). Hawaii.

Scarus ahula Jenkins, Bull. U. S. Fish Comm., 1899 (1900), 61, fig. 19, Honolulu. Snyder, Bull. U. S. Fish Comm. 1902 (1904), 531, Honolulu.

1057. Callyodon mutabilis Gronow. New Guinea (Macleay); Shortland I. (Seale); Celebes; Amboina.

Calliodon mutabilis Gronow, Cat. Fish., ed. Gray, 1854, 86, Amboina.

Pseudoscarus pentazona Bleeker, Atlas, I, Scar., 46, tab. xr, fig. 1, Celebes. 
1058. Callyodon dubius (Bennett). Hawaii; Samoa; Tahiti; Tubuai and Raiatea (Seale).

Scams dubius Bennett, Zool. Jour., IV, 37, Sandwich Is.

Preudoscarus dubius Günther, Cat., IV, 222, Sandwich Is., Fiji Is.

We have 3 specimens of this species from Apia.

1059. Callyodon lacerta (Cuvier \& Valenciennes). Samoa; East Indies.

Scarus lacerta Cuvier \& Valenciennes, II ist. Nat. Poiss., XIV, 217, 1839, Pondicherry.

Pseudoscanis eruginosus Günther, Cat., IV, 229; not Scarus xruginosus Cuvier \& Valenciennes.

This is the commonest fuga, or parrot-fish, at the Samoan Islands. We have about 60 specimens from $A$ pia and 16 from Pago Pago.

Head 3.10 in length; depth 2.75; eye 6.50 in head; dorsal $\mathbf{I x}, 10$; anal III, 10; scales 2-21-6, three rows on cheek, the lower row of 4 scales on lower limb of preopercle.

Body oblong, compressed, the anterior profile bluntly rounded; depth of caudal peduncle 2.10; a posterior canine in upper jaw; lips wide, fully covering all but tip of teeth; five scales in front of dorsal fin; base of dorsal 1.75 in length of fish without caudal, its lower ray 3.14 in head; base of anal 1.25 in head, 2.50 in base of dorsal, its longest ray $3.75 \mathrm{in}$ head; pectoral 1.14; ventral 2; caudal rather deeply lunate 1.14. The specimen described is 9.55 inches long, from Pago Pago.

Life colors of various specimens were as follows:

(1) Dark dull purplish olive; chin and space below eye paler; vertical fins marbled with dall reddish purple, no clear markings; a dark bar across throat. Specimen from Apia.

(2) Also from Apia. Dull olive, shaded with lilac-brown; a blackish blotch above pectoral; hase of pectoral dusky; fins all dull lilac-brown.

(3) From Pago Pago. Dirty mottled blackish olive; iris dusky; three silver streaks alorg side of belly; axil black; dorsal mottled with salmon colored patch at tips of third and fourth spines; caudal brown mottled, tips paler; anal dusky; pectoral and ventral mottled olive.

(4) From Pago Pago. Body mottled olive-brown; iris golden; three dull silvery streaks along side of belly; axil black; dorsal olive with salmon tinge, edge black; caudal dull olive, medially salmon; anal blackish; pectoral brownish, tinged with salmon; ventral dirty gray.

(5) From Pago Pago. Dark olive-brown, more olive on cheek; three well defined whitish streaks along side of belly; belly dark, like sides, or a little paler; dorsal dark reddish brown, with an orange edge; caudal pale and redder, but still plain reddish brown; anal a little darker; pectoral and ventral similar; forehead darker brown; a dark axillary spot.

(6) From Pago Pago. Purplish brown, with olive shades along sides; reddish on breast; dorsal reddish, edged with purplish; caudal plain reddish brown, lunate; pectoral dull orange, the lower rays purplish; ventral redder; anal olive and purplish; a dark shade across branchiostegal region.

Color in spirits, a dull olive-brown, lighter below, 3 distinct white lines on each side of belly and a wide indistinct blackish band-like area on side below posterior two-thirds of spinous dorsal, invading the lighter coloring of the belly; top of snout with slight wash of purplish; dorsal brownish, unmarked; anal brownish, lighter at base; pectoral grayish; ventral yellowish, gray at tip; caudal brownish, unmarked; iris golden; teeth white.

1060. Callyodon lepidus (Jenyns). Tahiti; Rarotonga (Seale).

Scarrs lepidus Jenyns, Zool. Beagle, Fish., 108, 1812, Tahiti.

1061. Callyodon paluca (Jenkins). Hawaii.

Scrrus paluca Jenkins, Bull. U. S. Fish Comm., $1889(1900)$, 60, tig. 18, Honolulu. Snyder, Bull. U. S. Fish Comm., $1902(190-1)$, 531, Honolulu.

1062. Callyodon upolensis Jordan \& Seale, new species. Samoa.

Head 3 in length; depth 3 ; eye 4.95 in head; dorsal $I x, 10$; anal III, 9; scales 2-2t-6, three rows on cheek, the lower row of three scales on lower limb of preopercle; snout 3 in head; interorbital 3.18 .

Body oblong, compressed; anterior profile rather pointed; depth of caudal peduncle 2.55 in head; no posterior canines; lips wide, almost covering tip of teeth; base of dorsal fin 1.85 in length without caudal, its longest ray 2.50 in head; base of anal fin 1.50 or 2.50 in base of dorsal; jectoral 1.45 in head; ventral 1.98; caudal almost square, the upper and lower margin of fin scarcely produced. 
Color in spirits, dull brown, the center of each scale lighter, giving the appearance of about 8 lighter longitudinal stripes; tip of snout, chin, thorax, and belly a shade lighter than body color, the lips and side of snout with slight wash of dull yellowish; a yellowish blotch on opercle; dorsal fin dull yellowish with wash of dusky and a darker margin; anal, ventral, and caudal yellowish with wash of dusky; pectoral yellow; iris yellow; teeth white.

The young are similar in coloring to adults, except that the fins do not show so much dusky; being without the dark tip to dorsal, but with a narrow dark line at base of dorsal and anal.

Three specimens from Apia, 2.10 to 4.50 inches long. The type is no. 51751, U. S. National Museum, 4.50 inches long, from Apia.

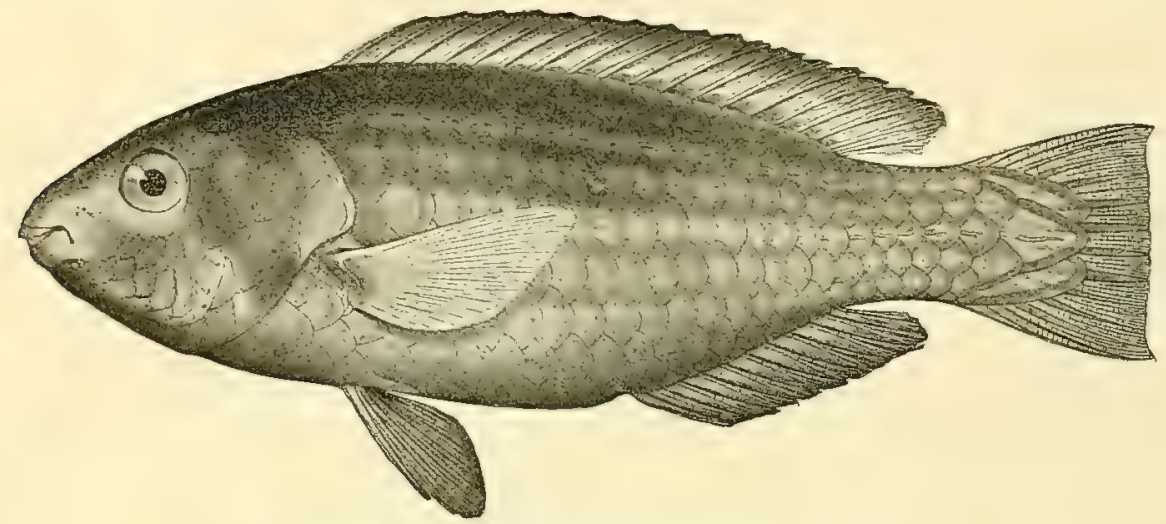

FIG. 59,-Callyodon upolensis Jordan \& Seale, new species, Type.

1063. Callyodon macrocheilos (Bleeker). Faté, New Hebrides (Seale); East Indies.

(Scarus macrocheilos Bleeker, Gilolo, 60.)

1064. Callyodon balinensis (Bleeker). Fuga pa'i; Fuga pa'ipa'i; Fuga mea. Samoa; East Indies. Scarus balinensis Bleeker, Verh. Bat. Gen., xxIr; Bijdr. Ichth. Bali, 8 .

Pseudoscarus balinensis Bleeker, Atlas, I, 39, tab. xvI, fig. 3, Bali, Banda.

Head 3.10 in length; depth 3.10 ; eye 6.50 in head; dorsal IX, 10; anal III, 9; scales 2-24-6, three rows on cheek, the lower row of three scales on lower part of preopercle; snout 2.50 in head; interorbital 3.10.

Body oblong, compressed, rather elongate; the anterior of head rather pointed; depth of caudal peduncle 2.12 in head; no posterior canines; lips wide, covering all but small tip of jaws; seven rows of scales in front of dorsal; dorsal 1.85 in length without caudal, its longest ray 2.75 in head; base of anal 1.20 in head, 1.25 in base of dorsal, its longest ray 3 in head; pectoral 1.25 in head; ventral 1.70; caudal moderately lunate, 1.12 in head.

Color in spirits, dull, grayish, lighter below; four yellowish lines along sides of belly, lower lip yellowish, upper lip grayish; a slight dusky wash on posterior margin of opercle and at axis of pectoral; dorsal grayish with dark margin, and a lighter submarginal line, the fin somewhat splashed with yellowish; anal yellowish, with dark margin, and a few dusky blotches at base; pectoral yellowish; yentral yellowish, with narrow indistinct darker margins; caudal dark grayish; a fine line of gray at tip, with a narrow submarginal dusky line; iris golden; teeth white.

Description of a specimen 11 inches long, from Apia. We have 10 specimens from this locality.

Life colors of one specimen drab, the scales above edged with bronze brown; a faint diffuse blotch of darker drab on lateral line, above vent; dorsal gray with a brownish reddish submarginal band, the edge bluish gray; caudal grayish olive, darker at edge; anal light reddish brown, the edge bluish; ventral pale reddish; pectoral rather bright yellow, axil black; head plain gray.

Another specimen in life was rather light brown, the belly pinkish brown; each scale above margined all around with clear olive brown; lower jaw abruptly pale brown with shades of livid bluish; dorsal dull orange, grayish at base, with a blue-black edge; anal brighter orange, with a broader edge of blne black; caudal grayish at base, then sooty brown, the edges dusky blue; ventral light orange, 
edged with bluish; pectoral dusky yellow, edged before with bluish; lips reddish, the upper dark; side of belly with three pale stripes.

1065. Callyodon oviceps (Cuvier \& Valenciennes). Fuga uli. Tahiti; Samoa.

Scarus oviceps, Cuvier \& Valenciennes, Hist, Nat. Poiss, xiv, 241, Tahiti.

Pseudoscarus ovicep8, Günther, Cat., IV, 225; copied from Valenciennes.

Head 3.10 to end of vertebra; depth 3.10 ; eye 6.75 in head; dorsal $1 x$, 10 ; anal Ir, 8 ; scales 2-2t-6; three rows on cheek, the lower row of three scales on lower limb of preopercle.

Body oblong, compressed, the anterior of head broadly rounded, the snout in front of eye slightly gibbous; depth of caudal peduncle 2.10 in head; no posterior canines; lips broad, covering teeth; six scales in front of dorsal; longest ray of dorsal 2.75 in head; base of anal 1.14, 1.95 in base of dorsal, its longest ray 3.10 in head; pectoral 1.30 in head; ventral 1.90 ; caudal lunate 1.18 .

Life colors of an immature example from Apia, light olive, golden on sides of head; below a dark brown diffuse band from snout through eye to gill-opening; two diffuse yellowish shades from spinous dorsal downward, a darker area between; fins dull pinkish olive, the caudal darker above and below; the ventral almost white.

An adult example, also from Apia, was dusky mottled olive, almost black on back anteriorly; a dull golden area bounding the black, from cheek to end of pectoral, then obliquely upward; another yellow blotch on back behind it; a whitish stripe below eye bounding the yellow; dorsal reddish brown with a black edge which fades behind; caudal lunate, dull orange brown; anal brownish red, rather bright, paler at base; ventral colorless; pectoral colorless, blackish above toward tip; lips reddish brown; chin and below clear brown, the belly whitish. Brighter colored than the preceding specimen.

A specimen from Pago Pago was slaty blackish above; broad pale greenish-yellow blotch below eye and running up to dorsum about even with tip of pectoral when laid back; below whitish; ventrals and anal thin salmon scarlet; dorsal with blackish margin and base, and broad median, rather dark, reddish band; pectoral dark near anterior margin, then yellowish, then uncolored.

Color in spirits brownish, darker above, a yellowish band from middle of dorsal fin obliquely down to point of pectorals, a similar but much smaller and less distinct band down from middle of soft dorsal; upper part of head dusky with bluish wash distinctly separated from yellowish lower half of head by a dark line from snout through lower part of eye to posterior margin of opercles; tip of the lips yellowish; dorsal brownish with yellowish blotches, the posterior tip of fin being yellowish; anal, pectoral, and ventral yellowish, unmarked. Some specimens show a slight dusky wash on pectoral; caudal grayish; iris golden; teeth white.

Seven specimens from Apia and 5 from Pago Pago. The one described is 8.55 inches long, and was obtained at Apia. The species is rather common at Samoa.

1066. Callyodon zonularis Jordan \& Seale, new species. Fuga mea. Samoa.

Head 3 in length; depth 3 ; eye 6.75 in head; snout 2.10 ; interorbital 2.85; dorsal $1 \mathrm{x}, 10$; anal II, 9 ; scales 2-2t-6, three rows on cheek, the lower row of four scales, covering the lower limb of preopercle.

Body obloug, compressed; snout gibbous; caudal peduncle thick and strong, its depth equal to snout; no canines; lips covering more than two-thirds of upper teeth; gill-rakers small, numerous; opercle and preopercle entire; six scales in front of dorsal; origin of dorsal over posterior margin of opercle; longest dorsal spine $3.20 \mathrm{in}$ head, the longest ray 2.50; base of anal 1.50, 2.30 in base of dorsal, its longest ray 3 in head; pectoral 1.20 ; ventral 1.98, its origin on line with middle of base of pectoral; caudal square.

Life colors of a specimen from Apia, olive yellow, clear golden in a bar behind pectoral; back with four dusky crossbars overlying yellow; a blackish shade on side of head across eye; breast and lips creamy reddish; fins all yellow, shaded like neighboring parts of body, the pectoral clear yellow; traces of pale golden streaks along side of belly; also a diffuse yellow lateral stripe.

A specimen from Pago Pago had a pale greenish yellow suffusion over body; four indistinctly marked smoky bands from dorsum half way down sides, fading ventrally; belly yellowish whitish, also ventral; cheeks rather yellow; lips saffron; black bar behind eye; caudal reddish saffron.

Color in spirits grayish white, with 5 wide oblique bands of black which extend over back and to about the median line of sides, the bands of greater width than the interspaces, the first at origin 
of spinous dorsal, and more or less amalgamated with the dusky upper half of head, the second band from fifth to eighth dorsal spines, the third from first to fifth dorsal rays, the fourth from seventh to tenth dorsal rays, and the posterior band, which is very indistinct and more or less united with the fourth, on the middle portion of caudal peduncle; a black band from eye to posterior margin of opercle, the dusky upper half of head sharply separated from lighter lower half by a line of dusky with a whitish line below it, extending from orbit to angle of mouth; lips yellowish; teeth yellowish; iris dusky with inner ring of golden; dorsal grayish, the dusky bands of body invading the fin more or less; caudal grayish; pectoral, ventral, and anal yellowish white, unwarked.

This strongly marked species is common at Samoa; we have three examples from Apia and ten from Pago Pago.

Described from the type, no. 51752, U. S. National Museum, from P.'o Pago, length 10.50 inches.

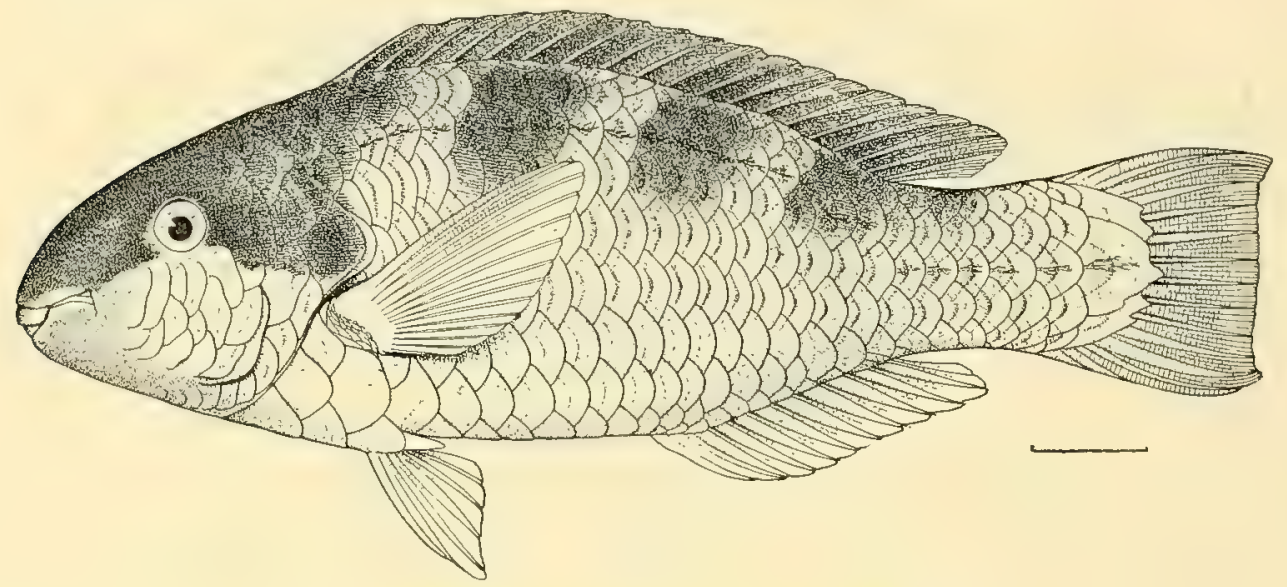

Frg. 60.-Callyodon zonularis Jordan \& Seale, new species. Type.

1067. Callyodon roseiceps (Cuvier \& Valenciennes). Ulea, Caroline Is. Scarus roseiceps Cuvier \& Valenciennes, Hist. Nat. Poiss., xiv, 279, 1839, Ulea.

1068. Callyodon cruentatus (Cuvier \& Valenciennes). Ulea.

Scarus cruentatus Cuvier \& Valenciennes, op. cit., XIv, 277, Ulea.

1069. Callyodon ocellatus (Cuvier \& Valenciennes). Caroline Is.

Scarus ocellatus, Cuvier \& Valenciennes, op. cit., xIv, 278, Caroline Is.

Pseudoscarus ocellatus, Günther, Cat, Iv, 233; after Valenciennes.

1070. Callyodon perspicillatus (Steindachner). Hawaii; Johnston I.

Scarus perspicillatus Steindachner, Denks, Ak. Wiss. Wien, $\mathrm{xL}, 1879,16$, taf. IV, fig. 1, Sandwich Is. Smith \& Swain, Proc. U. S. Nat. Mus. 1882, 134, Johnston I. Jenkins, Bull. U. S. Fish Comm., Xxir, 1902 (1903), 470, Honolulu. Jordan \& Evermann, Bult. U. S. Fish Comm., XxIII, 1903 (1905), 347, fig. 149, Honolulu, Puako Bay, Johnston I.

This large and beautiful scaroid is rather rare. It is highly esteemed by the Hawailans as a food tish.

1071. Callyodon brighami (Bryan \& Herre). Marcus I.

Scanıs brighami Bryan \& Herre, Bishop Museum, 1903, 1r, 131, Marcus I.

Described from a single specimen collected at Marcus Island by William Alanson Bryan.

1072. Callyodon quoyi (Cuvier \& Valenciennes). New Ireland; Shortland I. (Seale); East Indies. Scarus quoyi Cuvier \& Valenciennes, Hist. Nat. Poiss., Xxv, 273, 1839, New Ireland. Bleeker, Ternate, II, 607, Ternate.

Pseudoscarus quoyi, Bleeker, Atlas Ich., I, 29, tab. vx, fig. 3, Ternate. Günther, Cat., Ir, 239; after Bleeker.

1073. Callyodon lupus (Fowler). Thornton $\mathbf{I}$.

Scarns lupus Fowler, Proc. Acad. Nat. Sci. Phila. 1899, 491, Thornton I. 
1074. Callyodon jonesi (Streets). Fanning Is.

Scarus jonesi Streets, Bull. U. S. Nat. Mus., vir, 1877, Fanning I.

1075. Callyodon papuensis (Macleay). New Guinea.

Pseudoscanus papuensis Macleay, Proc. Linn. Soc. N. S. W. 1883, 590.

1076. Callyodon moresbyensis Macleay. New Guinea.

Pseudoscarus moresbyensis Macleay, 1. c., New Guinea.

1077. Callyodon bataviensis (Bleeker). Tapoli; Laea mumu. Samoa; Guam; East Indies.

Scarus bataviensis Bleeker, Java, 1v, 342, Batavia. Seale, Bishop Museum 1901, 96, Guam.

Pseudosccrus bataviensis Ileeker, Atlas Ichth., 45, tab. xiI, fig. 3, Batavia.

Head 3 in length; depth 3.10 ; eve 6.75 in head; dorsal $1 x, 10$; anal 11,9 ; scales 2-24-6; two rows of scales on cheeks, the lower of six scales; lower limit of preopercle bare; lips wide, covering two-thirds or more of teeth; snout 2.50 in head; interobital 1.20 in head.

Body oblong, compressed, the anterior profile evenly pointed; depth of caudal peduncle 2.10 in head; tubules of lateral line usually with but one or two very short branches; a strong posterior canine above and below; four scales in front of dorsal; longest dorsal spine 3 in head, the longest ray 2.75 in head, base of anal 1.25 in head; 2 in base of dorsal; pectoral 1.20 in head; ventral 1.75 in head; caudal deeply lunate, length of exposed outer ray 1.25 in head, exposed inner ray, 6 in head.

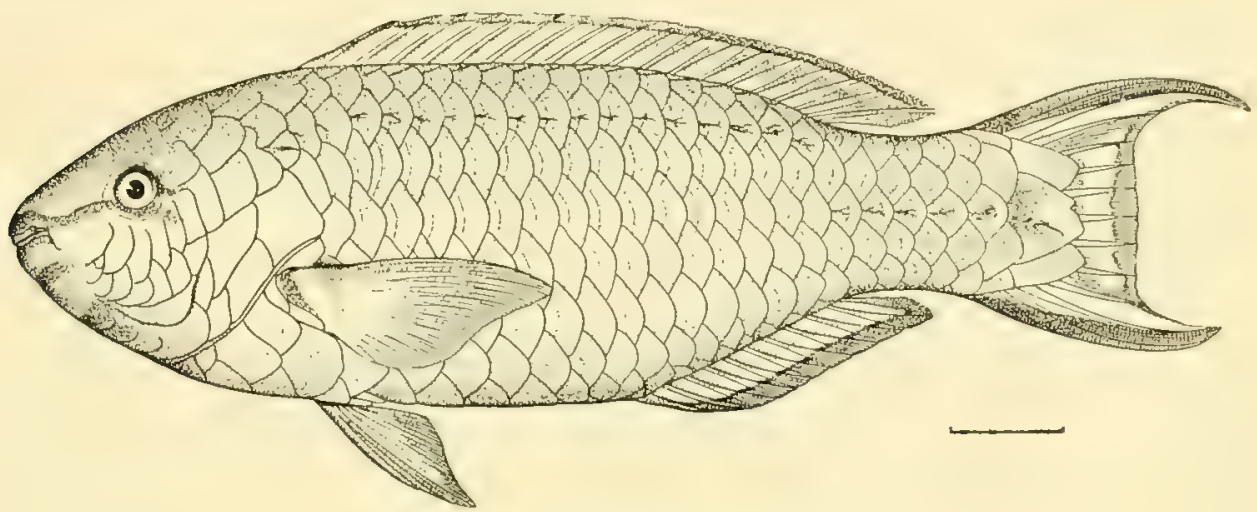

FIG. 61.-Calyodon bataviensis (Bleeker).

Life colors of a specimen from Apia, olive-green, with shades of rich light brown on side, becoming purplish olive on head, purplish gray on forehead and clear blue-green behind, the shades changing gradually; green stripes about eye; lips clear blue; a blue stripe across creamy red of lips; centers of scales on caudal peduncle dusky; dorsal orange, with a bluish dull median shade; a bright blue stripe at base and edge; caudal lunate, bright blue, especially on the margin, with shades of light grayish orange-brown; anal orange-brown, the margin blue with a bright orange-red stripe; pectoral blue, deeper above; axil blue; teeth white.

Color in spirits dull gray with wash of yellowish, the center of scales on posterior half of body showing a slight tint of pale green, darker on top of head; a bright green line through lower part of orbit along side of snout and around upper lip; also a green line on lower lip; chin yellowish, with a green cross-band and a green triangular patch on lower part of head uniting with its fellow on opposite side at middle of isthmus; a green line from isthmus through ventrals, along base of anal to caudal; two indistinct greenish lines on each side of belly; a dusky blotch on upper part of orbit; dorsal with a rather irregular broad yellowish margined center of green, the tip of fin with a broad line of deep green, a more or less broken line at base; outer third of anal deep green, the inner two-thirds yellowish, a narrow green line at base; pectoral greenish, slightly darker at axil; ventral with mid-portion yellowieh surrounded by a broad green margin; (audal with outer rays, posterior margin, and base green, the inner portion of fin and two or three rays of each lobe yellowish white.

Of this species we have 5 specimens from Apia. 
1078. Callyodon gilberti (Jenkins). Hawaii; Laysan.

?Scarus bataviensis, Steindachner, Denk. Ak. Wiss. Wien, Lxx, 1900, 508, Honolulu, Laysan.

Scarus gilberti Jenkins, Bull. U. S. Fish Comm., 1899 (1900), 59, fig. 17, Honolulu.

This scaroid is rather rare at Honolulu. It is close to $C$. bataviensis, but apparently distinct.

1079. Callyodon abacurus Jordan \& Seale, new speeies. Fuga meamea. Samoa. (Pl. xxxII.)

Head 2.85 in length; depth 2.90 ; eye 8.50 in head; snout 2.20 ; interorbital 3 ; dorsal Ix, 10 ; anal III, 9; scales 2-26-6, two rows on cheek, the lower preopercle limb bare.

Body oblong, compressed, the anterior profile bluntly rounded, the snout slightly gibbous; two large posterior canines on upper jaw, none on lower; upper lip broad, covering two-thirds or more of upper jaw; lower lip narrow, covering less than half of jaw; depth of caudal peduncle 2.45 in head; longest ray of dorsal 3 ; base of anal 1.30, 2.10 in base of dorsal; pectoral 1.35 in head; ventral 2; caudal slightly lunate.

Color in life of a specimen from Apia, bright green, the tail bright blue, a golden shade before it; belly creamy yellow; a dark shade behind pectoral; scales with broad brown bar which becomes an orange spot on posterior parts; cheeks green; forehead purplish olive; lips orange, yellow-edged, with a bright blue stripe across each, these meeting, running through the eye and sending a blue stripe to angle of mouth; the blue stripe green behind with an orange stripe below it; opercle edged with orange, preceded by a green stripe, a brown blotch above; dorsal bright blue with a continuous median stripe of golden; caudal (slightly lunate) bright blue, with golden bronze stripe on each lobe and cross spots and vermiculations at base; ventral golden witk bright blue anterior edge; pectoral black, golden washed, and edged in front with blue.

A larger example is rather golden than green, the dusky purplish area above pectoral more marked, the dorsal and caudal with marks of purplish brown rather than orange; eye blue above a green streak before it. In all specimens the blue caudal peduncle has a large golden spot on each scale, giving a checkered appearance.

A specimen from Pago Pago was colored as follows: Upper and under lips, bars on under side of head, ventrals except a pinkish salmon median blotch, margin of dorsal an't anal, and median longitudinal ventral line, all light blue; darker blue suborbital line from upper lip; postorbital blotches dark green next eye, lighter green farther back; top of head smoky olive green, farther back lighter green; body anteriorly yellowish-reddish-greenish with pinkish yellow coloration on sides of head and almost yellow on underside of head and bordering median ventral blue line; body posteriorly bluishgreen with pinkish-yellowish-brown markings or checkers, one on each scale; portions of dorsal, anal, and caudal which are not blue, yellowish salmon.

Color in spirits, dull yellowish; caudal peduncle green with three longitudinal rows of round yellow spots; a broad dusky band occupying all the nuchal region to base of third dorsal spine, this band extending obliquely down and back on the side to a line with base of anal fin and lower margin of pectoral; margin of lips yellow; top of head and snout purplish; a green line with dark margins at upper margin of orbit, another short one at posterior margin of orbit, and a third from opercle along lower part of orbit down side of snout around upper lip, a branch descending to axil, and another branch around lower jaw posterior to yellow margin; dorsal fin yellowish white, the margin and base each with a band of green; anal colored similar to dorsal except the distal blue band is broader; pectoral dark purplish; ventral yellowish with a slight trace of bluish margins; candal green with some scattered round yellowish spots, the middle portion of fin lighter; ris golden; teeth green.

We have 13 specimens of this beautiful species from the coral reef at Apia and 2 from Pago Pago. The type is no. 51754, U. S. National Museum, 12.75 inches long, from Pago Pago.

1080. Callyodon lauia Jordan \& Evermann. Hawaii.

This may be the same as Callyodon formosus.

1081. Callyodon formosus (Cuvier \& Valenciennes). Hawaii.

Scarus formosus Cuvier \& Valenciennes, Hist. Nat. Poiss., XIV, 283, 1839, Sandwich Is.

The description of Callyodon formosus seems to apply fairly well to Callyodon lauia. Callyodon jenkinsi is also closely related.

1082. Callyodon dimidiatus (Bleeker). Papua; Shortland I. (Seale).

Scarrs dimidiatus Bleeker, New Guinea, 17, Papua. 
1083. Callyodon zonatus (Macleay). New Guinea.

Pseudoscarus zonatus Macleay, Proc. Linn. Soc. N. S. W. 1883, 591.

1084. Callyodon spilonotus (Kner). Samoa; Fiji. (Pl. xurrr, fig. 1.)

Pseudoscarus spilonotus Kner, Sitz. Ak. Wiss. Wien, Lvu, 60, taf. IX, fig. 26, 1868, Kandavu (Fiji).

Head 3.12 in length; depth 2.85; eye 7 in head; snout 2.50; interorbital 2.75; dorsal $\mathrm{Ix}, 10$; anal $\mathrm{mr}$, 9 ; scales 2-2t-6; three rows on cheek, the lower row of four scales on lower limb of preopercle.

Body oblong, compressed, the anterior profile bluntly rounded; depth of caudal peduncle 2 in head; a distinct npper and lower posterior canine; lips rather wide, covering more than half of upper jaw, and all but tip of lower jaw; five rows of seales in front of dorsal; base of dursal 1.90 in length of fish without caudal, its longest ray 2.50 in head; base of anal 1.14, 1.95 in base of dorsal, its longest ray 2.75 in head; pectoral 1.20 ; ventral 1.75 ; caudal lunate.

Color in life of a specimen from Apia, deep blue, violet-brown-shaded on the back anteriorly, clear blue on the throat; creamy drab on the breast; anterior part of back down to pectoral closely spotted with bright blue-green; three blue stripes on side of belly and a median stripe; dorsal orangebrown, blue on edge, brighter behind, greenish blue at base; a row of round blue-green median spots; anal dull crimson, biue-green at base, blue on edge; caudal bright yellowish green, blue on angle, a purple red stripe on each lobe; ventral creamy, edged with blue; pectoral green with a violet-drab cross-bar at base and a violet-drab lengthwise stripe; throat bright blue; cheeks bright green; forehead bright violet-gray with a green cross-band and green stripes and spots behind eyes.

Another specimen from the same locality was deep greenish blue, tinged with reddish brown above, reddish below, each scale being brown at base; three blue-green stripes on side of belly; throat clear blue; snout and cheeks green blue; a brown band across eye, crossed by a green curved line; dorsal blue at base, the edge orange, with a row of green spots mesially; soft dorsal with more orange, the spots larger; caudal clear, green, with blue-green edges and a stripe of orange in each lobe; anal like dorsal, the red median stripe deeper orange-brown, the green spots smaller, the blue margin broader; pectoral blue-green, with long median orange-brown band; ventral blue-green, mesially orange-yellow.

A third specimen from Apia was deep bright orange-brown, more orange behind, the sides below becoming more pink, the belly orange yellow; the cheeks light vitriol-green, the lower jaw and throat clear livid blue, the upper jaw blue; two blue lines before eye, narrow, clear, and undulated; three behind eye, separated by orange-brown; head above dark brown, faintly spotted with dark blue; seales of anterior half of body above each with many small round blue spots, these coalescing in vermiculations behind eye; edge of opercle brown; posteriorly each scale centrally greenish blue, the brown forming broad edgings; caudal peduncle posteriorly bright green; sides of belly with one median (ventral line) and three other stripes, formed of a large blue spot on each scale, the hue of the ventral stripe sky-blue, the others progressively greener and more continuous; dorsal bright orange-brown, with a broad sky-blue margin, the basal scales bluish and green, the soft part with a median row of green spots; an irregular blackish blotch under third spine; caudal clear grass-green, edged above and below with bluish; an orange stripe along the next to lowest ray; a small orange spot at its base; anal dark orange, a broad sky-blue margin; bluish-green spots at base; ventral sky-blue in front, the rest orange-yellow; pectoral dusky in axil, an orange-brown band across base, the fin clear green, bluish above, with an orange-brown lengthwise stripe; some yellow edges to scales of lower part of head.

A specimen from Pago Pago was blue-green with yellowish-salmon scale spots; caudal grass-green with blue edging; on top of head orange-salmon markings; same color on dorsal and anal where not blue green; belly yellow white with robin's-egg-blue blotches; color in spirits, grayish with slight tints of green; upper half of body a shade darker and with scales of anterior half dotted with small round gray spots - three or four on each scale; three or four longitudinal green lines on sides of belly; tips of lips yellowish; about four greenish bands radiate from or pass through the eye, the lower one extending from opercles through lower part of eye around snout, joining its fellow of opposite side and dividing very distinctly the upper dark color of head from the lower lighter half. There is one additional green line around snont above this, and a short cross-line on anterior interorbital, a single green line around lower jaw; upper base of pectoral black; dorsal fin with a deep blue-green band at base, middle, and tip of fin, the fin otherwise yellowish; middle band more or loss broken up into blotches: anal with bluish-green band at base and tip, the fin otherwise pale green; yectoral grayish green, blotched 
with darker above, dusky at base; ventral yellowish, the first rays pale green; caudal with upper and lower margins pale green, middle portion yellowish, iris golden, teeth white.

Six specimens from Apia. Description from a specimen 10 inches long.

1085. Callyodon pulchellus (Rüppell). New Hanover I.; East Indies.

Scarus pulchellus Rüppell, Neue Wirbelthiere, 25, taf. 8, fig. 3, 1835, Red Sea.

Pseudoscarus pulchellus Bleeker, Atlas, I, Scar., 34, tab. X, fig. 3, Java, Celebes. Günther, Cat., IV, 219, 1862, Mauritius, China. Peters, Berl. Mon. 1876, 843, New Hanover.

1086. Callyodon blochi (Cuvier \& Valenciennes). New Guinea (Macleay); New Hanover (Peters); East Indies.

Scarus viridis Blocb, Ausl. Fische, taf. 222, 1790; not of Bonnaterre 1788.

Scarus blochi Cuvier \& Valenciennes, Hist. Nat. Poiss., IV, 219, 1839, Java.

Pseudoscarus viridis, Bleeker, Atlas, I, Scar, 45, tab. Xvir, fig. 2, East Indies. Peters, Berl. Mon. 1876, 843, New Hanover. Scarus chrysopomus Bleeker, Verh. Bat, Gen., xxII; Labr. Cycl., 53, East Indies.

Pseudoscarus chrysopoma, Günther, Cat., IV, 221, 1862, East Indies.

IVe follow Peters in the arrangement of the synonymy of this species and the next, noting that the name viridis is preoccupied in Callyodon.

1087. Callyodon frenatus (Lacépède). New Hanover; Louisiades; East Indies.

Scarus frenatus Lacépède, Hist. Nat. Poiss., IV, 13, pl. 1, fig. 2, 1802, no locality.

Pseudoscarus frenatus, Bleeker, Atlas, I, Scar., 40, tab. xvi, fig. 2, Celebes. Peters, Berl. Mon. 1876, 84t, New Hanover Pseudoscarus viridis, Günther, Cat., IV, 220, Louisiades; not Scarus viridis Bloch, nor of Bonnaterre.

1088. Callyodon globiceps (Cuvier \& Valenciennes). Tahiti.

Scarus globiceps Cuvier \& Valenciennes, Hist. Nat. Poiss., xıv, 242, Tahiti. Jenyns, Voy. Beagle, Fishes, 106, Tahiti Günther, Cat., IV, 224, Tabiti.

1089. Callyodon spinus (Kner). Fiji.

Pseudoscarus spinus Kner, Sitz. Ak, Wiss. Wien 1868, 62, taf. IX, fig, 27, Kandavu (Fiji).

1090. Callyodon pronus (Fowler). Thornton I.

Scarus pronus Fowler, Proc. Acad. Nat. Sei. Phila. 1899, 490, Thornton 1.

1091. Callyodon jenkinsi (Jordan \& Evermann). Hawaii.

Scarus jenkinsi Jordan \& Evermann, Bull. U. S. Fish Comm., xxII, 1902 (1903), 195, Honolulu.

1092. Callyodon fumifrons Jordan \& Seale, new species. Samoa. (Pl. xxxIv.)

Head 2.95 in length; depth 2.75; eye 8.50 in head; snout 2.01 in head; interorbital 2.75; dorsal Ix, 10; anal III, 9; scales 2-24-6, 3 rows on cheek, lower row of two large seales on lower limb of preopercle.

Body oblong, compressed; anterior of head bluntly rounded; upper jaw rather prominent; depth of caudal peduncle 2.12 in head; no posterior canines; lips very wide and thick, fully covering the lower teeth, and covering all but small tip of upper teeth; six scales in front of dorsal fin; base of dorsal fin 1.90 in length without caudal, its longest ray 2.75 in head; base of anal $1.25,2$ in base of dorsal, its longest ray 3 in head; pectoral 1.15 in head; ventral 1.95; caudal slightly lunate, length of exposed middle ray 2.20 .

Life colors: Forehead, chin, and throat bright sky-blue; crown behind forehead with broad transverse bar of smoky lavender; angulated green-blue band from blue chin to eye and postero-ventrally to gill opening; behind eye color of crown with greenish brown suffusion; below suborbital band greenish brown; anterior half of dorsum and upper sides robin's-egg blue; dorsal with two pinkishbrown longitudinal lines with the included space bluish green; pectoral color of suborbital band with pinkish purple broad central space; ventral robin's-egg blue with sky-blue anterior margin; hinder half of body more dark greenish than front part and scales broadly edged basally with brownish. growing pink brown posteriorly; caudal blue green with pink-brown markings at base; anal color of caudal with dark pink band along base; teeth white.

A young example had the following colors in life: Teeth white; lower lip sky blue; upper lip sky blue with narrow salmon margin; an angulated blue-green broad line from angle of mouth to eye and to gill opening; forehead smoky blue; below this band greenish brown with pink edging; above it a broad olive-brown band, then bright green; top of head violet-brown; pectoral bright blue, with dark purple median blotch; body blue green with pinkish-brown scale markings so arranged as to make on 
posterior two-fifths of body green pentagons, with broad pinkish-brown borders; ventral sky-blue; anal green blue, with pink-salmon basal lines; caudal green blue with four complete and several short longitudinal bars of pinkish brown; dorsal blue, margin with two pink-salmon lines and included space, then blue green.

Color in spirits: Anterior half of body to a line with sixth dorsal spine is pale pea-green; posterior to this line the color is darker, with a tint of bluish; a wide bright green line with narrow blue margins extends from posterior margin of opercle forward under eye, curving down under chin, the upper margin touching eye and the axis of mouth, this band lost on the pale green general color of the chin; anterior third of snout bright green, separated from darker color of upper part by a narrow navy-blue line; a more or less distinct dusky band from eye to posterior margin of opercle above the bright green line; a narrow margin of yellowish on upper lip; dorsal with a margin of bluish and a lighter submarginal line of grayish, the general color of fin green, with some purplish on posterior portion; outer two-thirds of anal pale green; inner third bluish-green crossed by two narrow lines of blue; pectoral greenish with purplish wash through center; ventral uniform pale green; caudal rather dark uniform green; iris golden; teeth white.

Four specimens from Pago Pago. The type is no. 51745, U. S. National Museum, length 13 inches.

1093. Callyodon kelloggii Jordan \& Seale, new species. Samoa.

Head 3 in length; depth 2.75; eye 7.25 in head; snout 2.25; interorbital 2.75; dorsal Ix, 10; anal III, 9; scales $2-2 \downarrow-6$; 3 rows on cheek, the lower row of one large scale covering anterior half of preopercular limb, and a minute scale anteriorly; lips broad, covering two-thirds or more of teeth.

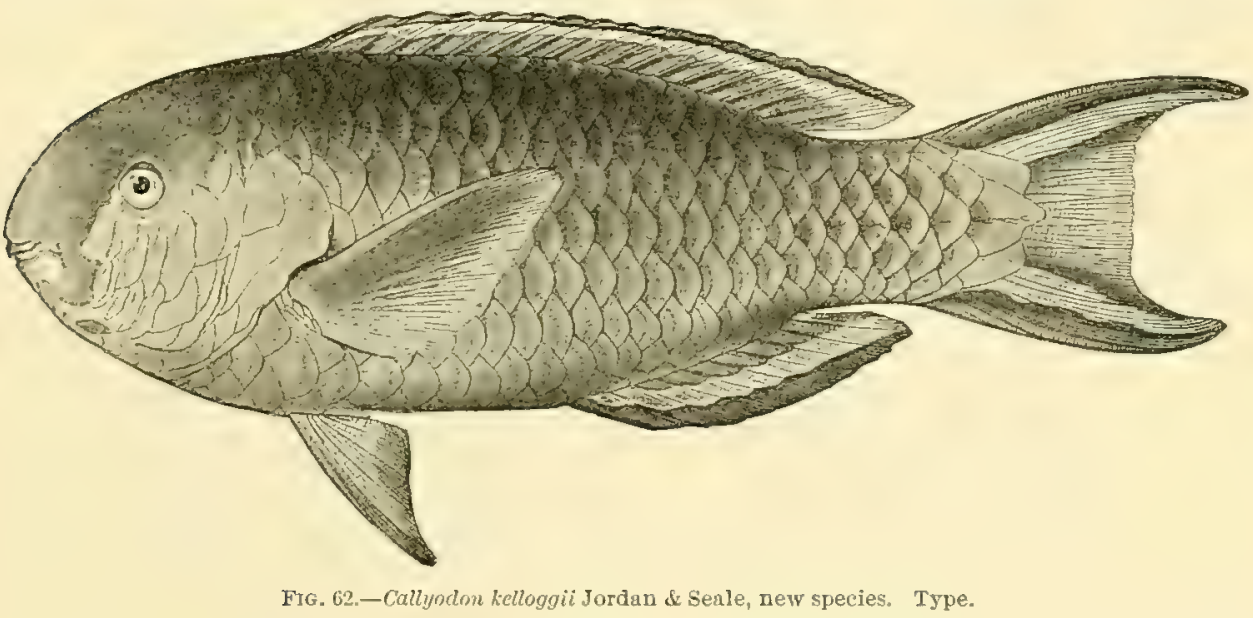

Body oblong, compressed; anterior profile bluntly rounded, the forehead being somewhat gibbous; depth of caudal peduncle 2 in head; teeth with posterior canine above and below; three rows of scales in front of dorsal, longest dorsal ray 2.50 in head, base of anal 1.30 in head, 2 in base of dorsal, the longest ray 2.75 in head; pectoral. 1.10 in head; ventral 1.55 in head; caudal deeply lunate; exposed outer ray 1.25 in head, middle ray 3.25 in head. Color blue in life, with markings described below.

Color in spirits, dull olive-brown, top of head and an irregular line around chin livid green, a line of green on lower lip; a round green spot at end of lower limb of preopercle; a round green spot on isthmus with a green line just posterior to spot; a large yellowish area covering most of opercle and posterior part of cheek; a green line on lower half of orbit; three or four round green spots in front of anal; iris golden; teeth white; lower two-thirds of dorsal and a broad marginal line green, a rather wide submarginal line of yellowish white; the outer and the inner third of anal green, the middle third whitish, the white color taking its origin at base of third spine; pectoral unmarked, greenish; ventral broadly margined with green, the mid-portion being yellowish; caudal with upper and lower margins bright green with an intramarginal line of whitish which is bordered by very dark green; middle portion of caudal whitish with a wash of very pale green, no posterior marginal line or marking. 
One specimen from Apia, type no. 51746, U. S. National Museum, length 11.50 inches. Named for Vernon Lyman Kellogg.

1094. Callyodon tricolor (Bleeker). Shortland I. (Seale); East Indies. Scarus tricolor Bleeker, Verh. Bat. Gen., Xxir, Labr. Cyci., 59, East Indies.

1095. Callyodon dussumieri (Cuvier \& Valenciennes). Faté (S'eale); East Indies.

Scarus dussumieri Cuvier \& Valeneiennes, Hist. Nat. Poiss, XIv, 252, 1839, Seychelles. Pseudoscarus dussumieri, Bleeker, Atlas, I, Scaridæ, 46, tab. vin, fig. 1, Java.

1096. Callyodon pyrrhostethus (Richardson). Faté and Rarotonga (Seale); East Indies.

Scarus psittacus Forskăl, Descr. Anim., 29, 1775, Red Sea, not Scarus psittacus L.

Scarus pyrrhostethus Richardson, Ich. Chin., 262, 1838, Canton.

Pseudoscarus pyrrhostethus, Günther, Cat., IV, 223.

1097. Callyodon pepo (Bennett). New Guinea (Macleay); East Indies.

Pscudoscarus cantori Bleeker.

1098. Callyodon fasciatus (Cuvier \& Valenciennes). Faté (Seale); East Indies.

Scarus fasciatus Cuvier \& Valenciennes, op. cit., 222, 1839, Moluccas.

Scarus rivulatus Cuvier \& Valenciennes, op. c1t., 223, 1839, Java; name preoccupied.

Scarus rivulatoides Bleeker, Verh. Bat. Gen, XxIr, Labr. Cyel., 55, East Indies.

Scanus micrognathus Bleeker, op. cit., 56, East Indies.

Pseudoscarus rivulatus, Günther, Cat, IV, 2222, East Indies.

1099. Callyodon festivus (Cuvier \& Valenciennes). Polynesia.

Scarus restivus Cuvier \& Valenciennes, Hist. Nat. Poiss, XIV, 282, 1839, no locality.

1100. Callyodon frontalis (Cuvier \& Valenciennes). Oualan.

Scarus frontalis Cuvier \& Valenciennes, Hist. Nat. Poiss., XIV, 280, 1839, Oualan (Caroline Is.).

1101. Callyodon forsteri (Cuvier \& Valenciennes). Tahiti.

Scarus forsteri Cuvier \& Valenciennes, Hist. Nat. Poiss, XIV, 275, Tahiti.

1102. Callyodon prasiognathus (Cuvier \& Valenciennes). Amasapupema. Samoa; New Ireland.

(Pl. XLviII, fig. 2.)

Scarus prasiognathus Cuvier \& Valenciennes, op. cit., 272, 1839, New Ireland.

We have 5 specimens of this fish from Pago Pago. It seems not to have been collected since the time of Quoy and Gaimard.

Head 3 in length; depth 2.85; eye 5.95 in head; snout 2.75; interorbital 3; dorsal $1 x, 10$; anal III, 9 ; scales 2-24-6, three rows on cheek, the lower row of two scales on lower limit of preopercle.

Body oblong, compressed; anterior profile rather sharp-pointed; depth of caudal peduncle 2.16 in head; no posterior canines; lips broad, covering more than two-thirds of jaws; 6 scales in front of dorsal fin; longest ray of dorsal 2.55 in head; base of anal $1.25,2.10$ in base of dorsal, its longest ray 3 in head; pectoral 1.30; ventral 1.80; caudal 1.40, the middle portion rounded, the rays very slightly produced.

Color in life, uniform very dark coppery brown; fins of same shade, much mottled; teeth dee blue.

Color in spirits, brown, a tint of bluish or violet on head; dorsal dark bluish with some blotches of gray on soft dorsal; pectoral purplish; ventral grayish, darker at tip; anal grayish, irregularly blotched with purplish; caudal purplish, darker at tip; margin of upper lip grayish; teeth green; iris golden.

The specimen degcribed above is 7.50 inches long.

1103. Callyodon maoricus Jordan \& Seale, new species. Woalefuga. (Pl. xLviII, fig. 3.)

Head 3 in length; depth 2.95; eye 5.95 in head; snout 2.20; interorbital 2.95; dorsal Ix, 10; anal IIr, 9 ; scales 2-24-6, three rows on cheek; lower row of 3 scales which almost cover the lower limb of preopercle.

Body oblong, compressed; anterior profile evenly rounded, the tip of head rather bluntly pointed; depth of caudal peduncle 2.30 in head; a single small posterior canine on upper jaw; upper lip wide, almost covering upper teeth, lower lip less wide, covering about two-thirds of lower teeth; base of dorsal fin 1.85 in length without caudal, its longest ray $2.95 \mathrm{in}$ head; base of anal 1.30 in head, its 
longest ray 2.85 in head; caudal almost square, $1.75 \mathrm{in}$ head; some specimens have outer rays prolonged; pectoral 1.14 in head; ventral 1.80 in head.

Life colors of one specimen, brilliant dark copper-red; lips and belly brighter; a bright blue-green stripe across upper jaw; two across lower, with 3 irregular green spots behind; dark green marks radiate irom eye; a bright oblong spot of pale green above opercle; teeth deep blue; dorsal dark orange, dark shaded below and a broad edge of deep blue; caudal dark coppery; edged all around with bright blue, the stripe largest below; anal coppery red, with a very broad edge of deep blue; ventral coppery red, edged with blue; pectoral deep coppery red.

A large adult specimen was deeper in color and bluer than the type, but similar in all essentials: Teeth bluish; body deep reddish brown; upper lip brilliant green-blue with narrow pinkish margin; upper head smoky greenish brown, green-blue circumorbital ring, narrow; sides of head below eye paler, then irregular greenish longitudinal band; under head robin's-egg blue in front, paler behind with saffron-yellow, faint, ring-like blotches with small robin's-egg blue spot within; sides blue-green with broad pinkish brown basal edging on scales; dorsal with blue margin, saffron-pink median space with dark greenish blotehes in series, weak to wanting anteriorly; ventral pale blue with bright blue anterior margin; pectoral smoky bluish, smokiest just before tips of rays; caudal green blue, bluer along dorsal and ventral margins, with uneven bluish pink at base and smoky clouds in web; anal like dorsal with the green blotches coalescent.

Color in spirits, dark brown, almost black; some specimens purplish, with a yellowish wash on belly, thorax, and under part of head, some specimens not lighter below; top of head green, tip of snout yellow; margin of lips yellow; a deep green line around upper third of upper lip; two green lines around lower lip, one near tip of lip, the other, which is margined with yellow, from lower part of orbit around base of lip, more or less united with green line running back on isthmus; a greenish black just in front of lower limb of preopercle, and a line of green dots along lower margin of lower limb of opercle; dorsal fin greenish; a wide, deep bluish green margin, with a sub-marginal area of yellowish; anal similar in color to dorsal; pectoral brownish with tint of blue; ventral yellowish with green margin, purple in some specimens; caudal bluish green, margin of deep bluish green; iris golden; teeth green; jaws well covered, deep blue; 3 rows of scales on cheek; a posterior canine. Caudal somewhat lunate.

Three specimens of this beautiful and strikingly marked species were secured at. Pago Pago. It is called by the fishermen Maolifuga (Maori parrot-fish) because the green markings on the face suggest closely the paint on the face of a Maori chieftain. The species is near Callyodon prasiognathus, differing in the green marks on the head, and the deep blue edgings to the fins.

Type, no. 51747, U. S. National Museum, from Pago Pago, 10.25 inches long.

1104. Callyodon nuchipunctatus (Cuvier\&Valenciennes). Fiji (Günther); New Guinea(Macleay).

1105. Callyodon latax Jordan \& Seale, new species, Laea pulepule; Laeamumu. Samoa. (Pl. XLrx.)

Head 3.10 in length; depth 2.75; eye 7.50 in head; dorsal $1 \times, 10$; anal, III, 10: snout 2.10 in head; scales 2-24-6; two rows of scales on cheeks; lower limb of preopercle bare.

Body oblong, compressed, the anterior profile evenly rounded; caudal peduncle strong, its depth 2.10 in the head; tubules of lateral line with several branches; a single small canine tooth on upper jaw at angle; lips thin, covering the basil third of the teeth; four rows of scales in front of the dorsal fin; longest dorsal spine 2.10, the longest ray of about equal length; base of anal 1.75 in head, 2.75 in base of dorsal, its longest ray 2.50 in head; pectoral 1.30 in head; ventral 1.50 in head; caudal lunate, the exposed outer ray 1.50 in head, exposed middle ray 3.50 in head.

Life colors, all clear deep blue, some scales on sides with brownish edges; jaws blue; lips blue; angles of mouth brownish red; head with slaty red markings about eyes and a band between them; dorsal slaty with blue base and edging and some spots; caudal blue with slaty blue markings; anal with slaty edgings and spots; ventral blue with olive center; pectoral blue with blackish slaty center.

Color in spirits uniform dull bluish green on body, a shade lighter below; the top of head and about eye is splashed with blotches, lines or dots of dull gray, irregular in form, and varying in different specimens. The short lines may cither radiate from eye, or reticulate over head, or extend down the side of snout; either a line or row of dots at angle of jaw's usually extending around under jaw; either a line or row of dots over the snout just in front of nostrils; no light colored line on upper jaw; teeth green; dorsal green, with oblique lines and umargin of blue; anal similar in color to dorsal; 
pectoral bluish without markings; ventral pale bluish green; caudal green with four or five irregular blue lines; iris golden.

Three large specimens of this fish were obtained at Apia. A specimen was taken at Rarotonga by Mr. Seale. It is a handsome and showy species.

The type is no. 51755, U. S. National Museum, and is 15 inches long, from Apia.

1106. Callyodon celebicus (Bleeker). Guam; East Indies.

Scarus celebicus Bleeker, Celebes, v, 253, Celebes. Seale, Bishop Museum 1901, 95, Guam

Pseudoscarus celebicus Bleeker, Atlas Ichth., I, 26, tab. Xv, fig. 2, Celebes. Günther, Cat. Iv, 237, Sea of China.

1107. Callyodon cyanogrammus Jordan \& Seale, new species. Samoa.

Head 2.75 in length; depth 2.75; eye 7.95 in head; snout 2.15 in head; interorbital 2.95; dorsal IX, 10; anal III, 9; scales 2-24-6, two rows on cheek; lower limb of preopercle bare.

Body oblong, compressed, the upper profile from origin of dorsal to middle of snout almost straight; from this point to base of lower jaw the profile is bluntly rounded; a single small posterior canine on upper jaw; upper lip broad, covering two-thirds or more of upper teeth, lower.jaw narrow, covering less than half of lower teeth; depth of caudal peduncle 2.50 in head; three scales in front of dorsal fin; longest ray of dorsal about 3 in head; base of anal 1.50;2.20 in base of soft dorsal,

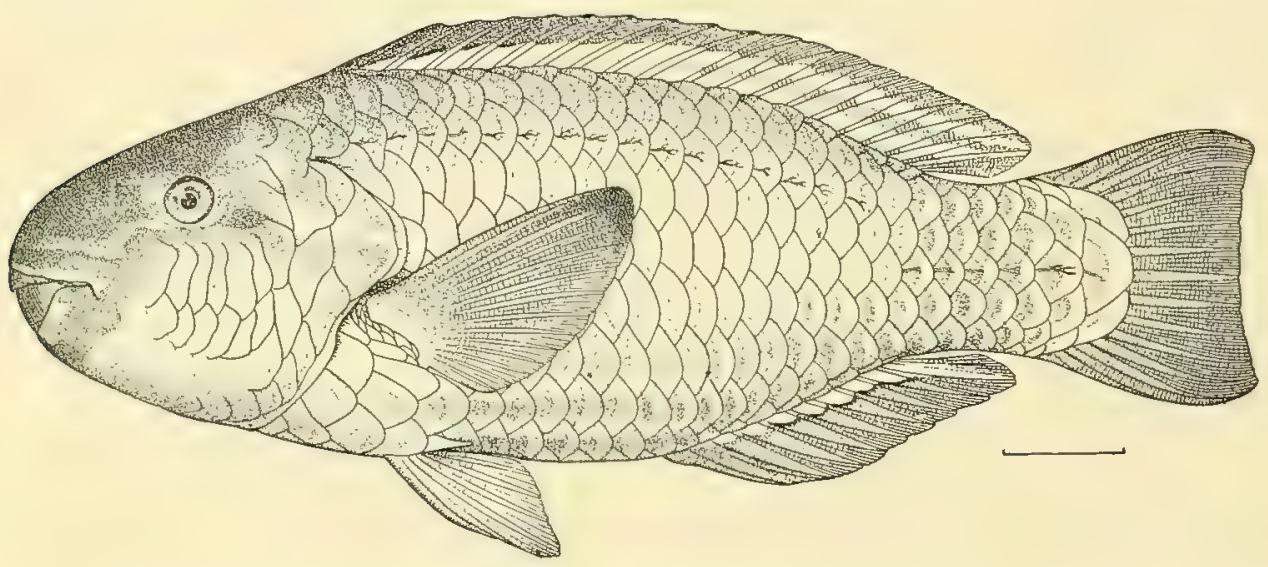

Fig.63,-Callyodon cyanomammus Jordan \& Seale, new species. Type.

its longest ray about 3 in head; pectoral 1.35; ventral 2, its origin slightly posterior of a line with pectoral and dorsal; caudal very slightly emarginate, longest exposed ray 2 in head; exposed middle ray 3.50 .

Color in life, green, brownish green on back, washed with golden behind middle of pectoral, the region midway between middle of anal and dorsal being distinetly bright yellow; scales above brown edged, those below edged with pinkish; head dark brownish above, the sides mostly bright greenish blue; belly light clear blue, as is caudal peduncle; cheeks golden washed; three green stripes, with purplish drab behind eye; lips blue, green behind and whitish in front; side of belly with four brightblue stripes, one median, the interspaces of bright pinkish brown, which might be described as three pale brownish red stripes through the blue; dorsal deep gray-blue in the distal half, the rays brownish; the proximal half light greenish white, with a median green shade most distinct behind; caudal clear blue with some brassy shades; anal clear green, bright blue at edge, with a stripe made of greenish white spots at base; ventral blue green, deeper and bluer on edge; pectoral greenish blue, its upper distal third a diffuse blackish blotch, the breast at its base deep blue; teeth and jaws blue.

Color in spirits, back light brown; sides dull yellowish green; lower part of belly through sides and caudal peduncle pale green; three rather distinct greenish longitudinal lines on sides of belly; top of head, including nuchal region and snout, purplish; margin of lips yellowish; iris golden; teeth green; a green line with darker margins extending around lips posterior to yellow margins, these lines uniting at angle and extending back through lower part of orbit across the cheek to posterior 
margin of opercle; a short, indistinct green line through upper part of orbit extending back to upper margin of opercle; upper third of dorsal green, the color broadening and extending to base of fin anteriorly; lower two-thirds of fin yellowish with a more or less distinct greenish central area which broadens posteriorly and anteriorly is represented by dusky blotches on webs; anal livid green, a narrow yellow line at base which extends out to tip of seventh anal ray; pectoral greenish, the tip purplish; ventral uniform pale green; caudal uniform dark green.

This species is represented by one specimen from Apia, the type, no. 51756, U. S. National Museum, length 10.50 inches.

\section{Callyodon cypho Seale. Guam.}

Scarus cypho Seale, Bishop Museum 1901, 95, Guam.

IIead 3 in length; depth 3.20 ; interorbital 3.50 ; dorsal IX, 10 ; anal IIr, 9; pectoral 14; scales 2-21-6, lateral line intermpted, the tubes branched; two rows of scales on cheek, with tive scales in lower row, preopercular limb) bare; pharyngeal teeth pavement-like, about twice as long as wide, the anterior ones the longest; teeth quite projecting, their length equal to orbit, two posterior canines at angle of upper jaw.

Body oblong, compressecl, the upper profile of back quite convex; snout much produced; lips narrow, scarcely covering one-half of jaws; caudal lunate; pectoral 1.33 in head, its base 5 , their shortest ray 4 ; ventral 1.50 ; base of anal $1.50,2.83$ in base of dorsal; 4 scales in front of dorsal, and 4 behind, its base convex, its posterior rays longest, 3 in head.

Color in spirits a uniform light green, a darker blotch extending over top of head and upper part of opercles; teeth greenish at base with white margin; lips a brighter green with a wash of yellowish, a narrow black line near their margins; fins greenish, dorsal with narrow intramarginal line of black, anal with a broad edge of brighter green, a narrow black line through its outer third, inner two-thirds white with wash of green; ventrals white with slight greenish wash; caudal green, lighter in center, with a dusky intramarginal line.

In spirits the coloring is similar to Callyodon bataviensis. The type, no. 160, Bishop IIuseum, is 9.5 inches long, from Guam.

1109. Callyodon troscheli (Bleeker). Laysan; East Indies.

Scarus troscheli Bleekcr, Batavia, 408, Java.

Peudoscarus troscheli Bleeker, Atlas Ichth., 1, 25, tab. v1, fig. 2, Java. Steindachner, Denks. Ak. Wiss. Wien, Lxx, 1900, 508, Lnysan.

1110. Callyodon macleayi Jordan \& Seale; new name. New Guinea.

Pseudoscarts frontalis Macleay, Proc. Linn. Soc. N. S. W. 1883, 590; not of Cuvier \& Valenciennes.

1111. Callyodon gymnognathos (Bleeker). New Guinea (Macleay).

1112. Callyodon jordani (Jenkins). Galo; Laea galo. Hawaii; Samoa.

Pseudoscants jordani Jenkins, Bull. U, S. Fish Comm., xrx, 1889 (1900), G3, fig. 21, Honolulu.

We have 1 fine specimen of this large and brilliant parrot-fish, 20 inches long, from Apia. The species is highly valued at Honolulu by the natives, who eat it raw. A color drawing of the specimen from Apia is published in Jordan \& Evermann's report on the fishes of Hawaii.

Head 2.85 to end of vertebre; depth 3.75 ; eye 8.75 in head; snout 2.25 in head; interorbital 2.85 ; dorsal $1 x, 10$; anal $I I, 9$; scales 2-24-6,3 rows on cheek, the lower row of 3 scales on lower limb of preopercle.

Body oblong, compressed, anterior prolile bluntly pointed, the snout in front of eye being gibbous; depth of caudal peduncle 2.80 in head; a distinct upper posterior canine; lips rather narrow; covering about one-half of upper jaw and one-third of lower; 6 rows of scales in front of dorsal; longest ray of dorsal 3.90 in head; base of anal $1.75,2.75$ in base of dorsal, its longest ray 3 in head; pectoral 1.50 ; ventral 1.90 ; caudal deeply Iunate, the upper and lower rays prolonged.

Color in life, green, bright, clear, on back and posteriorly; belly and head bright blue, the belly pale; nape and shoulder region with a deep wash of purplish brown; cheek and opercle washed with golden; lips very blue, each with a pale creany red band; sky-blue clouds on throat; iris golden; a pale drab streak before eye; dorsal with blue spmes and ray's, and a deep blue margin verging on black anteriorly; the color of the spines and rays varying with that of the body, blue, then purplish, and posteriorly green; orange ground-color of the membrane growing brighter behind and encroaching on 
the green, so that the last rays are green at base and blue at margin; caudal purplish brown toward the bluish base, then green, blue, and finally light orange on the edge; the lobes and upper and lower margins deep blue; anal dull orange, blue-shaded at base, the distal half bright blue; ventral greenish blue, the membranes mostly orange; pectoral greenish blue, the edge faintly orange.

Color in spirits, dull yellowish, shading into green anteriorly; a slight wash of purplish on head and nuchal region; two green bands around lower lip, the anterior one forming the margin, the posterior one uniting nore or less with green coloring on isthmus; margin of upper lip yellow; an irregular green line from orbit to angle of jaws, and two or three indistinct green lines on cheek; a dark bloteh back of eye, and on posterior lobe of opercle; posteriorly the scales of body have a slight wash of greenish on margin; spinous dorsal greenish, with darker margin; solt dorsal yellow; except its lower anterior third which is greenish; anal broadly margined with green, inner part of fin grayish, with some greenish blotches; pectoral green, with yellowish posterior margin; ventral green, their midportion yellowish; caudal green with some darker blotches, the margin yellowish; iris golden; teeth green.

1113. Callyodon strongylocephalus (Bleeker). Tahiti (Seale); Java.

Scarus strongylocephalus Bleeker, Java, I1, 439, Java.

1114. Callyodon microrhinos (Bleeker). Fiji (Günther); New Guinea (Macleay).

1115. Callyodon ultramarinus Jordan \& Seale, new species. Fuga galu-moana. Samoa.

Head 2.80 in length; depth 2.75; eye 8 in head; snout 2.20; interorbital 3; dorsal Ix, 10; anal IIr, 9; scales 2-24-6, three rows on cheek, the lower row of 7 unjoined scales on lower limb of preopercle.

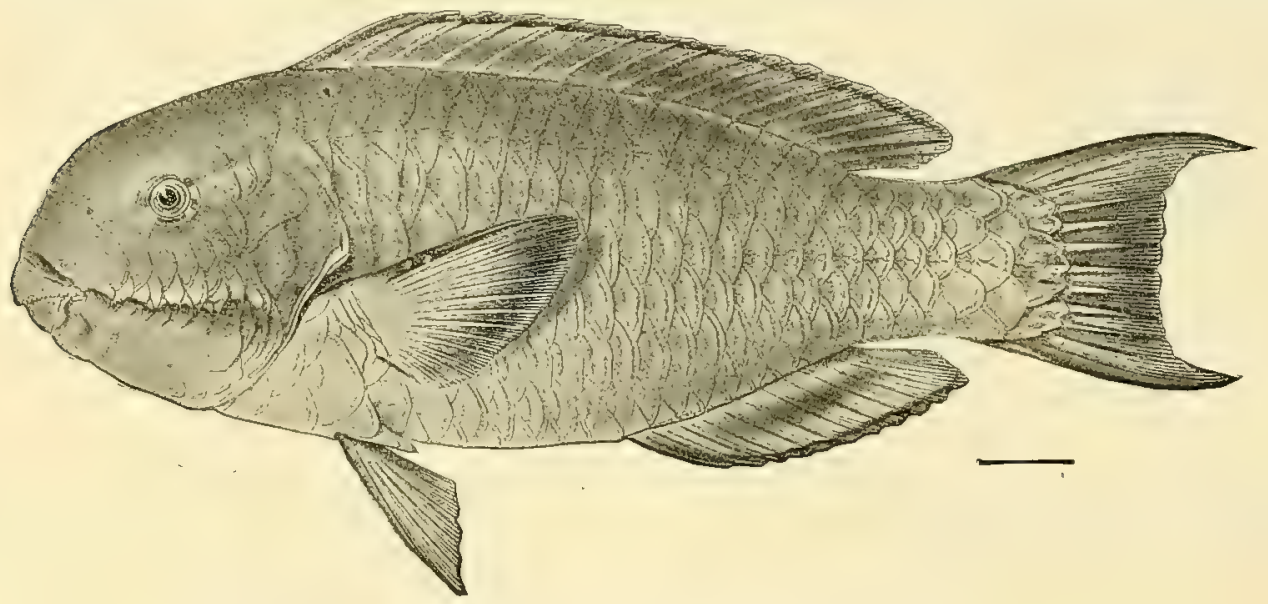

Fig. 61.-Callyodon ullramarinus Jordan \& Seale, new species. Type.

Body oblong, compressed; anterior of head not evenly rounded because of the strongly gibbous forehead; depth of caudal peduncle $2.25 \mathrm{~m}$ head; three rows of scales in front of dorsal; two small blunt posterior canines in upper jaw, none in lower; lips narrow, not covering one-half of teeth in either jaw; base of dorsal fin 1.75 in length without caudal, its longest ray 2.40 in head; base of anal 1.50 , 2.35 in base of dorsal, its rays longer than rays of dorsal, the longest ray 2.75 in head; pectoral 1.25 ; ventral 1.90; caudal lunate, exposed outer ray 1.75 , exposed inner ray, 2.95.

Life colors of one specimen were dark greenish blue, rather abruptly slaty blue below, the two colors separated by a broad irregular blackısh area which passes below the eye and around the snout; head-pad violet-blue; Iips and throat brilliant blue green; a stripe of same back to base of pectoral, then upward along opercular edge; caudal peduncle clear blue green; dorsal dull olve, with a bright blue margin; caudal violet with blue spots on margin and posterior edge; anal light blue violaceous, edged with deep blue; ventral bluish, edged with bright blue; breast light blue; pectoral light blue with a median violet band, iris orange; no red or orange or yellow. 
Another specimen, from Apia, was clear bluish green, of the same shade everywhere above the pectoral; each scale with a brown base and edge; lower parts of a clear crockery blue, less shaded with brown; head olive-green above, clear bright brown on the sides, golden olive on throat; lower lip orange, then a broad blue stripe, a narrow orange and a narrower blue one separating from the olive of throat; breast and median line of throat blue; upper lip blue with a narrow orange edge; dorsal dull orange, its margin bright blue; a series of large green spots mesially; caudal bright blue, an orange-brown streak in each lobe, brown shades at base; anal dull dark orange, its edge bright blue with a broad greenish blue median stripe; pectoral blue, with a longitudinal stripe of brown; ventral pale blue, with a bright blue edge; iris blue with a golden ring within.

A specimen from Pago Pago was brassy green, livid bluish below and more bluish on caudal peduncle, head more smoky; each body scale with reddish brown edge; dark green streaks radiating from eye; upper lip deep blue, margined with reddish; lower lip blue, with reddish edge and a yellow cross-band from angle of mouth; an angular blue green band from angle of mouth to gill opening far below eye; axil dusky; dorsal smoky orange, edged with blue, a median blackish stripe posteriorly; caudal bright blue, darker on margin and edge; anal blue washed with orange, with blue saargin and a median stripe; pectoral blue, with blackish submarginal band; ventral robin's-egg blue, with bluer margin.

Another specimen from Pago Pago was very rich dark Nile green, with dark purplish brown scale-edgings, behind eye dark green linear blotches, and farther back a single light gold-green oblong bloteh, edged with blackish; teeth blue; upper lip broadly scarlet, then green, then narrowly scarlet, then merging into fuliginous; lower lip narrowly margined with scarlet, then bluish green, then smoky lilac, then bluish green, then smoky lilac; ventrals lilac, with navy-blue anterior margin and sky-blue posterior margins; pectoral dark lilac-purplish, with bluer margins; anal with bright sky-blue margin and pinkish submarginal line merging into greenish; dorsal like anal; caudal with very light blue margin and mixed greenish bluish and thin yellowish green in middle; dorsal and ventral margins sky-blue, with pinkish salmon inside.

Color in spirits dull green with a wash of bluish, darker above, somewhat purplish on top of head, lighter below, shading into a pale green on under part of head, thorax, and belly; the very narrow margin of lips yellowish, the upper lip with a single dark bluish green band above the yellow margin, and with a narrow yellowish area above the blue line; a rather wide and rery distinct bluish green line extends around under the jaw from which two other lines also extend around under the jat;, all the bands uniting near angle of mouth and extending back across the cheeks to posterior margin of opercles, on a line with upper base of pectorals; about 5 very short purplish lines radiate from eye; a lighter bloteh at base of caudal; dorsal fin margined with deep blue, the spinous portion of fin pale green, the soft portion more or less blotched with purplish, the color assuming a rather wide band-like form in middle of fin; anterior, posterior, and outer margins of anal fin deep blue, an incomplete blue line at base, body of fin dull grayish, with wide blue band through center; pectorals greenish, the upper margin deep blue, the posterior margin gray with intramarginal dusky area; ventral pale green with first and second rays blue; caudal with upper and lower margins blue; the distal end of fin broadly margined with purplish about two irregular purplish bands near base; iris golden; teeth green.

Of this fish we have 7 specimens, all large, from Apia and Pago Pago. One from Apia, a rery large example $2 \frac{1}{2}$ feet long, has the fleshy pad on the forebead highly developed. A specimen similar to this was taken by Mr. Seale at Mangareva. The type is no. 51757, U. S. National Museum, 13 inches long, from Pago Pago.

\section{Callyodon lazulinus Jordan \& Seale, new species. Fugausi. Samoa.}

Head 2.55 in length; depth 2.85; eye 7.50 in head; dorsal $1 x$, 10; anal Ir, 9; scales 2-21-6; three rows of scales on cheeks, the lower row of four scales covering lower limb of preopercle.

Body oblong, compressed; anterior of head bluntly rounded; the snout slightly gibbous; depth of caudal peduncle 2.20 in head; no posterior canines; lips rather wide, covering slightly more than one-half of teeth; five scales in front of dorsal; base of dorsal 1.90 in length without candal, its longest ray 3 in head; base of anal 1.50 in head, 2.10 in base of dorsal; pectoral 1.20 -in head; ventral 2 in head; caudal deeply lunate, the upper and lower rays much prolonged, the upper slightly the longest, 1.10 in hear. 
Life colors of a specimen from Apia, deep blue-green, the head above and shoulders indigo; not much brown shade on scales; upper lip, stripe below eye, and streaks about eye clear blue-green; a red stripe on upper lip; lower with two of reddish brown, two of clear blue; breast and lower parts clear blue; dorsal blue in front and on edge, green at base behind; a median band of deep reddish brown; caudal deeply lunate, blue-green with a band of deep brown on each lobe; anal purplish blue at base, then a clear blue line, then bluish green, blue at tip; ventral purplish blue behind, greenish blue in front; pectoral clear green above, blue below, with a blue-brown dark stripe between; teeth blue.

A young example from Pago Pago had the iris white; above eye black-green; below eye greenblue; sides green-blue with brown-maroon scale markings; pectoral with longitudinal median blackish blotch and very bright anterior edge; ventral robin's-egg blue on anterior margin, salmon tinge within; anal bright green blue with pink-salmon basal band; dorsal green-blue with pink-salmon median band; caudal green-blue with pink-salmon blotches; green black stripe through eye and snout forming patch on opercle and one behind eye; teeth sky-blue; upper lip green-blue with maroon margin; lower lip with broad salmon-maroon bar behind margin and pinkish irregular blotch farther back.

Color in spirits pea-green, top of head and shoulders back to sixth dorsal spine and to a line with eye dark bluish green, with shading of purplish; this color separated very distinctly on line with eye from the pea-green of lower half of head; a short pea-green line through upper part of eye; tip of

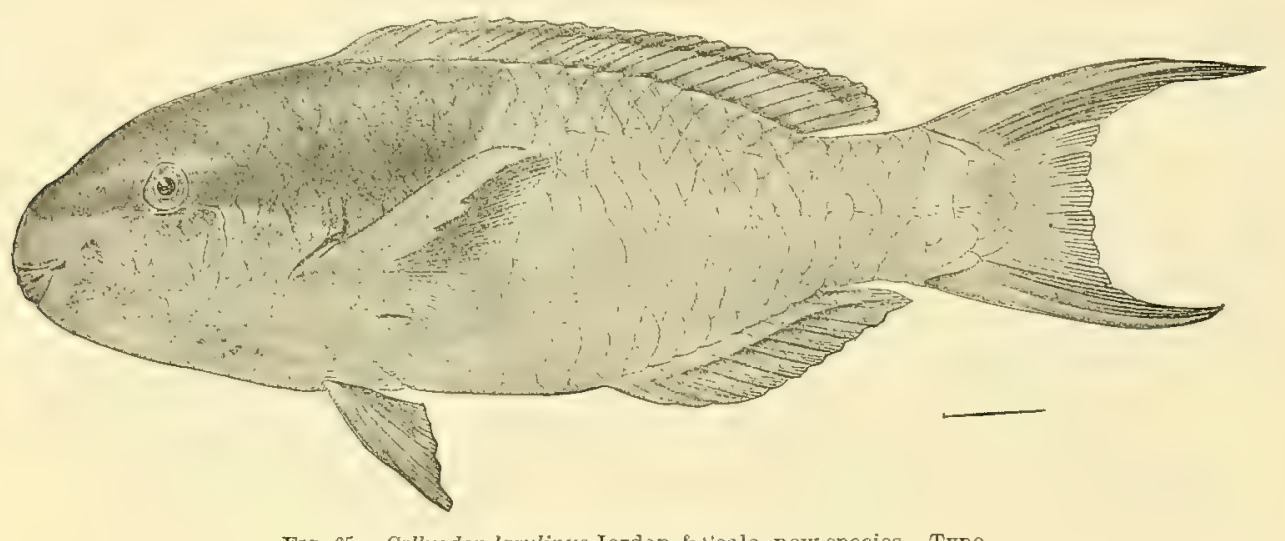

Frg. 65,-Callyodon lazulinus Jordan \& seale, new species. Type.

snout and lips pea-green, with an indistinct but slightly darker greenish line around upper lip, and two similar but broad lines on lower lip, the posterior one zigzaging down from eye to anterior margin of isthmus; a bluish spot on isthmus; dorsal greenish with a darker submarginal line, lower part of fin with an indistinct dusky line at base anteriorly and some dusky blotches posteriorly; outer twothirds of anal yellowish green, the inner third pea-green, this pea-green area margined by narrow line of dusky; pectoral markings conspicuous, the upper four rays being olive-green, the middle portion purplish, the margin gray; ventral uniform greenish; caudal with outer rays bright green, the sublateral rays grayish, the middle of fin bright green; the distal margin is grayish; iris golden; teeth very dark green, almost dusky.

Fifteen specimens from Apia and Pago Pago. The type is no. 51758, U. S. National Museum, from Apia, length 12.90 inches.

1117. Callyodon cyanognathus (Bleeker). Faté and Shortland I. (Seale); East Indies.

Scaras cyanognathus Bleeker, Verh. Bat. Gen., xxIr, 62, Java.

Pseudoscarus cyanognathus, Günther, Cat, I\%, 234, Java.

1118. Callyodon mertensii (Cuvier \& Valenciennes). Ulea.

Scarus mertensii Cuvier \& Valenciennes, Hist. Nat. Poiss., XIV, 281, 1839, Ulea.

1119. Callyodon spilurus (Cuvier \& Valenciennes).

Scamus spulurus Cuvier \& Valenciennes, op. cit., 279, 1839, Caroline Is. 


\section{Family ANTIGONIHDE.}

ANTIGONIA LOWE.

1120. Antigonia steindachneri Jorlan \& Evermann. Hawaii; Japan.

1121. Antigonia eos Gilbert. Hawaii.

\section{Family EPHIPPIDE.}

\section{EPHIPPUS Cuvier.}

Ephippus Cuvier, Règne Annual, ed. 1, 335, 1817 (argus).

Scatophagus Cuvier \& Valenciennes, Hist. Nat. Poiss., vi, 136 (argus).

Creodoxus Cantor, Malay. Fish., 163, 1850 (argus: substitute for Scalophagus on account of the earlier genus Scatophaga).

1122. Ephippus argus (Gmelin). New Guinea (Macleay); New Britain (Peters, Berl. Mon., $1876,833)$.

1123. Ephippus multifasciatus (Richardson). New Guinea; East Indies.

Scatophagus multifasciatus Alleyne \& MIacleay, Proc. Linn. Soc. N. S. W., 1883, 277, New Guinea.

\section{DREPANE Cuvier \& Valenciennes.}

Drepane Cuvier \& Valenciennes, Hist. Nat. Poiss., vir, 129, 1831 (punctatu).

Harpochims Cantor, Malay. Fish., 162, 1850 (punctata); substitute for Drepane, there being genera of prior date, Drepana, Drepanis, Drepanus, and Drepania.

Cryptosmilia Cope, Trans. Am. Phil. Soc. 1867, 401 (luna).

1124. Drepane punctata (Gmelin). Samoa (Günther); New Ireland (Peters); East Indies.

\section{PLATAX Cavier.}

1125. Platax orbicularis (Forskål). Pe'ape'a uli. Samoa; Tahiti; Papua; Fiji; New Ireland; Shortland I. (Seale); East Indies.

Chxtodon orbicularis Forskil, Descr. Anim., 59, 1775, Red Sea.

Platcu orbicularis, Günther, Fische der südsee, 140, Tahiti. Klunzinger, Fische Rothen Meeres, 118, Red Seg; with good diagnosis of the two species.

Chretodon v'espertilio Bloch, Ichth., 67, taf. 199, fig. 2, 1787, East Indies.

Plalax respertilio, Bleeker, Atlas, Chæt., 74, tab. xvir, fig. 1, tab. xvir, figs. 2 and 3, Sumatra, New Guinea, and all other East Indian islands. Peters, Berl, Mon, 1876, 836, New Ireland.

Chatodon pentacanthus Lacépède, Hist. Nat. Poiss., IV, 454, 471, tab.11, tig. 2, 1803, Pacific Ocean.

Platax albipunctatus Rüppell, Atlas, 69, taf. 18, fig. 4,1828 , Red Sea.

Platax ehrcnbergi Cuvier \& Valenciennes, Hist, Nat, Poiss, yil, 221, 1831, Red Sea.

Platax gutlulatus Cuvier \& Valenciennes, Hist. Nat. Poiss., vit, 227, pl. 186, fig. 1, 1831, Ile de France.

This fish, widely distributed throughout the East Indies, is rather common about Namoa. We have three specimens taken in the seine at Pago Pago and two from Apia.

The species is distinguished from the next by the fact that the middle cusp of each tooth is longer than the others. The scales are considerably larger than in Platax teira, and the anterior profile is a little less vertical. The color is similar in the two species, the cross-bands disappearing with age.

A specimen from Apia was olive-gray, with blackish on the fins; no bright colors. A young example from Pago Pago was blackish in life, with a diffused blackish ocular band; breast soiled yellowish; base of pectoral with a large black spot; caudal abruptly whitish; ventral black; dorsal v, 37; scales 63.

1126. Platax teira (Forskål). Palau Is; New Guinea; East Indies.

Chatodon teira Forskil, Descr. Anim., 60, 1775, Red Sea.

Platax teira, Günther, Fische der Südsee, 141, 1876. Pnlau Is. Bleeker, Atlas, Chrt, 73, tab. xwi, fig. 2, tab. xx, fjg. 1: Sumatra, New Guinea, Borneo, and all the Fast Indian islands. Klunzinger, Fisehe Roth. Meeres, 119. Red Sen. Jordan \& Fowler, I'roc. U. S. Nat. Mus., xxv, 1903, 526, Formosa, Riukiu Is., Tokyo, Kagoshima, Bonin Is., Kezen.

Chatodon arthriticus Bell, Philos. Trans. 793, 8, pl.6, Sumatra. 
Platax gaimardi Cuvier \& Valenciennes, Hist. Nat. Poiss, vi, 216, 1831, New Guinea. Plata 2 borsi Bleeker, Derde Bijdr. Celebes, 758, 1852, Celebes.

Platax xanthopus Bleeker, Verh. Bat, Gen., xxIIr, 28, 1850, Sumatra.

This species, known by the smaller scales, is common in the East Indies and north ward to southern Japan. It is recorded by Günther from the Palau Islands.

1127. Platax pinnatus Bleeker. New Guinea (Macleay).

\section{Family CHETODONTID E.}

\section{FORCIPIGER Jordan \& McGregor.}

Forcipiger Jordan \& McGregor in Jordan \& Evermann, Bull. 47 U. S. Nat. Mus., 1898, 1671 (longirostris).

This genus differs from Chelmon Cuvier in the long and high spinous dorsal, which is composed of 12 stout spines (9 in Chelmon). The snout, as in Chelmon, is very long and slender, bearing the short, forcep-like jaws at the end. From Prognathodes, a genus still more closely related, Forcipiger differs in the small scales, there being about 75 in a horizontal series.

1128. Forcipiger longirostris (Broussonet). Hawaii; Samoa; Tahiti; Paumotu Is.; Kingsmill I.; Tonga; Raiatea (Seale); East Indies; Clarion Is. (as Forcipiger flavissimus Jordan \& McGregor).

This curious and brightly colored fish ranges widely through the South Seas and eastward to the off-shore islands of Mexico. It seems to be nowhere common, and but one specimen was found by us at Pago Pago. A few specimens were taken also at Honolulu.

Color in life bright yellow, from a line connecting front of dorsal with axil of pectoral and a point behind ventrals; scales of side shaded with orange; top of snout to nape and opercular region jet black; lower parts of head and breast abruptly black; dorsal, anal, ventral, and pectoral yellow; a large black spot on last rays of anal; caudal grayish.

A specimen from Pago Pago was in life brilliant yellow, deeper and orange-shaded behind, a black triangle on head, livid white below; ventral and pectoral yellow; caudal colorless; a large jet black spot on anal.

\section{MEGAPROTODON Guichenot.}

Megaprotodon Guichenot, Rev. Zool., 18 18,12 (bijascialis).

Eteira Kaup, Arch. Nat., xxvi, 1860, 147 (triangularis).

This genus is characterized by the constant presence of four anal spines. It is close to the group called Limophora in Chatodon, having the series of scales meeting at right angles. The body is oblong and compressed, the soft dorsal and anal produced and concave on the margin. Outer teeth of lower jaw a little longer than inner. The genus or subgenus Gonochatodon is near Megaprotodon, but it has the body almost as deep as long, as in Coradion.

1129. Megaprotodon trifascialis (Quoy \& Gaimard). Mutu uli. Samoa; Guam; Tahiti; East Indies. (Pl. I, fig. 1.)

Chatodon trifascialis Quoy \& Gaimard, Voy. Uranie, Ir, 379, pl. 62, fig. 5, 1824, Guam, Batu. Toung with the caudal pale instead of "black as in the adult.

Chrtodon triangularis Rüppell, Atlas, 42, pl. 9, fig. 3, 1828, Red Sea.

Megaprotodon triangularis, Seale, Bishop Museum 1901, 101, Guam.

Chatodon strigangulus Solander, in Cuvier \& Valenciennes, Hist. Nat. Poiss., vir, 42, 1831, Tahiti. Günther, Fische der Südsee, 35, pl. 26, fig. $A$, Polynesia.

Megaprotodon strignngulus, Bleeker, Atlas, Chæt., 54, tab. xıII, fig. 4, Java, Batu, Celebes, Halmahera, Cer̨m Banda, Amboina, Timor, Obi-major.

Chrtodon bifascialis Cuvier \& Valenciennes, Hist. Nat. Poiss., viI, 48, 1831, Guam.

Chatodon leachi Cuvier \& Valenciennes, Hist. Nat. Poiss., vir, 49, 1831, no locality.

This species, generally common throughout the East Indies, is abundant about the coral reefs of Samoa. The young closely resemble the adult in form and general color, but differ in the markings posteriorly. A broad dark band includes the soft dorsal and anal. This grows narrower with age, and finally vanishes. In the young the caudal is yellow with a narrow dark cross-band. In the adult it is black, with a narrow pale band near its tip. The nominal species trifascialis is the young of the one called triangularis or strigangulus. The name trifascialis has priority.

Fifteen specimens from Apia and Pago Pago. One from Apia was in life gray, white below, $V$-shaped stripes, bright grayish blue, the angle toward the head; ocular band broad, edger with white 
and golden; snout and forehead gray, with orange marks about jaws; two oblong whitish clouds on side just above level of eye, the one ending near end of pectoral, the other at base of soft dorsal; dorsal orange, dusky behind on base of soft dorsal, edged with orange, black and white; caudal black, edged above and below with orange-yellow; a golden yellow cross-band, a black, then a drab edge; anal creamy orange, edged with black and white; ventral yellowish white; pectoral colorless, orange-yellow at base.

Small specimens have the tail yellow, not black as in the adult; a broad black band involving soft dorsal and anal and the space between.

\section{GONOCHATODON Bleeker.}

Body very deep; dorsal and anal fins nearly vertical posteriorly. Sides with vertical streaks, meeting at an angle along the axis, the angle pointing forward.

1130. Gonochætodon triangulum Cuvier \& Valenciennes. New Guinea (Macleay); East Indies. (Chætodon triangulum, baronessa, and karraf, Cuvier \& Valenciennes.)

\section{CHETODON (Artedi) Linnæus, Tintifi.}

ANALYSIS OF POLYNESIAN SPECIES OF CHETODON.

a. LINOPHORA: Rows of scales of anterior part of body running upward and backward, each marked by a dark line, those of posterior part of body running downward and backward almost at right angles with the first; snout acute.

b. Dorsal fin with the first soft ray prolonged into a whip; a black ocellus below it; ocular band broad; ventral pale; two black lines reross caudal.

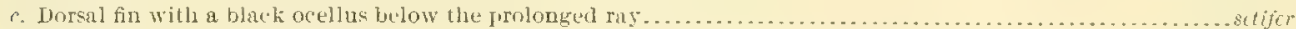

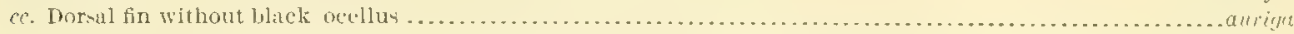

6b. Dorsal fin without produced raj; no black ocellus; ocular band broad, white-edged; a broad black band across base of dorsal to middle of base of anal; two black bands on caudal; ventral pale .........................vagabundus

ad. Scales not arranged as above indicated, or at least not marked by lines meeting at an angle.

d. Scales large, arranged in rows which are very distinct, both upward and backward and downward and backward, forming a checker-board appearance; scales on middle of body very large.

e. Ocular band very broad below; a black band on soft dorsal; a broad, black band on caudal; rentral pale; snout

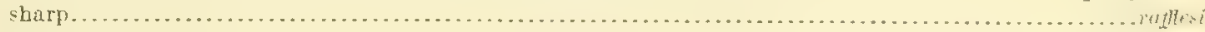
ee. Ocular band not broader than eye; a short black nuchal bar; dorsal and anal narrowly edged with dark; caudal

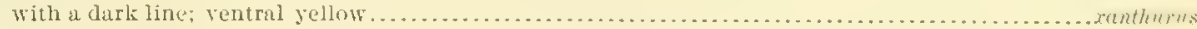

da. Scales not arranged as above indicated.

f. Scales unequal, those on middle parts of body larger than the others, the series usually extending upward and backward, at least posteriorly; teeth very small.

g. Chitodostops: Snout acute, concave in upper profile.

h. Ocular band mesially yellow, with dark edges.

i. Body with 7 oblique dark stripes running upward and backward; caudal with a black crosabar: rentral

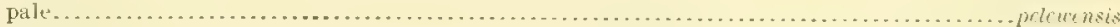

Wh. Ocular band black.

j. Ocular band broad, as broad as eye.

k. Body with two dark violaceous cross-bands coalescent above, with narrow vertical streaks between them; caudal pecuncle with a jet-black spot; a black line acroas caudal; ventral pale ...ulietensis k*. Body without black cross-bands.

l. Black area at base of soft dorsal broad, sending oblique streaks downward and forward across the

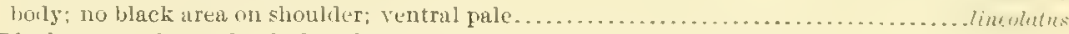

2l. Black area at base of soft dorsal narrow, the oblique cross-streaks along rows of scales orange; shoulder region black, with a median triangular orange area on each side; ventral pale..lunula

jj. Ocular band faint or narrow, not so broad as eye.

$m$. Ocular band obscure; a black band from soft dorsal across to ana; caudal with a black bar:

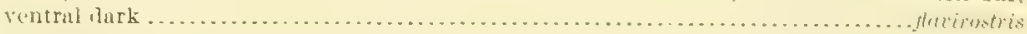
$m m$. Ocular band distinct, narrower than eye.

$n$. Body with numerous $V$-shaped eross-bands, the angle toward the head; a broad yellow band

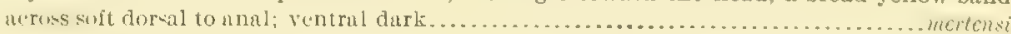
$n n$. Body with about six dark, curved cross-bands, each scale posteriorly with a black spot; back with $\pi$ dark shade; fins mostly yellow ......................................... dironi nm. Buck blackish; side with oblique dusky lines; a black spot at base of anal spines; a black spot on breast, and two on base of caudal peduncle; a pale blotch on side of back; Fentral

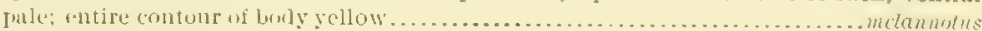

gg. Snout obtuse, the profile not concave; ocular band very broad, extending from the nape to the rentral, edged on both sides with yellow; snout black; body dusky, dove-colored above, each scale with a yellowish spot; anal and band across catudal peduncle black; tips of last rays of anal fiery red; tro blnck lines nerosicaudal. 
ff. LEPIDOCH ETODON: Scales unequal, those of the middle part of the body above largest; teeth much larger than in related species; rows of scales nearly horizontal; snout moderate; the profile projecting above eye.

$o$. Side of back with a large black ocellus, of ten produced downward in a wedge-shaped blotch; octular band broad, meeting its fellow on breast; a black band on margin of dorsal and anal across caudal peduncle; ventral pale; caudal plain ........................unimaenlatus 00. Side of body with a black cross-blotch from last dorsal spines to above anal spines; ocular band broad below; ventral black; caudal plain; teeth undeseribed .................trichrous ooo. Side of body from front of anal backward entirely blackish; a black bax from front o dorsal to ventral, which is black; ocular band broad...............................klemi

fff. RABDOPHORUs: Scales subequal, the series extending horizontally or slightly extending posteriorly; teeth small; snout obtuse or moderately acute.

p. Soft dorsal with its first ray produced and whip-like; snout acute.

q. Back with a large black saddle-shaped area covering most of the dorsal and edged with white below; ocular band very narrow and faint; ventral pale; caudal plain. .ephippium qq. Body bright orange, with blue spots along the rows of scales; ocular band broad, distinct; base of dorsal and anal black; ventral pale; caudal plain.................semeion

$p p$. Soft dorsal without elongate or whip-like ray; snout obtuse or slightly acute, not convex above.

$r$. Body with about six transverse cross-bands; ocular band narrow, faint, a black spot above it; a reddish band on caudal peduncle; eaudal with a black bar; ventral pale .................................................... pretatofaciatus rr. Body without dark cross-bands.

s. Body with about 10 narrow dark cross-streaks, each a row of small spots; ocular band narrow; a black bar across caudal peduncle; anal with a narrow dark edge; ventral pale ..............................................................miliaris

ss. Body with many oblique dark cross-streaks, each a series of spots along the row of scales, those above ascending, those velow horizontal; no black on caudal peduncle; anal with a broad black streak and a bright yellow one above it; ocular band narrower than eye, sharply detined ...................................citrinellus

sss. Body without series of streaks, either oblique or vertical.

t. Ocular band present; snout obtuse.

u. Ocular band preceded by a black bar.

$v$. Black bar before eye covering snout; a black bar behind ocular band; body with dark streaks along rows of scales; a black area surrounded by golden on dorsal, anal and caudal; ventral pale; a black spot on breast....... trifasciatus $v v$. Black bar before eve, not covering upper lip, which is pale; a black area above eye; three black bands behind eye, the first one extending backward to last ray of soft dorsal; body with 6 oblique orange stripes; caudal with two black stripes; anal with one; ventral pale ............................ornatissimus

uu. Ocular band not preceded by a black bar.

w. Side of body with a black spot or ocellus; ocular band moderate, edged with blue; no black on fins.

$x$ Sides of body below with 2 or 3 blue streaks; lateral spot $\&$ rounded ocellus................................................ bennelti 2x. Sides of body below with about 13 faint streaks; lateral spot large, oblong ..............................................speculum ww. Side of tail with a black ocellus; pale streaks along rows of scales; no black on fins; ocular band pale-edged................................ plebeiz www. Side of body and tail without ocellus.

$y$. Back blackish, with two whitish blotches; ocular band orange, with dark edges; fins pale, with dark lines..................... quadrimaculatus yy. Body with diffuse dark spots; ocular band broad, diffuse; snout black: ventral black; no yellow...............................corallicola

tt. Ocular band none; body with about nine oblique stripes of clear blue; caudal peduncle and posterior part of dorsal black; caudal with a broad black band; ventral pale; snout rather acute .....................................fremblyi

1131. Chætodon setifer Forskål. Si'u; Tifitifi sama. Hawaii; Samoa; Johnston I.; Guam; Tubuai; Rarotonga and Faté (Seale); East Indies.

Chatodon setifer Bloch, Ichth., tab. 426, fig. 1, 1788, Coromandel. Cuvier \& Valeneiennes, Hist. Nat. Poiss., VII, 77, Bolabola, rle de France: Günther, Fische der Südsee, 36, taf. 26, fig. B, Sandwich Is. Smith \& Swain, Yroc. U. S. Nat. Mrus., V, 1882, 137, Jobnston I. Seale, Bishop Museum, 1901, 98, Guam.

Tetragonopterus auriga Bleeker, Atlas, Chæt., 47, tab, xI, Sumatra, Java, and all islands of the East Indies; not Chatodon auriga of Forshål.

Chatodon auriga, Steindachner, Sitz. Ak. Wiss. Wien 1900, 488, Ionolulu; not of Forskål.

This fish is common throughout the South Seas. We have 45 specimens from Apia and Pago Pago, where next to Chrtodon vagabundus it is the most abundant of the tifitifis. It is known at once by the black ocellus on the dorsal, one of the rays of which is produced. The dorsal ocellus with other 
characters separates the species from the closely related Chatodon auriga of the southern coasts of Asia. The lines at right angles on the body are also characteristic. The name tifitifi is given to all chretodonts in Samoa, though primarily applied to Zanclus canescens. Tifi means angle; tifitifi the horns of the moon. The word corresponds to kihikiti of the Ilawailans.

Life colors of a Samoan specimen, anteriorly gray, posteriorly deep lemon-yellow, with opposing stripes of violet-gray; forehead gray, with deep orange-yellow cross streaks; ocular band broad, meeting its fellow below; soft dorsal edged with black, with a large black spot; a yellow streak on soft dorsal within the blackish edge; filament black before, yellow behind; caudal lemon-yellow; band light bright yellow, bordered before and behind with brown; tip of caudal translucent; anal gray at base, orange behind and outside, edged with a black line and yellow; pectoral and ventral clear gray.

1132. Chætodon auriga Forskâl. Melanesia; East Indies.

Chatodon anriga Forskal, Deser. Anim., 60, 175, Red Sea. Günther, Cat., II, 7, Red Sea.

This species of the Indian region iy not certainly known from the islands of the Pacific.

1133. Chætodon vagabundus Linnæus. Tifitifi matı-ume; Samasama. Samoa; Vanicolo; Fiji; Faté; Shortland and haiatea (Seale); East Indies.

Chatodon vagabundus Linnaus, Syst. Nat, I, 465, Indies, Cuvier \& Valenciennes, IIist. Nat. Poiss, vir, 50, 1831, Ile de France, Fanicolo, Amboina. Günther, Fische der Südsce, 43 , everswhere in Polynesia.

Tetrayonoptrus ragabundus, Bleeker, Atlas, Chat., 48, trb. xv, Sumatra, Java, Celebes, and all other islands of the East Indies.

This fish, abundant throughout Polynesia, is by far the most abundant species of the group at Samoa. Seventy specimens were taken at Apia and Pago Pago. The species is uot one of the brightest in color. In the presence of narrow streaks meeting at right angles it resembles Chatodon setifer, but it has neither dorsal filament nor ocellus.

Life colors of one specimen, gray, olivaceous above, becoming golden behind; oblique streaks of purplish gray meeting at angles; ocular band broad, not pale-edged except below in front; forehead gray, with six orange cross-shades; first dorsal black, with a median yellow streak which widens to cover most of soft dorsal; a broad black margin to soft dorsal; a black bar at its base, edged before and behind with yellow, which crosses caudal peduncle, ending below on center of anal; anal otherwise dark yellow, grayish at base, with black and light yellow edge; spines very pale yellow; caudal golden yellow with a black crescent, a black crossbar behind it, and a colorless tip; ventral and pectoral pale.

This species seems obviously near Chatodon setifer, and lends some support to Bleeker's group Linophora.

1134. Chætodon xanthurus Bleeker. New Britain; East Indies.

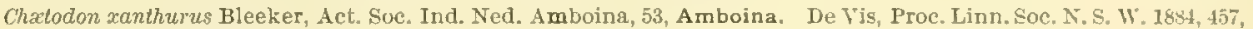
Apî, New Britan.

Tetragonoptems mertensi Bleeker, Atlas, Chat., 50, tab. Xvi, fig. 3, Amboina; not type

1135. Chætodon raffesi Bennett. Samoa; Palan; Fiji; Waigiu; Papua; New Hanover; East Indies.

Chatodon rufhesi Bennett, life of Rafles, 689,1830 , Sumatra. Günther, Fischeder Südsee, 41, taf. 35, fig. C., Melanesia, Palau, Fiji. Peters, Berl. Mon. 1876, 832, New Hanover.

Tetragonoplcrus raplesi Bleeker, Atlas, Chat., 49, tab. xir, Sumatra, Jara, Bawean, Celebes, Sumbrwa, Timor, Halmahera, Ternate, Ceram, Amboina, Goram, Aru, Waigiu, New Guinea.

Chatodon princeps Cuvier \& Valenciennes, Hist. Nat. Poiss., VIr, 33, 1831, New Ireland.

This pretty species is rare about Samoa, nine specimens in all being taken at A pia and Pago Pago. Günther's figure is fairly good, but the color is too pale, the fish being more olive in shade. The checker-like orange markings on the edges of the scales give a characteristic mosaic appearance.

Colors in life, deep yellow, greenish-tinged on body, very bright on fins; the body checkered with two sets of pinkish brown cross-streaks on edges of scales, these colors purplish on small scaleg at base of fin; snout brown; forehead gray; chin bright yellow; ocular band broad, whitish-edged only below in front; soft dorsal greenish on scales, then clear brown, then clear yellow, black and yellow; spines brownish, with greenish membranes; anal yellowish-green and purple-dotted on scales, then clear brown with two yellow bars on last rays and a yellow edge, with a black and white bounding line; caudal clear yellow with a black band, broadest in the middle, clear yellow behind, the edge clear gray; pectoral gray; ventral bright golden. 
1136. Chætodon pelewensis Kner. Tifitifi i' $u$ sama (orange-tailed). Palau Is.; Samoa; Tonga; Tahiti; Paumotu Is.; New Hebrides; Faté (Seale).

Chxtodon pelewensis Kner, Sitz. Ak. Wiss. Wien 1868, 306, Palau Is. Günther, Fische der Südsee, 43, taf. 31, fig. B, Tonga, Palau, Samoa, Tahiti, Paumotu, New Hebrides.

Of this handsome little Chrtodon we secured 6 specimens from Apia and Pago Pago. From most other species, Chictodon pelewensis is known by the yellow median stripe on the black ocular band.

Life colors of a specimen from Apia, yellow-olive, clear yellow behind, gray on sides; forehead black; ocular band yellow, edged on each side by black and gray; preorbital yellow; yellow on preopercle; dots and wavy bands purplish black; dorsal brown- jlive, clearer behind, a broad golden edge set off by a black line; caudal peduncle clear bright orange, as in Holacanthus (flavissimus), then light yellow, then black, the fin mostly translucent; anal creamy brown, with a black streak above and below, the edge soiled greenish gray; ventral dusky; pectoral colorless; a black blotch on nape before dorsal.

1137. Chætodon ulietensis Cuvier \& Valenciennes. Samoa; Paumotu; Tahiti; Guam; Kingsmill I.; Raiatea (Seale)

Chætodon utietensis Cuvier \& Valenciennes, Hist. Nat. Foiss, viI, 39, 1831, Ulietea.

Chatodon falcula Günther, Fische der Südsee, 39, taf. 27; Paumotu, Tahiti, Harvey, Samos, Kingsmill I.; not of Cuvier. Seale, Bishop Museum 1901, 101, Guam.

Of this fish we have 8 specimens from Apia and $t$ from Pago Pago. It is well distinguished from the closely, related Chrtodon falcula of the East Indies, with which Bleeker and Günther have confounded it.

Colors in life, light gray or clear whitish, slightly brownish in front, bluish mesially, with two broad cross-bands of deep drab, the posterior deepening to black above, both fading below but evident. below the level of the pectoral fin; above they extend on the dorsal fin, the anterior bar narrowed and sharply turned backward at base of spinous dorsal; the two cross-bands and the pale interspace marked by 15 or 16 narrow, sharp, nearly vertical lines of drab-black, like pencil marks, these corresponding to the rows of scales; area behind second lateral band clear golden-yellow on body and fins; ocular stripe broad, deep black, without edge; snout dusky above; an oblong vertical jet-black spot crossing narrowest part of caudal peduncle; spinous dorsal clear light yellow along edge; soft dorsal and anal golden yellow like the body; dorsal with two narrow brown streaks not parallel, then light yellow, brown, and finally a blackish edge: anal spines bright light yellow, the fins with three dark parallel streaks, two brown, one black, then a golden edge; caudal golden yellow, with a black curved crossstreak and a broad transparent edge; pectoral colorless; ventral soiled white; forehead with faint brownish yellow cross-streak. Another specimen with bands black rather than violet.

1138. Chætodon lineolatus Cuvier \& Valenciennes. Hawaii; Samoa; New Hanover; New Guinea; Faté (Seale); East Indies.

Chetodon lineolatus Cuvier \& Valenciennes, Hist. Nat. Poiss., vII, 40, 1831, Ile de France. Quoy \& Gaimard, Voyage de 1'Astrolabe, 381, 1835, Ile de France. Günther, Fische der Südsee, Hawaii, Samoa, Tahiti, Iringsmill I. Steindachner, Sitz. Ak. Wiss. Wien 1900, 469; Honolulu.

Tetragonoptrus lineolatus, Bleeker, Atlas, Chrt., 5i, tab. xv, Cocos, Sumbawa, Flores, Ternate, Amboina, Banda. Chrtodon lunatus (Ehrenberg) Cuvier \& Valenciennes, Hist. Nat. Poișs, vII, 57, 1831, Red Sea.

Chxtodon oxycephalus Bleeker, Ternate, 9de Beidr., 603, Ternate, Peters, Berl. Mon. 1876, 232, New Hanover. Chatodon tallii Bleeker, Banda, 3de Beidr., 97, Banda.

This large and handsome species is common at Honolulu and westward to the East Indies. It is recorded from Samoa, but we did not find it there.

1139. Chætodon lunula (Lacépede), Tifitifi laumea. Hawaii; Samoa; Papua; Oualan; Tahiti; Rarotonga; Nukahiva; Makatea and Tahiti (Seale).

Pomacentrus lunula Lacépède, Hist. Nat. Poiss., IV, 507, 1803, Ile de France.

Chatodon lunula, Cuvier \& Valenciennes, Hist. Nat. Poiss., 59, pl. 173, 1831, Ile de France, Prince of Wales I., New Guinea, Australia. Günther, Fische der Südsee, 42, Hawaii, Tahiti.

Chatodon biocellatus Cuvier \& Valenciennes, Hist. Nat. Poiss, 62, Oualan; young.

Tetragonoptrus fasciatus, Bleeker, Atlas, Chæt., 44, tab. XII; not Chatodon fasciatus Forskall; Java, Bawean, Borneo, Celebes, Sangi, Timor, Halmahera, Buro, Amboina, Ceram, New Gtinea.

This splendid species is rather common about Samoa, as at Honolulu. It has been confounded by Bleeker and others with Chatodon fasciatus Forskål of the Red Sea. The varied markings of the 
shoulders, with the broad white postocular band, are characteristic in the adult. The changes in the young are well figured by Dr. Günther.

We have 15 specimens from A pia and Pago Pago. One was colored in life as follows: Deep golden, a little olive-tinged and more dusky on back; chin gray; patch behind ocular stripe clear gray; oblique black band bordered before and behind by clear golden brown, a blackish blotch at first dorsal spine with golden brown behind it; spot on caudal peduncle and stripe on dorsal golden; a brown shade across dorsal and anal besicies black tips and dark brown bands; ventral golden with some dusky; pectoral and edge of caudal colorless.

1140. Chætodon flavirostris Günther. Vavau; Tonga; Faté (Seale).

Chxtodon flarinostris Güther, Fische der Südsee, $\mathbf{4 1}$, Vavau (Friendly Is.).

1141. Chætodon mertensi Cuvier \& Valenciennes, Tifitin pa'ipa'i. I'aumotu Is.; Samoa.

Chatorlon merlensi Cuvier \& Valenciennes, Hist. Nat. Poiss. VI, ti, 1831; after a drawing by Jertens from a epecimen from an unknown locality, Gỉnther, Fische der Südsee, 45, taf, 36, fig. B, I’umotu.

Of this rare species, hitherto known only from the scanty original description and from the excellent figure given by Dr. Günther, we have four specimens from Apia and Pago Pago. This species is known by the presence of fow distinct angular cross-bands, with some fainter ones. Behind these is a broad yellow cross-band involving most of the dorsal and anal.

The species (Chrtodon xanthums) called Tetragonoptrus mertensi by Bleeker is distinct from this species.

Colors of a specimen from Pago Pago, bluish gray; rich orange-yellow behind last dorsal spine, on body and dorsal and anal fins, including all of solt dorsal and nost of anal; forehead and a scapular bar dark brown; ocular stripe broader above, where it is white-edged, the two not meeting below; five $V$-shaped blackish cross-bars on body behind shoulder, the angle toward the head; 4 rows of spots in concavity of last bar, between it and the immaculate golden area; first dorsal light yellow; second with edge of black and light yellow; anal dusky gray in front, edged with orange, posteriorly like dorsal; caudal light yellowish gray at base, then deep orange-yellow, edged with a fine line of black, then yellow; ventral soiled gray; pectorals plain.

1142. Chætodon dixoni Regan. New Hebrides.

Chaloclon dixoni Regan, Ann. Mag. Nat. Hist., 1904, 276, New Hebrides.

1143. Chætodon melannotus Bloch \& Schneider. Tifitifi mulepule pa'ipa'i. Samoa; Fiji; New Guinea (Macleay); East Indies.

Chrtodon melannotus Bloch \& Schneider, Syst. Ichth., 224, 1801, Moluccas. Günther, Fische der Südsee, 44, Samog, Fiji Day; Fishes of India, 108, pl. 28, fig. 1, India. Steindachner, Ichth. Beitr., xvI, 230, 1893, Fiji. Chatodon dorsalis Cuvier \& Valenciennes, Hist. Nat. Poiss, vif, 70, Moluccas; name preoccupied.

Chatodon marginatus (Ehrenberg) Cuvier \& Valenciennes, Hist. Nat. Poiss., vif, 57, Massuah: name preoccupied, Chatodon abhortani Cuvier \& Valenciennes, Hist. Nat. Poiss, viI, 58, Ile de France.

Tetragonoptrus melanotus Bleeker, Atlas, Chrt., 43, tab. xiv, Batu, Celebes, Flores, Timor, Ternate, Ceram, Amboina, Goram, Banda.

This species is rather rare about Samoa, only seven specimens being taken at Apia and Pago Pago. The diffuse black spot at the base of the anal and the black spot at the throat are characteristic traits. Day has given a fair figure of the species.

Life colors of a specimen from Apia, gray, the contour all bright yellow; a broad, blackish patch occupying the whole back, this edged below by dull whitish; a large whitish blotch in the middle of the back; scales with dusky rows of diffuse blackish spots running upward and backward, these more streak-like above, the spots separate below, most distinct at base of anal, where they are gathered into an oblique jet-black spot of irregular outline; a black sireak along lateral line posteriorly, widened into a jet-black blotch below last soft dorsal rays; a smaller black blotch above last ana' ray on edge of caudal peduncle; ocular band narrow, edged on both sides with bright yellow; region before it brownish yellow, clear yellow at throat, a dusky spot on breast; spinous dorsal deep brownish yellow; solt dorsal dusky, then yellow, then a broad blackish band with a black line above, then clear yellow, with a dusky edge: anal broadly clear yellow, with a brownish shadeacross it, then dusky, then a black line, then clear yellow; caudal bright yellow, with a narrow; dusky shade, then a blackish cross line, the posterior half translucent; pectoral colorless, light yellow at base; ventral golden yellow.

Another specimen from Apia had the lower half of side light bluish gray, above blackish with a pale area; margin all around yellow, golden below, orange above, with black markings, peetoral and also broad tip of caudal colorless. 
1144. Chætodon reticulatus Cuvier \& Valenciennes. Matagi pulepule; Tifitifi a'au Samoa; Tahiti; Ulea; Paumotu Is; Rarotonga and Raiatea (Seale).

Chatodon reticulatus Cuvier \& Valenciennes, Hist. Nat. Poiss., VII, 32, Tahiti, Ulea.

Chatodon collaris Günther, Fische der Südsee 40, Paumotu; not of Bloch nor of Bleeker.

? Chxtodon bellicosus Quoy \& Gaimard, Voy. Astrolabe, 1835; a handsome brown-colored species seen at Guam but not secured; "bit at the finger when approached."

This splendid species is rather rare about Samoa, only 12 specimens being taken at Apia and Pago Pago. It is quite different from Chrodon collaris of the East Indies, with which it has been confounded by Günther, who gives a good figure, but the colors of the fish are brighter than his plate would indicate. The scarlet pateh on the anal is especially characteristic.

Life colors of a specimen from Apia, black, dove-gray above and behind ocular band; spots on scales bright yellow below, gray above; edge of ocular stripe golden; forehead and snout drab; lips golden; dorsal drab, edged with golden, with a dark and white streak; caudal black, then drab, black, yellow, black, then a drab edge; anal black, being scarlet behind, with 2 black stripes, a dull yellow one, the edge white; ventral and breast black, continuous with ocular band; pectoral colorless.

1145. Chætodon unimaculatus Bloch. Tifitif pulepule; Tifitifi samasama. Hawaii; Samoa; Tahiti; New Guinea (Macleay); Bonham I.; Faté (Seale); East Indies.

Chretodon unimaculatus Bloch, Ichth., taf. 201, 1787, Tahiti. Cuvier \& Valenciennes, Hist. Nat. Poiss., vir, 72, Tahiti. Günther, Fische der Sïdsee, 37, Bonham I., Tabiti, Samoa. Günther, Cat., II, I1, Amboina.

_Chxtodon sphenospilus Jenkins, Bull. U. S. Fish Comm., xIx, 1899 (1901), 395, Honolulu.

Tetragonoptrus umimaculatus, Bleeker, Atlas, Chæt, 45, tab. xIII. Java, Solor, Timor, Amboina, Ternate, Boro, Ceram, Banda.

This handsome species is widely diffused throughout the South Seas and to the East Indies and Hawaii. We have 20 examples from Samoa. The single black spot on the side well characterizes the species.

Life colors of a specimen from Apia, clear bright light yellow, becoming bluish gray below; ocular band broad, meeting below; faintly edged with gray; snout gray; golden edges to scales making faint oblique yellow streaks on shoulder; black lateral spot, broadly surrounded by gray, with a wedgeshaped downward extension of dusky gray; dorsal light bright yellow, a black bar across its posterior part and across caudal peduncle and anal fin, where it is narrower, the band bordered before and behind by gray, the posterior edge very narrow; caudal colorless; anal deep golden yellow, darker than dorsal; ventral deep golden yellow; pectoral colorless.

Another specimen was in life light golden above; gray beneath shoulders and front of sides, with $V$-shaped vertical bars of deep yellow, the angle directed toward the tail; ocular band very broad from front of dorsal, meeting across breast; snout and forehead gray; a large round black spot on middle of side of back, surrounded by gray; dorsal and anal clear yellow; a dark bar posteriorly on both, extending across caudal, edged on both sides with gray; posteriorly this is the margin of the dorsal and anal fins, both with whitish edge; caudal grayish white at base behind bar; rest of fin like pectoral, translucent with black dots; ventral golden yellow.

Compared with Hawaiian specimens there is a tendency in these to form a larger spot, more extensively produced into wedge-shaped process below. There is no other difference.

Chatodon unimaculatus differs strikingly from Chatodon ephippium and ulietensis in the teeth, which are stronger, not flexible, not more than two series functional, those of the two halves of each jaw converging toward median line. The horizontal series of enlarged scales on anterior part of sides are less marked than the oblique series, but are distinguishable and usually continuous with the horizonta] series of smaller scales behind. The larger scales have margin unequally curved (Lepidochatodon), but this character seems to have little value.

\section{Chætodon trichrous Günther. Tahiti.}

Chatodon trichrous Günther, Fische der Südsee, 40, pl, 36, Tahiti; on a drawing. Jordan \& Snyder, Proc. U. S. Nat. Mus., xxix, 1905, 355, fig. 2, Tahiti.

This species is known from an incorrect drawing made by Andrew Garrett, and published by Dr. Günther, and from a specimen, also from Tahiti, taken by Mr. Henry P. Bowie.

1147. Chætodon kleini Bloch. Yap; New Britain; East Indies.

Chatodon kleini Bloch, Ichth., IV, 7, taf, 218, fig.2, after Klein. Günther, Cat, Ir, 22, Amboina, Mauritius. Peters, Berl, Mon. 1876, 832, New Britain. 
Chatodon melanomysiax Bloch \& Schneider, Syst. Ichth., 1801, 224.

Chxtoclon melastomus Bloch \& Schneider, op. cit., 224, Tranguebar.

Chatodon favescens Bennett, Proc. Comm. Zool. Soc., 1830, I, 61, Mauritius.

Chatodon virescens Guvier \& Valenciennes, Hist. Nat. Poiss, vir, 30, 1831.

1148. Chætodon ephippium Cuvier \& Valenciennes. Tifitif taiona; Tifitifi ila; Tifitifi tusi. Hawaii; Tahiti; Sauoa; Kusai; Borabora; Guam; Tonga; New Guinea (Macleay); Woodlark 1.; East Indies; Rarotonga, Raiatea, and Faté (Seale).

Chxtodon ephippium Cuvier \& Valenciennes, Iist. Nat. Poiss., vil, s0, 1831, pl. 174, Moluccas, Borabora, Tahiti. Günther, Fische der Sidsee, 36, taf. 27, Tonga, Tahiti. Seale, Bishop Museum 1901, 97, Gltam.

Chxtodon principalis Cuvier \& Valenciennes, op. cit., 81, East Indies; on a drawing by Renard (young, showing a black area on and above the anal).

Chxtodon mulsanti Thiolliere, Fauna Woodlark, 163.

Tetragonoplms ephippinm, Bleeker, Atlas, Chat., 36, tab. xw, Cocos, Java, Celebes, Flores, Timor, Ternate, Amboina, Ceram, Haraucka, Goram, New Guinea.

This beautiful species is common in the coral reefs about Samoa. We have also a specimen from Kusai, Caroline Islands.

The species is known at once by the large black saddle, with a long filament on the soft dorsal above it. It is well figured by Günther, although the ground-color is darker than indicated by him. A young example has the dark anal area indicated in the description of chatodon pruncipalis.

Twenty-five specimens from A pia and Pago Pago. Life colors of one trom Apra, Irght grayish olive, side with five or six streaks of light violet; edge of opercle volet; side of head graysh; a grayish preorbital patch; black ocular stripe very narrow and faint; a narrow dark streak $11 k e$ a pencil-mark from fourth donsal spine downward and forward nearly to base of pectoral; snout and breast bright orange-yellow, brighter anteriorly; a bright orange-yellow streak across base of pectoral within and without; back with black saddle, broadly edged below with white; spinous dorsal yellow at tip, then gray, then a black streak, then orange-brown, then olive with blackish lines; filaments orange, edged before with yellow, behind with white; soft dorsal black, edged with yellow, orange-brown, black, white, and finally blackish; anal white, edged with yellow, grayish orange, grayish yellow, and finally blackish, the yellow predominating; the orange a bright streak; caudal translucent dark gray with deep orange blotch at base, the edges and posterior border orange-yellow.

In adults the ocular band is well marked only on the upper and lower borders of the eye, rapidly fading out on the cheek and supraocular region. In young individuals it is continued downward and backward across cheek and interopercle, and upward and backward to meet its tellow at the nape, but even in the young it is most intensely black near the eye. In the young the anal fin is blackish with a broad, light, submarginal band and blackish edge, and the caudal peduncle is crossed by a black ring, widest at the mid-lateral line.

1149. Chrtodon semeion Bleeker. Samoa; Tahiti; Thornton I.; Shortland I. (Seale).

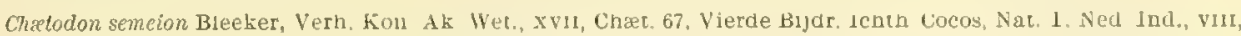
450, 1555, Keeling 1. Gunther, Fische der Sudsee, 37, taf. 28, Iahit, samoa Fowler, Proc. Ac. Nat. Sc. Pbila. 1899,492, Thornton 1 .

Tetragonoptrus semeron Bleeker, At!as, Chæt, 37, tab. xı (poor), Coeos, Celebes, Goram.

This species, one of the most beautiful of the group, is rare in the South Seas, and scarcely more common in the East Indies. We have bùt one specimen Irom Apia, which was colored in lile as follows: Deep rich lemon-yellow or orange-yellow, with blue-black dots on the scales; torelsead gray; ocular band black; pectoral and ventral lemon-yellow; dorsal yellow, streaked with blackish, the tips of the spines light clear yellow, a blue line separatıng this from the body color; last part of dorsal largely black, edged with dark yellow, light yellow, grayısh and blackısh, tinally brownısh; dorsal filament yellow; anal with less black and much more orange, otherwse similar; caudal IIght brownish, translucent behind, the upper and lower edge, also the midle brownisn, a yellowish inner stripe lining the brown margin.

1150. Chætodon punctatofasciatus Cuvier \& Valenciennes. Hawaii; East Indies.

Chatodon punctatofasciatus Cuvier \& Valenelennes, Hist. Nat. Folss., Vu, 2צ, no Jocalny.

Chatodon punctatolneatus Gronow, Cat. Fisn, ed. Gray, 1854, 70, 10calty unknown.

Chatodon mulucinctus Garrett, Proc. Ca. Ac. Scr. 1803, 05, Hawax. Gunther, Fisene der Sudsee, 11, taf. 34, fig. B, Sandwich 1 s.

Tetragonoptrus punctatofasciatus, Bleeker, Atlus, Chet., 40, tub. xir, Buro, Obi-major, Solor, Amboina, Bunda, Aneiteum. 
Of this rare species very few specimens are known. The specimens from the Hawailan Islands called multicinctus are probably identical with Chatodon punctalofasciatus, originally described from an unknown locality, but located by Bleeker in the East Indies.

Bleeker finds 6 to 8 dark bars on his species, and figures 8 . Those seen by us, all from Hawaii, have, like the type of Chxtodon multicinctus, but 6 bars.

1151. Chætodon miliaris Quoy \& Gaimard. Hawaii.

Chalodon milaris Quoy \& Gaimard, Voy. Astrolabe, 2s0, Maui, Hawaii, Günther, Fische der Südsee, in part, Sandwich Is. Steindachner, Sitz, Ak. Wsss. Wien 1900, 4\$9, Honolulu, Laysan. Jordan \& Evermann, Bull.

U. S. Fisb Comm, xxIII, 1903 (1905), 371, fig. 163, Honolulu.

Chatodon mantetrger Jenkıns, Bull. U. S. Fish Comm., xix, 1899 (1901), 394, Honolulu.

This little fish much resembles Chatodon cutrinellus, but the lines of dots form vertical stripes, and the anal is nearly plain, without the broad stripes of black and of glossy yellow characteristic of Chatodon citrnellus. Chatodon maliaris seems to be confined to the Hawalian Islands. a

1152. Chætodon citrinellus (Broussonet). Tifitifuli; Tifitifi lanifi; Manini. Samoa; Fiji; Paumotu Is.; Bonham I.; Papua; Tahıti; Rarotonga; Raiatea and Faté (Seale).

Chrtodon cutrnellus (Broussonet) Cuvier \& Valenciennes, Hist. Nat. Yoiss., VI1, 27, Guam. Gunther, Fische der Sudsee, 47, pl. 35, lig. B (poor figure), Paumotu, Tahit, Bonham, Samoa, Fiji. Jordan d: Evermann, Proc. U. S. Nat. Mus. 1902, Formosa.

Tetragonoptrus mizarı, Bleeker, Allas, Chæt., 39, tab. Xv, Sumatra, Padang, Java, Celebes, Sangi, Ternate, Buro, Amboina, Ceram, New Gunea, not Chætodon matians of Quoy \& Gaimard.

This species is distingushed from Chxlodon milians, which it much resembles, by a bright golden stripe just above (dorsad) a jet black stripe along the edge of the anal fin. The dark stripes extend in most specimens for the whole length of the body. Chatodon citrinellus is one of the smallest species, rarely exceeding four inches. It is common about the coral reefs of Samoa. We have 15 specimens from Pago Pago and 50 trom Apla.

Life colors of a specimen from Apia, dull light yellow olive, with series of blue spots along rows of scales; torehead brown, clear; ocular band narrowly edged above on both sides with grayish white, this border yellow-washed in larger examples; anal with a broad, black edge above a band of bright yellow; caudal plain orange, rather bright; solt dorsal yellow, with a narrow black, then a white line.

1153. Chætodon trifasciatus Park. Tifitif tala. Hawari; Samoa; Woodlark I.; Raiatea and Shortland I. (Seale); East Indies.

Chatodon trifascialus M ungo Parli, Trans, Linn. Soc., III, 34, 1792, Sumatra.

Tetragonoptrus trzasczatus, Bleeker. Atıs, Cnæt., 35, ta. xv. Sumatra, Java, Celebes, and all other East Indies.

Chxtodon vuttatus Blocn \& Scnnelder, byst 1 cntn, 227, 1501, Sumatra, alter Park. Gunther, Fische der Sudsee, 41, Paumotu. Gunther Cat, 11,23 , Ceram, Ambona.

Chætodon tau-nzorum Cuvier \& Valenciennes, Hist. Nat. Polss, vi!, 32, Guam, young.

? Chætodon austracus Ruppell, Neue Wirdetiniere, 3u, taf. 9, 1835, Red Sea.

Chxtodon ovals Tholhere, Fauna Woodlark, 164, 1857, Woodlark I.

Chatodon melapterus (Guichenot) Mastard, Reunion, 6, lle de Reunion.

This species is rather common about samoa, 42 specimens being in our collection. It is rather rare about Honolulu, where it is taken, however. We have one young example corresponding to Chatodon tau-nigrum. The species is common in the East Indies.

a We may here add an uncertain species

Chatodon species.

Chxtodon miliaris Gunther, Fische der Südsee, 46, in part; coloration of taf, 35, fig. $\mathbf{A}$, taken from a drawing by Garrett.

The coloration shown in Günther's plate of Chrtodon miliaris is not at all that of the species in question, which is not known outside ot Hawal. We nave notes on two young examples from Samoa corresponding to Güther's plate, but we have not been able to find the spectmens irom which the notes were taken. These probably represent a species still indescribed.

Life colors of a specimen from Apia, ohve yellow; clear yellow on head and breast; small bright blue stripes along Iows of scales; soft dorsal with black edge; anal with a wider one, and a white stripe at pase with one at edge; a black bloich on base of caudal peduncle, with two bright yellow spots and edged betore and behind with pale; caudal behind bar whitish. Young.

Another specimen, from the same localıty, was gray wath oblique dark blue stripes upward and packward; whole outline ot body deep gelden yellow; ocuar band broad, the part before 1 t golden; dorsal and anal all golden, the soft dorsal dark at base and with a dark edge, the dorsal and anal brighter yellow near the edge; caudal colorless, a broad black par at base surrounded by golden, this not on the fin. 
Colors in life of a specimen from Apia, creamy orange, grayer above, with many streaks of violet blue; head with jaws blackish, forehead brown; a golden streak, then the ocular band, then a whitish streak, yellow below, then brownish, whitish, and purplish black, the black stripe parallel with the ocular band; spinous dorsal light yellow with a purplish line below; soft dorsal yellow, black, yellow, violet, gray-purplish, violet-gray, the outsile creamy brown, the black surrounded by golden; caudal peduncle slaty, then whitish, golden, black, golden, and transparent, the black forming a broad bar; anal with a golden stripe at base, then black, becoming rich brown on spines, then golden, then dark brown, then golden, the black area surrounded by golden as on the dorsal; breast golden with a black blotch; ventral golden; pectoral pale yellow.

1154. Chætodon ornatissimus (Solander). Tifitif a'au. Hawaii; Samoa; Tahiti; Guam; New Guinea; Rarotonga (Seale); East Indies.

Chrtodon ormatissimus Solander, in Cuvier \& Valenciennes, Hist, Nat. Poiss., vir, 22, 1831, Tahiti. Günther, Fische der Südsee, 38, with plate, Sandwich Is. Seale, Bishop Museum 1901, 100, Guam.

Tetrayonoptrus ornatissimus, I3leeker, Atlns, Chrt., 32, tab. $\mathrm{xr}_{1}$ Amboina, New Guinea.

Chretodon ornatus Gray, Zool. Mise. 1834, 33, Sandwich Is.

A large and very handsome species generally common in the Sonth Seas and northward to Hawaii. We have 15 examples from Hawaii and Pago Pago. It is readily known by the presence of six oblique stripes of orange on the side of the body:

Life colors of a specimen from $\mathrm{Apia}$, gray; head and belly golden; five or six black vertical stripes across head, the interspaces yellow, these all parallel with the ocular band, which is the broadest; three orange bars before pectoral; six oblique stripes on body upward and backward, of rich orangebrown; a seventh stripe of dark brown on anal, this edged with a narrow black streak, then clear yellow, then black; dorsal with two yellow and a black stripe; caudal with two black stripes and a dull yellowish stripe between; base of fin gray; ventral golden; pectoral dull orange; breast anteriorly black at the meeting of the ocular bands.

1155. Chætodon bennetti Cuvier \& Valenciennes. Tahiti; Paumotu Is.; Gilbert Is.; Kingsmill I. ; East Indies.

Chætocion bennetti Cuvier \& Valenciennes, Hist. Nat. Poiss., VIr, 84, Sumatra. Günther, Fisebe der Südsee, p. 37, pl. 29, fig. A, Paumotu, Tahiti, Gilbert Is., Kingsmill I.

Chxtodon vinctus Bennett, Zool. Beechey's Voy. 62, pl. 17, fig. 1, 1849, Sumatra.

Tetragonoptrus benneti, Bleeker, Atlas, Chæt., 31, tab. xIv, Sumatra, Java, Halmahera, Amboina.

1156. Chætodon speculum Cuvier \& Valenciennes. New Guinea (Macleay); -East Indies.

1157. Chætodon plebejus (Broussonet). South Seas (Tahiti?); New Guinea (Macleay); India.

Chxtodon plebcjus (Broussonet) Cuvier \& Valenciennes, Hist. Nat. Poiss., VII, 68, South Seas. Günther, Fische der Südsee, 35, taf. 32, fig. B, same specimen. Day, Fishes of India, 104, pl. 26, from Broussonet's specimens, Andaman Is.

This species was long known from Broussonet's original type only, supposed to be from the South Seas, and preserved in the British Museum for one hundred and thirty years. The presence of four anal spines would necessitate the reference of the species to Megaprotodon, but the number is certainly accidental, as in other regards the species is a true Chxtodon. Day counts three dorsal spines only in his description, presumably drawn from a specimen from the Andaman Islands. His figure is from Broussonet's specimen and shows four. The species is recorded by Macleay from New Guinea.

1158. Chætodon quadrimaculatus Gray. Hawaii.

Chatodon quadrimaculatus Gray, Zool. Misc., 33, 1831, Sandwich Is. Günther, Fische der Südsee, 38, taf. 30, fig. A, Upolu, Sandwich Is. Jordan \& Evermann, Bull. U. S. Fish Comm., xxıI, 1903 (1905), 373, pl, xyıx, Hawail.

This fish is rather common about Honolulu. It has been recorded by Günther from Samoa, the figure published differing a god deal from our specimens of the fish. The species is well distinguished by the black back with two pale blotches and by the mesial yellow of the ocular stripe.

1159. Chætodon corallicola Snyder. Hawaii.

Chxtodon corallicola Snyder, Bull. U. S. Fish Comm., xxil, 1902 (1904), 53, with pl, 11, fig. 20, Albatross Station 4032, on Penguin Bank, south coast of Oahu $I$.

This species is known only from the specimens collected by the Albatross. It is a dull-colored species, with a broad, diffuse ocular band. It is an ally of Chrododon flavirostris.

B. B. F. 1905-23 
1160. Chætodon fremblii Bennett. Hawaii; Laysan.

Chrtodon fiemblii Bennett, Zool. Journ. IV, 42, 1829, Sandwich Is. Günther, Fische der Südsee, II, 39, taf. 29, fig. B, Sand wich Is. Steindachner, Sitz. Ak. Wiss. Wien 1900, 488, Laysan.

Chrtodon fremblii, Cuvier \& Valenciennes, Hist. Nat. Poiss., viI, 24, 1831; after Bęnzett.

This handsome species, well distinguished by its stripes of clear blue, has been found only about the Hawaiian Islands, where it is rather rare.

\section{MICROCANTHUS Swainson.}

Microcanthus Swainson, Class. Anim., II, 1839, 215 (strigatus).

This genus differs from Chretodon chiefly in the small scales, there being about 60 in the lateral line. The soft dorsal and anal are shorter than is usual in Chatodon, the fin formula of the typical species being dorsal XI,17; anal III,14. It is in fact doubtful whether the genus contains another species, as the other species with small scales have the soft fins many-rayed and constitute Bleeker's genus Hemiiaurichthys (type polylepis), which is apparently a valid genus, with no close relation to Microcanthus strigatus.

\section{Microcanthus strigatus (Cuvier \& Valenciennes). Hawaii; East Indies.}

This species, common in southern Japan and the East Indies, is occasionally taken about Hawaii. It was found there by Garrett, by Jenkins, and by Jordan \& Evermann.

\section{HENIOCHUS Cuvier \& Valenciennes.}

Heniochus Cuvier \& Valenciennes, Hist. Nat. Poiss., vir, 92, 1831 (macrolepidotus).

Taurichthys Cuvier \& Valenciennes, Hist. Nat. Poiss., vIr, 146,-1831 (varius).

Diphreutes Cantor, Malayan Fisbes, 159, 1850 (macrolepidotus); substitute for Heniochus, on account of Henioche, a prior genus of Lepidoptera.

This genus is characterized by the deep body and by the prolongation of one of the dorsal spines. The species are all marked by dark cross-bands.

1162. Heniochus acuminatus (Linnrus). Laularfau. Hawaii; Samoa; Fiji; New Britain; New Hanover; New Guinea; East Indies.

Chælodon acuminatus Linnæus, Syst. Nat., ed. $\mathrm{X}, 272,1758$, Indies; after Chxtodon fascius 9 -fusca.

Chrtodon macrolepidotus Linnæus, Syst. Nat., ed. $\mathrm{x}, 274,1758$, Indies; after Chrotodon lineis utruique \&-nigris, of Artedi.

Heniochus mactolepidotus, Cuvier \& Valenciennes, Hist. Nat. Poiss., vir, 93, 1831, Molucca, Ile de France, Manila, New Guinea, Trincomalee. Günther, Fische der Südsee, 48, taf. 37, Polynesia.

Taurichthys macrolepidotus, Bleeker, Atlas, chæt., 29, tab. v, fig. 1, Luzon, New Guinea, Singapore, Sumatra, and all East Indian islands.

This widely distributed species is not common in the South Seas. We have specimens from Hawaii and a single large specimen from Apia.

The latter in life showed the following colors: Head gray; snout black above, a gray streak between eyes; no ocular band; two black bands, the first including the short dorsal spines across to breast, ventrals, and whole front of anal; second including last dorsal spines and most of soft anal; a short white bar behind this; second dorsal and caudal bright golden; pectoral golden; lips pale; long spine white.

The name acuminatus has two pages priority over macrotepidotus.

1163. Heniochus permutatus Bennett. Tahiti; Samoa; New Guinea; Woodlark I.; East Indies.

Heniochus permutatus Bennett in Cuvier \& Valenciennes, Hist. Nat. Poiss., vir, 99, 1831, no locality.

Heniochus chrysostomus Cuvier \& Valenciennes, Hist. Nat. Poiss., viI, 99, 1831, Tahiti. Günther, Fische der Südsee, 49, taf. 39, fig. A, Paumotu, Tahiti.

Taurichthys chrysostomus, Bleeker, Atlas, Chret., 29, tab. IV, fig. 2, Flores, Ternate, Ceram, Amboira, Banda, Goram, New Guinea.

Heniochus melanistion Bleeker, Bydr. Ich: Banda, Banda.

Heniochus drepanoides Thiollière, in Montrouzier, Fauna Woodlark Island, 166, Woodlark I.

This species is rather rare about Samoa, where 7 specimens were taken, 5 from Pago Pago, and 2 from Apia. It is apparently identical with the species called Heniochus permutatus by Bennett, suc- 
cinctly described as having the colors of Heniochus macrolepidotus reversed, black for white and white for black.

Life colors of a specimen from Apia, 3 bands dark brown, the first blackish, alternating with white; yellowish tinged in places; the snout and lips orange; forehead duil orange with a black median stripe; dorsal colored like the body, the posterior part and caudal dull yellowish; yentral black; anal with a black, gray-edged ocellus in the center of the black area, most distinct in the young; long dorsal spines black, the tips of the spines whitish.

1164. Heniochus intermedius Steindachner. Pacific.

Heniochus intermedius Steindachner, Sitz. Ak. Wiss. Wien 1893, 222, locality unknown.

1165. Heniochus monoceros Cuvier \& Valenciennes. Samoa (Günther); Tahiti; East Indies.

Heniochus monoceros Cuvier \& Valenciennes, Hist. Nat. Yoiss, vII, 100, 1831, Ile de France. Günther, Fische der Sudsee, 49, taf. 38, Samoa, Tabiti.

Taurichthys monoceros, Bleeker, Atlas, Chæt., 28, tab. IIr, fig. 3, Java.

This rare species is recorded by Dr. Günther from Samoa. It was not seen by us.

1166. Heniochus varius (Cuvier \& Valenciennes). Samoa; East Indies.

Taurichthys varius Cuvier \& Valenciennes, Hist. Nat, Poiss., v1I, 148, pl. 181, East Indies.

Taurichthys varius Bleeker, Atlas, Chæt., 27, tab. II, fig, 2, Batu, Java, Cclebes, Timor, Amboina, Ceram, Banda.

Taurichthys viridis Cuvier \& Valenciennes, Hist. Nat. Poiss., VII, 152, Amboina.

One specimen of this species was taken by us at Apia. Otherwise the species is not recorded from Polynesia. Life colors, olive brown, blackish below where black streaks follow the rows of scales; lips, head, and nape black; breast gray, not black, as figured by Bleeker; a grayish olive band to front of spinous dorsal; a clear white bar from tip of long dorsal spine to lower base of caudal; dorsal olive, the first spines dusky; caudal pale olive; ventral, anal, and pectoral black.

HOLACANTHUS Lacépède. Alamu.

Holacanthus Lacépède, Hist. Nat. Poiss., Iv, 525, 1803. (H. tricolor; scales large; caudal forked.) Genicanthus Swainson, Class. Fishes, II, 212, 1839. (G.lamarckii; scales large; caudal forked.) Centropyge Kaup, Wiegmann's Archiv, xxvI, 138, 1876. (C. titicen; erroneously said,to have four anal spines.)

Chrtodontoplus Bleeker, Archiv Neerl. Sci. Nat., xiI, 26, 1876. (C. mesoleucus; isthmus broad.) Acanthochatodon Bleeker, Archiv Neerl. Sci. Nat., xiI, 5, 1876. (A.lepidolepis; isthmus narrow; body elevated.)

Angelichthys Jordan \& Evermann, Check-list of fishes, 420, 1896. (A. ciliaris.)

Preopercle with a stout spine; dorsal spines 12 to 14 . The species of this genus are almost all gaudily colored and some of them reach a large size. They differ widely among themselves, but not so as to permit generic subdivision. The different subgeneric groups-IIolacanthus, with relatively large scales and angular dorsal and anal; Angelichthys, with strong spines on the preopercle; Chxtodontoplus, with very small scales and rounded dorsal and anal; Acanthochatodon, with moderate sized scales and elevated dorsal and anal-are recognizable groups. Another subgenus equally well marked may be based upon Holacunthus fisheri, a species with strong spines on the preorbital. Most of the species in the South Seas belong to the typical subgenus Holacanthus.

1167. Holacanthus diacanthus (Boddaert). Aimeo; Alamu. Samoa; Paumotu Is; Tahiti; New Guinea; East Indies.

Chrtodon diacanthus Boddaert, De Chæt., 1772.

Iolacanthus diacanthus Günther, Fische der Sudsee, 50, taf. 40, fig. B, Samon, Tahiti, Paumotu. Bleeker, Atlas, Cbet., 65, tab. vi, fig. 5, Celebes, Flores, Ceram, Java, Amboina, Timor, New Guinca, Banda.

Chatodon fasciatus Bloch, Ichth., taf, 195, 1788, after Boddaert.

Chxtodon boddaerti Gmelin, Syst. Nat., 1243, 1788, after Boddaert.

Chxtodon dux Gmelin, Syst. Nat, 1255, 1788, after Bloch.

This lavishly gaudy fish is very common about the coral reefs of Samoa. About 16 specimens were preserved from Apia and Pago Pago. Life colors of one from Apia, about 9 broad curved stripes, pale blue with dark-blue edges, the interspaces deep orange-yellow, pale yellow below; another narrow blue stripe at base of caudal; two others above eye; lips yellow; a blue curved streak below eye; 
lower parts livid gray; stripes of body extending back on dorsal above them, in paler yellow and purplish blue; upper part of fin of deep orange with two pale-blue stripes with dark-blue edge; second dorsal almost black-orange, washed with dark; caudal light clear yellow, with a few dark specks; anal with many stripes of steel-blue and orange, the margin black-blue; ventral golden-yellow, edged anterioriy with dusky; pectoral colorless; a median blue streak on forehead; serrated edge of preopercle blue; preopercular spine blue.

1168. Holacanthus bicolor Bloch. Ulapua. Samoa; Hawaii (Günther); Solomon Is.; New Guinea; East Iudies.

Chalodon bicolor Bloch, Ichth., taf. 206, Indies; plate from this species; description confused with the American species, $\boldsymbol{H}$. tricolor:

Holacanthus bicolor, Cuvier \& Valenciennes, Hist: Nat. Poiss., vir, 168, 1831, East Indies. Gunther, Fische der Südsee, 51, taf. 39, fig. B, Samoa, Solomon Is., Hawaii. Bleeker, Atlas, Chæt, 61, tab.vir, fig. 3, Sumatra, Flores, Solor, Ternate, Ceram, Amboina, Saparua, Banda, Aru, New Guinea.

This handsome species is moderately common about the coral reefs of Samoa. We did not find it at Hawaii, and it is possible that Garrett's sketch on which the Hawaiian record rests was made at Tahiti. The coloration of this species is almost exactly that of the West Indian "fock beauty," Holacanthus tricolor, but the form of the body and fins is different.

Four specimens were taken at Apia, and 8 at Pago Pago. Life colors of one from Pago Pago, anteriorly brilliant yellow, slightly brownish tinged above pectoral, bordered behind by clear yellow which covers throat, breast, pectural, and ventral; body posteriorly lustrous blue-black, the color including anal and most of dorsal; caudal and end of caudal peduncle brilliant yellow; a broad, blueblack bar connecting eyes above, this bar fading below; an orange spot above gill-opening; edge of opercle orange; lower lip slightly bluish; four orange spots below it, the anterior largest; spine of preopercle grayish blue.

1169. Holacanthus flavissimus Cuvier \& Valenciennes. Lega; Aimeo. Ulea; Samoa; Fiji; Tahiti; New Hebrides; Harvey Is.; Kingsmill I.; Raiatea.

Holacanthus flarissimus Cuvier \& Valenciennes, Hist. Nat. Poiss,, VII, 197, 1831, Ulea.

Holacanthus luteolus Cuvier \& Valenciennes, Hist. Nat. Poiss., vir, 197, 1831, Tahiti; on a drawing by Parkinson.

IIolacanthus cyanotis Günther, Cat., II, 517, 1860, Aneiteum. Günther, Fische der Südsee, 52, taf. 40, fig. A, New Hebrides, Kingsmill, Tahiti, Harvey, Samoa, Fiji.

Holacanthus monophthalmus Kner, Sitz. Ak. Wiss. Wien 1867, 714, fig. 2, Raiatea, young. Kner, op. cil., 1868, 16, Savay.

Holacanthus ocularis Peters, Berl, Mon. 1868 147, South Seas.

Five specimens from A pia, 12 from Pago Pago. This beatiful species is rather common about the coral reefs of Samoa. The first good account of it is that of Dr. Günther, under the name of Holacanthus cyanotis. Holacanthus flavissimus is evidently the same, the blue markings on the head being inconspicuous in faded specimens.

Life colors of a specimen from Apia, clear deep yellow, citron-yellow below, fins all the same; dorsal, anal, and caudal with very narrow bright blue edge; a deep blue ring around orange eye; $\mathbf{a}$ deep violet-blue bar on opercle with an orange edge behind; preopercular spines and two bars across chin slaty blue; two slaty spots on breast; upper lip slaty. Gill membranes scarcely joined to isthmus.

1170. Holacanthus bispinosus Günther. Tu'u'u pulepule mumu. Hawaii (Günther); Samoa; Tahiti; New Hebrides; Amboina.

Holacanthus bispinosus Gunther, Fische der Südsee, 51, pl. 56, fig. C, Tahiti, New Hebrides, Hawail. Bleeker, Atlas, Chæt, 60, tab. VI, fig, 1, Amboina.

This very small and neatly colored species resembles a Pomacentrus. It is rare about the reefs at Tutuila, but two specimens being taken at Pago Pago. It was not found by us at Hawaii. The plate in the Fishes of Hawaii is taken from a specimen from Pago Pago.

Life colors, deep orange- or copper-red, clearer below; the head, back, and vertical fins blue-black, the dark color forming about 18 narrow dark cross streaks on side as wide as the ground color; breast and belly orange; sides of head dull orange, the lips and spines violet; lower lip very bright blue; anal and dorsal edged with blue; caudal with a broader blue stripe inside the margin; pectoral yellow, dusky at base; ventral orange, edged with blackish.

1171. Holacanthus navarchus Cuvier \& Valenciennes. New Guinea (Macleay); East Indies. 
1172. Holacanthus Ioriculus Gụnther. Tahiti.

IIolacanthus toriculus Güinther, Fische der Südsee, 53, taf. 40, fig. 6, Tahiti.

This species is known only from a drawing by Ir. Garrett of a specimen $2 \frac{1}{2}$ inches long, taken frow the stomach of an Epinephelus at Tahiti.

1173. Holacanthus arcuatus Gray. Hawaii.

Iolacanthus arcuatus Gray, Zool. Misc. 33, 1831, Hawaii. Günther, Fische der Südsee, 50, taf. 32, fig. C, same specimen.

Of this species only the original type specimen from Hawaii is known.

1174. Holacanthus fisheri Snyder. Hawaii.

IIolacanthus fisheri Snyder, Bull. U. S. Fish Comm., xxI, 1902 (1904), 532, p], 11, fig. 21, Hawaii.

This species, notable for the great size of its preorbital spines, is known from numerous specimens taken about the Hawailan Islands.

1175. Holacanthus imperator (Bloch). Papua; Guam; Tahiti; Paumotu Is.; East Indies.

Chretodon imperator Bloch, Ichth., taf. 94, 1788, Moluccas.

IIolacanthus imperator, Günther, Fische der Sïdsee, 53, taf. 41, fig. A, Tahiti, Paumotu, Ile de France, Red Sea. Seale, Bishop Museum, vol. I, no. 3, 101, 1901, Guam.

Acanthochatorion imperator, Bleeker, Atlas, Chrt, 70, tab. v, fig. 2, pl. 12, fig. 4, Celebes, Amboina, Niew Guinea.

This large and showy species was not seen by us at Samoa.

1176. Holacanthus marianas Seale. Guam.

Holacanthus manianas Seale, Bishop Mfuseum, vol, I, no. 3, 104, 1901, Guam.

This species, apparently distinct from $I I$. imperator, is unknown to us.

1177. Holacanthus nicobariensis (Bloch \& Schneider). Samoa; Misol; Tahiti; Waigiu; Guam; East Indies.

Chrtodon nicobariensis Bloch \& Schneider, Syst. Ichth., 219, pl. 50, Nicobar Is.; misprinted Nicobarcensis, all error corrected in the errata.

Holacanthus nicobariensis, Günther Fische der Südsee, 54, Misol, Tahiti, Samoa. Seale, Bisbop Museum, vol. I, no. 3, 105, 1901, Guam.

Acanthochatodon nicobariensis, Bleeker, Atlas, Chæt., 69, in part (the plate represents some other fish), Timor Amboina, Ceram, Waigiu.

Holacanthus geometricus Lacepède, Hist. Nat, Poiss., IV, 537, 1803.

This beautiful fish seems to be rare about Samoa. A single young specimen was taken in a tidepool at Pago Pago. Life colors, blue-black, the concentric streaks part white, part pale blue, the widest and the fin edgings pure white; ventrals blue edged.

1178. Holacanthus bishopi Seale. Guam.

IIolacauthus bishopi Seale, Bishop Museum, vol. I, no. 3, 106, 1901, Guam.

This species is apparently distinct from $I$. nicabariensis.

1179. Holacanthus semicirculatus Cuvier \& Valenciennes NewGuinea (Macleay); Waigiu; New Ireland; Woodlark; East Indies.

Holacanthus semicirculalus Cuvier \& Valenciennes, Hist. Nat. Poiss., vi, 191, Buru, Waigiu, New Ireland. Acanthochatodon semicuculatus Bleeker, Allas, Chat. 69, pl. 8, fig. 5, Sumatra, Java, Timor, and the islands of the East Indies generally.

Chitodon macrolepis Blceker, Fish. Sumatra, 257, Sumatra.

Holacanthus iburu Thılliere, in Montrouzier, Fuuna Woodlark, 169, 1857, Woodlark I.

This species, common in the East Indies, extends eastward to Melanesia, but has not been found about Samoa.

1180. Holacanthus altemans Cuvier \& Valenciennes. New Britain; Madagascar.

Holacanthus culernans Cuvier \& Valenclennes, Hist. Nat. Poiss., v11, 193, 1831, Madagascar. Peters, Berl. Mon. $1876,83^{3}$, Xew Britain. 


\section{Family ZANCLIDE.}

\section{ZANCLUS (Commerson Ms.) Lacépède.}

Zanclus (Commerson Ms.) Lacépède, Hist. Nat. Poiss., rv, 473, 1803 (cornutus).

Pomacanthus Lacépède, Hist. Nat. Poiss., Iv, 1803, 517 (canescens, etc.).

Zanclus Cuvier \& Valenciennes, Hist. Nat. Poiss., viI, 102, 1831 (cornutus).

Gonopterus Gronow, Cat. Fish., ed. Gray, 77, 1854 (morens).

Gnathocentrum Guichenot, Ann. Maine et Loire, Ix, 1866, 4 (centrognathum; young).

1181. Zanclus canescens (Linnæus). Tifitifi; Galafa. Hawail; Samoa: Papua; Waigiu; Woodlark I. ; East Indies; Revillagigedo Is.

Chrtodon canescens Linneus, Syst. Nat., ed. $\mathrm{x}, 272,1758$, Indies; after Artedi, youms

Pomacanthus canescens Lacepede, Hist. Nat. Poiss., IF, 517, 1803.

Zanclus canescens Guinther, Cat., II, 493, 1860. Bleeker, Atlas, 78, tab. v, fig. 3, 1877-8, Celebes, Amboina. Jordau \& Fowler, Proc. U. S. Nat, Mus., 549, 1902, Misaki (Japan).

Chrtodon cormutres Linnæus, Syst. Nat., ed. $\mathrm{x}, 273,1758$ after Artedi, adult. Lacépède, Hist. Nat. Poiss., Iv, 473, 1803, pl, 2, fig. 1. Jordan \& Evermann, Fish North and Mid, Amer, 11, 1687, 1898.

Zanclus comutus Cupier \& Valeneiennes, Hist. Nat. Poiss, vir, 102, pl. CLxxvir, 1831. Bleeker, Atlas, 77, tab. Iv, figs. 1, 2, 1877-8, Sumatra, Java, Celebes, Ceram, New Guinea, Waigiu, etc.

Zanclus centrognahus Cuvier \& Valenciennes, Hist. Nat. Poiss, vir, 528, 1831, near equator, 75 E.

Gonopterus merens Gronow, Cat. Fish. ed. Gray, 77, 185t, India.

Chatodon nudus Gronow, Cat. Fish,, ed. Gray, 76, 1854, Mari indico.

Zanclus montrouzieri Thiollière, in Montrouzier, Fauma Woodlark, 168, 1857, Woodlark I.

This species is everywhere common throughout the Pacific Ocean, from the off-shore islands of Mexico to Hawaii and southern Japan. We have 20 examples from Apia and 3 from Pago Pago.

\section{Family ACANTHURIDE.}

\section{HEPATUS Gronow, 1763.}

(Teuthis Linnæus, 1766; Harpurus Forster; Acronurus Gronow, 1854.)

1182. Hepatus achilles (Shaw). Pone i'umumu. Hawaii; Samoa; Marcus I.; Rarotonga and Makatea (Seale).

This beautiful fish is rare about Samoa, as about Hawaii. We have two large specimens from Pago Pago and one from Apia. The red tail-patch is very brilliant in life.

1183. Hepatus aliala (Lesson). Llamea samasama; Loata. Oualan; Samoa; New Guinea; Guam; Clarion Is.

This well-marked species is not rare about Samoa. We have ten specimens from Apia and Pago Pago. It is found also on the off-shore islands of Mexico.

Life colors of a specimen from Apia, called alamea samasama, olive-black; pure black in front; dorsal dusky mottled olive with black and blue edge, and a bright yellow line at base, which widens and covers most of last ray of dorsal; caudal drab gray with a pale violet-gray edge and a golden crescent; spine golden; anal like dorsal in color; pectoral and ventral blackish, both edged with grayish blue, edged in front with sky-blue; a whitish patch below eye and a white ring around throat behind chin; edge of opercle light golden olive.

1184. Hepatus olivaceus (Bloch \& Schneider). Tahiti; Paumotu Is.; Samoa; Palau Is.; Hawaii; New Guinea; East Indies.

This species, easily recognized by the mark at the shoulder, is frequently taken about Hawaii and Samoa. We have 5 examples from Samoa.

Color in life of a specimen from Apia, lemon-yellow, olive-shaded above; fins all yellow with dark edgings; axil and tip of cauda! bright orange-yellow; a blackish brown stripe on pectoral, extending to its middle, without edging in young. Another specimen trom Apia was black, with orange-black edged stripe, and a third was bright brownush yellow, the black stripe mesially bright orange.

1185. Hepatus pyriferus (Kittlitz). Ulea.

Acanthurus pyriferus Kittlitz, Senckenberg Museum, I, 193, taf. 12, fig. 2, 1834, Ulea. Gunther, Fische der Südsee, 113.

Acanthurus armzger Cuvier \& Valenciennes, Hist. Nat. Poiss, X, 234, 1835.

This species is unknown to us. 
1186. Hepatus nigricans (Linnæus). Uliuli maia; $T u$ sina. Tahiti; Paumotu Is.; Samoa; Fiji; Harvey Is. ; Bougainville Is.; Gilbert Is.; New Guinea; East Indies.

Chatodon nigricans Linnæus, Syst. Nat., ed. $x, 1758$, Red Sea; after Artedi.

Chxtodon gahhm Forskal, Descr. Anim., 64, Red Sea.

Acanthurus gahm, Günther, Fissche der südsee, 113, taf. 74, Tahiti, Paumotu, Samoa, Harvey Is., Bougainville Is., Gilbert Is.

This widely distributed species is rather common about Samoa. - We have ten specimens. In all the adult specimens the caudal fin has no white ring at base, being except for the pale crescent at tip dark brown like the body. In one young example the caudal fin is abruptly gray.

The name Chxtodon nigricans, based on a fish from the Red Sea, dusky, with the caudal whitish, could be no other species. Acanthurus dorënsis is probably the same, the anal rays miscounted.

Life colors of a specimen from Apia called uliuli maia, very dark olive; fins black; a black oblong stripe or spot behind gill opening on level of eye extending about to middle of pectoral; this is black, faintly and narrowly edged with pale blue; pectoral with agolden vertical stripe, behind which the fin is colorless; caudal conspicuously edged with white; dorsal and anal with dark and light blue, the streak very narrow, faint on dorsal; ventral reddish brown on inner rays; no white spot before eye; lips dark; no caudal ring nor axil spot.

A specimen from Pago Pago called $i$ 'u sina, was black, with brownish shade; no streakg, but a sanding of darker specks; a horizontal oblong black stripe or spot from angle of gill opening toward near end of pectoral; fins all black, the anal narrowly edged with clear blue; dorsal more narrowly edged with black; caudal very lunate, edged with white; pectoral with a bright yellow cross-bar.

1187. Hepatus doreensis (Cuvier \& Valenciennes). New Guinea.

Acanthurus doreënsis Cuvier \& Valenciennes, Hist. Nat. Poiss., $\mathrm{X}, 220$, Dorey Harbor (New Guinea).

This species has the coloration of the young of Hepatus nigricans. It is said, however, to have but 20 soft rays in the anal fin, a number lower than in any other species. It is perhaps the young of Hepatus nigricans, perhaps that of $I I$. elongatus, a species in which the caudal shows usually a narrow pale edge. It is, however, by Macleay recorded as a distinct species.

1188. Hepatus aterrimus (Günther). Samoa.

Acanthurus aterrimus Günther, Proc. Zool. Soc., 1871, 660, Savay. Günther, Fische der Südsee, 114, taf. 77, fig. B, Savay.

This species, described from Samoa, was not seen by us., The deep body and the white crescent on the caudal are the characteristic traits.

1189. Hepatus lineatus (Gmelin). Alogo. Tahiti; Samoa; Guam; New Guinea; Faté (Seale); Zanzibar.

Chelodon lineatus Gmelin, Syst. Nat., 1246, 1789, "America, Australis et India."

Acanthurus lineatus Güther, Fische der Südsee, 111, taf. 70, Samoa, Tahiti, Zanzibar. Kner, Novara Fische, 210; Tahiti. Streets, Bull. U. S. Nat. Mus., vir, 100, Samoa,

Teuthis linealus Seale, Bishop Museum, 1901, 108, Guam.

This gaudily colored species is very common about Samoa. We have about 50 examples from the reefs at Apia and Pago Pago.

Life colors of a specimen from Apia, deep blue stripes, each with a pale median line, alternating with golden stripes; belly livid blue, the breast golden, the region behind ventrals orange; two golden and two vertical cross-stripes at base of tail; dorsal olive with pale blue stripes and blue edge; caudal blackish with blue crescent; anal olive-green, pale blue at edge, orange at base; ventral orange, with a deep blue edge; pectoral orange at base, dusky behind, with sky-blue spots.

1190. Hepatus dussumieri (Cuvier \& Valenciennes). New Guinea; Hawaii; East Indies.

Acanthurus argenteus Quoy \& Gaimard, Voy, Uranie, 373, 1824, pl, 63, fig. 3, Maui; larva, the species ,uncertain, nearest Teuthis dussumieri, perhaps $T$. matoides.

Acanthurus dussumieri Cuvier \& Valenciennes, Hist. Nat. Poiss., x, 201, 1835, Ile de France. Günther, Fische der Südsee, 112, taf. 72, Hawaii. Steindachner, Sitz. Ak. Wiss. Wien 1900, 493, Honolulu.

:Acanthurus lincolahus Cuvier \& Valenciennes, Hist. Nat, Poiss, $x, 207,1835$, Indian Ocean.

This species is the commonest of its genus about the Hawailan Islands. We did not find it at Samoa. 
1191. Hepatus atramentatus Jordan \& Evermann. Hawaii; Samoa; Laysan; Marcus I.; Tahiti. Acanthurus lineolatus Günther, Fische der Südsee, 112, taf. 73, fig. A, Tahiti; not of Cuvier \&. Valenciennes. Steindachner, Sitz. Ak. Wiss. Wien 1900, 493, Honolulu.

Teuthis atramentalus (by misprint atrimentatus) Jordan \& Evermann, Bull. U. S. Fish Comm., XxIr, 1902 (1903), 198, Hawaii. Snyder, Bull. U. S. Fish Comma., XxIr, 1902 (1903), 533, Laysan. Bryan \& Herre, Bishop Museum 1903, 133, Marcus I.

Of this species, rather common at Hawaii, we found but one specimen in Samoa. The body is striped with blue, as in Hepatus dussumieri, but there is an ink-like spot at the base of the last dorsal and anal rays.

1192. Hepatus elongatus Cuvier \& Valenciennes. Unavau. Hawaii; Samoa; New Hebrides; Palau; Tahiti; Marcus I.; Guam; Faté, and Tubuai (Seale).

Chratodon elongatus Lacépède, Hist. Nat. Poiss, IV, 471, pl, 6, fig, 2, 1803, Pacific Ocean.

Acanthurus nigroris Cuvier \& Valenciennes, Hist. Nat. Yoiss., X, 208, 1835, Hawaii.

Acanthures bipunctatus Günther, Cat., III, 331, Sea of China, Fiji Is. Steindachner, Sitz, Ak. Wiss. Wien 1900, 494. Honolulu.

Acanthurus nigros Günther, Cat, III, 332, New Hebrides. Günther, Fische der Südsee, 110, New Hebrides, Palau, Tahiti.

Teuthis bipunctatus Jordan \& Fowler, Proc. U. S. Nat. Mus. 1901, 554, Riukiu Is., Kotosho, Formosa. Bryan \& Herre, Bishop Museum 1903, 134, Marcus I.

Teuthis mata Seale, Bishop Museum, 1901, 107, Guam; not of Cuvier \& Valenciennes.

This species is common about Samoa, and also about Hawaii. It is often distinguishable by the black bloteh at base of soft dorsal and anal, but in dark colored examples, as most of ours are, this spot is inseparable from the black ground-color of the fins. The body is very dark brown, without stripes. Hepatus mata Cuvier \& Valenciennes of India, has the same color but the profile is straight and not so steep.

Of the various names given to fishes of this sort we have chosen as earliest the name elongatus of Lacépède. While his description amounts to little, and that of Cuvier \& Valenciennes is scarcely better, his figure represents this species, which differs from all others in being plain blackish brown on body and fins, the black spot on last rays of dorsal and anal distinct only in paler specimens.

In this species the body is uniform brown; the caudal has usually a narrow pale edge and the snout is usually dusky.

1193. Hepatus fuliginosus (Lesson). Oualan, or Strong I.

Acanthurus fuliginosus Lesson, Voy, Coquille, II, 149, pl. 27, fig. 2, 1830, Oualan.

This species is said to have the lips blue, the body brownish with faint bluish streaks, and but 20 soft rays in the anal. We have not seen it. It may be identical with Hepatus elongatus.

1194. Hepatus bariene (Lesson). Waigiu.

Acanthurus bariene Lesson, Voy. Coquille, II, 149, 1830, Waigiu.

Acanthurus nummifer Cuvier \& Valenciennes, Hist. Nat. Poiss., x, 234, 1835, Waigiu; same type.

1195. Hepatus celebicus (Bleeker). Tahiti; Solomon Is.; East Indies.

Acanthurus celebicus Bleeker, 1852, 761, Celebes, Ternate. Günther, Fische dcr Südsee, 115, taf. 73, fig. B, Solomon Is., Tahiti.

1196. Hepatus leucopareius (Jenkins). Hawaii.

Teuthis leucopareius Jenkins, Bull, U. S. Fish Comm., XxII, 1902 (1903), 476, fig. 28, Honolulu.

1197. Hepatus matoides (Cuvier \& Valenciennes). Umelei. Hawaii; Samoa; Fiji; Oualan; Bougainville I.; New Guinea; East Indies.

Acanthurus matoides Cuvier \& Valenciennes, Hist. Nat. Poiss., $\mathbf{x}, 204$, 1835, Oualan. Sauvage, Poiss. Madagascar, 340; same type. Peters, Berl. Mon. 1876, 835, Bougainville I.

Acanthurus annularis Cuvier \& Valenciennes, op. eit., $\mathrm{x}, 209,1835$, lle de France.

Acanthurus blochii Cuvier \& Valenciennes, op. cit., $\mathrm{x}, 239,1835$, Ile de France, Seychelles.

Accuthurus xanthopterus Cuvier \& Valenciennes, op. cit., x, 215, 1835, Seychelles.

Acanthurus lamarrii Cuvier \& Valenciennes, op. cit., $\mathrm{x}, 236,1835$, Ile de France.

Teuthis guntheri Jenkins, Bull. U. S. Fish Comm., Xxir, 1902 (1903), 477, pl. 29, Hawaii.

This species is characterized by the pale ring at the base of the caudal, the body being plain brown or nearly so, and the vertical fins with a few distinct stripes. Taking the account given by Sauvage as authentic, we are unable to separate the species called xanthopterus, blochi, and guntheri from the scantily described matoides. 
The species is common about Hawai, and Samoa as well. We have about a dozen specimens from Samoa from 2 to 10 inches in length. The largest, a little more elongate than shown in Jenkins's figure, shows a very distinct bluish streak along base of dorsal. This, with the pale caudal band and the yellow margin to the pectoral, are characteristic of this species.

Life colors of a young specimen from Apia, dusky olive, with very faint bluish horizontal streaks; a whitish olive ring around caudal peduncle; dorsal and anal with faint bluish horizonal streaks; pectoral more or less pale.

1198. Hepatus bishopi (Bryan \& Herre). Marcus I.

Teuthis bishopi Bryan \& Herre, Bishop Museum 1903, 134, Marcus I.

This species is based on an adult example, very close to Hepatus matoides but probably distinct, as the pectoral is without yellow and the dorsal and anal not striped. The profile is also somewhat S-shaped.

1199. Hepatus umbra (Jenkins). Hawaii.

Teuthis umbra Jenkins, Bull, U.S. Fish Comm., xxIr, 1902 (1903), 477, Honolulu.

This species is rather rare about Honolulu. It is very similar to Irepatus matoides, differing chiefly in the absence of lines on the fins.

1200. Hepatus aquilinus Jordan \& Seale, new species. Palagi samasama.

This species is allied to Hepatus matoides, but is much more elongate, with the profile more convex than in any other species, the general form more distinctly elliptical. We have a single very large specimen from Apia.

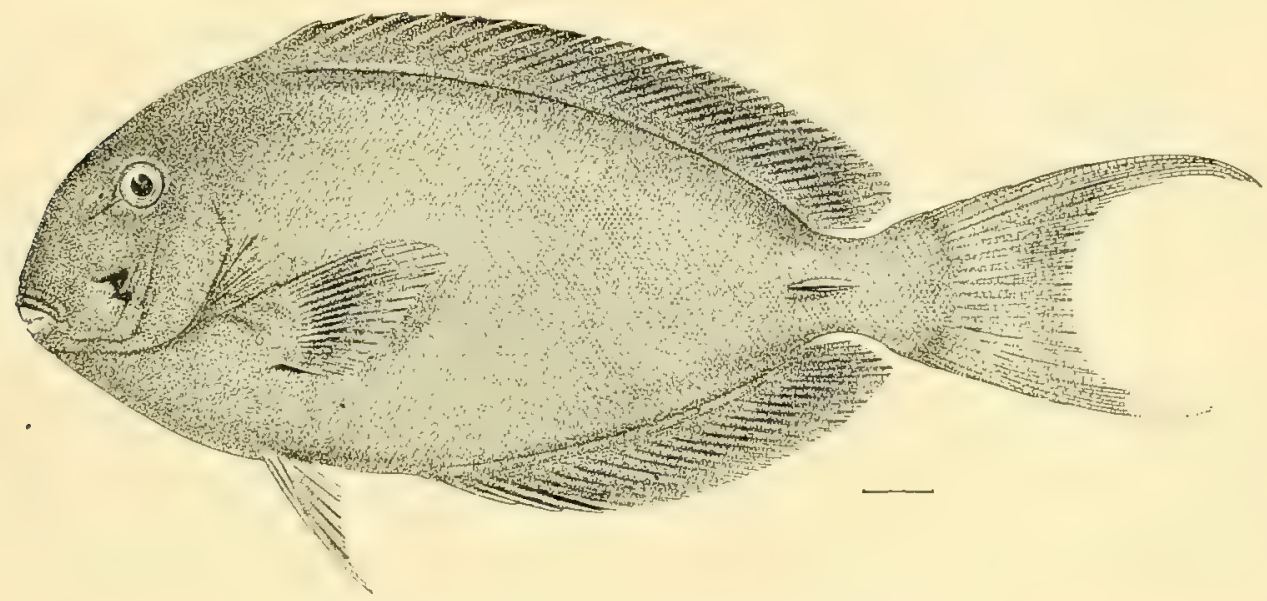

FIG. 66:-IIepatus aquilinus Jordan \& Seale, new species. Type.

Head 4 in length; depth 2.12; eye 5 in head; dorsal Ix, 26; anal II, 24; scales small, abont 1.25 in lateral line; snout 1.25 in head; interorbital 2.85; spine on caudal peduncle fully a third greater than width of orbit.

Body compressed, elevated, anterior profile rounded, slightly gibbous in front of eye; depth of caudal peduncle 2.50 in head, the spine distinct, equal in length to about two-thirds of depth of peduncle; mouth small; teeth flat, their margin toothed, 16 teeth in upper jaw, 21 in lower jaw; distance from tip of snout to origin of dorsal 2.55 in length without caudal; posterior margin of dorsal rounded, its longest ray 2 in head; base of anal 2 in length without caudal, 1.45 in base of dorsal, longest anal ray 2 in head; pectoral equal to head; ventral 1.25 in head; caudal deeply lunate, the marginal rays being prolonged, longest outer ray 2.50 in length without caudal, middle ray 1.50 in head.

Color in life, purplish brom with some bluish shades on tail; very faint traces of stripes; dorsal with four horizontal olive-bronze and gray stripes; anal with five and a dark edge; caudal very deeply lunate; pectoral with posterior half golden; ventral dark olive; no black spot on dorsal or anal; caudal dark, without pale edge; caudal peduncle dark; olive about eye, and a streak to snout. 
Color in spirits, uniform dark brown, shaded somewhat darker, almost black at tip of snout and chin; base of caudal spine dusky; all the fins except pectoral dusky, almost black, darker than body color; anterior two-thirds of pectoral dusky, posterior third yellowish white; no black spots at axil of any fins; iris golden.

Type no. 51759, U. S. National Museum, from Apia, length, 17 inches.

1201. Hepatus flavoguttatus (Kittlitz).

Acanthurus favaguttatus Kittlitz, Senckenberg Museum, 195, 1834, Caroline Is.

Acanthurus kittlitzi Cuvier \& Valenciennes, Hist. Nat. Poiss, $\mathrm{x}, 222$, 1835, Caroline Is.

1202. Hepatus marginatus (Cuvier \& Valenciennes). Caroline Is.

Acanthurus marginatus Cuvier \& Valenciennes, Hist. Nat. Poiss., X, 221, 1835, Luganor, one of the Carolines.

1203. Hepatus triostegus (Linnæus). Manift. Samoa; Tabiti; New Guinea; Fiji; Faté; Rarotonga and Nukahiva (Seale); East Indies.

Acanthurus zebra De Vis, Proc. Linn. Soc. N. S. W. 1884, 447, Duke of York I.

This species is the most abundant of the genus about Samoa, swarming everywhere on the reefs. The black bar through the pectoral does not descend much below the fin, the caudal mark is a vertical bar or else two spots in a vertical line, and the adults have the white of the belly bounded above by an undulating dark line.

Life colors of a specimen from Apia reef, called manifi, light olive, darker on back, silvery below; bars black. This seems like sandwichensis, but lacks one cross-band and is very pale; only four bands on sides.

1204. Hepatus sandvicensis (Streets). Hawaii; Johnston I.; off shore islands of Mexico.

Acanthurus triostegus sandvicensis Streets, Bull. U. S. Nat. Mus., vII, 67, 1877, Honolulu.

Acanthurus triostegus, Smith \& Swain, Proc. U. S. Nat. Mus. 1882, 138, Johnston I. Steindachner, Sitż. Ak. Wiss. Wien, 1900, 493, Honolulu, Laysan.

Teuthis triostegus, Jordan \& Evermann, Fishes North \& Mid. Amer., II, 1690 (description not synonymy), 1898, offshore islands of Mrexico.

This is the most abundant species of the genus about Hawaii, where it replaces the closely allied Hepatus triostegus. The differences, although slight, are constant.

1205. Hepatus guttatus (Forster). Moana; Aau. Tahiti; Hawaii; Samoa; New Hebrides; Kingsmill I.; Palau; Guam; New Guinea.

Acanthurus guttatus Forster, in Bloch \& Schneider, Syst. Ichth., 1801, 215. Günther, Fisehe der Südsee, 109, taf. 69, fig. A, New Hebrides, Tahiti, Samoa, Kingsmill I., Palau, Sandwich I. Seale, Bishop Museum 1901, 110, Guam.

This strongly marked species is common at Samoa, whence we have 20 specimens. At Hawail it is rather rare.

Life colors of a specimen from Apia, called moana and - $a^{\prime} a u$, dark brownish olive, paler olive behind; a whitish vertical bar above vent; spots on posterior parts white; caudal olive-yellow, blackish behind; ventral bright yellow, dusky edged; pectoral dusky olive, paler. above; no yellow; anal dull orange.

\section{LARVAL FORMS OF HEPATUS.}

Larval forms of Hepatus, constituting the supposed genus Acronurus of Günther, abound in all warm seas. In all cases, these are deep in body, with a large silvery area on the thorax, and with the scales replaced by vertical striæ. These forms can be identified only with great difficulty, and chiefly by means of the count of fin-rays. The following have been described from the Pacific Ocean:

Acanthurus argenteus Quoy \& Gaimard, Voy. Uranie, 373, pl. 63, fig. 2, 1824, Maui. This is probably the young of Hepatus dussumieri, possibly of Teuthis matoides.

Acanthurus striatus Quoy \& Gaimard, Voy. Uranie, 373, pl.63, fig. 3, 1824, Guam. This is regarded by Günther as the young of Clenochretus strigosus (striatus), an identitication which is probably correct. We have, however, three different species of young fish, all having the coloration ascribed to Acanthurus striatus, two of them from Samoa and one from Tabiti. We can identify but one of them, the Ctenochrtus, which is, without much doubt, the form originally named striatus by Quoy \& Gaimard.

Acanthurus orbicularis Quoy \& Gaimard, in Cupier \& Valenciennes, Hist. Nat. Poiss., $\mathrm{x}, 237,1835$, Guam. This can not be identified.

Acanthurus brevispinus Günther, Cat., III, 346, 1861, from unknown locality; defies conjecture. 


\section{CTENOCH正US Gill.}

Ctenodon Swainson, Nat. Hist. Fish, II, 256, 1839 (strigosus); name preoccupied.

Ctenochretus Gill, Proc. U. S. Nat. Mus., 1884, 277 (strigosus).

This genus contains species with slender movable teeth, each dilated at the apex.

1206. Ctenochætus striatus (Quoy \& Gaimard). Palagi; Ponepone; Aau. Hawaii; Samoa; Aneiteum; New Ireland; New Britain; New Guinea; Guam; Carolines; Tahiti; haiatea; Faté; Rarotonga; Tubuai and Shortland I. (Seale).

Acanthurus striatıs Quoy \& Gaimard, Voy. Uranie, 373, 1824, Guam, larra.

Acanthurus strigosus Bennett, Zool. Journ., IV, 1828, 11, Sandwich Is. Cuvier \& Valeneiennes, Hist. Nat. Poisg, $\mathrm{X}$, 243, 1835. Günther, Cat., IIr, 342, 1861, Sandwich Is. Günther, Fische der Südsee, 1v, 116, taf. 79, figs. B and C, 1s75, Sandwich Is, Seale, Bishop Museum, 1901, 109, Guam. Peters, Berl. Mon.. 1876, 835, New Britain.

Acanth:urts (Ctcnorion) strigosus, Steindachner, Denks. Ak. Wiss. Wien, Lxx, 1900, 494, IIonolulu.

Acanthurus ctenodon Cuvier \& Valenciennes, Hist. Nat. Poiss., x, 211, pl. 289, Caroline Is. Gunther, Cat., III, 312, Aneiteum, Eust Indies. Peters, 1. c., New Britain, New Ireland.

This species is generally common throughout Oceania. We found it abundant both at Hawaii and Samoa. The faint spots about the head and the faint streaks along the sides disappear in spirits.

Life colors of a specimen from Apia, called palagi, blackish brown, unmarked; dorsal with very faint horizontal streaks of bluish and bronze; anal very obscurely marked in the same way; caudal deeply forked; no stripes on body.

Another specimen was exactly like Hepatus atramentatus, but the profile of the head was much more convex; many wavy blue and bronze stripes on a blackish ground.

\section{COLOCOPUS Gill.}

Colocopus Gill, Proc. U. S. Nat. Mus. 1884, 279 (lambdurus).

This genus differed from Hepatus in having but two or three soft rays in the ventral fins.

1207. Colocopus lambdurus Gill. New Britan; Kingsmill I.; New Guinea (Macleay); Mauritius. Acanthurus hepahus Günther, Fische der Südsee, 115, taf. 75; not Teuthis hepatus Linnæus, which name properly belongs to the American species usually known as cæruleus. Peters, Berl. Mon. 1877, 835, New Britain. Colocopus lambdurus Gill, Proc. U. S. Nat. Mus, 1881, 279 (after Günther), Kingsmill I., Mauritius.

\section{ZEBRASOMA Swainson.}

Zebrasoma Swainson, Nat. Hist. Anim., II, 256, 1839 (velifer).

Scopas Kner, Novara Fische, 1865, 212 (scopas).

This genus differs from Hepatus in the short spicous dorsal of 4 or 5 graduated spines; soft dorsal high; snout short, projecting at an angle.

1208. Zebrasoma flavescens (Bennett). Samasama. Hawaii; Marcus I.; Guam; New Guinea (Macleay).

Acanthurus flavescens Bennett, Zool. Journ., IV, 1828, 40, Hawaii.

Zebrasoma flareseens, Steindachner, Sitz. Ak. Wiss. Wien 1900, 493, Honolulu, Bryan \& Herre, Bishop Museum, 1903, 234, Marcus I.

Acanthurus virgatus Vaillant \& Sauvage, Ann. Scí, Niat., 1875, 283, Honolulu.

Acanthurus agana Seale, Bishop Museum, 1901, 110, Guam.

This species is rather common about the Hawaiian Islands, and is reported from Guam under the name of Zebrasoma agana. Zebrasoma virgatum must be the young of this species, with blue spots on the head and brown blue streaks and pale cross-shades on the body. The description differs from Zebrasoma flarescens as the young of Zebrasoma rhombeum differs from the adult.

This species apparently agrees with Zebrasoma rhombeum in all respects except color. Were it not for its geographical separation we should follow Günther in uniting rhombeum with facescens. The two are in fact probably the same species, the name flarescens being the older.

1209. Zebrasoma rhombeum (Kittlitz). Iliu; Ali palagi. Samoa; Ulea; Fiji; Aneiteum; East Indies.

Acanthurus rhombeus Kittlitz, Senckenberg Museum, I, 1834, 196, pl. xir. fig. 16.

Acanthurus scopas Cuvier \& Valenciennes, Hist. Nat. Polss., x, 245, pl, ccxc, 1835, Ile de France, Ulea. Bleeker, Nat. Tijds. Ned. Ind., 1851, 318. Guichenot, Sagra IIist. Cuba, 122, 1851, Cuba by error. Günther, Cat., rII, 34? 1861, Ceram, Sandwich Is., Aneiteum.

Acanthurus altivlis Curier \& Valenciennes, op. cit., $\mathbf{x}, 249,1835$, Ile de France. Acanthurus goramensis Cuvier \& Valenciennes, op. cit., x, 1835, Goram, young. 
This species ranges widely through the East Indies. We have 50 specimens from Apia and Pago Pago. The yellow form, called flavescens, we did not find in Samoa. The two forms, flavescens and rhombeum, are without much doubt color variations of one dichromatic species.

Life colors were noted in various specimens as follows:

(1) Specimen from Apia, called itiu. Dark olive, somewhat clouded (a curved light blue streak behind the eye, parallel with the golden iris, in young only); everywhere fine oblong light blue spots, smaller and sharply defined on side of head, not evident on snout nor along the back; larger below and behind; fins all plain olive-black, the pectoral lighter olive; caudal spine hluish white; a short oblique streak of light olive above pectoral.

(2) An older example with light blue wavy streaks on .body, not spots; streak above pectoral light yellow and very conspicuous; no blue behind eye; pectoral scarcely olive.

(3) From Apia. Dark brown, grayish behind, with about 20 fine bluish white cross-streaks; a whitish lateral streak above pectoral; fins all dusky. Larger ones more sharply colored.

(4) From Pago Pago. Posterior hall of body fuliginous, darkest behind and merging anteriorly into yellow-green with fine pale blue specks; olive-green above eyes; iris yellow.

(5) From Apia. Blackish; faint bluish horizontal lines over body as in Hepatus lineolatus; a yellowish white short band above pectoral; head unspotted; fins dark.

(6) Specimen from Pago Pago, called iliu. Blackish brown; head, breast, and shoulders everywhere covered with fine bluish white dots; body with horizontal wavy stripes of the same color, on a bronze-brown ground; fins dusky olive, unstriped; dorsal, anal, and caudal with a fine paler edge; pectoral dark orange, dusky above and below; a long whitish stripe above pectoral.

(7) One specimen was almost black, the spots very distinet, the stripes mostly obsolete; the yellowish white line reduced to a round bright yellow spot near gill-opening, wanting on the other side; iris pink red, not gray as usual.

1210. Zebrasoma rostratum (Günther). Ali. Tahiti; Samoa.

Acanthurus rastratus Günther, Fische der Südsee, 117, taf. 66, fig. B, Tahiti.

This species is close to Zebrasoma rhombeum, but the snout is longer, the fins rather higher, and the color almost black. We have two examples from Apia, a little smaller than Günther's type, and with the body deeper.

Life colors of a specimen called iliu, black, with brownish tinge; snout reticulate; a vertical bar behind pectoral golden olive, with blue cross streaks; a similar bar from beginning of dorsal across opercle and obliquely across breast; five blue stripes and four olive between; below pectoral obscurely reticulate, with bluish around dull olive spots; fins uncolored; candal with narrow pale edge; caudal spine black, as are all fins.

1211. Zebrasoma veliferum (Bloch). Lupo. Hawaii; Samoa; Fiji; East Indies.

Acanthurus velifer Bloch, Ix, 106, taf. 427, fig. 1, 1788. Acanthurus blochit Bennett, Proc. Zool. Soc. 1835, 207.

Acanthurus hypselopterus Bleeker, Nat. Tijds. Ned. Ind., VI, 185 4 , 313, Flores. Günther, Fische der Südsee, 1875, 117, Fiji Is. Steindachner, Denks. Ak. Wiss. Wien, LXx, 1900, 494, pl. Iv, fig. 1, Honolulu.

Zebrasoma hypselopterum Jenkins, Bull. U. S. Fish Comm., xxII, 1902 (1903), 479, Honolulu. Snyder, Bull. U. S. Fish Comm., xxir, 1902 (1904), 533, Honolulu.

This species is rather common about Samoa, whence we secured four examples. It is even more frequent about Honolulu. Our largest example, about a foot long, corresponds very closely to Bloch's figure of velifer. The caudal is dark, and the body is crossed by many dark cross-streaks, which cross six or seven obseure dark cross-shades, the most distinct being the ocular and scapular bands. In younger examples the cross-streaks are fainter, and in still younger they are wanting. The face is spotted with pale and the six or seven dark cross-bands become more distinct. This form from 4 to 8 inches long represents hypselopterum. Still younger forms have the snout and caudal yellow. We have none which correspond exactly either to desjardinii or to ruppellii.

Life colors uf a specimen from Pago Pago, violet-black with four distinct yellowish cross-bands (grayish in formalin); these and rest of body crossed by regular dark bronze streaks; broad black ocular band reaching base of ventrals; head before it with network of bluish white spots; another dark area from lase of dorsal to front of anal; fins blackish; caudal with narrow pale edge; breast unspotted.

A specimen from Apia, called lupo, had the snout and forehead dark yellow; ocular streak black 
edged with gray; then a broader black band edged with gray; then four brown bands, yellow between, then the caudal peduncle black, the pale stripe before it nurow; tail yellow, grayish behind, thus seven dark bands; dorsal and anal dusky deep yellow, the dorsal with some spots behind; rentral golden.

\section{ACANTHURUS Forzkål.}

(Monoceros, Naso, and Naseus of authors.)

1212. Acanthurus unicornis (Forskal). Ili'ilia segi; Ume; Cmelei. Hawaii; Samoa; Aneiteum; Guam; Tahiti; Waigiu; New Guinea; Raiatea (Seale); East Indies; Japan.

This species, widely diffused through the tropical Pacific and varying excessively at various stages of growth, is common about Hawaii. At Samoa we found it rather scarce, but four specimens being obtained. The caudal spines are bluish on a pale ground, while those of 1 canthurus lituratus are orange.

Life colors of a specimen from Apia, tark olive, brownish below, paler on tail; spines clear blue; dorsal light brown, with light bluish spots and a dark edge; caudal dusky, paler behind; anal clear orange-brown, with a row of pale blue spots at base, then two pale bluish stripes and a whitish edge; pectoral and ventral mottled orange-gray.

Another specimen from Apia was grayish black, the spines dark blue; caudal peduncle brown, paler; dorsal light orange, with oblique bluish streaks; caudal gray; anal light orange, with horizontal bluish streaks; head, pectoral and ventral gray.

1213. Acanthurus brevirostris (Cuvier \& Valenciennes). Hawaii; Tahiti; Kingsmill I., New Guinea; Ile de France.

Naseus brevirostris Cuvier \& Falenciennes, Hist. Nat. Poiss, X, 277, pl. 291, 1835, East Indies, Ile de France, New Guinea. Günther, Cat., 111, 349, 1861. Günther, Fische der Stidsee, 121, taf. 79, fig. A, 1875, Kingsmill I., Tahiti. Accnthum bretirostris Jenkins, Bull. U. S. Fish Comm., XxII, 1902 (1903), 481, Honolulu. Snyder, Bull. U. S. Fish Comm., Xxir, 1902 (1904), 534, Honolulu.

This species, rather common about Hawaii, was not found in Samoa.

1214. Acanthurus incipiens Jenkins. Hawaii; Samoa.

Acanthun incipiens Jenkins, Bull. U. S. Fish Comm., xxII, 1902 (1903), 480, Honolulu.

Two specimens were seen at Samoa, similar in form to Jenkins's type. One of these is plain blackish, the other covered with blue spots. The caudal fin in both is blackish. This fin is largely yellow in Acanthurus breviostris, otlerwise we might regard Acanthurus incipiens as the young of that species. It is apparently an immature form.

Life colors of one specimen from Apia, black, with a brownish shade; upper parts with small rounded spots of deep violet-blue; belly paler, slaty; lips blue; a blue streak below eye; dorsal dark brown, slightly bluish on spines, dusky on edge; ventral dark brown, paler behind, the edge blackish; anal dark brown with two dark blue streaks and a dusky edge; ventral and pectoral dark brown; caudal black with a faint trace of a pale edge. No trace of horn or of spines on tail. Length, 6 inches.

1215. Acanthurus annulatus (Quoy \& Gaimard). Tonga; Palau; Aneiteum; Fiji; Guam.

Priodon annulatus Quoy \& Gaimard, Voy. Uranie, 377, 1824, Polynesia, young. Seale, Bishop Muselzm, 1901, 113, Guam,

Naseus marginatus Cuvier \& Valenciennes, Hist. Nat. Poiss, $x$, 280, 1835, Tonga; not Acanthurus marginatus Kittlitz. Günther, Fische der Südsee, 122, Palau, Aneiteum.

Yonoceros marginatus Seale, Bishop Museum 1901, 114, Guam.

Priodon annularis Cupier \& Valenciennes, Hist. Nat. Poiss, x, 302, pl. 291, 1835, Guam, young.

1216. Acanthurus tuberosus Lacépède. Guam; Aneiteum; New Guinea; Mauritin:

Vaso tz’3erosus Lacépède, Hist. Nat. Poiss., III, 111, 1802, Ile de France.

Naseus tuberosus, Günther, Fische aer Südsee, 123, Aneiteum, Ceylon, Zanzibar, Mauritius.

Acanthurus nasus Shaw, Gen. Zool., v, 376, pl. 51, 1803, Ile de France.

Naseus carolinaruma Quoy \& Gaimard, Voy. Uranie, 3'5, pl. 63, fig. 1, 1824, Guam.

Naseus tuber Cuvier \& Valenciennes, Hist. Nat. Poiss, X, 290, 1835, Ile de France.

Naseus tonganus Quoy \& Gaimard, in Cuvier \& Valenciennes, Hist. Nat. Poiss, X, 292, 1835, Tonga; specimen immaculate.

Naseus punctulatus Steinäuchner, 1874.

This species we have not seen. It is probably rare in Polynesia.

a This species, marked by green blotehes, is imperfectly described, and has not been recognized by recent anthors. It is perhaps nearest Acanthurus tuberosus. 
1217. Acanthurus metoposophron (Jenkins). Hawaii.

Callicanthus metoposophron, Jenkins, Bull. U. S. Fish Comma., XxII, 1902 (1903), 481, fig. 31, Honolulu.

1218. Acanthurus vlamingi (Cuvier \& Valenciennes). Marshall Is.; Aneiteum; East Indies.

Naseus vlamingi Cuvier \& Valenciennes, Hist. Nat. Poiss., x, 293, 1835, Moluccas. Günther, Fische der Südsee, 123, Ebon, Marshall Is., Aneiteum, Ceram. Fowler, Proc. Ac. Nat. Sci. Phila., 1899, 193, South Seas.

1219. Acanthurus lituratus (Forster). Ili'ilia; Unelei; Ume. Tahiti; Hawaii; Samoa; Johnston I.; Guam; New Guinea; East Indies.

Acanthurus lituratus Forster, in Bloch \& Schneider, Syst. Ich. 1801, 218, Tahiti.

Harpurus lituratus Forster, Descr. Anim., 218, 1814, Tabiti.

Naseus lituratus, Günther, Fische der Südsee, 124 (with plate representing "garretti"), Sandwich Is., Tahiti, Red Sea.

Ionoceros lituratus Seale, Bishop Museum 1901, 112, Guam.

Aspisurus elegans Rüppell, Atlas, Fische, 61, tab. xvr, fig. 2, 1828, Red Sea.

Prionurus eoume Lesson, Voy. Coquille, II, 151, 1830, Tahiti.

Naseus lituratus Smith \& Swain, Proc. U. S. Nat. Mins. 1882, 139, Johnston I. Steindachner, Sitz. Ak. Wiss. Wien 1900, 495, Honolulu.

?. Monocerus garretti Seale, Bishop Museum 1901, 112, Guam.

This species is common at Samoa, as about Hawaii. In both places, and almost equally abundant, occurs the form described as Monoceros garretti. The only permanent difference seems to be this-in the true lituratus there is a line of clear blue along the base of the dorsal, and in garretti, old and young, this is wanting. As we find no other difference, the senior author is very doubtful as to whether Acanthurus garretti is a valid species.

Life colors were noted in various specimens as follows:

(1) Specimen from Apia called ume. Dark olive, brownish below, paler on tail; spines clear blue; dorsal light brown, with light bluish spots and a dark edge; caudal dusky paler behind; anal clear orange-brown, with a row of pale blue spots at base, then two pale bluish stripes and a whitish edge; pectoral and ventral mottled orange-gray.

(2) From Apia (young of preceding?). Dusky olive; belly yellowish brown; lips yellowish brown; a blue streak along base of dorsal, which is black except for a long white stripe; caudal dark olive, edged with greenish, then white; anal dull orange, edged with black; two anal spines dull orange; ventral dull orange.

(3) Specimen called umelei, ume, also from Apia. Grayish black, the spines dark. blue; caudal peduncle brown, paler; dorsal light orange with oblique bluish streaks; caudal gray; anal light orange, with horizontal bluish streaks; head, pectoral, and ventral gray.

(4) Specimen from Apia called umelei. Dusky grayish, yellowish above eye; a bluish streak along base of dorsal; caudal whitish behind; dorsal and anal deep maroon red and dusky.

(5) Specimen called ili' itia. Black, brownish tinged; dorsal black, a pale blue streak at base, the edge gray with black margin and a row of bluish spots; spines orange; caudal black, with broad white edge; anal orange, black and white on margin, olive green at base; ventral olive orange; pectoral black; lips brown, a light yellow-brown streak from eye.

1220. Acanthurus garretti (Seale). Guam; Hawaii; Samoa.

Monoceros garvetti Seale, Bishop Museum, 1901, 112, Guam.

This species, if such it be, is distinguished from ilcanthurus lituratus by the absence of a blue line along the base of the dorsal and by the yellow spots on caudal peduncle separated by sharply defined black area. It is found at Hawail and Samoa with Acanthurus lituratus. It is represented in Günther's plate of Naseus lituratus in Fische der Südsee. It is probably a color variation of Acanthurus lituratusa view not shared by the junior author, however.

\section{AXINURUS Cuvier \& Valenciennes.}

1221. Axinurus thynnoides Cuvier \& Valenciennes. New Guinea; East Indies. 


\section{Family SIGANIDE. \\ SIGANUS Forskål. Lo.}

1222. Siganus marmoratus (Quoy \& Gaimard). Lo pa' u'ulu. Samoa; Fiji; Guam; New Hanover; New Britain; Tahiti; East Indies.

Amphacanthus mamoratus Quoy \& Gaimard, Voy. Uranie, Zool., 367, 1824, Guam.

Teuthis marmoratus Günther, Fische der Südsee, 93, Caroline Is. Peters, Berl. Mon., 1876, 835, Amboina, New Hanover, New Britain.

Siganas marmoratus Seale, Bishop Museum 1901, 111, Guam.

Amphacanthus guamensis Cuvier \& Valenciennes, Hist. Nat. Poiss., $\mathbf{x}, 163,1835$, Guam.

Amphacanthus scaroides Bleeker, Nat. Tijds., 853, 262, East Indies.

Teuthis striolata Günther, Fische der Südsee, taf, LIX, fig. A (not description), Samoa, Tahiti.

This species is very common about Samoa. We have 40 specimens from A pia and Pago Pago.

It is possible that the specimens called Teuthis striolata by Günther, from Samoa, belong to this species, which is very close to Sigants striolatus, the body a little deeper than in the latter. Günther's figure of striolatus is much like Siganus marmoratus except that the body in the latter is deeper and the fins more sharply banded. In the type of striolatus the fins are said to be immaculate.

Life colors of a specimen from Apia called lo, olive green above, livid gray below; vermiculations of blaish gray around dark olive; fins similar, browner, also vermiculated or blotched.

1223. Siganus nebuiosus (Quoy \& Gaimard). Guam; East Indies.

Amphacanthus nebulosus Quoy \& Gaimard, Voy. Uranie, 1824, 369, Timor, Guam, Port Jackson.

Amphacanthus maculosus Quoy \& Gaimard, op. cit., 370.

This mottled species we have not seen, and it may not belong to the South Seas. Probably the specimens from Guam belong to Siganus marmoratus.

1224. Siganus striolatus (Günther). Samoa (Günther); New Hebrides; Solomon Is.; Tonga; Tahiti; Raiatea (Seale).

Teuthis striolata Günther, Cat., III, 319, 1861, New Hebrides. Günther, Fische der Südsee, 89, New Hebrides, Solomon Is., Samoa, Tonga, Tahiti.

This species is unknown to us.

1225. Siganus concatenatus (Cuvier \& Valenciennes). Kusai; Palau Is.; East Indies.

Amphacanthus concatenalus Cuvier \& Valenciennes, Hist. Nat. Poiss., $\mathrm{X}, 127,1833$, Buru, Java.

Teuthis concatenatus, Günther, Fische der Sïdsee, 88, Palau Is., East Indies. Günther, Challeager, Shore Fishes, 46,1880 , Admiralty Is.

Not found in Samoa. We have a specimen from Kusai, Caroline Islands, collected by Mr. A. P. Lundin.

1226. Siganus vermiculatus (Cuvier \& Valenciennes). Admiralty Is.; New Guinea; Shortland I. (Seale); East Indies.

Amphacanthus vermiculatus Cuvier \& Valenciennes, Hist. Nat. Poiss, x, 126, 1835, New Guinea, Java, Ile de France, Teuthis vermiculatus, Günther, Challenger, Shore Fishes, 1880, 46, Admiralty Is.

1227. Siganus puellus (Schlegel). A pamana; Gilbert Is.; Palau Is.; East Indies.

Amphacanthus puellus Schlegel, Bydr., 1852, 39, East Indies.

Teuthis puellus, Günther, Fische der Südsee, 91, A pamana, Palau.

1228. Siganus doliatus (Cuvier). Vanicolo; Fiji; Ponape; Palau Is.; New Hebrides; New Britain; Raiatea (Seale); East Indies.

Amphacanthus doliatus Cuvier \& Valenciennes, Hist. Nat. Poiss., x, 132, 1835, Buru, Vanicolo.

Teuthis doliatus, Günthen, Fische der Sudsee, 96, New Hebrides, Fiji, Palau, Ponape. Kner, Novara Fische, 209, Ponape, Peters, Berl. Mon., 1876, 835, New Britain.

1229. Siganus lineatus (Cuvier \& Valenciennes). Vanicolo; New Guinea. 
1230. Siganus fuscescens (Houttuyn). Palau Is.; Howland I. (Günther); Mareus I. (Bryan \& Herre); Japan.

Siganus dotiatus Cuvier, Regne Animal. Centrogaster fuscescens Houttuyn, Mem de Haerl., xx, 333, Nagasaki. Amphacanthus albopunctatus schlegel.

This species, characteristic of southern Japan, is recorded from the South Seas, but was not found by us.

1231. Siganus argenteus (Quoy \& Gaimard). Guam.

Amphacanthus argenteus Quoy \& Gaimard, Voy, Uranie, Zool., 368, 1824, Guam.

Teuthis argentec Günther, Fische der Südsee, 90, Jocality unknown

1232. Siganus canaliculatus (Park). Vanicolo; New Britain; East Indies.

Chrtodon canaliculatus MIungo Park, Trans. Linn. Soc, IHI, 1797, 473, Sumatra.

Amphacanthus margaritiferus Cuvier \& Valenciennes, Hist. Nat. Poiss, $x, 145,1885$, Amboina, Vanicolo.

Teuthis margaritiferus, Peters, Berl. Mon. 1876, 835, New Britain. Günther, Challenger Shore Fishes, 46, 1880, Admiralty Is.

1233. Siganus vitianus (Sauvage). Fiji.

Teuthis vitianus Sauvage, Bull. Phil. Soc., vI, 173; Fiji.

1234. Siganus oligostictus (Ǩner). Fiji.

Teuthis oligostictus Kner, Sitz. Ak. Wiss. Wien 1868, 30, Fiji.

1235. Siganus punctatus (Bloch \& Schneider). Lo 'ele'ele. Tonga; New Caledonia; Guam; Fiji; Samoa; East Indies.

Amphacanthus punctatus Bloch \& Schneider, Syst. Ichth., 1801, 210, Pacific Ocean (Tonga, New Caledonia).

Siganas heragonatus Bleeker, Nat. Tijds. Ned. Ind., VII, 1854, 41, East Indies. Seale, Bỉshop Museum 1901, 111, IIr, Guam.

Teuthis heragonata, Günther, Fische der Südsee, 80 , Fiji, Samoa.

This species is abundant at Samoa. We have about 10 specimens from Apia and Pago Pago. This is certainly the species called hexagonatus by Bleeker, and it is without much doubt the punctrats of Bloch and Schneider, as Forster's notes, copied by Schneider, indicate a compressed species with small yellow spots on a bluish ground. Kner (Novara Fische) records some similar species as Amphacanthus guttatus Bloch from Java and Ponape, but the Amphacanthus guttatus of Bloch and Schneider is another species of Siganus.

Life colors of a specimen from Apia called elieli, deep dusky blue, the color forming a.network around bronze orange spots; vertical fins marked in like fashion, but duller; pectoral olive; ventral blackish gray. Body deeper than in Siganus rostratus.

1236. Siganus rostratus (Cuvier \& Valenciennes). Palau; Tahiti; Guam; Samoa; Gilbert Is.; Raiatea; Tubuai; Fate and Shortland I. (Seale); Zanzibar.

Amphacanthus rostratus (Cuvier \& Valenciennes), Hist. Nat. Poiss, $\mathrm{X}, 158,1835$, Red Sea.

Teuthis rostratus Günther, Fische der Südsee, 89, with plate, Palau, Tahiti, Gilbert Is., Zanzibar.

Siganus rostratus, Seale, Bishop Museum 1901, 112, Gnam.

This species is colored very much like Siganus punctatus, but the body is more elongate, the caudal fin still more deeply forked. We have four large specimens from Apia.

Life colors of one of these, sky-blue, dark above, vermiculated with golden; dorsal mottled olive; caudal dusky, paler behind; anal dusky; ventral gray, barred with dark olive; pectoral golden.

1237. Siganus corallinus (Cuvier \& Valenciennes). Palau İs.; East Indies.

Amphacanthus corallinus Cuvier \& Valenciennes, Hist. Nat. Poiss, $\mathbf{x}, 139,1835$, Seychelles, East Indies. Teuthis corallinus, Günther, Fische der Südsee, 88, Palau.

1238. Siganus studeri (Peters). New Britain.

Teuthis studeri Yeters, Berl. Mon, 1876, 834, New Britain.

Lo Seale, new genus.

Lo Seale, new genus of Siganidæ (type Amphacanthus vulpinus Schlegel \& Müller).

This genus is defined by the short tubular snout. Lo is the vernacular name applied to ail the Siganidx in Samoa. 
1239. Lo vulpinus (Schlegel \& Müller). Solomon Is.; Palau Is.; Alu, Solomon Is. (Seale); East Indies.

Amplacanthus mulpinus Schlegel \& ML̈̈ller, Bydr, Dierk,, v, 1852, 38, East Indies.

Teuthis vulpinus, Günther, Fische den Südsee, 91, Solomon Is, Palau Is,

This species, distinguished by the deep body, the slender elongate snout, and the peculiar coloration, is known to us from one specimen, brought by Mr. Seale from Alu, one of the Solomon Islands. We present a figure taken from this specimen, together with Mr. Seale's notes upon it.

Head 3.3 in length; depth 2.2; eye 4 in head; interorbital equal to eye; snout 2 in head; scales minute; dorsal xıII, 10; anal vir, 9; ventral I-3-I.

Body compressed, snout produced, mouth small; a single row of small flat teeth fixed in each jaw, 12 on each side; opercle striate; none of the dorsal or anal spines greatly elongate; the dorsal spines, excepting the short anterior one, of abont equal length, the longest 2 in head; anal spines similar, the longest 2; soft rays of dorsal, 1.75; ventral 1.4; caudal emarginate, the lobes rounded; caudal peduncle short, its depth equal to eye.

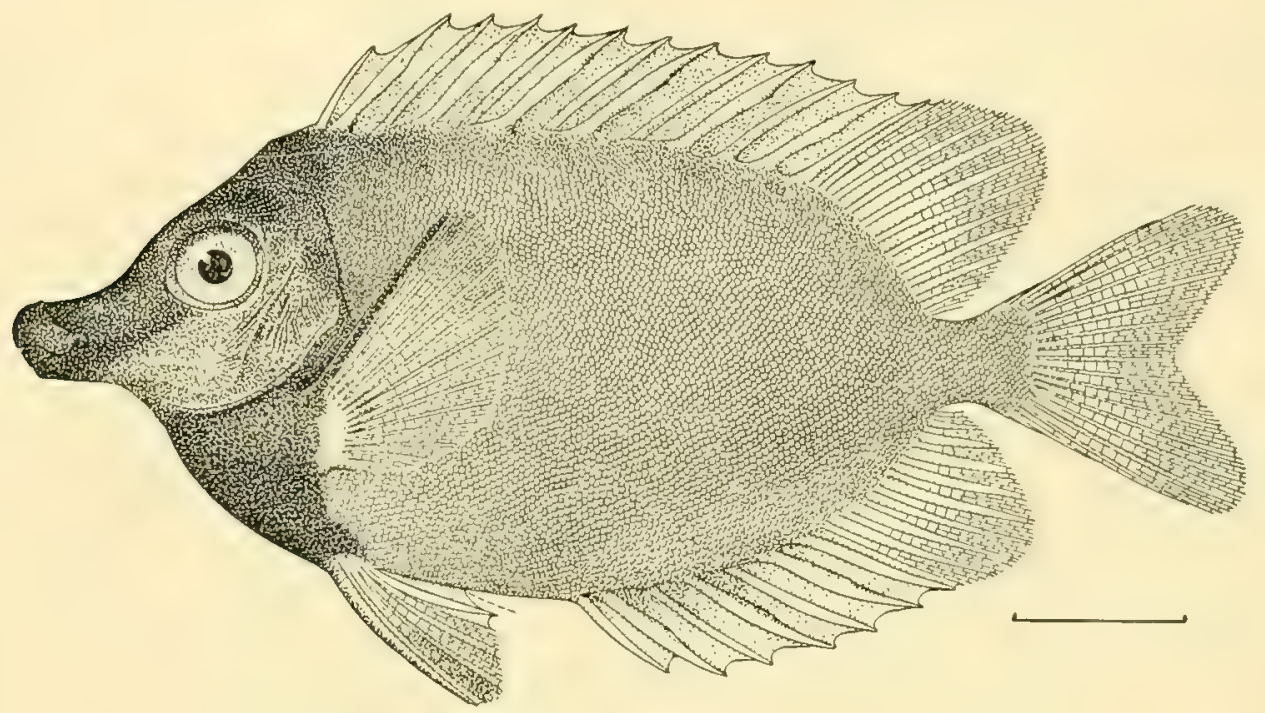

FIG. 67.-Lo vulpinus (Schlegel \& Müller).

Color in life, light bister brown; thorax and first ray of pectoral deep black; head and shoulders a deeper brown than the body; caudal, dorsal, and anal orange; spines of ventral and the first ray dusky; pectoral yellowish, with a slight dusky wash.

Color in spirits, dull grayish brown, thorax and head much darker; anterior ray of pectoral black; fins yellowish white. inches.

One specimen (no. 1325 Bishop Museum) from Alu, nne of the Solomon Islands, length, 7

\section{Family BALISTIDE.}

\section{BALISTES (Artedi) Linnæus. Sumu.}

1240. Balistes vidua Richardson. Sumu pa'epr'e mumu; Sumu i’u mumu. Hawaii; Samoa; Nukahiva (Seale).

Life colors of a specimen from Pago Pago called sumu pa'epa'e mumu, body dark smoky, paling a little below; pectoral canary-yellow with black edge; dorsal white with black margin; ana! same; caudal Chinese white at base, the rest scarlet. 
1241. Balistes castaneus Richardson. : Pacific; west coast of Mexico.

Balistes castrneus Richardson, Voy. Sulphur, 126, pl. 59, figs. 5, 6, Pacific, locality unkown. Regan, Ann. Nat. Hist. 1902, 297, Pacific, same specimen.

Balistes polylepis Steindachner, Ich, Beitr., v, 21, 1876, Magdalena Bay, Mazatlan, Acapulco. Jordan \& Evermann, Fishes North \& Mid. Amer., Ir, 1700, 1898, Lower California, Panama.

According to Regan's account this is a true Balistes, and agrees very closely with Batistes polylepis Steindachner, a species common from Cerros Island to Panama. We have also a specimen from San Diego. Richardson's specimens probably came from the Panama region, and it is likely that the species does not belong to the Polynesian fauna at all.

1242. Balistes capistratus Shaw. Hawaii; Nukabiva (Seale); East Indies.

1243. Balistes niger Bonnaterre. New Guinea; East Indies.

(Baisstes conspicillum Bloch \& Schneider.)

1244. Balistes bursa Bloch \& Schneider. Hawaii; Nukahiva (Seale); East Indies.

1245. Balistes viridescens Bloch \& Schneider. New Guinea (Macleay); East Indies.

1246. Balistes nycteris Jordan \& Evermann. Hawaii.

1247. Balistes chrysopterus Bloch \& Schneider. Sumu pa'epa'e. Samoa; Aneiteum; Micronesia; New Britain; Faté (Seale).

Balistes niger Mungo Park, Trans. Linn. Soc., III, 37, 1791, Sumatra; not of Bonnaterre, 1788, which is Balistes niger = Balistes conspicillum. Günther, Cat, viı, 218, Red Sea, Mauritius, Ceylon, Sumatra, Amboina, Aneiteum, Micronesia, Zanzibar. Day, Fish Ind., 688, pl. 181, fig. 1, Malaysia. Peters, Berl. Lon. 1876, 852; New Britain. Balistes armé Lacépède, Hist. Nat. Poiss., I, 336, 382, 1798.

Balistes chrysopterus Bloch \& Schneider, Syst. Ichth., 466, 1801, Coromandel.

Balistes mungopark Lacépède, Hist. Nat., Poiss., IV, 682, 1803; after Park.

Balistes subarmatus Gray \& Hardwicke, Ill. Ind. Zool., India

Balistes albicaudatus Rippell, Neue Wirbelthiere, 54, Xvr, fig, 1, 1835, Red Sea.

Balistes vericosus Gronow, Syst., ed. Gray, 33, 1854; not of Bonnaterre.

Balistes armatus, Bleeker, Atlas, v, 115, tab. ccxvi, East Indies; name after Lacépède.

Of this East Indian species we obtained two specimens at Samoa, where it is apparently, rare. Life colors of a specimen from Apiacalled pae pae, olive-gray, without color, whitish about jaws; a whitish band across lower jaw, another across chin, the latter extending backward across lower part of cheek; candal gray with a blackish cross-streak and a white crescent at edge.

1248. Balistes fuscolineatus Seale. Hawaii.

1249. Balistes fuscus Bloch \& Schneider. Fiji (Günther); Tahiti (Seale); New Guinea (Macleay); East Indies.

1250. Balistes flavomarginatus Rüppell. Sumu laolao. Samoa; New Britain (Peters); New Guinea (Macleay); Shortland I. (Seale); Last Indies; Japan.

A single large specimen of this East Indian species was taken at Apia. It agrees closely with Bleeker's figure. According to Dr. Peters, this is the Balistes brasiliensis of Bloch and Schneider. The description of Schneider agrees fairly, but it is confused with some of the American species and purports to be drawn from an $A$ merican specimen.

Life colors of a specimen from Apia called sumu laolao, light olive-green, the head abruptly creamy reddish brown, sides with many blackish spots covering or partly covering individual scales; back more brownish; first dorsal brownish with dusky membrane; second dorsal dusky brownish at base with orange-brown edge; anal same; caudal orange-brown, deeper on edges and margin with a dusky crescent; pectoral pale orange; naked "grooves" on cheek raised, reddish brown, the scaly stripes darker.

\section{BALISTAPUS Tilesius,}

1251. Balistapus aculeatus (Linnæus). Sumu uliull. Hawaii; Samoa; Johnston I.; Fiji; Guam; New Guinea; Marcus I.; New Ireland; East Indies.

Monacanthus chiverti Alleyne \& Macleay, Proc. Linn. Soc. N. S. W., 1876, 355, New Guinea.

Balistes aculeatus Steindachner, Sitz. Ak. Wiss. Wien, 1900, 517, Samoa, Laysan. Peters, Berl. MIon. 1876, 852, Niew Ireland, Swain \& Sraith, Proc. U. S. Nat. Mus., V, 1882, 139, Johnston I. Seale, Bishop Museum 1901, 115, Guam. Bryan \& Herre, Bishop Museum 1903, 135, Marcus I. 
This handsome species is generally common at Honolulu and Samoa, thence throughout the South Seas and East Indies.

1252. Balistapus rectangulus (Bloch \& Schneider). Sumu pulepule. IIawaii; Guam; Marens I.; Samoa; New Guinea; Faté and Nukuhiva (Seale).

This pretty species is rather common about Hawail, thence through the South Seas and East Indies. We have a few specimens from Samoa.

1253. Balistapus undulatus (Bloch \& Schneider). Sumu uli. Samoa; New Britain; New Guinea; New Hanover; Guam; Tahiti; Shortland I., Fate and Raiatea (Seale); East Indies.

Of this common East Indian species we have about a hundred specimens from the reefs of Samoa, where it is very abundant. It was not seen at Honolulu.

Life colors of a specimen from Apia called sumu uli, deep livid olive green, shaded on back and head; stripes anteriorly, scarlet on chin, yellow on lower lip; body corered by oblique stripes running forward and backward; brassy orange on head; violet streaks on snout and side of head; golden brown stripes on side; first dorsal golden, with blue spots; second dorsal golden, orange at base, violet blue lower, the membranes bluish; caudal centrally yellow-orange, with violet stripes on margin; anal like doreal; a black patch on caudal peduncle; pectoral scarlet, black at base, pale at tip.

1254. Balistapus oire (Bennett). Raiatea; Tabiti.

Balistes oire Bennett, Whaling Voyage, 11, 262, 1840, Raiatea, Tahiti.

1255. Balistapus papuensis (Macleay). New Guinea.

Balistes papuensis Macleay, Proc. Linn. Soc. N.S.W. 1884, 279.

1256. Balistapus verrucosus (Linnreus). New Ireland; New Guinea; Shortland I. (Seale); East Indies.

CANTHIDERMIS Swainson.

1257. Canthidermis rotundatus (Procé). South Seag?; Philippines; East Indies.

1258. Canthidermis angulosus (Quoy \& Gaimard). Hawaii (Quoy \& Gaimard); Laysan; Galapagos Is. (Snodgrass \& Heller); East Indies.

Balistes angulosus Quoy \& Gaimard, Voy. Uranie, Zool.210, 182t, Maui. (Dorsal 23, anal 20. Color black, fins high.) Balistes aureolus, Richardson, Voy. Sulphur, Fishes, 126, pl, 59, fig. 1, 2, East Indies. Guinther, Cat,, vin, 215, 1870, young, East Indies. Steindachner, Sitz. Ak. Wiss. Wien 1900, 5117, Laysan.

Of this species we know the published descriptions only, and these do not distinguish it from Canthidermis rotundatus. Balistes aureolus, from the East Indies, based on young examples, is said to differ from Canthidermis rolundatus in the larger scales. Balistes willughbei Bennett from Mazatian and Balistes adspersus Tchudi from Peru belong in this neighborhood.

In all our explorations we have taken no species of Canthidermis in the Pacific.

\section{XANTHICHTHYS Richardson.}

1259. Xanthichthys lineopunctatus (Hollard). Hawail; Revillagigedo Is.; Bourbon I.

(Xanthichlhys mento Jordan \& Gibert.)

This species, not rare in rather deep water about volcanic rocks in the neighborhood of Hawaii, was not seen in Samoa. It occurs among the Revillagigedo Islands off the coast of Mexico, and at Laysan. The West Indian species, Janthichthys ringens, is probably different, but the species called Balistes lineopunctatus by Hollard, based on an example from Bourbon Island, is apparently the Hawaii-Mexican species.

1260. Xanthichthys rivulatus (Rüppell). Faté, New Hebrides (Seale); Red Sea.

\section{MELICHTHYS SWainson.}

1261. Melichthys radula Richardson. Hawaii; Marcus I.; Johnston I.; Laysan; offshore islands of Mexico.

(Melichuly/s bispinosus Gilbert.) 
ABALISTES Jordan \& Seale, new generic name.

Abalistes Jordan \& Seale, new generic name in Balistidx (stellaris).

Leiurus Swainson, Nat. Hist. Fish., II, 326, 1839 (L. macrophthalmus); not of Swainson, op. cit., 242 , which is Gasterosteus.

This strongly marked genus is known at once by the depressed tail. The name Leiurus, first used for a stickleback, is not available for it.

1262. Abalistes stellaris (Bloch \& Scbneider). 'Fiji (Günther), Louisiades (Günther); Australia; East Indies.

\section{Family HONACANTHIDA.}

\section{CANTHERINES Swainson.}

1263. Cantherines sandwichensis (Quoy \& Gaimard). Aimeo. Hawaii; Samoa; Guam (Seale); East Indies; Clarion I.

Of this species, common at Hawaii and on the offshore islands of Hexico, we have three specimens from Apia and one from Pago Pago. Ali specimens from Hawail and Mexico and Samoa are uniformly dark colored, none showing the network of pale lines about dark spots characteristic of the East Indian variety called pardalis. Of the Samoan species, one is covered with a network of brown lines arranged honeycomb fashion, while the others are piain. The West Indian species Cantherines pullus is very similar to Cantherines sandwichensis. In any event the last-mentioned name must stand, being prior to all others.

Life colors of a specimen from Apia, rich purple-black, unmarked; pectoral, second dorsal, and anal golden; first dorsal and caudal black; lips black.

Another specimen from Apia was dark gray, reticulate with olive brown; second dorsal and anal light yellow, with a bluish streak along the base; caudal dirty yellow. Spine unserrated; ventral spine immovable.

1264. Cantherines albopunctatus $u$ (Seale). Hawaii; Tahiti.

\& Monacanthus howensis Ogilby, Rec. Austr. Mus., 1889, Lord Howe I. Waite, Austr. Mus., 1901, pl. viII, Lord Howe I.

Monacanthus albopunctatus Seale, Occ. Papers Bishop Museum, vol. 1, no. 4, 13, fig. 6, Honolulu.

Pseudomonacanthus multimaculates Regan, Ann. Nat. Hist., 1902, 299, with plate, Tahiti.

Cantherines albopunctatus Jordan \& Evermann, Bull. U. S. Fish Comm., XxiI, 1903 (1905), 420, Hawaii.

This species is very close to Cantherines howensis described by Ogilby and figurea by IVaite from Lord Howe Island. That species has, however, but 33 dorsal rays, while albopunctatus, with the same form and color, is said to have 38 .

1265. Cantherines punctulatus (Regan). Tahiti.

Pseudomonacanthus punctulatus Regan, Ann. Nat. Hist., 1902, 298, with plate, Tahiti.

1266. Cantherines armatus (Garman). Fiji.

Alutera armata Garman, Bull. Mus. Comp. Zool., 1903, Fiji.

This species we have not seen. It is apparently well distinguished by the numerous (over 40 ) soft rays in the dorsal and anal. Ventral spine immovable; dorsal spine barbed.

1267. Cantherines nigricans (Macleay). New Guinea.

Yonacanthus nigricans Macleay, Proc. Linn. Soc. N. S. W. 1883, 596.

1268. Cantherines fuliginosus (Macleay). New Guinea.

Monacanthus fuliginosus Macleay, op. cit., 596.

AMANSES Gray.

Amanses Gray, Indian Zoology, 1830 (hystrix).

Trichoderma Swainson, Nat. Hist. Fish., II, 1839 ("scapus").

In the males of this genus there is a sheaf of long needle-like spines, about ten in number and nearly as long as the head on each side of the tail. In the femalo a brush of shorter spines takes the place of these. In other regards the genus is close to Cantherines.

a This species and the next two, having the dorsal spine serrate, belong to the subgenus Pseudomonacanthus. 
1269. Amanses scopas (Cuvier). Sisitui. Samoa; New Guinea (Macleay); Fast Indies.

Of this singular species we have four fine examples from Apia, the first recorded from Polynesia. Life colors of a specimen called sisitui, dark brown, a little paler below, a little darker on head and tail; dorsal anal and pectoral colorless, the rays olive, with some bluish on menabranes, caudal black; spines of side black at base.

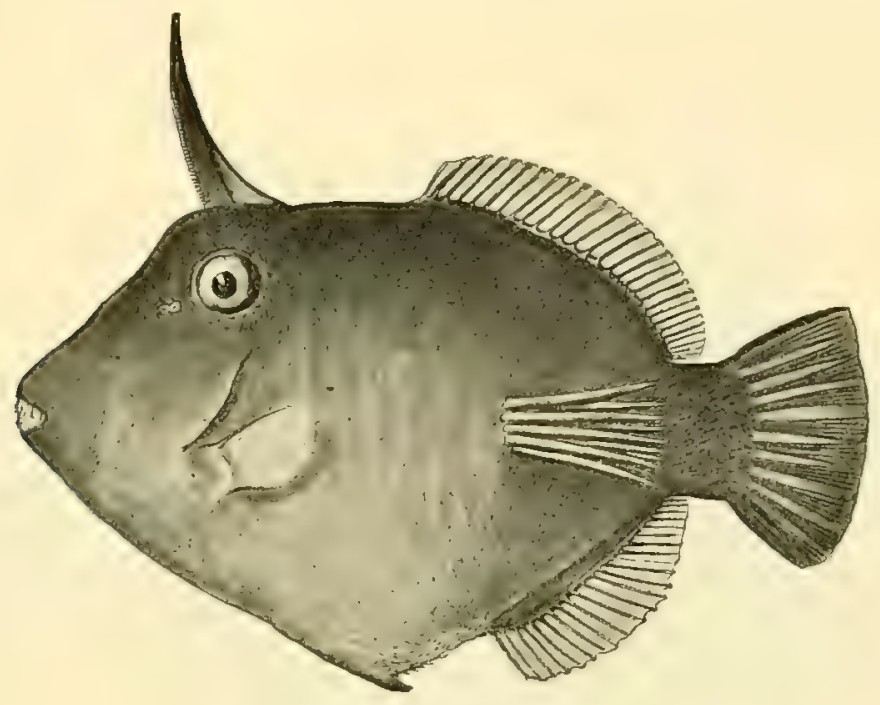

FIG. 68.-Amanses scopas (Cuvier).

OXYMONACANTHUS Bleeker.

This genus is near Cantherines, from which it differs in the elongate form and very long, sharp snout. Unlike the other filefishes, the single species of this genus is gaudily colored.

1270. Oxymonacanthus longirostris (Bloch \& Schneider). Aleca. Samoa; Guam; Fiji; New Caledonia; East Indies. (Pl. L, fig. 2.)

Of this fantastic little fish we have about $15^{\circ}$ specimens, none over 3 inches long, frow the reefs of Apia and Pago Pago. Life colors of one from Apia, sky blue with rows of bright orange spots; ventral flap orange; a brown area above it with fine white dots; fins pale; dorsal and anal reddish, the caudal yellowish brown with two faint broad cross shades; breast light green.

\section{CH死TODERMIS Bleeker.}

1271. Chætodermis penicilligerus (Cuvier). New Guinea; Fast Indies; Australia.

\section{MONACANTHUS Cuvier.}

This genus is characterized by the movable ventral spine. In most of the species the ventral flap is moderate, and the dorsal spine serrated. These belong to the subgenus Stephanolepis, which differs from Monacanthus only in the reduction of the ventral flap, a character of slight importance.

1272. Monacanthus chinensis (Bloch). New Guinea (Nacleay); East Indies; China.

1273. Monacanthus melanocephalus Bleeker. Pa'u-mea; Noloasi. Samoa; New Guinea (Macleay); East Indies.

Monacanthus melanocephalus Bleeker, Nat. Tijds. Fed. Ind., v, 95, East Indies, Bleeker, Atlas, v, 127, tab. ccrxirt. fig. 1, East Indies, Günther, Cat, vri, 212; from Bleeker's type.

Monacanthus janthinosoma Bleeker, Nat. Tijds. Ned. Ind., vi, 503, East Indies.

Monacanthus aspricaudus Hollurd, Ann. Sci. Nat. 1854, Ir, 530, Batavia.

Of this well-marked species we obtained about a dozen specimens from -Apia and one from Iago Pago, the first record in I'olvnesia. It reaches a small size, and is known at once by the checkeren 
band at the end of the caudal fin. The dorsal and anal fins are checkered with black, but these markings are faint in the young. The gill-opening lies in a dark bar.

Life colors of a specimen from A pia called $p a^{\prime} u$-mea, dull blackish green; black around gill-opening; bluish around vent; membrane of first dorsal spine bright orange; soft dorsal and anal finely mottled blue and orange; edges translucent; caudal bright orange with round yellow spots, the edge, with four alternating wavy streaks of blue and orance; side of abdominal cavity livid bluish.

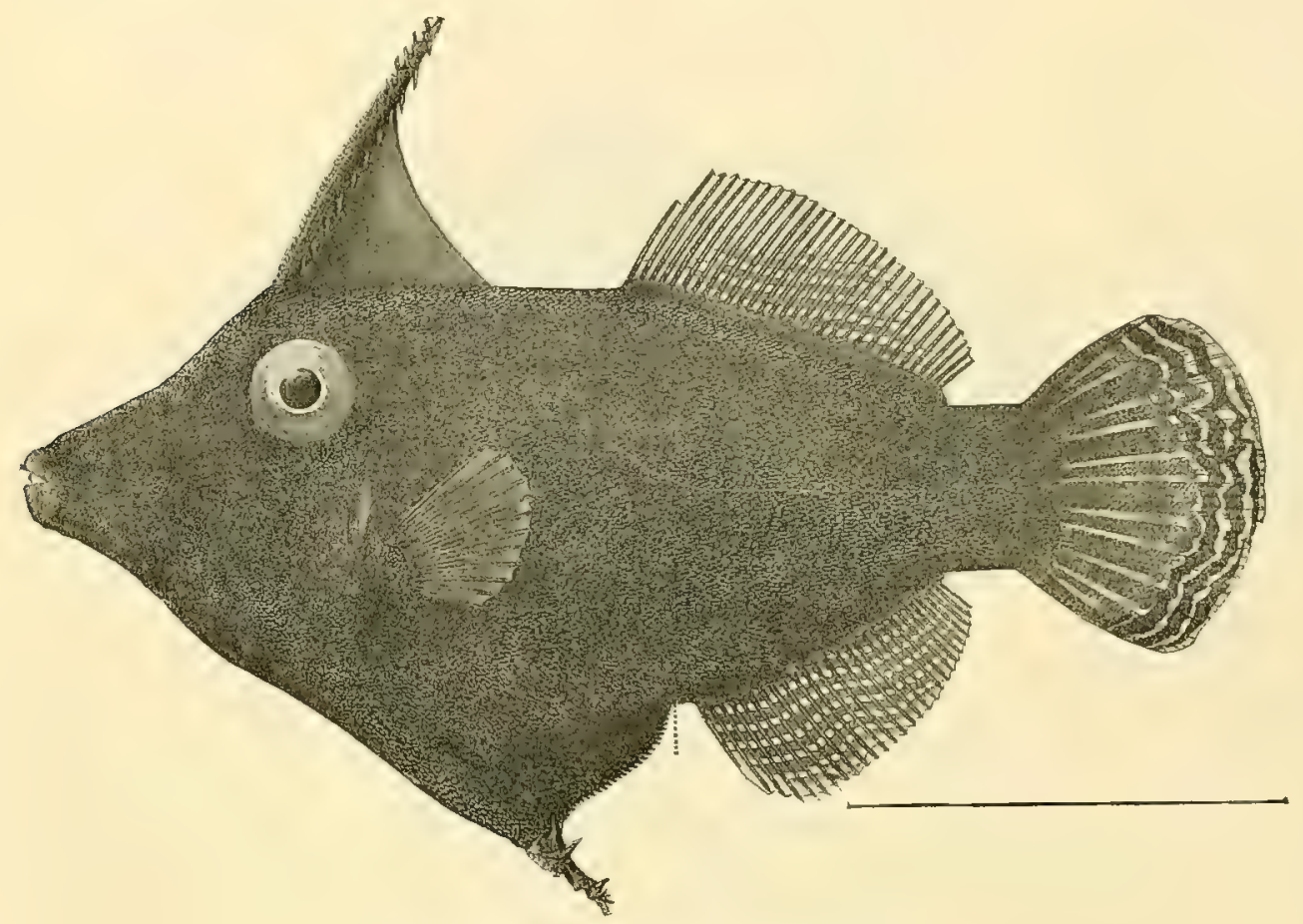

FIG. 69.-Monacanthus melanocephalus Bleeker.

Another specimen has the sides very finely marked with wavy blue streaks, most distinct on bluish lower parts, but very faint; dorsal membrane dull yellow; blue and orange streaks on dorsal more evident; ventral flap blackish.

1274. Monacanthus spilosomus Bennett. Hawaii.

1275. Monacanthus pricei Snyder. Kauai I., Hawaii.

1276. Monacanthus nitens Hollard. Tonga.

This species is unknown to us. It has the dorsal rays 30 ; anal 24; and the color is brownish without distinct spots or stripes. The dorsal spine is serrated, and the armature of the ventral spine is very strong. The spine, being large, is probably movable, but this is not stated. The species probably lelongs to the section Stephanolepis of Monacanthus.

1277. Monacanthus filicauda Günther. New Guinea.

Monacanthus filicauda Günther, Challenger Report, Fishes, 50, 1880.

PARALUTERES Bleeker.

1278. Paraluteres prionurus (Bleeker). New Guinea; East Indies.

OSBECKIA Jordan \& Evermann.

1279. Osbeckia scripta (Osbeck). Hawaii; New Guinea (Macleay); East Indies; west coast islands of Mexico. 
1280. Osbeckia liturosa (Shaw). Tahiti.

Balistes liurosus Shaw, Gen. Zool., V, 405, 1803, Tahiti.

Ifonacanthus liturosus, Günther, Cat., vir, 253; copied.

This species was probably founded on a large example of Osbeckia scripta.

\section{ALUTERA (Cuvier) Oken.}

1281. Alutera monoceros (Linnzeus). Hawaii; New Guinea (Macleay); East Indies.

Family OSTRACIIDA.

OSTRACION LinnæRS.

1282. Ostracion tuberculatum Linneus. Ioamoa uli. Samoa; Fiji; Guam; New Guinea; Marcus I. : New Britain (Peters: Berl. Mon. 1876, 852); East Indies.

This species, known by the round blue-black spots, is moderately common about Samoa. We have six specimens from Apia and Pago Pago. One of these was yellow in life, the others olive. This species seems well separated from its Japanese cognate, Ostracion immaculatum. The species, called Ostracion trigonim and Ostracion cubicum, is identical with Ostracion uberculatum.

Life colors of a specimen from Apia called moamoa, dark olive brown with bluish spots, which are white in spirits; fins dull golden, blackish at base; caudal with a few rounded black spots at base.

All the specimens from Pago Pago had blue-black spots; one with the caudal deep orange yellow, the other fins paler yellow; another with the caudal dusky shaded with light yellow, the other fins bright yellow.

1283. Ostracion nasus Bloch. Guam; East Indies.

1284. Ostracion ornatum Hollard. Marquesas Is. Ostracion ormalus Follard, Ann. Sei. Nat., vir, 1857, 166, Marquesas Is.

This well-marked species, distinguished by the two pale lateral stripes, is unknown to us.

1285. Ostracion lentiginosum Bloch \& Schneider. Moamoa uliuli. Hawaii; Samoa; Guam; Johnston I. ; Last Indies.

This species, common in the East Indies and South Seas, occurs both in Hawaii and Samoa. We have eight examples from Apia and Pago Pago. The color is plain dark olive, with small whitish spots above, below, and on sides.

Life colors of a specimen from Apia, blackish brown, spotted everywhere with grayish white, marbled on orange shades; caudal and belly also spotted; other fins olive; dorsal blackish at base.

1286. Ostracion sebæ Bleeker. Moamaa samasama. Hawaii; Samoa; New Guinea (Macleay); East Indies.

Ostracion sebre Bleeker, Verh. Bat. Gen., XxIv, 32, taf. 6, fig. 13, East Indies.

Ostracion bombifrons Hollard, Ann. Sci, Nat, 1857 , viI, 168.

Ostracion camurum Jenkins, Bull. U. S. Fish Comm., XIX, 1899 (1901), 396, fig. 9, Honolulu.

Four specimens of this handsome species were taken on the reef at A pia. The color, well showa in Bleeker's figure, is characteristic, especially the undulating yellow stripe, most distinct on the tail.

The species is not rare on rocky shores about Hawail, whence it was described as Ostracion camurum. The yellow undulating stripe is sometimes faint in Hawailan examples, but these often agree fully with the Samoan.

1287. Ostracion oahuensis Jordan \& Evermann. Hawaii.

This species is known from two examples from Honolulu. It is near Ostracion sebx, but the spots are smaller, with none on the sides of the body.

\section{LACTORIA Jordan \& Fowler.}

Lactoria Jordan \& Fowler, Proc. U. S. Nat. Mus., Xxv, 278, 1903 (cornutus).

1288. Lactoria galeodon Jenkins. Hawaii.

Ostracion draphanus Steindachner, Denks. Ak. Wiss. Wien, Lxx, 517, 1900, Laysan, Hawaii: not of Lácépéde.

This species is rather rare about Hawaii, all the examples seen being small. It is nearly related to Lactoria diaphuma of Japan. 
1289. Lactoria schlemmeri Jordan \& Snyder. Laysan.

Lactoria schlemmeri Jordan \& Snyder, Proc. U. S. Nat. Mus, xxvir, 945, 1904, Laysan.

1290. Lactoria cornuta (Linnæus). Moamoa. Samoa; Fiji; Guam; Marcus I.; New Guinea; Tahiti and Shortland I. (Seale); East Indies; Japan.

Of this fantastic species, the most abundant of the group in the East Indies, we have two specimens from Apia. Dr. Günther records it from Fiji, Seale from Guam, and Bryan \& Herre from Marcus Island. In the length of the horns this species is subject to considerable variation.

\section{ARACANA Gray.}

1291. Aracana spilonota Gilbert. Hawaii.

\section{Family TETRAODONTIDE.}

Species of this group are more abundant in the East Indies than in the South Seas. About Samoa they are not very common. They are known as sui and are regarded as poisonous, although none of the species has the bad repute possessed at Hawaii by Tetraodon hispidus.

SPHEROIDES (Lacépède) Duméril.

1292. Spheroides oceanicus (Jordan \& Evermann). Hawaii.

Lagocephalus oceanicus Jordun \& Evermann, Bull. U. S. Fish Comm., XXII, 199, 1902 (1903), Honolulu.

This species is known from two young examples taken at Honolulu. It is a typical Lagocephalus, close to the European Spheroides pennanti. There is a most perfect gradation between the type of Lagocephalus and that of Spheroides.

1293. Spheroides sceleratus (Forster). Tahiti; New Guinea (Macleay); East Indies.

1294. Spheroides hypselogeneion (Bleeker). Fiji; Samoa; East Indies; Australia.

Tetraodon hypselogeneion Bleeker, Nat. Tijds. Ned. Ind., 11I, 300, East Indıes. Bleeker. Atlas, v, 61, tab. ccxin, fig. 5, East Indies. Günther, Cat., viII, 277, 1870, Zanzibar, Seychelles. Fiji, Austral1a

Of this species we found four examples, two at Apia and two at Pago Pago. The coloration is well represented in Bleeker's plate. The specimens from Apia have the rlark bars on the head and the dark lateral stripe strongly marked.

Life colors of a specimen from Apia, dark olive, much speckled with whitish; a dark lateral stripe with a creamy area below it; belly yellowish; iris golden yellow; four dark bars on side of head between gill opening and snout, most distinct below eye; fins unicolored.

1295. Spheroides oblongus (Bloch). Faté (Seale); East Indies.

1296. Spheroides florealis Cope. Hawaii.

This species is known to us from a few young examples from Hawail.

1297. Spheroides insularum De Vis. New Hebrides.

Spheroides insularum De Vis, Proc. Linn. Soc. N. S. W., vin, 456, 1884, Api (New Hebrides).

1298. Spheroides lævis (De Vis). South Seas.

Tetraodon lævis De Vis, Proc. Linn. Soc. N. S. W., viII, 456, 1884, South Seas.

\section{TETRAODON Linnæus.}

This genus contains short-bodied species, with the nasal tentacle bifid, without opening. The species are especially abundant in the East Indies.

1299. Tetraodon aerostaticus (Jenyns). Tahiti: Guam; New Guinea (Macleay); Faté (Seale); Japan; East Indies.

Tetraodon lincatus Bloch, Ausland. Fische, I, 1785, 128, pl. CXLI, and of various authors (not of Linnæus). Schlegel, Fauna Japonica, Poiss., 287, pl. cxxv, fig. 2, 1847, Nagasaki. 
Crayracion lincatus Bleeker, Atlas, v, 70, tab. ccvi, fig. 1, tab. ccxir, fig. 1, Bali, Singapore, Celebes, Amboina. Tetraodon aërostaticus Jenyns, Voyage Beagle, 152, 1842, locality unknown.

Tetraadon lineatus, Kner, Novara Fische, 409, Tahiti.

This species, common from Japan to the East Indies, is recorded by Günther from Fiji, by Kner from Tahiti, and by Seale from Guam. The black stripes on the abdomen on this and other species disappear with age.

It is very close to Telraodon stellatus Bloch \& Schneider, of the East Indies, with which Dr. Günther identifies it. The latter has, however, the dorsal spotted, like the caudal, besides other minor differences. In Tetraodon cerostaticus the dorsal is immaculate. The hack in both is profusely spotted with black.

\section{Tetraodon mappa Lesson. New Guinea (Macleay); East Indies.}

1301. Tetraodon hispidus Linnæus. Sue. Hawaii; New Guinea; Samoa; Aneiteum; New Hanover (Peters); China; Last Indies; I'anama.

Petraodon hispidus Linnæus, Syst. Nat. ed. $x, 1758$, 33, China; after Lagerstrom (probably this species, the spots not indicated in Lagerstrom's figure); Syst. Nat., ed. xII, 1766, 411.

Tetraodon hispidus, Günther, Cat., VIII, 297, 1870, Red Sea, Zanzibar, Ceylon, Mozambique, Port Natal.

Tetraodon perspicillaris Rüppell, Atlas Fische, 63, Red Sea.

Tetraodon implutus Jenyns, Voy. Beagle, Fish, 152, 1812, Vanicolo.

Crayracion implutus (as latema in plate), Bleeker, Atlas, v, 71, tab. ccv, fig. 3, Sumatra, Cocos, Solor, Timor, Batjan, Amboina, Banda.

Tetraodon laterna Richardson, Voy. Sulphur, 1842, 124, pl. LxI, fig. 2, Canton; after an incorrect drawing by John Reeves. Richardson, Ichth. China, 199, 1846, Canton.

Arethron laterna, Bleeker, Enum. Pisc. Archip. Ind., 200.

Tetradon hispidus (semistriatus), Günther, Cat., vıI, 1870, 297, Amboina, Aneiteum, Australia.

Arothron erethizon Jordan \& Gilbert, Proc. U. S. Nat. MI us., V, 1852, 631, Panama.

This species is very abundant in the lagoons and mullet ponds about Honolulu. It is regarded as excessively poisonous, muki-muki, or deadly death, being its local name. A single specimen nearly a foot long was taken at Apia. It is common in the East Indies, and we can see no difference between Hawailan specimens and others from the Riukiu Islands. It is not certain, however, that this species is the original Tetraodon hispidus of Linnæus.

The Samoan specimen is nearly smooth, dark olive, with round brown spots on sides of head as well as on sides and back of body; base of caudal fin with many round spots, smaller than those on body; dark stripes on belly persistent; gill-opening black with white rings; eye with white rings; vent pale; tip of caudal dusky and unspotted.

1302. Tetraodon reticularis Bloch \& Schneider. New Guinea; New Britain; Guam; East Indies.

Tetraodon reticularis Bloch \& Schneider, Syst, Ichth., 1801, 506, Malabar. Gunther, Cat. vir, 296, Amboina, Celebes, Pinang. Peters, Berl. Mon., 1876, 853, New Britain. Seale, Bishop Muscum 1901, 119, Guam. Arothron testudinarius Muller, Arch. Nat., IX, 330

Crayracion testudineus Bleeker, Atlas, $\mathrm{v}, 71$, tab. CcxiI, fig. 3, East Indies; not Tetraodon testudineus of Linneus.

1303. Tetraodon nigropunctatus Bloch \& Schneider. Sue. New Guinea; Fiji; Samoa; East Indies. ( $\mathrm{Pl}, \mathrm{xxxv}$.)

Tetraodon nigropunctatus Bloch \& Schneider, Syst. Ichth., 1801, 507, Tranquebar. Günther, Cat., vilI, 293, Zanzibar, Amboina, Flores, sumatra, Halmahera.

Crayracion nigropunciatus, Bleeker, Atlas, v, 7 , tab. ccvi, fig. 4, East Indies.

Tetraodon dicuematus Rúppell, Atlas Fische, 65, pl. xvir, fig. 3, Red Sea.

Tetraodon trichodcrma Bleeker, Nat. Tijds. Ned. Ind., v, 532, Sumatra; examples with long bristles.

Tetrandon irichodermatoides Bleeker, Nat. Tijds. Ned. Ind., V1, 330, Flores.

Arothron melanorhmehus Bleeker, Nat. Tijds. Ned. Ind., IX, 111.

Tetraodon nigropunctatus var. citrinella Güther, Cat., vir, 293, 1870, Fiji; bright yellow examples.

This species is very common about Apia and Pago Pago. It is known as sui, and is regarded as poisonous. Most of our specimens are very typical, brown with black vent and snout, the caudal edged with pale, and the spinules short. Some similarly colored have the body covered with bristles so long as to give the appearance of coarse fur. Others are intermediate in this regard, and one has the ground-color bright lemon-yellow. It seems clear that all belong to the same species that Günther has indicated. 
We have 20 specimens from Apia and Pago Pago. Life colors of one from Apia, blackish olive, unmarked, the spines white; gill-opening black; all the tins dull olive, the posterior part fading to yellow, brightest on pectoral. Some have sparse black spots on belly. Others are dark olive above, bright yellow below, with or without black spots. Margin of caudal always yellowish, vent always black.

One specimen from Pago Pago, the variety citrinellus, was lemon-yellow, the back irregularly blackish olive.

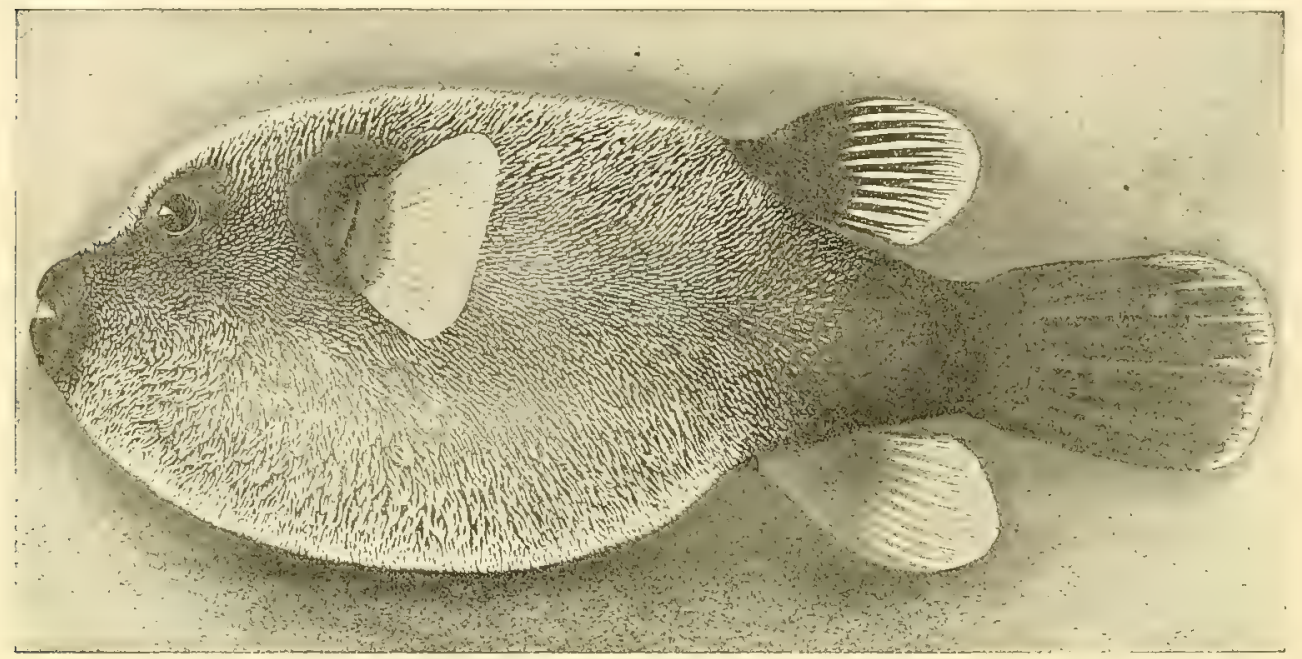

FIG. 70.-Teiraodon nigropunctatus Bloch \& Schneider

1304. Tetraodon immaculatus Bloch \& Schneider. Fiji (Günther); Samoa; New Ireland; Micronesia; New Caledonia; Faté; Shortland I. (Seale); New Guinea; East Indies.

ADULT EXAMPLS.

Tetraodon immaculatus Bloch \& Schneider, Syst. Ichth. 1801, 507; after Tetraodon sans tache of Lacépède, I, 475. Güther, Cat., vin, 291, Natal, Zanzibar, Mauritius, Pinang, New Caledonia, Australia.

Crayracion immaculahus, Bleeker, Atlas, v, 75 , tab. ccxI, fig. 1, East Indies.

Tetraodon sordidus Rüppell, Atlas Fische, 64,1828 , Red Sea.

Tetrcodon parvus De Joannes, Mag. Zool. 1835, IV, pl. 15.

Tetraclon seaber Eydoux \& Souleyet, Voy. Bonite, 214, pl. 10, fig. 1.

Tttraodon brsitevskianus Basilewsky, Mem. Soc. Mosc., X, 1855, 202.

Tetraodon kwh harlti Bleeker, Nat. Tijds. Ned. Ind., 197.

Tetraodon aspilus Bleeker, Nat. Tijds. Ned. Ind., II, 495, East Indies.

YOUNG EXAMPLES.

Tetraodon manillensis Procé, Bull. Philom. 1822, 130, Manila. Peters, Berl. Mon. 1876, 853, Amboina; New Ireland. Crayracion manillensis Bleeker, Atlas, $v, 69$, tab. ccvin, fig. 2, East Indies.

Tetraodon virgatus Richardson, Voy. Erebus and Terror, 62, pl. 39 , figs. 8 and 9, 1816.

Tetrcodon immaculatus var, virgutus, Gunther, Cat., vıı, 292, Ceram, Amboina, Philippines, Cape York, Sydney, Micronesid.

Tetradon carduus Cantor, Malay, Fish, 375, 1850, Pinang.

Holacanthus pilosus Gronow, Syst., ed. Gray, 28, 1854.

Dilobomycter Longicaudus Bibron, Rev. Zool. 1855, 279.

Tetraodon immaculatus, Fowler, Proc. Ac. Nat. Sci. Phila. 1900, Samoa.

Of this species we have five young from Apia, agreeing very closely with Dr. Bleeker's figure of Crayracion manillensis. The color is greenish with about 8 dark streaks on each side, the caudal dark with darker edge, the gill-opening black.

A pparently Dr. Günther is right in regarding Tetrcodon manillensis, with the back streaked, as the young of Tetraodon immaculatus, in which species the back is plain olive. Specimens before us from Negros, in the Philippines, show that the black stripes on the back disappear with age. Both Günther and Bleeker record specimens of the struped form, manillensis, of 10 to 12 inches in length. All our 
Samoan specimens are young, and all have the black stripes, but we have no doubt that they are specifically identical with the unstriped Tetraodon immaculatus. The best distinctive character of this species is the black edge to the caudal.

Color in life of a specimen from Apia, olive, white below, striped ali over back and sides of belly" with dark olive; fins pale gray, the caudal eiged all around with black.

1305. Tatraodon lacrymatus Cuvier. Hawaii; Raiatea (Seale).

Tetradon lacrymatus Cuvier. in Quoy \& Gaimard, Voy. Uranie, Fishes, 201, 1824, Maui. Oroides latifrons Jenkins, Bull. LZ. S. Fislt Comm, XIX, 1899, (1901), 398, fig. 10, Fonolulu.

Tetradon meleagris, Smith \& Swain, Proc. U. S. Nat. Mus., V, 1582, 111, Johnston I.; not of Lacépede.

This species, which is probably different from Telradom meleagris of the East Indies, is known from the Hawailan Islands. The specimens from Johnston Island, called Tetracton meleagris, probably belong here, as well as the type of Tetrudon lutifrons. Tutrodon meleagris is found in the seas of tropical Japan and China. The single specimen examined by us from the Iiu Kiu Islands is apparently different from those called Titradon lutirons. The species called lutifrons must be the same as the lacrymatus, described long before, from the same waters.

1306. Tetraodon ophryas Cope. Samoa; Tahiti; Mangareva (Seale).

Tetraodon ophryas Cope, Trans. Am. Phil. Soc. 1870, 479, Samoa.

?Tetraodon setosus Rosa Smith, Bull. Cal. AC. Sci., II, 6, 1886, west coast of Mexico.

Oroides ophryas, Fowler, Proc. Ac. Nat, Sci. I'hila. 1400, 528, pl. xx, fig. 2; after Cope's type.

This species is known only from the original type from Sanoa. It may be identical with Tetraodon setosus of the Mexican coast. Telraodon melengris Lacépède, from Asia, figured by Jordan \& Fowler (Proc. U. S. Nat. Hus., xxiv, 253, fig. 8), also is allied to it.

1307. Tetraodon giganteus Castelnau. New Caledonia.

Tetraodon gigantens Castelnau, Proc. Zool. Soc. Victoria, 1873, 121, New Caledonia.

\section{CANTHIGASTER SWainson.}

(Psitonotus Swainson; Tropidichthys Bleeker; Anosmius Peters; Eumycterias Jenkins.)

This genus consists of small globe-fishes with the back angulated and the nostrils obsolete or little deyeloped. The earliest name, Canthigaster, is defined without mention of any species, but the context admits of no doubt as to the species intended. The slightly better development of the nostrils in Eumycterias Jenkins is a character of very light weight, and the genus Eumycterias can not be maintained.

1308. Canthigaster solandri (Richardson). Sue mimi. Tahiti; Samoa; Guam; Raiatea (Seale).

Tetraodon solandri Richardson, Voy. Sulphur, Fish, 125, pl. 57, fig. 4-6, 1845, Tahiti. Richardson, Voy. Samarang, 19, 1848, Tahiti.

Tropidichthys papua, Seale, Bishop Nuseum 1901, 118, Guam; probably not of Bleeker.

i Tetraodon papua Bleeker, Journ. Ind. A Trch., II, (i38, New Guinea.

This little species from Tahiti was originally described as having the body covered with greenish yellow spots, each with a dark border with blue cross streaks between the eyes, with some of the stripes on the back extended as streaks; caudai with blue spots, forming interrupted blue streaks. As one of our Samoan species agrees perfectly with this description, we identify it as Canthigaster solundri. The fish called solandri by Steindachner from Laysan seems to be Canthigasler jactator. The specimens from Guam, called Tropidichthys papua, evidently belong here. Cunthigaster papua Bleeker, from New Guinea, is evidently closely related, but it has the blue streaks on the back more or less confluent into lines.

In our eight typical examples of Canthigaster solnndri, from Apia, the spots are small on the cheek and snout and distinctly blue in color. In eight examples irom Pago Pago, the spots on the body are duller, and those on the chin, throat, and cheek, as far back as the gill-opening, are dark bronze-blue, eye with radiating streaks, caudal distinctly barred. This may be a distinct species, but it seems to intergrale perfectly with the typical form, one specimen of the latter having larger bronze-blue spots at the throat. We have about 25 specimens from Apia aud Pago Pago.

Life colors of two specimens from Apia, dark brown, orange on side, yellow below, with a median blue, orange-edged streak before vent; sides with round sky-blue spots, most distinct on head; caudal orange, barred with blue spots; dorsal, anal, and pectoral clear translucent; a black spot at base of dorsal. 
A series of six specimens, mostly from Pago Pago, were very aberrant. Life colors of one of these, rich orange-brown, paler bright orange on snout, light orange on belly; everywhere round pale blue spots edged with darker blue, these largest on side of belly, smaller on side of tail, deepest on middle of back; a faint blue median ventral streak; blue cross-streaks on snout and as far back as behind eye, 7 in all, the posterior darker edged; spots confluent into a streak on front of back; a black spot below dorsal, with 4 blue spots and streaks about it, a curved blue streak above it on fin; back of tail with spots only; tail orange, with blue spots in vertical rows, and a dark blue edge; fins otherwise colorless orange, with blue spots about verit.

In alcohol these specimens have the spots larger and sparser, and the spots below the eye and on the ventral pouch are very much enlarged, separated by a narrow network of the ground-color; chin and throat with an irregular patch of olive; streaks across eye very distinct; spots on sides of snout generally brown, the color very different from that of the spots on the body.

Life colors of a young individual from Apia, dark olive with blue spots; blue stripes on head and a black blue-edged ocellus at base of dorsal; caudal with pale blackish cross-streaks.

1309. Canthigaster papua (Bleeker). New Guinea; East Indies.

1310. Canthigaster jactator (Jenkins). Hawaii; Laysan.

This species, profusely covered with large pale spots, was found on the reef about Honolulu. The specimens called by Steindachner Tetraodon solandri, from Laysan, seem to be the same. A very near relative is Canthigaster punctatissimus from the Panama region and the Galapagos.

1311. Canthigaster bitæniatus (Jenkins). Hawaii.

?Ttraodon caudofasciatus Günther, Cat., viII, 301, 1870, no locality with plate.

Tetraodon caudofasciatus, Steindachner, Denks. Ak. Wiss. Wien 1900, 518, Laysan.

Eumycterias bitæniatus Jenkins, Bull. U. S. Fish Comm., XIX, 1899 (1901), 400, fig. 12, Honolulu,

This species is found about Honolulu. In coloration it is almost exactly identical with the common Japanese species, Canthigaster vivulatus Schlegel. In view of the remote habitat, the Hawailan species may be kept provisionally distinct.

Apparently the species called Tetraodon caudofasciatus by Steindachner is the same as Canthigaster bitaniatus. The original Tetraodon caudofasciatus of Güther is from an nnknown locality. It may be the same also, as the difference in description is slight. The back is said to be spotted with brown in Canthigaster caudofasciatus, and the caudal is crossed with dark bands. These traits are not found in Canthigaster bitæniatus nor in Canthigaster rivulatus.

1312. Canthigaster caudofasciatus (Günther). Laysan (Steindachner, as T. callisternis Ogilby).

1313. Canthigaster janthinus (Vaillant \& Sauvage). Hawaii.

Tetraodon janthinus Valllant \& Sauvage, Ann. Mus, 1875, 286, Honolulu.

This species, an ally of Canthigaster psegma, has not been recognized since it, was originally taken by Ballieu at Honolulu. We should regard janthinus and psegma as identical, were it not that Sauvage describes the lateral spots as large, and the dorsal fin is stated to be black. Only the caudal is black in Canthigaster psegma.

\section{Canthigaster psegma (Jordan \& Evermann). Hawaii; Samoa.}

This species has been found about Honolulu and about Samoa. The Samoan examples, four in number, differ a little from the original types, especially in having less clearly defined streaks about the eyes.

We have two large specimens from Apia. The species is very close to Canthigaster oahuensis as figured by Dr. Jenkins. The markings of the head and fins are almost identical, and the oblong black spots on the sides are the same. But our specimens show no trace whatever of stellate blue spots, and these are very conspicuous in Canthigaster oahuensis.

Life colors of a specimen from Apia, dark olive with orange-brown shades and faint blue spots; blue and bronze streaks with a few blue specks radiating from eye; cheeks brownish gray with thickset dark-blue spots above and bronze spots behind them; dorsal and anal pale olive, a black bar across base of each; no black blotch on back; caudal dusky, blackish; pectoral dusky; cheek closely covered with close-set dark spots, which form narrow oblique brown streaks in front; sides of belly with oblong black spots, all smaller than pupil. 
Another specimen from Apia was brownish black; cheek grayish with blue-black spots, forming streaks below; side with a few blackish streaks and blue spots; middle line of belly darker; dorsal and anal dusky at base; caudal all black, the fins otherwise colorless.

1315. Canthigaster epilamprus (Jenkins). Hawaii.

1316. Canthigaster oahuensis (Jenkins). Hawaii.

- This species is found in the reefs about Honolulu, where it is apparently rare. It is one of the deep-bodied species, like Canthigaster psegma.

1317. Canthigaster cinctus (Solander). Tahiti; Samoa; New Guinea (Macleay); Hawaii; East Indies.

Tctraodon gronovii Cuvier, Regne Anim., ed. II, 1827, nodescription.

Titraodon cinctus Solander, Richardson Voy. Samarang, 19, 20, 1850, Tahiti; on a drawing by Solander.

Tropidichthys valentini Bleeker, Nat. Tijds. Ned. Ind, IV, 130, 1853, Amboina.

Tropidichthys valentini Bleeker, 3de Bijdr. Amboina, 130, Amboina.

Psilonotus valentini Bleeker, Atlas, Gymnodontidæ, v, 80, tab. ccvirt, fig. 4.

Tetraodon valentini Günther, Cat., vıI, 305.

Holacanthus balistaformis Gronow, Cat. Fish, ed. Gray, 1854, 25.

Tetraodon coronatus Vaillant \& Saluvage, Ann. Mus. 1875, 2s5, Hawaii.

This species, distinguished at once by two blackish cross-bars, was seen by us at Hawaii only. The species called coronatus is certainly the cinctus of Solander.

Tetrciodon cinctus is described as studded above with small round dots, which are also found on the caudal fin. Besides these there are two oblique black bars which embrace the fore part of the belly; the interval between them light yellow; traces of other dark bars appear behind.

It is evidently identical with Canthigaster coronatus. Dr. Gilbert's single specimen of the latter from Hawaii agrees perfectly with Günther's description of Canthigaster valentini. Bleeker's figure, however, differs in showing blue streaks on the head, the posterior far less developed, and the caudal fin unspotted, the black stripes on its lower and upper margins less plain than in coronatus.

Bleeker's description fits well the specimen obtained in Hawaii by Dr. Gilbert, and there seems no reason for doubting the identity of $C$. cinctus and $C$. coronatus with the East Indian form, Cunthigaster valentini. The name cinctus has priority.

1318. Canthigaster compressus (Procé). Faté (Seale); East Indies.

(Tetrandon striolatus Quoy \& Gaimard.)

1319. Canthigaster bennetti (Bleeker). New Guinea (Macleay); East Indies.

\section{Family DIODONTIDE.}

\section{DrODON Linnæus.}

1320. Diodon hystrix Linnæus. Tauta. Samoa; Hawaii; Tahiti; Guam; Johnston I.; New Guinea; all warm seas.

Occasionally taken in Samoa. WVe have 2 specimens.

1321. Diodon holacanthus Linnæus. Laysan (Steindachner, Denks. Ak. Wiss. Wien 1900, 518, as Diodon sexmaculatus); warm seas.

This species may be the young of the preceding.

1322. Diodon nudifrons Jenkins. Hawaii.

\section{CHILOMYCTERUS Bibron}

1323. Chilomycterus affinis Günther. Hawaii; Lower California; Galapagos Is.; Japan.

Family MOLIDE.

RANZANIA Nardo.

1324. Ranzania makua Jenkins. Hawaii; Japan. 


\section{Family SCORPENIDE。 ${ }^{a}$}

\section{MERINTHE Jordan \& Evermann.}

1325. Merinthe macrocephala (Sauvage). Hawaii.

1326. Merinthe bandanensis (Bleeker). Faté (Seale); East Indies.

Scorprena bandanensis Bleeker, Banda, I, 237, 1851, Banda.

Scorpana haplodactylus Bleeker, Ceram, Ir, 698, 1852, Ceram.

Scorpæna haplodactyla, Günther, Cat., II, 117, Banda, Ceram, Fiji(?).

\section{IRACUNDUS Jordan \& Evermann.}

1327. Iracundus signifer Jordan \& Evermann. Hawaii.

\section{SEBASTOPSIS Gill.}

1328. Sebastopsis parvipinnis (Garrett). Hawaii (Garrett); Raiatea.

Scorprna parvipinnis Garrett, Proc. Cal. Ac. Sci. 1863, 105, Sandwich Is., Raiatea. Günther, Fische der Sïđsee, 75 , taf. 51, fig. D, Raiatea.

This species is known to us only from the accounts of Günther and Garrett. It seems well distinguished by its low dorsal spines.

1329. Sebastopsis kelloggi Jenkins. Hawaii.

This little fish is abundant about the Hawaiian islands. It is close to Sebastopsis guamensis (polylepis), but it differs from all the Polynesian species examined by us in having, besides an auxiliary spine, four spines on the edge of the preopercle. There are three of these spines in Sebastopsis guamensis and Sebastopsis scabra.

1330. Sebastopsis guamensis (Quoy \& Gaimard). La'otale. Samoa; Tahiti; Guam; Caroline Is.; Tonga; Palau; Fiji; East Indies.

IScorpxna rawakensis Quoy \& Gaimard, Voy. Uranie Zool., 325, 1824, Rawak.

Scorprna guamensis Quoy \& Gaimard, Voy. Uranie Zool., 326, 1824, Guam.

Sebastopsis guamensis, Streets, Bull. U. S. Nat. Mus., vir, 96, Samoa. Fowler, Proc. Acad. Nat. Sci. Phila, 1900, 521, Tahiti.

Scorpæna guamensis, Klunzinger, Fische Rothen Meeres, Tuhiti. Günther, Fische der Südsee, 74, Caroline Is., Red sea, samor, ronga, Palau.

Sconpana rubropunctata Ehrenberg in Cuvier \& Valenciennes, Hist. Nat. Poiss., IV, 324, 1829, Red Sea.

Scorpana chilioprista Rüppell, Nene Wirbelthiere, 107, taf. 27, fig. 3, 1835, Red Sea. Günther, Cat., II, 121.

Sebastes polylepis Bleeker, Nat. Tijds. Ned. Ind., 1851, II, 173, Amboina. Gunther, Cat., II, 106, Amboina, East Indies.

Sebastopsis erinacea Garman, Bull. Mus Comp. Zool., xxxIx, 8, 231, pl. I, fig. 2, Viti Levu (Fiji).

Sebastes minutus Cuvier \& Valenciennes, Hist. Nat. Poiss., Iv, 345, 1829, Moluccas, Ladrones, Society Is. Günther, Cat., II, 106.

Of this species we have about 50 specimens from Samoa. It is well separated from Sebastopsis scabra by the shorter anal spine. It is impossible for us to tell certainly what species was intended in the descriptions of Scorpicna guamensis and minutus, but this species is certainly the guamensis of Günther and Klunzinger, as also the polylepis of Bleeker and the erinacea of Garman. We can not identify Scorpæna rawakensis.

Life colors of a specimen from Apia, light olive with many brown spots and three dark brown cross-shades; a white bar across base of caudal; fins all reddish brown, bright brick-red at tip, barred with pale bluish gray; throat and belly dark.

Another specimen was dusky brown, four dusky cross-bars, sides with greenish reticulations around dusky spots; fins all closely reticulated reddish brown and bluish gray; throat paler.

1331. Sebastopsis scabra (Ramsay \& Ogilby). Samoa; north Australia.

Sebastes scaber Ramsay \& Ogilby, Proc. Linn. Soc. N. S, W, x, 1885, Shark reef (Australia).

a Scorpæua vaigienss Irom Waigiu (Quoy \& Gaimard, Voy. Uranie, 324) we can not place. It has dorsal XIV, 11, anal III, 5. 
This species is distinguished from Sebastopsis guamensis by the very much longer second anal spine. It is equally abundant at Samoa, and has doubtless been confused by authors with Setastopsis guamensis under that and other names. We have about 40 examples from crevices in the reefs of Apia and Pago Pago. Scabra has an orbital tentacle.

Life colors of a specimen from Pago Pago, brown, the fins barred with brownish red; a large jet black spot on opercle; ventrals and belly yellowish.

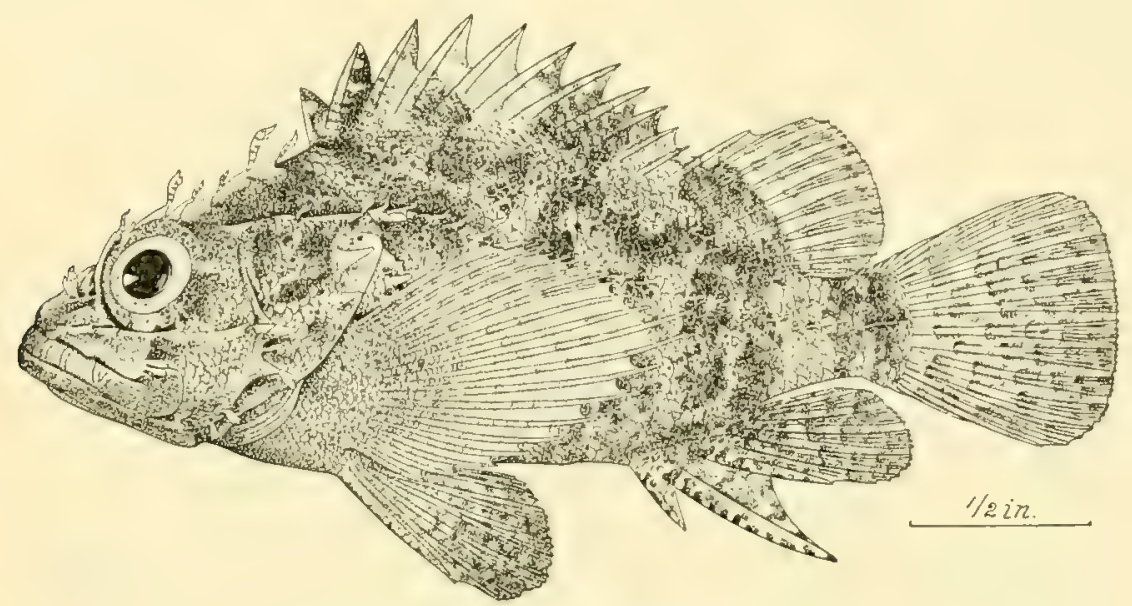

Fí. 71. - Sebastopsis scabra (Ramsay \& Ogilby).

1332. Sebastopsis novæ-guinea (Sauvage). New Guinea (Nouv. Arch. Mus. 1878, 129).

\section{SCORPANOPSIS Bleeker.}

1333. Scorpænopsis cirrhosa (Thunberg). Tahiti (Günther); New Guinea (Macleay); Japan; Fast Indies.

1334. Scorpænopsis gibbosa (Bloch \& Schneider). Nofu. Tahiti; Palau; Hawaii; Samoa; New Guinea; East Indies.

(Scarpænopsis catocala Jordan \& Evermann, Hawaii.)

This species is rather common about Samoa, where we obtained three good-sized specimens, and still more common about Hawaii. It is certain that the diabolus of Cuvier \& Valenciennes is the same as the gibbosa of Bloch \& Schneider. The characters used by Bleeker to distinguish these species can not be trusted. $\$$. giblosa is best known by its wide, depressed interorbital area, much wider than the eye, and by the deep nuchal pit; there is a black band at the shoulders covering part of the spinous dorsal fin and a black notch at tip of upper jaw. Scorpacnopsis catocale from Hawail and Scorpxna nesogallica from Ile de France can not be separated from S. gibbosa.

There is a broad black band on the inner side of the pectoral fin near the margin, and this, in the adult, breaks up into spots.

Life colors of a specimen from Apia, violet-black, the dark shades light olive-gray, the throat very dark; lining membranes of jaws bright yellow; axillary region light gray, mottled with olive; belly creamy yellowish; pectoral banded with black, orange and yellow within, grayish at tip; ventrals black, pale-edged; caudal with a broad black band, pale gray at base and tip; spinous dorsal with a purple blotch continued as a band on body.

Another specimen, from the same locality, was dark reddish brown, light bright reddish brewn below; fins with the pale parts all reddish brown of varying shades; axil dark with pale spots.

1335. Scorpænopsis cacopsis Jenkins. Hawail; Tahiti.

1336. Scorpænopsis novæ-guineæ Cuvier \& Valenciennes. Samoa; New Guinea.

iScorprena nove-guince Cuvier \& Valenciennes, Hist. Nat. Poiss., IV, 320, 1829, New Guinea. scornarna papuensis Cuvier \& Vulenciennes, II ist. Nat. Poiss, 1W, 321, 1829, New Guinea.

Scorpana gibbosa, Günther, Cat., 11, 119. Sinvige, Poiss. Madagascar, 279; not of Schneider. 
This species, distinguished from the true Scorprnopsis gibbosa by the narrow incerorbital and smoother body, is known to us from a single example from Samoa. Among its best distinctive characters is that of the very long second anal spine, a feature not shown in the plate of Quoy \& Gaimard, who may have had some other species in mind.

Life colors of a specimen from Apia, blackish, the belly creamy yellowish, with no red and no orange except in the inner angle of ventrals; all pale markings creamy white or creamy brown, a little orange-shaded in dorsal and anal and inner edge of ventral; inner side of pectoral olive with orange shades next to the black cross-band; axil olive with round brown spots.

1337. Scorpænopsis altirostris Gilbert. Hawaii.

1338. Scorpænopsis zanzibarensis (Playfair). New Guinea (Günther); Zanzibar.

SCORPENA (Artedi) Linnæus.

1339. Scorpæna cooki Günther. Raonl I.; Cook Is.; Raiatea (Seale). Ścorprena cooki Günther, Fisehe der Südsee, 78, taf. 55 , Raoul I.

\section{SEBASTAPISTES Gill.}

1340. Sebastapistes dentatus (Günther). Palau Is.

Scorpaena dentata Günther, Fische der Südsee, 76, 1873, Palau Is.

1341. Sebastapistes coniorta Jenkins. Hawaii.

1342. Sebastapistes galactacme Jenkins. Hawaii.

1343. Sebastapistes corallicola Jenkins. Hawaii.

2Scorpena asperella Bennett, Zool. Jour., IV, 1829, 40, Sandwich Is. Günther, Fisehe der Südsee, 80, Hawaiian Is. Sebastapistes corallicola Jenkins, Bull. U. S. Fish Comm., XxII, 1902 (1903), 493, Honolulu.

It is impossible to identify Bennett's $S$. asperella with certainty. It is probably Sebastapistes corallicola, the red spot on the dorsal and the tentacle over the eye favoring this identification.

1344. Sebastapistes ballieui (Sauvage). Hawaii.

1345. Sebastapistes coloratus Gilbert. Hawaii.

1346. Sebastapistes albobrunneus Günther. Palau Is.

Scorpæna albo-brunnea Günther, Fische der Südsee, 77, 1873, Palau Is.

1347. Sebastapistes strongius (Cuvier \& Valenciennes). Oualan, or Strong Island; Amboina.

We are unable to idéntify this species. Were it not for the plain-colored lower parts of the head, in the figure of Quoy \& Gaimard, we should regard Sebastapistes la' otale as this species.

1348. Sebastapistes laotale Jordan \& Seale, new species. La'otale. Samoa; Rarotonga.

Scorpæna tristis; Günther, Fische der Südsee, 77, Rarotonga; not of Klunzinges.

Head 2.45 in length; depth 2.75; eye 4 in head; dorsal XII,10; anal III, 6; about 22 modified scales in lateral line; snout 3.50 in bead; interorbital 1.50 in eye, this space very concave with two small longitudinal ridges.

Body oblong, moderately compressed; depth of caudal peduncle equal to eye; mouth large; maxillary 1.75 in head; minute teeth in jaws and vomer, none on palatines; head spinate, preorbital encling in two sharp spines, one directed forward, the other downward and back, a st ong spine at posterior end of the bony stay of cheek; three distinct spines below at the angle of preopercle; four distinct supraocular spines and four spines on each side of nuchal region; posterior nostril with a distinct spine, the anterior nostril with a short divided tentacle; opercle with three spines from its posterior part; origin of dorsal fin at posterior part of nuchal region, its longest spine 2.75 in head; base of anal fin 2.25 in length of head; second anal, spine 2 in head; pectoral 1.20 ; ventral 1.80 ; caudal rounded 1.50 in head.

Life colors of a specimen from Pago Pago called la'otale; black and gray, with rosy tinge on caudal. Another from the same place has the red rosy salmon, the ground-color whitish, it and the rosy every where tinely speckled with black points. A specimen from Apia was purplish black, mottled with gray with scarcely any shades of pink; the chin profusely barred. 
Color in spirits, grayish mottled with brown, which takes somewhat the form of 6 irregular crossbands, the first of which encircles the sides and upper part of head at eye, and the last one encircles the base of caudal fin; each side of lower jaw marked with about 6 alternating white and brown spots; a similar marking shown on upper jaw; dorsal fin with oblique brown bands, caudal with a wide brown band near the middle and tipped with white, and with about 5 dusky bands; rentral with 3 dusky bands; pectoral spotted with dusky black at the base, caudal with a wide brownish area near the middle.

This species is common in the tide-pools of the coral reefs of Samoa with Sebastopsis scatru and Selastopsis guamensis, as described by Klunzinger. It difiers from Sebastapistes tristis in the absence of orbital cirrus. Otherwise it agrees very closely with that species, but not one of our examples shows any trace of the orbital cirrus, which is well developed in S. tristis.

Many specimens from A pia. The type is no. 51761, U. S. National Nuseum, length 2 inches.

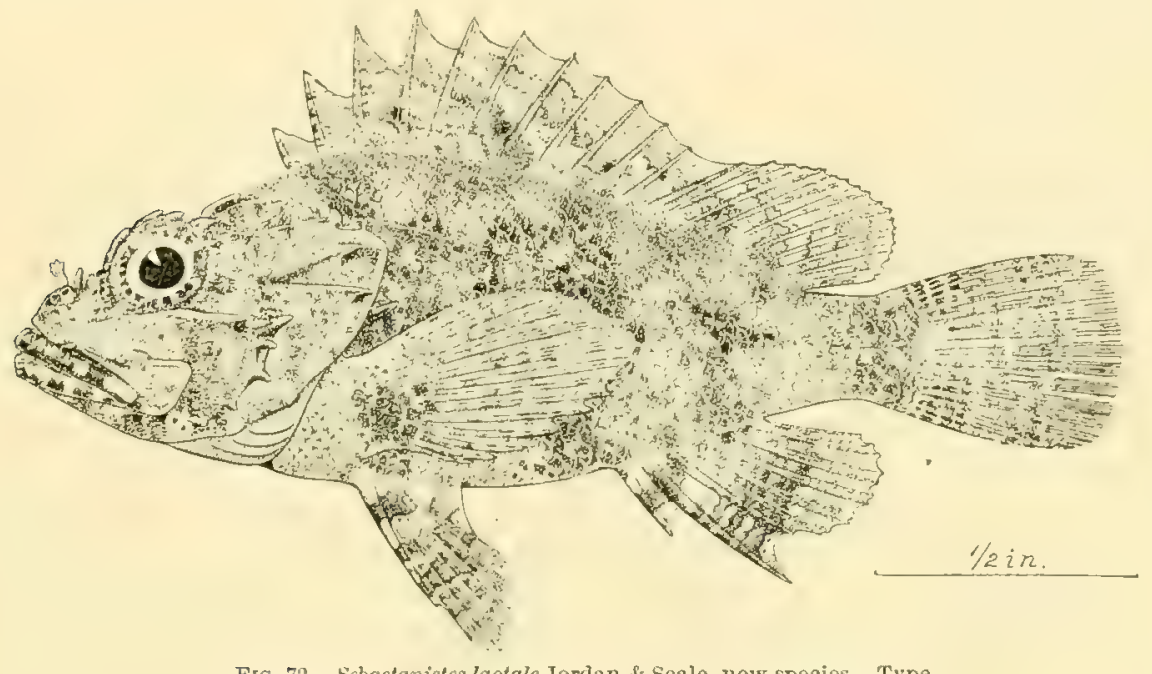

FrG. 72._Sebastapistes laotale Jordan \& Seale, new species. Type.

1349. Sebastapistes tristis (Klunzinger). Guam; Red Sea; Philippines.

Scorpana tristis Klunzinger, Syn. Fische Rothen Meeres, 802, 1870, Red Sea.

Scorpana bakeri Seale, Bishop Museum 1901, 126, Honolulu; op. cit, vol, r, no. 3, 120, Guam.

This species, distinguished by its orbital cirrus and by the blackish cross bands on the lower jaw, was not taken by us. Seale's description of Scorprena bakeri agrees well with Klunzinger's account, and may be the same fish. Günther's Scorpina tristis is said to have not "Hautläppchen." This may be our Sebastapistes laotali. We have examples of $S$. tristis from the Philippines, with the orbital cirrus well developed.

1350. Sebastapistes laniarius (Cuvier \& Valenciennes). Guam.

1351. Sebastapistes nuchalis (Günther), Rarotonga.

Scorpæena muchalis Günther, Flsche der Südsee, 76, 1873, Rarotonga.

\section{SETARCKES Gunther.}

1352. Setarches remiger (Gilbert \& Cramer). Deep seas of Hawaii.

1353. Setarches fidjiensis (Günther). Fiji.

Setarches fidjiensis Gunther, Challenger Fishes, 87, 19, Fiji.

\section{PONTINOS Poey.}

1354. Pontinus spilistius Gilbert. Deep seas of Hawaii. 
HELICOLENUS Goode \& Bean.

1355. Helicolenus rufescens Gilbert. Deep seas of Hawaii.

\section{PLECTROGENIUM Gilbert.}

1356. Plectrogenium nanum Gilbert. Deep seas of Hawaii.

CENTROPOGON Günther.

1357. Centropogon australis (IVhite). Erromango; Palacky; Australia.

\section{AMBLYAPISTUS Bleeker.}

1358. Amblyapistus tænianotus (Cuvier \& Valenciennes). Melanesia (Seale); East Indies.

1359. Amblyapistus vestitus (De Vis). South Seas.

Tctraroge vestitus De Vis, Proc. Linn. Soc. New South Wales 1884, 496, South Seas. (Dorsal xvy, 9.)

TENIANOTUS Lacépède.

1360. Tænianotus triacanthus (Lacépède). Tahiti; Raiatea (Günther); East Indies.

1361. Tænianotus garretti Günther. Hawaii.

1362. Tænianotus citrinellus Gilbert. Hawaii.

MINOUS Cuvier \& Valenciennes.

1363. Minous pictus Günther. New Guinea.

(Minous pictus Günther, Challenger Fishes, 1880,41.)

\section{DENDROCHIRUS Swainson.}

1364. Dendrochirus zebra (Cuvier \& Valenciennes). Guam; Palau Island; Fiii; New Guinea; East Indies.

Pterois zcbra Cuvier \& Valenciennes, Hist. Nat. Poiss, IV, 367, Ile de France. Günther, Fische der Südsee, 82, Indian Ocean, Pelew I. Seale, Bishop Museum 1901, 122, Guam. Garman, Bull. Mus. Comp. Zool, vol. xxxix, ¿32, Fiji. Gunther, Cat., II, 126, Amboina.

1365. Dendrochirus brachypterus (Cuvier \& Valenciennes). Samoa (Günther); East Indies.

1366. Dendrochirus sausaulele Jordan \& Seale, new species. Sausaulele. Samoa. (Pl. LI, fig. 1.)

Head 2.45 in length; depth 2.80; eye 3.55 in head, equal to snout; interorbital 2 in eye; dorsal $\mathrm{x} I I, 10$; anal II, 6 ; pectoral 17; scales 8-44-13; maxillary 2.50 in head, reaching to below anterior third of eye.

Body elongate, compressed, profiles of trunk evenly curved; snout short, rounded; bands of minute teeth in jaws and vomer; a simple orbital tentacle one-half length of eye; a simple fleshy flap prolonged into a tentacle over anterior nostril; five simple tentacles on the anterior margin of snout; a wide flap from lower anterior margin of preorbital, and two similar flaps from lower limb of preopercle; a single small nasal spine on each side of snout; four orbital and seven nuchal spines on each side; bony stay of cheek without distinct spines; a small sharp spine on preopercle at posterior termination of the bony stay and two small spines below this on the angle; gillrakers short, $10 \cap n$ lower limb; depth of caudal peduncle scarcely equal to eye; pectoral fin $2.10 \mathrm{in}$ length, reaching to below posterior axil of dorsal, the membranes of lower rays only being slightly incised; ventral reaching to origin of anal; caudal and anal of about equal length, 2.50 in head.

Color in spirits, dull whitish with seven broad brown bands around the body; first over nuchal region, where the band is broken and the mid segment is in advance, second from origin of dorsal through axil of pectoral, third from 4th-5th dorsal spines, fourth from 8th-9th dorsal spines, fifth from 1st-3d dorsal rays, sixth from 7 th-9th dorsal rays, the seventh band circling the caudal peduncle and sending a brown line back to base of caudal; a narrow indistinct line between the $2 \mathrm{~d}$ and $3 \mathrm{~d}$ bands and another between the 4th and 5 th bands; a black line from base of orbital tentacle through eye to posterier end of bony stay; a dark blotch on cheek below anterior part of bony stay, another on 
side of snout, and another round spot on anterior part of interorbital; eye with five radiating black lines; fins all with black cross bands except the ventral, which is bluish; axil of pectoral black, with an upper and lower white spot, and some white dots on inner base of rays; a black spot on base of pectoral, and on lower part of opercle; under part of head and top of snout white.

Four specimens from Apia, where it lurks in the crevices of the reefs. The type is 00. 51760 U. S. National Museum, 4.85 inches long, from Apia. IVe have also one specimen from Pago Pago, represented in the accompanying colored figure.

1367. Dendrochirus chloreus Jenkins. Hawaii.

1368. Dendrochírus barberi (Steindachner). Hawaii.

(Dendrochirus hudsoni Jordan \& Evermann.)

\section{PTERoIs Cuvier.}

1369. Pterois sphex Jordan \& Evermann. Hawaii.

1370. Pterois volitans (Linnæus). Sausnulele. Samoa; Tahiti; Palau . ; New Guinea(Macleay); New Britain (Peters); East Indies. (PI. L. )

This large and violently stinging fish is not rare about Samoa, where half a dozen examples were taken. Life colors of one from Apia called sausaulele, blackish red, fading to pale olive-brown posteriorly, the front of head abruptly bright pale brownish red; body covered by narrow sharply defined white streaks, bounding black streaks of the ground color, one pair below eye, one pair across nape; 5 more streaks on body, the first three Y-shaped, divided above and one of them below also; breast and belly with alternating white and blackish cross-bars; cirrus black, light red at tip; dorsal light and dark red; soft dorsal, anal, and caudal with dark cross-bars; ventral deep red, streaked with white, the spine white; pectoral dusky red, with two white crescents at base and a white axillary spot, the rays bright pink-red; two horizontal dark-edged streaks on caudal peduncle; interorbital pale pink.

1371. Pterois radiata Solander. Tahiti; Paumotu Is.; Sarioa; Kingsmill I.

One specimen, called sausaulele, was taken by us at Samoa. Life colors, black with whitish streaks, these brownish red on head; long dorsal rays reddish brown at tip.

1372. Pterois vittata Sauvage. Marquesas Is.

Pterois viltata Sauvage, Nouv. Arch. Museum, 1878, 135, Nukahiva.

PELOROPSIS Gilbert.

1373. Peloropsis xenops Gilbert. Deep seas of Hawaii.

INIMICUS Jordan \& Starks.

1374. Inimicus maculatus (Cuvier \& Valenciennes). Waigiu; New Britain; New Guinea.

Inimicus maculalus Cuvier \& Valenciennes, Hist. Nat. Poiss, IV, 434, 1829, Waigiu. Lesson, Voy. Coquille, 210, plate 20. Günther, Cat, 1n, 150, Waigiu.

Pelor maculalum, Peters, Berl. Mon. 1876, 834, New Britain.

SYNANCEJA Bloch \& Schneider. (Smancidium MIüller; Symanceichthys Bleeker.)

According to Bleeker, the genus Spurco, or Synanceichthys, to which our species belongs, differing from Synanceja in the absence of palatine teeth, can not be maintained as a distinct genus, these teeth being frequently wanting in Synanceja horrida.

1375. Synanceja verrucosa Bloch \& Schneider. Nofu. Samoa; Fiji; Tahiti; New Hanover; Strong I.; Borabora; Guam; New Guinea (Macleay); East Indies.

Synanceia thersutes Seale, Bishop Museum, vol. I, no. 3, 1901, 121, Guam.

This most uncomely fish abounds in the tide pools of the coral reefs of Samoa. It is much dreaded by the natives on account of its poisonous dorsal spines.

- A specmen from Apia called nofu in life was the color of coral sand, the surface mud-colored, with concealed orange patches showing on head and body; caudal with a blackish cross-band; a whitish cross-band at base and one at tip. 
1376. Emmydrichthys vulcanus Jordan \& Rutter. Tahiti.

Lmmydrichthys vulcanus Jordan \& Rutter, Proe. Cal. Ac. Scỉ., 2d ser., V1, 1896, 562⿺ , Society Is. (by error stated to be from Hawaii).

This species is known only from the original type from Tahiti.

\section{Family CARACANTHIDE.}

\section{CARACANTHUS Kröyer.}

1377. Caracanthus maculatus Gray. Tu' $\iota^{7} u$. Hawaii; Samoa; Tahiti.

This little fish is not rare in the coral reefs of Samoa, where several specimens were takon in company with Pseudogobiodon citrinus.

Life colors of a specimen from.Apia called tu'u'u, dark uniform, coppery brown.

\section{AMPHIPRIONICHTHYS Bleeker.}

This genus is very close to Caracanthus, differing in the continuous dorsal fin. It was taken by us with the preceding on the reefs of Honolulu.

1378. Amphiprionichthys unipinna (Gray). Hawaii; Tahiti; Vavau; Fiji; Palau Is.; East Indies.

\section{Family PLATYCEPHALIDE. \\ PLATYCEPHALUS Bloch.}

1379. Platycephalus punctatus Cuvier \& Valenciennes. Vanicolo; Guam (Seale, Bishop Museum, 1901, 129); East Indies.

1380. Platycephalus otaitensis (Parkinson). Tahiti.

Cottus otaitensis Parkinson, in Cuvier \& Valenciennes, Hist. Nat. Poiss., IV, 241, Tahiti.

1381. Platycephalus quoyi Bleeker. New Guinea (Macleay); East Indies.

1382. Platycephalus tentaculatus Rüppell. Palau Is.; East Indies.

1383. Platycephalus nematophthalmus Bleeker. New Guinea (Macleay); East Indies.

1384. Platycephalus serratus Cuvier \& Valenciennes. New Ireland (Peters, Berl. Mon., 1876, 839); East Indies.

1385. Platycephalus variolosus Günther. Samoa.

Platycephalus variolosus Günther, Fische der Südsee, 167, taf. cIx, fig. A, Samoa.

1386. Platycephalus isacanthus Cuvier \& Valenciennes. New Guinea; East Indies.

INSIDIATOR Jordan \& Snyder.

1387. Insidiator pristiger Cuvier \& Valenciennes. New Guinea; East Indies.

1388. Insidiator bataviensis Bleeker. Ponape (Günther, Fische der Südsee, 167); East Indies. 1389. Insidiator spinosus (Schlegel). New Guinea (Bleeker); Japan.

\section{Family BEMBRADIDE.}

BEMBRADIUM Gilbert.

1390. Bembradium roseum (Gilbert). Deep seas of Hawaii.

Family HOPLICHTHYIDE.

HOPLICHTHYS Cavier \& Valenciennes.

1391. Hoplichthys citrinus Gilbert. Deep seas of Hawaii.

1392. Hoplichthys platophrys Gilbert. Deep seas of Hawaii. 


\section{Family PERISTEDIIDE.}

PERISTEDION Lacépède.

1393. Peristedion engyceros Günther. Deep seas of Hawaii.

1394. Peristedion hians Gilbert \& Cramer. Deep seas of Hawaii.

1395. Peristedion liorhynchus Günther. Admiralty Is. (Fish. Challenger, 1880, 46).

\section{Family CEPHALACANTHIDE.}

\section{CEPHALACANTHUS Lacépède.}

1396. Cephalacanthus orientalis (Cuvier \& Valenciennes). Hawaii; New Guinea; Waigiu; Tahiti (Seale); East Indies.

\section{Family GOBIID E:}

ANAIYSIS OF GENERA OF GOBIDDE FOUNI IN TIE SOUTH SEAS.

[This table is quite tentative, many of the genera named being of uncertain boundaries and doubtful value.]

A. Soft dorsal and anal free from the caudal: no pit above the operele.

$B$. Spinous dorsal present; rentral fins well dereloped.

C. Ventral rays, $\mathrm{I}, 5$.

D. Ventral fins more or less divided.

E. ELEotrine: Ventral fins wholly separate; pectorals normal; eyes normal.

F. Body scaly.

$f_{i}$. Vomer with teetlu: a caudul ocellus; scales small.

BOSTRYCHCS

$G G$. Vomer without teeth.

II. Scrles small (fewer than 50).

$I$. Sides of head naked; one or more dorsal spines prosuced.

$I I$. Sides of head scaly; none of the dorsal spines produced; head depressed.

J. Preopercle with a small hook or antrorse spine at its angle.

VALENCIENNEA

$J J$. Preopercle unarmed.

HII. Scales moderate or large (fewer than 50 ).

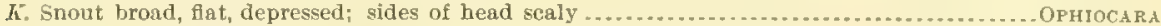

KK. Snout moderate.

$L$. Top of head with bony crests: a black spot at base of pectoral.

Butrs

LI. Top of head without crests.

U. Sides of head sealy; scales large

N. Sides of head with vertical series of small cirri; lower jaw heavy; body robust ....GoBiomorpHrs $N N$. Sides of head without cirri,

O. Preopercle with 2 or 3 rather strong upturned spines; body robust ASTERROPTERIX

no. Preoperele unarmed; body compressed, the form and habit similar to that of Fundulus: head

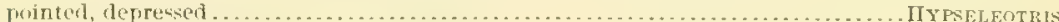
Mr. Sides of head naked; preopercle unarmed.

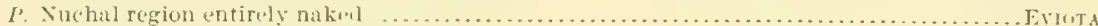

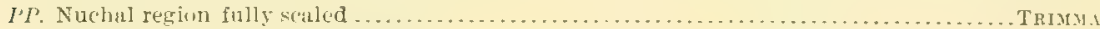

$F F$. Body entirely naked, slender, ind elongate.

Q. Dorsal fins separate, the second moderate........... METERELENTRIS

QQ. Dorsal fins connected, the second many-rayed; chin very prominent; tongue notehed ......... VITREOLA

EE. PERIOphthalMix: Ventral fins partly united at the fleshy base; pectoral with a scaly muscular base; eyes more or less stalked; scales very small, cycloid; tongue short, rounded, adnate; istbmus broad.

r. Dorsal rays $x$ to $x \mathrm{~V}-12$; teeth not horizontal and not exserted.

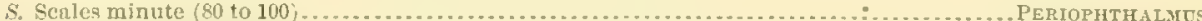

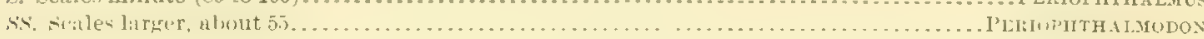

DD. GoBIIx.E: Ventral fins completely united; pectornl without scaly muscular base; eyes not erectile.

T. Ventral fins not adnate to the belly, in a short rounded disk; upper teeth not movable.

U. Body scaly.

V. Vomer without teeth.

II. Teeth not all in one series in each jaw.

1. Caudal fin not lanccolate nor greatly produced: tecth all simple, no barbels.

1. Cheeks and opercles each well scaled.

Z. Scales small; pectoral with silky rays above

('III.TMYTE-

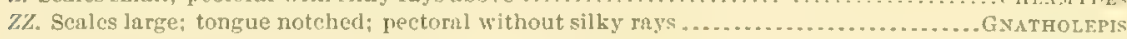

I1: Cheeks naked; opcreles scaly; scales of body large.................................... VAIMos.

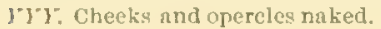


a. Scales large, ctenoid; dorsal and anal fins short.

b. Tongue truncate or rounded at tip; isthmus rather broad; lower jaw usially not strongly projecting.

c. Pectoral without silk-like rays above.

d. Preopercle with 2 small hooked spines at angle; dorsal spine rigid

dd. Preopercle unarmed; shoulder-girdle without fleshy slips; dorsal spines slender.

e. Dorsal spines 7 .

ee. Dorsal spines 6 .

f. Head almost spherical; body short and plump; small canines present

ff. Ilead not spherical

g. Body before dorsal fin largely naked; head very large; mouth subvertical .

ARAGOBIODON $g g$. Body before dorsal chiefly scaled.

$h$. Ventrals short, eup-like; body elongate; head depressed; small canines present ............... VAILMA hh. Ventrals well deveioped.

i. Head very large, with cross-lincs of minute cirri (as in Gobiomorphus and in Mars) ............ Drombus

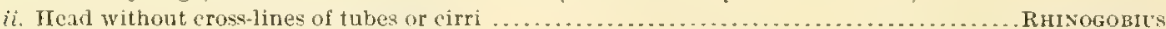

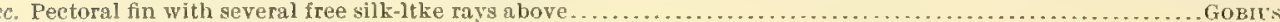

bb. Tongue emarginate at tip.

i. Pectoral with free silk-like rays; dorsal spines, 6; mouth moderate

ij. Pectoral without free silk-like rays above; mouth large, oblique, the chin very prominent............GLossogobius aa. Scales 36 or more; pectoral without silk-like rays.

k. Tongue emarginate; lower jaw projecting; mouth large.

CHENOGOBIUS

kl. Tongue entire (so far as known).

l. Shoulder-girdle with fleshy slips or flaps; dorsal and anal short, of about 11 or 12 rays; scales moderate, ctenoid; preorbital region broad; tongue adnate to floor of mouth; fresh-water species.

7" Cheeks nitked . .

77. Shoulder-girdle without fleshy flaps; dorsal and anal long ( 15 to 29 rays)

$m$. Body opaque; caudal rounded; dorsal spines 6 .

$n$. Scales moderate (50 to 60 ), ctenoid; lower jaw with small canines.

AMBLYGOBIV

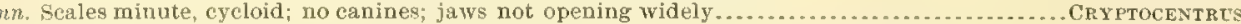

mm. Body elongate, translucent; caudal emarginate; mouth small; dorsal spines seven................. VITRARIA

X.Y. Caudal fin lanceolate, much produced; no barbels at chin

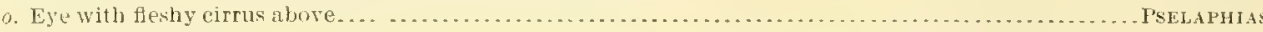
on. Eye without cirrus.

p. Mouth very large, the maxillary produced backward somewhat as in Opisthognathus.

WAITEA

pn. Mouth moderate; no canines; soft dorsal and anal moderate, of 12 to 20 rays.

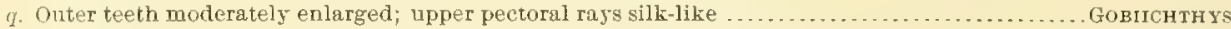

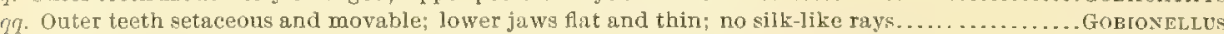

WW. Teeth all uniserial; canines present; soft eaudal more or less pointed.

$r$. Scales ruther large (25 to 35$)$; soft doraal and anal short.

GOBIUPTERL:

rr. Scales moderate ( 40 to 50 ); soft dorsal and anal of about 23 rays $\ldots$

$r r$. Seales very minute, about 200 ; soft dorsal and anal of about 30 rays .................... . . 3 EUDAFOCRYPTEs

$V T$. Vomer with about 3 large blunt teeth; head with numerous lines of small cirri running in various directions

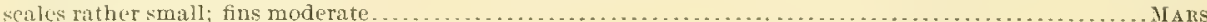

$U U$. Body naked or very nearly so.

s. Body rather elongate, not greatly compressed.

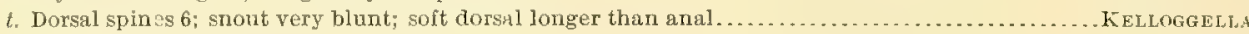
ss. Body greatly compressed and clevated.

u. Canines present, small

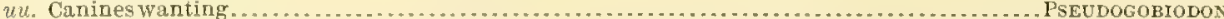

it. Ventral fins short, round, cup-shaped, adnate to the belly; outer teeth more or less flexible, peculiarly formed. 11. Body sealy or chiefy so.

w. Teeth clavate, not pointed.

.i. Sesles small ( 50 to 80 ); body well scaled.

SICYOPTERUS

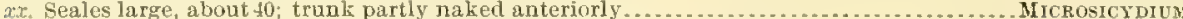

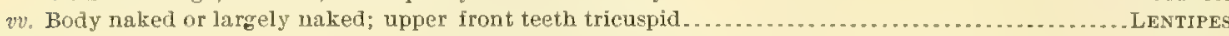

AA. GobIodine. Soft dorsal and anal very long, joined to the caudal; body eel-shaped, the scales mincte or wanting no pit above opercle; eyes minute; teeth very long, curved; dorsal moderate, its rays about v I, 16...........GoBIoIDEs

\section{BOSTRYCHUG Lacépède.}

Eleotrids with vomerine teeth, as in the American genus Philypnus.

1397. Bostrychus sinensis Lacépède. Oualan; Kanathia, Fiji; East Indies; China.

VALENCIENNEA Bleeker.

1398. Valenciennea muralis Quov \& Gaimard. Tucopia, Vanicolo; Fiji; East Indies; Australia.

1399. Valenciennea longipinnis Lay \& Bennett. Fiji (Günther), Riukiu Is.

Eleotris longipinnis Lay \& Bennett, Zool, Beechey's Vovage, 64, tab, 20, fig. 30, Riuliu Is. Günther, Fische der Südsee, 190, Fiji. 
Recorded by Günther from Fiji. The species is very close to Valenciennea muratis, with which it is identified by Jordan \& Snyder (Proc. U. S. Nat. Mus., xxiv, 42) from the Riukiu Islands. Dr. Günther, however, regards it as distinct.

1400. Valenciennea strigata (Broussonet). Tahiti; Fiji; Samoa (Günther); East Indies.

Gobius strigatus Broussonet, Ichth., Dec. 1, pl. 1, 1782, Tahiti.

Eleotris strigata, Günther, Fische der Südsee, 190, taf. 111, fig. E, Fiji, Samoa, T'ahiti.

The species was not taken by us at Samoa. It is easily recognized by the much longer dorsal and anal fins. Dorsal vi, I, 18; anal $\mathrm{I}, 16$.

1401. Valenciennea violifera Jordan \& Seale, new species. Ti'oto. Samoa. (Pl. LIr, fig. 2.)

Head 3.45 in length; depth 5 ; eye 5 in head; dorsal VI-I, 12; anal I, 12; scales 75; interorbital 5.50 ; snout 3.10 .

Body elongate, compressed; snout rounded; mouth large, lips rather thick, the angle of the jaws under middle of eye; jaws with 2 rows of small, curved, sharp-pointed teeth; opercle and preopercle entire; gillrakers short, soft, with elongate point on lower limb; caudal peduncle strong, its depth 2.50 in head; origin of spinous dorsal on line with base of ventrals; third and fourth spines of first dorsal slightly elongate, 1.14 in head; base of soft dorsal equal to head, its longest ray about 2 in head; base of anal 1.20 in head, its longest ray 1.25 in base, its origin midway between base of caudal and posterior margin of eye; pectoral 1.30 in head; ventral 1.90 in head; caudal rounded, equal to head.

Life colors of a specimen from Apia (very young), very pale olive, with two faint livid blue lateral streaks connected with cross lines of the same color; fins all pale; dorsal tipped with black.

An adult specimen from Pago Pago was light olive, mottled with pale pinkish brown; a pinkish brown stripe from lower pectoral axil straight to base of caudal; six violet spots darker edged, on side of head; one on base of pectoral; dorsal light reddish, a jet black spot edged with white on the tips of the longest spines; caudal pale, mottled light green and pink at base; the larger examples have a black spot on upper part of caudal; blue spots plainer; anal light yellow; pink brown at base and darkedged, often pink at base and edge; rentral and pectoral pale; pectoral without dark in axil.

Color in spirits dull yellowish white with tint of brown; some specimens show traces of 7 dusky blotches along back; five or six bluish white spots on opercle and cheek; an indistinct brownish line from axil of pectoral to caudal; belly and chin bluish white; third and fourth spines of dorsal tipped with black; spinous and soft dorsal with indistinct blue lines; caudal (except in young) with a black blotch on its upper middle portion; anal with narrow dark line at margin and abother near the bace; some specimens show a dusky tip to caudal; pectoral and ventral unmarked.

This handsome species is common in the crevices of the coral reefs about Apia and Pago Pago. It seems to be distinct from the two species. muralis and sexguttata of the western Pacific. It has the head markings of the latter with the body markings of the former.

Seven specimens from Pago Pago and 23 from Apia: Specimens also from the island of Negros, P. I., collected by Dr. Bashford Dean.

The type is no. 51771, U. S. National Nuseum, 4.60 inches long, from Apia.

\section{ELEOTRIS (Gronow) Bloch \& Schneider.}

1402. Eleotris fusca (Bloch \& Schneider). Pa'ofu. Samoa; Tahiti; Oualan; Fiji; Guam; Waigiu; Vanicolo; Aneiteum; Solomon Is.; New Hebrides; Borabora; Tubuai and Nukahiva (Seale); East Indies.

Fifty-three specimens from the lower course of Vaisigano River at Apia and from Gasegase River in the neighboring village of Vaimosa; 15 specimens from brackish water at Pago Pago.

This species is widely distributed through the South Seas. It is common in the sluggish waters of the lower reaches of the Vaisigano and other streams.

E'eotris sandwichensis of IIawaii, a species entirely similar in size, appearance, and habit, differs in having larger scales.

1403. Eleotris sandwichensis Vaillant \& Sauvage. Streams of Hawaii. 
GUAVINA Bleeker.

This genus resembles Eleotris, but lacks the preopercular spine characteristic of that genus.

1404. Guavina gyrinoides (Bleeker). New Guinea (Macleay); Palau 1s.; East Indies.

1405. Guavina immaculata (Macleay). New Guinea.

Eleotris immaculatus Macleay, Proc. Linn. Soc. N. S. W. 1883, 69, 268, New Guinea

\section{OPHIOCARA Gill.}

Ophiocara Gill. Proc. Ac. Nat. Sci. Phila: 1863, 270 (ophiocephala).

This genus is characterized by the large scales and short depressed head, the form being like that of the genus Ophicephalus. Cheeks scaly.

1406. Ophiocara porocephala (Cuvier \& Valenciennes). Palau Is.; Caroline Is.; New Ireland; Vanicolo; New Guinea (Mracleay); East Indies.

1407. Ophiocara aporos (Bleeker). Fiji; Gilolo; Oualan; East Indies.

1408. Ophiocara cantoris (Günther). Fiji; East Indies.

1409. Ophiocara macrolepidota (Bloch). Fiji; New Guinea (Macleay); East Indies.

BUTIS Bleeker.

1410. Butis butis (Hamilton-Buchanan). New Guinea (Macleay); East Indies.

\section{GOBIOMORPHUS Gill.}

This genus contains short-bodied Eleotrids with large scales, the cheeks and opercles naked, and the cheeks with rows of papillæ.

1411. Gobiomorphus eugenius (Jordan \& Evermann). Hawaii.

1412. Gobiomorphus sclateri (Steindachner). Tahiti; Samoa.

Eleotris sclateri Steindachner Ichth. Beitr., vIII, 157, 1880, Tahiti.

This handsomely colored little fish occurs in some abundance in the reefs about Apia and Pago Pago. We have 7 specimens from Apia and 5 from Pago Pago.

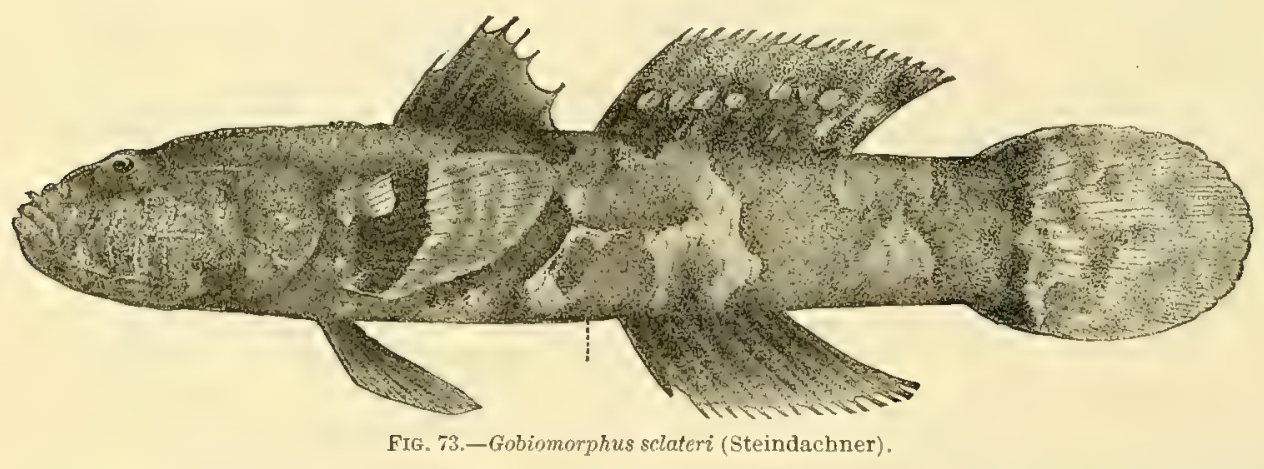

Life colors of a specimen from Apia, light gray, with three broad brown cross-bands; first dorsal yellowish spotted; second dorsal brown, yellowish at tip, mottled; caudal profusely spotted; anal and ventral blackish; pectoral barred; head very much mottled.

Another, from Pago Pago, was grayish white, with blackish brown transverse bands; everywhere with black points; on dorsal and caudal weak blotches of thin yellowish.

Still another, a very small specimen from Apia, was pale gray, with a black bar at tase of caudal; two black dots below eye; four yellowish white cross-bars, alternating with black; a jet-black spot in axil; fins whitish, scarcely dotted. 


\section{ASTERROPTERIX Rüppell. (Brachyeleotris Bleeker.)}

In this genus the body is short and robust, the scales large, the sides of the head scaly, without papillary ridges; paired fins not fringed. Small fishes of the coral reefs.

1413. Asterropterix semipunctatus Rüppell. Hawaii; Samoa; Tahiti; Palau Is.; East Indies. (Pl. xxxvi, fig. 1.)

This small fish is rather common in the crevices of the reefs about Samoa. We have 55 specimens from Apia and 1 from Pago Pago. The blue spots, distinct only in the largest examples, are subject to much variation.

Life colors of an Apia specimen-a compressed eleotrid with scaly head, large scales, and filamentous first dorsal-dark olive-brown; a dark bar below eye; base of spinous dorsal blackish; soft dorsal and anal dark gray; dorsal paler on upper half; caudal gray; ventral dark gray.

Another from Apia was brownish black with obscure markings, and still another had the head with pale blue spots, edged with darker; pectoral bright olive, dusky at base; caudal light brownish, with black spots above, ocellated with gray and some black below; fins dusky.

\section{HYPSELEOTRIS Gill.}

Hypseleotris Gill, Proc. Ac. Nat. Sci. Phila. 1863, 270 (cyprinoides). Giuris Sauvage, Bull. Soc. Philom. 1879, 15 (ranicolensis; no definition). ?Carassiops Ogilby, Proc. Linn. Soc. N. S. IV. 1897, 784 (compressus). Caulichthys Ogilby, Proc. Linn. Soc. N. S. W. 1897, 784 (guntheri).

This genus is made up of handsome fresh-water fishes, with the appearance and habit of Fundulus, swimming freely in the water, not lying on the bottom as is the habit with most gobies.

The genus Caulichthys Ogilby, based on Eleotris cyprinoides, is synonymous with Hypseleotris of Gill.

1414. Hypseleotris guntheri (Bleeker). Malu vai. Streams of Samoa, Oualan, and Fiji.

Eleotris cyprinoides Günther, Cat, III, 118, Oualan; not of Cuvier \& Valenciennes. Asterropteryx guntheri Bleeker, Ver. Med., XI, 1876, after Günther.

Eleotris guentheri Günther, Fische der Südsee, 186, taf. 113, fig. A, Oualan, Savaii, Fiji.

We have about 100 specimens from Vaisigano, Gasegase, Vailima, and other streams about Apia. The native name is malu vai.

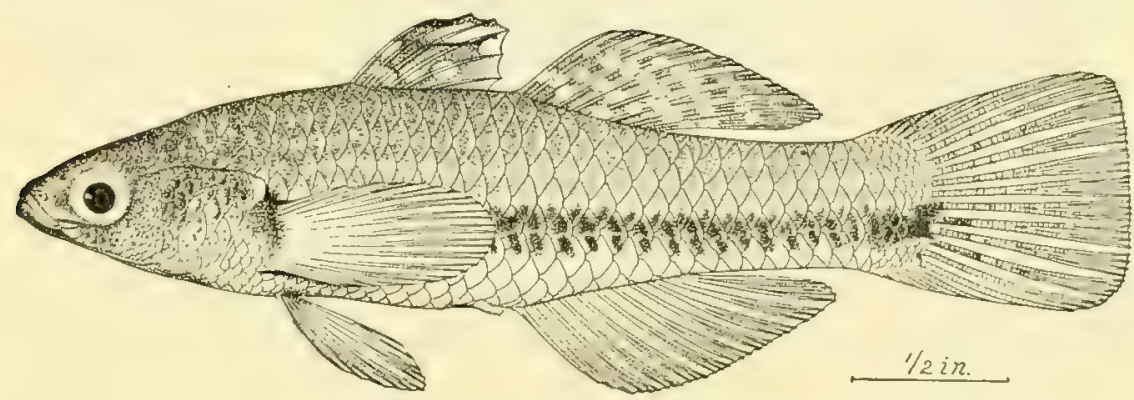

FIG. 74.-Hypseleotris guntheri (Bleeker).

This handsome goby is found in abundance in all the fresh waters of Upolu. Unlike others of this group it does not lie on the bottom, but swims freely. In appearance, as in habits, it has much in common with cyprinodont fishes.

A specimen from Apia showed no bright colors; a black lateral band, pectoral black, a black spot on caudal. It agrees fairly well with Günther's short account of the species.

1415. Hypseleotris vanicolensis (Sauvage). Vanicolo.

Eleotris (Giuris) vanicolensis Sauvage, Bull, Soc. Philom. 1850, 54, Vanicolo.

1416. Hypseleotris macrolepidotus (Bloch). Palau; Fiji; New Hebrides; East Indies.

1417. Hypseleotris godeffroyi (Günther).

Eleotris godeffroyi Günther, Fische der Sudsee, 188, Raiatea, Tahiti.

A diminutive fish of the coral reefs, not scen by us. 


\section{EVIOTA Jenkins.}

Eviota Jenkins, Bull. U. S. Fỉsh Comm., XxII, 1902 (1903), 501 (epiphanes).

This genus contains Eleotrids of diminutive size, none (except $E_{\text {. }} a b a x_{0}$ ) an inch in length, abounding in the pools on the coral reefs and in the heads of corals. The species are very numerous about Samoa. Much of our large collection was obtained by a native boy named Afele, who would dive for the coral heads and crack them in a boat, "The Coral Queen," picking up the little fishes from the deck.

The fringing of the ventral rays and lower rays of the pectorals is a characteristic of this genus. It is especially distinguished from Asterropterix by the naked sides of the head and by the entire preopercle.

The earliest known species of this genus and much the largest in size is Eviotı abax, deseribed by Jordan \& Snyder, from Misaki, in Japan.

1418. Eviota epiphanes Jenkins. Hawaii.

1419. Eviota miniata (Seale), Guam.

Eleotris miniatus Seale, Occ. Papers Bishop Museum, I, no. 3, 1901, 125, Guam.

1420. Eviota zonura Jordan \& Seale, new species. Lili. Samoa.

Head 3.50 in length; depth 4.50; eye 3 in head; dorsal vi,11; anal 9; scales 28.

Body elongate, compressed; anterior profile rounded; caudal peduncle 2 in head; mouth of moderate size; angle of mouth below middle of eye; small sharp-pointed teeth in jaws; males with prominent papillæe near origin of anal, the females with a sac; distance from origin of spinous dorsal to snout 2.50 in length of fish without caudal; height of spinous dorsal about equal to its base; base of soft dorsal

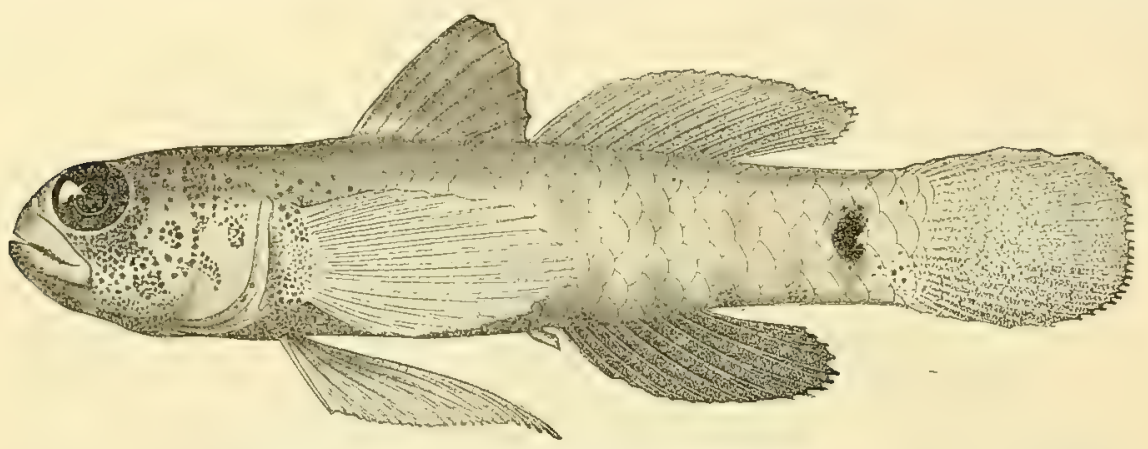

Fig. 75._Eviota zonura Jordan \& Seqle, new species. Type.

1.25 in head, its longest ray 1.50 in head; origin of anal under second dorsal ray, nearer to base of caudal than to eye, length of its base 1.75 in head; pectoral longer than head, the tip on a line with first anal ray, about equal to length of ventrals; ventrals have their origin directly below the base of pectorals, their posterior extremity extending to base of anal papillæ; caudal rounded, 1.14 in the head.

Life colors of a specimen from Apia, olive, with orange-brown cross-bars; a black bar before base of caudal; fins brown dotted, the anal with blackish half bars at base. Length three-fifths of an inch.

A specimen from Pago Pago was bright grass-green, with round orange spots on head; scales on body edged with orange; four or five faint dark cross-bars (not plain at base of anal); a large blackish bar-like spot just before base of caudal; first dorsal dusky, mottled with orange; second dorsal pale, with rows of orange spots; caudal dusky below, pale green above, with some orange spots; anal dusky, mottled with orange; pectoral and ventral pale green. Another specimen from Pago Pago was translucent bluish green; small orange spots and irregular black dots.

Color in spirits, yellowish white, a distinct black spot on caudal peduncle, three scales from base of caudal fin; six dusky bands extending a short distance vertically up from base of anal fin; these are usually darker at base of fin; shadings of dark spots on sides and top of head (this varies greatly and is absent in some specimens); caudal fin black; spinous dorsal at anterior base is white; the upper 
two-thirds and posterior base is black; soft dorsal shaded slightly with dusky; caudal with indications of many narrow vertical lines, the fins white.

Of this species we have 16 specimens from Apia and 28 from Pago Pago. The type is no. 51776, U. S. National Museum, seven-eighteenths of an inch in total length.

1421. Eviota prasites Jordan \& Seale, new species. Lili. Samoa.

Head 3.20 in length; depth 4; eye 3.50 in head; dorsal vr, 9 ; anal 9 ; scales 22.

Body elongate, compressed; caudal peduncle 2 in head; mouth of moderate size, the lower jaw slightly protruding; angle of jaw under anterior of pupil; small, sharp-pointed teeth in jaws; intromittant organ of males prominent; distance from origin of spinous dorsal to snout 2.75 in length of fish without caudal; anterior dorsal spines more or less elongate, sometimes very much longer than head, this elongation perhaps confined to the males, as in others the spines are shorter; base of soft dorsal about equal to its longest rays; pectoral slightly longer than head; ventral of equal length or less than pectoral, its origin posterior to origin of pectoral; caudal rounded, about 1.50 in head.

Life colors of a specimen from Pago Pago called lili, translucent yellowish white with brown pink points (under microscope rose red spots with brown pigment specks) arranged along dorsum and

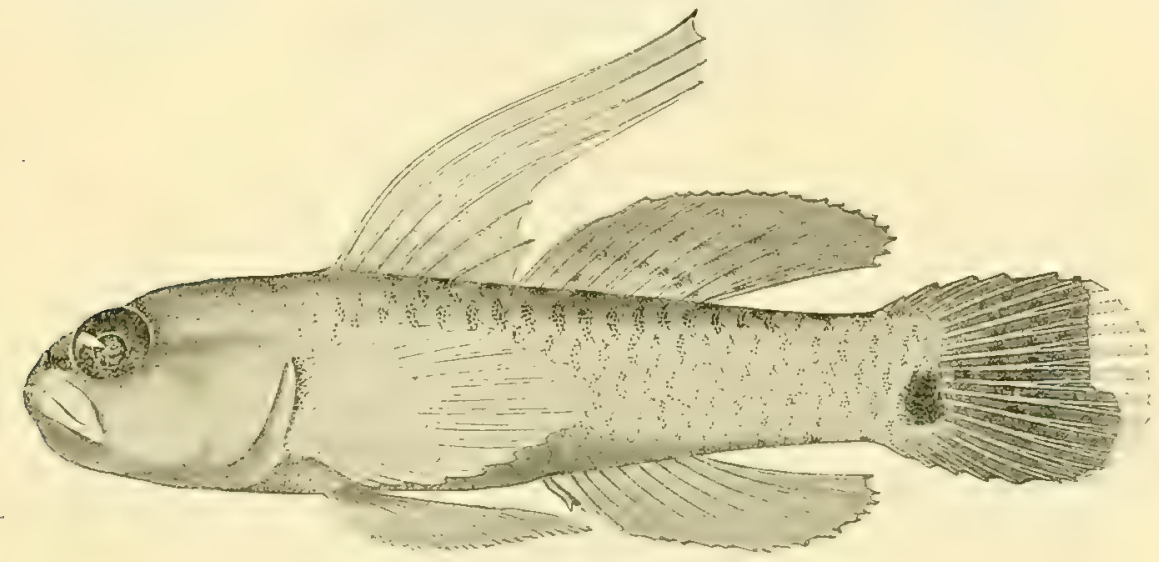

FIG. 76. - Eviotn prasites Jordan \& Seale, new species. Type.

very weakly in narrow transverse bars on sides; all fins rosy; eye with two greenish yellow longitudinal bands, dorsal one continued on forehead. Another specimen from this locality was very pale grayish with dark specks and markings.

Color in spirits, yellowish white, the margin of the scales shaded with fine black dots; a distinct black spot on lower posterior portion of caudal peduncle at base of caudal; usually a more or less distinct dusky blotch abore this spot on the upper base of the caudal; a black stripe from upper posterior part of opercle through the eye and around snout; another black stripe around lower lip; a dusky blotch in upper axil of pectoral; darker shadings along the back, taking the form of more or less regular black spots along base of the dorsal; six indistinct dark band-like spots along the base of anal and under part of caudal peduncle; all the fins excepting the pectoral, which is white, have a dusky sharling of fine dots; the spinous and soft dorsal have dark spots arranged in regular longitudinal lines, about four of these lines on the soft dorsal; caudal with five bands of dusky formed by separated dusky spots.

Five specimens from Pago Pago. The type is no. 51768, U. S. National Museum, length 1 inch.

1422. Eviota afelei Jordan \& Seale, new species. Samoa.

Head 3.20 in length; depth 4.20 ; eye 3.40 in head; scales 27 ; dorsal ri, 10 ; anal 8.

Body elongate, compressed, the anterior profile rounded, the jaws equal; depth of caudal peduncle 2 in head; angle of jaws under middle of eye; sharp-pointed teeth in jaws; the inner row of lower jaw seems to have enlarged, curved canine-like teeth; nasal tubule distinct; origin of spinous dorsal slightly posterior to line with origin of ventrals, its longest spine 1.50 in head; the base is greater than the 
height of fin; base of soft dorsal 1.10 in head, its longest ray equal to base; pectorals slightly greater than length of head; base of anal about equal to its longest ray; pectoral reaching to a line with base of anal; origin of dorsal nearer base of anal than tip of snout; origin of ventrals posterior to origin of pectorals, their length about equal to pectorals; caudal rounded, its length 1.20 in head.

Color in spirits, whitish, the margin of scales shaded with minute dusky dots; 9 distinct rlusky spots along lower side of body-3 on candal peduncle, 3 at base of anal fin, and 3 on belly; all of

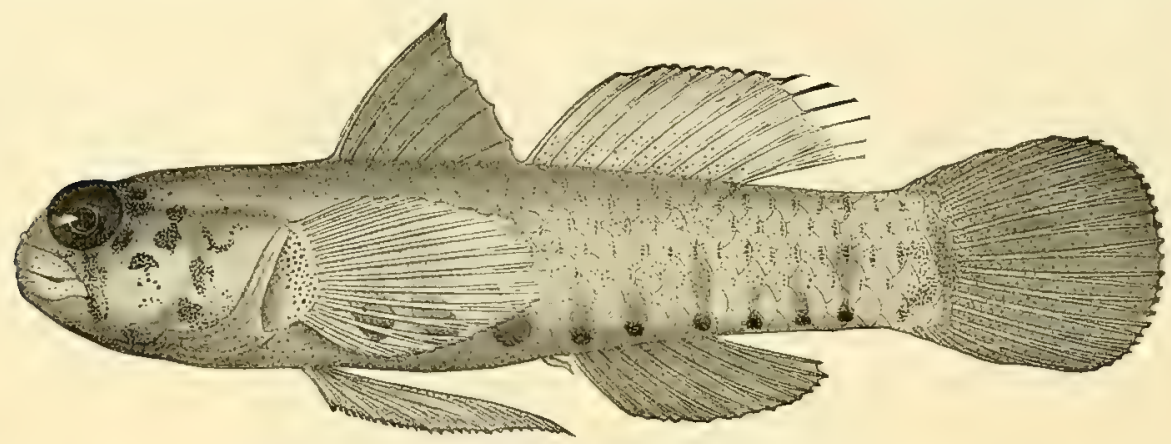

Fig. 77.-Eviota afclei Jordan \& Seale, new species. Type.

these tend to extend more or less up on the side of body where they fade out; the abdominal blotches are much the largest; side of head with about 6-8 irregular brown blotches more or less run together, one forming a band from eye to angle of mouth, two on the opercle, one or two on preopercle, and two or three just posterior of eye; nuchal region shaded darker; an indistinct dusky blotch on the caudal peduncle, three scales from base of caudal; some specimens with faint traces of dusky spots along the back; spinous dorsal and anal dusky, other fins only slightly shaded with minute dark dots like those on the margin of the scales.

Ten specimens from Pago Pago, collected from coral heads by the Samoan boy, Afele, of Pago Pago. Type no. 51763, U. S. National Museum, five-eighthe inch long, from Pago Pago.

1423. Eviota smaragdus Jordan \& Seale, new species. Samoa.

Ilead 3.75 in length; depth 4.50 ; eye 3 in head; scales 24 ; dorsal vi, 10 ; anal 9.

Body elongate, compressed; the anterior profile of head rounded, the jaws equal; caudal peduncle 1.75 in head; jaws with small, sharp curved teeth; anterior rays of first dorsal elongate and filiform,

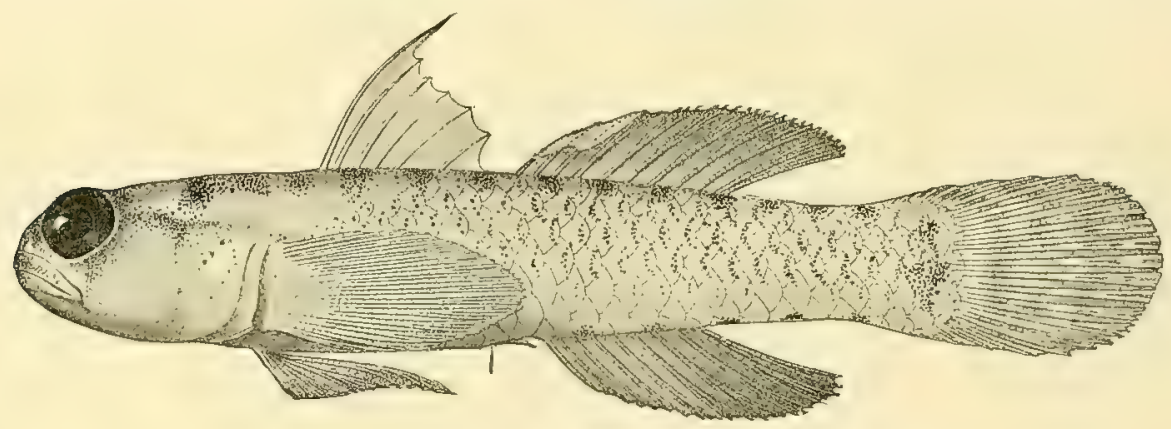

FIg. 78.-Eviota smaragdus Jordan \& Seale, new species, Type.

except in young, their longest ray when fin is prone extending to middle of soft dorsal; base of soft dorsal equal to length of head, the longest ray 1.75 in head; base of anal 1.20 in head, its longest ray 1.50; pectorals slightly greater than length of head, ventrals having their origin below base of pectorals and extending to the anal papillæ; caudal rounded, 1.10 in head.

One specimen from Pago Pago in life was greenish yellow, with bright red spots and black points; reddish spots on caudal; two black spots at the nape. 
Another specimen from Pago Pago was translucent, bright grass-green, with orange-bruwn specks on cach scale along side; 12 orange-brown short bars along back, on each side of dorsal a black bar across nape and opercle and one behind eye; orange dashes under chin; a scarlet bar, sharply defined, across base of pectoral, deep green before it; five dark violet-brown bars across base of anal; dorsal brownish, the spines dull orange, the first soft ray dusky; caudal greenish barred with orange; anal violet brown; pectoral and anal green; throat deep blue-green, with a heart-shaped orange spot; ana! papilla deep green.

Color in spirits, yellowish white, the scales usually margined with black dots; a characteristic marking is the presence of two large distinct black spots on posterior nuchal region above the opercle; in addition to these spots there are 13 dark band-like spots on the dorsal surface; nuchal region and upper part of head shaded with small dots; 6 indistinct dark blotches along base of anal and lower margin of caudal peduncle; a dusky band-like blotch at base of caudal fin; excepting the pectorals all the fins have a slight shading of dusky, the anal being the darkest; the caudal with four dusky bands.

Twelve specimens from Pago Pago. The type is no. 51764, U. S. National Museum, length 1 inch.

1424. Eviota distigma Jordan \& Seale, new species. Samoa.

Head 3.10 in length; depth 4.10; eye 3.18 in head; dorsal vi, 9 ; anal 9 ; scales 24.

Body elongate, compressed; caudal peduncle 2.10 in head; mouth rather small, maxillary not reaching to below middle of eye; minute sharp teeth in the jaws; intromittant organ of males

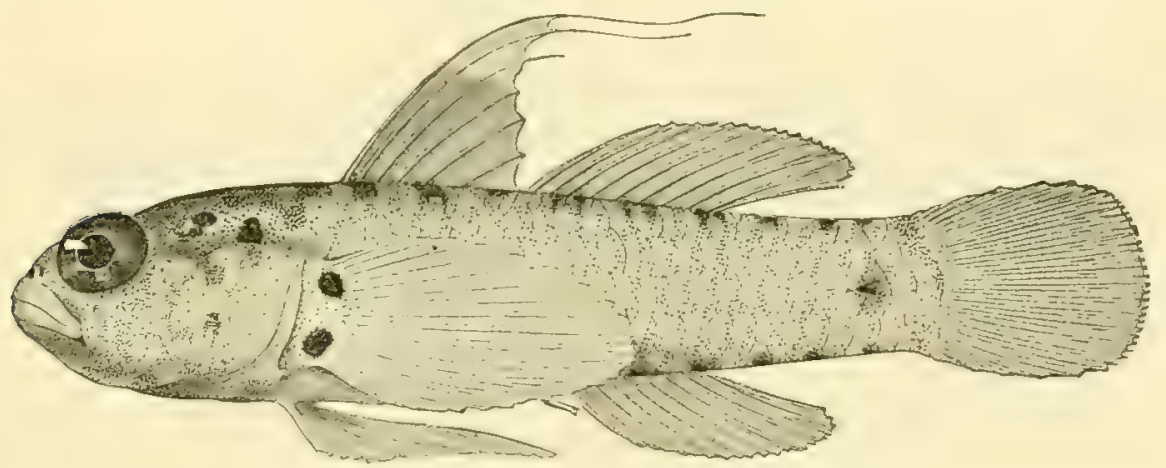

FYG. 79.-Eviota distigma Jordan \& Seale, new species, Type.

prominent; origin of spinuous dorsal nearer snout than posterior axil of soft dorsal; the two anterior dorsal spines elongate and filiform, reaching when in repose the posterior axil of soft dorsal; the base of the fin 1.50 in head; base of soft dorsal $1.45 \mathrm{in}$ head, the longest ray 1.75 in head; base of anal 2.80 in head, its longest ray 1.75; pectorals slightly longer than head; ventrals of about equal length and extending to tip of anal fin; caudal rounded, 1.20 in head.

A very small fish from the crevices of the coral reefs at Pago Pago. Easily known by the two black spots at the base of the pectoral, these rarely faint or obsolete.

Life colors of a specimen from Pago Pago, translucent gray, with faint bluish green anteriorly; small orange spots with many black points; interior blackish transverse bars showing through distinctly.

Color in spirits yellowish white, with slight shading of dusky. The type specimen has two distinct round spots on base of pectoral, a black spot on side of caudal peduncle with an indistinct vertical band through it and around peduncle; two black spots above opercle; about 10 black blotches taking the form of short bands over the back, in some specimens extending indistinctly to ventral surface; 6 dusky band-like spots along base of anal and caudal peduncle; margin of the scales usually shaded with minute brown dots; opercle and nuchal region with brown blotehes, some forming more or less irregular lines; the 2 dorsal fins about equally shaded with dusky; pectoral white; caudal, anal, and ventral with dusky shadings. 
Fourteen specimens from Apia and Pago Pago. The type is no. 51767, U. S. National Museum, from Pago Pago, length five-eighths inch.

1425. Eviota sebreei Jordan \& Seale, new species. Samoa.

Head 3.35 in length; depth 5 ; eye 3.25 in head; scales 26 ; dorsal vi, 9; anal 10.

body elongate, compressed; anterior profile of head rounded; jaws equal; the snout, however, more pointed than in other species of Eviota; caudal peduncle 2 in head; jaws with small sharp-pointed teeth, angle of jaws below middle of eye; base of spinous dorsal greater than its height, its base 1.30 in head; base of soft dorsal 1.20 in head; pectoral 1.10 in head; the ventrals slightly longer, reaching to base of anal, their origin posterior to base of pectorals; caudal rounded, 1.20 in head.

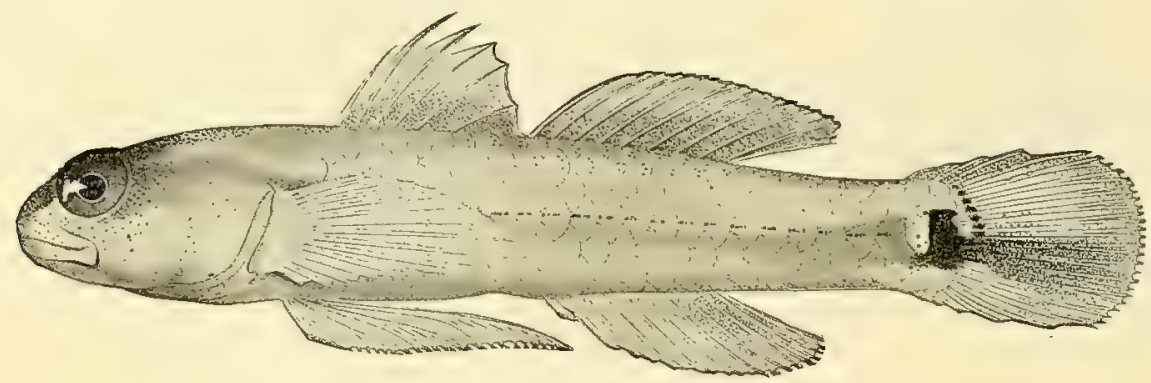

FIG. 80.-Eviota sebreei Jordan \& Seale, new species. Type.

Color in spirits white; a wide grayish band from posterior of eye along lower part of side to caudal; a narrow brown line from posterior of eye along middle of body to caudal; a big deep black blotch on base of caudal, which extends out upon the fin; a dark line from eye down side of snout; upper half of spinous dorsal whitish, lower half dusky; soft dorsal, anal, and caudal more or less shaded with dusky; pectoral and ventral white.

One specimen, no. 51765, U. S. National Museum, from Apia, length 0.65 inch.

1426. Eviota herrei Jordan \& Seale, new species. Samoa.

Head 3.10 in length; depth 3.75 ; eye 2.75 in head; scales 24; dorsal vI, 9; anal 8 .

Body rather short and thick for a fish of this genus; anterior profile rounded, the lower jaw slightly the longer; minute round, pointed teeth in each jaw, those of upper jaw rather widely

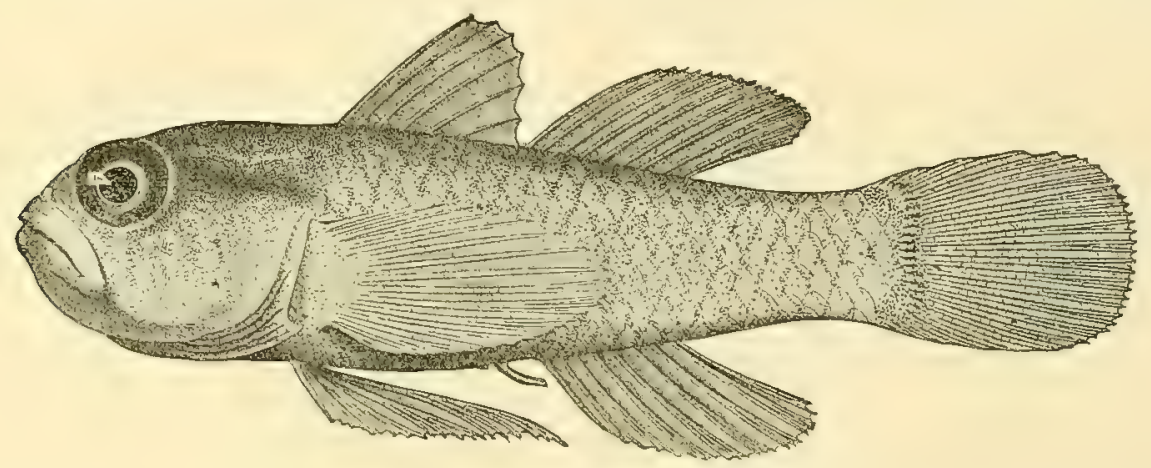

FIG. 81.-Eriota herrei Jordan \& Seale, new species. Type.

separated; caudal peduncle thick, its depth 2 in head; origin of spinous dorsal slightly posterior to a line with origin of ventrals, its height about equal to its base; base of soft dorsal equal to its longest ray; pectoral long, extending to below the 7th ray of soft dorsal; origin of anal much nearer base of caudal than tip of snout, its base less than length of its longest ray; ventrals reaching base of anal, their origin directly below and scarcely in advance of origin of pectorals; caudal rounded, 1.20 in head. 
Life colors of a specimen from Apia, gray, scales orange-edged; fins clear orange, barred with grayish.

Color in spirits whitish, with scales margined with dusky dots, giving the fish a brownish appearance; the shadings on the head with light lines reticulating more or less distinctly, and separating the marking with irregular spots, or squares or polygons; a very indistinct dusky bloteh on sides of caudal peduncle, 3 scales from base of caudal; most specimens (including type) show about three indistinct longitudinal white lines on the sides; there is a dark line from posterior of eve to upper posterior margin of opercles; some specimens show 6 indistinct dusky spots along base of anal and lower surface of caudal peduncle; the two dorsal fins and the anal dusky; other fins but slightly shaded with dusky.

This ipecies closely resembles Eviota distigma, differing in the larger mouth, and in having usually but one spot at base of pectoral.

Three specimens (237) from Pago Pago and five from Apia. The type is no. 51769, U. S. National Museum from Apia, length 0.75 inch.

Named for Mr. Ir. C. T. Herre.

1427. Eviota pruinosa Jordan \& Seale, new species. Samoa.

Head 3.20 in length; depth 5; eye 3.50 in head; dorsal VI, 9; anal 8; scales 28; snout 4 in head.

Body elongate, compressed, the head rather pointed; the mouth small; angle of jaw under anterior margin of eye; opercles and preopercles entire; teeth minute, in jaws only; a distinct tube at nostril; depth of caudal peduncle 2 in head, also about 2 in its length; anal papilla distinct; origin of

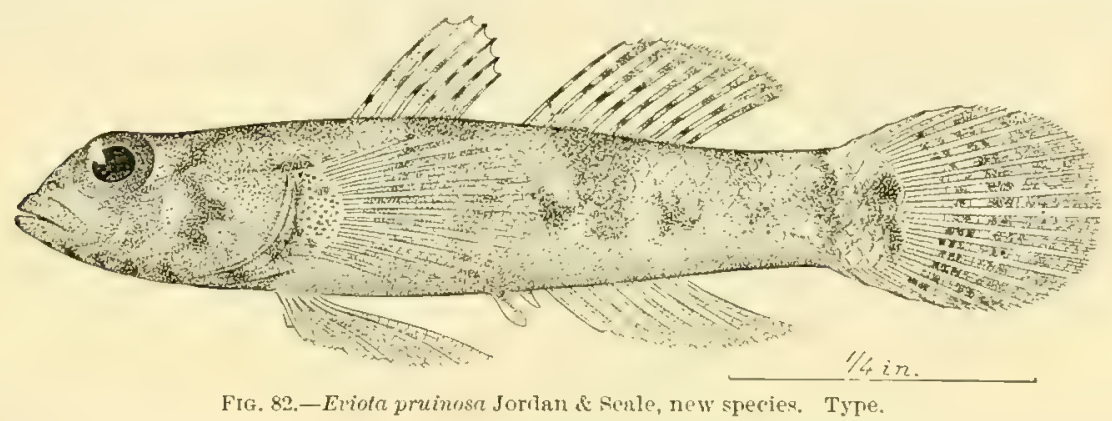

spinous dorsal slightly posterior to line with axil of ventrals, the longest $\mathrm{s}$ pine 2 in head; base of soft dorsal 1.50 in head, its longest ray 1.75 in head; anal similar to soft dorsal, its base and length of rays being slightly less; pectorals extending to a line with base of soft dorsal, 1.12 in hear; ventrals separate, their tips extending to anal opening; caudal rounded, 1.20 in head.

Life colors of a specimen from Pago Pago, white with blackish mottlings and very faint orange yellowish dashes; a faint dusting of whitish as though frosted.

Color in spirits yellowish white, shaded with brownish; five or six dark blotches along the side rather distinct wide dusky blotch extending down from base of each dorsal fin, a distinct white stripe between the two, and a white stripe over anterior base of spinous dorsal; two dusky blotehes at base of caudal; a rather black spot directly posterior to eye; cheeks and usually under part of head more or less blotched with dusky; dorsal fins marked by three or four rows of oblique dark spots; caudal with abont five dusky bands; pectoral with four or five narrow indistinct lines, and usually with about four dark spots on base; anal and ventral unmarked.

Two specimens from crevices in the coral reefs at Pago Pago. The type is no. 51779, U. S. National Museum, length 0.90 inch.

TRIMMA Jordan \& Seale, new genus.

Trimma Jordan \& Seale, new genus of Gobiidre (crsiur $\ell$ ).

This genus, typified by Trimma cresiura, is near Eviota, but the region before the dorsal is fully scaled. In texture the species is firmer and less translucent.

1428. Trimma cæsiura Jordan \& Seale, new species. Samoa.

Head 3.10 in length; depth 4.50; eye 3.18 in heal; dorsal vi, 8 ; anal 9 ; scales 25 from posterior margin of opercles; snout 5 in head; interorbital less than pupil. 
Body elongate, compressed; anterior profile rounded, the lower jaw slightly the longer, the angle under anterior margin of eye; several rows of small, sharp teeth in each jaw; opercles and preopercles entire; depth of caudal peduncle 2.50 in head; origin of dorsal fin above base of pectorals, its longest spine 1.75 in head, slightly greater than length of fin; base of soft dorsal about equal to its longest ray, 2.50 in head; base of anal 1.75 in head, scarcely equal to its longest ray; the origin of anal much nearer base of candal than tip of snout; pectoral scarcely equal to head; ventral 1.10 in head; caudal rounded, 1.50 in head.

Life colors of the type from Apia plain bright red, with a gray spot on back of tail and gray spots on many scales of back and head; fins all bright red.

Color in spirits yellowish white, the margin of the scales thickly shaded with dusky; lighter below; 3 dark bands across interorbital space; cheek shaded with scattered dark brown dots which take the form of 2 or 3 short stripes down from the eye; snout and lips shaded with brownish;

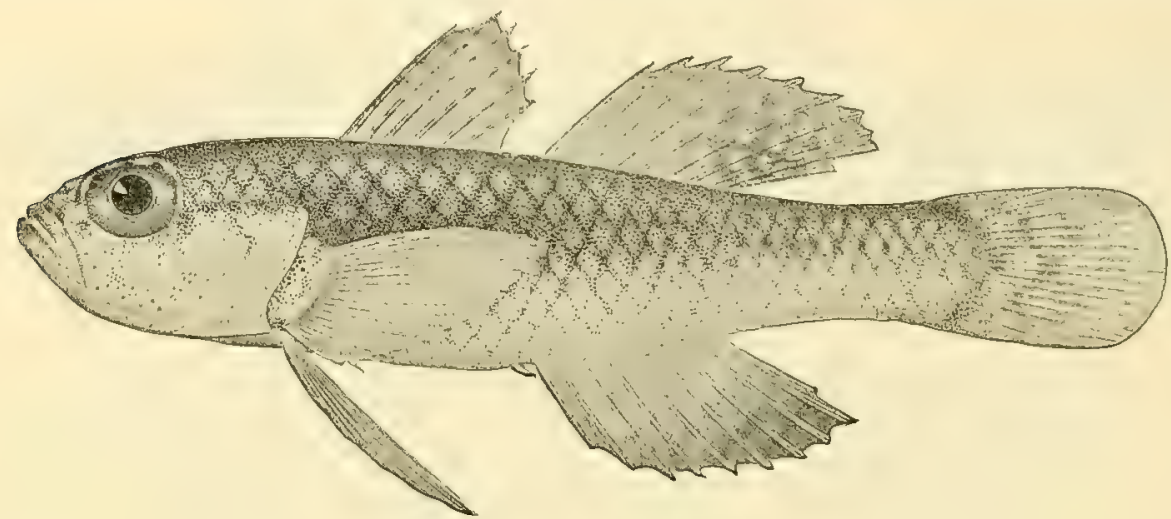

Frg. 83.-Trimma cæsiura Jordan \& Seale, new species. Type.

slightly darker shadings along upper margin of opercle and base of pectoral; scattered over body are a few darker dots of coloring shading into the marginal coloring of the scales; spinous dorsal yellowish, with indistinct oblique bands; soft dorsal darker with round, lighter spots; caudal yellowish white with dusky blotches; anal shaded with dusky blotches; pectoral and ventral yellowish.

One specimen from Apia, no. 31772, I'. S. National Museum, length 1.26 inches.

\section{HETERELEOTRIS Bleeker.}

Hetereleotris Bleeker, Arch. Neerl. 1875, 306 (diadematus).

This genus contains small eleotrids of elongate form, the body translucent and scaleless. The type species Hetereleotris diademata of the Red Sea is near the species described below.

1429. Hetereleotris clara Jordan \& Seale, new species. Samoa. (Pl. xxxvi, fig. 2.)

Head 4 in length; depth 6.50; eye 4.25 in head; dorsal vr, 13; anal $\mathrm{r}, 11$; snout 5 in head.

Body elongate, compressed; lower jaw considerably the longer; the opening to tip of mouth is above the median line of body; the angle of jaws is under the anterior margin of eye; mouth large, with small teeth in jaws, also teeth on the palatines; tube at nostril rather distinct; opercles and preopercles not denticulate; depth of caudal peduncle 2.60 in head; origin of spinous dorsal on a line with middle of pectoral rays, its base 1.75 in head, its longest spine 3.50 in head; base of soft dorsal a third longer than head, 2.87 in length without caudal; base of anal longer than head, 3.25 in length without caudal, its origin midway between middle of eye and base of caudal, its longest ray 2.50 in head; pectorals about equal to head; ventrals separate, situated slightly anterior to base of pectorals, the tip a little more than midway to base of anal; caudal rounded, 1.20 in head.

Life colors of a specimen from Pago Pago creamy white, thickly dotted with dark brown points; on each side a single broad black-brown band extending from tip of snout to tip of caudal; caudar otherwise clear with yellowish suffusion; below dead flesh-white. 
Color in spirits yellowish white, a broad deep brown band from tip of snout to tip of caudal on and below the median line of body; this band is broader and diffused along base of anal fin; tip of under jaw dusky; the base of anal and the dorsals with indistinct dusky band-like spots at the base of each ray and spine; three or four dark spots on caudal above the black band; posterior ray of dorsal with a black spot on its middle portion; remaining fins white, unmarked.

Two specimens from Pago Pago. The type is no. 51773, U. S. National Museum, length 1 inch.

1430. Hetereleotris phaenna Jordan \& Seale, new species. Samoa. (Pl. xxyvr, fig. 3.)

Head 3.12 in length; depth 5 ; eye 4.50 in head; snout 4.50 ; dorsal vr, 10 ; anal 1 , 10 ; no scales.

Body elongate, compressed, snout rounded, with dull point, the lower jaw being the longer; angle of mouth under anterior half of eye; mouth rather large, with minute pointed teeth in the jaws; depth of caudal peduncle 3 in head; opercles and preopercles entire; origin of spinous dorsal slightly posterior to line with axil of ventrals; base of spinous dorsal $1.75 \mathrm{in}$ head, its longest spine $2.50 \mathrm{in}$ head; base of soft dorsal 1.10 in head, its longest ray 2.10 in head; base of anal 1.75 in head, its origin about midway between base of pectorals and base of caudal; pectorals scarcely equal to length of head; origin of ventrals below axil of pectoral, their tips reaching to anal opening; ventrals separate, joined at base; caudal long, its rays graduate to tip, length greater than head.

Color in life, black below, the top of the head and the back abruptly white.

Color in spirits, the upper third of body and head white, the lower two-thirds black, the black running out on lower half of caudal fin, and the white running around tip of head, the black coloring on base of pectorals, and to some extent on sides of head taking the form of deep black spots; fins all yellowish white, except the black on lower part of caudal.

One specimen, the type, 0.75 inch, from the reef at Pago Pago, no. 51786, U. S. National Museum.

VITREOLA Jordan \& Seale, new gezus.

Titreola Jordan \& Seale, new genus of Gobiidæ ( $I$. sagitta).

This genus is distinguished from Hetereleotris by the very slender, naked body and the form of the head and dorsal fin. The body is slender and perfectly translucent, the head sharply pointed, the point being formed by the very heavy lower jaw.

1431. Vitreola sagitta Jordan \& Seale, new species. Samoa. (PI. xxxvi, fig. 1.)

Head (to tip of under jaw) 3.50 in length; depth 9; eye situated on dorsal surface of head, 2 in snout; dorsal vi, 13; anal I, 13; snout 6 in head; the anterior projection of lower jaw about equal in length to snout.

Body elongate, compressed; anterior profile of head formed by the long, conical projection of the lower jaw; opening of mouth on the dorsal profile; the angle of jaws under anterior margin of eye; minute teeth in jaws and palatines, tongue deeply bilobed; the lower membrane of opercles, posterior and lower margin of preopercles, the upper and lower jaw all have distinct tooth-like fringes on their marginal membrane; depth of caudal peduncle 5 in head; origin of dorsal on line with tip of pectorals, the fin incised to one-half its depth, the anterior spines being placed much nearer each other than the posterior spines; the base of dorsal is 1.75 in length of fish without caudal; base of anal 2.75 , its origin slightly nearer to base of candal than to eye, its longest ray 3 in head; pectoral very short, about 4 in head; ventrals separate, short, 2.50 in head, their origin slightly anterior to origin of pectorals; caudal rounded, 1.90 in head.

In life, clear translucent white without dots or color of any sort.

Color in spirits white, shaded above the median line with an irregular band of brownish dots which extend from snout to base of caudal; fins white, unmarked.

Three specimens from Pago Pago. The type, 1.45 inches long, is no. 5178t, U. S. National Museum.

PERIOPHTHALMUS Bloch \& Schneider.

1432. Periophthalmus barbarus Linneus. Mano'o; Talae. Samoa; Fiji; Waigiu, Oualan; Tonga; Palau Is.; New Guinea; Faté (Seale); East Indies. (Fig. 1, p. 174.)

Gobius barbarus Linnæus, Syst. Nat., ed. xil, 450, 1766, no locality. Pectornls fan-shaped; dorsal xII-13. Periophthalmus koclreuteri Bloch \& Schneider, Syst. Ichth., 65, 1801, locality unknown. Periophlhalmus kalolo Lesson, Voy. Coquille, III, 1t6, 1830, Waigiu, New Ireland, Oualan. Periophthalmus argentilineatus Cuvier \& Valenciennes, Hist. Nat. Poiss., Xı, 191, Oualan, New Guinea, Irawaddy R. 
Of this species we have 8 specimens from Aua, on the north shore of Tutuila, 9 from Pago Pago, 50 from mouth of Vaisigono River at Apia, and 1 from Apia collected by Dr. Lung, U. S. N., in 1890.

This extraordinary little fish is very abundant in the sluggish and brackish waters in the mouths of the streams of Samoa. It abounds especially in muddy bayous, freely leaving the water to elimb bushes, to skip through the grass or to lurk under piles of stones to await the returning tide. It is exceedingly quick of movement and very tenacious of life. Specimens placed in a pail of formalin escaped when the lid was raised.

Life colors of one from a mud puddle at Apia, mottled gray; speckles on head pure white, others dull whitish; silvery cross-streaks on side, some light and a few dark streaks on body; dorsal with spots of pure bluish white below, then black, then edged with dull white; second dorsal reddish brown above, then a white band, then a black one, then dull olive reticulations around pale spots; caudal light and dark olive; anal pale grayish; ventral gray, with dusky center; upper surface black, pale edged; under side of head livid gray, with pale or white spots; pectoral dotted much like cauclal.

A specimen taken in coral sand in the sea at Pago Pago was olive, back with nine dark cross-bands, unequal, some of them oblique; head and sides with gray dots and marblings; a dark bar from front of eye down and forward; one down and back from posterior part of eye; first dorsal very small, vir, with a dark bar at base; second with oblique black cross-streaks; caudal with four or five dark crossstreaks; pectoral with a black dot at base above and faint cross-streaks; ventral and pectoral pale; ventral separate. In spite of the small number of dorsal rays, this specimen is probably identical with the others of this variable species.

\section{PERIOPHTHALMODON Gill.}

This genus is close to Periophthalmus, differing in the shorter spinous dorsal, the ventrals mostly united in the adult.

1433. Periophthalmodon schlosseri (Pallas). Fiji; New Guinea (Ramsay \& Ogilby); East Indies.

1434. Periophthalmodon australis (Macleay). New Guinea.

Periophthalmus australis Macleay, Proe. Linn. Soc. N. S. W. 1884, 334.

\section{CHLAMYDES Jenkins.}

Chlamydes Jenkins, Bull. U. S. Fish Comm., xxII, 1902 (1903), 503 (laticeps).

This genus has the general character of Gobius, including the silk-like fringe to the pectorals, but the cheeks and opercles are covered with scales.

1435. Chlamydes laticeps Jenkins. Hawaii.

1436. Chlamydes cotticeps (Steindachner). Tahiti.

Gobius cotticeps Steindachner, Sitz. Ak. Wiss. Wien 1830, 237, Tahiti.

\section{GNATHOLEPIS Bleeker.}

Gnatholepis Bleeker, Arch. Neerl. 1875, 318 (anjerensis).

Hazeus Jordan \&.Snyder, Proc. U. S. Nat. Mus., xxiv, 1902 (1901), 51 (otakii).

This genus has the character of Rhinogobius, except that the cheeks and opercles are covered with large scales. The species are small, pale in color, and live about the coral reefs. Gnatholepis thompsoni is found in the West Indies, Gnatholepis otakii in Japan. The tongue is notched in Gnatholepis delloides, thompsoni, knighti, and otakii. Gnatholepis anjerensis we have not seen, but the scanty description approaches $G$. delloides.

1437. Gnatholepis deltoides (Seale). Guam; Samoa.

Gobius deltoides Seale, Occ. Papers Bishop Museum, vol, I, no. 3, 1901, 125, Guam.

?Gobius anierensis Bleeker, Blennioiden en Gobioıden, 1850, 251, Anjer (Java).

?Gnatholep is anjerensis Bleeker, Arch. Neerl., IX, 318, 1875. "Caput superne lateribusque squamatum."

This species apparently differs from Gnatholeps anjerensis (Bleeker), the type of the genus Gnatholepis, in the smaller scales and more elongate body. The scanty description of the latter, with no reference to the color, renders it difficult to make a positive identification. The longer caudal, $4 \frac{1}{2}$ instead of 5 in total length, also may be distınctive.

Gnatholopis knighti from Hawaii is very close to the present species, but has smaller scales, 32-9. The coloration is very similar to that of our specimens called Gnatholepis samoensis. 
We have 35 specimens from Apia and two from Pago Pago.

Life colors of Gnalholepis deltoides, from A pia, plain gray and mottled, with no color; a sharp band across head and through and below eye.

Another specimen from Apia was pale gray, a black bar at base of caudal; two black dots below eye; 4 yellowish white cross-bars, alternating with black; a black spot on middle of base of pectoral; fins whitish, scarcely dotted, Tongue notcherl.

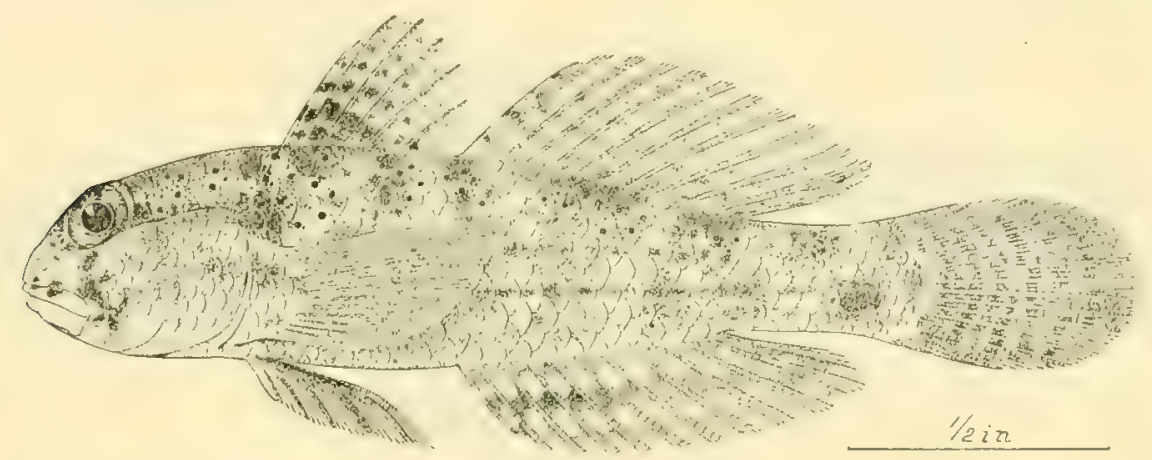

Fig. 84,-Gnatholcpis elcltoides (Senle).

1438. Gnatholepis knighti Jordan \& Evermann. Hawaii.

Gnatholepis knighti Jordan \& Evermann, Bull. U. S. Fish Comm., XxiI, 1902 (1903), 204, Honolulu.

This little fish is found in abundance in coral pools and tide ponds in the Hawaiian Islands.

1439. Gnatholepis canalæe (Sauvage). New Caledonia.

Gobirs canale Saluvage, Bul1. Soc. Philom, 1981, 102, Canala, in New Caledonia.

1440. Gnatholepis maculipinnis (Macleay). New Guinea.

Gobius maculipinnis Macleay, Proc. Linn. Soe. N. S. W. 18s4, 267. (Dorsal vir.)

VAIMOSA Jordan \& Seale, new genus.

Vaimosa Jordan \& Seale, new genus of Gobiidae ( $\mathrm{T}$. fontinalis).

This genus differs from Gnatholcpis and Rltinoyotius in having the cheeks naked and the opercles covered with large scales. The species inhabit mountain brooks of the South Sea Islands. The type is Vaimasa fontinalis, from the Gasegase stream at Vaimosa in Upolu. Gobius jacanicus Bleeker probably belongs to the same genus.

1441. Vaimosa fontinalis Jordan \& Seale, new species. Samoa.

Head 4 in length; depth 4.75 ; eye 3.85 in head; dorsal $v$, 9; anal 9; scales 37 from posterior margin of opercles; the scales are much smaller on anterior of body; head from a line with posterior of eyes unscaled; no scales on cheeks or opercles; interorbital spot equal to eve; snout equals two-thirds of eye.

Body elongate, compressed; the head bluntly rounded; mouth moderate, the angle under middle of eye; small teeth in jaws, none on vomer or palatines; opercle and preopercle entire; nuchal region concave; caudal peduncle strong, its depth 2 in head; origin of spinous dorsal over the anterior third of pectoral rays, its longest spine 2 in head; hase of soft dorsal 1.20 in head, equal in length to its longest ray; base of anal 1.25 in head, equal in length to its longest ray; pectoral equals length of head; ventrals united, 1.20 in head, their origin below base of pectorals; caudal rounded, equal to length of hearl.

Life colors of a specimen from the Gasegase River at $A$ pia ( 1.5 inches long), olive; 3 black spots at base of caudal; body with dusky shades; side of head with 3 oblique blackish stripes, meeting obscurely across throat; spinous dorsal reddish at base, the upper half black; other fins obscurely markerl.

Color in spirits, dull greenish with about 7 broad irregular block-like dusky bands over back and on side, more or less connected on median line of body and near base of dorsal fins; lower third of 
body unmarked, but with 2 or 3 indistinct lines under chin; 5 or 6 short curved dusky lines on side of head; 1 from angle of mouth to posterior margin of preopercle where it forms a crescent-like curve upward, uniting with a line from the posterior of eye and another from below the eye; a short line from lower anterior margin of eye to middle of each side of jaw; a short line from upper posterior part of eye to opercle; a black blotch just above upper axil of pectoral; a spot on base of spinous dorsal dusky, a white line near the top, and a lighter area at base; remaining fins dusky; 2 black spots at base of caudal fin.

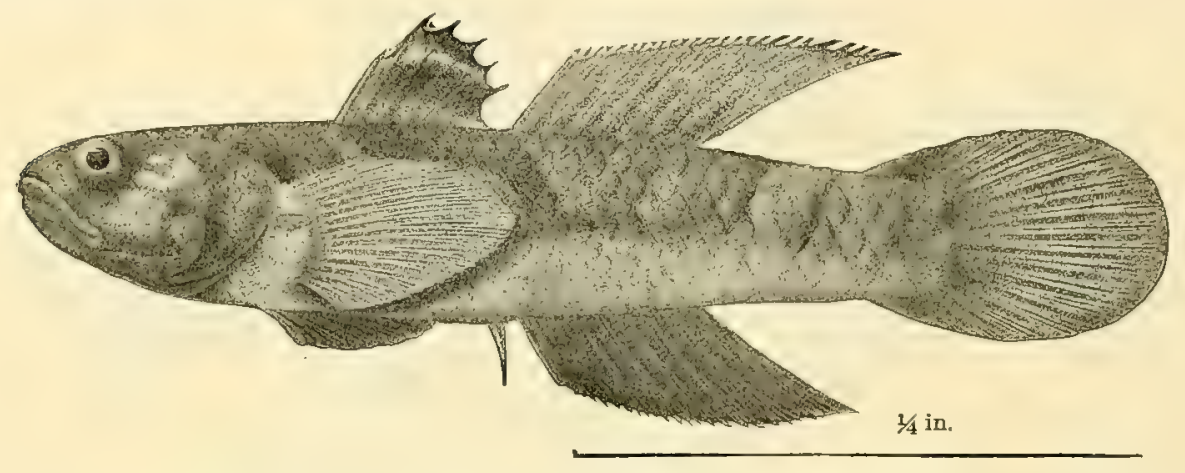

FIG. 85.-Vaimosa fontinalis Jorãan \& Seale, new species. Type.

Common in the strearns of Upolu and Tutuila, with Vaitima stevensoni, but in water less swift.

We have 23 specimens from Vaisigano River and 8 from Vailima brook and tributaries near Apia, 2 specimens from Gasegase River at Vaimosa near Apia, and 42 specimens from the stream at Pago Pago.

The type is no. 51776, U. S. National Museum, from near Apia, length 2 inches.

1442. Vaimosa notospila (Günther). Streams of Fiji.

Gobius notospilus Günther, Fische der Südsee, 173, taf. 110, fig. B, 1873, Namusi in Viti Levu (Fiji).

OPLOPOMUS Steindachner.

Centrogobius Bleeker, Arch. Neerl. 1875, 321 (notacanthus); not Oplopoma Girard.

This genus is characterized by the presence of a small spine on the preopercle. The dorsal spines are rigid. In other respects it resembles Rhinogobius.

1443. Oplopomus oplopomus (Cuvier \& Valenciennes). Tahiti; East Indies.

Gobius oplopomus Cuvier \& Valenciennes, Hist. Nat. Poiss, XII, 66, 1S39, Red Sea. Günther, Fische der Südsee, 170, Philippines, Macao, Tahiti.

Gobius bitelatus Cuvier \& Valenciennes, Hist. Nat. Poiss., xir, 89, 1839, Red Sea.

Gobius notacanthus Bleeker, (Boram, 110, Goram.

ABOMA Jordan \& Starks.

Abomat Jordan \& Starks, Proc. Cal. Ac. Sci. 1895, 497 (etheostoma).

This genus differs from Rhinogobius in the presence of 7 dorsul spines.

1444. Aboma græffei (Günther). Rivers of Fiji.

Gobius græffei Günther, Fische der Südsee, 179, Viti Levu, in fresh water.

This species unknown to us is recorded by Günther and Kner from the streams of Fiji.

\section{PARAGOBIODON Bleeker.}

Paragobiodon Bleeker, Arch. Neerl. 1875, 309 (melanosoma).

This well-marked group is distinguished by the very ch abby body, subglobular head, short cupshaped ventrals, and by the presence of numerous short prickles or filaments on the head. The scales are large, the sides of the head naked and the fins short. The lower jaw has 2 small canines. The resemblance of these species to Gotiodon indicates no close affinity. 
1445. Paragobiodon echinocephalus (Rüppell). Tonga; Samoa; Tahiti.

Gobius cchinocephalus Rüppell, Atlas Fische, 136, 1823, Red Sea. Cuvier \& Valenciennes, Hist. Nat. Poiss., XII, 134, 1839, Massuah, Red Sea. Klunzinger, Fische Roth. Meer, 475, Red Sea. Günther, Fische der Südsee, 175, taf. 108, fig. D, Samoa, Tahiti, Tonga, Meduro, lort Bowen, China Sea, Red Sea.

Gobins amiciensis Cuvier \& Valenciennes, II ist. Nat. Poiss, xII, 133, 1839, Tonga. Sauvage, Poiss. Madagascar, 352, pl. xur, Madagascar (figure bad, seales given by error as 3.9 in text).

Of this remarkable species we have 11 specimens from the coral reef at $A$ pia, and 3 from Pago Pago. The fish is not rare in the crevices of the coral reefs. It reaches a length of little more than an inch, but all our specimens are less than an inch in length.

The genus Paragobiodon is separated from Rhinogobius by the short plump body, the globular head, the presence of papille on the skin of the hear, by the short, cup-shaped ventrals, and by the short oblique mouth, with two small canines. The suales are large, the fins short, the first dorsal with 6 spines, and the sides of the head are without scales.

Life colors of a specimen from Pago Pago, all fins and body up to base of dorsal and pectoral black; in front of that smoky red or flesh color; finely rugose and punctate; ventrals fused to form a fleshy rugose and papillate pad.

Another specimen from Apia was in life golden-yellow, with the fins all deep brownish black, mouth very small, lips black, iris red, head more brownish.

$\Lambda$ third specimen from this locality differs in the yellow pectoral and ventral, the pectoral dusky at tip. (This may be a female.) A faint pale edge to anal, etc.; vertical fins deep blue-black.

1446. Paragobiodon xanthosomus (Bleeker.) Samoa.

Fubius xanthosoma Bleeker, Ceram, 11, 103, Ceram, Buru, Celebes, Amboina.

? Gobius waitei Garman, Bull. Mus. Comp. Zool, xxxrx, 1903, 284, pl, 3, fig. 3, Great Barrier Reef of Australia.

Other specimens which we identify as Purugobiadon ianthosomus are yellowish brown throughout, the fins scarcely darker. Twenty-two specimens were all taken in the reef at Apia in company with Pseudogotiodon citrimes, which they much resemble in color.

Gobius waitei is a species of Paragobiodon closely resembling the present species.

\section{ZONOGOBIUS Bleeker.}

Zonogobius Bleeker, Arch. Neerl. 1875, 323 (semifasciatus=semidoliulus.)

This genus includes diminutive gobies of varied coloration, similar to Rhinogobius but with the nape and whole head naked, the head large, and the mouth almost vertical. Tongue pointed; pectoral without silk-like rays; teeth moderate; preopercle with a slight fringe of papillæ.

1447. Zonogobius semidoliatus (Cuvier \& Valenciennes). Mano'o. Vanicolo; Samoa; Tonga; Huahine; East Indies.

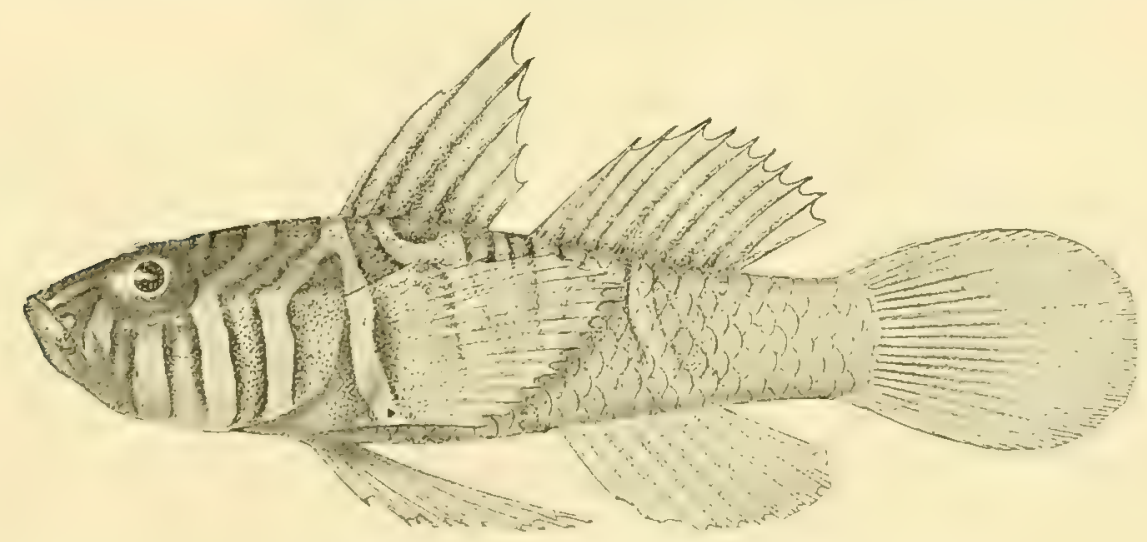

FIG. 86.-Zonogabius semidalialus (Cuvier \& Valenciennes).

This dainty little fish is rather common in the coral reefs about Apia and Pago Pago. It reaches a length of less than an inch. We have 18 specimens from Pago Pago and 4 specimens from $A$ pia. 
Life colors of one from Apia; brown anteriorly, olive-yellow behind; anterior parts to vent sharply marked by blunt gray cross-bars, each darker edged; fins dull olive-yellow, the dorsals with a pale and a dark band; the ventrals with a dusky center.

A specimen from Pago Pago was clear olive, paler behind; anterior parts to middle of soft dorsal with seven bluish white dark-edged cross-bands, the one behind eye forking above, the next forking below; both dorsals finely checked, bluish and pale orange; anal dark, pale edged; caudal yellowish; ventral mesially dusky; ventral and pectoral pale olive. The first dorsal of this specimen is filamentous.

Another specimen from Apia was greenish, with orange stripes alternating with bluish ones; fins dull golden.

\section{VAILIMA Jordan \& Seale, new genus.}

Taitima Jordan \& Seale, new genus of Gobiidse (stevensoni).

This genus consists of gobies allied to Rhinogolius with long bodies, depressed head and peculiar physiognomy, the ventral fins short and rounded. It is near Rhinogobius, but is distinguished by the more elongate body, the low mouth with two small canines, and the short, cup-shaped ventrals. Scales large; head scaled above only; dorsal v, 10; anal 11.

1448. Vailima stevensoni Jordan \& Seale, new species. Pu'ofu. Samoa.

Head 4.50 in length; depth 5.75; eye 3.50 in head; doreal vi, 10; anal I, 10; scales 34 from posterior margin of opercles; snout 3 ; interorbital concave, $3.20 \mathrm{in}$ head.

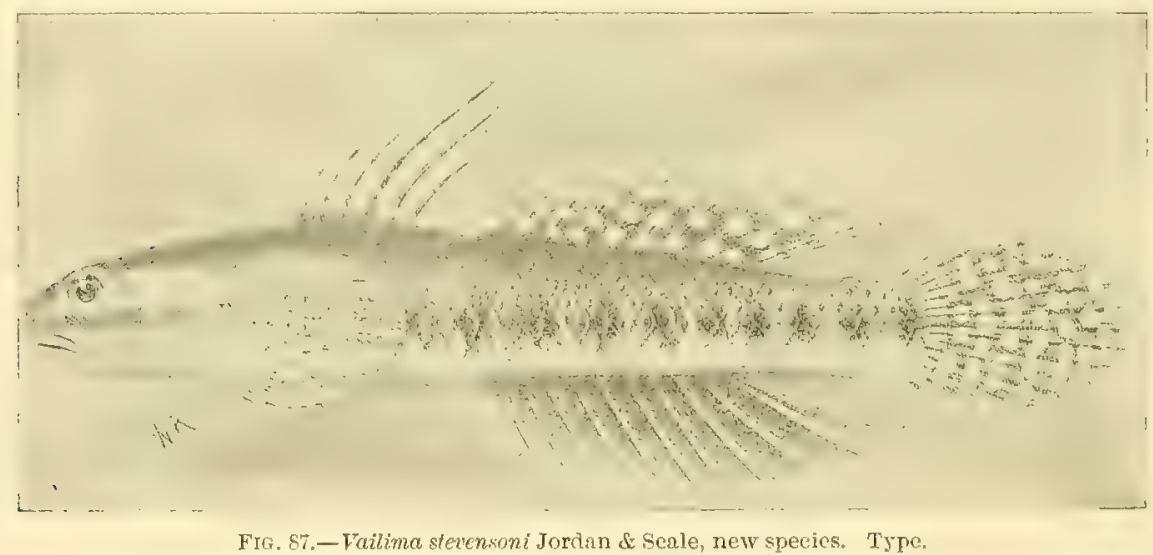

Body elongate, compressed; anterior of head rounded; the upper part of snout anc interorbital taken up by a broad concave groove, which extends to base of spinous dorsal; head and nape depressed, with small scales; mouth rather small, the angle under anterior margin of eye; lips broad; a row of small, sharp-pointed teeth in jaws, none on vomer or palatines; opercles and preopercles entire; gillrakers very small; depth of caudal peduncle 2 in head; origin of spinous dorsal over axis of ventrals, the third and fourth spines elongate, the fourth about a third longer than head; base of soft dorsal 3.75 in length of fish without the caudal, the posterior ray longest, 1.30 in base of fin; base of anal and its rays about equal to soft dorsal; pectorals 1.18 in head, their tips under the last spine of first dorsal; ventrals united, disk-like, short, $1.50 \mathrm{in}$ head; diameter of disk about 2 in head; caudal large, rounded, its length 3.75 in length without caudal.

Life colors of a specimen from Gasegase River at Tambiyou, near Apia, olive-green; scales mottled golden and black; a black lateral band, interrupted by grayish spots; first dorsal cherry-red; spines with black spots; second dorsal reddish with dark checkers; caudal clear yellow above, then a median dash of cherry reddish, the lower half yellowish; all but upper erlge closely reticulated, dark around pale spots; anal dark; ventral dirty yellow; pectoral yellow, checked with black; head with an olive lateral band.

Other specimens (female) with less red and yellow; 2 lateral bands, very distinct on head, the lowest broken into 3 dark cross-bars; anal dotted with black. 
Color in spirits, a light mottled brownish, lighter below; a distinct row of black blotches along the side, these blotches about 14 in number, and all more or less connected; anterior to pectoral fin these blotches take the form of a dusky band, across the side of head and around the snout; another very indistinct dusky band about the width of eye above the blotches on sides, also extends out of upper side of head, and around upper part of snout; some specimens show about 7 whitish cross-bands over the back; spinous dorsal yellowish with about 5 oblique lines of dark dots; soft dorsal with dark lines reticulating in many ways, forming ring-like figures around white dots; caudal fin colored like soft dorsal, except that the dark lines run more regularly, forming 7 or 8 irregular cross-bands; anal uniform dusky; pectoral yellowish, crossed with about 8 narrow lines of dusky; ventral yellowish.

A beatiful little goby found on the bottom of swift streams near Apia. Its motions are remarkably lizard-like, and the pale yellow spots glisten as the tish moves. Seen in the Vaisigano River, the Gasegase River, and the Vailima Brook, from which we have 19 specimens. We have one from Pago Pago. It was abundant in the Vailima Brook on the estate of Robert Louis Stevenson, for whom the species is named.

The type is no. 51775, U.S. National Museum, from Gasegase River, at Vaimosa, Samoa, length 2 inches.

\section{DROMBUS Jordan \& Seale.}

This genus, typified by $D$. palackyi from the Philippines, has the head crossed with rows of cirri as in Mars and in Gobiomorphus. The scales are much larger than in Mars, and the ventrals are united. There are no teeth on the vomer.

1449. Drombus tutuilæ Jordan \& Seale, new species. Samoa.

Head 2.75 in length; depth 4.5 ; eye 3.5 in head; snout 4.2 ; scales rather large, albout 23 from posterior margin of operele; dorsal vi, 8 ; anal 8 .

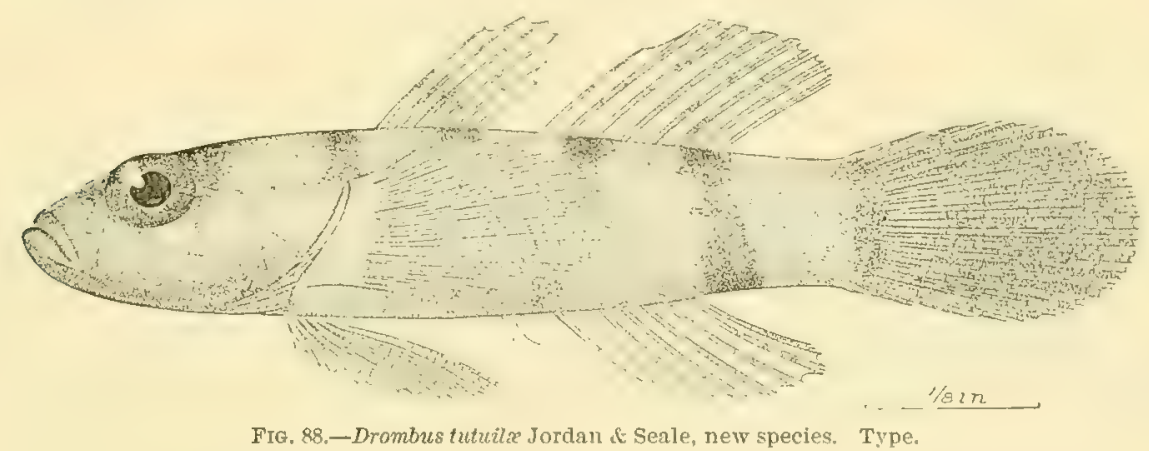

Body elongate, compressed, anterior profile rounded; lower jaw the longer, projecting; head roughened with numerous raised lines of rather large size which radiate from eye; others cross the cheek, snout, and nuchal region, these probably functioning as mucus canals; minute teeth in jaws, none on vomer or palatines; caudal peduncle 2.6 in head; origin of spinous dorsal slightly posterior to a line with axil of ventrals, the longest spine 2 in head; base of soft dorsal about equal to its longest ray, 1.75 in head; anal similar to soft dorsal, its base slightly less; pectorals rounded, rather long, the tips under base of fifth dorsal ray; ventrals united into a flat disk which reaches to anal opening; caudal rounded, about 1.1 in head.

Color in spirits, yellowish white, with 5 rather distinct vertical bands of black, the first at posterior margin of opercle, the second from posterior half of spinous dorsal, the third from anterior half of soft dorsal, the fourth from posterior half of soft dorsal obliquely down to axil of anal, the fifth at base of caudal fin; there is also a dusky bloch on nuchal region just back of eye; top of head more or less dusky; fins slightly darker than the body coloring, the dark bands of the body extending more or less upon the dorsal fins; otherwise the fins apparently without distinct markings.

One specimen from Pago Pago, type no. 51770, U. S. National Museum, length 0.75 inch. 
1450. Drombus filamentosus (Sauvage). New Caledonia.

Gobius filamentosus Sauvage, Bull. Sei. Philom. 1883, 157, New Caledonia.

This species is said to have a multitude of small filaments on the lower side of the head and elsewhere. We therefore refer it, with much doubt, to our genus Irombus.

\section{RHINOGOBIUS Gill.}

(Ctenogobius Jordan \& Snyder, not of Gill; Coryphopterus Gill; Mugilogobius Smith.)

The genus contains small gobies allied to Gobius, but of feeble organization and with no silky rays to the pectoral. The profile of the head is convex, anteriorly rounded. It differs from Ctenogobius in having the tongue convex at tip and not forked or notched.

1451. Rhinogobius corallinus Jordan \& Seale, new species. Samoa.

Head 3.2 in length; depth 5; eye 3.1 in head; dorsal vi, 10; anal 8; scales 34.

Body elongate, compressed, largest at pectoral girdle; anterior profle of head obliquely pointed; mouth small, the angle under the anterior of eye; small sharp-pointed teeth in jaws; opercle and pre-

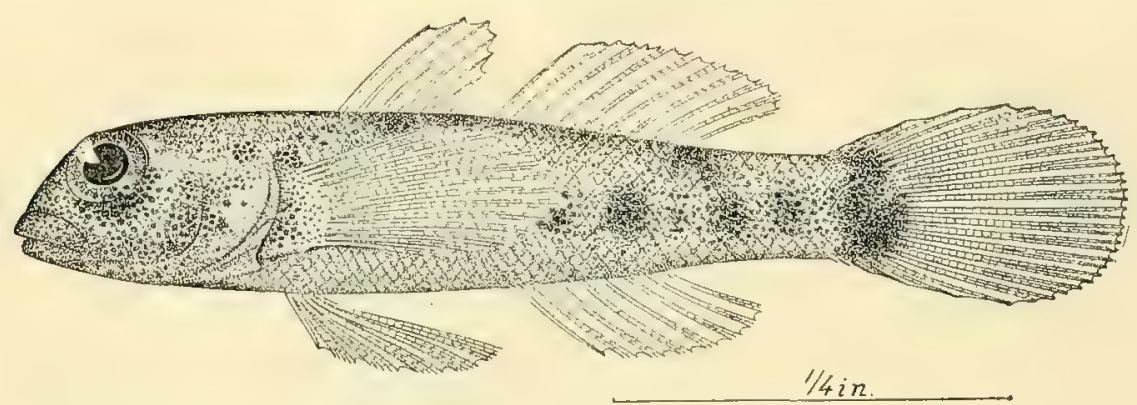

Frg. 89.-Rhinogobius corallinus Jordan \& Seale, new species. Type.

opercle entire; caudal peduncle slender, its depth 2.5 in head, 2.2 in its length; origin of spinous dorsal slightly posterior to line with axil of ventrals; the longest spine 1.95 in head; base of soft dorsal 1.2 in head, its longest ray 2.1; anal similar to soft dorsal, its base and length of rays slightly less, the origin of the fin nearer to base of caudal than eye; pectorals greater than length of head, the tips extending to below base of fifth dorsal ray; ventrals very large, united and extending to base of anal; caudal rounded, equal to length of head.

Color in life of a specimen from Pago Pago, light gray with 3 dark brown cross-bars on back, the third black, forming 2 confluent spots at base of caudal; five quadrate black spots along side, the last being the lower part of the caudal bar; a narrower dark vertical spot between each pair; head grayish, dotted; caudal pale orange, faintly barred; dorsal pale, faintly barred with darker; pectoral, anal, and ventral pale.

Color in spirits, yellowish white with a slight shading of brown; about 9 brownish blotches along side; 3 bands of brown over the back, the first at base of spinous dorsal, the second at posterior base of soft dorsal, the third encircling base of caudal; side of head shaded with small black dots forming a more or less distinct blotch under eye; 2 indistinct blotches near upper axil of pectoral; fins unmarked, except an indistinct shading of dusky on caudal; 2 or 3 indistinct dusky spots on dorsal.

One specimen from Pago Pago, type no. 51780, U. S. National Museum, length 0.75 inch.

1452. Rhinogobius circumspectus (Macleay). New Guinea.

Gobius circumspectus Macleay, Proc. Linn. Soc. N. S. W. 1884, 268, Milne Bay (New Guinea).

1453. Rhinogobius neophytus (Günther). Samoa; Ponape; Tahiti; Huahine. (Pl. xxxvı, fig. 2.) Gobius neophytus Günther, Fische der Südsee, 17t, taf. 108, fig. E, Ponape, Huahine, Apia, Tahiti.

Three specimens from Pago Pago, one from Apia, the body more slender than shown in Günther's figure. In the slender pointed head this species differs notably from other species of Rhinogobius. The lower jaw is projecting; the mouth oblique and placed low, the preorbital region being very broad; 
tongue entire, its substance translucent. Rhinogobius muscamm agrees with $R$. neophytus in these respects and perhaps the two should form a distinct genus.

Color in life perfectly translucent, with spots of dark orange, and some of pure black, one especially on caudal peduncle.

1454. Rhinogobius muscarum Jordan \& Seale, new species. Samoa.

Head 3 in length; depth 5 ; eye 3.25 in head; scales about 25 ; dorsal vi, 9; anal 10.

Body elongate, compressed, anterior profile rounded; upper jaw slightly the longer and overhanging the lower; tongue not notched; angle of mouth under middle of eye; depth of caudal peduncle 3 in head; teeth on jaws and vomer, a clump of enlarged teeth in middle of lower jaw; tube at nostril rather distinct; anal papilla distinct; origin of spinous dorsal on a line with axil of pectoral, the

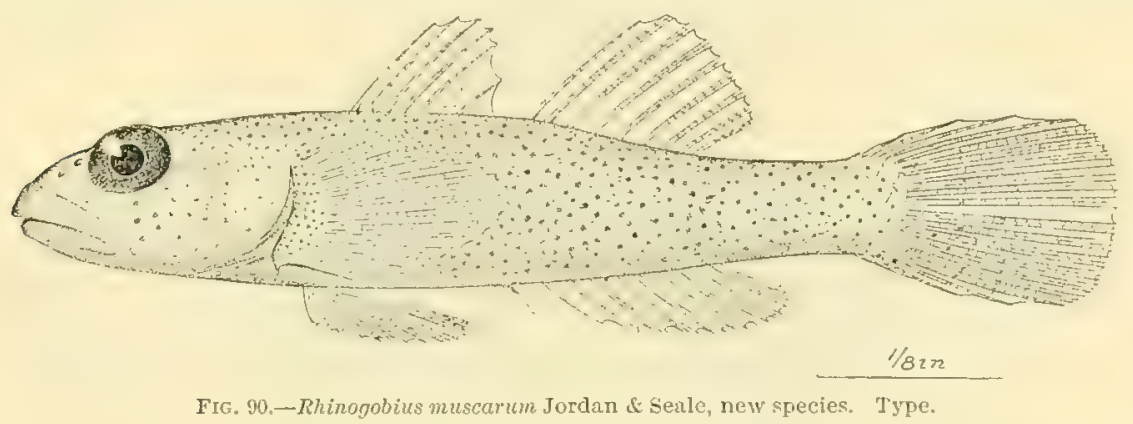

height of the fin being about equal to its base; base of soft dorsal equal to its longest ray; base of anal 1.5 in head, its longest ray 2.75 in head, the origin of the fin slightly nearer base of caudal than posterior margin of eye; pectoral 1.2 in head; ventrals united and disk-shaped, the anterior margin of the membranous cup with 2 lobe-like points; ventrals rather short, not reaching to base of anal; caudal $1.2 \mathrm{in} \mathrm{head.}$

Life colors of a specimen from Apia, translucent whitish with rather large black points and with angulated transverse narrow yellow bars; yellow markings on head.

Color in spirits, yellowish white, covering all the body with distinct round black spots slightly larger than pin points; head, thoras, and belly with fewer spots; dorsal fins showing a few scattered dark specks, caudal showing several bands of minute dots; anal with a few scattered dark spots; ventrals marked indistinctly with dusky dots; pectoral white with numerous dark dots on base.

Six specimens from the coral reef of Pago Pago. Type no. 51782, U. S. National Museum, length 0.7 inch. This species belongs to the same group as lihinogobius neophylus, distinguished from typical Rhinogobius by the shape of snout and translucent body.

1455. Rhinogobius nebulosus (Forskâl). Samoa; Papua; Palau Is.; Raiatea (Seale); East Indies. Gobius nebulosus Forskål, Deser. Anim., 24, 1775, Red Sea.

Gobius crinige" Cuvier \& Valenciennes, Hist. Nat. Poiss., Xi, 82, 1837, Dorey Harbor, New Guinea, Malabar.

Two specimens from the mouth of the Vaisigano River at Apia. Olive-green in life with darker blotches and spots.

\section{G0BIUS (Artedi) Linnæus.}

As now restricted the genus Gobius (type Gobius niger of Europe) includes the Old World species only, having the dorsal rays about vi-12, the scales rather large, silk-like, the teeth not large, and the tongue rounded.

1456. Gobius ornatus Rüppell. Samoa; Fiji; Yap; New Guinea (Macleay); Ionape (Kner, Novarn Fische, 173); Shortland I. (Seale); Last Indies. 
Nape scaly; tongue rounded; upper rays of the pectoral somewhat silky. This species represents the typical genus Gobius and is found in shallow waters over coral sand behind the coral reefs of Apia. It is not very common. Our specimens are all immature and have but a trace of the pearly spots on the sides of the head and bodv. We have 4 specimens from Apia and 9 from Pago Pago.

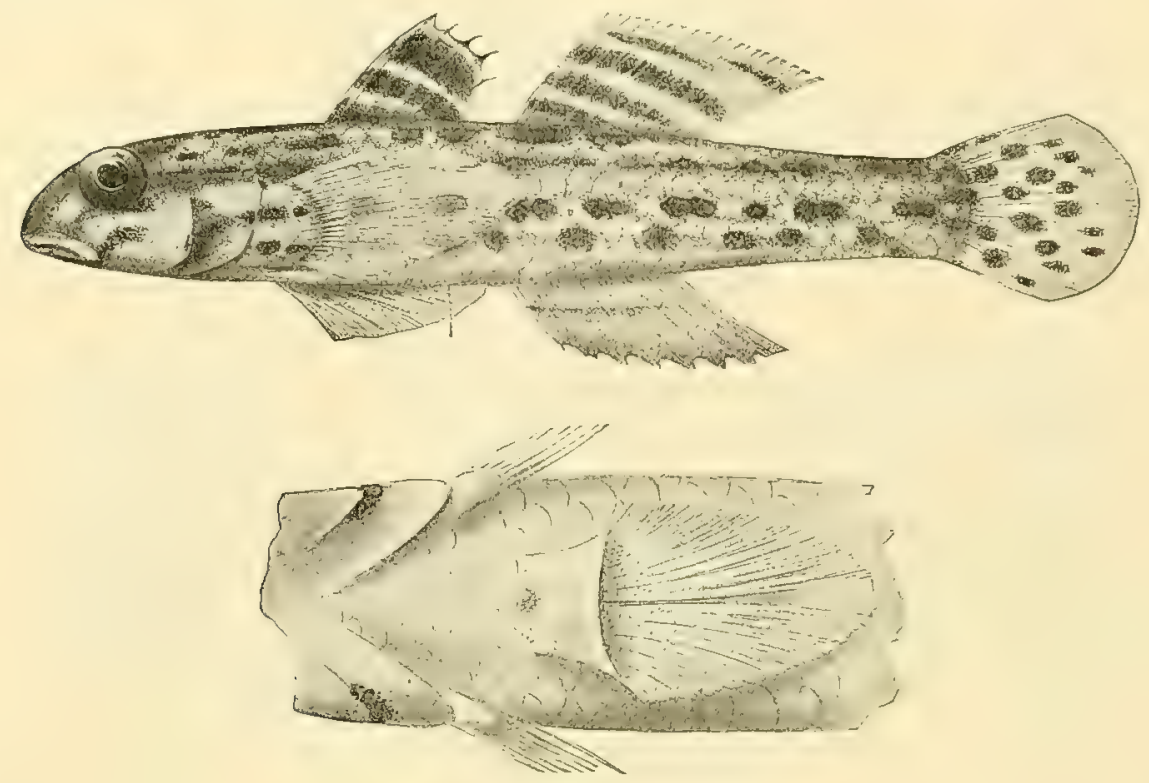

FIG.91--Gobius ornatus rïppell.

1457. Gobius elegans Cuvier \& Valenciennes. Vanicole; New Guinea.

1458. Gobius caledonicus Sauvage. New Calerlonia.

Gobius caledonicus Sauvage, Büll. Sci. Philom. 1879, p. 8, New Caledonia.

1459. Gobius oligolepis Bleeker. New Hebrides (Seale); East Indies.

1460. Gobius concavifrons Ramsay \& Ogilby. New Guinea.

Gobius concavifrons Ramsay \& Ogilby, Proc. Linn. Soc. N. S. W. 1886, 12, New Guinea.

\section{MAP0 Smitt.}

Mapo Smitt, Afh. Vet. Kong. Ak. Stockholm 1899, 543 (soporctor).

This genus is very close to Gobius, differing chiefly in the emarginate tongue. One of the species is the most widely distributed of the gobies.

1461. Mapo fuscus (Rüppell). Pa'oju. Samoa; Hawaii; Fiji; Tahiti; Nukahiva and Makatea (Seale); West Indies; East Indies; Panama.

Gobius abbopunctatus Cuvier \& Valeneiennes, Hist. Nat. Poiss, XII, 57, 1837, Ile de France.

This species is very common throughout the South Seas, living by preference in rocky tide pools, away from the coral reefs, in the region known as "iron-bound coast." Five of our specimens are from Vailele, 5 miles east of Apia; 3 from Aua, on the north shore of Tutuila, and 49 from the rocks near Point Distress at Pago Pago.

Tongue notched; upper rays of pectoral silk-like; head broad; first dorsal vi, low.

Life colors of a specimen from Pago Pago, grayish olive, with oblong irregular spots of orange brown, lighter or darker, and forming irregular lines; a dark dash below eye; head speckled with gray and brown; dorsals spotted like body; candal more spotted, with a dark brown marginal band and a pale tip; anal paler, also with a dark cross-shade; pectoral pale, spotted, with 3 blackish spots at base; ventral pale. A larger example was darker and browner, with traces of 3 broad cross-bands. 
Those found in lava are largely black. The young have black cross-bands which vanish with age. Those from Panama and Clarion islands show a little spotting of white and a trace of a black lengthwise band.

We have thus far failed to separate the Pacific species called Gobius albopunctatus from the widely liffused and very common Gobius or Mapo soporator of the American coasts.

1462. Mapo crassiceps Jordan \& Seale, new species. Samoa.

Hear 3 in length; depth 4.75; eye 4.5 in head; dorsal v, 10; anal 9; scales 32 counting from posterior margin of opercle; interorbital very narrow, scarcely wider than profile of eye; snout 3.75 in head; tongue emarginate.

Body elongate, compressed, largest at head, the cheeks being extremely gibbous, the bead being as wide as long, and much wider than deep; cheeks and interorbital region, naked; mouth rather large, with several rows of small sharp-pointed teeth; angle of jaws not reaching to below middle of eye; jaws equal in length; opercle and preopercle entire; about 12 fine silky rays on upper base of pectoral; clepth of caudal peduncle 2.95 ; origin of spinous dorsal posterior to a line with axil of

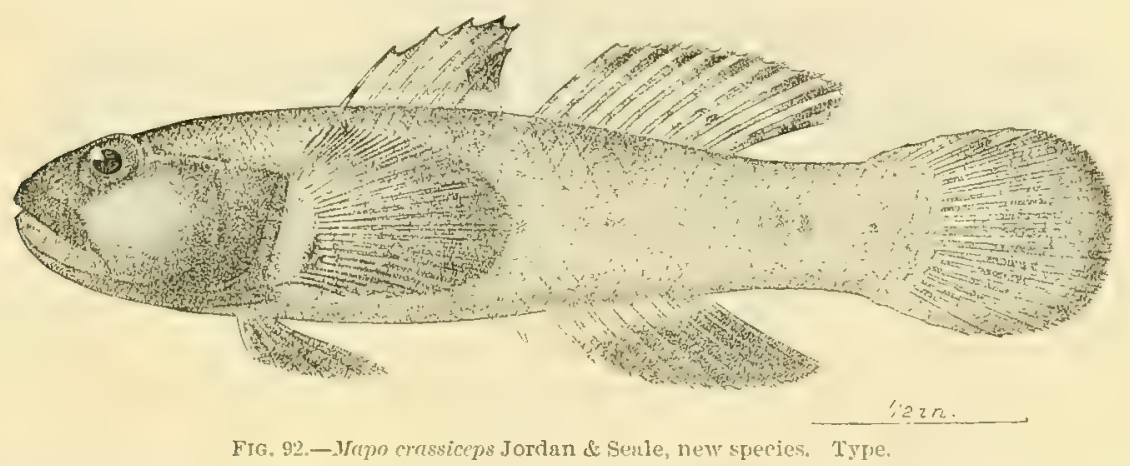

ventrals; base of spinous dor:al $2 \mathrm{in}$ length; base of soft dorsal 1.7.) in head, its longest ray 2.5 in head; base of anal 2.18 in head, longest ray about 2 in head, origin of anal midway between base of caudal and posterior margin of preopercle; pectorals $1.1 \mathrm{in} \mathrm{head,} \mathrm{the} \mathrm{tips} \mathrm{on} \mathrm{a} \mathrm{line} \mathrm{with} \mathrm{origin} \mathrm{of} \mathrm{soft} \mathrm{dorsal;}$ ventral disk 2 in head, the anterior membrane of the fin with 3 points; caudal rounded, 1.25 in head.

Color in spirits, whitish with slight dusky wash, a small black dot just back of eye; opercle and base of pectorals usually darker; posterior part of spinous dorsal with a black blotch; soft dorsal dusky; darker in middle; , caudal dusky; anal dusky, lighter on base, pectoral and ventral dusky.

Life colors of a specimen from A pia, yellowish-olive, mottlert all orer with blackish and grayish; grayish spots on cheeks; fins all dusky, more or less barred; axil dusky.

The species is very close to IIapo fuscus, differing in the tumid cheeks and plain coloration.

Nine specimens from Apia taken in the mouth of the river Vaisigano and one from the Bay of Apia. The type is no. 51777 , U. S. National Museum, from Apia, length 2.1 inches.

\section{GLOSSOG0BIUS Gill.}

1463. Glossogubius vaisiganis Jordan \& Seale, new species. Samoa.

Head, to tip of lower jaw, 3 in length; depth 5.5; eye 6 in head; dorsal vi, 10; anal 10; scales 29; snout 3.6 in head; interorbital very narrow, scarcely greater than pupil; eyes on ilorsal profile.

Body elongate, compressed, largest at pectoral girlle; head pointed, the lower jaw the longer, about one-half the width of eye, longer than upper jaw; mouth large, the angle below the posterior margin of eye; several rows of fine sharp-pointed teeth in the jaws and on romer; tongue deeply forked; caudal peduncle 3.25 in head; anal papilla distinct; origin of spinous dorsal slightly posterior to line with axil of ventral, its base 3 in head; base of soft dorsal 1.5 in head, its longest ray 2 in head; anal fin similar to soft dorsal, its size slightly smaller and its origin a little posterior to line with origin of soft dorsal, its origin nearer to base of caudal than to eye; pectoral extending to a line with origin of soft dorsal; origin of ventrals directly below base of pectoral, their tip extending to anal papilla; ventral fins united and with a shallow membranous cup; cautal rounded, 1.5 in head. 
Life colors of a specimen from Vaisigano River, dark olive, with lighter yellowish olive; no bright colors. Dorsal vi-I, 9 .

Color in spirits, olive-brown, lighter below, 7 dusky blotches along median line of sides, and about 6 narrow blackish longitudinal lines along middle of scales; a black spot on base of pectoral with a short black line below it; head more or less mottled with black blotches, some lighter dots and lines on lower jaw; spinous dorsal yellowish, a broad black band crossing its upper third; soft dorsal dusky yellow with about 5 indistinct blackish oblique bands; caudal with about 6 vertical dusky bands, the lower part of the bands being the broader; anal colored similar to soft dorsal; pectoral yellowish with indication of 5 or 6 narrow darker lines; ventrals dusky with white margin.

This species has the form, general coloration, and forked tongue of the Japanese species, Glossogobius brunneus, but it differs in some details of coloration, notably the presence of dark lengthwise streaks.

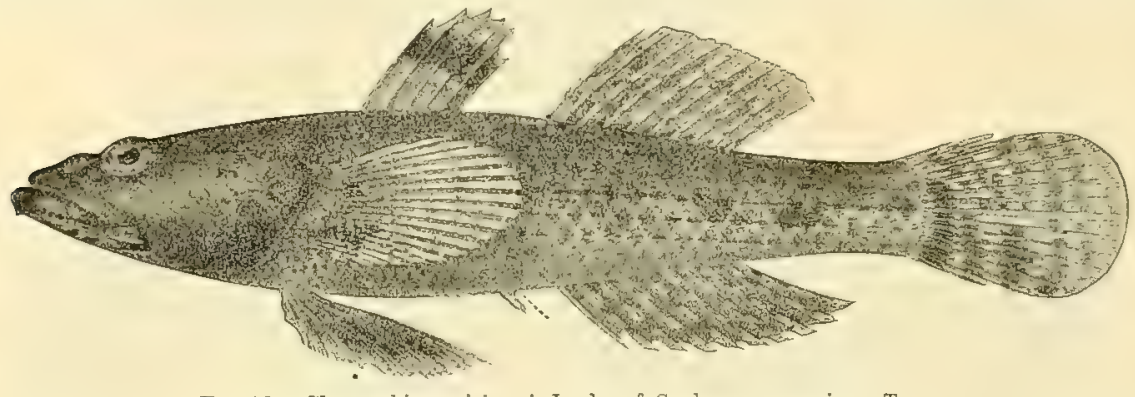

FIG. 43.-Glossogobius vaisiganis Jordan \& Seale, new species. Type.

Four specimens from the lower reaches of Vaisigano River at Apia, and one specimen from Pago Pago. The type is no. 51774, U. S. National Museum, from Vaisigano River, near Apia, length 3 inches.

\section{CHANOGOBIUS Gill.}

We refer a Samoan species to this Japanese genus. It agrees with the type in the elongate body, the small scales, the projecting lower jaw, notched tongue, and in the short fins, the dorsal having but 6 spines.

1464. Chænogobius erythrops Jordan \& Seale, new species. Samoa. (Pl. xxxvir, fig. 3.)

Head 3.1 in length; depth 5.5; eye 3.2 in head; dorsal vr, 9; anal 7; scales about 41 counting from posterior margin of opercle; snout 3.4 in head.

Body elongate, compressed; snout pointed, the under jaw decidedly the longer; mouth large, the angle under the anterior margin of eye; teeth in jaws in a single row, with some of the anterior ones enlarged and distinet; teeth on vomer, none on palatines; tongue notched at tip; opercle and preopercle entire; anal papilla distinct; depth of caudal peduncle 2.7 in head; spinous dorsal with its origin above base of ventrals, its longest spine 2 in head; base of soft dorsal 1.75 in hear, its longest ray about 2; anal similar to soft dorsal, its base and length of rays slightly less; origin of anal about midway between eye and base of caudal fin; pectoral 1.75 in head; in the type specimen the upper 5 rays are not connected except on basal half, but they may have been torn loose accidentally; ventrals united, disk-shaped; the anterior membrane with 2 points, the diameter of disk 2 in head; caudal rounded, 1.75 in head.

Life color, pearly white above; sides darker and with black points; eye rosy around pupil; rosy Jongitudinal preocular bars on head.

Color in spirits, almost uniform white, with scattered fine dots like pin points, a slight dusky blotch at base of caudal, one on snout, and another posterior to eye; markings all indistinet; fins without markings, except sone very fine scattered dots like pin pricks.

One specimen, from Pago Pago, type no. 51781, U. S. National Museum, length 0.6 inch.

AWAOUS Steindachner.

Les Awrous Cuvier \& Valenciennes, Hist. Nat. Poiss., xir, 95, 1837 (ocellaris, etc.).

Awaous Valenciennes, Steindachner, Verh. Akad. Wiss. Wien 1860, 289, after Cuvier \& Valenciennes, no explanation; no type named, reference to Valenciennes implied. 
Chonophorus Poey, Syst. Gob., 320 1874, (bucculentus=banana).

Awaous Bleeker, Rev. Gob., 320, 1875 (ocellaris).

Trichopharynx Ogilby, Proc. Linn. Soc. N. S. W. 1897, 769 (crassilabris).

This genus contains large gobies of the tropical rivers, characterized by a peculiar physiognomy, and by the presence of small fleshy flaps on the shoulder-girdle; tongue adnate to floor of mouth. It is probable that the generic name Awous should be adopted for this group, on the strength of its use in a subgeneric sense by Steindachner.

1465. Awaous stamineus (Valenciennes). Hawaii.

1466. Awaous oceliaris (Broussonet). Mano'o; I'a pala. Tahiti; Samoa; Rarotonga; Fiji, in streams.

Gobius occllaris Broussonet, Dee. Ichth., pl, 142, 1782, Tahiti, coll. Solander. Cuvier \& Valenciennes, Hist. Nat. Poiss, XII, 98 1837, Ile de France, Günther, Fische der Südsee, 177, taf. 10s, fig. c, Samoa, Rarotongi, Viti Leru.

We have 2 specimens from the stream at Pago Pago and 20 specimens of various sizes from the Vaisigano River at Apia. The species is common in the river where the current is broad and swift. It reaches a length of 6 inches. There are scales on upper edge of cheeks and opercles, not on the whole side of head as shown in Günther's tigure.

Life colors of 2 specimens from Apia, called mano'o ia pala, mottled green; dorsals and anal redtinged; a large black ocellus on dorsal; caudal with 2 or 3 black bars; soft dorsal with 3 black bars; anal reddish, pale-edge; ventral reddish. Adult males nearly black with black lower fin.

1467. Awaous crassilabris (Günther). Rivers of Oualan; Aneiteum; Shortland I. (Seale).

Gobius crassilabris Günther, Fische der Süôsee, 178, 1873, Oualan, Aneiteum.

This species is common in the streams of Malanesia. It was not taken by us. It resembles Awaous acellaris, but lacks the black ocellus on the dorsal. It may not be different from Awcous guamensis.

1468. Awaous guamensis (Cuvier \& Valenciennes). Guam.

Gobius guamensis Cuvier \& Valenciennes, Iist. Nat. Polss., XII, 103, 1837, streams of Guam. Sauvage, Bull. Sci. Phil. 1879, 7, Guam.

1469. Awaous genivittatus (Cuvier \& Valenciennes). Teli. Rivers of Hawaii; Fiji; Samoa; Tahiti; New Hebrides.

Gobius geniviltatus Cuvier \& Valenciennes, op. cit., 64, 1837, Tahiti. Günther, Fische der Südsee, 170, taf. 910, fig. C, Tahiti, Fiji, Samoa, Hawaii.

Abundant in the quiet pools and sluggish reaches of the Yaisigano and other rivers. We have 5 specimens from Vaisigano River.

EXYRIAS Jordan \& Seale, new genus.

Exyrias Jordan \& Seale, new genus of Gobiila (Gobius puntangoides Bleeker).

1470. Exyrias puntangoides (Bleeker). Ponape; Shortland 1. (Seale); Cebu.

Gobius puntangoides Bleeker, Nat. Tijd. Ned. Ind., v, 1853, 242.

This East Indian species, not seen by us, resembles an Awaous, although figured as having the cheeks fully scaled.

\section{AMBLYG0BIUS Bleeker.}

Amblygobius Bleeker, Arch. Neerl. 1875, 322 (sphinx).

Odontogolius Bleeker, Arch. Neerl. 1875, 323 (bynoensis).

This genus is distinguished by the small scales, the robust form, and the presence of strong canines in the lower jaw. The species, like most of those of the related genus, Pterogobius, are cross-banded. We can see no generic differences separating Odontogobius from Amblygobius.

1471. Amblygobius semicinctus (Kner). Fiji; Oualan. Gobius scmicinctus, Kner, Sitz. Ak. Wiss. Wien, 31, Oualan, Fiji.

1472. Amblygobius phalæna (Cuvier \& Valenciennes). Vanicolo; Samoa; Palau Is.; Tonga; Faté (Seale).

Gobius phalana, Cuvier \& Valenciennes, 1tist. Nut. 1'oiss, Xu, 92, 1837, Vanicolo. Günther, Fische der Südsee, 178, taf. 111, Palau, Samoa, Tonga. 
This handsome species is rather common on the soft bottom behind the coral reefs of $\Lambda$ pia. It is closely related to 1 mblygobius bynoensis, the genus being characterized by the presence of rather strong canines on the side of the jaw. Scales small, covering top of head, and extending on opercle above; pectorals with no silk-like rays; dorsal vi, 15 ; anal 14.

Life colors of a specimen from Apia, dark olive; 5 dark brown bands, each edged on both sides with light blue, the bands broader than the grayer interspaces; from middle of each brown band a narrower bar crosses the back; head with many oblong and round sky-blue spots darker than the interspaces; 2 rows of orange spots on each side of nape; a round black shoulder spot; some bluish oblong dashes on front of side; first dorsal olive, with a black central blotch and a black erlge; second dorsal mottled gray, then edged with light yellow, black and brown; caudal brownish, dusky behind; a black ocellus near base above; anal grayish with a row of whitish spots at base and a black edge; ventral black, paler centrally; pectoral bright golden yellow, with a blue horizontal streak and 2 blue spots at base. Body compressed, the scales rather small.

Another specimen, male, has 4 plain black cross-bars and 5 ocelli on caudal irregularly placed; the black margin broader, the dorsal with 2 rows of bluish dots, the anal with a bluish streak.

A third specimen from this locality was olive-green with round spots of grayish blue on hear surrounded by dark blue streak; first dorsal olive with a black spot; second dorsal olivaceous mottled with dark brown; caudal light brownish with 2 black spots; a black spot above gill-opening; lower fins pale.

Seven specimens from Apia.

1473. Amblygobius papuanus (Peters). New Guinea. Gobius papuamus Peters, Berl. Mon. 1876, 839, New Guinea.

1474. Amblygobius sphinx (Cuvier \& Valenciennes). New Guinea; East Indies.

A very robust species with black cross-bands.

\section{CRYPTOCENTRUS Ehrenberg.}

Cryptocentrus (Ehrenberg) Bleeker, Arch. Neerl. 1875, 322 (cryptocentrus).

This genus, as understood by us, comprises species allied to Rhinogobius but covered with small scales, instead of large ones.

1475. Cryptocentrus leucostictus (Günther). Tonga.

Gobius leucostictus Günther, Proc. Zool. Soo. 1871, 664, Tonga. Günther, Fische der Südsee, 176, Tonga.

This species, which we have not seen, seems to belong near Cryptocentrus.

VITRARIA Jordan \& Evermann.

1476. Vitraria clarescens Jordan \& Evermann. Hawaii.

PSELAPHIAS Jordan \& Seale, new genus.

Pselaphias Jordan \& Seale, new genus of Gobiidæ (Gobius ophthalmonemus).

This genus is close to Gobionellus (hastatus), and still closer to Oxyurichthys (belosso), differing from both in the presence of a tentacle above the eye.

1477. Pselaphias ophthalmonemus (Bleeker). Samoa; Fiji; Akyab; East Indies.

Gobius ophthalmonema Bleeker, Nat. Tijds. Ned. Ind, 1856, x1I, 208.

Euctenogobius ophthalmonemus, Günther, Fische der Suidsee, 180, taf. 111, fig. B, Tonga, Fiji, Akyab.

Life colors of an Apia specimen, a black bar below eye; dull olive with quadrate and other blotches along side; back mottled; no pale spots; no bright colors; fins much mottled; dorsal with a black blotch on last rays.

Three specimens from a sluggish bayou of Vaisigano River at Apia. Dorsal filamentous. 
WAITEA Jordan \& Seale, new genus.

Waitea Jordan \& Seale, new genus of Gobiidae (type Gobius mystacina).

This genus, of which Gobius mystacina is the type, is close to Gobionellus, but it has the maxillaries produced backward after the fashion of Opisthognathus. It is named for Mir. Edgar R. Waite, of Sydney, the excellent curator of fishes in the Anstralian Museum (now at the Museum of Christchurch, New Zealand).

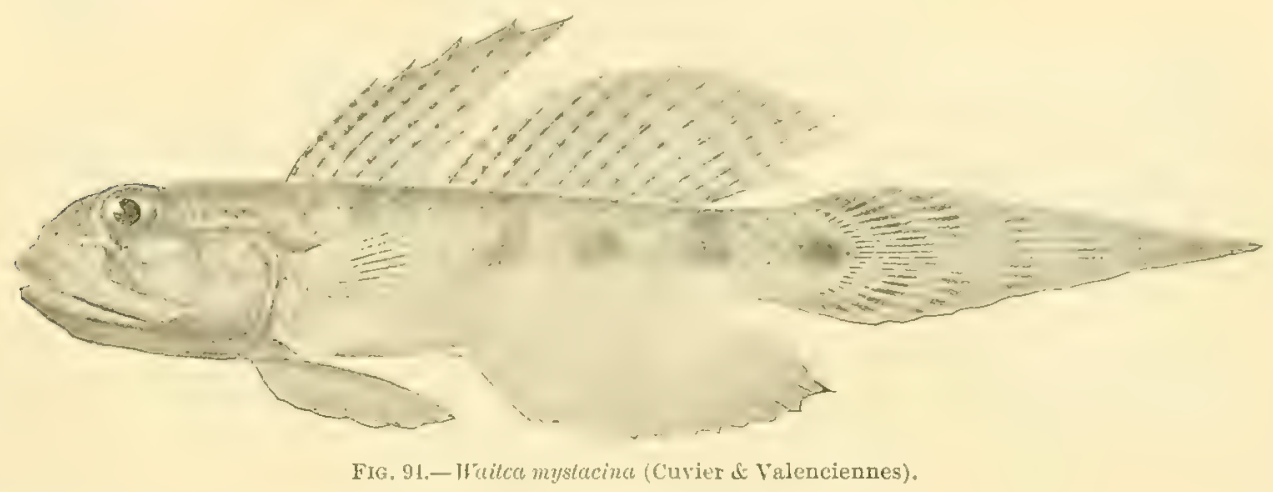

1478. Waitea mystacina (Cuvier \& Valenciennes). Samoa; Java.

Color nearly plain olive-green.

GOBIICHTHYS Klunzinger.

This genus has the elongate body and sharp caudal fin of Gobionellus, but the upper teeth are in one series.

1479. Gobiichthys lonchotus (Jenkins). Hawaii.

1480. Gobiichthys papuensis (Cuvier \& Valenciennes). New Guinea; East Indies.

\section{GOBIONELLUS Girard.}

This genus contains elongate species with the caudal fin produced, the lower jaw flat, and the teeth small, in bands.

1481. Gobionellus atriclypeus (Garman). Fiji.

Gobius atriclypeus Garman, Bull. Mus, Comp. Zool., 1903, 233, xxxix, with plate, Fiji.

This species, from Fiji, is unknown to us. From the slender form and acuminate caudal and the teeth in bands we refer it to Gobionellus.

GOBIOPTERUS Bleeker.

Gobiopterus Bleeker, Arch. Neerl. 1875, 311 (brachypterus).

This genus differs from Apocryptes in the large scales and short dorsal and anal.

1482. Gobiopterus farcimen Jordan E Evermann. Hawaii.

Scales ahout 50 .

\section{APOCRYPTODON Bleeker.}

1483. Apocryptodon fasciatus (Macleay). New Guinea (Proc. Linn. Soc. N. S. W. 1884, 268).

\section{PSEUDAPOCRYPTES Bleeker.}

Pseudapocryptes Bleeker, Arch. Neerl. 1875, 327 (lanceolatus).

This genus is said to differ from Apocryptes (bato) in the tumid teeth and the minute scales.

1484. Pseudapocryptes lanceolatus (Bloch \& Schneider). Tahiti (Kner, Novara Fische, 180); East Indies. 
1485. Pseudapocryptes punctularum (De Vis). South Seas (probatly Banks Group).

Gobiosoma punctularum De Vis, Proc. Linn. Soc. N. S. W. 1884, 449.

This species, and the closely allied Gobiosoma gutulatum Macleay from Australia, said to be scaleless, must be based on specimens of Pserdapocryptes, in which the minute scales have been overlooked. They have no affinity with Gobiosoma.

MARS Jordan \& Seale, now genus.

Mars Jordan \& Seale, new genus of Gobiidze (strigilliceps).

This genus, typified by Mars strigilliceps, has the appearance of an ordinary goby with small scales, as in Cryptocentrus, which it much resembles. On the vomer, however, are 2 or 3 large blunt teeth, and the head is provided with minute filaments and pores arranged in straight lines and running in various directions, somewhat as in Quisquilius and in Drombus. The canals on the planet Mars perhaps justify the name of this genus.

1486. Mars strigilliceps Jordan \& Seale, new species. Samoa.

Head 3.2 in length; depth 5; eye 4 in head; snout 5 in head; dorsal vi, 11; anal 1 , 9 ; scales 65 , counting from posterior margin of opercle.

Body elongate, compressed, the anterior profile rounded; jaws equal; mouth rather large, the angle below middle of eye; several rows of small, sharp-pointed teeth in jaws; rather large blunt

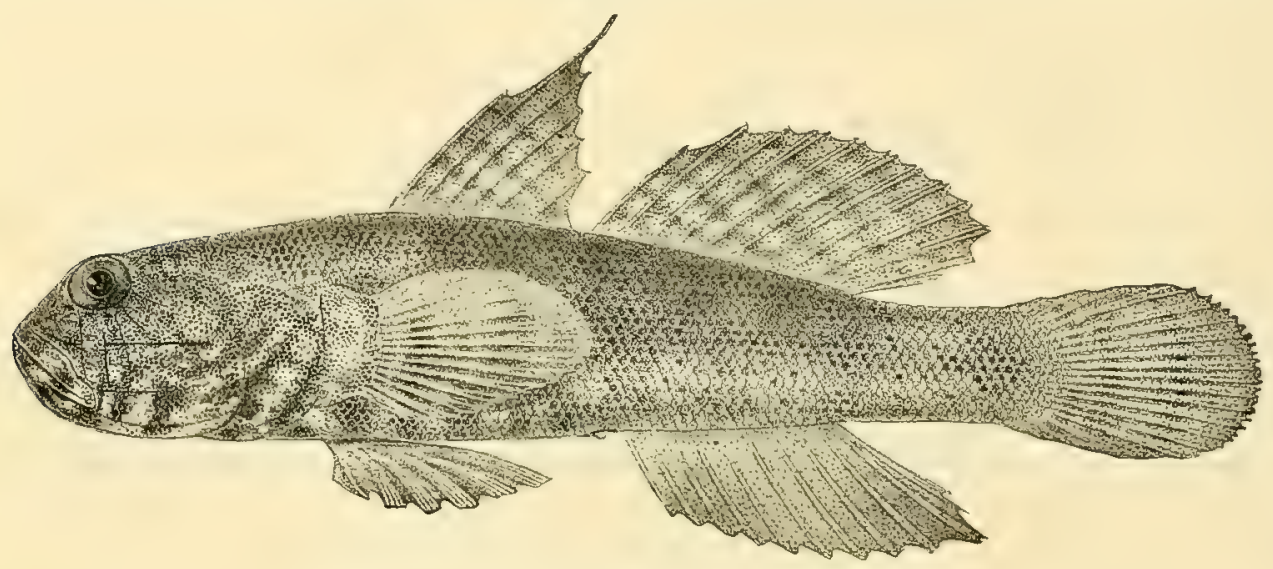

FiG. 95.,-Mars strigilliceps Jordan \& Seale, new species. Type.

teeth on palatines and vomer, no teeth on tongue; opercle and preopercle entire; head without scales; a number of fine distinct raised chain-like lines radiating from eye and extending over or across the cheek; one across the nuchal region, joined by 3 or 4 other similar lines which run longitudinally on nuchal region; these probably serve as a mucus system; caudal peduncle 2.75 in head; second spine of soft dorsal elongate, filiform, about equal to length of head; base of soft dorsal 1.25 in head, its longest ray 1.75 in head; anal similar to soft dorsal, but with base and the anterior rays slightly shorter; pectorals 1.1 in head, the tips under origin of soft dorsal; ventrals mited, rather elongate, 1.25 in head, a distinct shallow membranous cup at base, the membrane entire; caudal rounded, about 1.25 in head.

Life colors, dark olive with 4 narrow grayish cross-bands, rather obscure; front of head dusky; lower part of head brcnze-olive, with 6 sharply defined irregular white cross-bands; similar fainter cross-bands on belly; the white bar from front of spinous dorsal crossing base of pectoral and forming a ring about body; base of pectorals with white marblings; fins dusky olive with no clear markings; scales small; head with numerous lines of small pores each with a minute filament.

Color in spirits gray, with slight bluish wash; about 4 indistinct dusky blotches along side, the blotch on side of caudal peduncle being most distinct; 5 distinct bands of black alternating witl bluish white surrounding the under part of head and throat, the posterior band white and extending 
from upper posterior margin of operele around thorax at base of ventrals; about 5 light-blue bands around belly; 3 indistinct lighter lines over the back, 2 on nuchal region and 1 extending obliquely down from base of spinous dorsal; dorsal fins grayish with about 5 oblique dusky lines; 2 or 3 indistinct dusky bands on caudal; pectoral with 3 or 4 very indistinct dusky cross-bands, the base of the fin bluish with 2 or 3 dusky blotches: anal and ventral dusky without distinct marking.

One specimen from Apia. Type no. 51778, U. S. National Museum, length 2 inches.

KELLOGGELIA Jordan \& Seale, new genus.

Kelloggella Jordan \& Seale, new genus of Gobiidæe (cardinalis).

Brilliantly colored little fishes, allied to Gobiosoma, the body naked, but with only 6 dorsal spines, the body and head more elongate. Coral reefs of Samoa. The genus, typified by Kelloggellacardinalis, is named for its discoverer, Vernon Lyman Kellogg, professor of entomology in Stanford University.

1487. Kelloggella cardinalis Jordan \& Seale, new species. Samoa. (Pl. LII, fig. 1.)

Head 4.5 in length; depth 6 ; eye \pm in head; dorsal vi, 13 ; anal 9 ; no scales; interorbital one-half of eye; snout 4 .

Body elongate, compressed; anterior profile rounded; the lower jaw a little the shorter, the angle under middle of eye; small sharp teeth in jaws, none on vomer or palatines; opercle and preopercle entire; width of gill-opening 2.1 in head; caudal peduncle strong, its depth 1.5 in head; origin of spinous dorsal posterior to a line with base of ventral; base of spinous dorsal 1.15 in head, its longest spine 2 in head; base of soit dorsal 2.8 in length of fish without caudal, its longest ray 2 in head; pectoral slightly longer than head, its tip on line with sixth dorsal spine; rentrals small, 1.2 in head, their origin below axil of pectorals, their tips on line with base of fifth dorsal spine; the 2 fins fully united; caudal rounded, equal to head.

Life colors of the type specimen clear grass green, rather pale; both dorsals, caudal, and anal bright cherry-red; anal greenish in front; pectoral and ventral green. Two larger specimens were greenish black, more greenish anteriorly; dorsal and anal bright orange edged with black; pectoral and ventral bright golden green; candal gray.

Color in spirits, a uniform dull green, a little less shaded on head and belly; fins all yellowish white; some specimens with a dusky margin to dorsals, caudal, and anal; the dorsals are also darker at base. inches.

Three specimens from Pago Pago. The type is no. 51785, U. S. National Museum, length 1.12

1488. Kelloggella oligolepis (Jenkins). Hawaii.

This species bears little resemblance to the genus Enypnias to which it has been referred. It may be provisionally placed in Kelloggella, from which it differs in form and in the presence of a few scales on the posterior part of the body.

\section{GOBIODON Kahl \& Van Hasselt.}

Gobiodon Kuhl \& Van Hasselt, Bleeker, Boroe, 407, 1851 (histrio).

Small, deep-bodied gobies, entirely scaleless; jaws with canine teeth.

1489. Gobiodon histrio (Kuhl \& Van Hasselt). Tonga; East Indies.

1490. Gobiodon rivulatus Rüppell. Tahiti; Guam; Tonga; Bonham I.; Vavau; Solomon Is.; Meduro; New Britain (Peters, Berl. Mon. 1876, 840); East Indies.

1491. Gobiodon ceramensis Bleeker. Fiji; East Indies.

Gobiodon ceramensis, Günther, Fische der Südsee, 180, Fiji.

1492. Gobiodon atrangulatus Garman. Fiji.

Gobiodon atrangulatus Garman, Bull. Mus. Comp. Zool. Xxxıx, 1903, 235, Fiji.

1493. Gobiodon flavidus De Vis. Banks Group, east of New Guinea.

Gabiadon flavidus De Vis, Proc. Linn. Soc. N. S. W. 1881, 449.

1494. Gobiodon axillaris De Vis. Banks Group, cast of New Guinea.

1495. Gobiodon lineatus De Vis. Banks Group, east of New Guinea.

1496. Gobiodon inornatus De Vis. Banks Group, east of New Guinea.

$$
\text { 1., 13. IF. 190\%-2 }
$$




\section{PSEUDOGOBIODON Bleeker.}

Pseudogobiodon Bleeker, Arch. Neerl. 1875, 309 (citrinus).

No canine teeth, otherwise like Gobiodon.

1497. Pseudogobiodon citrinus (Rüppell). Ulitui (big-head). Samoa; Ponape (Günther); East Indies.

This species is very abundant in the coral reefs at Apia, where we obtained 32 specimens. The ground color varies from yellow to brown, but the blue vertical stripes are very constant.

One specimen in life from Apia, yellow-olive; fins all orange, the edges deep orange, the first dorsal edged with black; iris orange. Another was brown, tinged with orange; a blue line down from eye; a black opercular spot with a vertical blue line before and behind it; orange deepest under eye and on edge of pectoral. Other specimens were blackish olive; fins all broadly edged with blackish orange; no black edge on dorsal; a black spot on end of opercle.

1498. Pseudogobiodon verticalis (Macleay). New Guinea.

Gobiodon verticalis Macleay, Proc. Linn. Soc. N. S. W. 1884, 333.

\section{SICYOPTERUS Gill.}

Sicyopterus Gill, Proc. Ac. Nat. Sci. Phila. 1860, 101 (stimpsoni).

Lower jaw with 2 canines in front, snout tumid, projecting over the small mouth; body with small scales.

1499. Sicyopterus stimpsoni Gill. Streams of Hawaii.

Sicyopterus stimpsoni Gill, Proc. Ac. Nat. Sci. Phila. 1860, 101, streams of Hawaii.

Sicydium nigrescens Günther, Shore Fishes Challenger, 60, 1880, streams about Hilo.

1500. Sicyopterus tæniurus (Günther). Fiji; Aneiteum; Samoa; in streams.

Sicydium lagocephalus Iner, Sitz. Ak. Wiss. Wien 1868, 35, Viti Levu (Fiji), Namusi stream; not of Cuvier \& Valenciennes.

Sicydinus macrostetholepis Kner, op. cit., 35, Samoa; not of Bleeker.

Sicydium trniurum Gủnther, Fische der Südsee, 183, Viti Levu, Aneiteum, New Hebrides. Ogilvie-Grant, Proc. Zool. Soc. London 1884, 161, Aneiteum, Viti Levu.

Life colors of a specimen from Pago Pago, dark olive; 7 or 8 diffuse spots along side; a trace of lateral stripe along head; a black bar below eye; caudal pale olive with 3 black lengthwise stripes, the upper and lower oblique; dorsals plain dusky olive; pectoral plain olive; scales small; first dorsal pointed; ventral very small; head depressed; mouth inferior; teeth large; body low.

Two specimens agreeing very well with Günther's figure were taken in the stream at Pago Pago.

1501. Sicyopterus albotæniatus (Günther).

Sicyopterus albotæniatus Günther; Fische der Südsee, 184, Hawaii.

This fish is known only from the drawing of Mr. Andrew Garrett, made at Hilo, and published by Dr. Günther.

1502. Sicyopterus pugnans (Ogilvie-Grant). Samoa (Grant).

Sicydium pugnans Ogilvie-Grant, Proc. Zool. Soc. London 1884, 160, pl. xI, Savaii.

This species, from the rivers of the island of Savaii, was not seen by us.

1503. Sicyopterus tauæ Jordan \& Seale, new species. Samoa.

Head 4.5 in length; depth 6.75 ; eye 4 in head; dorsal vi, 13 ; anal 11; scales about 62 ; snout 3.5 ; interorbital 3 in head.

Body elongate, compressed; the snout somewhat projecting, overhanging the small mouth; minute teeth in jaws and on vomer and palatines; depth of caudal peduncle 2 in head; origin of spinous dorsal posterior to line with distal end of ventrals, its longest spine 1.5 in head; base of soft dorsal 3.45 in length without caudal, its longest ray about 1.35 in head; anal similar to soft dorsal, its longest ray about 1.5 in head; origin of anal distinctly below origin of soft dorsal, being about equally distant between tip of snout and base of caudal fin; pectoral, 1.1 in head; ventral disk 2 in head, the anterior membranous margin of the cup entire; caudal almost square, its length 1.1 in head. 
Color in spirits, yellowish with 7 rather broad bands of brownish over the back and down on side to a little below median line, the posterior one being at base of caudal and forming a complete dusky ring around caudal base; a row of about 10 small dark spots along base of soft dorsal; a dusky line at base of anal; sides and top of head somewhat shaded with minute dark dots; fins without distinct markings, a dark spot between eye and angle of mouth.

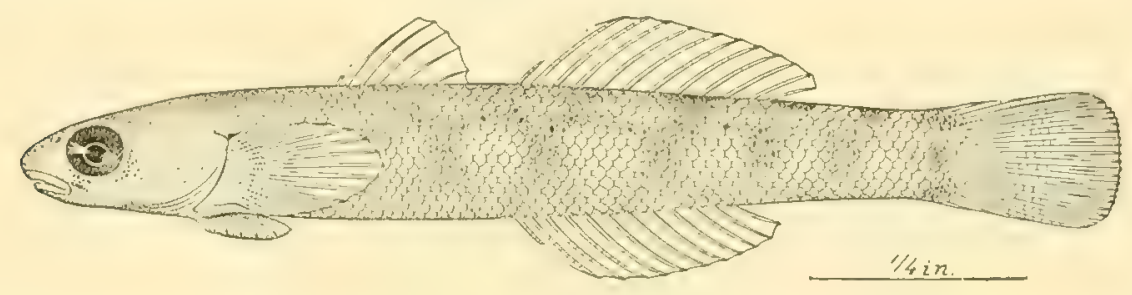

FiG. 96,-Sicyopterus taux Jordan \& Seale, new species. Type.

One specimen, type no. 51756, U. S. National Museum, from Vaisigano River, Apia; length 1.35 inches. It is named for Taua, a Rarotonga man, the most skillful of the fishermen of Apia.

\section{MICROSICYDIOM Bleeker.}

Microsicydium Bleeker, Arch. Neerl. 1875, 315 (gymnauchen).

This genus may be provisionally distinguished from Sicyopterus by the large scales, 30 to 40 .

1504. Microsicydium elegans (Steindachner). Tonga.

Sicyclium elegans Steindachner, Sitz. Ak. Wiss. Wien 1579, 152, Tonga.

This strikingly colored species is well distinguished by its large scales (32). It was not taken by us.

Body naked, or nearly so.

\section{LENTIPES Günther.}

1505. Lentipes concolor (Gill). Rivers of Hilo, Hawaii.

1506. Lentipes seminudus Günther. Rivers of Hilo, Hawaii.

This species, which we have not seen, may be the type of a distinct genus.

\section{GOBIOIDES Lacépède.}

1507. Gobioides totoyensis Garman. Fiji.

Gobioides totoyensis Garman, Bull. Mus. Comp. Zool., vol. xxxix, no. 8, 1901, 235, Totoya (Fiji Is.).

\section{Family ECHENEIDIDA \\ PHTHEIRICHTHYS Gill.}

1508. Phtheirichthys lineatus (Menzies). Pacilic Ocean (Günther, Fische der Südsee, 156); tropical Atlantic (as a parasite on barracudas).

\section{LEPTECHENEIS Gill.}

1509. Leptecheneis neucrates (Linnæus). Talitaliuli. Samoa; Hawaii; New Guinea; warm seas generally.

One very large specimen of this common fish was taken at Apia. Dorsal xxiv, 37.

Life color, all dark brown; lateral band obscure.

ECHENEIS (Artedi) Linnæus, (Remora Gill.)

1510. Echeneis remora Linneus. IIawaii; warm seas generally. 
REMORINA Jordan \& Evermann.

1511. Remorina albescens (Schlegel). Marcus I. (Bryan \& Herre, Bishop Museum, 1903); New Guinea; China and Japan; America.

\section{REMOROPSIS Gill}

1512. Remoropsis brachyptera (Lowe). Pacific Ocean; warm seas; Japan.

Family ṔLEURONECTIDA.

PLATOPHRYS Swainson. Ali.

1513. Platophrys mancus (Broussonet). Ali. Samoa; Johnston I.; New Guinea; Bougainville Is.; Rarotonga; Tahiti; Makatea; Tubuai and Faté (Seale); East Indies.

Pleuronectes mancus Broussonet, Ich. Decas., 1782, with plate, Tahiti; not mancus of Risso or Günther=Platophrys podas.

Rhombus macropterus Quoy \& Gaimard, Voy. Uranie, 236, 1824, Rawak (New Guinea), on a rough drawing. Rhombus pavo Bleeker, Kokos, IIr, 177, Kokos.

Rhomboidichthys pavo, Günther, Cat., IV 435; East Indies. Peters, Berl. Mon. 1876, 814, Bougainville Is.

This species is common on the sandy shores of Samoa, where it reaches a considerable size. It may be readily distinguished from Platophrrys pantherinus by the larger number of anal rays (about 80 ), by the more varied coloration, by the form of the arch of the lateral line, and by other characters. It has been found at Johnston Island, but has not yet been recorded from Hawaii. We have 6 specimens, large and small, from Apia and Pago Pago.

Life colors of a specimen from Apia. yellowish gray; spots bluish gray with rim of darker gray; those on fins grayish white and grayish orange; 2 dark spots on lateral line.

1514. Platophrys pantherinus (Rüppell). Ali. Hawaii; Samoa; Marquesas Is.; East Indies.

Passer marchionessarum Valenciennes, Voy. Venus, Poiss, 344, pl. 9, Marquesas Is.

This species is very common about Hawaii. It is not rare about Samoa, where it is confounded with Platophrys mancus by the natives under the name of ali. We have 4 specimens from Apia. It is easily distinguished on comparison of specimens, the constantly smaller number of anal rays being diagnostic.

1515. Platophrys chlorospilus Gilbert. Deep seas of Hawaii.

1516. Platophrys inermis Gilbert. Deep seas of Hawaii.

\section{SCEOPS Jordan \& Starks.}

1517. Scæops spilura (Günther). New Guinea.

Rhomboidichthys spilurus Günther, Challenger Fishes, 1880, 47 .

1518. Scæops xenandrus Gilbert. Deep seas of Hawaii.

\section{ENGYPROSOPON Günther.}

1519. Engyprosopon arenicola Jordan \& Evermann. Hawaii.

1520. Engyprosopon hawaiiensis Jordan \& Evermann. Hawaii.

PSEUDORHOMBUS Bleeker. (Rhombiscus Jordan \& Snyder.)

1521. Pseudorhombus triocellatus (Bloch \& Schneider). Tahiti (Kner, Novara Fische, 1867, 284); East Indies.

This East Indian species is once recorded from Tahiti. We doubt the accuracy of the record.

1522. Pseudorhombus guttulatus Macleay. New Guinea.

Pseudorhombus guttulatus Macleay, Proc. Linn. Soc. N. S. W. 1881, 276.

1523. Pseudorhombus ocellatus Günther. Admiralty Is.

Pseudorhombus ocellatuв Günther, Challenger Fishes, 1580, 46. 
THE FISHES OF SAMOA.

PECILOPSETTA Günther.

1524. Poecilopsetta hawaiiensis Gilbert. Deep seas of Hawail.

\section{T无IOPSETTA Gilbert.}

1525. Tæniopsetta radula Gilbert. Deep seas of Hawaii.

\section{ANTICITHARUS Günther.}

1526. Anticitharus debilis Gilbert. Deep seas of Hawail.

SAMARISCUS Gilbert.

1527. Samariscus corallinus Gilbert. Hawaii.

CFASCANOPSETTA Gilbert.

1528. Chascanopsetta prorigera Gilbert. Deep seas of Hawaii.

NEMATOPS Günther.

1529. Nematops microstoma Günther. Admiralty Is.

Nematops microstoma Günther, Challenger Fishes, 1880, 57.

PELECANICHTHYS Gilbert \& Cramer.

1530. Pelecanichthys crumenalis Gilbert \& Cramer. Deep seas of Hawaii.

Family SOLEIDE.

SOLEICHTHYS Bleeker.

1531. Soleichthys heterorhinos (Bleeker). Fiji (Günther); Samoa (Kner); East Indies.

MICROBUGLOSSUS Günther.

1532. Microbuglossus nigrostriolatus (Kner \& Steindachner). Fiji. Solea nigrostriolata Kner \& Steindachner, Sitz. Ak. Wiss. Wien 1870, 427, Viti Levu (Fiji).

ASERAGGODES Bleeker.

1533. Aseraggodes melanostictus (Peters). Bougainville Is. Achirus melanostictus Peters, Berl, Mon, 1876, 815, Bougainville Is.

1534. Aseraggodes pellucidus (Bennett). Open Pacific. Achirus pellucidus Benmett, Whaling Voyage, 277, 1840, Pacific, open sea.

This larval sole has not been recognized since the original description. We do not know to what genus it belongs.

\section{PARDACHIRUS Günther.}

1535. Pardachirus pavoninus (Lacépède). Faté; New Hebrides (Seale); East Indies.

ZEBRIAS Jordan \& Snyder.

1536. Zebrias dicholepis (Peters). New Hanover; Bismarck Is.

synaplura dicholepis Peters, Berl. Mon. 1875, 844, New Hanover (Bismarck Is.).

\section{SYMPHURUS Rafinesque.}

1537. Symphurus undatus Gilbert. Deep seas of Hawaii.

1538. Symphurus strictus Gilbert. Deep seas of Hawaii.

\section{Family URANOSCOPIDE. URANOSCOPUS Cuvier.}

1539. Uranoscopus sulphureus Cuvier \& Valenciennes. Tonga.

Uranoscopus sulphureus Cuvier \& Valenciennes, Hist. Nat. Poiss., vin, 495, 1831, Tonga. Günther, Cat., Ir, my, Tongn. 
1540. Uranoscopus fuscomaculatus Kner. Kandavu in Fiji.

Uranoscopus fuscomaculatus Kner, Sitz. Ak, Wiss, Wien 1868, 319, Kandavu (Fiji).

1541. Uranoscopus papuensis Bleeker. Waigiu.

\section{Family CHAMPSODONTIDE.}

CHAMPSODON Günther.

1542. Champsodon vorax Günther, Admiralty Is.; Japan.

1543. Champsodon fimbriatus Gilbert. Hawaii.

\section{Family PERCOPHIDIDE. \\ MACRIAS Gill \& Townsend.}

1544. Macrias amissus Gill \& Townsend. Deep seas of the Southern Pacific. Macrias amissus Gill \& Townsend, Science, 1901, 937, Pacific, deep sea.

Known from the type only. Said to be the largest bathybial fish known.

\section{Family PTEROPSARIDE.}

\section{PARAPERCIS Bleeker.}

1545. Parapercis tetracanthus (Lacépède). Ta'oto. Samoa; Fiji; Guam; Palau Is.; East Indies.

Percis tetracanthus Bleeker, Nat. Tijds. Ned. Ind. 1853, 458. Günther, Cat., II, 241, Fiji, Amboina. Günther, Fische der Südsee, 158, taf. xcırı, fig. B, Pelew, Samoa, Fỉi.

Parapercis tetracanthus Garman, Bull. Mus. Comp. Zool., xxxix, no. 8, 233, Fiji.

Parapercis cephalopunctatus Seale, Bishop Museum 1901, 124, Guam.

Of this interesting species, half a dozen specimens were obtained in the reefs of Apia.

Life colors of one specimen: The dark markings bright olive brown, the belly white, the upper parts light olive; no red; a large pure white spot on caudal with black before it.

1546. Parapercis hexophthalma (Ehrenberg). Fiji (Günther); Louisiades; East Indies.

1547. Parapercis xanthozoma (Bleeker). Shortland I.; Solomon Group (Seale); East Indies.

1548. Parapercis alboguttata (Günther). Misol.

Percis alboguttatus Günther, Ann, Mag, Nat. Hist. 1872, 422, Misol.

0sURUS Jordan \& Evermann.

1549. Osurus schauinslandi (Steindachner). Samoa.

Parapercis pterostigma Jenkins, BuIl. U. S. Fish Comm., xIx, 1899 (1901), 402, fig. 15, Honolulu.

\section{NEOPERCIS Steindachner.}

1550. Neopercis roseoviridis Gilbert. Hawaii.

BEMBROPS Steindachner.

1551. Bembrops filifera Gilbert. Hawaii.

\section{CHRIONEMA Gilbert.}

1552. Chrionema chryseres Gilbert. Hawaii.

1553. Chrionema squamiceps Gilbert. Hawaii.

OSOPSARON Jordan \& Starks.

1554. Osopsaron incisum Gilbert. Hawaii. 
Family HARPAGIFERIDE.

DRACONETTA Jordan \& Fowler.

1555. Draconetta hawailensis Gilbert. Deep seas of Hawaii.

Family RHYACICHTHYIDE.

RHYACICHTHYS Boulenger.

Platyptera Cuvier \& Valenciennes, Hist. Nat. Poiss., XII, 321, I835 (aspro); name preoccupied. Rhyacichthys Boulenger, Ann. Mag. Nat. Hist. 1903 (aspro).

1556. Rhyacichthys aspro (Kuhl \& Van Hasselt). Swift rivers in the Solomon Is. (Günther, Fische der Sudsee, 191); East Indies.

\section{Family CALLIONYHIDE.}

\section{CALLIURICHTHYS Jordan \& Snyder.}

1557. Calliurichthys simplicornis (Cuvier \& Valenciennes). Guam.

1558. Calliurichthys decoratus Gilbert. Hawaii.

1559. Calliurichthys japonicus (Houttuyn). New Guinea (Günther); Japan.

\section{CALLIONYMUS Linnæus.}

1560. Callionymus cooki Günther. Rarotonga.

Callionymus cooki Günther, Proc. Zool: Soc. 1871, 605, Rarotonga. Günther, Fische der Südsee, 192, taf. 113, fig. B, Rarotonga.

1561. Callionymus calauxopomus Richardson. New Ireland (Peters, Berl. Mon. 1876, 841); Australia.

1562. Callionymus cæruleonotatus Gilbert. Hawaii.

1563. Callionymus rubrovinctus Gilbert. Hawaii.

1564. Callionymus corallinus Gilbert. Hawaii.

\section{SYNCHIROPUS Gill.}

1565. Synchiropus microps (Günther). Tonga.

1566. Synchiropus lineolatus (Cuvier \& Valenciennes). Bougainville I. (Peters, Berl. Mon. 1876,841 ); East Indies.

1567. Synchiropus lili Jordan \& Seale. Liti. Samoa. (Pl. LII, fig. 2.)

Head 3 in length; depth 5 ; eye 3.5 in head; dorsal $I V-8$; anal 7; lateral line complete, running near base of dorsal fins; interorbital equal to pupil; snout 4 in head.

Body elongate, widest at base of pectoral, compressed posteriorly; the anterior profile rounded to the mouth; lower jaw slightly the longer; angle of mouth under anterior margin of eye; mouth small, protractile, with minute teeth in jaws; caudal peduncle 3.75 in head; preopercular spine very strong with 2 strong curved claws, one of which is directed inward; origin of dorsal fin directly above posterior margin of opercle, its longest spine 2 in head; base of soft dorsal 1.1 in head; pectoral 1.3 in head, its tip under third ray of dorsal; base of the large ventrals entirely anterior to base of pectorals, the anterior margin of the base being anterior to preopercular spine; base of anal 1.1 in head, its origin an equal distance from tip of snout and base of caudal fin; caudal rounded, 1.1 in head.

Color in spirits lark brown with tint of green, white below; 3 rather wide irregular bands of white over the back, the first of these at posterior end of spinous dorsal and at origin of soft dorsal, this band separated above by a small brown band, but the whole area joining into one band on the lateral line; second white band at middle of soft dorsal, third over caudal peduncle, the 3 joined by irregular blotches of whitish; 3 round white spots below median line of body, and a few scattered small white dots over body; small blue dots over checks; 3 dark bands on underpart of head alternating with 
white bands; spinous dorsal brown, the base black, with 4 distinct black ocelli on upper half of fin, posterior to which are 4 vertical blue lines; soft dorsal with about 4 irregular oblique dusky bands; caudal with a broad black band near middle, and a half band on upper posterior part; anal dusky, with narrow white tip, a broad black intramarginal area and some narrow oblique blue lines; pectoral clear yellow; ventral blackish with white band near middle, and a white margin.

Life colors, black mottled with dark gray; pectoral yellow, edged broadly with golden.

Two specimens from Apia. Type no. 51762, U. S. National Museum, length 1.35 inches.

\section{Family BATRACHOIDIDE.}

\section{OPSANUS Rafinesque.}

1568. Opsanus dubius (White). New Guinea (Macleay); Australia.

\section{MARCGRAVIA Jordan.}

1569. Marcgravia grunniens Linnæus. New Guinea (Macleay); East Indies.

1570. Marcgravia diemensis (Richardson). New Guinea (Günther, Challenger Rept. 1880, 39); Austrulia.

Family BLENNIIDE.

ENNEAPTERYGIUS Rüppell. (Enneanectes Jordan; Gillias Evermann \& Marsh.)

This genus as understood by us includes most of the Pacific species referred to Tripterygion. It differs from Tripterygion as typified by the Mediterranean species, T. tripterygion, in the shorter jaws, the presence of a cirrus above the orbit, and in the larger scales. The lateral line is always incomplete. The species found in coral heads in Samoa are all minute, similar in size and habit to the species of Eviota, but those found on the coast of Japan are much larger.

\section{Enneapterygius minutus (Günther). Samoa.}

Tripterygium minutum Günther, Fische der Südsee, 211, taf. 118, fig. D, 1876, Apia.

Described from a specimen an inch long taken at Apia, from which place we have a similar example. Apparently the fin rays were wrongly counted by Günther, as ours has the dorsal rays III-XI, 10.

1572. Enneapterygius atriceps (Jenkins). Hawaii.

1573. Enneapterygius hemimelas (Kner \& Steindachner). Samoa.

Tripterygium hemimelas Kner \& Steindachner, Sitz. Ak. Wiss. Wien, LIY, 1866, 372, Samoa. Günther, Fische der Suidsee, 210, 1876, Samoa.

Life colors of a specimen from Apia, deep red mottled with dusky; posterior half of head blackish olive above and below; posterior half of trunk abruptly black, with 3 white rings; fins all cherry-red, the caudal abruptly pale red.

Another specimen from this locality had the middle third of body strongly rosy, also pectoral, ventral, and anal, and head in front of eyes; behind eyes and in front of pectoral greenish with yellow spots and rosy and black points; hinder third greenish yellow and brownish bands alternately; caudal clear with slight rosy tinge.

Five specimens from Apia and one from Pago Pago.

1574. Enneapterygius tusitalæ Jordan \& Seale, new species. Samoa.

Head 3.30 in length; depth 5.20; eye 3.10 in head; dorsal $I I-x I-9$; anal 17 ; scales 29,9 in the lateral line. Another-specimen had dorsal $\mathrm{r}(\mathrm{I}-\mathrm{xI}-8$; anal 16.

Body elongate, compressed, largest at shoulder-girdle; snout pointed, the angle of mouth under the anterior margin of eye; minute teeth in jaws; middle of first dorsal fin over the posterior tip of opercle; base of second dorsal equal to head, its longest spine 2 in head; base of third dorsal 2 in head; base of anal 2.4 in length of fish without caudal, the origin nearer tip of snout than base of caudal; pectorals long, 2.75 in fish without caudal, the tips under the posterior third of second dorsal; ventrals 2.1 in head, situated anterior to base of pectorals; caudal rounded, 1.14 in head.

Color greenish in life, the fins dark. In spirits, owing to the thick dots of brown all over the body, this fish has a dusky appearance, but the ground color is really dull yellowish white; many of 
the brown dots, especially on the cheek, belly, and thorax are modified into distinct ocelli, the center being a black dot with the surrounding ring of brown; the cheek and a line to tip of snout are deep black; no dark bands on the borly, but traces of about 5 indistinct whitish blotches; dorsal fins slightly shaded with 5 dark dots without lines; pectoral and caudal very dark, without bars or spots; anal also thickly dotted with fine black specks, but not so dark as caudal or pectoral; eye golden with one dark line through its length.

This species is very near T. pardochir and an examination of a series may prove them to be identical.

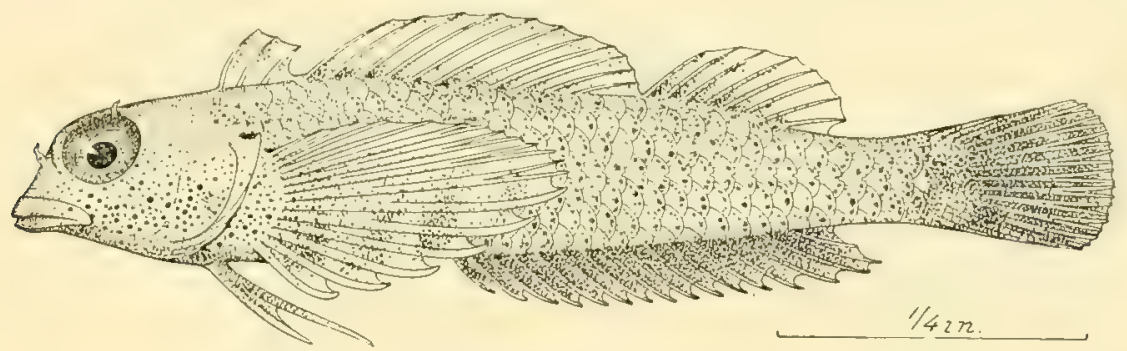

Fig. 97.-Ennenutcry/uius tusifalx Jordan \& Seale, new species. Type.

We have about 10 specimens from the reef at Apia. Type no. 51800, U. S. National MIuseum, from Pago Pago, length 0.85 inch. Named for the "tusitala" (story-teller) of Samoa, Robert Louis Stevenson.

1575. Enneapterygius pardochir Jordan \& Seale, new species. Samoa.

Head 3.5 in length; depth 4.14; eye 3.1 in head; snout 4.5 in head; interorbital narrow, one-half as wide as eye; dorsal $i i \mathrm{I}-\mathrm{XI}-9$; anal 18; scales 33 ; lateral line short, ending under posterior third of second dorsal.

Body elongate, compressed, scaled; depth of candal peduncle 3 in head; the lower anterior profile of head slightly produced; angle of mouth under anterior third of eye; snout rather pointed and beak-

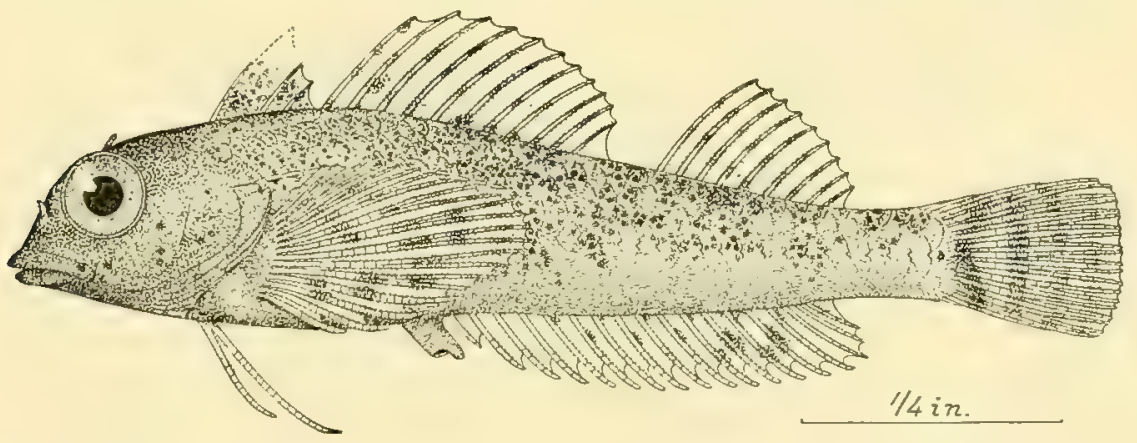

FIG. 98,-Enneapterygius pardochir Jordan \& Seale, rew species. Type.

like; minute teeth in jaws; a minute simple tentacle over eye and at nostril; middle of first dorsal over the posterior margin of opercles; base of second dorsal slightly greater than length of head, its longest spine 1.9 in head; 2 rows of scales between the second and third dorsal; base of third dorsal 1.4 in head, its longest ray 2 in head, its distal end some distance from the caudal; a very prominent anal papilla modified into an intromittent organ in wales; anal fin rather long, its base 2.5 in length of fish, its origin under the base of the sixth spine of second dorsal and its distal end on a line with end of soft dorsal, the origin of the fin nearer tip of snout than base of caudal; pectoral equal to length of head, its tip under the ninth spine of second dorsal; ventral 1.5 in head, its origin anterior to base of pectoral; caudal rounded, 1.5 in head.

Life colors of various specimens were as follows:

(1) From Apia. Cherry-red with darker bars, most distinct and paired along side; iris scarlet; fins all reddish, barred with brown; a black dot surrounded by pale at base of caudal. 
(2) From Pago Pago. Rose-pink, with bands of dark brown-red, and of white; pectoral, dorsal, and caudal barred with dark red-brown.

(3) From Pago Pago. With maxks showing through from inside; outside whitish with abundant black points; transverse blackish bar; pectoral barred.

(4) From Apia. Bright green, with bronze dots; sides with large white spots; 2 white dots at base of cauda]; pectoral banded white and reddish brown; iris golden; upper fins pale and dotted; lower darker, the anal dark brown barred with white.

(5) Less green than the preceding, with traces of a brown lateral band.

Color in spirits, from yellowish white to light brown with shading of darker brown spots, which in young specimens show a tendency to form vertical irregular bands along sides, this showing only at base of dorsal in type; the distinctive markings found on all specimens are 4 dark bands across the pectoral, and 4 similar bands on the caudal, the 2 near the base the most distinct; dorsal fins also with 3 or 4 oblique dark band-like rows of blotches on their spines and rays; a few larger black spots on cheeks and opercles.

Of this well-marked species we have 15 specimens from Pago Pago and Apia. Type no. 51799, U. S. National Museum, from Apia, length 1.06 inches.

1576. Enneapterygius tutuilæ Jordan \& Seale, new speries. Samoa.

Head 3 in length; depth 4; eye 3.1 in head; dorsal III-xII-9; anal 18; scales about 33; lateral line ending under middle of second dorsal.

Body elongate, compressed, scaled; depth of caudal peduncle equal to eye; lower profile of head projecting, the large eyes forming a convexity in the profile, otherwise the profile somewhat rounded

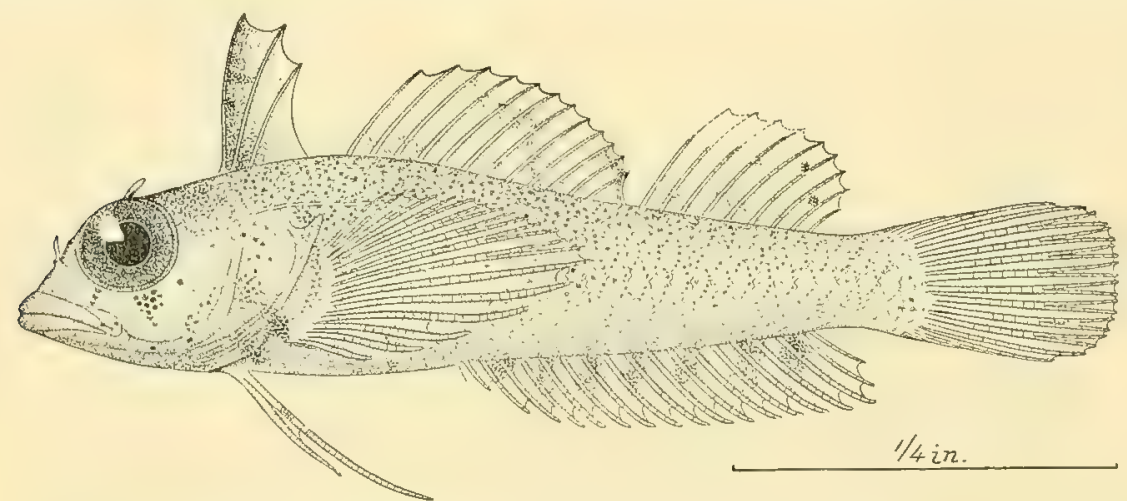

Frg. 99.-Enneapterygius tutuilæ Jordan \& Seale, new species. Type.

to the mouth, angle of mouth under middle of eye; snout rather pointed; minute teeth in jaws; a short simple tentacle over eye and at nostril; first dorsal fin rather high and distinct, its base in front of posterior margin of opercle; base of second dorsal about equal to head, its longest ray 2.5 in head; base of third dorsal 1.75 in head, its longest ray 2.25 in head; origin of anal under sixth spine of second dorsal, its base 2.5 in length of fish without caudal; its origin at equal distance between tip of snout and base of caudal; pectoral slightly greater than length of head; caudal rounded, 1.25 in head; ventral situated anterior of pectoral, its length 1.25 in head.

Life colors of one specimen, greenish pinkish, with about 9 dark cross-bars, which become blackish bars across base of anal; a green bar between 2 white ones at base of caudal; fins barred with reddish brown; first and second dorsal blackish; head dotted and mottled with reddish.

Another specimen was translucent yellow white with many fine points, some rose-red, some blackbrown, mixed all over body and fins; head darker; the fine spots weakly segregated into transverse bars, more distinct on belly.

Color in spirits, yellowish white, shaded with black spots tending slightly toward wide band-like arrangements on back; a heart-shaped dusky area on nuchal region; the most conspicuous marking is the 7 distinct vertical black bands of the anal fin; one dark band just in front of lower base of pectoral; a black spot in front of intromittent organ, 2 or more dark blotches below the eye; a dusky 
wash on anterior of first dorsal fin; second and third dorsals each with about 4 rather irregular oblique blotches of dusky; caudal without markings; pectoral with 4 dusky blotches, ventral with 2 dusky bars.

Four specimens from the reef at Pago Pago. The type is no. 51801, U. S. National Museum, length 0.75 inch.

\section{Enneapterygius cerasinus Jordan \& Seale, new species. Samoa.}

Head 3.5 in length; depth 4.5; eye 3 in head; dorsal IrI-XII-9; anal 15; scales about 36; lateral line extending to below posterior part of second dorsal.

Body elongate, compressed, scaled; depth of caudal peduncle 3.15 in head; head pointed, the mouth small; minute teeth in jaws; angle of mouth under anterior margin of pupil; a minute orbital and nasal tentacle; middle of first dorsal fin not so high as second dorsal, its base 1.2 in height; base of second doreal slightly longer than head, its longest ray 2 in head; a space of one and one-half rows of scales between second and third dorsal, base of third dorsal 1.45 in head, its longest ray 2 in head, its last ray two-thirds of eye; origin of anal under seventh spine of second dorsal, midway between tip of snout and tip of caudal, its base 2.3 in length of fish without caudal, its longest ray 2.5 in head; pectoral 1.14 in head; caudal slightly shorter; ventral 1.5 in head, the origin anterior to pectoral.

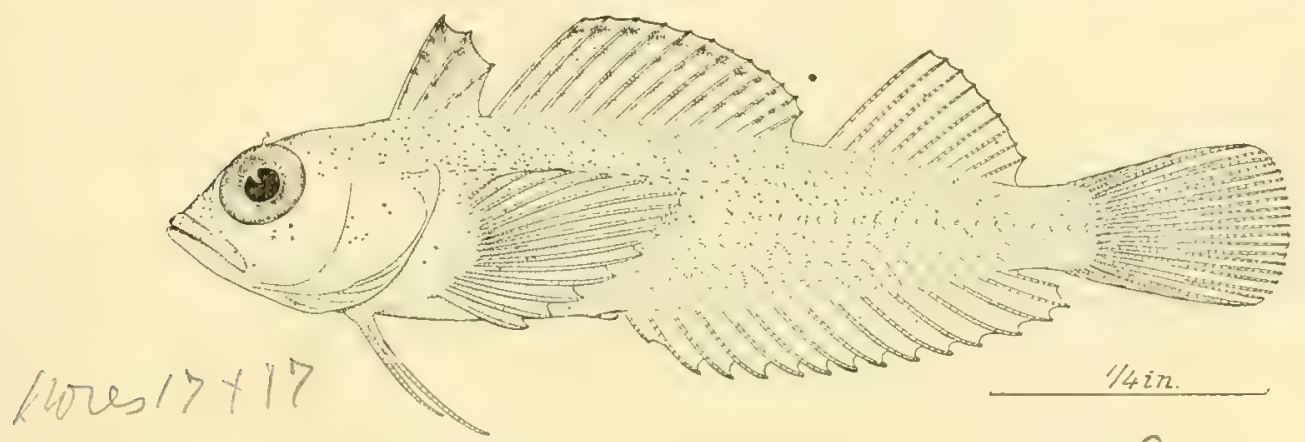

FIG. 100.-Enneapterygius cerasinus Jordan \& Seale, new species. Type. $Q$

Life colors, clear reddish brown marbled with olive; 2 blackish brown dots at base of caudal; pectoral mostly plain scarlet; caudal pale orange; other fins feebly barred with brownish.

Color in spirits, yellowish white with a few scattered dark spects on upper half of body and head; 4 distinct black dots below eye; a few minute dots on snout and maxillary; anterior dorsal with 4 indistinct oblique bands of dusky; the second dorsal with an indistinct dusky submarginal band with indications of 3 other longitudinal dusky bands, these being seen only under a good lens; all the other fins uncolored.

One specimen, type no. 51802, U. S. National Museum, from Apia, length 1 inch.

1578. Enneapterygius hudsoni Jordan \& Seale, new species. Samoa.

Head 3.2 in length; depth 4.5 ; eye 3 in head; dorsal III-XIV-10; anal 20; scales about 40; Iateral line extending to anterior third of last dorsal.

Body elongate, compressed, scaled, except head and a rather broad area on each side of first and second dorsal; apparently a well developed system of mucus canals about the head; depth of caudal peduncle equal to eye; anterior profile of head with the mouth slightly produced, forming an angle somew hat greater than $45^{\circ}$; mouth small, the angle being under the middle of eye; minute teeth in jaws; a small fringed tentacle at nostril; posterior margin of first dorsal over posterior margin of opercle, fin high, its base 1.95 in height; second dorsal extending to above the tenth anal ray; the base of last dorsal 1.5 in head, its longest ray 3 in head; origin of anal under base of seventh spine of second dorsal, its base 2.25 in length of fish without caudal, its origin nearer tip of snout than base of anal; pectoral slightly longer than head; ventral 1.75 in head; caudal rounded, about 1.5 in head.

Color in spirits, yellowish white with rather irregular brownish blotehes, which are more regular along the middle of sides, forming round dusky spots with slight oblique upward projections, these 
lark spots alternate with distinct white spots; top of head shaded darker, a rather distinct black band from eye down sides of snout to near the tip; a number of fine black dots on opercle; an indication of aboot 5 dusky bands, alternating with bands of white dots over the back; anal fin with dusky spot at base; a rather prominent dusky spot on lower part of opercle; another just below eye; 3 dusky blotehes on pectoral; a slight dusky wash on posterior margin of second dorsal; 2 indistinet oblique bands on last dorsal; first dorsal with scattered dark dots; caudal without markings.

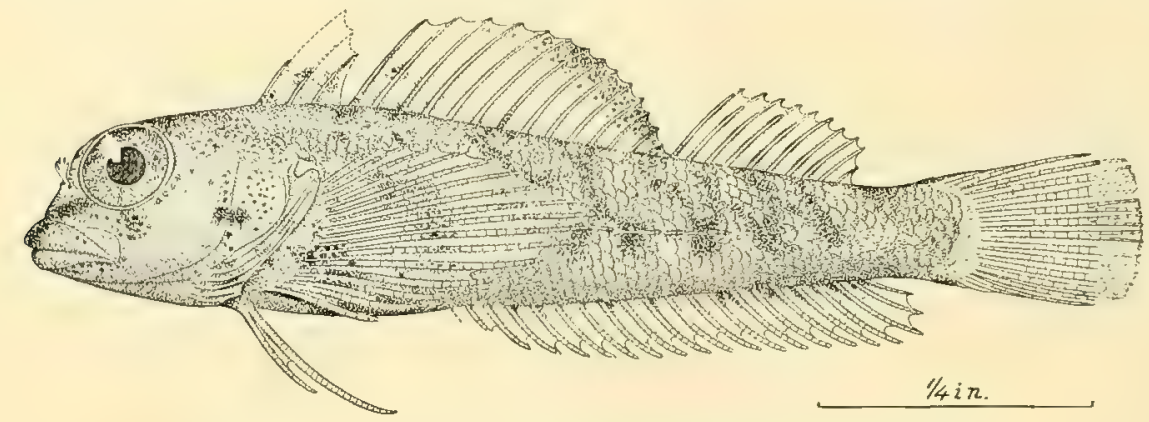

Frg. 101.-Enneapterygiz: hudsoni Jordan \& Seale, new species. Type.

One specimen from Apia, type no. 51798, U. S. National Museum, length 1 inch. Named for Mr. R. L. Hudson, the artist.

CRISTICEPS Cuvier \& Valenciennes.

\section{Cristiceps roseus Günther. New Guinea.}

\section{SADVAGEA Jordan \& Seale, new generic name.}

Sauragea Jordan \& Seale, new generic name in Blenniidæ (caledonica).

Lepidoblennius Sauvage, Rev. Zool. 1874, 337 (caledonicus); not of Steindachner, 1867.

This genus, with 2 dorsals, the first of 8 spines, and the body scaly, is an ally of Clinus. The name Lepidoblennius is preoccupied. We may therefore give the genus a new name in honor of its discoverer, Dr. H. E. Sauvage, of Boulogne-sur-mer.

1580. Sauvagea caledonica (Sauvage). New Caledonia.

Lepidoblennius caledonicus Sauvage, Rev. Zool. 1874, 338, New Caledonia.

\section{BLENNIUS Linnæus.}

1581. Blennius sordidus Bennett. Hawaii.

Blemius sordidus Bennett, Zool. Journ., IV, 1829, 34, Honolulu. Cuvier \& Valenciennes, Hist. Nat. Foiss., XI, 256, 1835, Honolulu. Günther, Fische der Südsee, 193, taf. 113, fig. D, Sandwich Is.

1582. Blennius canescens Garman. Fiji.

Blennius canescers Garman, Bull. Mus. Comp. Zool., vol. Xxxix, no. 8, 1903, Fiji.

1583. Blennius tonganus Jordan \& Seale, new name. Tonga.

Blennius cristatus, Günther, Fische der Südsee, 194, taf, 113, fig. E, Tonga; not of Linnæus.

This species from Tonga, characterized by the long row of nuchal filaments, is unknown to us. Dr. Günther identifies it with Blennius cristatus Linnæus, a species of the West Indies, originaliy described from Ascension Island. It is not at all likely that this Pacific species is identical with Blennius cristatus, and we therefore propose for it the new name $B$. tonganus.

\section{HYPLEUROCHILUS Gill.}

This genus differs from Blennius in having the gill-openings restricted to the sides, the membranes not forming a free fold across the isthmus as in Blenrius.

1584. Hypleurochilus vaillanti Jordan \& Seale, new species. Samoa.

Head 3.75 in length; depth 4; eye 2.75 in head; dorsal xI, 15; anal 17; lateral line consisting of about 6 separated pores. 
Body elongate, compressed; the anterior profile of head rounded, the month slightly produced beyond the forehead; angle of mouth under anterior margin of eye; mouth rather small with a single row of teeth in jaws and a pair of curved fang-like canines in under jaw; gill-openings rather narrow, 2.2 in head; dorsal fin not incised, extending to base of caudal, the nombrane of the fin united to rays of the caudal; origin of anal under first dorsal ray, nearer tip of snout than base of caudal, its distal end extending to caudal fin, where its membrane is slightly united to caudal; longest anal ray 1.75 in head; pectoral 1.2 in head; ventral 1.3 in head, the origin anterior to origin of pectoral; caudal rounded, 1.5 in head.

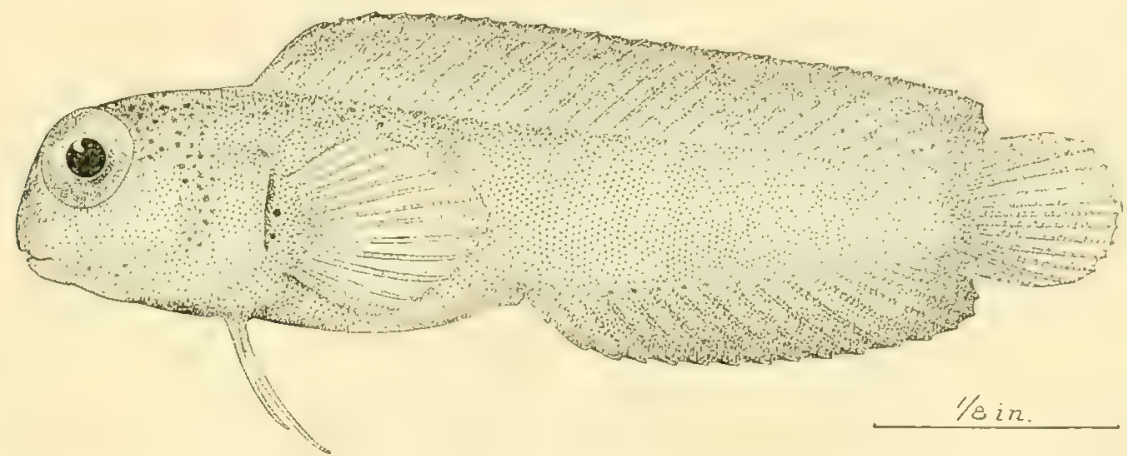

FIG. 102.-IIyplacrocheilus raillanti Jordan \& Seale, new species. Type.

Life colors, anterior part fuliginous; posterior third greenish with mottling of fine black points; top of head covered with small round black dots; 1 or 2 similar dots on base of pectoral; dorsal and anal plain brown, darker than body; caudal pale olive-green.

Color in spirits, yellowish white shaded everywhere with minute dusky dots like pin pricks, a few larger dots on top and sides of head; 2 distinct black dots on base of pectoral fins; fins colored like body, the dorsal and anal being a shade darker.

One specimen, length 0.56 inch, type no. 51788, U: S. National Museum, from Pago Pago, Samoa.

1585. Hypleurochilus periophthalmoides (Macleay). New Guinea.

Blennius periophthalmoides Macleay, Proc. Linn. Soc. N. S. W, 1883, 269. (Apparently a IIypleurochilus; teeth not described. )

\section{ALTICUS (Commerson) Lacépède. Mano'o.}

Alticus (Commerson MS.) Lacépède, Hist. Nat. Poiss., Ir, 458, 1800 (sallatorius=saliens).

Alticus Cuvier \& Valenciennes, Hist. Nat. P'oiss., x1, 337, 1836 (alticus).

Erpichthys Swainson, Class. Anim., II, 275, 1839 (allanticus).

Rupiscartes Swainson, Class. Anim., Ir, 275, 1839 (alticus).

Entomacrodus Gill, Proc. Ac. Nat. Sci. Phila. 1859, 168 (nigricans).

This genus differs from Salarias in the presence of posterior canines in one or both jaws. In both genera the teeth are loosely inserted, and the gill-membranes form a broad fold, free from the isthmus.

The case of Alticus, quoted by Lacepede from manuscripts of Commerson, is parallel to that of Zunclus (vs. Pomacanthus), and of Antennarius (vs. Histrio), and in all these cases we allow precedence to the earlier name.

1586. Alticus saliens (Forster). Tanna; Samoa; New Britain; Vavau; Nukahiva (Seale). (Fig. 111, p. 439.)

Plennins saliens Forster, Itin., II, 313, 1785, Tanna.

Blcmilus salicns, Lacépède (Alticus saltatorius Commerson), Uist. Nat. Poiss., Ir, 458, 1800, New Britain.

Blennius amphibius Walbaum, Artedi Pisc., III, 187, 1792, Tanna, aiter Forster.

Blcnnius lridactylus Bloch \& Schneider, Syst. Ichth., 1801, 176; after Btcnius gobioidcs Forster.

Salarias tridactylus, Günther, Fische der Südsee, 200, taf 117, figș. C, D, Vavau.

salarias alticus Cuvicr \& Valenciennes, IIist. Nat. Poiss., $\mathrm{xI}, 337,1536$.

Blennius gobioides Forster, Descript. Anim., 283, 184, Tanna. 
This wiry little blenny covers the lava rocks on the "iron-bound coast" of the Samoan Islands; leaping on the bare rocks in the sun like a lizard and leaping into the sea with the greatest velocity when disturbed. It is not found in the coral. At Apia it swarms in the wreck of the German warship Adler, but it could not be taken there by any means at our disposal.

We have 7 specimens from Pago Pago. Life colors of one of these, violet-black, with a few pale bluish spots along middle of side; dorsal pale-edged; body with about 9 pale, poorly defined, transverse double bars, which form a series of pale spots along middle of side; throat and belly pale, becoming yellowish posteriorly; anal pale in some specimens, the rays faintly spotted with black specks; in others this fin is colored like the dorsal, and nearly or quite as dark; caudal and pectoral black.

1587. Alticus periophthalmus (Cuvier \& Valenciennes). Ticopia; Samoa; Santa Cruz; Rarotonga; Futuna; Tahiti; Mangareva; Nukahiva and Makatea (Seale); India.

Salarias periophthalmus Cuvier \& Valenciennes, Hist. Nat. Pois\$, xI, 311, pl, 328, 1836, Ticopia. Guinther, Fische der Südsee, 207, taf. 114, figs. D, E, Santa Cruz, Samoa, Rarotonga, Futuna, Society Is., Savaii. Day, Fishes of India, 333 , pl. 69 , fig. 5 , Andamans Is.

Salarias andamanensis Day, Proc. Zool. Soc. 1869, 611, Andamans Is.

Life colors of a specimen from Apia, body mottled gray-olive and purplish, the latter in paired bars, or inverted $Y$-shaped, about 8 in number; side with a few oblong spots of bright violet, arranged in 2 rows, about 5 in each row; an orange blotch behind eye, with a greenish violet bar behind it; a greenish violet dash below eye; cirri orange; dorsal much mottled brown, grayish and orange, the edge pale, with orange spots; caudal pale above, purplish black below, ending in blackish orange, the lower lobe darkest; anal mainly black, orange at base; pectoral pale, never sprinkled with black dots as in Alticus evermanni.

Another specimen was light olive; 9 quadrate spots or bars of dark brown along side, these alternating above with another series of irregular blotches; crest high, edged with dull red; second dorsal and upper part of candal edged with creamy red, rather bright; cirri pink.

Other specimens have the margin of the spinous dorsal with dark spots; still others have the spinous dorsal plain and in some both dorsals are crossed by the dark bars on the body. In some specimens the characteristic blue spots on the sides are obsolete.

This species is abundant in the coral reefs at Samoa; we have 50 specimens from Apia and 4 from Pago Pago.

1588. Alticus evermanni Jordan \& Seale, new species. Samoa.

Sararias nitidus Gủnther, Fische der Südsee, 200, taf. 113, fig. G, Samoa; not Salarias nitidus Günther, Cat., III, 243, from China. Seale, Bishop Museum 1901, 127, Guam.

Head 4.75 in length; depth 6; eye 4 in head; dorsal $\mathrm{XII}, 21$; anal 25; lateral line short, ending under tenth dorsal spine; interorbital equal to one-half of eye; angle of mouth under posterior margin of eye, slightly posterior.

Body elongate, compressed, anterior profile slightly subvertical, the forehead projected beyond the jaws; a divided orbital tentacle whose length equals two-thirds diameter of eye; a short fourfringed tentacle at nostril; a row of small movable teeth in jaws, with the posterior canines present; dorsal fin notched to one-half its depth, the origin of the fin slightly in advance of posterior margin of opercle, and its posterior membrane not extending on the anal, its longest spine 1.75 in head, its longest ray 1.5 in head; origin of anal nearer head than base of caudal, the base of fin 2 in length of fish without caudal; pectoral 1.18 in head; ventral 2 in head; caudal square, its length equal to head; a slight ridge on top of head.

Color in life, ground-color a pale olive-brown, with 9 broad transverse bars of darker brown, fading out below, but above extending well up on the dorsal fin; a round black spot in the fourth transverse bar, a little above middle of body; body thickly sprinkled with small oblong or linear pearly or bluishwhite spots, most conspicuous posteriorly, where they form irregular longitudinal rows on the lower part of the body; upper part of head with round white spots, which extend backward above lateral line to posterior end of spinous dorsal; in some specimens numerous small black dots below this on anterior part of body; underside of head pale, with irregular violet streaks; dorsal spines tipped with black; spinous dorsal with irregular horizontal streaks of violet, in some specimens fading to yellowish white; 3 narrow dark longitudinal streaks near the broad pale margin of soft dorsal; caudal and anal plain dusky; pectoral yellowish, with 5 transverse rows of conspicuous dark dots. 
In spirits our large series shows a great intergradation of color among the individuals of this species, but the following marks are constant in all: 5 lines of black spots on the pectoral; 2 dusky bands over the head, one directly behind the eye down to angle of mouth, the other over nuchal region on posterior border of preoperele; caudal washed with dusky; anal with a dusky wash on entire fin; body grayish, slightly tinted with blue to purplish, some specimens banded with darker gray, others having scarcely a trace of bands; the type with 9 very distinct vertical dark bands, wider than the interspaces, along the side of body; a number of round yellowish white spots over head and shoulders; some pearl-blue spots on posterior part of body; a round spot on middle of body under anterior of soft dorsal-some of the specimens not showing this spot at all, and others showing it only on one side; dorsal (in type) with the brown bands of body extending up into the fin, a number of rather indistinct narrow longitudinal lines on upper half of fin, the spinous dorsal tipped with black; some 'specimens with a row of dark spots along middle of dorsal, others with no black dots, but a large number of fine narrow lines on outer half of fin, and between these in many forms our series show an almost perfect gradation; belly usually with a more or less decided purplish wash. The younger individuals show less of color markings, some being almost uniform gray on body.

Twenty-one specimens from Apia. The type is no. 51789, U. S. National Museum, length 3.5 inches. These specimens agree fairly with Salurias nitidus of Günther's Fische der Südsee, from Samoa. The type of Salarias nitidus from the China Sea is apparently a different species. The species resembles Alticus periophthalmus, but may be known at once by the spotted pectoral.

Named for Dr. Barton Warren Evermann.

1589. Alticus caudolineatus (Günther). Tahiti; Samoa; Makatea and Nukahiva (Seale).

Sularias caudolineatus Günther, Fische der Südsee, 209, taf, 116, fig. F, 1876, Otaheite.

We have 3 specimens of this very handsome blenny from the reef at Apia, where it is the commonest species in the coral pools, and 7 specimens from Pago Pago.

Life colors of a specimen fiom Apia, gray; lengthwise dark olive streaks like pencil-marks on side; no bright colors except on the crest, which is edged with orange-red; an orange dash on eye above; 9 transverse double brown bars on side, running from base of dorsal to the lowest lengthwise streak; caudal with from 7 to 9 transverse rows of dark dots; dorsal pale; 3 rows of small dark dots running longitudinally across both dorsals; traces of 2 more rows on the soft dorsal in some specimens; anal pale, with a row of faint brown dots posteriorly, near the base of the rays; pectoral pale, unspotted.

1590. Alticus aneitensis (Günther). Aneiteum.

Salarias aneitensis Günther, Fische der Suidsee, 205, taf. 118, fig. A, 1876, Aneiteum.

1591. Alticus gibbifrons (Quoy \& Gaimard). Hawaii; Marcus I.

Salarias gibbifrons Quoy \& Gaimard, Voy. Uranie, 253, 1824, Maui. Snyder, Bull. U. S. Fish Comm., xxIr, 1902 (1904), 536, Honolulu, Hilo; not of Cuvier \& Valenciennes.

Entomacrodus gibbifrons, Bryan \& Herre, Bishop Museum, II, 1903, 138, Marcus I.

Salarias saltans Jenkins, Bull. U. S. Fish Comm., Xxir, 1902 (1904), 508, fig. 48 (male), Honolulu. Salarias rutilus Jenkins, op, cit., 509, fig. 49 (female), Honolulu.

1592. Alticus striatus (Quoy \& Gaimard). Mano'o a'au. Samoa; Nukahiva (Seale).

Salarias striatus (Quoy \& Gaimard) Cuvier \& Valenciennes, Hist. Nat. Poiss., XI, 309, 1835, Yle de France. Salarias marmoratus, Gunther, Fische der Südsee, 201, taf. 116, fig. B; not type.

Two specimens from Aua in Tutuila, the species occurring in the sea along the "iron-bound coast", not in the coral reefs.

Color in life, white ground-color with dark spots on side with purplish blue tinge; spots on caudal smoky; belly white; head with a weak bluish streak behind eye; lower side of head with 3 white stripes radiating from the throat on each side; dorsals irregularly and obliquely streaked with dark; caudal with about 6 irregularly transverse rows of dark spots; anal pale, its edge dusky; pectoral plain, uncolored.

Dr. Günther has evidently confused this species with Alticus marmoratus, which was described by Bennett from the Sandwich islands, and has since been collected there by Dr. Jenkins, by Jordan \& Evermann, and by Professor Snyder at Laysan Island. Fishes from other localites described under the name of S. marmoratus belong to still other species. This is apparently the species called Salarias striatus by (quoy \& Gaimard. but it is probably different from Sularias urenatus Bleeker. It is called "the outside skippy", mano'o $a^{\prime} a u$ in the Samoan vernacular. 
1593. Alticus marmoratus (Bennett). Hawaii; Laysan.

Salarias marmoratus Bennett, Zool. Journ., IV, 35, Hawaii; not of Günther. Snyđer, Bull, U. S. Fish Comm., XxII 1902 (1904), 536, Laysan.

1594. Alticus griseus (De Vis).

Salarias griseus De Vis, Proc. Linn. Soc. N. S. W. 1884, 450 , South Seas.

This scantily described species is unknown to us. The presence of tentacles at the nape indicates a regemblance to Alticus marmoratus.

1595. Alticus coronatus (Günther). Solomon Is.; Samoa; Nukahiva (Seale).

Salarias coronalus Günther in Brenchley, Cruise of the Curaçoa, 424, pl. 33, fig. B, Solomon Is. Günther, Fische der südsee, 206, taf. 116, fig. $\mathbf{E}$, Solomon Is.

Of this rare fish we have 14 examples from the coral reefs at Apia. Color in life, light green with about 8 paired cross-bands of reddish brown; stripes across chin and throat dusky; sides and top of head with small round whitish spots, which extend backward along base of spinous dorsal. Alticus erermanni has the same kind of dots on its head, but they are differently arranged.

In alcohol the paired cross-bands fade, leaving 2 longitudinal rows of small brown dots, prominent only posteriorly; dorsals pale, colorless; dorsal spines tipped with black; anal pale, dusky-edged; caudal pale, unspotted; pectoral with from 3 to 5 irregnlar transverse rows of dark brown spots.

1596. Alticus variolosus (Cuvier \& Valenciennes). Guam; Samoa; Tonga; Hawaii.

Salarias variolosus Cuvier \& Valenciennes, Hist. Nat. Poiss, XI, 317, pl. 330, 1836, Guam. Gủnther, Fische der Südsee, 203, taf. 116, fig. $\Lambda$, Samoa, Tonga, Society Is. Fowler, Proc. Ac. Nat. Sci. Phila. 1900, 518, Sandwich Is. Jenkins, Bull. U.S. Fish Comm., X.x.r, 1902 (1904), 507, Honolulu.

Salarias nigripes Seale, Occ. Papers Bishop Museum, vol, I, no. 3, 1901, 127, Guam.

Eight examples of this widespread Polynesian blenny were obtained at Apia, from the lava rocks.

Color in life, jet-black with brownish shade; pectoral edged below with cherry-red, spinous dorsal with brownish; the upper anterior portion abruptly pale, its boundary extending from the tip of near the last spines forward to the base of the first; no distinct spots; caudal above and below with pale dull olive; upper portion of caudal always more or less pale, the pale color not sharply defined; fins otherwise nearly black; body unmarked; 7 narrow dark blue cross-bars on boly and a dark blue line from nape to opercle.

1597. Alticus alboguttatus (Kner). Samoa; Fiji.

Salarias alboguttalus Kner, Sitz. Ak. Wiss. Wien, Lvi, 1867, 16, pl. 4, fig. 4, Samoa. Günther, Fisehe der Südsee, 205 taf. 118, fig. B, Kandavu.

Of this pretty little blenny but 3 specimeng have previously been collected, 1 at Samoa and 2 at Kandavu, one of the Fiji Islands. We have 18 specimens from Apia and 3 from Pago Pago.

Color in life of a specimen from Pago Pago, a faint red blotch behind eye; eye with 7 red spots in iris; body pale olivaceous green, with white spots; a large blue spot on each side of the throat.

Another specimen from Apia in life was olivacoous brown, with pale oblong horizontal spots on sides; head speckled with small round white spots; a large steel-blue spot on each side of the throat; faint orange spots on base of dorsal; soft dorsal and caudal pale; faint olive bars on middle of caudal; tip of caudal cherry-red; anal dusky; pectoral pale, its base spotted like head.

1598. Alticus guttatus (Cuvier \& Valenciennes). Vanicolo; Samoa.

Salarias gutlatus Cuvier \& Valenciennes, Hist. Nat. Poiss., XI, 308, Vanicolo. Gunther, Cat, In, 250 (copied). Gïnther, Fisc be der Südsee, 204.

This rare little fish was described from 2 small specimens from Vanicolo, and seems not to have been collected since. We have 2 specimens, 25 millimeters in length, from Apia. They differ from the types in having a small crest, colored like the body.

Color in alcohol, ground-color of body uniform pale brown, with about 4 rows of larls-brown spots, made up of numerous fine specks, the spots in the two lower rows much larger than those in the upper rows; 2 rows of oblong, pearly white spots, commingled with the two lower rows of brown spots; above these are numerous small pearly spots; head covered with many small pearly and brown specks, commingled; a dark streak behind eye; behind this a dark band extending from nape diagonally downward and forward to throat; under side of head pale, with white specks; a small black spot on each side of throat; chin and upper lip with black streaks; belly pale; margin of dorsal dark; 
a narrow dark longitudinal band near base of soft dorsal; anal clear, its edge dusky; caudal clear; basal portion of pectoral covered with pearly white spots, otherwise clear. Another specimen agrees exactly with the above, but lacks the pearly spots.

1599. Alticus thalassinus Jordan \& Seale, new species. Samoa.

Head 4.5 in length; depth 5 ; eye 4 in head; dorsal xm, 14; anal 18; interorbital one-half as wide as eye; a short curved lateral line ending under tenth dorsal spine.

Body elongate, compressed, the head blunt, the anterior profile almost vertical; an outer row of fine movable teeth in the jaws; posterior canines present; a short, fringed orbital tentacle, its length less than width of eye; a minute fringed tentacle at nostril; dorsal notched to about one-half its depth; origin of dorsal directly above posterior margin of opercle, its posterior membrane not united with caudal, its longest ray 1.75 in head; origin of anal midway between snout and base of caudal, its longest rays 2.2 in head; total length of pectoral about equal to head, ventral small, slightly anterior to pectoral, 2.25 in head; caudal rounded 1.14 in head.

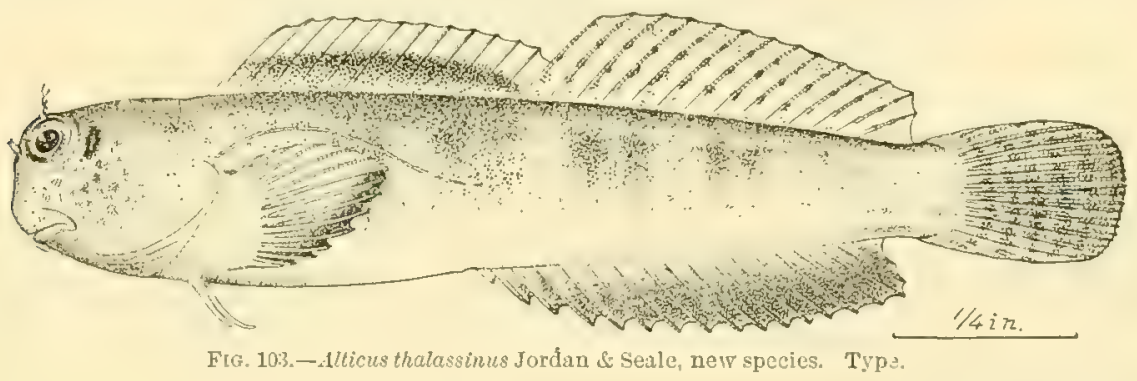

Life colors, green, with dark brown bands and many spots arranged in cross-series; chin and spot behind eye blackish; a broad dark band on basal half of spinous dorsal; margin clear; soft dorsal with 3 longitudinal rows of large dark spots, its margin dusky; caudal irregularly streaked with transverse bars of brownish hlack; anal blackish brown, the tips of the rays white; lower part of pectoral dusky; upper portion clear.

Color in spirits, whitish, with slight wash of pale green, head rather thickly covered with round spots made up of minute brown dots like pin-pricks, a deep black spot the size of pupil just posterior to eye; upper half of body with scattered brown dots assuming indistinct band-like arrangements on sides; chin with a dark blotch; caudal with 6 brown eross-bands; spinous dorsal with dark shading through its center; soft dorsal with about 3 rows of brown dots and a dark margin to fin; anal dusky shaded, with lighter margin; pectoral and ventral slighty shaded with dusky; iris golden.

Three specimens from Apia. The type is no. 51795, U. S. National Museum, length 1.5 inches.

1600. Alticus musilæ Jordan \& Seale, new species. Samoa. of eye.

Head 4.1 in length; depth 4.1 ; eye 2.1 in head; doreal $x 1,14$; anal 17 ; interorbital one-half width

Body elongate, compressed; profile of head vertical; a short lateral line, ending brokenly under the posterior margin of spinous dorsal; an outer row of moveable teeth in each jaw; posterior canines present; origin of dorsal on line with posterior margin of opercle, the fin not extending posteriorly upon base of caulal, its longest spine $2.2 \mathrm{in} \mathrm{head,} \mathrm{the} \mathrm{fin} \mathrm{notched} \mathrm{to} \mathrm{its} \mathrm{base;} \mathrm{a} \mathrm{short} \mathrm{fringed} \mathrm{orbital}$ tentacle, and a very short fringed nasal tentacle; pectoral fin equal to head; ventral small, situated anterior to pectoral, its length equal to postocular part of head; base of anal about 3 in length of fish, its longest ray 2.25 in head; caudal rounded, its length equal to head.

Life colors, light cherry-red, 8 pairs of bars of crimson brown, a red brown spot behind eye; fins pale reddish, dotted, the caudal whitish; cirri red; front and top of head thinly spotted with small reddish brown specks; chin and sides of head thickly spotted; a few brown spots scattered about orer body; from 1 to 3 larger, round blue-black dots on body under pectoral.

Color in spirits, whitish with slight wash of pale green; head and shoulders with a few small scattered brown dots; a small black spot behind eye, less than size of pupil; body with 2 or 3 longi- 
tudinal rows of brown dots; fins without color or markings except a few small irregular dark spots on dorsal and caudal.

Four specimens from Apia. The type is no. 51790 , U. S. National Museum, length $1 \frac{3}{3}$ inches.

The species is named for Musila, of Apia, a young Samoan of fine parts whom we found efficient as a fisherman.

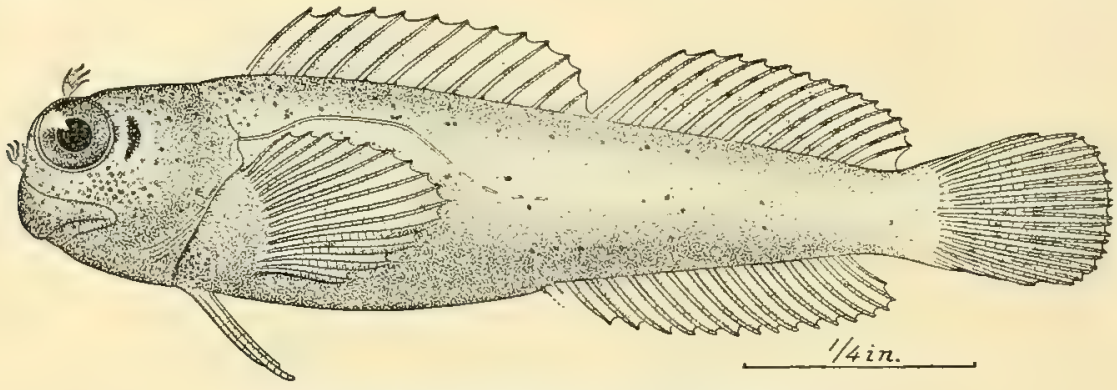

FIG. 104.Alticus musilæ Jordan \& Seale, new species. Type.

1601. Alticus sebs (Cuvier \& Valenciennes). Fiji; Tahiti; Samoa (Günther).

Salarias sebæ Cuvier \& Valenciennes, Hist. Nat. Poiss, XI, 323, 1835, East Indies. Kner, Sitz, Ak. Wiss. Wien 1868, 41, Fiji. Günther, Fische der Südsee, 202, Samoa, Fiji, Trhiti.

This species, known by the lengthening of the first 1 to 3 dorsal spines, was not taken by us.

1602. Alticus sealei (Bryan \& Herre). Marcus $I$.

Entomacrodus sealei Bryan \& Herre, Occ. Papers Bishop Museum, II, 1903, 138, Marcus I.

SALARIAS Cuvier. Mano'o.

Scamtes Jordan \& Evermann, Check-List Fishes, 471, 1896 (rubropunctatus), name preoceupied by Scartes Swainson, 1829 , a genus of mammals.

Scartichthys Jordan \& Evermann, Fishes North and Mid. Amer., mr, 2395, 1900 (mubropunctatus). Not Salaria Forskâl = Blennius.

1603. Salarias zebra Vaillant \& Sauvage. Hawaii.

(Salarias cypho Jenkins, Honolulu.)

This species is very abundant in the rock-pools of the lava about Hawaii, being the commonest of all the blennies in that region. It has not been found elsewhere.

1604. Salarias sertatus Garman. Fiji.

Salarias sertatus Garman, Bull. Mius. Comp. Zool., xxxix, 1903, 237, Fiji.

This species, which we have not seen, resembles Alticus saliens in form and in habits, but is uniformly colored.

1605. Salarias lineatus Bleeker. Samoa; Faté (Seale); East Indies.

Salarias lineatus Bleeker, Verhand. Batav. Genootsch., XxIr, Blenniidæ-and Gobiidæ, 18. Günther, Cat., III, 254, Java. Dry, Fishes of India, 332, pl. Lxx, fig. 8 (male), Red Sea, Andaman Is., Malay Archipelago.

We have 5 specimens from Pago Pago and one from Apia. Life colors of one from Pago Pago, dark olive; side with about 6 to 8 dark lengthwise stripes, the 3 or 4 lowermost more continuous and regular, the upper very wavy, these interosculating with each other so that the back and region behind head show dark network; 6 paired blackish cross-shades on back and sides; fins dull olive; dorsals separate, the first with oblique dashes at base and a dusky edge, second with oblique streaks like those on body, the edge pale; caudal dusky; anal pale, the edge dark; pectoral and ventral rather pale; head with vertical marblings; 2 converging lines on base of caudal. Dorsal XII-24. Differing from current descriptions in having no crest; tentacles small. The other specimens have a high crest.

Another specimen from Pago Pago was blackish olive, with a bright yellow or tawny shade in life; 5 or 6 diffuse cross-shades on back; side with 4 or 5 series of short oblong horizontal dashes of 
paler olive, forming interrupted lines, the lowest nearly continuous; some dark cross-shades on lower part of head; fins dark olive; dorsal and caudal pale edged; tentacle and crest dull olive. Dorsal notched, the epines higher than the soft rays.

1606. Salarias fasciatus (Bloch). Samoa; Tonga; Vanicolo; Ponape; East Indies.

Blennius fasciatus Bloch, Ir, 112, taf. 162, fig. 1, 1870, Japan.

Salaricu quadripinnis Rüppell, Atlas Fische, 112, taf. 28, fig, 2, 1828, Red Sea, Cuvier \& Valenciennes, Hist. Nat, Poiss, XI, 318, 1836, Timor, Tongatabu, Vanicolo.

Salarias fasciatus Cuvier \& Valenciennes, op. cit., 32t, 1836. Güther, Fische der Südsee, 201, taf, 115, Ag. G, Ponape. Salarias semilinealus Kner, Sitz. Ak. Wiss. Wien, LVI, 1867, fig. 3, Samoa.

Life colors of a specimen from Apia, brown, with oblong bluish spots; numerous small dark dots and dashes on sides, back of head and above pectoral, soon fusing and becoming lines which extend backward to below middle of soft dorsal; dorsal brown with greenish white spots and brown dots, its edge creamy red; caudal olive, speckled with brown and whitish, its upper eige washed with cherryred; anal like dorsal, dusky-edged; pectoral and ventral barred; belly livid; eight dark shades at base of dorsal.

We have abuut 80 specimens of this species from the coral reef at Apia, where it is very common; we have also 6 specimens from Pago I'ago.

1607. Salarias biseriatus (Cuvier \& Valenciennes). Mano'o a'au. Tahiti; Samoa.

Salarias biseriatus Cuvier \& Valenciennes, Hist. Nat. Poiss, XI, 316, 1828, Tahiti. Kner, Novara Reise, Fische, 197, taf, 8, fig. 4, 1865, Tahiti. Günther, Fische der Südsee, 208, Tabiti.

Life colors of a specimen from Pago Pago, blackish olive, violaceous below; sides with 4 rows of violet-white round spots, the third series most distinct and regular, the spots of the fourth row larger and more diffuse; fins all dark, nearly plain.

Another example was blackish olive with 8 to 11 white partial bands across belly and base of anal, often not distinct before vent; head with small bluish white spots; a row of these spots more distinct along upper line of ventral bars, others on sides forming a second irregular row, usually gathered in pairs, one above the other, about 6 pairs of dark blotches along base of dorsal; fins dark, mottled with darker; a black spot on front of first dorsal; soit dorsal with oblique pale streaks; caudal dusky olive; ventral black; pectoral olive, with fine white dots. Dorsal divided, xir, 18.

A young individual from Pago Pago was violet-black or brown, with some 7 or 8 pale cross-streaks, violet-tinged, narrower than the interspaces; 4 or 5 sharply defined white spots along side; head with violaceous and greenish mottlings; caudal light yellow; dorsals dusky, mottled; anal pale; ventral and anal dusky-translucent. Dorsal divided; no crest.

Two specimens from near Aua, on the north shore of Tutuila, together with 152 other examples from the same place, taken with dynamite among the lava rocks on the "iron-bound coast." One specimen from Apia.

1608. Salarias sindonis Jordan \& Seale, new species. Samoa.

Head 4.2. in length; depth 5.75; eye 3 in head; interorbital space scarcely equal to eye; dorsal xIr, 19; anal 21; lateral line short, ending under posterior part of spinous dorsal.

Body elongate, compressed, the anterior profile of head rounded, the forehead not projecting; angle of jaws under middle of eye; a short, simple orbital tentacle and a minute, fringed nasal tentacle; teeth in jaws in a single series, no posterior canines; dorsal fin incised to one-half its depth, its origin over posterior margin of opercle, and its distal end terminating some distance anterior to caudal base, the greatest vertical height of the fin about 3.5 in head; origin of anal nearer tip of snout than base of caudal, considerably in advance of soft dorsal, the fin long, its base equal to distance from tip of snout to origin of the fin, its longest ray 2.5 in head; pectoral equal to length of head; caudal rounded, 1.25 in length of head.

Life colors, translucent gray, the head black, the body with about 6 pairs of dark cross-bands; conspicuous dark spots along base of dorsal; fins all pale, the concave caudal whitish; top of head with many round, dark-brown dots; on nape these form a crescent, the horns of which reach posterior margins of eyes; within this crescent the dots form a large spot; body and fins everywhere thickly sprinkled with minute black specks.

Another specimen was dark blackish green, with darker cross-bands and no other colors; top of head and nape covered with many comparatively large, round, brown'dots; boty and fins everywhere covered with minute black dots. 
Color in spirits, ground-color yellowish white, thickly punctulate with minute dark dots, these taking the form of numerous (18-20) rather irregular vertical bands on sides of body, some of the bands more or less connected at top; in older examples the bands seem to group themselves in pairs and become fewer in number; a characteristic oblique black band on the head from nuchal region through eye to middle of each maxillary; the dark markings of body extending a little way into dorsal, the fin also shaded slightly with minute dark dots; anal white, with slight tint of dusky; pectoral, ventral, and caudal whitish, without distinct markings.

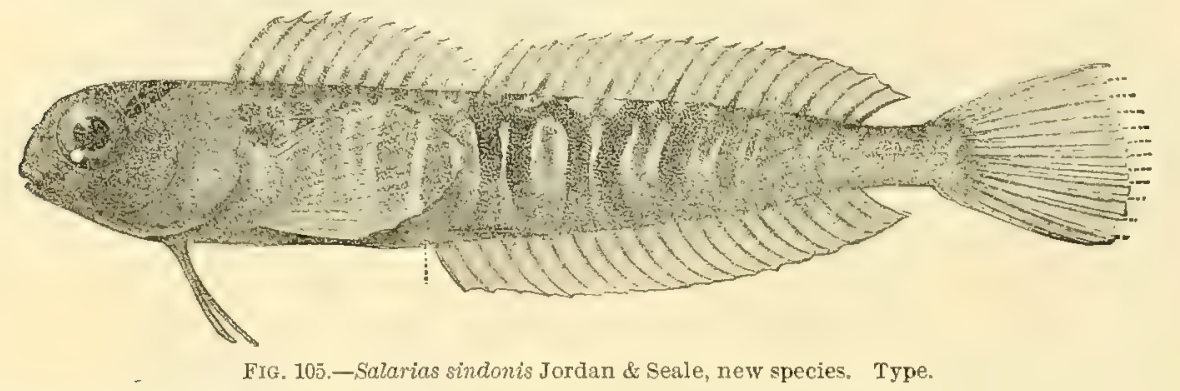

Numerous specimens (50) collected at Pago Pago, by Mr. Michitaro Sindo, for whom the species is named. The type is no. 51792, U. S. National Museum, length 0.99 inch.

1609. Salarias atkinsoni Jordan \& Seale, new species. Samoa.

Head 3.75 in length; depth 3.75 ; eye 2.75 in head; interorbital equal to one-half of eye; dorsal xrrr, 17; anal 21; a short lateral line ending under eighth dorsal spine.

Body elongate, compressed, rather short; anterior profile of head vertical; the angle of mouth under posterior third of eye; depth of caudal peduncle 2.75 in head; a simple, short orbital tentacle, a small fringed one at nostril; teeth in a single row in each jaw, no posterior canines; dorsal fin incised almost to base, the incision being broadly rounded; origin of dorsal about 1 spine in front of posterior margin of opercle, its distal end reaching to lyase of caudal, not attached to caudal by

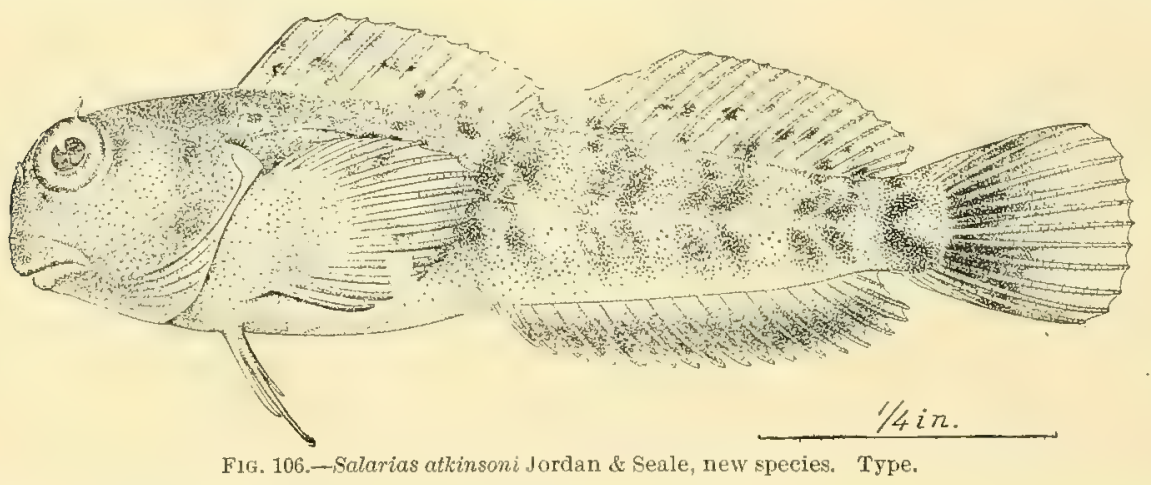

membrane; longest spine of dorsal 2.3 in head, longest ray 1.85 in head; origin of anal slightly anterior to dorsal incision, its base 2.5 in fish without caudal, its origin an equal distance from tip of snout and base of caudal, its longest ray 2.5 in head; pectoral scarcely equal to length of head, its tip under tenth dorsal spine; ventral about 1.75 in head; caudal rounded, 1.25 in head.

Color in spirits, dull whitish with slight tint of pale green; 6 very distinct pairs of dark bands on sides, which are divided in the middle by a narrow space, the portion of line above being sloped obliquely forward, those below obliquely back; no marking on chin or throat; dorsal fin with distinct brown spots scattered through it; anal with a narrow margin of white and a broad intramarginal band of black, fading into whitish at base of fin; caudal with dusky blotch at base; other fins uncolored.

One specimen from Pago Pago, type no. 51791, U. S. National Museum, length 0.98 inch. Named for the artist, Mr. William Sackston Atkinson. 
1610. Salarias rivulatus Rüppell. Samoa; Paumotu Is.; Tahiti; East Indies.

Salarias rivulatus Rüppell, Atias, Aírica, 114, 1828, Ređ Sea.

Salarias quadricornis Cuvier \& Valenciennes, Hist. Nat. Poiss., XI, 329, pl. 329, 1836, Ile de France. Günther, Cat., III, 255, Indian Ocean, Chinese Sea. Günther, Fische der Südsee, 209, taf. 117, fig. B, Upolu, Paumotu, Tahitł.

Life colors of a specimen from Pago Pago, dark olive; several pairs of darker brown cross shades, the last 3 resolving themselves into oblique streaks upward and backward; soft dorsal with oblique dark streaks; caudal plain; anal dusky-edged. No crest; dorsal divided.

Another specimen from the same locality was olive, with about 8 pairs of dark cross-bars, with cross-streaks between, the last obscure; a dark oblique streak behind eye; dorsal with horizontal rows of light olive spots, these more oblique on second dorsal; anal dusky-edged, with 2 pale blue longitudinal lines; fins otherwise dusky olive.

A third specimen from Pago Pago was blackish olive in life, with a series of dark marblings and spots above lateral line, most distinct posteriorly, fainter below; dorsals similarly marbled; head dark; cirri dusky; fins all blackish, uncolored; anal with 2 faint pale longitudinal lines. A younger one shows faint paired dark cross-bands.

About 75 specimens from the coral reefs of $A$ pia and Pago Pago, where it is very abundant.

1611. Salarias edentulus (Bloch \& Schneider). Huahine; Samoa; Paumotu; Bonham; Rarotonga; Faté; Nukahiva and Nakatea (Seale); East Indies.

Blennius cdentulus Bloch \& Sehneider, Syst. 1chth., 172, 1801, Huahine.

St larias forstcri Cuvier \& Valenciennes, Hist. Nat. Poiss., XI, 315, 1836; described from Forster's specimen from Huahine.

Blenmius truncatus Forster, Descr. Anim., 231, 1844, Huahine.

Salarias edentulus, Günther, Cat., III, 252, 1861, Polynesin, enstem parts East Indies. Günther, Fische der Südsee, 206, taf. 117, fig, A, Samoa, Paumotu, Bonham, Rarotonga.

Life colors of a specimen from Apia, dark olive, the body and fins much spotted with bright reddish brown; belly livid bluish; caudal pale, slight yellowish below; anal pale-edged.

A specimen from Pago Pago had several dark, irregular, paired cross-bands on body, with dark brown dots along base of anal and on caudal peduncle; dorsal divided, with oblique rows of black dots besides numerous whitish ones; anal with 2 rows of dots and whitish edge; pectoral and ventral plain olive; no crest; tentacles small.

Another Apia specimen was dark bluish-olive, with dark-brown markings; head and anal blueblack; caudal mostly black; caudal peduncle with several rows of brown dots; spinous dorsal with 2 longitudinal rows of dark dots; soft dorsal with several oblique rows of dots; caudal and pectoral plain dusky; anal dusky, pale-edged.

We have 60 specimens from Apia and Pago Pago, where it swarms in the crevices of the coral reefs.

1612. Salarias meleagris Cuvier \& Valenciennes. New Caledonia; New Hanover; Nukahiva and Makatea (Seale).

Salarias melcagris Cuvier \& Valenciennes, Hist. Nat. Poiss., XI, 232, 1836, Tasmania. Günther, Fisehe der Südsee, 208, taf. 116, fig. G, New Caledonia, Cape York, Zanzibar. Peters, Berl. MIon. 1876, 841, New Hanover.

This species, unknown to us, is recorded from MIelanesia and Polynesia, but these specimens may be distinct from the original type, which came from Tasmania.

1613. Salarias garmani Jordan \& Seale, new species. Samoa.

Head 4.18 in length; depth 5; eye 3 in head; interorbital equal to one-half of eye; dorsal xur, 21; anal 24; a short, indistinct lateral line ending under the ninth dorsal spine; a short, simple tentacle over eye, another over nostril.

Body elongate, compressed, the anterior profile of head vertical; caudal peduncle about equal to eye; angle of jaws under posterior third of eye; teeth in jaws in single series, no posterior canires; dorsal fin incised two-thirds of its height, the incision being posterior to origin of anal; origin of dorsal directly over posterior margin of opercle, its distal end at base of caudal, the membrane not attached to caudal fin, the height of longest dorsal spine 2.1 in sead, and of the longest ray $1.75 \mathrm{in}$ head; anal fin long, its base $\mathbf{2 . 2}$ in length of fish without the cudal, its origin being under base of tenth dorsal spine and nearer tip of snout than base of caudal by a distance about equal to depth of caudal peduncle; longest ray of anal 1.75 in head; pectoral slightly longer than head; ventral 1.95 in head; caudal rounded, 1.2 in head. 
Color in life gray-green, everywhere finely punctate with black; indications of broad transverse bars, most pronounced on middle of body; subsurface spots lilac-red anteriorly, orange-red posteriorly; anterior two-fifths of body white below; dorsal fin clear, with many fine black specks, more or less definitely arranged in 2 longitudinal rows; other fins all clear, with numerous tiny black specks; on anal they form a dusky submarginal band, the tips of the rays white.

Color in spirits, dull light gray with a wash of pale green, slightly darker above; 7 pairs of indistinct vertical bands of darker coloring along sides, a distinctive brown band from lower anterior margin of eye vertically down to middle of each maxillary; no markings on chin or throat; dorsal with numerous, more or less regular brown spots; 2 dusky blotches on base of caudal; otherwise the fins are without distinet markings of any kind.

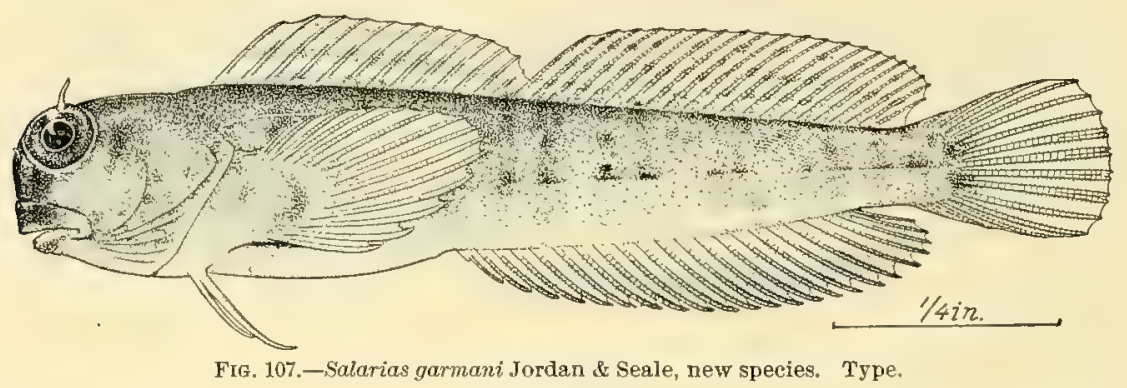

One specimen, the type, no. 51792, U. S. National Museum, from Apia, length 1.2 inches. Named for Prof. Samuel Garman.

1614. Salarias hasselti Bleeker. 'Fiji; Loyalty Is.; Faté (Seale).

Salarias hasselli Bleeker, Nat. Tijds. Ned. Ind., I, 257, fig. 14, Java, Sumatra, Cocos. Günther, Fische der Südsee, 210, Fiji, Loyalty Is.

1615. Salarias bryani Jordan \& Seale, new species. Samoa.

Head 4 in length; depth 5.5; eye 3.1 in head; interorbital very narrow, less than width of pupil; dorsal xII, 22; anal 21; lateral lines short, ending near tip of pectoral.

Body oblong, compressed, anterior profile of head rounded; forehead scarcely projecting over mouth; angle of jaws under posterior margin of eye; a short simple tentacle over eye and-a minute fringed tentacle at nostril; teeth in jaw in a single series; no posterior canine teeth; dorsal fin incised

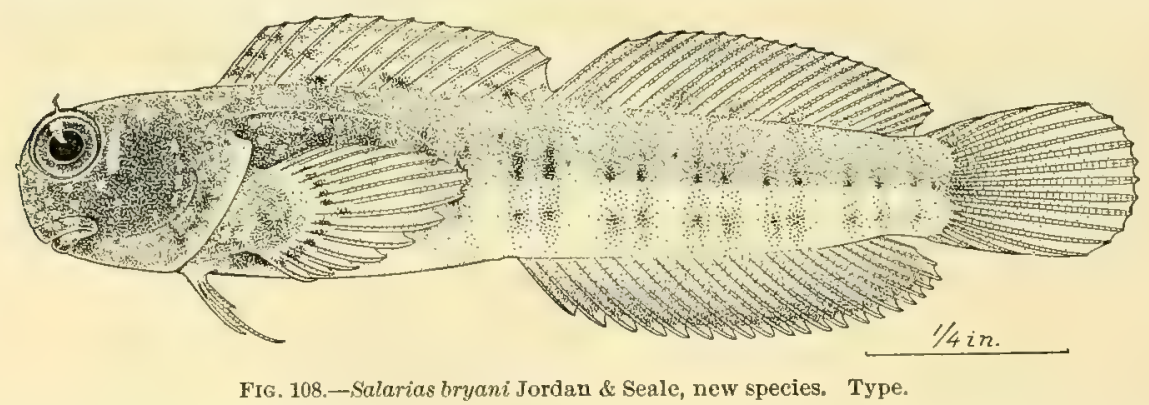

almost to base; its origin a little anterior of posterior margin of opercle, its incision directly over origin of anal, its posterior extremity ending on base of caudal but not attached to caudal; base of anal 2.45 in length of fish, its origin nearer tip of snout than to base of caudal, the distance between tip of snout and origin of the fin, considerably greater than base of fin; longest ray of anal 2 in head; pectoral equal to head; ventral minute, 1.85 in head; caudal rounded, 1.1 in head.

Color in spirits dull light gray, with 8 vertical double dark bands on side, these bands about equal to interspaces; head and shoulders punctulate with yellowish white spots; head shaded darker than other parts; 2 dusky bands under chin; a single row of rather distinct black dots across nectoral; a 
few scattered dusky blotches on spinous dorsal; anal with margin of white with intramarginal area of dusky, other fins unmarked.

One specimen, the type no. 31794, U. S. National Museum, from Apia, length 18 inches. Named for William Alanson Bryan, curator in the Bernice Pauahi Museum, in Honolulu

1616. Salarias gilberti Bryan \& Herre. Marcus I.

Salarias giberti Bryan \& Herre, Occ. Papers Bishop Museum, II, 1903, 137, Marcus 1.

1617. Salarias marcusi Bryan \& Herre. Marcus I.

Salarias marcusi Bryan \& Herre, Occ. Papers Bishop Museum, 1I, 1903, 137, Marcus I.

1618. Salarias paulus Bryan \& Herre. Mareus I.

Salarias paulus Bryan \& Herre, Oce. Papers Bishop Museum, II, 1903, 136, Marcus I.

1619. Salarias holomelas Günther. Palau Is.; Vavau.

१ Salarias fuscus Rüppell, Neve Wirbelthiere, Fische, 135, taf. 32, fig. 2, 1835, Red Sea.

i Salarias ruficaudus Cuvier \& Valenciennes, Hist. Nat.Poiss, XI, 328, 1836. Red Sea.

Salarias phrosoma Bleeker, Batoe, 317, Batoe.

Salarias holmmelas Günther, Ann. Mag. Nat. Hist. 1872, Cebu.

Salarias fuscus, Günther, Fische der Südsee, 202, taf. 116, fig. c, 1873, Palau, Vavais,

This strongly marked species is not represented in our collections. It is close to Salarias fuscus of the Red Sea, but we may retain it as a different species, as according to Dr. Günther the caudal is black in $S$. holomelas and yellow in $S$. fuscus.

1620. Salarias atratus Macleay. New Guinea.

Salarias atratus Macleay, Proc. Linn. Soc. N. S. W. 1882-3, 361.

1621. Salarias goesi Bleeker. New Guinea.

\section{EXALLIAS Jordan \& Evermann.}

Exallias Jordan \& Evermann, Bull. U. S. Fish Comm., xxur, 1903 (1905), 503 (Salarias brevis Kner).

1622. Exallias brevis (Kner). Mano'o gatala. Samoa; Hawaii.

Salarias brevis Kner, Sitz, Ak. Wiss. Wien 1866, 334, taf, 16, fig. 18, Savaii. Günther, Fische der Südsee, 203, taf. 118, fig. C; after Kner. Jenkins, Bull. U. S. Fish Comm., XXII, 1902 (1903), 506, Honolulu.

Of this species only 15 specimens are known, 14 from Hawaii, the other from Savaii. We obtained no specimens in Samoa, but Dr. T. D. Wood obtained in Honolulu one specimen, which is now in the Stanford University Museum.

\section{PETROSCIRTES Rüppell.}

Petroscirtes Rüppell, Atlas Fische, 110, 1828 (mitratus).

Blennechis Cuvier \& Valenciennes, Hist. Nat. Poiss., x, 1836, 279 (flamentosus).

Aspidontus (Cuvier) Quoy \& Gaimard, Voy. Astrolabe, III, 1834, 719 (tieniatus).

Omobranchus (Ehrenberg, pl. xI, fig. 91) Swainson, Class. Fishes, II, 1839, 274 (fasciolatus).

1623. Petroscirtes longifilis Kner. Samoa.

i Petroscirtes mitratus Rüppell, Atlas Fische, Im, taf. 28, fig. 1, i828, Red Sea. Günther, Fische der Südsee, 198, Samor.

IPetroscirtes barbatus Peters, Wiegmann's Archiv, 1855, 248, Mozambique.

i Petroscirtes hypseloptens Bleeker, Amboina, VI, 423, Amboina.

Petroscirtes longifilis Kner, Sitz. Ak, Wiss, Wien 1866, LIV, 5, Samoa.

Life color of a specimen from Apia olivaceous, with broad dark cross-bars; head much banded below; dorsal yellowish, barred and spotted with black; anal similar; caudal pale with cross-bars of dots; ventral long, dotted or barred, as is the pectoral. Dorsals 2, the first short and elevated in front.

We have 2 specimens of this fish from Apia. Dr. Günther identifies it with $P$. mitratus, thus throwing nearly all the species with elevated anterior dorsal spines into one, an arrangement open to serious question. We may provisionally retain the name longifilis, applied to a Samoan specimen.

1624. Petroscirtes filamentosus (Cuvier \& Valenciennes). Papau; Paumotu Is.; Huahine; East Indies.

Blennechts filamentosus Cuvier \& Valenciennes, Hist. Nat. Poiss, xI, 280, 1836, pl. 326, Papua.

Petroscutes filamentosus, Gunther, Fische der Sudsee, 196, taf. 114, fig. B, 1873, Paumotu, Huahine.

Petroscintes rostratus Bleeker, Act. Soc. Sci. Ind. Neederl., $11_{1} 62$, Amboina. 
1625. Petroscirtes azureus Jordan \& Seale, new species. Samoa.

Head 4 in length; depth 5.5; eye 4.5 in head; snout projecting, 3.20 in head; dorsal 37; anal 27; interorbital equal to orbit; chin with 6 small barbels.

Body elongate, compressed, naked; depth of caudal peduncle 2.2 in head; mouth narrow, situated on the ventral surface of head, overhung by snout; a single outer row of round pointed teeth in each jaw, 18 in upper and 26 or more in lower, with several additional inner rows in lower jaw, an immense curved fang-like tooth on each side of lower jaw, the length of which is two-thirds of eye; one small tooth on head of vomer; a single dorsal fin, whose origin is on nuchal region just above the posterior margin of postorbital, and which terminates at base of anal, its anterior rays not filamentous, the vertical height of the fin about 3.2 in head; origin of anal midway between tip of snout antl base of caudal, vertical height of fin equal to orbit; caudal rounded, equal in length to pectoral, 1.65 in head; origin of ventral in front of pectoral, its length 2.18 in head.

Life colors olivaceous, a deep blue-black lateral band, broader and more distinct indigo-color behind; dorsal, anal, and caudal jet-black, edged with white, the indigo-black caudal V-shaped, leaving the angles of the fin broadly white; head with the dark band continued forward as brown, edged above and below with black; pectoral and ventral clear, uncolored.

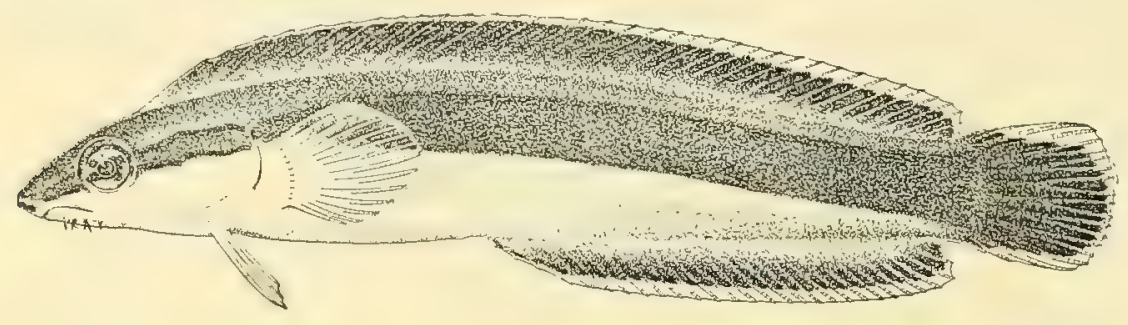

FIG. 109.-Petroscirtes azureus Jordan \& Seale, new species. Type.

Color in spirits yellowish brown; thorax, belly, and chin lighter, a darker band with black margins from snout to posterior margin of opercle, from this point to the caudal the entire band becoming black and broadening until it occupies the base of caudal and entire fin except the upper and lower posterior margins and tip, which are yellow; anal black with yellow margin; caudal dusky', becoming black posteriorly, with a narrow margin of yellow; pectoral and ventral white.

This handsome fish is close to Petroscirtes filamentosus, but differs in having 8 barbels or tentacles on the chin and throat, and in not having the anterior dorsal spines elongate.

One example from Apia, type no. 51796, U. S. National Museum, length 3.75 inches.

1626. Petroscirtes grammistes (Cuvier \& Valenciennes). Yap; East Indies.

Llennechis grammistes, Cuvier \& Valenciennes, Hist. Nat. Poiss., XI, 2S5, 1836, East Indies.

Pctroscintes grammistes Günther, Fische der Sudsee, 197, 1873, taf. 115, tig. F, Yap, China. Petroscirtes anema Bleeter, Amboina and Ceram, 273.

This handsome species, with 3 black stripes, is unknown to us.

1627. Petroscirtes rhynorhynchus Bleeker. Palau Is.; Faté (Seale); East Indies.

Petroscirtes rhynorhynchus Bleeker, Amboina and Ceram, 273. Gunther, Fische der Sudsee, 195, ta F. 115, fig. E, Palau.

This species is unknown to us. It has 2 black lateral bands besides 1 on the dorsal.

1628. Petroscirtes tæniatus (Quoy \& Gaimard). Tahiti; Papua; Caroline Is.; Tonga; Guam; Paumoti; Fiji; East Indies.

Aspidontus traiatus Quoy \& Gaimard, Voy. Astrolabe, 719, pl. 19, fig. 4, 1834, Guam.

Pelroscirtes tranialus Gunther, Fische der Sudsęe, 195, Tahiti, Papua, Carolines, Tonga, Paumotu, Fiji.

Petroscirtes paradiseus Bleeker, Amboina, v, 495 .

This species we have not seen.

1629. Petroscirtes tapeinos̄oma Bleeker. Samoa (Günther); Faté; haiatea and Nukahiva (Seale); East Indies.

Petroscirtes tapeinosoma Bleeker, Ambonna, 64, Amboina. Gunther, Fische der Sudsee, 195, taf. 115, fig. D, Apia. 
This species, with 2 black stripes besides 1 on the dorsal, is unknown to us. It is near our Petroscirtes azureus.

1630. Petroscirtes atrodorsalis Günther. Samoa. (Pl. IIII, fig. 3.)

Petroscirtes atrodorsalis Günther, Fische der Südsee, 198, trf. 115, fig. B, Samoa.

We have 2 specimens of this rare and handsome little fish, from Pago Pago.

Life colors, clear dark blue, becoming golden on caudal peduncle and caudal fin; 2 sky-blue stripes on eye; a black stripe from edge of pupil to origin of dorsal; dorsal with a broad median band of jetblack, its margin white; caudal pale goiden; other fins dusky bluish; a black spot in axil of pectoral.

1631. Petroscirtes xestus Jordan \& Seale, new species. Samoa.

Head 2.85 in length; depth 2.75; eye 2.2 in head; dorsal 26; anal 17 ; interorbital equal to eye.

Body elongate, compressed, largest at head; anterior profile rounded, snout less than one-half of eye; angle of jaws below micldle of eye; teeth in a single row in jaws, a pair of large curved fang-like canines in each jaw, those of the lower jaw largest; gill-opening reduced to a narrow slit less in width

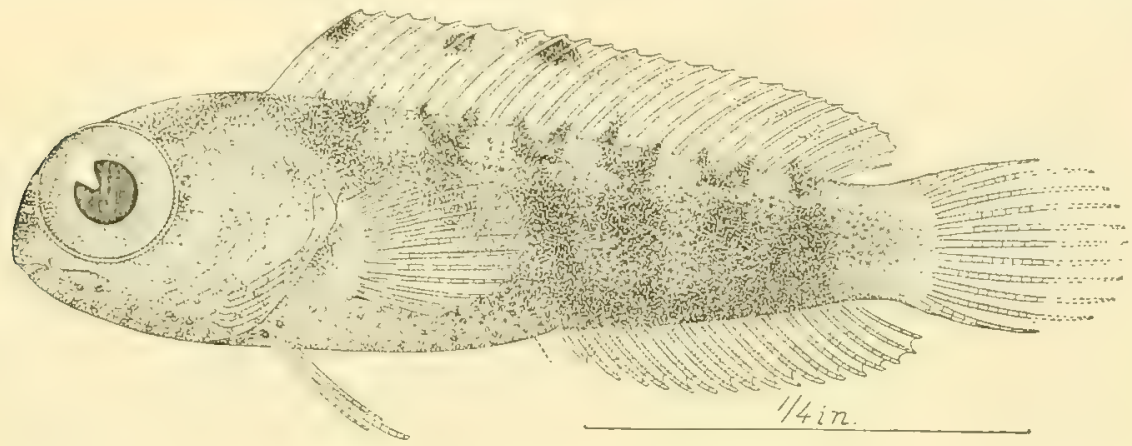

FIG. 110.-Pctroscirtes xcstus Jordan \& Seale, new species. Type.

than one-half diameter of eye; a single continuous dorsal fin whose origin is slightly anterior to gillopening and whose distal end does not extend quite to base of caudal; base of anal fin 3 in length of fish without caudal, its longest ray 3.95 in head; origin of anal much nearer base of caudal than tip of snout, its distal end not reaching quite to base of candal; pectoral 1.95 in head; ventral 2 in head, their base slightly anterior to base of pectoral; caudal rounded, 1.75 in head.

Color in life, light clear brownish red, with a broad silvery lateral stripe from eye to base of caudal; 6 dark cross-shades on body; top of head bright silvery, as if coated with mercury; throat and belly white, sprinkled with silvery spots; dorsal clear with a submarginal row of dark blotches; other fins all clear.

Color in spirits, silvery with small brown spots and shadings, yellowish white along base of dorsal; 7 or 8 incomplete vertical cross-bands on the side about as wide as interspaces, these most distinct at base of dorsal; nuchal region set with a heart-shaped coloring like new silver, a silvery wash less bright on sides of head, thorax, and belly; in front of ventral a number of prominent bright silvery dots with darker margins; dorsal with a few dusky spots, otherwise fins yellowish white.

Two specimens from Pago Pago. The type is no. 51797, U. S. National II useum, from Pago Pago, length 0.56 inch.

1632. Petroscirtes elongatus Peters. Fiji; East coast of Africa.

Petroscirles elongatus Peters, Wiegmann's Archiv 1\$55, 219, Zanzibar, Mozambique. Günther, Fisehe der Südsee, 196, Fiji.

Petroscirtes oualenensis Günther, Challenger Fishes, 1840, 35, Fiji.

1633. Petroscirtes lineolatus Kner. Fiji.

Pctroscirtes lincolatus Kner, Sitz. Ak. Wiss, Wien, LviIr, 1568, 331, taf. 6, fig. 17, Kandavu. Günther, Fische der Südsee, 197, taf, 115, fig. A (after Kner):

1634. Petroscirtes semilineatus Kiner. Fiji.

Petroscirtes semilinealus Kner, Sitz. Ak. Wiss, Wien, Lvı, 1868, 332, Kandavu. Günther, Fische der Südsee, 197̈; nfter Kner. 
1635. Petroscirtes obliquus Garman. Samoa.

Petroscirtes obliquus Garman, Bull. Mus. Comp. Zool., vol. Xxxix, no. 8, 1903, 237, with piate, Fiji.

Of this species we have one example from Apia more brightly colored than in Mr. Garman's figure, but with the characteristic oblique streaks.

Color in alcohol olive-brown with darker brown spots and diagonal or angled stripes; a large round dark spot behind eye; under side of head pale, with 5 narrow, dark cross-stripes; belly blue; a row of large dark spots on back and base of dorsal; fin otherwise dusky; margin of spinous dorsal pale; caudal pale, unspotted; anal dusky; pectoral pale, minutely spotted with darker; ventral pale.

1636. Petroscirtes germaini Sauvage. New Caledonia.

Petroscirtes germaini Sauvage, Bull. Soc. Philom. 1883, 158, New Caledonia.

This species, cross-banded, is quite unlike any other known to us.

\section{ENCHELYURUS Peters.}

Enchelyurus Peters, Berl. Mon. 1868, 268 ( flavipes).

This genus differs from Petroscirtes in having the vertical fins confluent, the body short and deep. The typical species is from the Philippines.

1637. Enchelyurus ater (Günther). Hawaii; Samoa; Tahiti.

Petroscirtes ater Günther, Fische der Südsee, 199, taf. 115, fig. E, 1873, Tahiti.

Aspidontus brunneolus Jenkins, Bull. U. S. Fish Comm., XXII, 1902 (1903), 510, fig. 50, Honoluiu.

This rare little fish seems to be rather common at Samoa. We have 25 examples from Pago Pago and 16 from Apia. Günther describes the ventrals as reaching the anal, but in his figure the fins are much shorter. Our specimens show much variation in this character, some having the ventrals twice as long as others; but 2 examples have them as long as shown in Günther's figure.

Jenkins' specimens from Hawaii, called Aspidontus brunneolus, seem to be identical with ours from Samoa.

Color in life of a specimen from Apia, uniform blackish, becoming clear olive green on caudal. Other specimens in alcohol have the head and body uniform black-brown, slightly lighter than fins, which are black.

\section{Family GOBIESOCIDE. CREPIDOGASTER Günther.}

1638. Crepidogaster lineatus Sauvage. New Caledonia: Crepidogaster lineatus Sauvage, Bull. Soc. Philom. 1883, 158, New Caledonia.

TRACHELOCHISMUS Brisout de Barneville.

1639. Trachelochismus pinnulatus (Forster). Fiji (Kner, Sitz. Ak. Wiss Wien 1868, 55); New Zealand.

\section{Family CONGROGADIDE.}

CONGROGADUS Günther.

1640. Congrogadus marginatus Vaillant \& Sauvage. Hawaii.

1641. Congrogadus subducens Richardson. New Guinea (Günther); Australia.

\section{Family XENOCEPHALIDE. \\ XENOCEPHALUS Kaup.}

1642. Xenocephalus armatus Kaup. New Ireland.

Xenocephalus armatus Kaup, Wiegmann's Archiv, 1858, 86, New Ireland. Günther, Cat., Iv, 399. 


\section{Family FIERASFERIDE.}

\section{FIERASFER Cuvier.}

1643. Fierasfer homei Richardson. Hawaii; Samoa; Fiji; New Britain; New Hanover; Tahiti (Fowler, Proc. Ac. Nat. Sci. Phila. 1900, 523); East Indies, not "Tasmania."

The type locality is Timor, and our species is identified with the one described by Richardson. Richardson's other specimen is doubtless not from Tasmania, and there is no reason for regarding Fierasfer brandesi as a species distinct from Fierasfer homei.

Our two Samoan specimens were taken from Holothuria, one at Apia, the other at Pago Pago. Another specimen was taken by Mr. W. K. Fisher at Hawaii, from the cloaca of a holothurian (Stichopus, n. sp.).

Color in life of a specimen from Apia, translucent with bluish and reddish shades anteriorly. Body with dark cross-shades in adult.

1644. Fierasfer microdon Gilbert. Hawaii.

\section{JORDANICUS Gilbert}

1645. Jordanicus umbratilis (Jordan \& Evermann). Hawaii.

This species is known from a few examples taken about lava rocks in Hawaii. One specimen in the Museum of Stanford University, was obtained at Hilo by Mr. H. W. Henshaw from the cavity of a holothurian. From its dark color, this species might be supposed to inhabit crevices of rocks only.

1646. Jordanicus boraborensis (Kaup). Borabora.

Fierasfer boraborensis Kaup, Apodes, 160, 1850, Borabora.

This species has not been recognized by writers subsequent to Kaup.

1647. Jordanicus parvipinnis (Kaup). New Ireland; Hanover; Tahiti.

Fierasfer parvipinnis Kaup, A podes, 160, pl. 16, 6g. 2, 1850, New Ireland. Peters, Berl. Hon. 1876, 811, New Hanover. Günther, Cat., Iv, 383, after Kaup. Fowler, Proc. Ac. Nat. Sei. Phila. 1900, 528, Tahiti.

This species was not seen by us.

\section{RHIZOIKETICUS Vaillant.}

1648. Rhizoiketicus carolinensis Vaillant. Caroline Is.

Ihtzoiketicus carolinensis Vaillant, Comptes Rendus, 1893, 745, Caroline Is.

\section{Family LYCODAPODIDE.}

\section{SNYDERIDIA Gilbert.}

1649. Snyderidia canina Gilbert. Deep seas of Hawaii.

\section{Family BROTULIDA.}

\section{DINEMATICHTHYS Bleeker.}

1650. Dinematichthys iluocœteoides Bleeker. Tapotopoto. Samoa; East Indies.

Of this species we have half a dozen specimens from A pia and Pago Pago, where it lives in pools on the reef. These specimens vary widely in the ground color, some being grayish with golden shades, and others bright orange-red. They agree well with Günther's cescription.

Life colors of a specimen from Apia, brilliant orange-red, the color varying a little with individuals, ihe head more orange. Another was grayish, the posterior parts golden shaded, the last rays of dor:ial, anal, and caudal golden. 


\section{BROTUla Cuvier.}

1651. Brotula multicirrata Vaillant \& Sauvacre. Hawaii.

(Brotula townsendi Fowler.)

1652. Brotula marginalis Jenkins. Hawaii.

NEMATOBROTULA Gill.

1653. Nematobrotula ensiformis (Günther). Aneiteum; New Hebrides. Brotula ensiformis Günther, Cat., IV, 372, 1562, Aneiteum, New Hebrides. Nematobrotula ensiformis Gill, Proc. Ac. Nat. Sc1. Phila, 1863, 252

\section{Family ATELEOPIDE.}

ATELEOPUS Schlegel.

(Podateles Boulenger, the name unnecessarily changed on account of the prior name Atelopus.)

1654. Ateleopus plicatellus Gilbert. Deep seas of Hawaii.

$$
\text { Family GADIDE. }
$$

\section{ANTIMORA Günther.}

1655. Antimora microlepis Gilbert. Deep seas of Hawaii.

\section{LEMONEMA - Günther.}

1656. Læmonema rhodochir Gilbert. Deep seas of Hawaii.

\section{Family MAROURIDA.}

\section{GADOMUS Regan.}

1657. Gadomus melanopterus Gilbert. Deep seas of Hawaii.

1658. Gadomus bowersi Gillbert. Deep seas of Hawaii.

\section{MELANOBRANGHUS Regan.}

1659. Melanobranchus micronemus Gilbert. Deep seas of Ilawaii.

CHALINURA Goode \& Beane.

1660. Chalinura ctenomelas Gilbert \& Cramer. Deep seas of Hawaii.

OPTONURUS Günther.

1661. Optonurus atherodon Gilbert \& Cramer. Deep seas of Hawaii.

\section{HYMENOCEPHALUS Giglioli.}

1662. Hymenocephalus antræus Gilbert \& Cramer. Deep seas of Hawaii. 1663. Hymenocephalus striatulus Gilbert. Deep seas of Hawaii.

1664. Hymenocephalus aterrimus Gilbert. Deep seas of Hawaii. 
MACROURUS BIoch.

1665. Macrourus ectenes Gilbert \& Cramer. Deep seas of Hawaii.

1666. Macrourus propinquus Gilbert \& Cramer. Deep seas of Hawaii.

1667. Macrourus holocentrus Gilbert \& Cramer. Deep seas of Hawaii.

1668. Macrourus gibber Gilbert \& Cramer. Deep sens of Hawaii.

1669. Macrourus burragei Gilbert. Deep seas of Hawaii.

1670. Macrourus obliquatus Gilbert. Deep seas of Hawaii.

1671. Macrourus habenatus Gilbert. Deep seas of Iawaii.

1672. Macrourus longicirrhus Gilbert. Deep seas of Hawaii.

\section{CELORHYNCHUS Giorna.}

1673. Cœlorhynchus gladius Gilbert \& Cramer. Deep seas of Hawail.

1674. Cœlorhynchus aratrum Gilbert. Deep seas of Hawaii.

1675. Colorhynchus doryssus Gilbert. Deep seas of Hawail.

MATAOCEPHALUS Berg.

(Crlocephalus Gilbert \& Cramer, not of Agassiz.)

1676. Matæocephalus acipenserinus (Gilbert \& Cramer). Deep seas of Hawaii.

\section{MALACOCEPHALUS Günther.}

1677. Malacocephalus hawaiiensis Gilbert \& Cramer. Deep seas of Hawaii.

TRACHONORUS Günther.

1678. Trachonurus sentipellis (Gilbert \& Cramer). Deep seas of Hawaii.

$$
\text { Family LOPHIIDE. }
$$

\section{LOPHIOMUS Gill.}

1679. Lophiomus miacanthus Gilhert. Deep seas of Hawaii.

1680. Lophiomus naresi Günther. Admiralty Is.; New Guinea. Lop)hius naresi Günther, Challenger Fishes, 18s0, 5t3.

\section{CHIROLOPHIUS Regan.}

1681. Chirolophius moseleyi Regan. Ad́miralty Is. Chirolophius moscleyi Regan, Ann. MIng. Nuut. Iist, 1900, $2 \div 0$.

\section{Family CERATIIDE. \\ CHAUNAX LOWE.}

1682. Chaunax umbrinus Gilbert. Deep seas of Hawail.

\section{MIOPSARAS Gilbert.}

1683. Miopsaras myops Gilbert. Deep seas of Hawaii. 


\section{Family ANTENNARIIDE.}

\section{ANTENNARIJ' (Commerson) Lacépède. (Histrio Fischer.)}

1684. Antennarius commersoni (Lacépède). Hawaii; Raiatea; Borabora; Tahiti; Shortland I. (Seale); East Indies.

1685. Antennarius niger (Garrett). Hawaii.

Chironectes niger Garrett, Proc. CaI. Ac. Sci. 1864, 107, Honolulu.

1686. Antennarius leprosus Eydoux \& Souleyet. Hawaii.

1687. Antennarius rubrofuscus Garrett. Hawaii.

1688. Antennarius sandwichensis Bennett. Hawaii.

( Anten arius horridus, Bleeker, East Indies.)

1689. Antennarius laysanius Jordan \& Snyder. Laysan.

1690. Antennarius hispidus (Bloch \& Schneider). Misol (Günther); Raiatea (Seale); East Indies.

1691. Antennarius striatus Shaw. Tahiti; Solomon Is. (Günther, Fische der Südsee, 162, taf. 99, fig. B) ; East Indies.

1692. Antennarius duescus Snyder. Hawaii.

1693. Antennarius nexilis Snyder. Hawaii.

1694. Antennarius dorehensis Bleeker. New Guinea.

1695. Antennarius nummifer (Cuvier). Samoa and Raiatea (Günther; perhaps Antennrrius drombus); East Indies.

This species seems to be very close to Antennarius drombus, differing perhaps in having the dusky shade below the soft dorsal intensified as a black ocellus. The specimens from Samoa and Raiatea, noted by Dr. Günther, probably belong to Antemarius drombus, if, indeed, the 2 species are distinct.

Intennarius coccineus (Lesson, Voy. Coquille, 143, pl. 16, fig. 1, 1830), from Vauritius and the East Indies, differs from Antennarius nummifer chiefly in the red color. It is equally near Antennarius drombus. It is not unlikely that Antennarius coccmeus is identical with Antennarius nummifer, and that the species is not found in Polynesia, where it is replaced by Antennarius drombus.

1696. Antennarius drombus Jordan \& Evermann. Hawaii; Samoa.

This small, dull-colored species is known from 2 specimens from Hilo, Hawaii, and from 1 taken by us at Samoa. None of the other species was obtained by us in Samoa.

In Antennarius drombus the dorsal filament or bait is short, and the last ray of dorsal and anal is adnate to the body. Antennarizs coccineus, as figured by Bleeker, may be this species, but the type figured by Quoy \& Gaimard must be something else.

In life our single Samoan specimen was dull mottled olive-green with blackish markings, and a few dull orange blotches, irregular and diffuse; no red. When captured, this fish swells its body like a Tetraodon.

1697. Antennarius bigibbus Lacépède. Hawaii.

PTEROPHRYNE Gill.

1698. Pterophryne histrio (Linnæus). New Guinea (Bleeker); East Indies.

\section{Family OGCOCEPHALIDE.}

\section{MALTHOPSIS Alcock.}

1699. Malthopsis mitrigera Gilbert \& Cramer. Deep seas of Hawaii.

1700. Malthopsis jordani Gilbert. Deep seas of Hawaii. 
THE FISHES OF SAMOA.

439

HALIEUTEA Cuvier.

1701. Halieutæa retifera Gilbert. Deep seas of Hawaii.

DIBRANCHUS Peters.

1702. Dibranchus erythrinus Gilbert. Deep seas of Hawaii.

1703. Dibranchus stellulatus Gilbert. Deep seas of Hawaii.

TETRABRACHIUM Günther.

1704. Tetrabrachium ocellatum Günther. New Guinea.

Tetrabrachium ocellatum Günther, Challenger Fishes, 41, 1 sso.

Fist. 111.-Hices sulens ( Forster). 


\section{VERNACULAR NAMES OF FISHES HEARD IN HAWAII AND SAMOA.}

In the following table, the vernacular names heard by us in Hawaii and Samoa are brought together for purposes of comparison. The Samoan names as given here were obtained by Professors Jordan and Kellogg in Apia and Pago Pago, most of them from the fishermen Taua and Vaiula. The authors are indebted to Mr. Edwin Gurr, of Pago Pago, for a preliminary correction of these names, and to $\mathrm{Mr}$. W. E. Safford for a very much more careful revision of their spelling and meaning, and for the following glossary of the principal nouns and adjectives in the list. It may be noted that $h$ in Hawaiian is replaced by $s$ or $f$ in Samoan, and that $k$ in Hawaiian is replaced by $t$ in Samoan. Intercourse between the two groups of islands has in recent years tended to corrupt the Samoan pronunciation, and we often hear in Apia, kifitifi and the like, when tifitifi is the correct Samoan form. The Samoan g (as in Pago Pago or Ga) is pronounced like ng. The rowels are pronounced as in Italian, ou not being a diphthong.

From Lorin Andrews's Hawaiian-English Dictionary we copy the following table, showing the shifting of the consonants in the Polynesian languages:

\begin{tabular}{|c|c|c|c|c|c|c|c|}
\hline Fakaofo. & Samoa. & Tonga. & $\begin{array}{l}\text { New } \\
\text { Zealand. }\end{array}$ & Rarotonga. & Tahiti. & Hawaii. & Marquesas. \\
\hline $\begin{array}{l}\mathrm{F} \\
\mathrm{K} \\
\mathrm{L} \\
\mathrm{MI} \\
\mathrm{N} \\
\mathrm{N} \\
\mathrm{NG} \\
\mathrm{P} \\
\mathrm{S} \\
\mathrm{T} \\
\mathrm{V}\end{array}$ & $\begin{array}{c}\mathrm{F} \\
\mathrm{L} \\
\mathrm{L} \\
\mathrm{MI} \\
\mathrm{N} \\
\mathrm{NG}(\mathrm{G}) . \\
\mathrm{P} \\
\mathrm{S} \\
\mathrm{T} \\
\mathrm{V}\end{array}$ & $\begin{array}{c}\mathrm{F} \\
\mathrm{K} \\
\mathrm{L} \\
\mathrm{M} \\
\mathrm{N} \\
\mathrm{NG} \\
\mathrm{P} \text { or B } \\
\mathrm{H} \\
\mathrm{T} \\
\mathrm{V}\end{array}$ & $\begin{array}{c}\text { W or } H \\
K \\
\mathrm{~K} \\
\mathrm{R} \\
\mathrm{M} \\
\mathrm{N} \\
\mathrm{N} \\
\mathrm{P} \\
\mathrm{P} \\
\mathrm{H} \\
\mathrm{T} \\
\mathrm{T}\end{array}$ & $\begin{array}{c}\text { Wanting } \\
\mathrm{K} \\
\mathrm{R} \\
\mathrm{I} \\
\mathrm{N} \\
\mathrm{NG} \\
\mathrm{P} \\
\text { Wanting } \\
\mathrm{T} \\
\mathrm{V}\end{array}$ & $\begin{array}{c}\text { F or } \mathbf{H} \\
\mathrm{R} \\
\mathrm{M} \\
\mathrm{N} \\
\text { Wanting } \\
\mathrm{P} \\
\mathrm{H} \\
\mathrm{T} \\
\mathrm{V}\end{array}$ & $\begin{array}{c}\mathrm{H} \\
\mathrm{L} \\
\mathrm{L} \\
\mathrm{MI} \\
\mathrm{N} \\
\mathrm{MI} \\
\mathrm{P} \\
\mathrm{H} \\
\mathrm{K} \\
\mathrm{IV}\end{array}$ & $\begin{array}{c}\mathrm{F} \text { or } \mathrm{H} \\
\mathrm{K} \\
\text { Wanting } \\
\mathrm{M} \\
\mathrm{N} \\
\mathrm{N} \text { or } \mathrm{KG} \\
\mathrm{P} \\
\mathrm{H} \\
\mathrm{T} \\
\mathrm{V}\end{array}$ \\
\hline
\end{tabular}

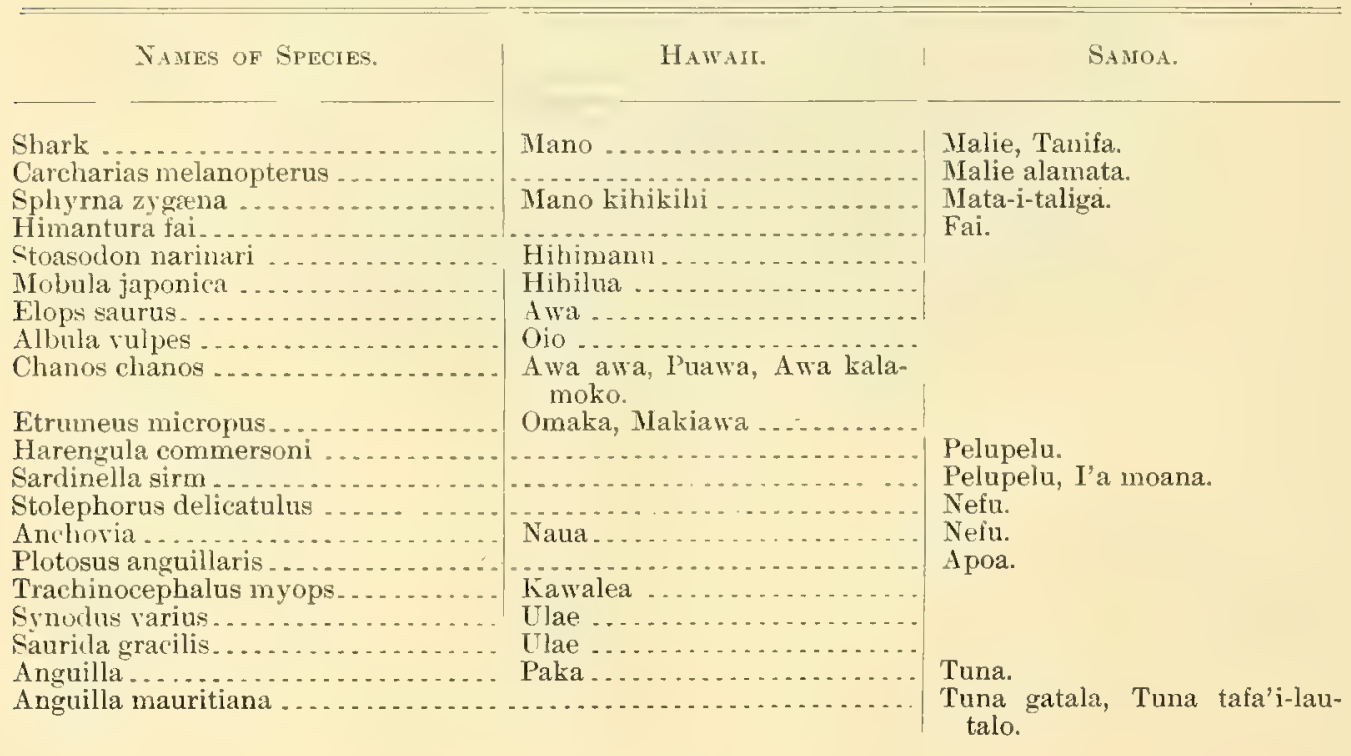


Ternacular names of fishes heurd in IIaucaii and Samoa-Continued.

Niales of Species

Anguilla megastoma

Leptocephalus marginatus.

Lejuranus semicinatus

Nuruna kailuae

(ivmuthorax

Gymnothorax flavomarginatus.....

Gymnothorax pictus .............

Gymnothorax undulatus.

Gymnothorax stellatus

Gymnothorax javanicus

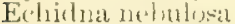

Echidna leihala

Scuticaria tigrina

Tylosurus giganteus

Tylosurus leiuroides

Athle nones lian:

Belone platyura

Hemiramphus affinis

epaperatus

Parexocotus brachypterus.

Zenarchopterus vaisiganis.

Cymilurus

Cipiluras simus

Aulostomus valentini

Wicrophis brachyurus

Atherina visila.

Liza melinoptera

Liza truscheli

Liza c:eruleomaculata

Chicnomugil chaptali.

Murvil cephalus.

Sohvrena helleri.

Sphyrena commersoni

Sphyrena obtusata.

Polydactylus pleleius

Polvdactylus sexfilis.

Lampris Iegia.

Holncentrus

Holotrachys lima

Iyrijulistio

Miripristis pualinius.

Myripristis microuthalmus

Myripristis sanguineus.

Myripristis chryseres.

Myripristis arlustus.

Myripristis nurdjan.

Holocentrus spinifer.

Holocentrus caudimaculatus

Holocentrus violaceus

Holocentrus diadema.

Holocentrus punctatissimus

Holocentrus sammara.

Lemuisoma thyrsitoides

Scomber loo.

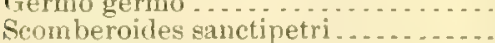

Gymnosarda pelamis

Gymnosarda alleterati.

Arinthocybium sulandri

Seriola purpuresceng.
HAWAII.

I'uhi aha................

Puhi kauila; puhi oa.......

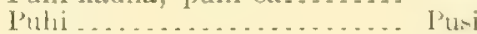

.

Puhi laumilo ............... I'usi pulepule.

Pusi pulepule.

Pusi maoa'e.

P'uhi kaya .....................

Puh leihala _. . . . . . . _. Pusi 'ai'aiuga.

Pusi solasulu.

A hasahar, luan .......... I'u.

A'u.

Mlatihlat...................

Ihe, Me'e-me'e, Puihi .......

Iheihi

P'ubiki'i...................

Taoto.

Malolo.

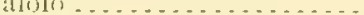

Nunti . . . . .

Tatao.

Cinila.

Afa, Fue'afa.

Aual.

Anae, 'Ana'analagi.

U'ou'oa (Wall wau)

Ana anid, dnat............

Kaku .....................

Welea.

Umiumia.

Moi ..... . . . . . . . . . .

Laukipala, Laui ala .... . . . .

Meihi.... . . . . . . . . .... Malau.

[11

11 .

(1).............

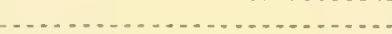

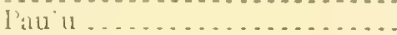

U'u

. ................................

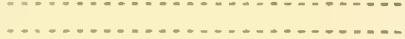

Manifiniti.

Malau toa.

Tamalau mumu, Tameno unuinsu.

Malau tifi, Malau pàuli.

Malau tusitusi, Malau piulul, Malan tui.

Malau faimu.

Malau peapea.

Hauliuli.................

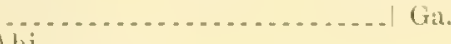

Thi $\ldots \ldots \ldots \ldots . . . . . . . . . . . .$. Lai, Papiopio .............. Lai.

Aku.........................

kawa kawa, Shua. .........

(1)1).....................

I'uakahula, Kahala.........

B. B. F. 190:5-29

\section{SAMOA.}

V.alau mamo, Mamo

Malau mataputa, Malau tea.

IIalau ula, Segusega. ria.

\author{
(1)
}

usi solasulu.

tolasulu 
Ternacular names of fishes heard in Hawaii and Samoa-Continued.

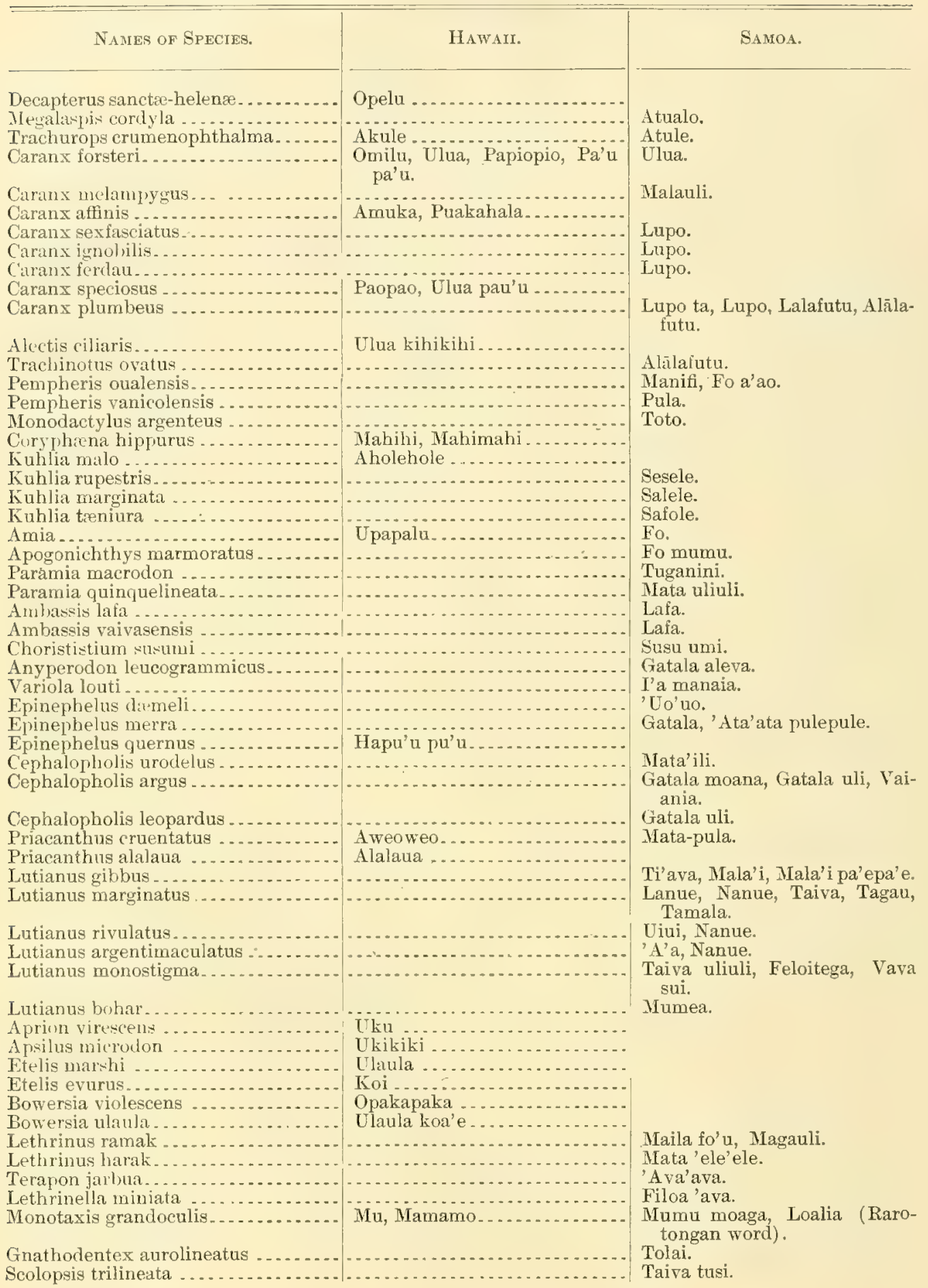


Vernacular names of fishes heard in Hawaii and Samoa-Continued.

NaMes of SPECIES.

Euelatichthys crassispinus

Plectorhynchus diagramma. .

Plectorhynchus chietodonoides

Iystema gigas.

Nyitemal argy remm

Kyphosus waigiensis.

Kyplusus furcus

Iilloides auriflamma.

Mulloides samoensis.

Pseudupeneus moana.

Pseudupeneus multifasciatus

Pseudupeneus bifasciatus

Pseudupeneus chryserydros.........

Premulutenens indicus:

Pseudupeneus barberinus .

Gecannes lativittata

Malacanthus parvipinnis

Upeneus arge

vittatus...

Cirrhitus marmoratus

Paracirrhites forsteri.

Paracirrhites arcatus.

Paracirrhites cinctus.

Chvilodactylus vittatus

Dascyllus aruanus.

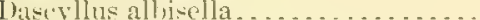

Pomacentrus albofaseiatus .........

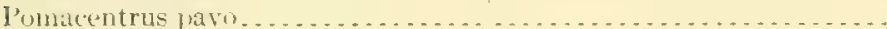

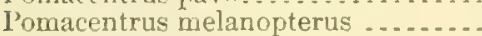

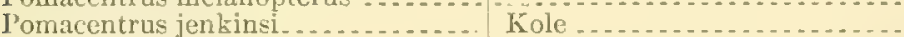

I'omacentrus vaiuli . . . . . . . . . . . . . . . . . . . . . . . . . .

Pomacentrus nigricans.

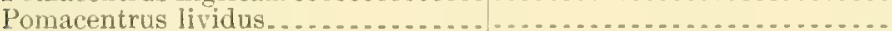

A budefiuf colestinus.

Abudefduf sordidus.

Abudefduf septemfasciatus

Abudefdui dicki

Abudeidui abiominalis

Alourlefilue lencomomus

Abudefduf uniocellatis

Abudefduf taupou.

Abudefduf metallicus.

Chromis creruleus

Chromis analis ..........................

Epibulus insidiator.

Labrichthys cyanotrenia

Anompses creruleopunctatu

Hemigymnus melapterus

Lepidaplois albotreniatus

Lepidaplois strophodes

Lepidaplois modestus.

Halichoeres centiquadrus

Halichmeres ornatissimus . . . . . .

Halichores dredalmar. -

Thalassoma

A' awa..................
HAWAII.

SAMTOA.

\section{Misi misi}

'Ava'ava moana.

I'a mai moana.

Matu loa.

Matu.

Matu mutu, Unue.

Manuarurs . . . . . . . . . . . . .

Vete, Ua oa.

I'a sina, Alolu.

Moaga, Moana, Maga, MLana faiava.

Matalau, Uliuli, Maga.

Matalan.

Ta'uleia, Lailui.

Ta'uleia.

Gatamani.

Weke pueo, Weke pahulu ....

Weke ula...................

O'opukai'a, po'opa'a ......... Potati

Pilikoa, Hilupilikoa ..........

Pilikoa,Oopukabaibai, po'opa'a

Kikakapu ...................

Ianm,

Ulavãpua.

Taumon.

I'u sina, Tu'u'u.

Vaiuli.

Tu'u'u.

Tu'u'u sue uli, I'u sina.

Fili mana.

Ulavāpua.

Alala saga; Mutu.

Tu'u'u.

I'u samasama.

Tu'u’u.

Taupou.

Vaiuli sama, Taupou.

Pipi.

Teatea, Mamo, I'a lanu-moana.

I'a lanu-moana.

Lapega, Gintu-ume.

Sugale uliuli.

sugille.

Sugale lupe.

Paumutu, Alati moana, Sugale aloa, Sugale uli, Tagitagi.
A' awa.................

A' awa..............................

....................................

La11 ................................

Ohua pa'awela

Hinalea................ Fataga loa.

sugale. 
Temacular names of fishes heard in Hawaii and Samoa-Continued.

Nayes of Species.

Thalassoma purpureum.

Thalassoma fuscun.

Thalassoma duperreyi

Thalassoma clorsale.

Thalassoma ballieui

Coris schauinslandi

Julis lepromis

Julivgaimardi

Julis pulcherrima

Novaculichthrs teniurus

Macropharyngodon geoffroyi

Gomphosus tricolor

Cheilio inermis. .

Cheilinus fasciatus. -

Cheilinus digrammus .

Cheilinus hexagoutus.

Cheinus hexagonatu.

Thalliurus chlorurus. .

Pseudocheilinus hexatrenia.

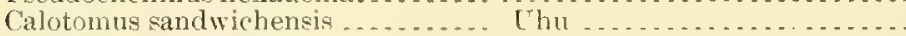

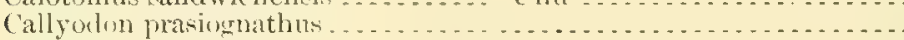

Callyodon maoricus. . . . . . . . . . . . . . . . . . . . . . . . . .

Callyodon pyrrhurus...

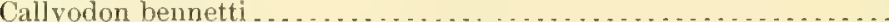

Callyodon ruberrimus

Callyodon erythrodon

Callyodon balinensis.

Callyodon oviceps

Callyodon zonularis

Callyodon bataviensis.

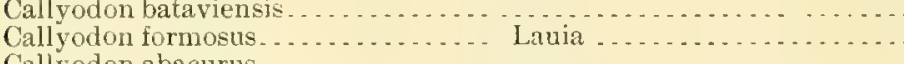

Callyodon abacurus . . . . . . . . . . . . . . . . . . . .

Callyodon gilberti . . . . . . . . . . . Panuhunuhu . . . . . . . . . .

Callyodon latax . . . . . . . . . . . . . . . . . . . . . . . . . . . . .

Callyodon palnea... . . . . . . . . Palukaluka . . . . . . . . . .

Callyodon jordani . . . . . . . . . . . . . . . . . . . . . . . .

Callyodon ahula ... . . . . . . . . Uhu uliuli, Panuhunuhu ...

Callyodon ultranarinus. . . . . . . . . . . . . . . . . . . . . .

Callyodon lazulinus.

Megaprotodon trifascialis

Chretodon setifer

(19.2.

Chetorlon eitrinellus .......... Kikakapu _............

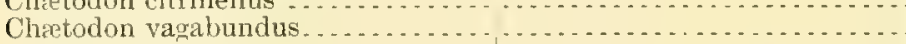

Chrotodon reticulatus

Chetodon trifasciatus.

Chretodon lunula .

Chætodon unimaculatus

Chretodon melannotus

Chetodon ornatissimus

Chietorlon mertensi.

Chretodon pelewensis.

Chretodon ephippium.

Holacanthus .

Holacanthus diacanthus . . . . . . . . . . . . . . . . . . . . . .

Holacanthus bicolor. .

Holacanthus flavissimus

Holacanthus bispinosus.

Heniochus acuminatus.
SAMOA.

Sugale.

Sngale sei, Sugale fa'a 'ele'ele, sugale pulepule.

Molemole.

Sugale.

Masamie, Moai.

Lalafi pulepule.

Sugale, Lalati.

Lalafi, Sugale matamumu.

Sugale gasufi.

l'a tusitusi.

Amasapupena.

Moalefuga.

Fuga mumu.

Amasapupema.

Fuga ulapo.

Fuga 'avasai.

F'uga pa'i, Fuga pa'ipa'i, Fuga mea.

Fuga uli.

Fuga mea.

Tapoli, Laea mumu.

Fuga meamea.

Laea pulepule, Laea mumu.

Galo, Laea galo.

Fuga galu-moana.

Fugausi.

Mutu uli.

Si'u, Tifitifi sama.

Tifitifi uli, Tifitifi lauif, Manini.

Tifitifi mata-ume, Samasanı.

Tifitifi a'o, Matagi pulepule.

Tifititi tala.

Tintifi laumea.

Tifititi pulepule, Tifitifi san: sama.

Tifitifi pulepule pa'ipa'i.

Tifitif a'au.

Tıfitifi pa'ipa'i.

Tifitifi i'u sama.

Tifitutila, Tifitifi taiona, Tifititi tusi.

Alamu.

Aimeo, Alamu.

Ulapua.

Leura Aimeo.

Tu' $u^{7} u$ pulepule mumu.

Lamlaufau. 
Vernacular names of fishes heard in IIavaii and Samoa-Continned.

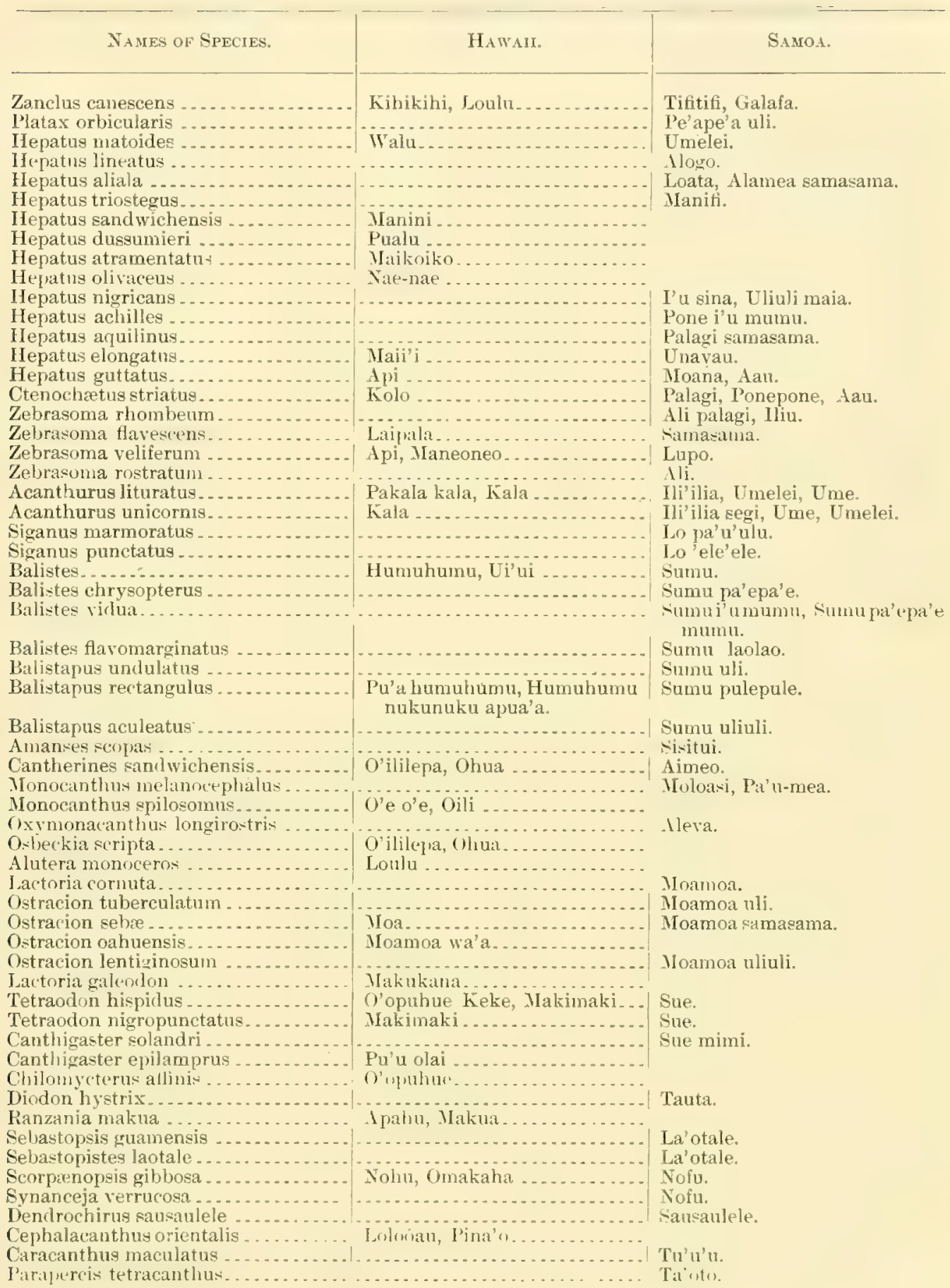


Vernacular names of fishes heard in Hawaii and Samoa-Continued.

\begin{tabular}{|c|c|c|}
\hline NAMES OF SPECIES. & HAWAII. & SAMOA. \\
\hline 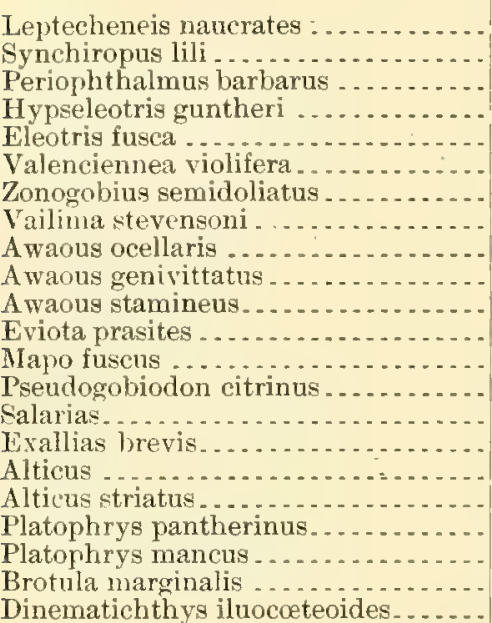 & 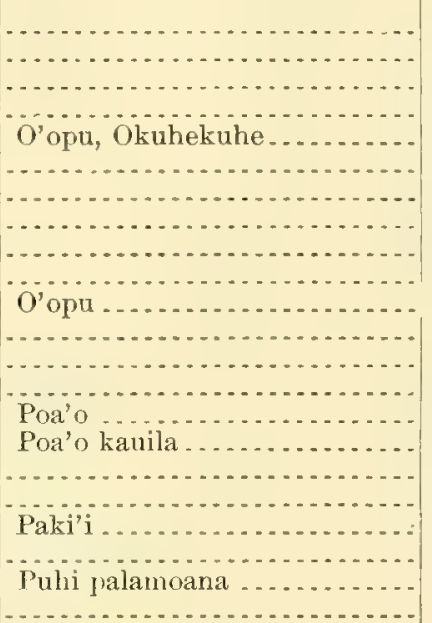 & $\begin{array}{l}\text { Talitaliuli. } \\
\text { Lili. } \\
\text { Mano'o, Talae. } \\
\text { Malu vai. } \\
\text { Pa'ofu. } \\
\text { Ta'oto. } \\
\text { Mano'o. } \\
\text { Pa'ofu. } \\
\text { Mano'o, I'a pala. } \\
\text { Teli. } \\
\text { Lili. } \\
\text { Pa'ofu. } \\
\text { Ulitui. } \\
\text { Mano'o. } \\
\text { Mano'o gatala. } \\
\text { Mano'o. } \\
\text { Mano'o a'au. } \\
\text { Ali. } \\
\text { Ali. } \\
\text { Tapotopoto. }\end{array}$ \\
\hline
\end{tabular}

GLOSSARY OF PRINCIPAI, WORDS COMPOSING NATIVE NAMES OF SAMOAN FISHES.

By W. E. SAFFORD.

The following vocabulary, based chiefly on notes taken in Samoa during the months of February, March, April, and May, 1888, was obtained from native fishermen, all of whom showed the greatest interest in telling me of the fishes of the reef, the ocean, and the stream, distinguishing those which were best for food from those which were unwholesome or poisonous, and warning me against those armed with stinging spines and those lurking in holes in the coral which inflict severe wounds with their sharp teeth. One of the most interesting lists I secured from an old native who was fishing for sharks from a canoe lying under our stern at Leone Bay. This man would attract the attention of a shark by shaking in the water a number of half shells of cocoanuts strung loosely on a stick, rim to rin. The shark would approach to within a few fathoms of the canoe to find out the cause of the commotion; then the native would throw out a bait (māumu), consisting of a fish's head attached to a string, and draw it gently toward the canoe, the shark following. When the shark was within reach, the fisherman would seize a heavy club he had in readiness and strike the shark a violent blow on the head to stun it, then slip a noose (maea) over its head and, holding it alongside the canoe, dispatch it with a knife. This was to me an example of the most primitive method of fishing. The rattle he called tui-ipu (string of cups); the shark was one of the kind called malie. The fisherman told me of a larger kind, called tanifa, which was known to attack men while swimming, and as he found an interested listener he followed his account with a list of the principal fishes of Samoa. The names I wrote down at once, later correcting the orthography with the aid of Dr. George Pratt's excellent dictionary 
of the Samoan language. Afterwards I supplemented my list by additional information obtained at native feasts and from fishermen returning from the reefs with their spears and nets and from their exciting chase for bonitos in their swift canoes provided with poles and trolling lines. Of course I could only record the native names, without attempting to do more than determine the genera or families of the most conspicuous kinds. The present work of Doctor Jordan makes it possible for the first time to identify the species of nearly all of the fishes in my list.

In this list there are certain names marked with an interrogation point. These I was unable to check with my list or to explain in a satisfactory manner. Some of the names of fishes are primitive, like atu, pusi, fai, and are widespread throughout Polynesia; others have a definite significance, such as "a sina, white fish; "u-samasama, yellow-tail; and others, like the long-beaked aleva, take their names from those of birds or other natural objects. I have included also the principal adjectives, verbs, and nouns from which compound names of fishes have been formed.

'a'a, $n$. A snapper, Lutianus argentimaculatus.

aau, $n$. A name applied to two laucet-fishes, Hepatus guttatus and Clenochaetus striatus. See au, a sharp fish spine, a needle.

a'au, $n$. The coral reef; chan (New Zealand), the border of land near the sea.

afa, $n$. A cord, or sinnet, braided from cocoanut-fiber, a string.

afa'afa, $n$. Name applied to a thread-fin, Polydactylus plebeius, a fish with its pectoral fins modified into string-like organs of touch.

afo, $n$. A fishing line. Ho (Hawail and Tahiti), a line or cord.

afolu, $n$. Name applied to a surmullet, Iulloides samoensis, a fish with thread-like barbels growing from the throat.

ago, v. To mark a pattern for tattooing; to mark with charcoal.

aimeo, $n$. Name applied to file-fishes of the genera Holacanthus and Cantherines.

alala, $n$. Plates or scales of tortoise-shell.

alala-saga, $n$. Name applied to a demoiselle-fish (Abudefduf septemfasciatus) with tortoise-shell-like markings.

alālafutu, n. Name applied to a pompano, Trachinotus oratus, and to Caranx plumbeus, fish having the first rays of the dorsal fin more or less tilamentous.

alamu (alamea?), n. Name applied to species of Holacanthus.

alamea, $n$. A many-rayed sea-urchin.

alamea, $n$. A surgeon-fish, Hepatus aliala.

alati-moana(?), n. Hemigymnus melaplerus.

aleva, $n$. A little file-fish with beak-like snout, Oxymonacunthus longirostris.

aleva, $n$. Name of a bird (Eudynumis tuitensis).

ali, n. A flounder (Platophrys); name applied also to a flat fish (Zebrasoma) with a superficial resemblance to a flounder.

ali-palagi, n. Zebrasoma rhombeum.

aloalo, $n$. The lagoon between the beach and the reef.

alogo, $\imath$. A beautifully marked surgeon-tish, Hepatus lineatus.

alomātū, adj. Partially dry.

'analagi, 'ana'analagi, $n$. A mullet-like, spotted fish, Liza cxmeleomaculata.

anaana (Tahiti), adj. Beaming, shining; kanakana (Paumutu), bright, radiant; kuna (New Zealand), the eyeballs.

'anae, n. The name of a fish (liza sp.); kanae (New Zealand), the gray mullet; anae (Taliti) a mullet; anae (Hawaii), a mullet.

anefe, $n$. Name applied to young of $l o$ (Siganus sp.).

'ao, adj. Small, slender.

apoa, $n$. An eel-like fish with stinging dorsal spine, Plotosus anguilluris. 
apo (Hawaii), $v$. To catch, to hook into; apoapo (Samoa), to poise a spear.

'ata'ata, n. A name applied to several fishes of the genera Epinephelus, Cephalopholis, and Leiurus.

ata'ata (Ilawaii), n. The falling off of the scarf skin after drinking awa; akaa (Hawaii), not cohering;

atua (Tahiti), split up into patches or areoles not adhering. Possibly the name applied to the sea-basses or groupers on account of their spotted coloration.

'ata'ata pulepule, $n$. A sea-bass, Exinephelus merru.

'ata'ata uli, "t. Dark-colored 'ata' ata.

atu, $n$. A bonito (Gymnosarda pelamis), Aku (Hawaii), a bonito.

atualo, n. A bonito, Negalaspis cordyla.

atule, $n$. The "goggle-eyed jack," or horse mackerel, Trachurops cmemenophthalma. Akuke (Hawaii); aturere (New Zealand), a highly prized fish.

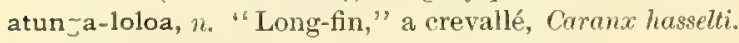

atunga, $n$. The fin of a fish.

au, n. A fish-spine, a needle.

a'u, n. Yame applied to hound-fishes, Tylosurus giganteus, etc.

aua, $n$. Name applied to a young 'ance, Liza troscheli.

ava, $n$. The name of a very scaly fish.

'ava 'ava, n. Terapon jarbua. Kawu (New Lealand), name of a traditional being which hmug like a veil upon the forehead of the eel-god, Tuna.

'ava 'ava moana, $x$. Pleclorhynchus diagramma.

'avasai, adj. Perhaps 'avasia, burnt by the sun.

'ele'ele, n. Siganus punctatus. 'Ele (Samoa) rust, red earth; ereere (Tahiti), black, dark, also blue; cleele (Hawaii) dark-colored-black, blue.

fa'a moana, adj. Pelagic, a name applied to fish found in schools far out from shore. Moana (Samoa), the ocean; moana (Hawaii, New Zealand), the ocean.

fai, n. A sting-ray, Himantura fai. Whai (New Zealand), a sting-ray; fai (Tahiti), a sting-ray; vai (Fiji), a sting-ray.

faiumu, $x$. To cook an oven of food.

fataga loa, n. Hulichneres disdalma.

feío, adj. Light yellow.

fili, $n$. Sinnet, braided cocoanut fiber; fil mama, a ring braided of cocoanut fiber.

filoa, n. Lethrinella miniata.

fo, $n$. Name applied to fishes of the genus Amia and related genera.

fo $\mathrm{m} \overline{\mathrm{u}} \mathrm{m} \overline{\mathrm{u}}, n$. Apogonichthys marmoratus.

foa'ao, n. Pempheris oualensis.

fui, n. A collection or cluster.

fuifui-atu, $n$. A school of bonito.

fuga, $n$. Name applied to parrot-fishes (Callyodontidæe).

fuga 'avasai, $n$. Callyodon erythrodon.

fuga galu-moana, $n$. Callyodon ultramarinus.

fuga mea, $n$. Callyodon balinensis; $C$. zonularis.

fuga meamea, $n$. Callyorlon obscurus.

fuga $\mathbf{m u} \overline{\mathbf{m}} \overline{\mathbf{u}}, n$. Callyodon pyrrhurus.

fuga pa'ipa'i, n. Callyondon bulinensis; C. oviceps.

fuga ulapo, n. Callyodon ruberrimus.

fuga usi, n. Callyodon oviceps.

ga, n. A mackerel, Scomber loo.

galo, n. A full-grown usiusi.

galo, n. Callyodon jordani.

galu, $n$. Wave. Galu-tai (Samoa), wave-of-the-sea; galu-moana (Samoa), wave of-the-ocean; gagalu, to be rippled, as the water by a fish swimming near the surface.

galu-moana, adj. Mispronunciation of lamu-moana, sea-blue.

galafa (?), n. Zanclus canescens.

gata, n. A snake. Ngata (Tonga, Fiji), a snake; ngata (New Zealand), a snail or slug. 
gaia-sami, n. Oceunops lativittata. Gata-sami (Samoa), sea-snake; sami (Samoa), the sea, salt water.

(Perhaps matasami, said to mean eye of the sea.)

gatala, adj. Name applied to a number of spotted fishes, especially sea-basses of the genera El vinephelus and Cephatopholis. Naka (Hawaii), to split or break open, as the ground in a drought; nakaka (Hawaii), full of cracks; ngatata (New Zealand), full of cracks, as skin which is chapped.

gatala, n. Eninephetis merru.

gatala aleva, n. Anyperodon leucogrammicus.

gatala moana, n. Cephalopholis argus.

gatala uli, n. Cephlalopholis leopardus; C. argus.

gutu-umi, n. Epibulus insidiator. Gutu (Samoa), mouth, snout; umi, drawn out, elongated.

i'a, n. Fish; the general name in Samoa for all fishes except the bonito. Ika (New Zealand, Tonga, Marquesas, Fiji), the general name for fish; ikan (Malay); guihan (Guam).

i'a lanu-moana, n. "Fish color-of-the-ocean," a name applied to Chromis ceruleus and C. analis.

i'a mai-moana, $n$. A name applied to Plectorhynchus chatodonoides.

i'a pala, n. Awaous ocellaris.

i'a sina, n. Mulloides samoensis.

i'a tusitusi, n. Pseudocheilinus hexutrnia.

i'a ui, $n$. Name applied to a large eel.

i'a vai, $n$. A name sometimes applied to fresh-water eels.

ifigi (?), n. Halichores centiquadrus.

ila, ilaila, adj. Spotted, or marked.

'ili, $n$. A rasp or file; a saw.

'ili'ilia, n. Acanthurus lituratus (juv.); A. unicornis.

ili, $n$. A fan.

iliū (ili-i'u), n. Zebrasoma rhombeum.

inato, n. Kuhlia rupestris.

ise, $n$. A half-beak (Iemiramphus) and Belone platyura. The (New Zealand), a gar-fish or half-beak; ihe (Hawaii, Tahiti), a spear; ihe (Marquesas), a fish with a long beak.

i'u, n. The tail of a fish; the end of anything. Hiku (New Zealand), the tail of a fish or reptile; ik $u$ (Tonga), the tail of animals; ikur (Malay), the tail of animals, the train of a garment; hiu (Hawaii), the tail of a fish.

i'u-mumu, adj. Red-tailed.

i'u-samasama, $n$. Yellow-tail, Abudefduf lacrymatus.

i'u-sina, n. White-tail, Pomacentrus melanopterus.

lae, $n$. The part between the lip and the chin without hair. Lae (Hawaii), any projecting part; the forehearl.

laea, 2 . Name applied to several fishes of the genus Callyodon.

laea galo, n. Cellyodon jordani.

laea mumu, $n$. Callyodon bataviensis and $C$. latax.

laea pulepule, $n$. Callyodon latax.

lai, n. A mackerel, Scomberoides sanctipetri.

lailai (?), n. I'seudipeneus indims.

laitiiti, adj. Small.

lalafi, $n$. Cheilinus diagrammus. Lafi (Samoa), to hide away.

lalafi pulepule, $n$, Cheilinus fasciatus.

lālāfutu, n. Curanx armatus.

lanifi, adj. Thin. (See manifi.)

lanu, n. Color.

lanu-moana, alj. Sea-color, sky-blue.

laolao, adj. Simooth.

laotale, n. Fishes with poisonous spines, Sebastopsis quamensis, and Sebastapistes lantate.

lau, n. I leaf. Lau-taro, a taro leaf; lau-ulu, hair (foljage) of the head.

laulaufau, $n$. IIeniochus permutatus. 
lele, $v$. To fly.

lega, adj. Yellow, turmeric.

lega, n. A yellow fish, Holocanthus flavissimus.

lili, $n$. Synchiropus liti.

lo, $n$. Name applied to several fishes of the genus Siganus.

lo-mea, $n$. Name applied to young fry of $l o$, loloa, and anefe (Siganus species). In Guam these are caught in great quantities and preserved by the natives, who call them mañaha.

lo pa'u'ulu, $n$. Siganus marmoratus. Pa'u-'ulu signifies "rind of a bread-fruit," which is composed of a number of areoles.

loa, adj. Long.

loata, n. Hepatus aliala.

logouli, $n$. Name applied to the maomao when it is changing color to become a pala' ia.

loloa, $n$. Name of a fish (Siganus).

lese pule (?), n. Crsio crrulaureus.

lupa, n. Zebrasoma veliferum.

lupe, $a d j$. Sometimes incorrectly used for pule (spotted).

lupo, n. Caranx ignobilis; C. sexfasciatus.

lupo tã, $n$. A large lupo.

mago, n. Name for one kind of shark. Mango (New Zealand), mano (Hawaii), mao (Tahiti), names for sharks.

mai, prep. From; mai-moana (Samoa), from the ocean, pelagic.

mala'i, n. A snapper (Lutianus sp.).

mala'i pa'epa'e, $n$. Lutianus gibbus.

malau, $n$. Name applied to squirrel-fishes (Iyripristis and Holocentmis).

malau faiumu, $n$. A rose-colored fish with silver lines, Holocentrus punctatissimusk, called also malau mataprea'a.

malau mataputa, $n$. A squirrel-fish, Myripristis microphthalmus, called also malau tea.

malau tea, $n$. A squirrel-fish, Nyripristis microphthalmus.

malau vai, $n$. A fish entering fresh-water streams, Hypseleotris guntheri.

malauli, n. A cavally, Caranx melampygus.

malie, n. General name applied to sharks.

malie alamata, n. Carcharias melanopterus. Malie alo (belly-shark), name applied to a shark found inside the lagoon; malie tua (back shark), another kind round outside the lagoon.

mālolo, n. General name for flying-fishes (Cypsilurus sp.). Malolo (Hawaii), name for flying-fishes (Parexocotus, etc.).

mamo, n. Name applied to Chromis cxruleus, Myripristis pralinius and Dascyllus aruanus. They feed on coral reefs.

mānaia, adj. Handsome; a dandy, or beau.

manifi, manifinifi, adj. Thin. A name applied to Hepatus triostegus, Holocentrus spinifer, Pernpheris oualensis, and Pseudupeneus sp. Nihinihi (Hawaii), anything standing on the edge, a sharp ridge. manini, n. The name of a fish, Hepatus triostegus.

mano'o, $n$. Name applied to blennies, or to goby-like fishes frequenting stones along the edge of the sea. mano'o, n. Awaous ocellaris; Alticus alboguttatatus.

mano'o a'au, $n$. Alticus striatus.

mano'o gatala, $n$. Salarias brevis.

maomao, $n$. Name applied to young pala'ia. .

māoa'e, $n$. Gymnothorax javanicus.

masamie (?), n. Cheilio inermis.

mata, $n$. Eyes; face; appearance.

mata-'ele'ele, $n$. Lethrinus harak.

mata-i-taliga, $n$. Name applied in Samoa to the hammer-head shark, Sphyrna zygrna, signifying "eyes-in-ears."

mata-pula, $n$. Name applied to a red-and-white mottled fish, Priacanthus cruentatus, having its iris marked with bright red blotches. (See pula.)

matagi pulepule, $n$. Chrtodon reticulatus. 
matagi, n., v. Wind; to blow.

matalau, $n$. Pseudupeneus chrysemydros. Name probably derived from barbels, called lau, like lau ulu. hair of the head.

matalau uliuli, n. Pseudupeneus bifasciatus.

matu, $n$. Tystrema argyreum.

matu loa, $n$. Iystrema gigas.

matu mutu, $n$. Kyphosus waigiensis.

mea, meamea, adj. Young; an infant.

mea, meamea, adj. Yellowish brown, brownish; mea. (Tahiti), to be red, as the skin after eating fish. mea-sili, adj. Exceedingly young.

mimi, $v$. To urinate.

misimisi, n. Pleclorhynchus crassispinus.

misimisi, $v$. To smack the lips.

moai (?), n. Cheilio inermis.

moaga, n. Pseudupeneus sp.

moaga faiava, $n$. Pseudupeneus moana.

moamoa, n. Lactoria comula, a horned trunk-fish. In Hawaii moamoa signifies a sharp point or spur at the stern of a canoe; the word may possibly be derived from moa (cock), as many of the Ostraciide have spurs.

moamoa samasama, n. Ostracion sebæ* (See samasama.)

moamoa uli, n. Ostracion tuberculatum.

moamoa uliuli, $n$. Tetraodon hispidus.

moana, $n$. Hepatus guttatus.

moana, $n$. The ocean.

moana, adj. Ocean-blue. Lanu-moana, color of the ocean, sea-blue, sky-blue.

molemole, $n$. Novaculichthys timiums.

moloasi, $n$. Monacanthus melanocephalus.

moloasi, $n$. A toadstool; fungus.

$\mathrm{mu}, v$. To glow, to become red.

mumea, n. Lutianus bohar.

mumu, $n$. To be red or ruddy, a sign of beauty.

mumu moana, $n$. Monotaxis grandoculis.

mutu, n. Holotrachys lima, a red squirrel-fish.

mutu, adj. to be cut off, blunt, truncated.

mutu uli, n. Megaprotodon trifasciatus.

nanue, $n$. Name applied to several species of snappers (Lutianus species). The word is sometimes pronounced lanue or nganue by the Samoans, who are apt to be careless in their use of consonants.

refu, n. A name applied to small fish swimming in shoals, like anchovies. The name probably has the same origin as nefunefu (Samoa), to be turbid; nehunehu (Hawaii), a multitude; nehu-tci (New Zealand), sea-spray.

nofu, $n$. Name applied to toad-fishes, Scorprenopsis gibbosa, and Synanceja verrucosa. Nohu (Mangaia), the name of a fish having poisonous spines; nufu (Guam), a toad-fish, Synanceja vermucosa.

pa'e, pa'epa'e, adj. White; light-colored.

paipai (New Zealand), $n$. A cutaneous disease; paipai (Hawaii), to peel off, as the bark of a tree or the skin of an animal.

pa'ipa'i, $n$. The name of a fish. Pa'ipa' $i$ (Samoa), useless, to no purpose. In many cases $p a^{\prime} i p a^{\prime} i$ is probably a corruption of pa'epa'e, white.

pala, n. Mud; parapara (New Zealand), mud, dirt.

pala 'ia, $n$. The name of a fisb which is called maomao when very young and logouli when changing to the adult stage.

palagi, $n$. A name applied to Ctenochactus striatus.

palagi samasama, $n$. Hepatus aquilinus.

pa'ofu, $n$. Name applied to Eleotris fusca, Mapo fuscus, and other gobies; oopu in Hawai.

pa'u, $n$. Skin, rind, bark.

pa'u 'ulu, $n$. The rind of the breadiruit. A name applied to Siganus marmoratus. 
pa'u-mai-moana, n. A poetic name applied to the bonito. pa'u-masunu, n. A poetic name applied to the bonito. pa'u-mea, 22. Monacanthus melanocephalus.

pāuli, artj. Purple.

paumutu (?), n. Hemigymnus melaptems.

pe'ape'a, n. A bat; a swift (bird).

pe'ape'a uli, $n$. Platax orbicularis.

pela, n. A name applied to the filoa (Lethrinello miniata).

pelupelu, n. Harengula commersoni.

pine, $n$. A shoal of young fishes.

pipi, n. Lbudefduf metallicus.

pipine, $n$. The name of a fish.

poi, $n$. The name of a small fish.

pone, $n$. A name applied to surgeon-fishes, Hepatus species.

pone i'u mumu, n. Ilequatus achilles.

potati (?), n. Cirrhitus marmoratus.

pua'a, n. A hog; mata-pua'a, hog-faced.

pula, adj. Shining, glowing. Pura (Tahiti), a spark of fire; pura (Mangaia), having anything like dust in the eyes.

pulepule, adj. Spotted; striped with various colors. Pulepule (Hawaii), spotted, speckled, of various colors; bulebule (Tonga), spotted.

pusi, $n$. General name for sea-eels (Gymnothorax, Echidna, Leptocephalus). Puhi (Hawaii), a sea-eel; puhi (New Zealand), a large eel; puhi (Tahiti), an eel; puhi (Mangaia), a sea-eel, which bites severely.

pusi 'ai'aiuga, n. Echidna leihala.

pusi gatala, n. Gymnothorax pictus; G. flavomarginatus.

pusi pulepule, n. Gymnothorax undulatus.

pusi sulusulu, $n$. Scuticaria tigrina.

pusi tafa'ilautalo, $n$. Same as tuna tafa' ilautalo, an eel.

safole, $n$. A fish found in salt water, Kuhlia tæmiura.

saga, n. Flipper of a turtle.

sama, samasama, adj. Yellow.

samasama, n. Zebrasoma flavescens.

sami, $n$. The sea; salt water. Gata sami ("sea-snake"), Oceanops lativittata.

sausau, $v$. To flutter the wings.

sausaulele, $n$. "To fly fluttering," Dendrochirus sausolele.

sega, $n$. A paroquet kept in captivity for the sake of its red feathers.

segasega, n. Holocentrus ruber.

segi, $v$. To burn a scar as a beauty-spot.

segisegi, n. Acanthurus unicornis, a species having brightly colored spots about the spurs on the tail. sele, $n$. A bamboo knife. Hele (Tonga), a bamboo knife; sele (Fiji), a bamboo knife.

sesele, $n$. A perch-like fish found in fresh water, Kuhlia marginata; when full grown called inato.

sila, $n$. Extremity of rainbow.

si'u, n. The name of a fish.

si'u muti, $n$. The name of the lalafi (Cheilinus diagrammus) when full-grown.

siuli (?), n. Chatodon setifer.

sisi, $n$. Eyes of a cocoanut.

sisitui, $n$. Amanses scopas, a file-fish with spines on each side of tail.

sola, $v$. To run away; to escape.

solasulusulu, v. To flee and hide away.

soloalalo, n. One kind of sea-eel.

sue, adj. To be puffed out; to project, as a fat belly.

sue, n. A name applied to puffers (Tetraodon).

sue mimi, $n$. "Urinating puffer," Canthigaster solandri. 
sugale, $n$. General name applied to wrasse-fishes of the genera Anampscs, Tialassoma, and Cheilnus; meaning choice.

sugale, n. Gomphosus tricolor; Thalassomä fuscum; Cheilinns diagrammus.

sugale aloa, n. Ilemigymnus melapterus.

sugale 'ele (?), n. Thalassoma dorsale.

sugale gasufi, $n$. Cheilinus chlorums.

sugale sa'a'ele'ele, $n$. Thalassoma dorsale.

sugale lupe (pule?), n. Anampses ciruleopunctatus, a blue-spotted wrasse.

sugale mata-mumu, $n$. Cheilinus trilobatus.

sugale pulepule, $n$. Thalassoma dorsale.

sugale uliuli, n. Labrichthys cyanotsmia.

sulu, $x$. To take refuge in.

sulusulu, $r$. 'To hunt with a torch.

sumu, $\imath$. To stick into the body like a spear.

sumu, sumusumu, $n$. Name applied to trunk-fishes or trigger-lishes (Balistes).

sumu i'u-mumu, $n$. Balistes vidna.

sumu-pa'epa'e, n. Balistapuis chrysopterus.

suma-pa'epa'e mumu, n. Balistes flaromarginutus.

sumu pulepule, $n$. Balistapus rectangulus.

sumu uli, $n$. Balistapus aculeatus.

sumu uliuli, n. Balistapus aculeatus.

susu, n. Nipples, teats.

susu umi, $n$. Chorististium susumi.

$\mathrm{t} \overline{\mathbf{a}}, n$. To jump a somersault. Lupo $t a$, Caranx plumbeus.

tafa'i, $n$. To break off, as a leaf.

tagi, $v$. To weep; to mourn.

tagitagi, n. I!emigymnus melapterus.

tagau, n. Lutianns marginatus.

tai, $n$. Sea, salt-water.

täiva, $n$. Name applied to a snapper, Lutianus marginatus, and to Scolopsis trilineatc.

tāiva uliuli, $n$. Lutianus monostigma.

ta'i-ono, adj. Six by six; by sixes; six on a side.

tala, $n$. The spur of a cock, barb of a spear.

talae, n. Periophthalmus barbarus, air-breathing fish found in mangrove swamps; mangrove-hopper.

tali, $v$. To wait for; to stand by to do something.

taliuli, $v$. To steer, without assisting to paddle.

talitaliuli, $n$. One who follows in the train of another; one who waits about for food. Yame applied to the pilot-fish, Leptecheneis nuucrates.

talinga, $n$. Ear. Turinga (New Zealand), ear; dalinga (Fiji), ear; talingu, tainga (Malay), ear; tulangu (Guam), ear.

tamala, $n$. Name applied to young tain.

tanifa, n. A large man-eating shark (Carcharias). Taniwha (New Zealand), a water-monster; danicu (Fiji), one kind of shark.

tao, n. A spear. Tao (Polynesia generally), a snear; kao (Høwaii), a spear or javelin; to throw or dart a spear.

taotao, n. Microphis brachyurus.

tao-tito, $n$. Aulostomus valentini. Tito, to fall headlong.

taoto, n. Parapercis tetracinctus; Zennrchoptemes raisiganis; Talenciennea violifera.

ta'uleia, n. Pseudupencus indicus; 1 's. barberinus.

taupou, $n$. A virgin; the princess of a village. A name applied to several demoiselle-fishes, especially. to Pomacentrus paro, dbudefduf unincellatus, and sbudefduf taupou.

tea, teatea, tetea, adj. White, light-colored, albino. Kea (IIwaii), white.

tega, $n$. Thigh; upper arm.

ti'ava, n. Lutianus gibbus. 
tifi, v. To adorn. Kihi (Hawaii), the outside corner or projection of a thing, the apex of a leaf; kihikihi (Hawaii), the curving of the horns of the moon, the curving of the wings of a bird; mano kinikihi (Hawaii), the hammer-head shark.

tifitifi, $n$. General name for chrtodonts or butterfly-fishes and swall fishes resembling them. tifitifi a'au pulepule, $n$. Chælodon omatissimus.

tifitifi 'ao, n. Chactodon reticulatus.

tifitifi laumea, n. Chrtodon lunula.

tifitifi tala, $n$. Chretodon trifusciatus.

tifitifi, $n$. Zanclus canescens.

tifitifi ila, $n$. Chatodon ephippium. Ila, a birthmark on the skin.

tifitifi i'u-sama, n. Chrotodon pelewensis.

tifitifi lauif, 2 . Chretodon citrinellus.

tifitifi magina (?), n. Chatodon citrinellus.

tifitifi mata-niu, n. Chxtodon vagabundus.

tifitifi paipai, n. Chxtodon mertensi.

tifitifi pulepule pa'ipa'i, n. Chxtodon melannotus.

tifitif pulepule samasama, $n$. Chætodon unimaculatus.

tifitifi sama, $n$. Chxtodon setifer.

tifitifi taiono, $n$. Chxtodon ephippium.

tifitifi tusa, n. Chetodon ephippium.

tifitifii uli, n. Chrotodon citrinellus.

tito, n. Aulostomus ralentini, a trumpet-fish; tito (Samoa), to dart or fall headlong.

tolai, $n$. A name of two birds, Petroicn pusilla and Nyzomela nigriventris.

tolai, $n$. Gnathodontex aurolineatus.

toto, n. Monodactylus argenteus.

tui, $v$. A spine; to thread a needle; to run a string through.

tuna, n. An eel, Anguilla sp. Tuna (New Zealand), an eel; tuna (Tonga), an eel; duna (Fiji), an eel; tona (Madagascar), the largest kind of eel.

tuna gatala, $n$. Anguilla mauritiana.

tuna iafa'ilautalo, $n$. See pusi tafa'ilautalo.

tusi, $n$. Scolopsis trilineata.

tusitusi, $n$. Striped. Tusi, to mark.

tusa, $n$. To be equal; the same on both sides.

tu'u'u, $n$. Name applied to fish with a broad, compressed body, as Pomacentrus nigricans, Abudefduf

leucopomus, and Abudefduf dicki.

tu'u'u pulepule mumu, $n$. Holocanthus bispinosus.

uga vai, n. Hepatus elongatus.

ui, adj. Dark colored; ili-ui, dark-skinned

ui, $v$. To pass along.

uisila, n. Name applied to Atherina sp.

'ula, 'ula 'ula, ad). Red. Kula (Tonga), red; kura (New Zealand), red; ura (Tahiti), reä feathers; ulaula (Hawaii), red; kulakula (Fiji), red.

ulavăpua, lava-ula-pua, vala-ula-pua, adj. Black in the fore and hind parts and white in the middle. ulavāpua, n. Pomacentrus albofasciatus; Abudefduf sordidus.

ula pua, n. Holocanthus bicolor.

uli, uliuli, adj. Dark blue, black.

uli, v. To steer.

ulitui, $n$. Pseudogobiodon citrinus.

uliuli (usiusi?), n. Megaprotodon trifascialis.

ulu, $n$. Head.

'ulu, n. Breadfruit.

ulua, n. Caranx forsteri.

ume, $n$. A name applied to surgeon or lancet fishes, species of Hepatus and Acanthurus.

umelei, n. Hepatus matoides, Acanthums lituratus, Acanthumes uniconnis. 
umi, v. To lengthen out. (See gutu umi, Epibulus insidiator, from the protractile jaws.)

umue (?), n. Kyphosus waigiensis.

usi, usiusi, adj. Green.

usiusi, $n$. Callyodon (juv.).

usiusi (?), n. Megaprotodon trifascialis.

va'a, n. Boat, canoe; vaka (Tonga), a boat; waka (New Zealand), a canoe; waa (Hawaii), a canoe. vae, $n$. Foot, leg.

vai, n. Fresh water; wai (Hawaii and New Zealand), fresh water.

vaiuli sama, $n$. Abudeficef taupou, Pomacentrus vaiuli.

vete, $n$. A surmullet, Upeneus villatus. Heke (Hawaii), INulloides sp. 



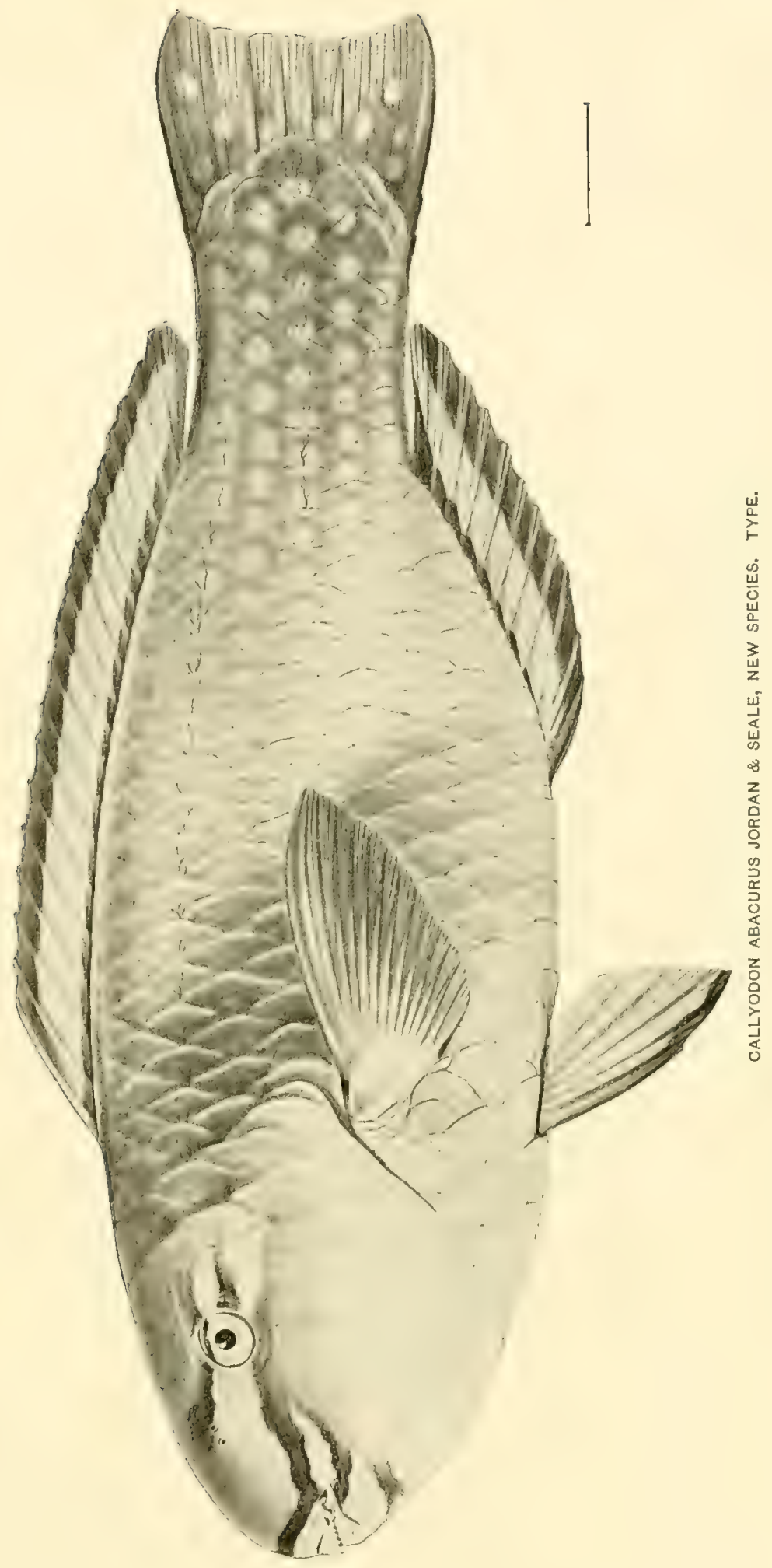





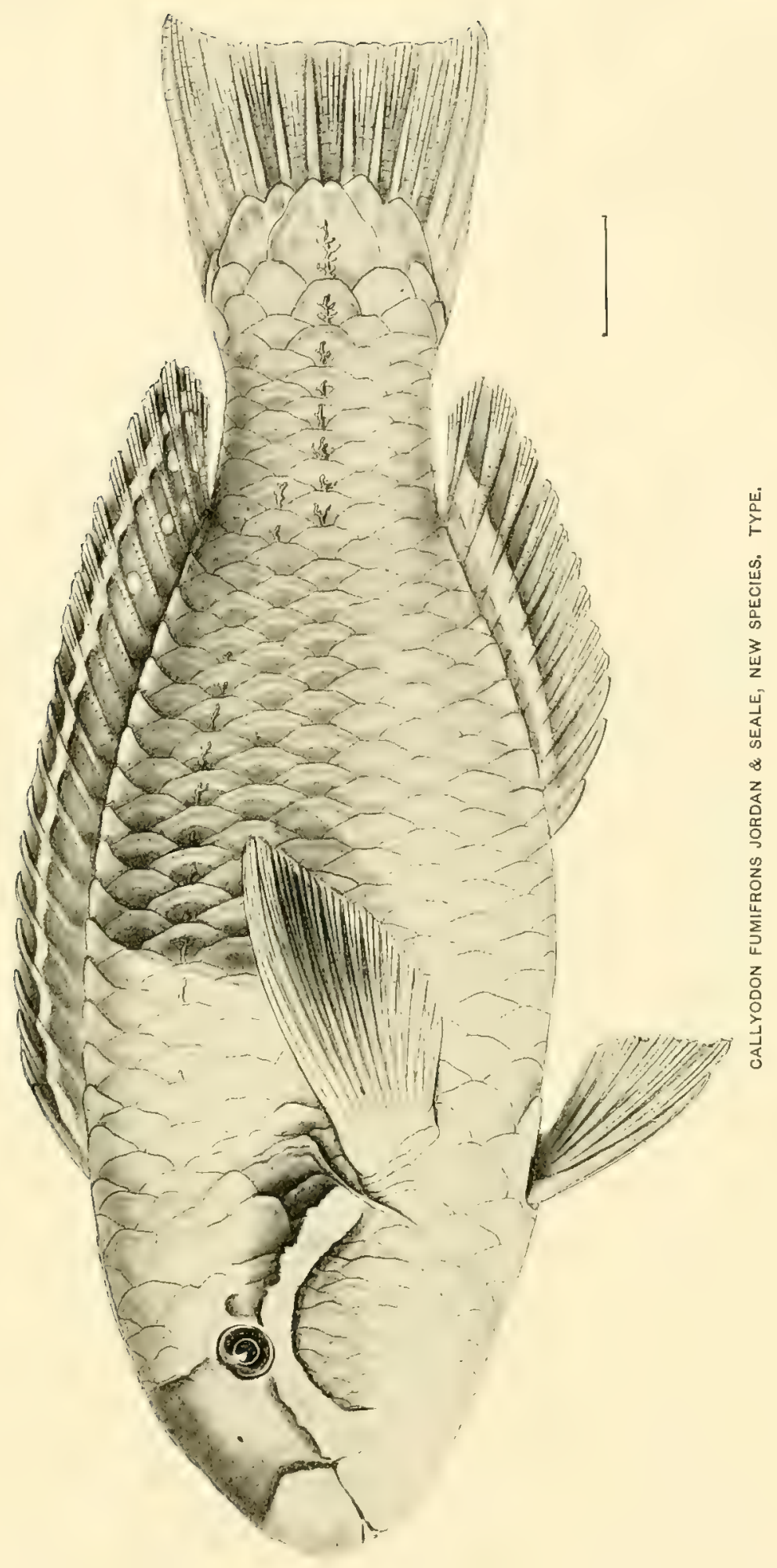





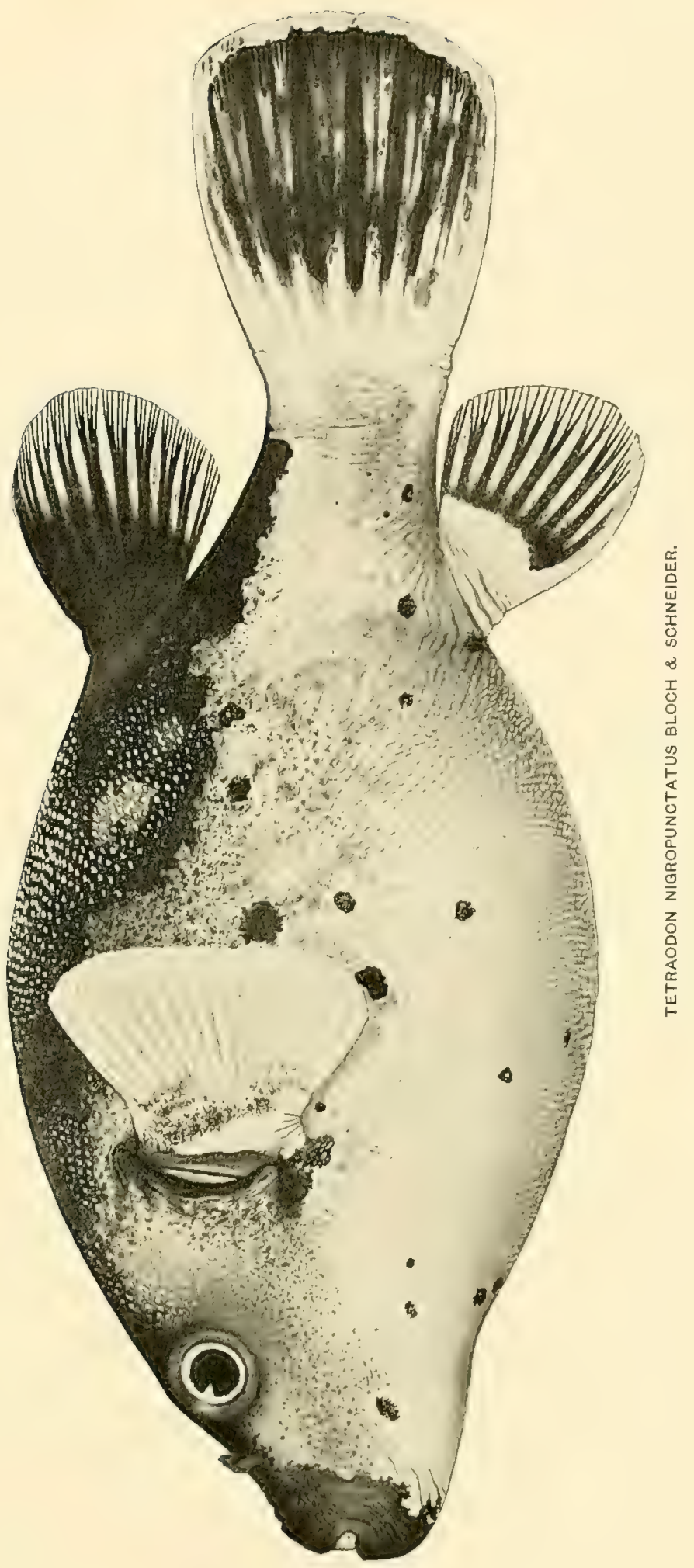





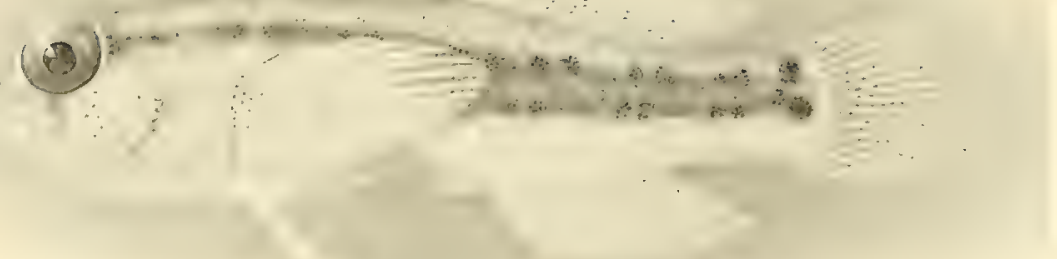

1. ASTERROPTERIX SEMIPUNCTATUS RÜPPELL.

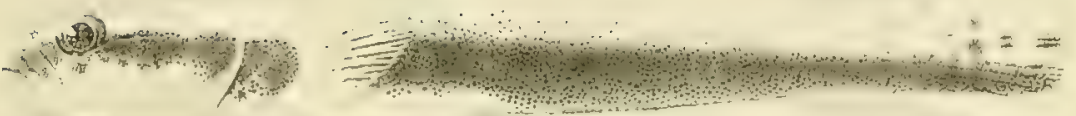

2. HETERELEOTRIS CLARA JORDAN \& SEALE, NEW SPECIES. TYPE.

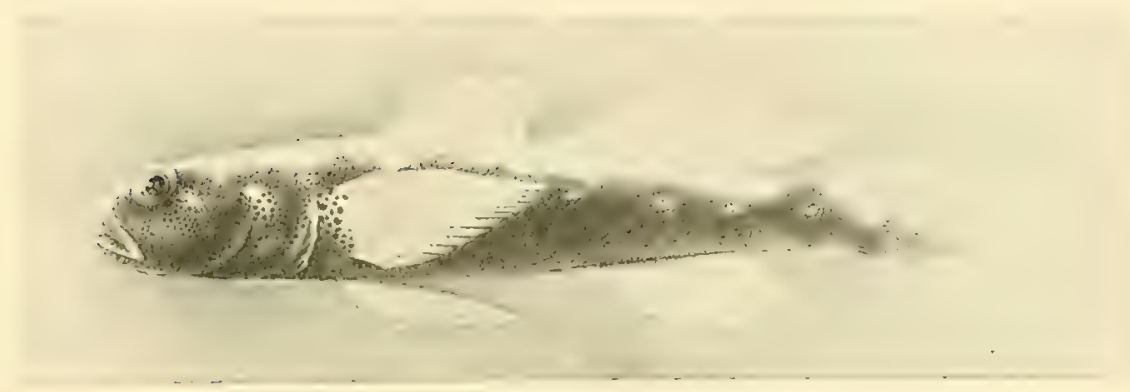

3. HETERELEOTRIS PHAENNA JORDAN \& SEALE, NEW SPECIES. TYPE. 



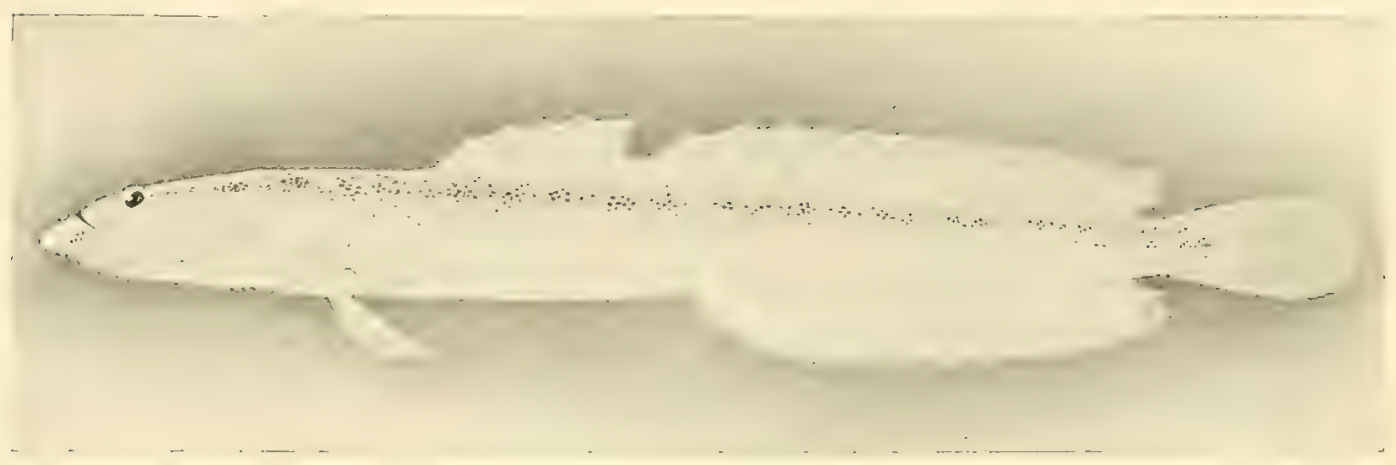

1. VITREOLA SAGITTA JORDAN \& SEALE, NEW SPECIES. TYPE.

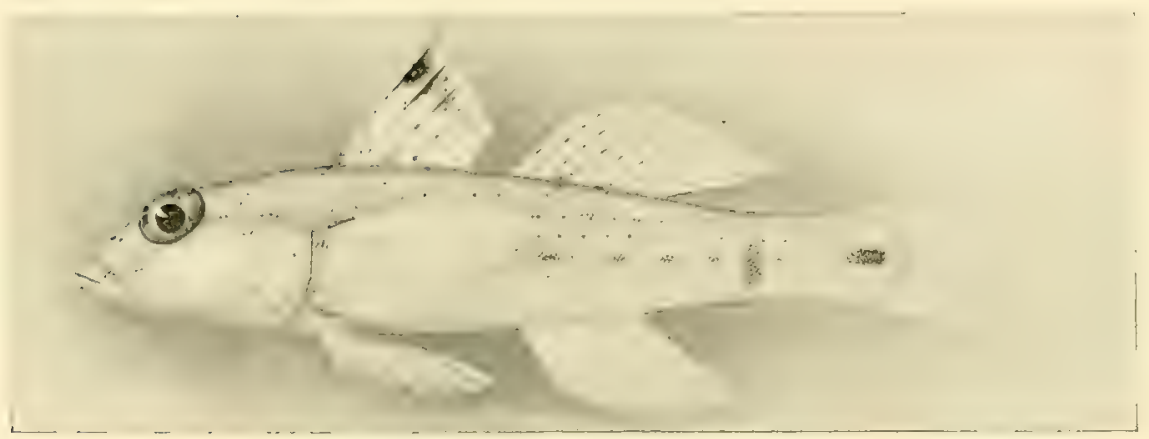

2. RHINOGOBIUS NEOPHYTUS (QUNTHER).

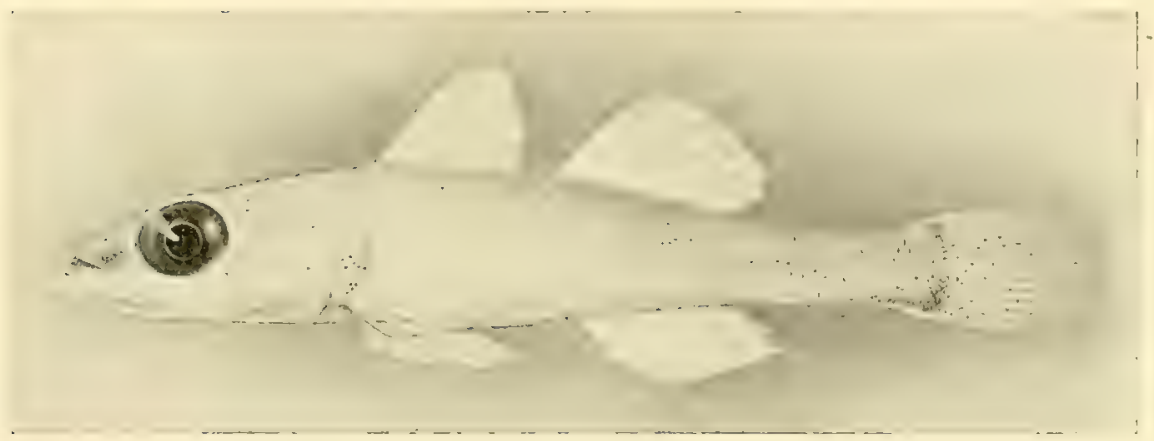

3. CHANOGOBIUS ERYTHROPS JORDAN \& SEALE, NEW SPECIES. TYPE. 


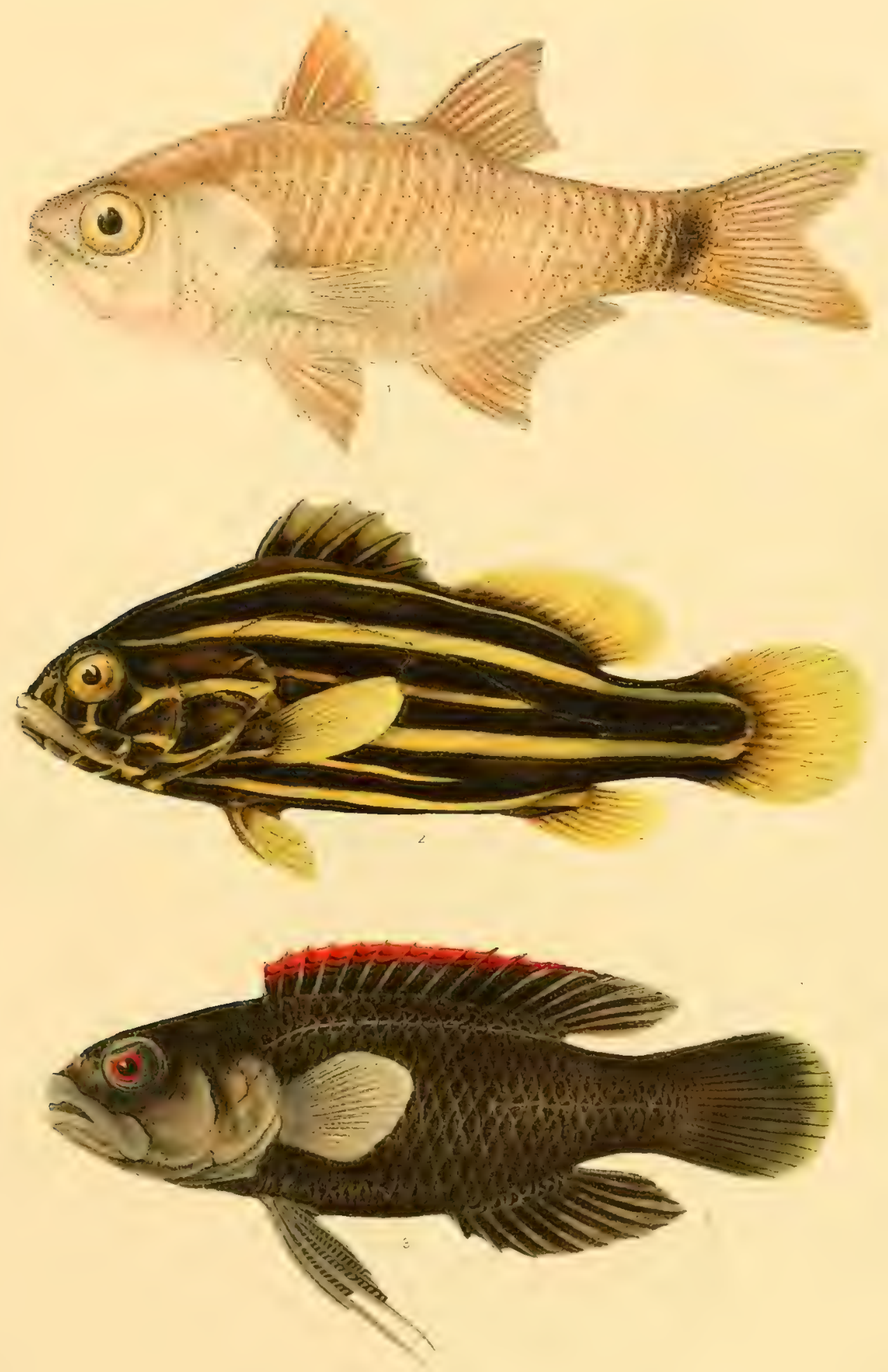

ARCHAMIA LINEOLATA (EHRENBERG)

2 GRAMMISTES SEXLINEATUS (THUNBERG)

3 PHAROPTERYX MELAS (BLEEKER) 


\section{,}

\section{,}




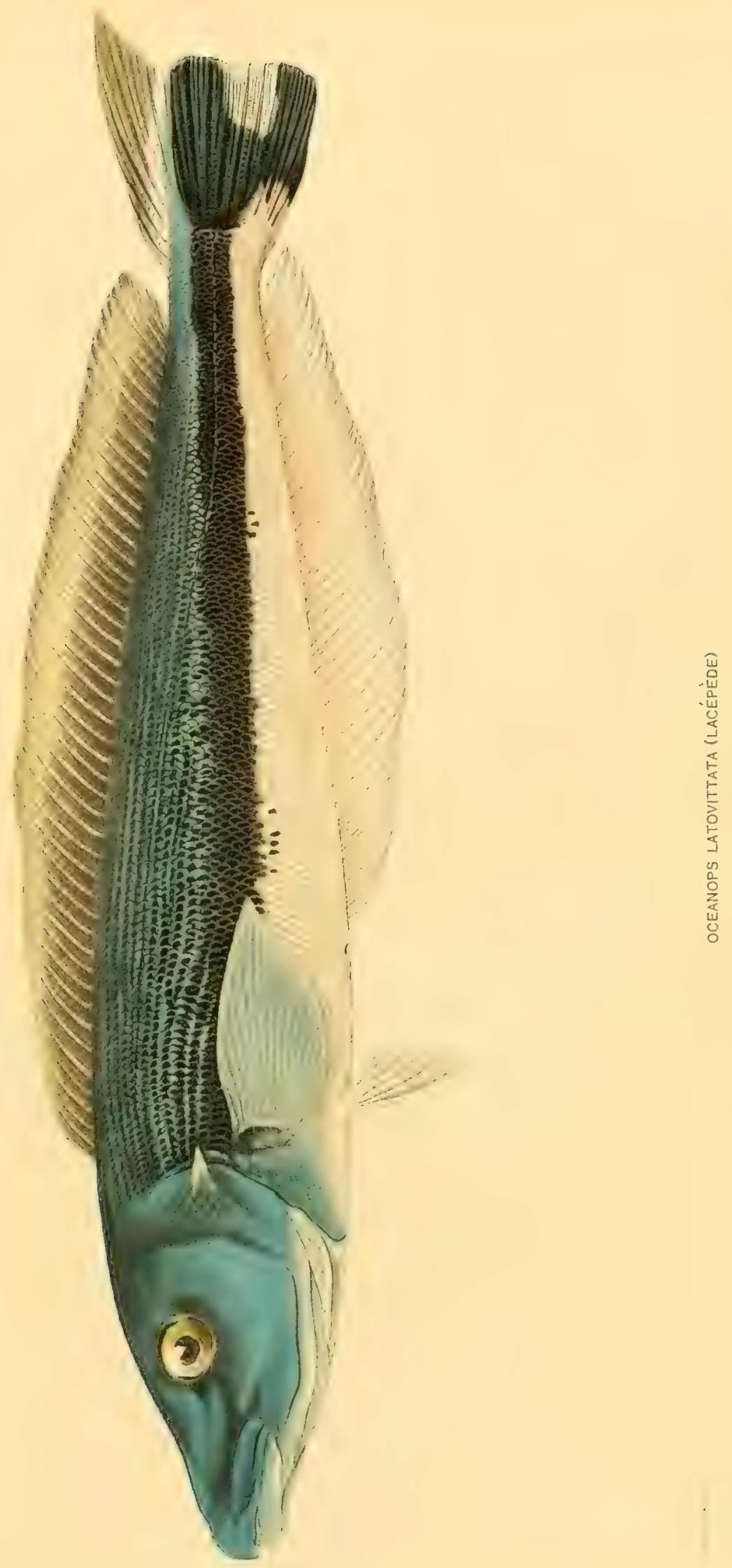




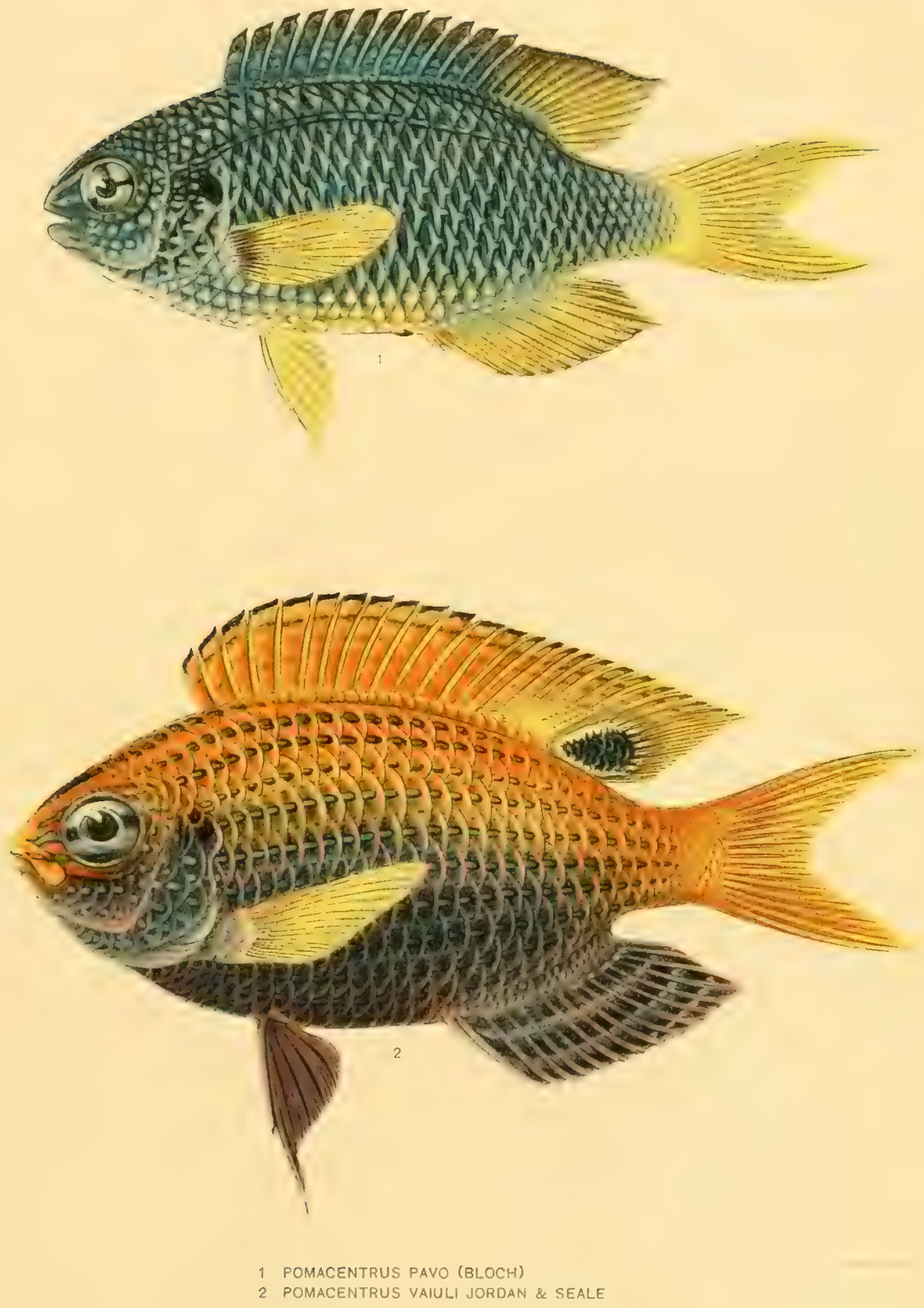


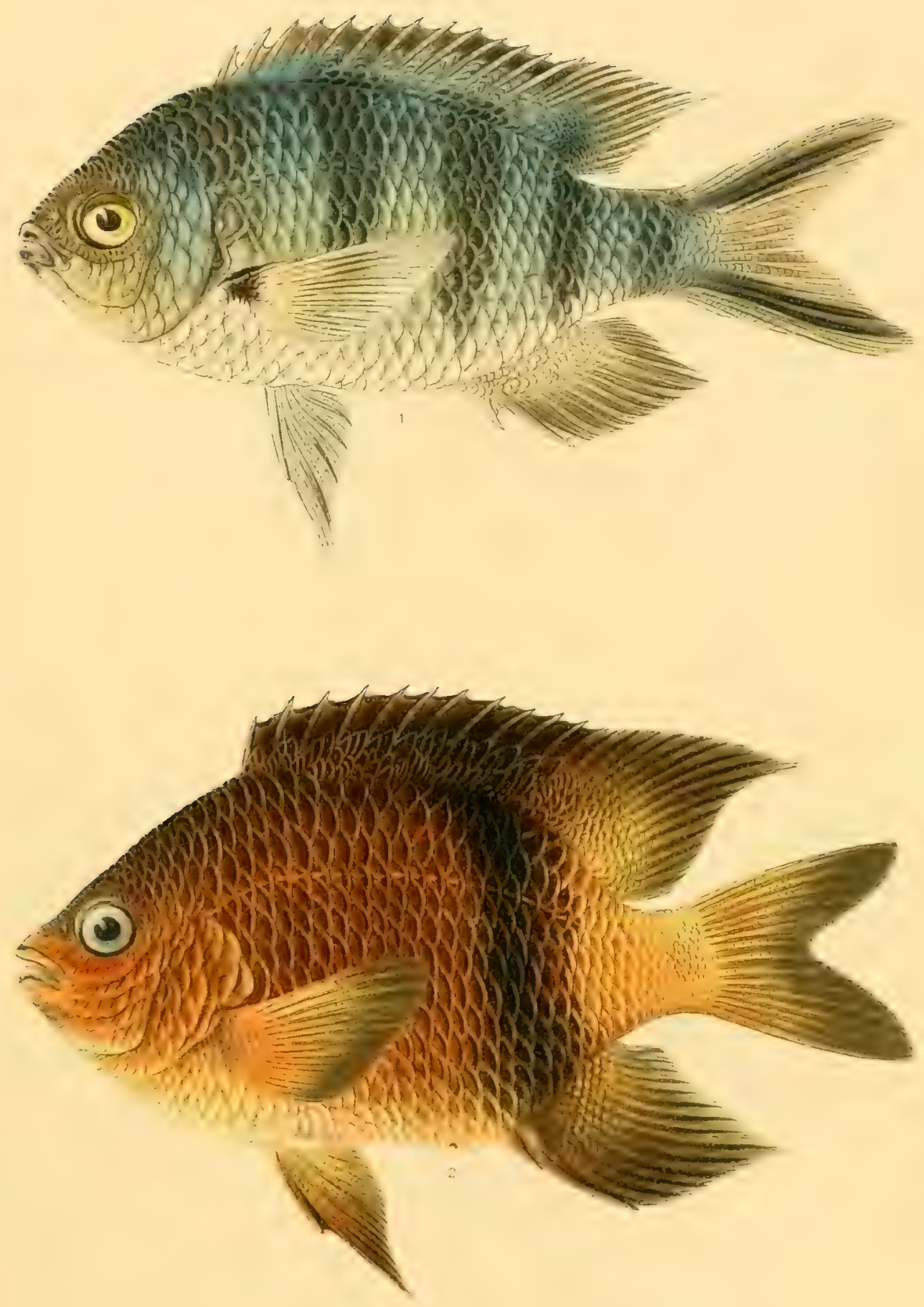

1 ABUDEFOUF CGLLESTINUS (CUVIER \& VALENCIENNES)

2 ABUDEFDUF DICKI (LIENARD) 


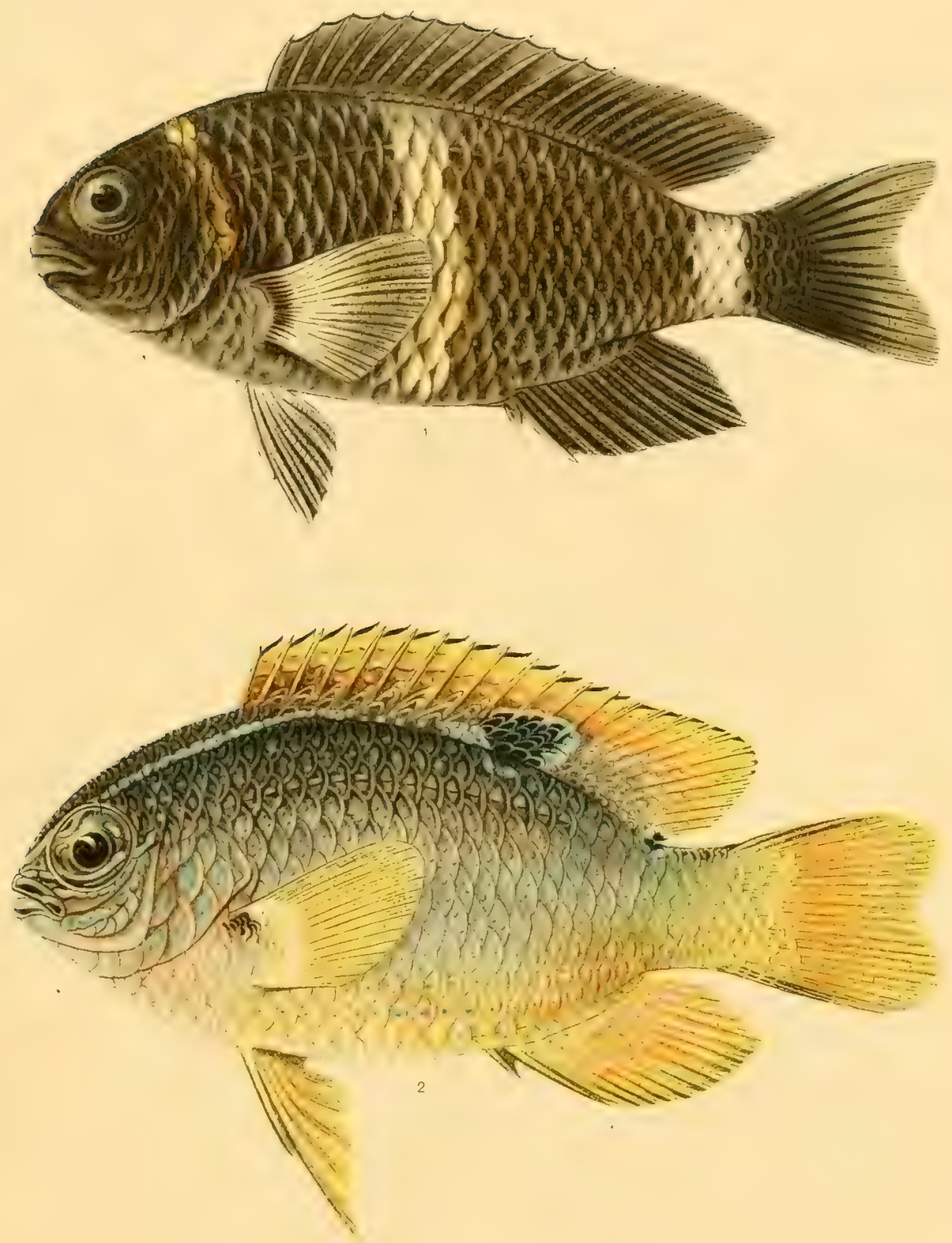

ABUDEFDUF AMABILIS (DE VIS)

2 ABUDEFDUF ANTJERIUS (KUHL \& VAN HASSELT) 


$$
\text { - }
$$



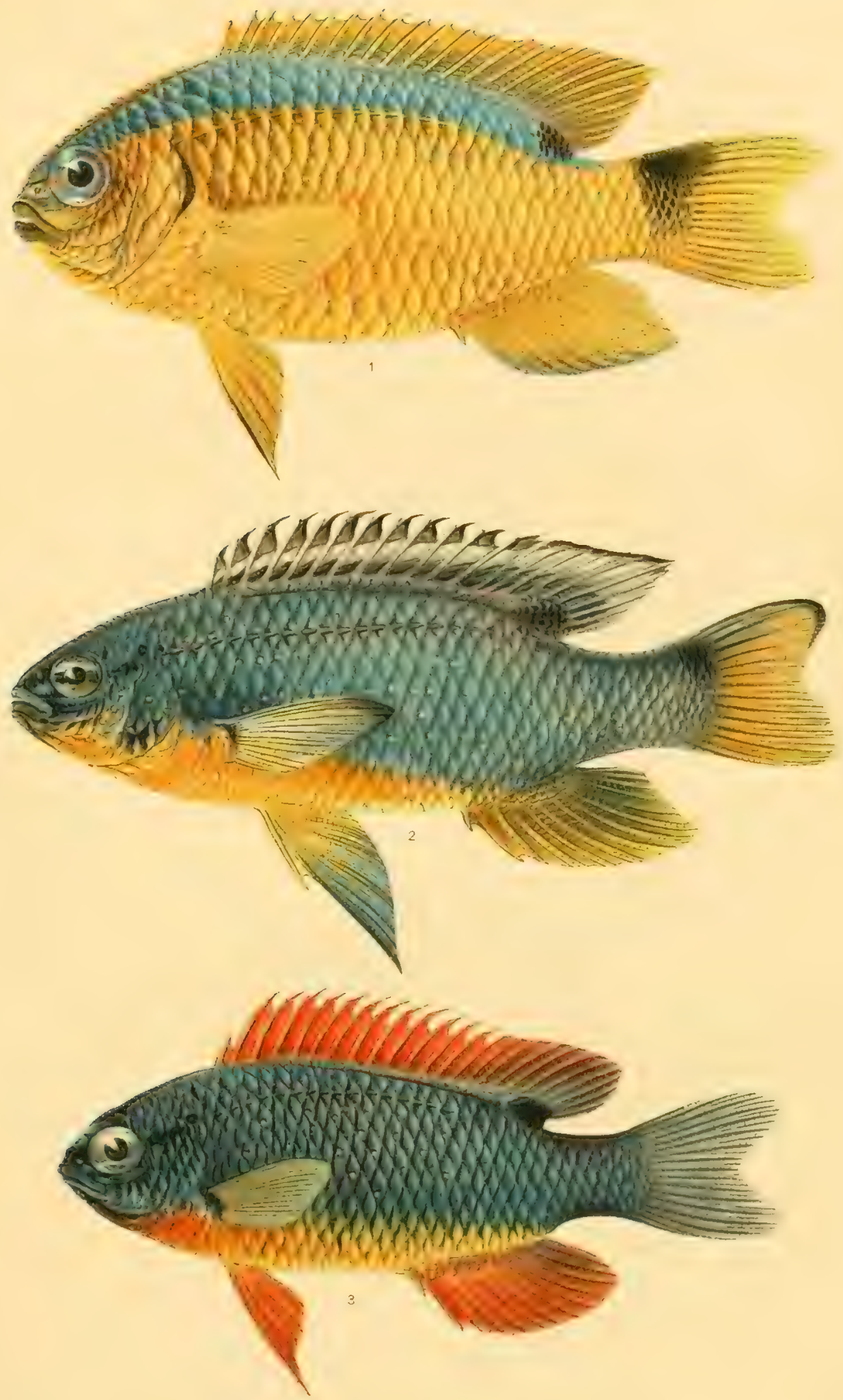

1 ABUDEFOUF LEUCOPOMUS (CUVIER \& VALENCIENNES)

2 ABUDEFDUF UNIOCELLATUS (QUOY \& GAIMARD)

3 ABUDEFDUF TAUPOU JORDAN \& SEALE. TYPE 


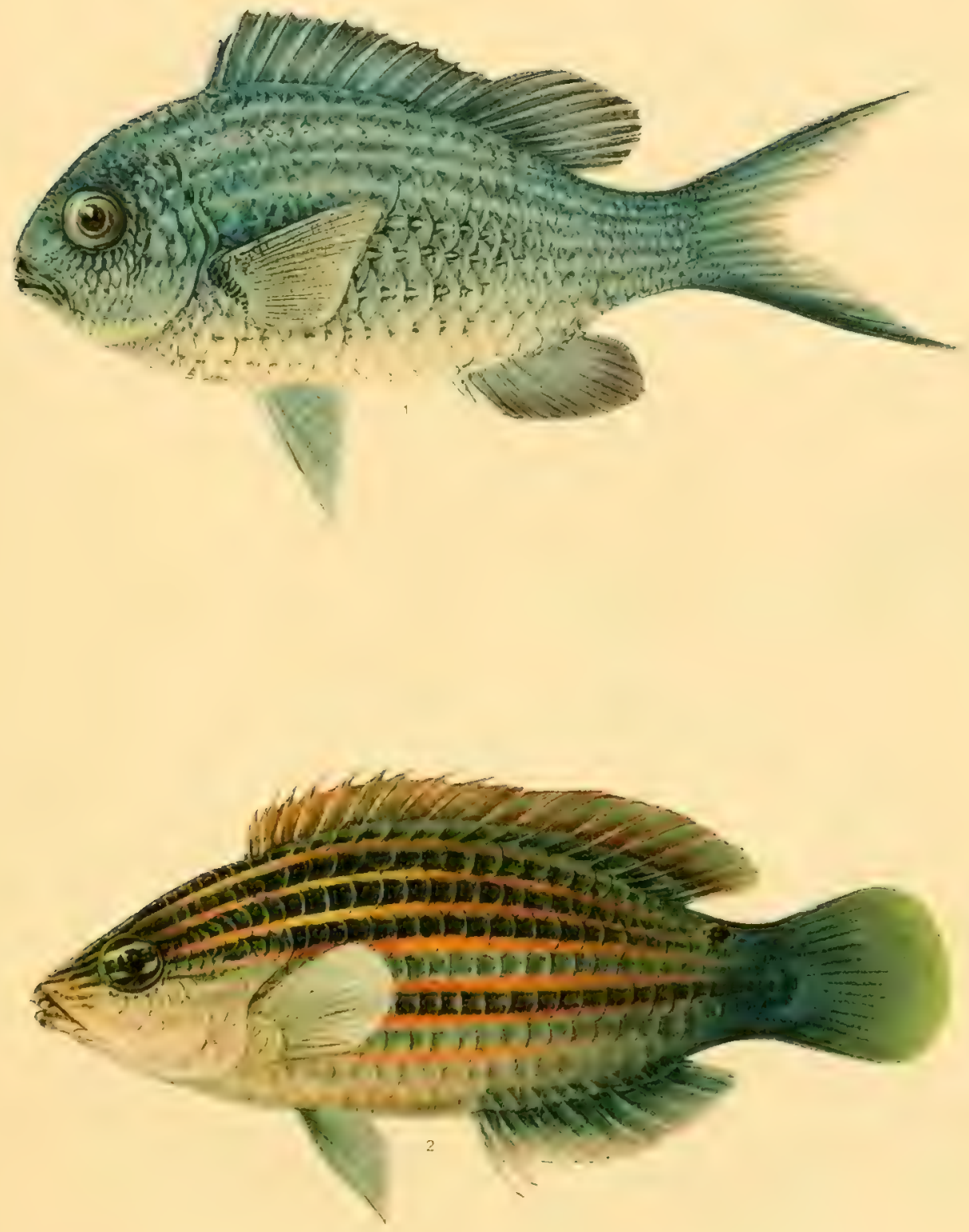


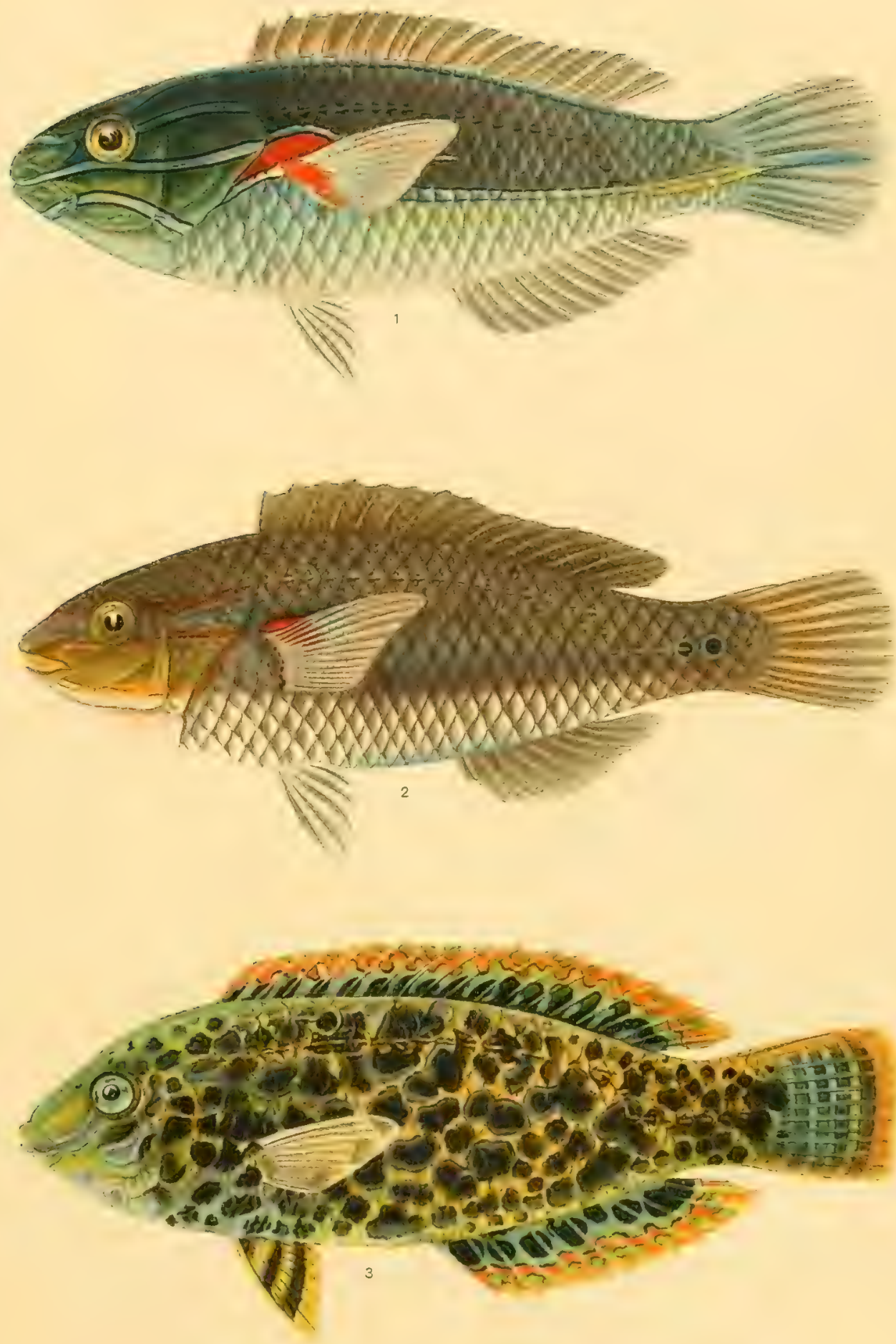


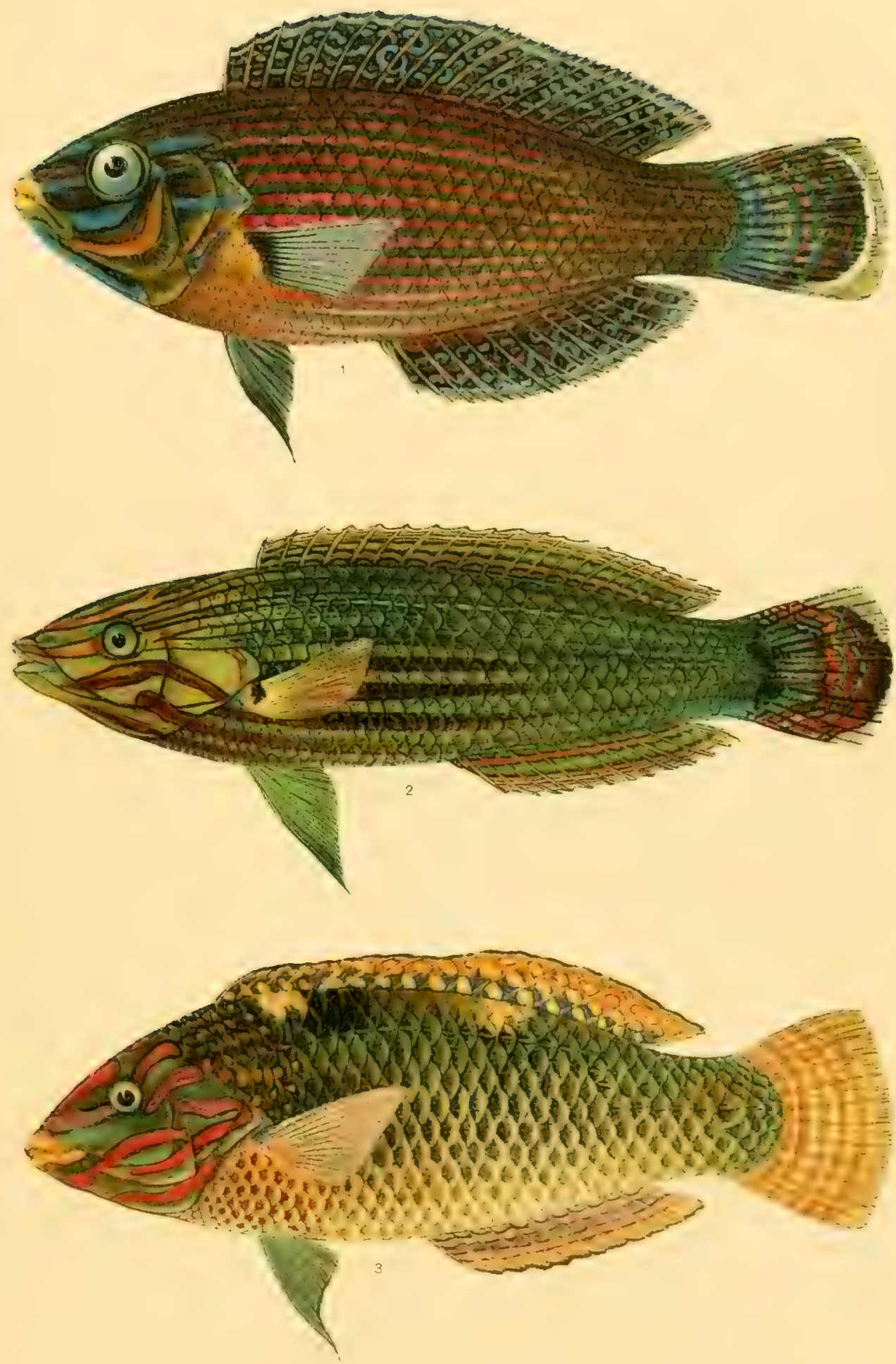

1 PLATYGLOSSUS MARGINATUS (RÜPPELL)

2 PLATYGLOSSUS FLOS-CORALLIS JORDAN \& SEALE. TYPE

3 HALICHERES CENTIQUADRUS (LACÉPĖDE) 


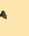



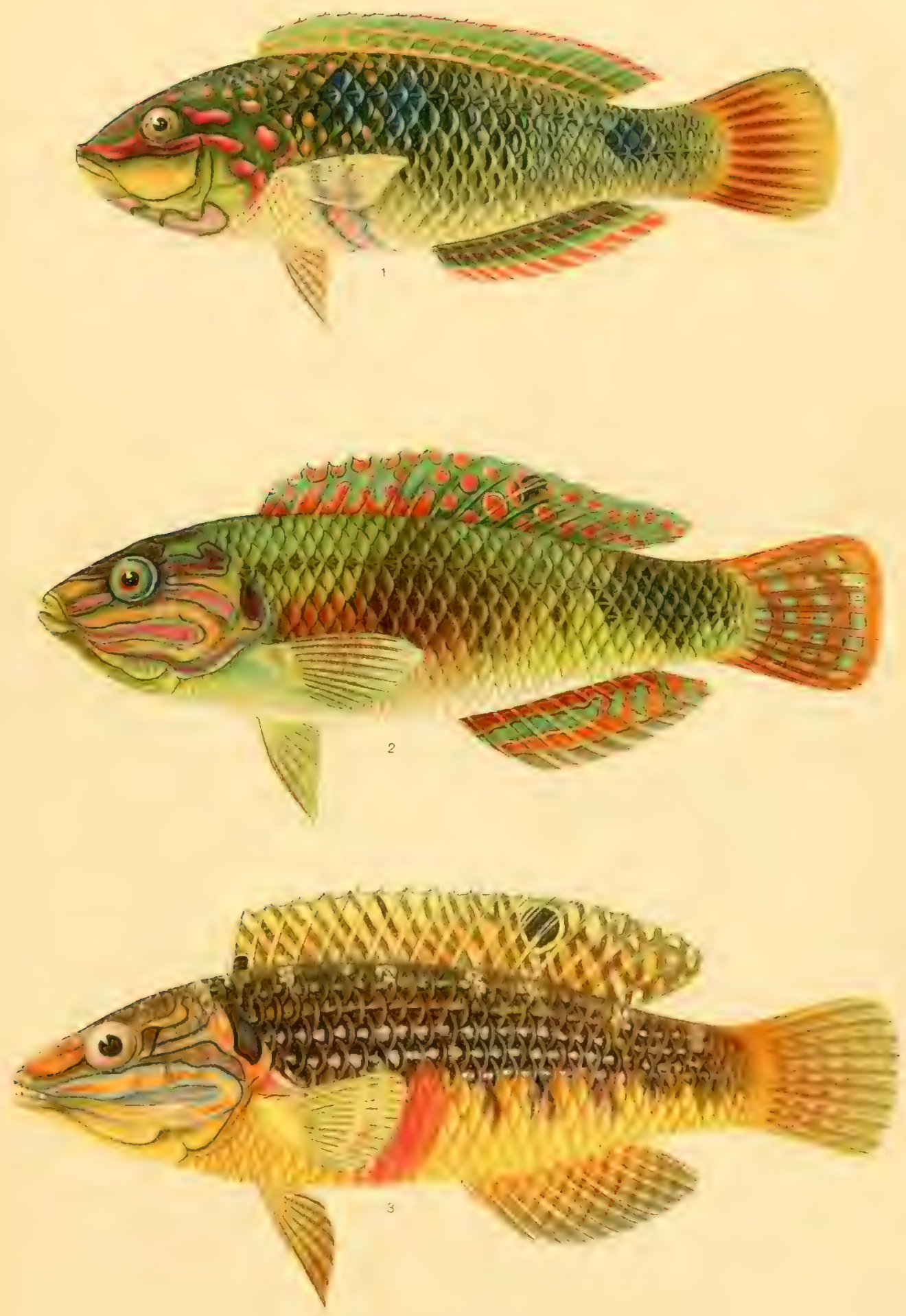

1 HALICHERES TRIMACULATUS (OUOY \& GAIMARO'

2 HALICHCERES DEDALMA JORDAN \& SEALE

3 HALICHCERES OPERCULARIS (GUNTHER) 



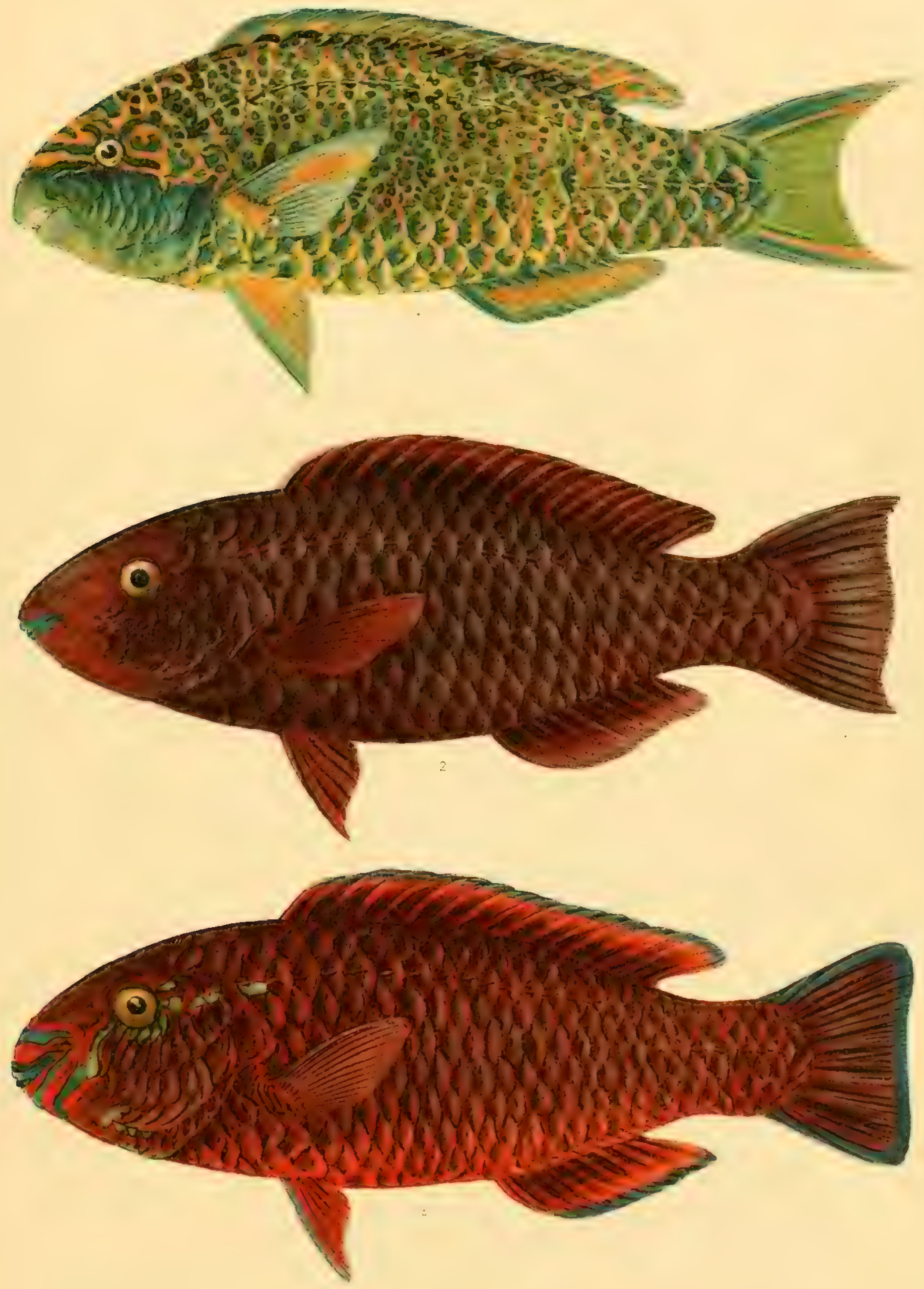

CALLYODON SPILONOTUS (KNER)

2 CALLYODON PRASIOGNATHUS (CUVIER \& VALENCIENNES)

3 CALLYODON MAORICUS JOROAN \& SEALE 



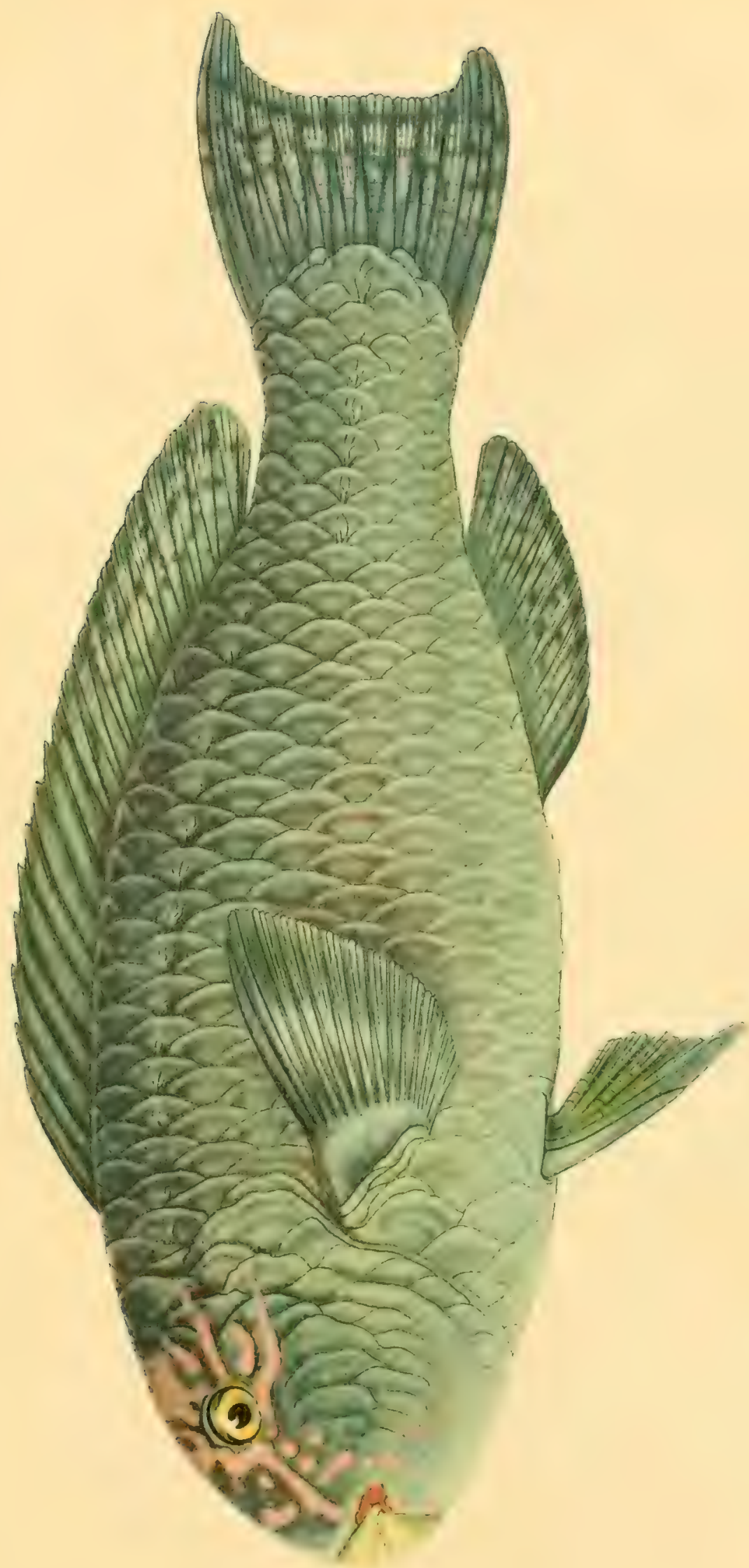

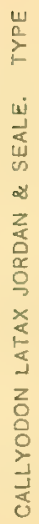




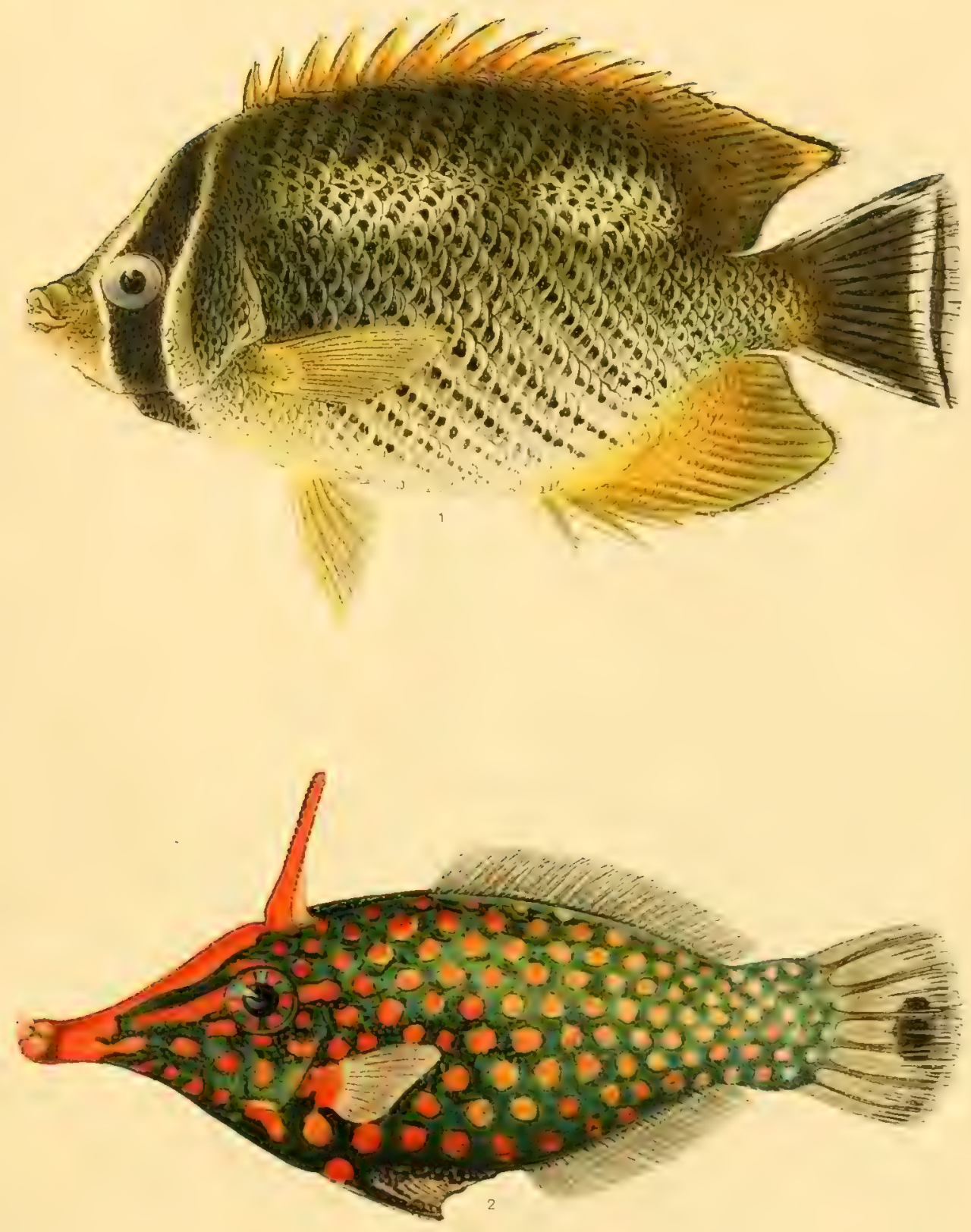



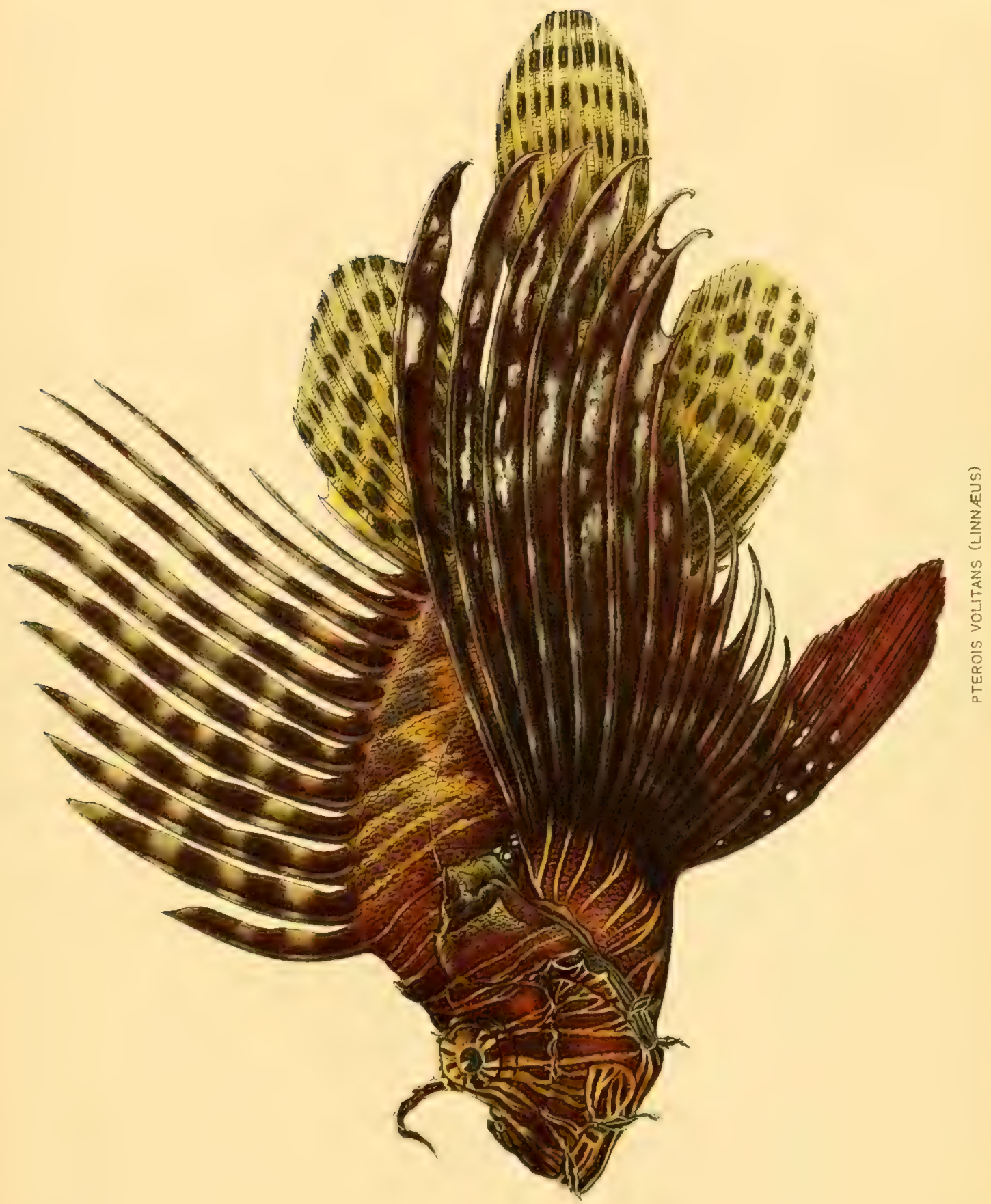




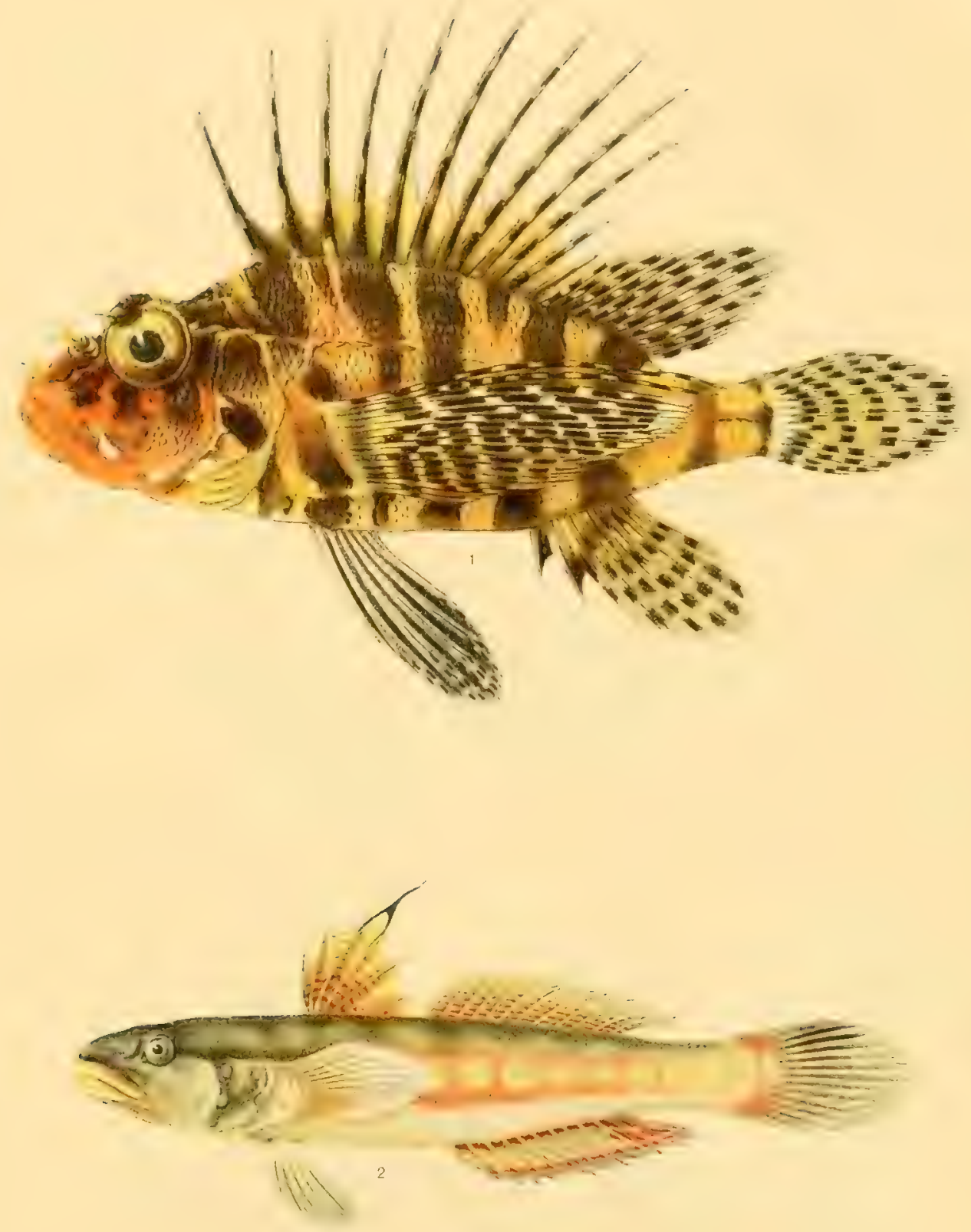


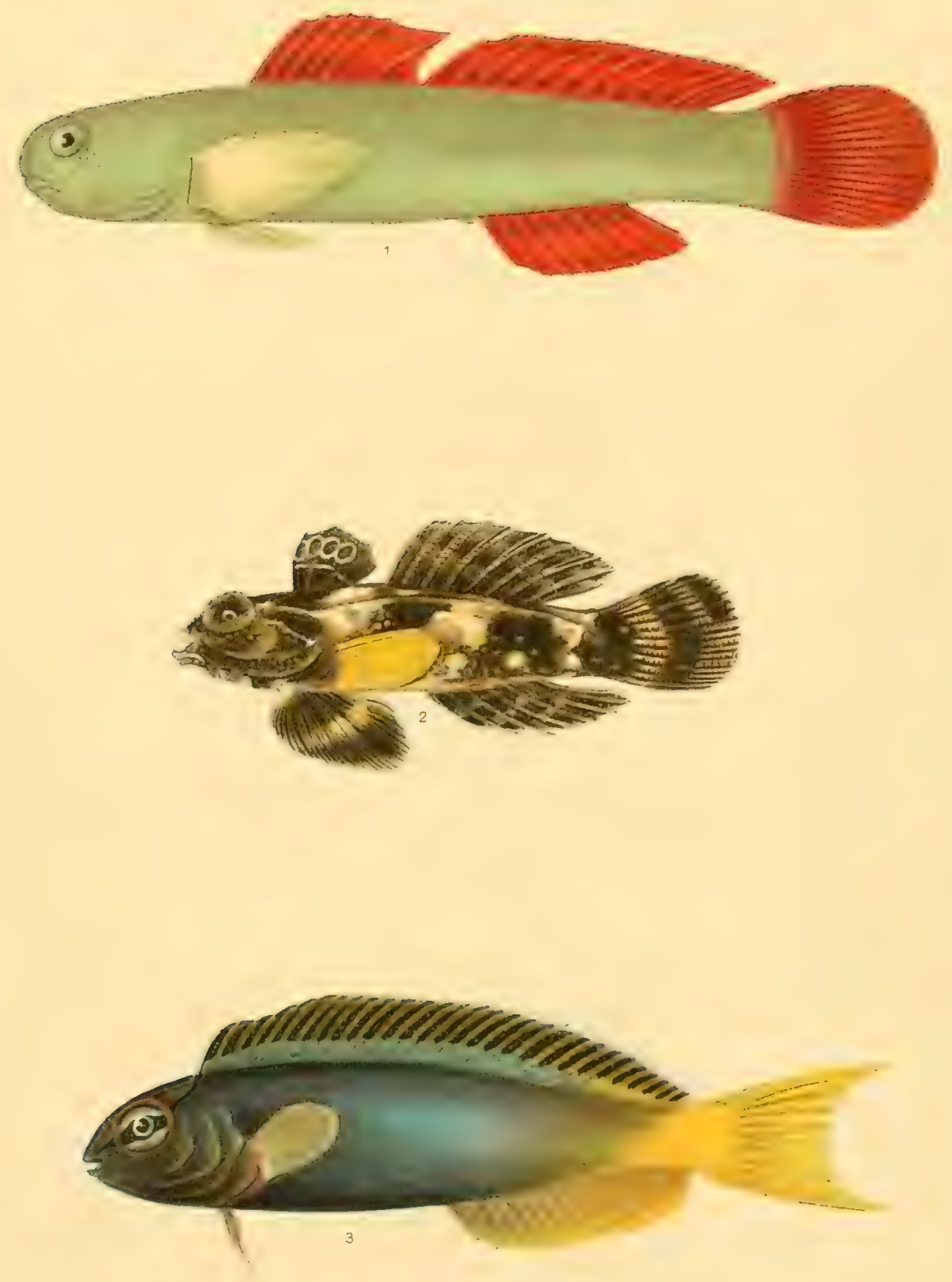


\section{N DE X.}

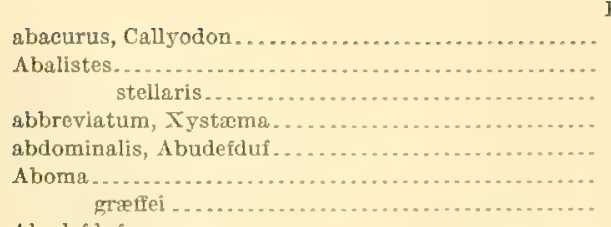

364 acipenserinus, Matæocephalus................... 437

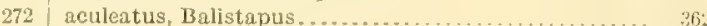

285 acuminatus, Hediochus. .......................... 340

396 | acuta, Dussumieria........................... 140

396 acutirostris, Eurymyetera ....................... 19.

Abudefduf .

auabatoides.

abuominalis.

amabilis.

antjerius . . . . . . . . . . . . . . . . . . . . . .

bankieri.

behni.

bimaculatus.

conlestinus.

curacao..

dicki

emano

filamentosus

filholi. .

glaucus.

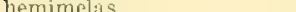

imparipennis

lacrymatus.

leucogaster.

leucopomus

melas..

metallicus

nigrifrons.

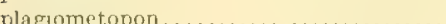

sqxatilis.

septemfasciatus.

sindonis.

sordidus.

taupou. .

uniccellatus.

zonatus.

Acauthochromis polyacanthus.

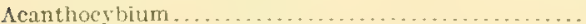
solandri

Acanthuridx.

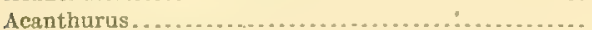

annulatus. .

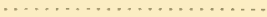

brevirostris. .

garretti.

incipiens

lituratus..............................

metoposophron...................... 358

tuberosus. .......................... 357

unicornis . . . . . . . . . . . . . . . . 357

rlamingi................ 3is

acutus, IIemiramphus...................... 207

adenomus, Diaphus .............................

adeti, Lutlanus.......................... 26.5

adustus, Myripristis . . . . . . . . . . . . . . . . . .

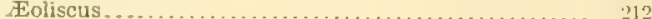

strigatus . ............................ 112

axquoreus, Congrellus . . . . . . . . . . . . . . . . 193

acrosd, Searided . . . . . . . . . . . . . . . . . . . 313

erostaticus, Tetracdon ................

Esclirichtliys. .

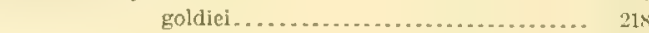

Retobatidre . . . . . . . . . . . . . . . . . . . . . .

Aetobatus ................................ 185

punctatus .............................. 19.5

afelei, Eviota............................... 397

aflinis, Chulomyeterus . . . . . . . . . . . . . . . . $\quad 373$

Caranx.......................... ${ }_{232}$

Hemiramphus . . . . . . . . . . . . . . . . . . 20 i

Scolopsis ...............................

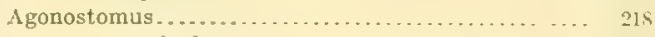

loalog......................... 21s

plicatilis...................... 214

agrammus, Priopis.............................. 25.

ahula, Cullyodon . . . . . . . . . . . . . . . . . . . . . .

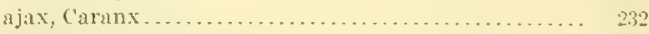

aliluua, Priacanthus ...................... $\$ 61$

albescens, Remorina..................... $\$ 12$

albisella, Dascyllus..........................

albobrunneus, Sebastapistes..................... 376

albofasciatus, Pomacentrus.................... 28.

albonguttata, Par $\perp$ rercis........................ 414

alboguttatus, Alticus........................... 424

Lethrinus........................... $\quad 20$

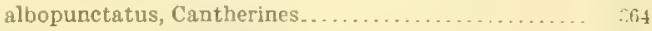

Epinep!rha.................. 260

albotæniatus, Lepidaplois ......................

Sicyopterus. . .................... 410

albovittata, Stethojulis...........................

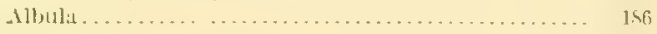

vulpes.

ulcocki, Xicoscojelus. . . . . . . . . . . . . . . . . .

Promyllantor . . . . . . . . . . . . . . . . . . . 193

Aldrovandia............................. 191

kauaiensis........................ 191

prohnscidea..................... 191

verticulis..................... 191

B. 13. F. 190, I I 


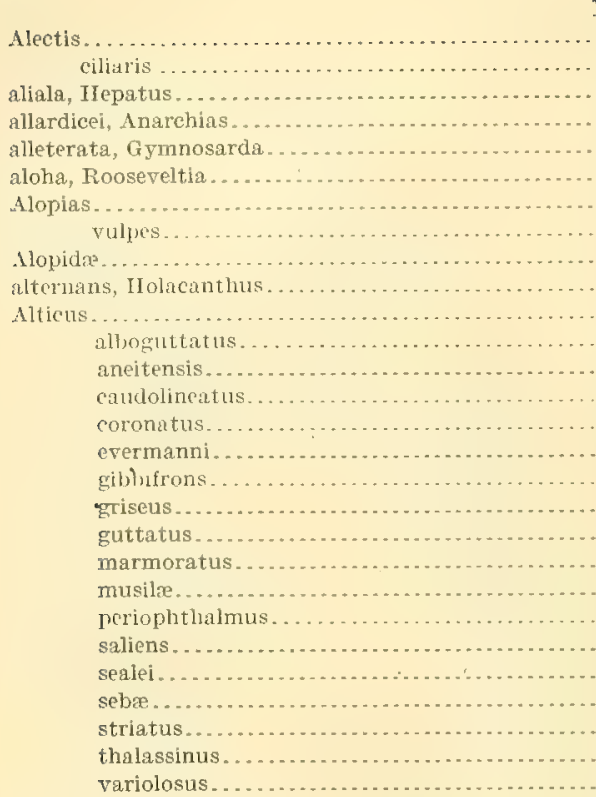

Page. 235 350

altirostris, Scorpænopsis.

Alutera.

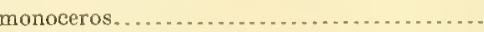

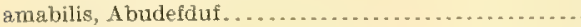

Imanses.

scopas.........................

Ambassida

Ambassis.

gigas.

lafa...

macracanthus.

miops. .

vaivasensis.

Amblyapistus.

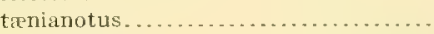

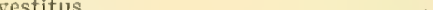

Amblygobius

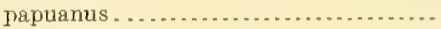

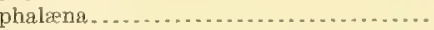

semicinctus.

sphinx.

amblyodon, Echidns.

amboinensis, Amir

Lethrinus........................

Pomacentrus

Amia.

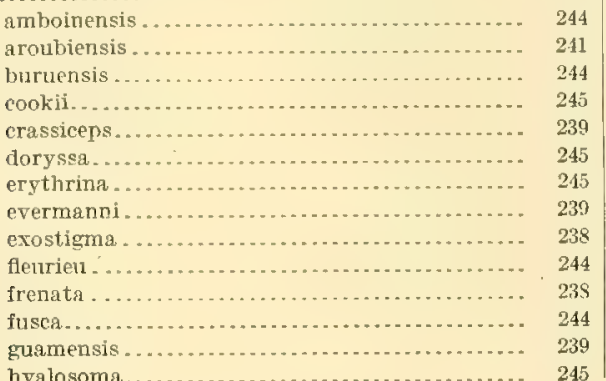

The

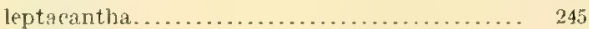

maculifera.................. 241

menesema. ............................. 239

nematophora.......................... 245

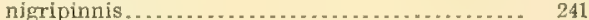

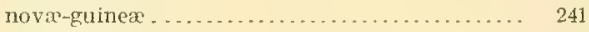

novemfasciata............................ 242

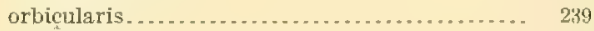

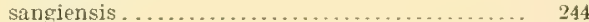

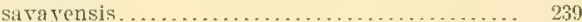

snyderi ............................... 237

tienioptera............................... 244

trimaculata............................ 244

zosterophora.......................... 24

amissus, Mrerias........................... 414

Ampheces...................................... 296

geographicus. . . . . . . . . . . . . . . . . . . . . 290

Amphioxides............................... 181

pelagicus . . . . . . . . . . . . . . . . . . 181

Amphiprion. ................................... 278

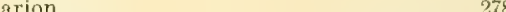

bicinctus. . . . . ................... 279

bifasciatus. ......................... 279

chrysopterus...................... 279

melanopus . . . . . . . . .................. 278

paptensis............................. 279

perenla

perideraion ........................... 279

polynnus.......................... 278

rosenbergi ........................... 279

tricolor ............................... 279

xanthurus ......................... 279

Amphiprionichthys . ................................ 380

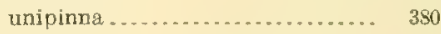

gnabatoides, Abudefduf . . . . . . . . . . . . . . . ....... 286

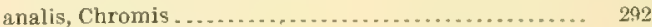

Pomacentrus . . . . . . . . . . . . . . . . . . . ..... 281

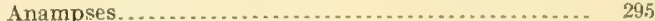

cæruleopunctatus .................. 295

euvieri .......................... 295

diadematus........................... 296

evermanni............................ 296

fidjiensis. . . . . . . . . . . . . . . . . . . . . . . 296

godefiroyi. ............................ 296

melanurus . ................. 296

neogninaicus......................... 296

pterophthalmus....................... 290

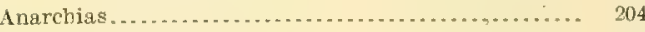

allardicei. . . . . . . . . . . . . . ............ 204

knighti . . . ......................... 205

anchorago, Chcerops ............................ 292

Anchovia.

apiensis.......................... 187

enchrasicoloides...................... 188

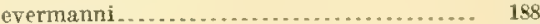

purpurea............................... 187

seratehleyi - -

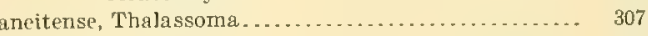

aneitensis, Alticus . ......................... 423

Inlistius ........................... 312

Anguilla australis. . . . . . . . . . . . . . . . . . . . . . . . 192

fidjiensis . . . . . . . . . . . . . . . . . . . . .... 192

mauritiana .......................... 192

megastoma............................ 192

obscura. . . . ............................ 192

otaheitensis . . ......................... 192 
Page,

Anguilla sidat .

anguillaris, Plotosus

Anguillida

angulosus, Canthidermis.

annulatus, Acanthurus.

Anorlontestomit..

\section{lorevicepe}

chacunda

Anomalopida

Anomalops.

$$
\text { palpebratus. }
$$

Antritlarihlir.

Antrinaturas.

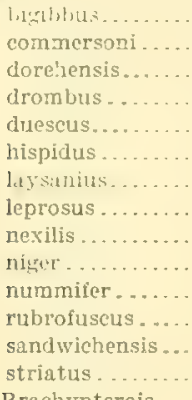

antennatus, Brachypterois

Antbias.

$$
\text { cheirospilos }
$$

Anticitharus

$$
\text { manadensis. }
$$

$$
\text { Ininilis. }
$$

Intignnial

$$
\text { steinduchneri }
$$

Intersmend:**.

Antumnrie.

$$
\text { microlepis. }
$$

antjerius, Abudefduí.

antraus, II ymenocephalus.

Any[uerolun.

$$
\text { leucogrammicus }
$$

Ipharius

, .

ariviltus.

furcatus .

apiensis, Anchovia.

Apocryptodon fosciatus..................... $\$ 107$

Apogonich thyide........................... 237

Apogonichthys............................. $\quad 250$

isostigma...................... 251

marmordtus................... 250

vilrientitiss.

apogonoides, Tetracentrum.

aporos, Ophiocara.

Aprion

\section{latifrons...}

microdnn...

virescens.

aquilinus, II pit1us.

Arucian.

$$
\text { spilonotal..... }
$$

aratrum, Coolorhynchus.

arcatus, Paracirrhites.

linxolit:1..

arcticens, cypslarus.
192 areuatus, Holacanthus. . . . . . . . . . . . . . .

$19 \mathrm{~L}$ arenicola, Engyprosopon .......................... 412

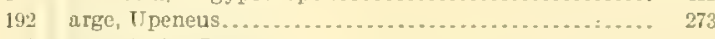

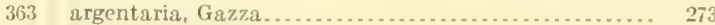

arenoteus, Cusio.

Ilemiraraphus. ..................... 207

Monorictylus

Mugil ............................ 217

Siganus........................... 300

Terapon ........................... 260

argentimaculatus, Lutianus. ..................... 262

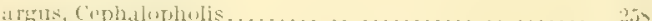

Ephippus..........................

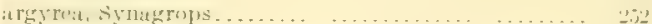

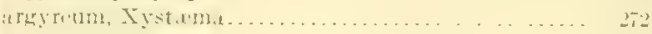

Argyripnus ............................... 190

ephippiatus......................... 190

argyromus, Myripristis . . . . . . . . . . . . . . . . . . . 221

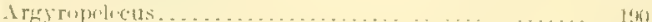

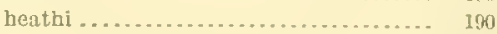

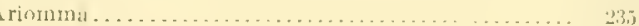

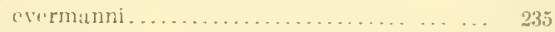

liriıla........................... 235

rion, Amphiprion ....................... 278

rnutus, Cantherines.......................... 364

Cariux. 232

Xenocephalus.......................... 434

armiger, Tachysurus, ............................ 191

aroubiensis, $A$ mia............................. 241

aruinus, Dascyllus........................... 296

Aseraggodes.......................................... 413

melinostictus ................... 413

pellucidus. ........................... 413

asper, Dasyscopelus . . . . . . . . . . . . . . . . . . . . . . . 189

aspro, Rhyacichthys............................ 415

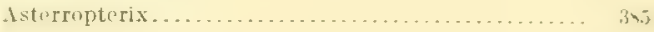

semipunctatus..................... $\quad 385$

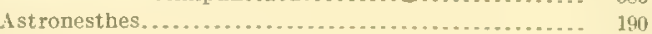
lucifer............................. 190

Ateleopide. .................................... 436

Ateleopus. ... . . . . . . . . . . . . . .

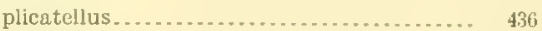

ater, Enchelyurus............................. 434

aterrimus, IInpatus. . . . . . . . . . . . . . . . . . 351

IIymenocephalus. .................... 436

Atherinidx.................................... 210

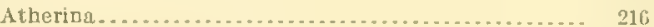

cudrachtensis .................... 216

forskili..................... 21ri

insularum ........................... 216

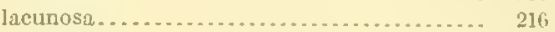

uisila. 216

waigiensis............................... 216

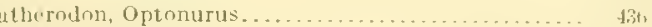

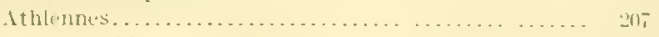

hians............................ 207

atkinson, salurias........................... th

atra, Lambertia................................. 191

Treniura..................................... 184

atramentatus, Ilepatus........................ 352

atrangulatus, Gobiodon......................... 409

atratus, Salarias............................ 431

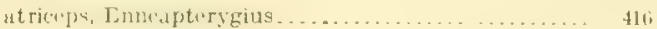

atriclypeus, Gobioncllus........................ 407

ut risigns, Cypsilurus . . . . . . . . . . . . . . . . .

atrocingulatus, 1 seudupeneus................... 274

ntrodorsnlis, Petroseirtes........................ 433

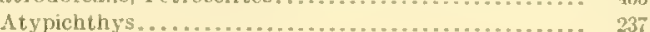


Atypichthys strigatus

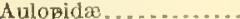

Aulostomida

Aulostomus.

$$
\text { valentini . }
$$

aurantius, Cephalopholis

aureovittatus, Lutianus.

auriflamma, Mulloides.

auriga, Chætodon...

auritus, Ialichores.

$$
\text { Scarichthys. . }
$$

aurolineatus, Gnathodentex.

$$
\text { Lethrinus. }
$$

aurora, pikea...

australiensis, Hemiramphus.

australis, Anguilla..

Centropogon

Epinephelus

Labrichthys

Periophthalmodon

Sparus.

Auxis .........

Awaous.

crassilabris.

genivittatus...

guamensis

ocellaris.....

stamineus.

axillaris, Chromis.

Gobiodon.

Lepidaplois.

Stethojulis.

Axinurus .

thynnoides

ayguia, Coris

azureus, Petroscirtes

Sectator...

bahiensis, Cypsilurus

bailloni, Tracbinotus.

baldwini, Hemipteronotus

balia, Scaridea.

balinensis, Callyodon.

Balistapus.

aculeatus.

$$
\text { oire. }
$$

papuensis.

rectanguius

undulatus.

verrucosus

Balistes.

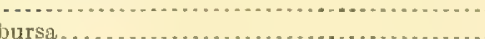

capistratus.

castaneus. . .

chrysopterus.

flavomarginatus -

fuscolineatus ............................

fuscus.

niger ........... .

nycteris.

vidus.

Balistida

viridescens.

ballieul, Coris.

Sebastapistes.

Thalassoma.

bandanensis, Merinthe

Stethojulis.
Page. bankanensis, Pomacentrus Page

bankieri, A budefduf.

barbarus, Pexiophthalmus....................... 393

barbatus, Orectolobus.......................... 182

barberi, Dendrochirus .

barberinoides, Pseudupeneus. . . . . . . ................. 276

barberinus, Pseudupeneus. ................... 27

bariene, Hepatus............................ 352

Bascanichthys ............................. 194

pinguis......................... 194

bataviensis, Callyodon............................ 323

Insidiator........ 350

Batrachoididæ........................... 410

beani, Serrivomer........................... 194

behni, Abudefduf . .............................. 285

Belone...................................... 306

platyura............................ 206

Belonidæ.................................. 206

Bembradidæ.............................. 380

Bembradium .............................. $\quad 380$

roseum......................... 380

Bembrops................................... 414

filifera............................... 414

bennetti, Callyodon ......................... 315

Canthigaster............................ 373

Chrotodon............................ 345

berda, Sparus............................. 271

berndti, Gymnothorax . . . . . . . . . . . . . . . . . .... 203

Myripristis............................ 221

Polymixia........................... 219

Berycidæ............................... 219

biaculeatus, Gasterotokeus...................... 215

Premnas............................ 278

bicinctus, Amphiprion . . ...................... $\quad 279$

bicolor, Holacanthus............................. 348

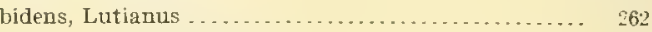

bifasciatus, Amphiprion...................... $\quad 279$

Pomacentrus........................ 279

Pseudupeneus...................... 274

bigiblus, Antennarius....................... 438

bilineata, Scolopsis........................... 269

bimacula, Cirrhitoidea......................... 278

Abudefduf........................... 286

Cheilinus.........................., 510

binotatus, Holocentrus. . . . . . . . . . . . . . . . . . . . . 224

bipinnulatus, Elagatis........................... 229

biseriatus, Salarias . . . . . . . . . . . . . . . . . . . . 427

bishopi, Hepatus . . . . . . . . . . . . . . . . . . . . .... 353

Holacanthus.......................... 349

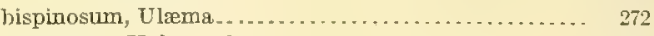

bispinosus, Holacanthus...................... 348

bitæniatus, Canthigaster . . . . ..................... 372

Blenniidæ................................... 416

Blennius......................................... 420

canescens.......................... 420

sordidus........................... 420

tonganus.............................. 420

blochi, Callyodon............................. 326

boa, Stomirs................................... 190

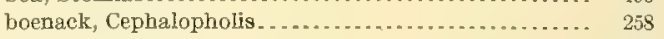

bohar, Lutianus............................. 262

bonhamensis, Lethrinus. . . . . . . . . ............... 270

boops, Caranx............................... ${ }_{232}$

boraborensis, Jordanicus .......................... 435

borborus, Callyodon............................... 315

Bostrychus.......................................... 382

sinensis................................ 382

bowersi, Congrellus .............................. 193 
Page.

bowersi, Gadomus

Bowersia.

violescens.

bowiei, Holocentrus.

brachygramma, Foa.

brachyptera, Remoropsis.

Brachypteroidæ...

(20. antennatus.

brachypterus, Dendrochirus

Parexocoetus

Brachysomophis. .

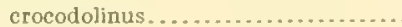
henshawi........................

brachysomus, Calotomus.

Synaphobranchus...................

brachyurus, Microphis

Bramida.

Branchiostomida.

brasiliensis, Isistius.

brenchlyi, Chcerops.

brevipinnis, Parexocoetus.

brevirostris, Aeanthurus..

brevis, Exallus

brevispinis, Macoramphosus . . . . . . . . . . . . . . . . . .

brighami, Callyodon..

Brotula.

$$
\text { Ronscreltia. }
$$

marginalis $\ldots \ldots \ldots$
multicirrata. $\ldots \ldots \ldots \ldots$

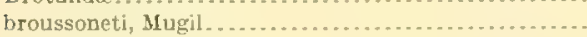

brummeri, Strophidon . ............................

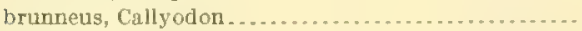

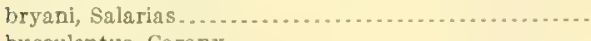

bucculentus, Caranx............................ 232

burragei, Macrourus........................ 437

buroensis, Gymnothorax......................... 199

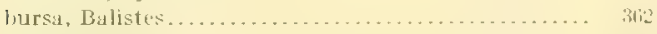

hurucnsis, $A$ mia . . . . . . . . . . . .

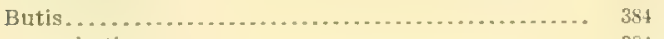

butis .................................... 384

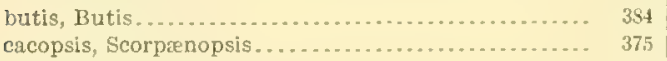

curulaureus, Carsio .........................

cæruleolineatus, Lutianus........................ 262

cæruleomaculata, Duymæria................... 203

Liza........................ 217

cæruleonotatus, Callionymus................. $\$ 15$

caruleopinnatus, Caranx..................... 232

creruleopunctatus, Anampses................... 29.

Epinephelus................... 259

ceruleus, chromis. .......................... $\quad 200$

Casio .................................. 260

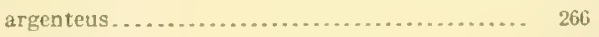

cirulatureus........................ 366

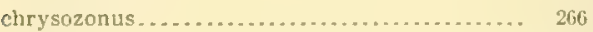

erythrogaster........................... 266

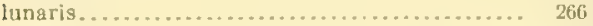

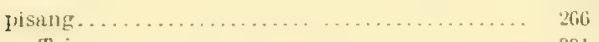

cæsiura, Trimma ............................ 391

calauropomus, Caltionymus.................. 415

calcarifer, Plectropomus...................... 255

caldwell, Mugil............................. 217

caledonica, Sauvagea....................... $\$ 20$

caledonicus, Gobius.............................. 402
Fage

callechelys................................ 194

filaris........................ 114

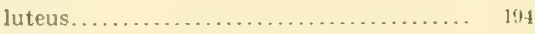

Callionymidxe......................... 41.5

Callionymus . . . . . . . . . . . . . . . 41.

cæeruleonotatus.................. 115

calauropomus.................. 41 .

cooki............................. 41.j

corullinus ..................... 415

rubrovinctus..................... 415

Calliurichthys, ......................... 415

lecnratus.................... 415

japonicus...................... 415

simplicornis.................. 41.5

Callyodon ................................. $31: 3$

abacurus.............................. 324

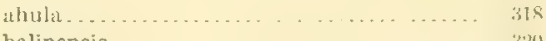

balinensis. ..................... 320

bataviensis . . . . . . . . . . . . . . . . 32.4

bennetti........................... 31.5

blochi........................... $\quad 3320$

borborus................................. 31.3

brighami.............................

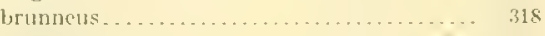

celehicus. . . . . . . . . . . . . .

cruentatus....................... $\quad: 322$

cyanognathus............................. 34

cyanogrammus...................... 830

cypho............................. 331

dimidiatus....................... 324

dubius........................... : 19

dessumieri . . . . . . . . . . . . . . . . . . . . . .

erythacus............................. 31 h

erythrodon.............................. 317

fasciatus. . . . . . ....................... 328

lerdau. . . . . . . . . . . . . . . . . . . 232

festivus ........................ 328

filholi . . . . . . . 31 .

formosus.............................. 324

forsteri . . . . . . . . . . .

frenatus.......................... 326

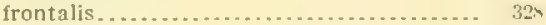

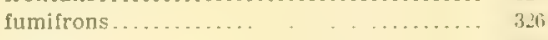

gilberti ........................... 324

globiceps.............................. 320

goldici ... . . . . . . . . . . ......... 315

gymnognathos......................... 331

jenkinsi ................................. 326

jonesi............. $\quad \ldots \ldots \ldots \ldots . .32 .3$

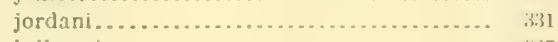

kelloggi ...........................

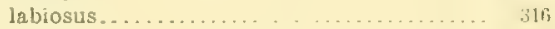

lacerta.............. . . . . . . . 319

$\operatorname{latax} \ldots \ldots \ldots \ldots \ldots \ldots \ldots \ldots \ldots \ldots$

lauia ...................... . 321

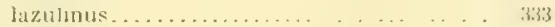

lepulus........... . . . . . . .

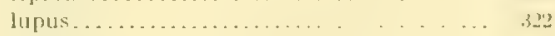

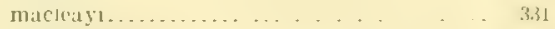

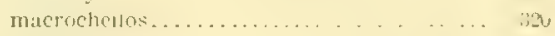

muoticus . .............. . . . . .24

mertensil................. $\$ 34$

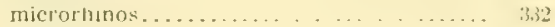

miniatus............................ ;1,

moensi ..................

moresbyensıs....... . . ... . . . . . . . . . . 323

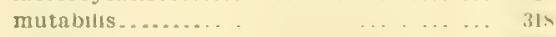

nuchipunctatus................ . .3241 


\begin{tabular}{|c|c|c|c|}
\hline \multirow{3}{*}{ 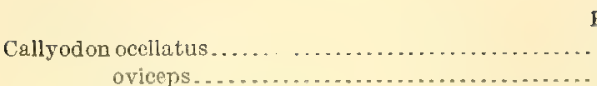 } & Page. & \multicolumn{2}{|c|}{ Page. } \\
\hline & 322 & capistratus, Balistes.................... & 362 \\
\hline & 321 & 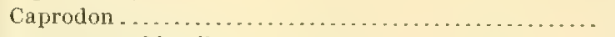 & 260 \\
\hline 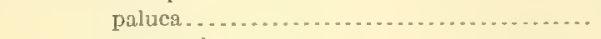 & 319 & schlegeli. $\ldots . . . . . . . . . . . . . . . .$. & 260 \\
\hline papuensis. . . . . . . . . . . . . . . . . . . & 323 & Caracanthidæ............... & 380 \\
\hline pepo. & 328 & Caracanthus..................... & 380 \\
\hline 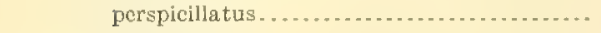 & 322 & maculatus............ & 380 \\
\hline 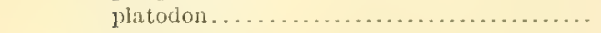 & 315 & Carangidæ $\ldots \ldots \ldots \ldots \ldots \ldots$ & 229 \\
\hline prasiognathus............................ & 328 & Caranx & 230 \\
\hline 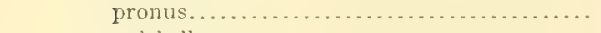 & 326 & 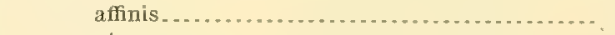 & 232 \\
\hline 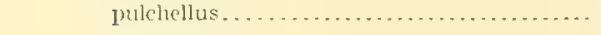 & 326 & 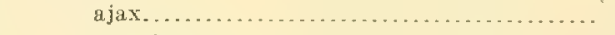 & 232 \\
\hline reus . . . . . . . . . . . . . . . . . . . & 316 & 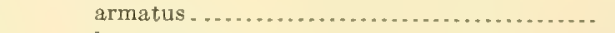 & 232 \\
\hline 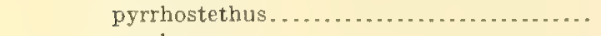 & 328 & 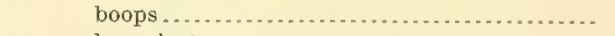 & 232 \\
\hline 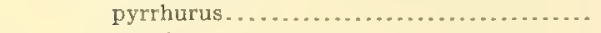 & 314 & 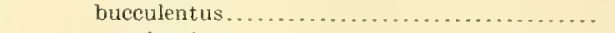 & 232 \\
\hline 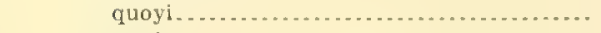 & 322 & cæruleopinnatus....................... & 232 \\
\hline 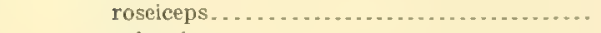 & 322 & 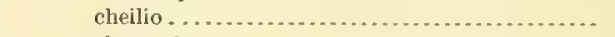 & 232 \\
\hline rimus.............................. & 316 & 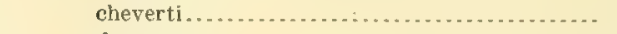 & 232 \\
\hline totus.............................. & 325 & asson & 231 \\
\hline 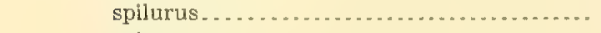 & 334 & 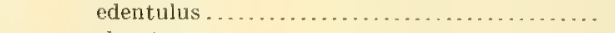 & 232 \\
\hline ( & 326 & 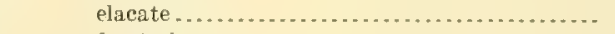 & 231 \\
\hline 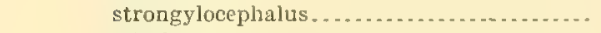 & 332 & 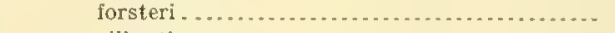 & 230 \\
\hline ( & 328 & 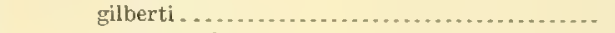 & 234 \\
\hline heli . . . . . . . . . . . . ................... & 331 & 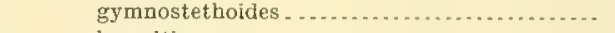 & 232 \\
\hline arinus................................. & 332 & 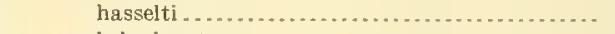 & 232 \\
\hline upolensis. . . . . . . . . . . . . . . . . . . . . . . . & 319 & helvolus . . . . . . . . . . . . . . . . . . . . . . . . . . . . & 232 \\
\hline 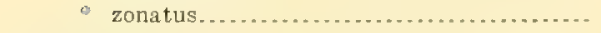 & 325 & ignobilis . . . . . . . . . . . . . . . . . . & 231 \\
\hline zonularis $\ldots \ldots \ldots$ & 321 & 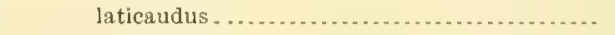 & 232 \\
\hline 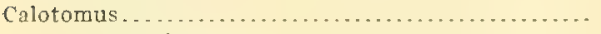 & 313 & 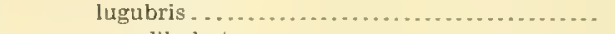 & 230 \\
\hline 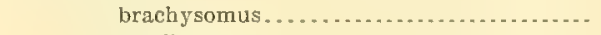 & 313 & 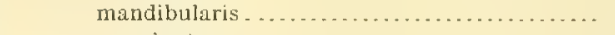 & 234 \\
\hline carolinus . . . . . . . . . . . . . . . . . . . . . & 313 & rginatus . ........................... & 231 \\
\hline 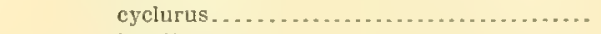 & 313 & melampygus ........ . . . . . . . . . . . . . . . . . & 230 \\
\hline 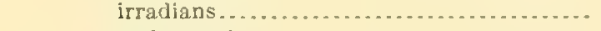 & 313 & moresbyensis . . . . . . . . . . . . . . . . . . . . . & 232 \\
\hline moluceensis.............................. & 313 & novæ-guineæ . . . . ......................... & 232 \\
\hline 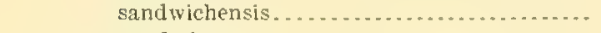 & 313 & oblongus ....................................... & 232 \\
\hline snyderi $\ldots . . .6$. & 313 & 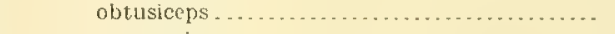 & 232 \\
\hline 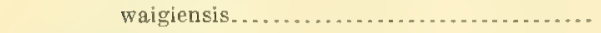 & 313 & 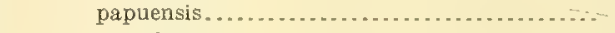 & 232 \\
\hline 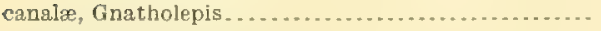 & 395 & 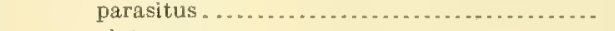 & 232 \\
\hline 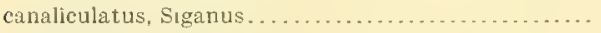 & 360 & platessa................... & 232 \\
\hline 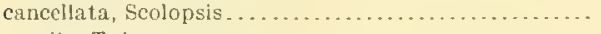 & 269 & 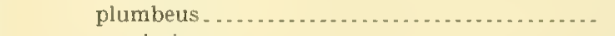 & 233 \\
\hline cancila, Tylosurus . . . . . . . . . . . . . . . . . . . . . & 207 & regularis . . . & 232 \\
\hline 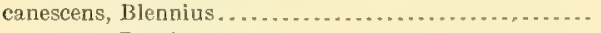 & 420 & sexfasciatus . . . . . . . . . . . . . . . . . . . . . . . . . . & 231 \\
\hline 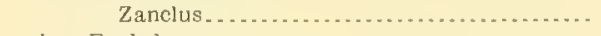 & 350 & 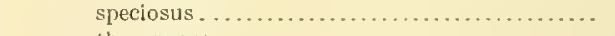 & 232 \\
\hline canina, Enchelynassa . . . . . . . . . . . . . . . . . . . . . . & 197 & 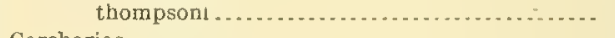 & 230 \\
\hline 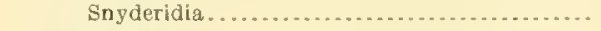 & 435 & 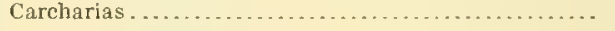 & 152 \\
\hline Cantherines. . . . . . . . . . . . . . & 364 & 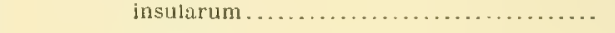 & 182 \\
\hline albopunctatus . . . . . . . . . . . . . . . . . . . & 364 & 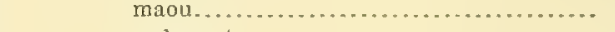 & 182 \\
\hline 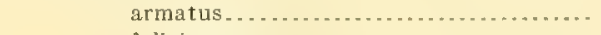 & 364 & 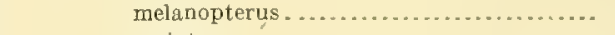 & 182 \\
\hline 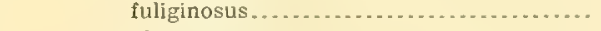 & 364 & 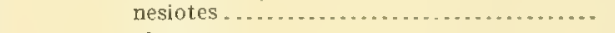 & 182 \\
\hline nigricans................................ & 364 & 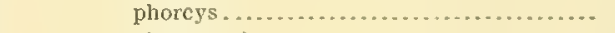 & 182 \\
\hline punctulatus............................. & 364 & pleurotania ................................... & 182 \\
\hline 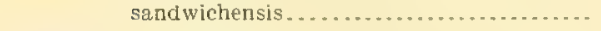 & 364 & sorrah $\ldots \ldots \ldots \ldots$ & 182 \\
\hline Canthidermis $\ldots$ & 363 & 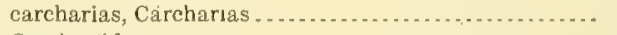 & 183 \\
\hline 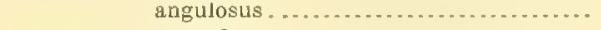 & 363 & 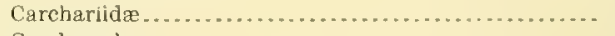 & 182 \\
\hline rotundatus $\ldots \ldots \ldots \ldots \ldots$ & 363 & 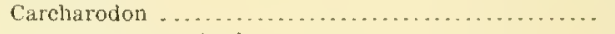 & 183 \\
\hline 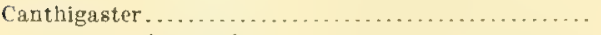 & 371 & carcharias $\ldots \ldots \ldots \ldots \ldots \ldots \ldots \ldots \ldots \ldots \ldots$ & 183 \\
\hline bennettí $\ldots \ldots \ldots \ldots \ldots \ldots \ldots \ldots$ & 373 & 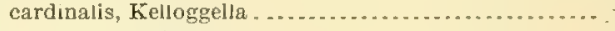 & 409 \\
\hline 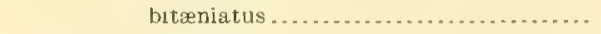 & 372 & 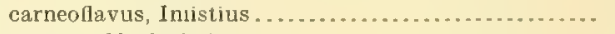 & 312 \\
\hline caudofasciatus . . . . . . . . . . . . . . . . . & 372 & 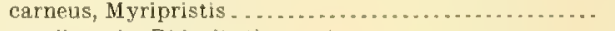 & 222 \\
\hline cinctus. . . . . . . . . . . . . . . . . . . . . . . & $\$ 73$ & 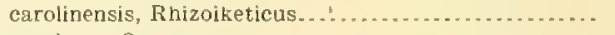 & 435 \\
\hline compressus . .......................... & 373 & 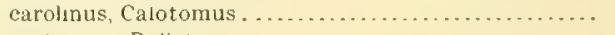 & 31.3 \\
\hline 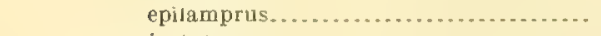 & 373 & 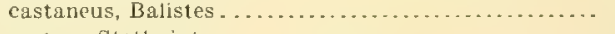 & 362 \\
\hline 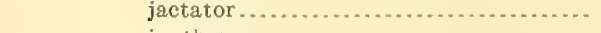 & 372 & 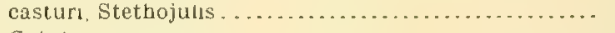 & 296 \\
\hline janthinus . . . . . . . . . . . . . . . . . . . . & 372 & Catulus $\ldots$ & 181 \\
\hline oahuensis . . . . . . . . . . . . . . . . . . . . & 373 & 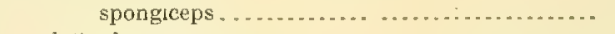 & 181 \\
\hline 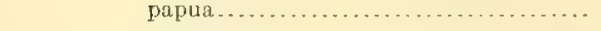 & 372 & 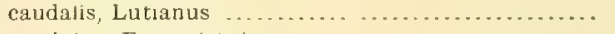 & 263 \\
\hline psegma & 372 & 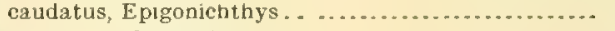 & 181 \\
\hline 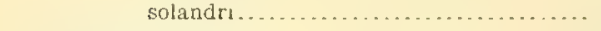 & 371 & 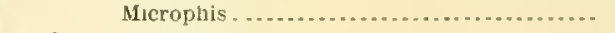 & 214 \\
\hline 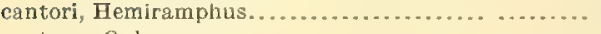 & 207 & 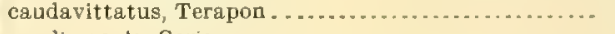 & 266 \\
\hline 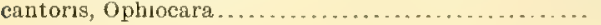 & 384 & 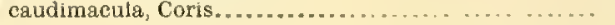 & 303 \\
\hline
\end{tabular}


caudimaculatus, Folocentrus.

Puge |

Page.

caudofasciatus, Canthigaster.

caudolineatus, Alticus.......

caudovittata, Kuhlia....

raulolepis...

longidens............

celebicus, Cally̆odon

Ihepatus

centiquadrus, II alichceres

Centriscida

Centriseus.....

Centrobranchus.

chorrocephitus

graciliceudus .

Centrogenys. -

$$
\text { waigiensis. }
$$

Centropogon

$$
\text { austrislis. }
$$

Centroseyllium

ruscostim .....

centurio, Spilotichthy

Cephalacanthirlo

Cephalacanthus.

orientalis.

Cephalopholis........

argus $\ldots \ldots \ldots \ldots \ldots \ldots \ldots \ldots \ldots$
aurantius $\ldots \ldots \ldots \ldots \ldots \ldots$

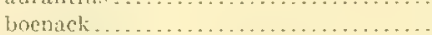

leopartus . . . . . . . . . . . . . . . . . .

miniatus.

sexmaculatus.

sonnerati. .

urodalus.

cephalus, Mugil

primensis, Cheilumus

$$
\text { Gohnion. }
$$

cerasina, Pseudojulis.

cerasinus, Enneapterygius -

Ceratiidze.................................

chacunda, Anodontostoma.

Chænogobius. . .

$$
\text { erytirops. }
$$

Chanomugil.

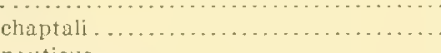

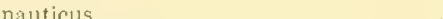

Chatodermis

penicilligerus.

Chætodon ..........

bennetti

citrinellus.

corallicola.

dixoni.....

ephippium .

flavirostris.

fremblii...

kleini ..... . .

lineolatus.

Iunuliz.....

melannotus

mertensi.

miliaris. . .

ornatissimus.

pelewensis.

\begin{tabular}{|c|c|}
\hline 72 & reticulatus................ \\
\hline 423 & semeion. ................................. \\
\hline & 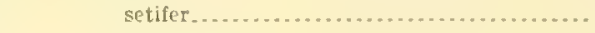 \\
\hline 19 & 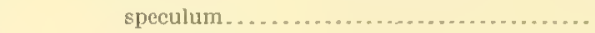 \\
\hline & richrous................. \\
\hline & trifasciatus............................. \\
\hline & 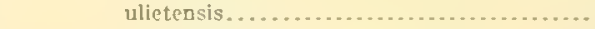 \\
\hline & nimaculatus. ........................... \\
\hline 12 & vagabundus.................................. \\
\hline & 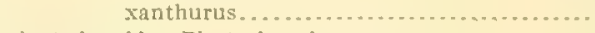 \\
\hline & chatodonoides, Plectorhynchus . . . . . . . . . . . . . . \\
\hline 53 & 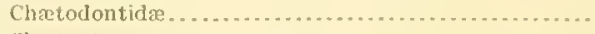 \\
\hline & ('haptopturus . . . . . . . . . . . . . . . . . . . . . . . \\
\hline 189 & 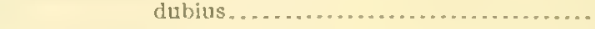 \\
\hline & 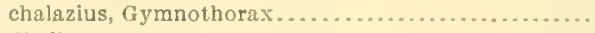 \\
\hline 256 & 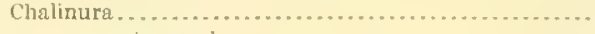 \\
\hline & ctenomelas.............................. \\
\hline 18 & 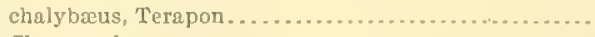 \\
\hline 183 & 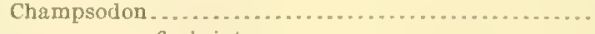 \\
\hline & 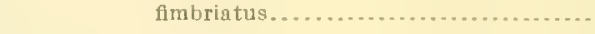 \\
\hline 268 & vorax....................... \\
\hline 381 & 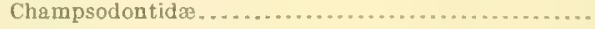 \\
\hline 81 & 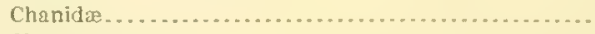 \\
\hline 381 & 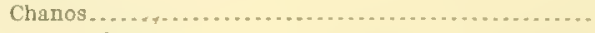 \\
\hline 57 & 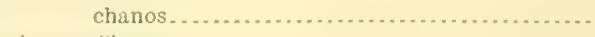 \\
\hline 2 & 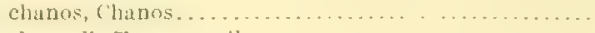 \\
\hline 58 & 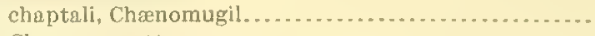 \\
\hline 258 & 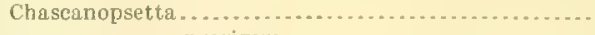 \\
\hline 258 & prorigera............................ \\
\hline 258 & 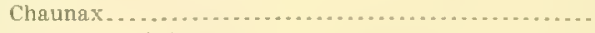 \\
\hline 258 & 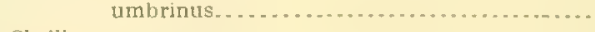 \\
\hline & 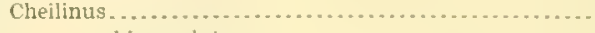 \\
\hline 2 & 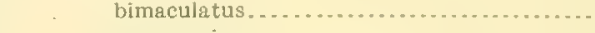 \\
\hline 2 & 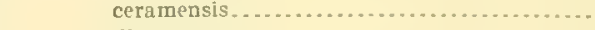 \\
\hline & digrammus. . . . . . . . . . . . . . . . . . \\
\hline 409 & 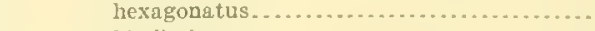 \\
\hline & 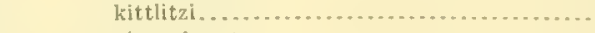 \\
\hline 419 & nigropinnatus. . . . . . . . . . . . . . . . . . . . \\
\hline & 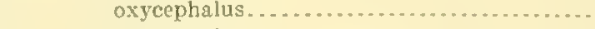 \\
\hline 187 & 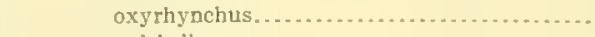 \\
\hline 404 & . puichellus..................................... \\
\hline 40 & roseus........................................... \\
\hline 218 & 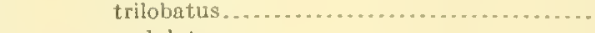 \\
\hline 218 & undulatus.................................... \\
\hline 2 & 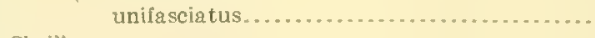 \\
\hline 36.5 & 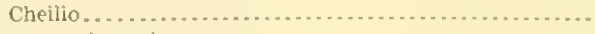 \\
\hline & 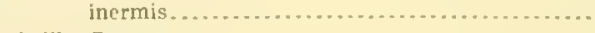 \\
\hline 3. & 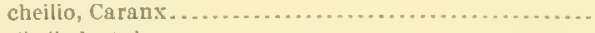 \\
\hline & cheilouluctylus . . . . . . . . . . . . . . . . . . . . . . \\
\hline 345 & 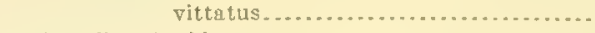 \\
\hline 344 & 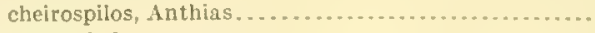 \\
\hline & 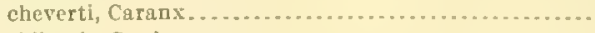 \\
\hline & 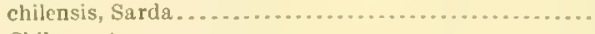 \\
\hline & 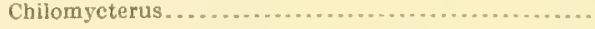 \\
\hline 341 & 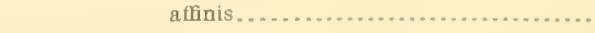 \\
\hline 346 & 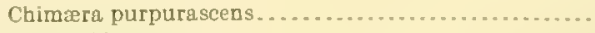 \\
\hline 342 & 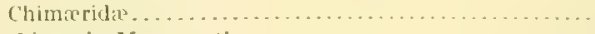 \\
\hline 340 & 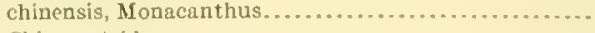 \\
\hline 340 & 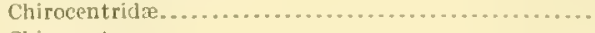 \\
\hline 34 & 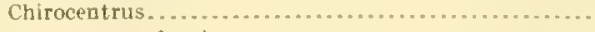 \\
\hline $3 \$ 1$ & 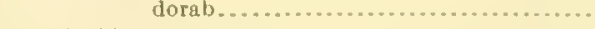 \\
\hline & 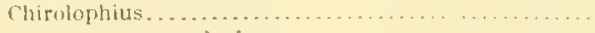 \\
\hline 345 & 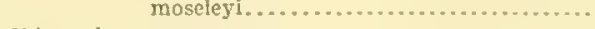 \\
\hline & 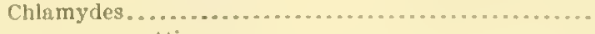 \\
\hline 34 & 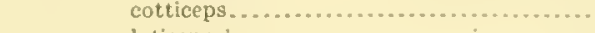 \\
\hline 3 & laticeps. \\
\hline & 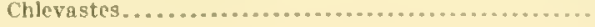 \\
\hline
\end{tabular}

plebejus.

punctatoiasciatus

quadrimaculatus. 
Chlevastes colubrinus

$$
\text { fasciatus. }
$$

chloreus, Dendrochirus

chlorocephalus, Epinephelus.

Chlorophthalmus.

proridens

chloropterus, Inalichoeres.

chlorospilus, Platophrys.

chlorurus, Thallurus

choerocephalus, Centrobranchus

Chorops.

anchorago.

brenchlyi

cyanodus.

cranostolus.

Chorististium

$$
\text { susumi }
$$

Chrionema

$$
\text { chryseres }
$$

squaraicep

Chromis...

$$
\text { analis }
$$

axillaris.

cæruleus.

dimidiatus.

elaphrus . .

iomelas. . . . . . . . . . . . . . . . . . . . . . . . . .

ovalis..

chryseres, Chrionema

$$
\text { Myripristis }
$$

chryserydros, Pseudupeneus

chrysonemus, Pseudupeneus

chrysopterus, Amphiprion.

$$
\text { Balistes. }
$$

chrysorhynchus, Diaphus.

chrysotæenia, II arengula

$$
\text { Lutinnus.. }
$$

chrysostomus, Lethrinus.

chrysozonus, Cresio...

$$
\text { Scomber. }
$$

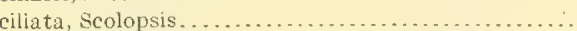

$$
\text { Sillago. . }
$$

einctus, Canthigaster.

$$
\text { Paracirrhites }
$$

cinereus, Murænesox

cingulum, Coris .

circumspectus, $\mathrm{Phipogobi}$

Cirrhilabrus.

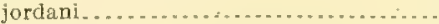

$$
\begin{aligned}
& \text { solorensis }
\end{aligned}
$$

Cirrhitide

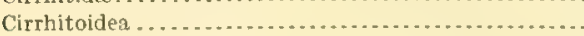
bimacula.............................

Cirrhitus......................... marmoratus.

oxycephalus.

cirrhosa, Scorpænopsis

citrinellus, Tænianotus.

$$
\text { Chætodon. . }
$$

citrinus, IIoplichthys.

Pseudogobiodon.

clara, Hetereleotris.

clarescens, Vitraria

Clupeida..

Cnidoglanis.

macrocephalus.

cobra, Leiuranus. page.
Page.

Abudefduf...........

Coelorhynchus........................... 437 aratrum....................... 437

doryssus. . . . . . . . . . . . . 437

gladius......................... 437

Collybus. .

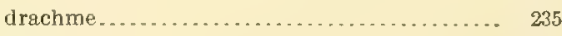

Colocopus.................................. 355

lambdurus...................... 355

coloratus, Sebastapistes. . . . . . . . . . . . . . . .... 376

colubrinus, Chlevastes........................ 195

commersoni, Antennarius. . . . . . . . . . . . . ....... 438

Harengula ........................ 180

Hemiramphus. . . . . . . . . . . . . . . 207

Scomberomorus................... 228

compressa, Liza.......................... 218

compressus, Canthigaster...................... 373

concatenatus, Siganws....................... 359

concavifrons, Gobius. ....................... 402

concolor, Lentipes............................. 411

Nebrius......................... 182

Uropterygus....................... 206

Congrellus............................... 193

æquoreus............................ 193

bowersi.......................... 193

fijiensis.......................... 193

guttulatus. . . . . . . . . . . . . . . . . . . . 193

neo-guinaicus......................... 193

Congrogadidæ. . . . . . . . . . . . . . . . . . . . . 434

Congrogadus ................................ 434

marginatus..................... 434

subducens....................... 434

coniorta, Sebastapistes...................... 376

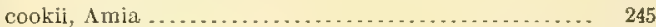

Callionymus............................ 415

Scorpæna........................... 376

copei, Ilemipteronotus........................ 311

corallicola, Chætodon ........................ 345

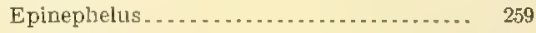

Sebastapistes .................... 376 .

corallinus, Callionymus..................... 415

Rhinogobius...................... 400

Samariscus....................... 413

Siganus....... . . . . . . . . 360

cordyla, Megalaspis . ............................... 229

Corica.................................. 186

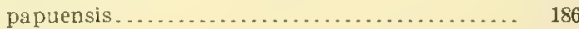

Coris ..................................... 303

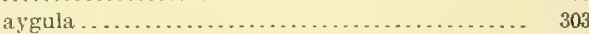

ballieui ................................. 303

caudimacula ... . . . . . . . . . . . .

cingulum ............................ 303

cyanea ............................. 303

multicolor ............................... 303

papuensis............................ 303

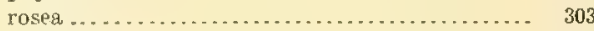

variegata $\ldots . \ldots \ldots \ldots \ldots \ldots \ldots \ldots \ldots \ldots \ldots . . . \ldots \ldots$

venusta............................. 303

cornuta, Lactoria........................... 368

coromandelicus, Tylosurus................... 207

coronatus, Alticus......................... 424

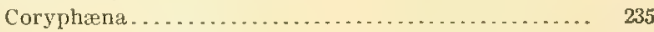

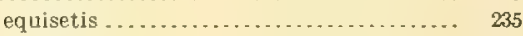

hippurus........................ 235

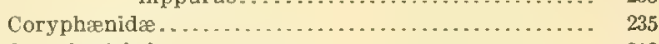

Corythroichthys........................... 212

mataafæ.

sealei............................ 213 
Corythroichthys trachypoma

$$
\text { waitei. }
$$

cotticeps, Chlamydes

crassiceps, $A$ mia

$$
\text { Mapo. }
$$

crassilabris, Awaous

Hemipimelodus

Pscudupeneus.

crassispinus, Euelatichthys.

crenilalis, Querimana.

Crepirlogaster.

$$
\text { lineatus. }
$$

$$
\text { Cristiceps......... }
$$

crocodolinus, Brachysomophis.

cruentatus, Callyouron.

$$
\text { Priacanthus }
$$

crumenulis, Pelecanichthys.

crumenophthalma, Trachurops.

$$
\begin{array}{r}
\text { Crsptncentrus............. } \\
\text { leucostictus. }
\end{array}
$$

Ctenochietus...

$$
\text { striatus. }
$$

ctenomelas, Chalinura .

Cubiceps.

$$
\text { patuciradintus }
$$

curacito, Abudefouf.

cuvieri, Anampses.

$$
\text { Julis. }
$$

cyanodus, Choerops

cranca, Coris.

cyanngaster, Thulassoma.

cyanognathus, Callyorlon

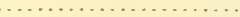

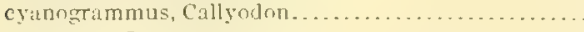

cyanomus, Pomacentrus

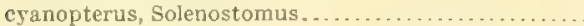

cyanostolus, Chcerops....

cyanotrenia, Labrichthys.

cyclostomus, Pseudupeneus.

Cyclothone.. rhodadenia

cyclurus, Calotomus.

Cymolutes.

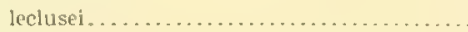

\section{cypho, Callyodon}

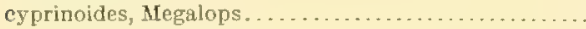

Cypsilurus.

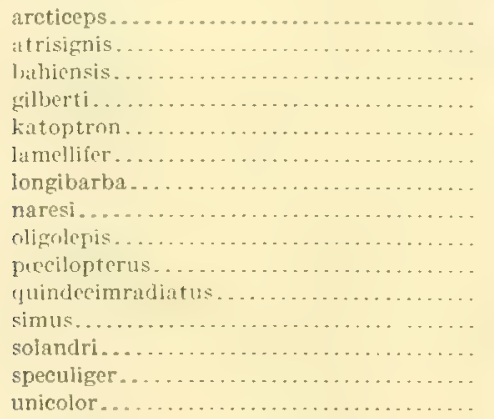

Cyttomimus.

$$
\text { stelgis. }
$$

dredalma, Trulichores

diemeli, lipinephelus.

Dalophis.
Page.

212

394

239

403

405

268

191

275

siv

218

434

434

420

$4 \geqslant 0$

195

322

261

413

230

406

$3=$

3.5.5

436
235

235

285

205

304

293

303

30 ;

334

330

279

212

292

294

275

190

190
Pasre.

Dalophis longipinnis....................... 1914 misolensis................................ 194

albisella.

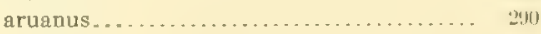

melanurus.

reticulatus .............................

trimaculatus.................

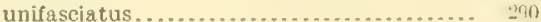

dasson, Caranx.......................... 231

Dosyatidæ.................................... 1

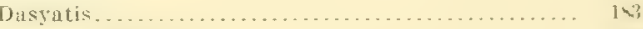

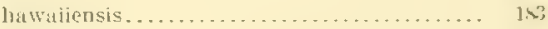

kuhli .......................... 16.

l.tta................................... 183

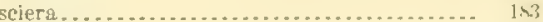

trigonoides............................ 1s3

dasyogon, Orectolohus.................... 1.2

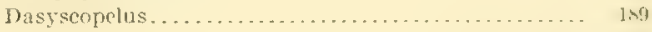

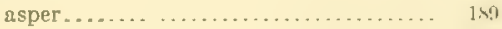

pristilepis...................... 1ng

spinosus....................... 189

duvi Ilemipimelodus........................... 191

delitis, Inticitharus..................... 413

Decupterus.............................. $2 y_{3}$

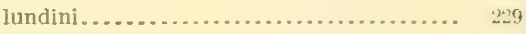

pinnulatus........................

decoratus, Calliurichthys. ..................... 415

delicatula, Echidna............................

delicatulus, Stolephorus .......................... 1mti

deltoidms, Griatholepis....................

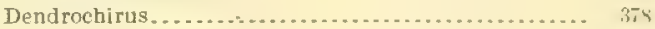

larberi.......................... 379

brachypterus...................... 378

chloreus. ........................... 379

sausaulele....................

zebra.........................

dentatus, Sebastapistes....................... 3it

denticulatus, Metopom jeter..................... 193

depauperatus, Hemiramphus................... 20.

detactus, Gymnothorax.......................... 201

devisi, lomucentrus............................

diacanthus, IInlacanthus.................. 347

diadema, IIolocentrus....................... 2.25

diadematus, Anampses...................... 29.

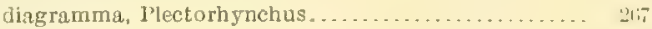

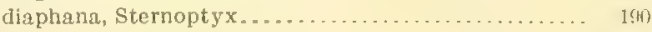

Diuphus. . . . . . ......................... 14!

adenomus. . ...................... 1*0

chrysorhynchus......................

urolampus.............................. 14

I)ibranchus............................

erythrinus........................... 4.4

stellulatus......................... $\quad \therefore 99$

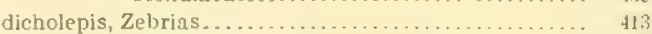

dickî, $\mathbf{A b u d e i d u f . . . . . . . . . . . . . . . . . . . . . . . . ~ . ~} 245$

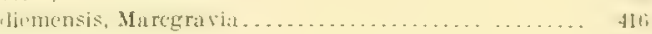

digrammus, Cheilinus............................. \$ \$

dimidiatus, Callyodon..................... 324

Chromis .............................

Luloroides.......................

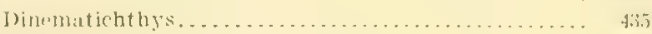

iluocuetenides ................. fili

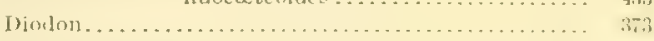

holacanthus.......................... 318.3

hystrix........................ $: 373$

nudifrons.............................. 373

Dioriontidar . . . . . . . . . . . . . . . . . 


\begin{tabular}{|c|c|c|c|}
\hline & age & & age. \\
\hline Diplophos......... & 190 & elegans, Gobius... & 402 \\
\hline pacifieus. & 190 & Microsicydium ....... & 411 \\
\hline Discoliatis............. & 183 & Eleotris................... & 393 \\
\hline matrginipinnis. & 183 & fusca. ........ & 383 \\
\hline dispar, Zenarchopterus.. . & 208 & sandwichensis... & $3 \times 3$ \\
\hline distigma, Eviota....... & 389 & elongatum, Gonostoma..... & 190 \\
\hline dixoni, Chætodon... & 341 & elongatus, Ilepatus . . . . . . . . . & 352 \\
\hline doliatus, Siganus.... & 359 & Petroscirtes... & 433 \\
\hline dorab, Chirocentrus. & 185 & Elopidx ..................... & 155 \\
\hline doreensis, IIepatus....... & 351 & Elops a $\ldots \ldots \ldots \ldots$ & 185 \\
\hline dorehensis, Antennarius... & 434 & saurus............... & 185 \\
\hline Trorosomatidr........... & 187 & emano, Abudefduf.... & 286 \\
\hline dorsale, Thalassoma..... & $30 \pi$ & Emmydrichtbys........... & 380 \\
\hline doryssa, Amia............ & 245 & vulcanus... & 380 \\
\hline oryssus, Cœlorhynchus... & 437 & Enchelynassa. ................... & 197 \\
\hline 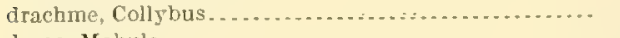 & 235 & caninu..... & 197 \\
\hline draco, Mobula........... & 185 & Enchelyurus................. & 434 \\
\hline Draconetta.............. & 415 & $\begin{array}{r}\text { ater............ } \\
\text { enchrasicoloides. Anchovia... }\end{array}$ & 434 \\
\hline $\begin{array}{l}\text { hawaliensis. } \\
\text { Drepane................ }\end{array}$ & 415 & $\begin{array}{l}\text { enchrasicoloides. Anchovia... } \\
\text { endrachtensis, Atherina...... }\end{array}$ & $18 \delta$ \\
\hline $\begin{array}{l}\text { Drepane.......... } \\
\text { punetatit. }\end{array}$ & $\begin{array}{l}335 \\
335\end{array}$ & 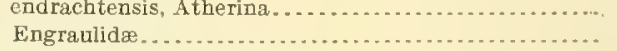 & 216 \\
\hline Drombus........ & $\begin{array}{l}353 \\
309\end{array}$ & $\begin{array}{l}\text { Engraulidæ................... } \\
\text { engyceros, I'eristedion . . . . . }\end{array}$ & 187 \\
\hline filamentosus. & 400 & $\begin{array}{l}\text { engyceros, Peristedion . . . . } \\
\text { Engyprosopon.............. }\end{array}$ & 351 \\
\hline tutuitæ...... & 399 & $\begin{array}{r}\text { arenicola... } \\
\text { arigyprosopon }\end{array}$ & 412 \\
\hline drombus, Antemnarius.. & 438 & hawailensis. & 412 \\
\hline dubius, Callyodon...... & 319 & Enneapterygius ........... & 416 \\
\hline Chætopterus.... & 245 & atriceps.... & 416 \\
\hline Opsanus................ & 416 & cerasinus... & $\$ 19$ \\
\hline ductor, Naucrates............ & 229 & hemimelas... & $\$ 16$ \\
\hline duescus, Antennarius... & 439 & hudsoni..... & 419 \\
\hline duperreyi, & 304 & minutus...... & 416 \\
\hline dussumieri, Callyodon... & 329 & pardochir..... & $\$ 17$ \\
\hline Ilepntus $\ldots \ldots \ldots \ldots \ldots$ & 351 & tusitalæ.... & 416 \\
\hline Leiognathus............... & 273 & tutuilæ..... & $\pm 1 s$ \\
\hline Dussumieria....................... & 186 & ensiformis, Nematobrotula... & 436 \\
\hline ucuta...... & 186 & eos, Antigonia....... & 335 \\
\hline Duymaria............ & 293 & stethopristis . .......... & $22 \pi$ \\
\hline caeruleomaculata. & 293 & ephippiatus, Argyripnus... & 190 \\
\hline nematopter & 29.3 & Ephippidæ. . . . & 335 \\
\hline Echeneididæ........................... & 411 & ephippium, Chætodon..... . & $3 \$ 3$ \\
\hline Echeneis..................... & 411 & Ephippus . . . . . . . . & 335 \\
\hline remora...... & 411 & argus $\ldots \ldots \ldots$ & 335 \\
\hline Echidna............ & 203 & multifasciatus..... & 335 \\
\hline amblyodon & 204 & Epibulus ............................. & 294 \\
\hline delicitulit. & 204 & insidiator ........... & 294 \\
\hline leibala...... & 203 & Epigonichthys ................. & 181 \\
\hline nebulosa.... & 203 & caudatus.... & 181 \\
\hline obscura..... & 203 & epilamprus, Canthigaster..... & 373 \\
\hline polyzona...... & 203 & Epinephelus.................... & 258 \\
\hline psalion........ & 203 & albopunctatus... & 260 \\
\hline tritor.......... & 203 & australis ........... & 259 \\
\hline trossula....... & 203 & cæruleopunctatus......... & 259 \\
\hline uniformis..... & 204 & chlorocephalus ........... & 259 \\
\hline zelira........... & 203 & corallicola....... & 259 \\
\hline & 203 & dæmeli........ & 259 \\
\hline . zonopha.............. & 203 & fasciatus..... & 259 \\
\hline echinocephalus, Paragobiodon... & $39 \pi$ & fuscoguttatus. & 259 \\
\hline eclancheri, Hemiramphus.......... & 207 & goldiei. . ......... & 260 \\
\hline ticus, Po & $2 \times 2$ & macrocephalus.. & 259 \\
\hline ectenes, Minerourus.... & $43 i$ & maculatus...... & 259 \\
\hline edentulus, Caranx............... & 232 & (n) & 260 \\
\hline Lciognathus....................... & 273 & megachir.... . & 259 \\
\hline 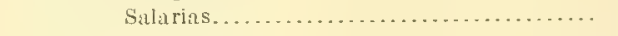 & 429 & merra $\ldots . . . . . . . . .49$ & 258 \\
\hline 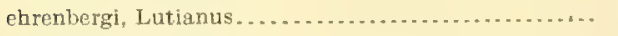 & 264 & pachycentron.. & 259 \\
\hline elucate, caranx......................... & 231 & 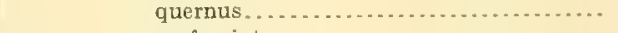 & 259 \\
\hline Elagatis............................. & 229 & sexfasciatus............ & 259 \\
\hline $\begin{array}{l}\text { lipinnulatus } \ldots \ldots \ldots \ldots \ldots \ldots \ldots \ldots \\
\text { elaphrus, Chromis }\end{array}$ & $\begin{array}{l}229 \\
292\end{array}$ & $\begin{array}{l}\text { socialis .......... } \\
\text { spiniger.......... }\end{array}$ & 259 \\
\hline & & spiniger...... - & 259 \\
\hline
\end{tabular}


Page.

Epinephelus stellans.

\section{summana.}

tauving.

undulosus.

epipluanes, Isvota...

equisetis, foryphanil.

Equulit. . . .

$$
\text { insidiator. }
$$

equula, Leiognathus

equulaformis, Gazza.

Fquulidie.

ereodes, fiymnothor:

erituma, Iibumuritnat.

erythacus, ('allyomlon.

ery thraus, Ifolocentrus.

lehthyocampus.

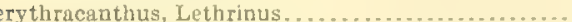

Erythrichthys .

$$
\text { selilegreli. }
$$

erythrina, Amia.

erythrinus, bil,runchus

Mulloides.

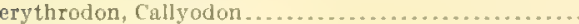

erythrogaster, Casio.

crythrops, chanogebiu.

erythropteris, Lethronus

I.utiuntus.

Etchs.

$$
\text { evurus }
$$

marshi.

Etmopterus.

$$
\text { r.llowus. }
$$

Etrumeus.............

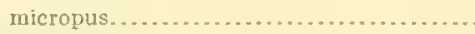

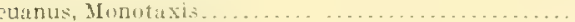

Euelatichthys.

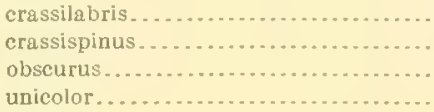

cugenius, Gobiomorphus

Eulentorhumphus

$$
\text { longirostris }
$$

curostus, fomnothorax.

euptera, Muræena

eupterus, Gymnothorax.

Eury mycters.

$$
\text { acutirostris. }
$$

evanidus, Pseudocheilinus.

evermanni. Alticus

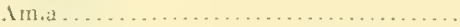

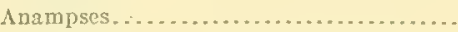

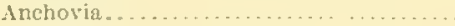

Ariomma....

Myctophum.

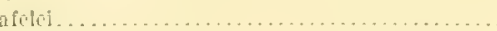

distigma.

epriphitnes. . . . . . . . . . . . . . . . . . .

herriei.

miniate.

prasites.

sebreei.

smaragdus.

Evoluntia. zonurd. .

micropturit.
$25 \mathrm{~S}$

259
Page.

Turus, Etelis ........

Exallias..................................... 4

brevis................................ $4: 31$

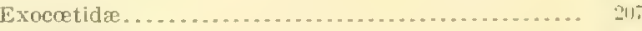

Exocretus................................ 2u.

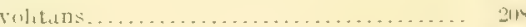

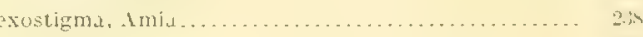

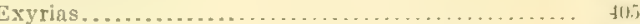

puntangoides.................... $40 \ldots$.

eydouxı, Julis ................................

fit, Ilimuntura......................... 141

fureimen, dobopterus . . . . . . . . . . . . .

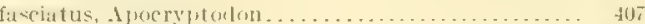

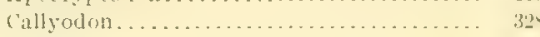

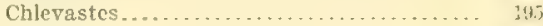

Epinephelus......................

Leiognathus......................... 273

Salurias......................... 427

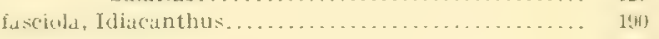

favagineus, Gymnothorax....................... 190

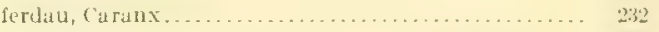

ferrugineum, Ginglymostoma......... ..... IN?

festivus, Callyodon ....................... 32.

Gbulatum, Myctophum . . . . . ................. $1 \backslash$ ?

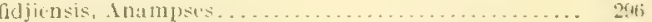

Inguilla . . . . . . . . . . .

sitarches..........................

Fieruser............................... $43 . ;$

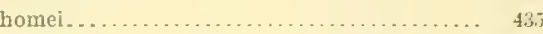

microdon....................... 43

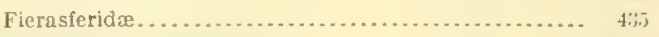

fijiınsis, Congrellus......................

dilamentosus. Aludeldue..................

Petroscirtes....................... 4i1

Dromtus . . . . . . . . . . . . . . . . tum

Pseudupeneus...................... $\quad 270$

Glaris, Callechelys............................... 19

flholi, Abudefduf. . . . . . . . . . . . . . . . . . . . . . .

Callyodon.................................

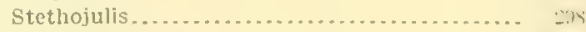

filicauda, Monacan thus.......................... \$ 36

filiferia, Bembrops........................ 111

fimbriatus, Champsodon...................... 111

finschi, Macrorhanihusus..................

fisheri, Hippocampus.... . . . . . . . . . . . . . . . . 21.

Holacanthus............................

Fishes of Samoa known prior to 1902 , list.......... 17s new speeies, list .................. 1,9

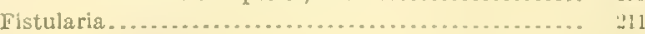

petumb:1 . . . . . . . . . .

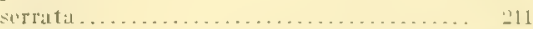

Fistulariidæ........................... 211

Gammeus, Mulloides..................... 2,

Gavescens, Zebrasoma...................... ;i;

devirostris, Chatodon........................ $: i l 1$

flavima rginata, Variola........................

Alavicaudus, Sphagebranchus................... 111

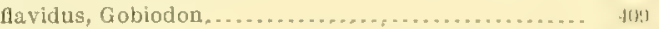

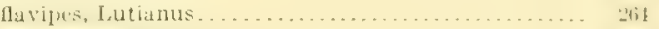

Giviroseds, Lutianus. . . . . . . . . . . . . . . . .

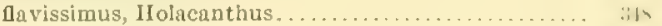

flavivultus, $\Lambda$ phareus........................

Gavoguttatus, IIepatus......................... . . int

flavomarginatus, Balistes. . . . . . . . . . . . . . . itil

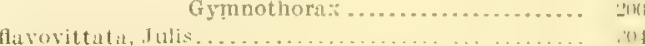

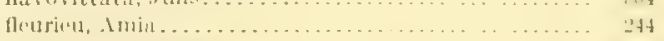

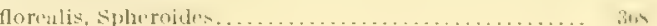




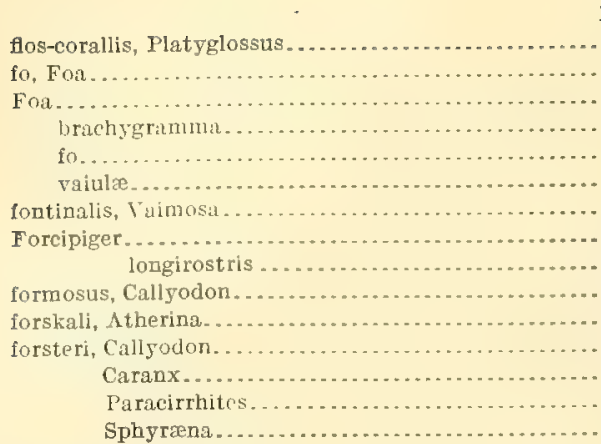

Page.

299

248

245

248

248

249

395

336

336

224

216

325

230

278

219

fowleri, Microdonophis ....

fraterculus, Pseudupeners.

fremblii, Chætodon.

frenata, Amia...

frenatus, Callyodion.

Ireycincti, Hemiscyllium .

froggatti. Galeichthys

frontalis, Callyodon.

fuliginosus, Cantherines.

IIemigymnus.

IIepatus..

fulviflamma, Lutianus.

fulvoventris, Stethojulis.

fulvus, Lutianus.

fureatus, iphareus.

Irolocentrus.

furcosus, Nemipterus.

fuscescens, Lutianus.

$$
\text { Siganus... }
$$

fuscipinnis, Odontanthias

fusca, Amia...

$$
\text { Eleotris. }
$$

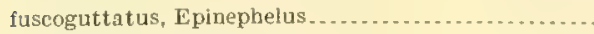

fuscolineatus, Balistes.

fuscomaculatus, U ranoscopus.

fuscum, Thalassoma. . . . . . . . . . . . . . . . . . . .

fuscus, Balistes...

Kyphosus.

Mapo.....

Pseudochromis

Gadida...

melanopterus

gaimardi, Hemiramphus.

Julis.

galactacme, Sebastapistes....................... 376

Galeichthys ............................. 191

froggatti......................... 191

latirostris.... .................. 191

Galencerdo ......................................... 182

tigrinus........................... 182

galeodon, Lactoria .......................... 367

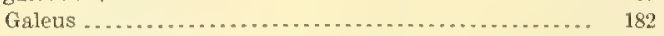

japonicus .............................. 182

garmani, Salirias........................... 429

garretti, Acanthurus ... . . . . . . . . . . . . . . $358^{\prime}$

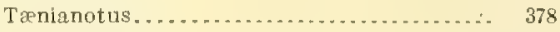

Gasterotokeus . . . ......................... 215

biaculcatus . . . . . . . . . . . . . 215

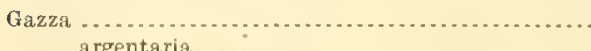

Gazza equalacformis..................... Page.

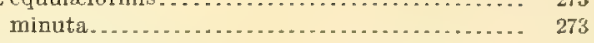

genivittatum, Thalassoma................... 307

genivittatus, $A$ waous...................... 405

geoffroy, Afacropharyngodon..................... 298

geographicus, impheces . . . . . . . . . . . . . . . . . 296

germaini, Petroscirtes...................... $\$ 34$

Germo = . . . . . . . . . . . . . . . . . . . . . . . . . . . 225

germo.............................. 228

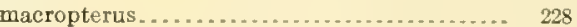

germo, Germo........................... 228

Gerridæ..................................... 272

gibber, Macrourus...................... 437

gibbifrons, Alticus . . .......................... 423

gibbosa, Harengula ............................ 187

Scorpænopsis........................ 375

gibbus, Lutianus.............................. 262

giganteus, Plectorhynchus, ................... 267

Tetraodon.......................... 371

Tylosurus ............................. 207

gigas, Ambassis................................. 255

Xystrma.......................... 272

gilberti, Callyodon........................ 324

Caranx.............................. 234

Cspsilurus........................ $\approx \nwarrow 99$

Salarias ................................... 431

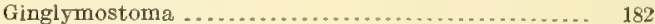

ferrugineum.................... 182

Ginglymostomatidæ............................ 182

gladius, Cœlorbynchus..................... 437

Xiphias... . . . . . . . . . . . . . . . . .... 229

glauca, Isuropsis.......................... 183

Prionace............................. 182

glaueus, 1 budefduf......................... 280

clobiceps, Callyodon............................ 326

Glossogobius .................................... 403

vaisiganis........................ 403

Gnathodentex ............................ 269

aurolineatus.................. 209

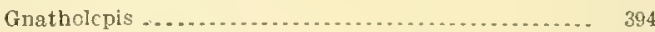

canalx.............................. 395

deltoides. . . . . . . . . . . . . . . . . . . . 394

knighti . . . . . . . .................... 395

maculipinnis...................... 395

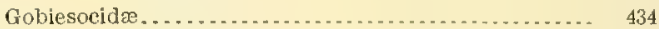

Gobilichthys . ............................. 407

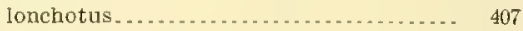

papuensis ................... 407

Gobiidæ. . . . . .............................. 381

Gobiodon . . . . . . . . .

atrangulatus........................ 409

axillaris.............................. 409

ceramensis. . . . . . . . . . . . . . . . . ..... 409

flavidus............................. 409

histrio... . . . . . . . . . . . . . . . . . .... 409

inornatus. . . . . . . . . . . . . . . . . . . . . . . 409

lineatus . . . . . . . . . . . . . . . . . . . . . 409

rivulatus. . . . . . . . . . . . . . . . . . 409

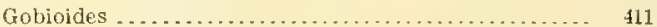

totoyensis....................... 411

Gobiomorphus ............................. 384

eugenius.......................... 384

sclateri.......................... 384

Gobionellus . . .

atriclypeus........................... 407

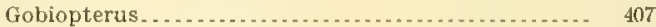

farcimen..................... 407

Gobius..................................... 401 
Page.

Golvius caledonicus

concavifrons

elegans.

oligolepis

ornatus.

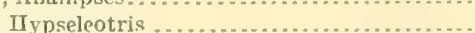

goesi, Sularias .

goldiei, Eschrichthys

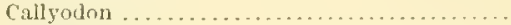

Epincphelus ....................... 2

Lutianus

Rhomhatractus ........................ 216

goldsboroughi, Gymnothorax.................. 199

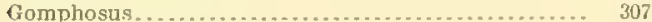

pacificus........................... 307

sand wichensis. . . . . . . . . . . . . . . . ..... 30 S

tricolor.......................... 307

undlulatus...................... 307

varius ........................... 307

Gonochetodon

triangulum

Gonostoma................................. 190

elongatum.......................... 190

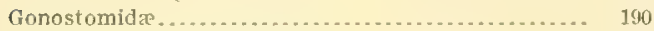

gracilicauda, Gymnothorax...................... 202

gracilicandus, Centrobranchus....................... 189

gracilis, Saurida............................... 189

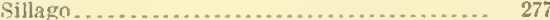

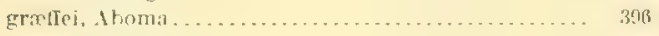

Mionorus . ............................. 247

Tachysurus................................ 191

Grammatonotis........................... 261

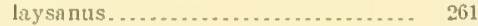

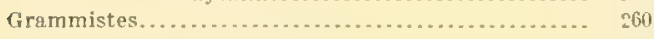

sexline.tus. . . . . . . . . . . . . . . . . .

grammistes, Petroscirtes...................... 432

grandisquamis, Saurida ...................... 159

sphyr:trit.................... $21^{17}$

grandoculis, Monotaxis. . .................... 27

granulatus, Himantura. ......................... 185

Rhinobatus...................... 18.3

greenovii, Julıs.................................. 304

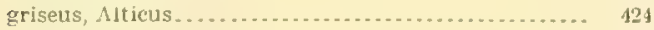

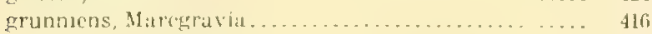

guamensis, $\Delta$ mia. . ............................. 239

Aw:1ภus.................... $40 . ;$

Sebastopsis............................. 374

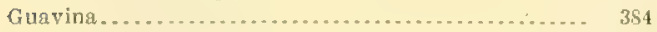

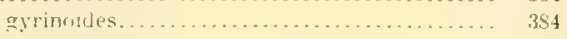

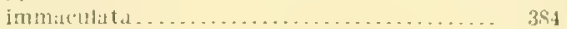

mulliver Kurtus........................ 237

guntheri, Hypseleotris........................... 385

Thatassoma......................... 305

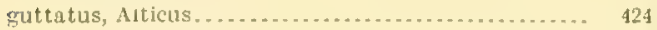

Halıchœres........................... 303

Ileparus............................... 351

guttulatus, Congrellus. ............................. 193

Ilalichores. . . . . . . .

Pseudorhombus........................ 412

gymnocephalus, Jialichores................... 303

gymnognathos C'altyodon........................ 331

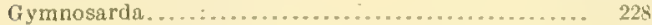

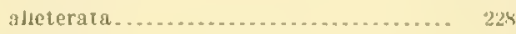

pelamis............................ $22 \mathrm{~s}$

gymnostethoides, Caranx...................... 232

Gymnothorax ................................. 197

berndti............................ 203 l'a:ce.

Gymnothoraxburoensis ...................

rhatazius ..................

detirtis

ercorles........................ 2113

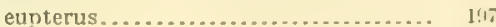

curostus................................... 194

favagineus. ....................... 1!!y

faromarginatus.

goldshoroughi.................. 19.

gracilicauda.................... 20.2

hilonis....................... $2(1)$

javanicus......................... 2(k)

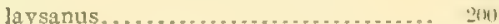

leurostictus . . . . . . . . . . . . . . . .

lineutus ..........................

litus............................ 19

nelcugris..................... 197

mucifer.......................... $2(x)$

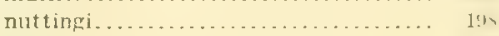

petelli........................ 19

pictus............................ 19

polyophthalmus................. 15

polyuranoton ................... 200)

rhodoceplalis .................. 20.

steindachneri......................

stellatus....................... 19,9

trenioides .......................... 190

talofit ........................... 201

tenebrosus.................... 20 .

thalassnpterus.................. 201

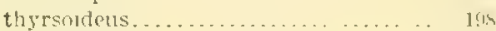

undulatus.............

wrialux....................... 197

ranthostomus, . . . . . . . . . . . . 19,

gyrinoides, Guavina..................... 31

habenatus, Macrourus. . . . . . . . . . . . . . .

hamatochir, Plectorhynchus................. 268

liæmatnpterus, Jethrinus. . . . . . . . . . . . . . . 270

IIxmuldat.................................

Halichneres........................... $36 n$

nuritus. ......................... $31, ?$

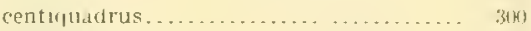

chloropterus..................... 3 .

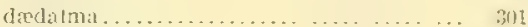

guttatus.....................

guttulatus... ... ................. 31)

gymnncephalus................... . 30.3

lao. ................. 31$)=3$

leparensis . . . . . . . . . . . . . . . . . . sos

macleayi . . . . . . . . . . . . . . . . . . . . 303

margarititceus. ......... . . . . . . . 3()$_{2}^{2}$

melanurus....................... . . . 30 ;

nebulosus,..................... . .

notophthalmus................... 301

opercularıs.....................

ornatissimus................

papilonaceus.........................

poecilus ....... . . . . . . . . . . . . . .

scapularis.................... sin

solorensis............. . . ........ 3us

trimacuatus.................. 301

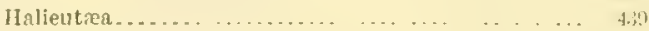

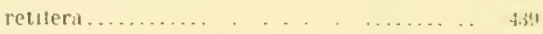

Halosqurudx..................... . . . . . . 1.11

hamruhr, Priacanthus.... . ............ $\$ n$

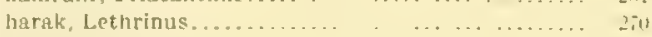

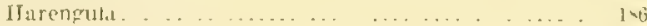

ehrysotmenia.................... 15i 


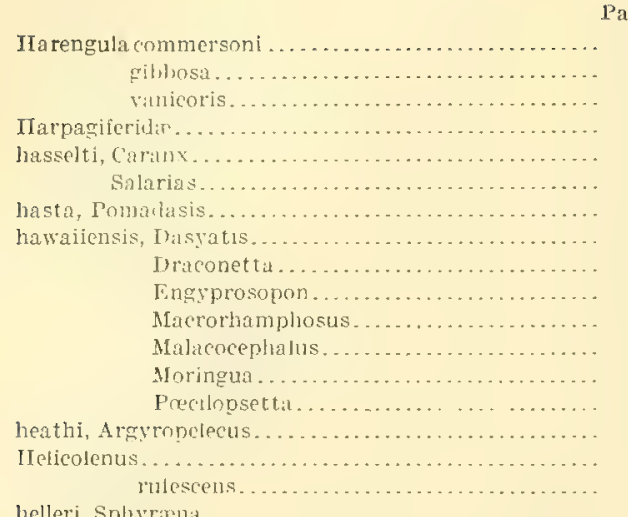

helleri, sptryrana

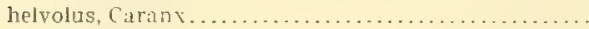

Hemipteronotus.

baldwin

copel.

pentadact ylus

umbrilatus.

Hemigymnus

fuliginosus.

melapterus.

hemimelas, $\mathrm{A}$ budefduf.

Enneapterygius.

IIemipmelodus.

('rassilabris

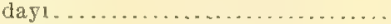

Hemiramphus.

aeutus.

affinis.

australiensis.

cantori.

commersoni

depauperatus.

eclancheri.

gaimardi.

laticeps.

limbatus . -

melanurus.

pacificus.

quoyi

Ifemiscyllidto

(2..................... 20

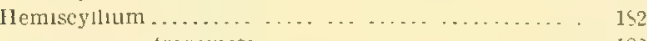

ireyemetı................... 18

ocellatum . . . . . . . . .

hemistictus, Paracirrhites.... . ............ 278

Hensochus ...................................... 340

acuminatus...................... 340

intermedus................... . . 347

monoceros . . . ............. $34 i$

permutatus. .................... 346

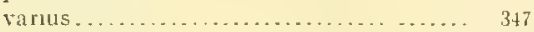

henshawi. Brachysomoplis. ................. 195

Hepatus .

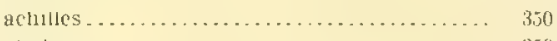

allala ......................... 350

aquulinus . ...................... 353

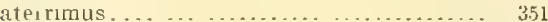

atramentatus. .................... 35.

bariene .......................... 359

bishopt....................... 353

celebicus..................... 352
Page.

Hepatus doreensis ........................ 351

dussumieri. ........................ 351

clongatus............................. 352

flavoguttatus...................... 35

fuliginosus . . . . . . . . . . . . . . . . . . . 352

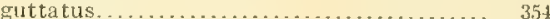

leucopareius ....................... 352

lineatus........................... 351

marginatus........................ 354

matoides ......................... 352

nigricans........................... 35

olivaceus . . . . . . . . . . . . . . . . . . . . . 350

pyrilerus......................... 350

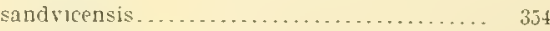

trinstegus . . . . . . . . . . . . . . . . . . 35

umbra............................. 353

herrej, Eviota................................... 390

Hetereleotris. . . . . . . . . . . . . . . . . . . . . . . . . . 39

clara.......................... 39.

phaenna.

heterorbinos, Soleichthys .................. 413

hexagonatus, Cheljinus.......................... 308

hexagonus, Afy ripristis..................... 221

hexatrola, Psuedocheilinus.................... 311

bexopthalma, Parapercis .................... 41

hians Atllennes........................... 207

Peristedion....................... 381

nilonıs, Gymnothorax .................... 200

IIıpocampus......................... 215

Himantura

fai . . . . . . . . . . .

granulatus ........................ 185

uarnak .......................... 185

Hippocampus ........................... 215

fisherı. ....................... 215

hilonis ....................... 215

kida........................... 215

hippurus, Coryphana ................... 235

hirsutus, Leprdaplo1s. .......... ............. 293

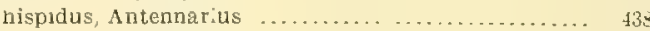

Tetraodon ................................. 369

histrio, Gobiodon ........................ 409

Pterophryne..................... 438

horen

Hlolacanthus . ............................ 347

aiternans ..................... 340

areuatus . . . . . . . . . . . 319

bicolor .................... 318

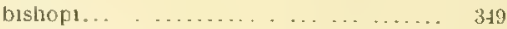

bispinosus..................... 348

diacanthus ...................... 347

fisheri.........................

Havissımus...... ............. 348

imperator...................... 349

loriculus . . . . . . . . . . . . . . . . . . 349

marlanas. . . . . . . . . . . . . . . . . . . 319

navarchus...... 318

nicobariensis....................... 349

semiereuratus. . . . . . . . . . . . . . . 349

Golacanthus Diodon ....... 373

IIolocentrida . . . . . . . . . . . . . . . . . . . . . 220

I Iolocentrus . . . . . . . . . . . . . . . . . . . . . . . . 223

bunotatus....................... 224

bowier ........................... 226

caudimaculatus ... ... . . . . . . . . ... 223

diadema ........................ 225

ensifer ........................... 296

erythrius . . . . . . . . . . . 
Page.

Holocentrus furcatus.

lacteoguttatus.

lictis

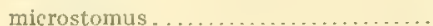

operoularis.

pruslin.

punctutissinus

rulier.

sammara.

scythrops.

spinifer.

tiere.

tierenides

vicilacels.

xantherythrus.

holocentrus, Macrourus.

Jologymnosus.

\section{longipes.}

somilisis tus.

holomelas, sularias.

Holotrachys

homei, Fierasfer

$$
\text { lima... }
$$

IIoplichthyidx.

IIoplichthys.

$$
\text { (itrinus. }
$$

jlatophrs:

hudsoni, Enneapterygius

hyalosoma, Amia. .

Hymenocephalus.

$$
\begin{aligned}
& \text { aterrimus. } \\
& \text { ant ratus... } \\
& \text { striatulus. }
\end{aligned}
$$

IIypleurochulus.

periophthalmoides.....

$$
\text { vallianti. }
$$

IIypolophus........

hypomelas, stemonidium. .

IIypoprionodon . . . . . . . . . . .

$$
\text { macloti. . }
$$

hypselosomus, Pseudanthias.

$$
\text { IIYTselentris. }
$$

$$
\begin{aligned}
& \text { godettroyi .... } \\
& \text { gunthrri...... } \\
& \text { maerolepidotus. } \\
& \text { vanicolensis.... }
\end{aligned}
$$

hypselogeneion, Spheroides.

hystrix, Diodon.

Ichthyocumpus. .

erythritus .

$$
\text { papuensis }
$$

Icosteidae.....

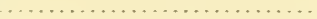

Idiacanthus.

$$
\text { fasciola }
$$

iluocceteoides, Dinematichth

immaculata, Guavina.........

immaculatus, Tetraodon.

imparipennis, Abudeiduf..

imperator, Holacanthus.

incipiens, Acanthurus.

incisum, ()sopsaron.

indicus, Pscudupeneus.

inermis, Cheilio.

$$
\text { Platophrys. }
$$

Prge.

Iniistius. . . . . . . . . . . . . . . . . . . . . . . . . . 312

aneitensis ............................. 312

carneoflavus.......................... $31 \%$

niger............................. 312

pavoninus . .......................... 312

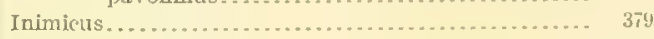

maculatus............................ 379

inornatus, Gobiodon . . ..................... 40y Pomacentrus...................... 2si

Invili,

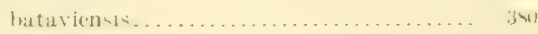

Epibulus............................ 294

Fquula.............................. 272

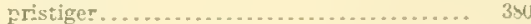

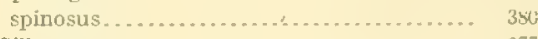

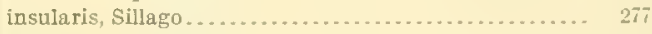

insularum, $\Delta$ therina........................... 210

Carcharias.......................... 182

Spheroides............................ 368

intermerius. Henirchus . . . . . . . . . . . . . . .

Myripristis.....................

interruptus, Terapon......................... 266

iomelas, Chromis............................ 29.

Iracundus

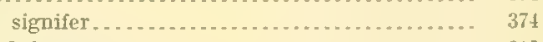

irradians, Calotomus. .............................. 313

isacanthus, Platycephalus....................... 380

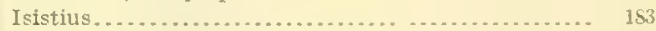

bræsilieasis............................. 183

Islands of South Seas, classification. . . . . ........... 150

isostigna, Apcgonichthys.......................... 251

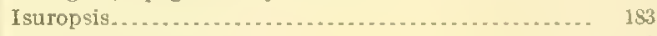

glauca................................. 183

jactator, Canthigaster.................... 372

jaculatrix, Toxotes...........................

janseni, Thalassoma ......................... 30.

janthinus, Canthigaster....................... 372

japonicá, Mobula............................. 1S

japonicus, Calliurichthys...................... 415

Galeus............................... 182

Scomber .......................... 228

javanica, Moringua............................. 195

javanicus, Gymnothorax ........................ 200

Psenes. . . . . . . . . .

jenkinsi. Callyodon............................. 326

Pomacentrus....................... 241

johni, Lutianus. . . . . . . . . . . . . .................. $26 t$

jonesi, Callyodon................................ 323

joram, Rhinobatu........................ 143

jordani, Callyodon............................ 331

Cirrhilabrus.......................... 308

Malthopsis............................ 438

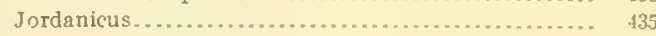

boraborensis......................... 435

parvipinnis.......................... 43

umbrntilis ............................

Julis......................................... 30

cuvieri.................................. 304

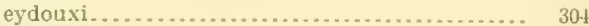

flavovittata........................... 3u

gitmardi........................... 30.

greenovii.................................. 304

lepomi. . . . . . . . . . . .

pulcherrima............................... 30.1

kaiqnus, Synodus.................................. 188

kailuer, Muriena........................ 19ti

kalosomu, stethojulis...................... gys

kallosomus, Novaculichtbys........................ 3il 
Page

kandavensis, Mugil

kasmira, Lutianus.

katoptron, Cypsilurus.

kauaiensis, Aldrovandia

kelaarti, Mugil.

Kelloggella

cardinalis

oligolepis .

kelloggi, Callyodon.

Pseudanthia

Sebastopsis.

kenie, Sphyræna.

kittlitzi, Cheilinus.

kleini, Chrtodon

knighti, Anarchias.

Gnatholepis.

koilonatodon, Amia

komis, Centriscus.

Konosirus.

$$
\text { thrissa. }
$$

kuda, Hippocampus

kuhli, Dasyatis

Kuhlia..

caudovittata.

malo.

marginata

rupestris.

tæniura - - - - - - - -

Kuhliidx

urvillii. . . . . . . . . . . . . . . . . . . . . . . . . . 255

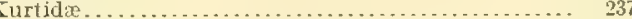

Kurtus.

gulliveri.

Kyphosidx

Kyphosus.

fuscus.

lernbus.

sandvicensis.

tahmel..

waigiensis.

labiosus, Callyodon.

Labrichthys

australis...

cyanotænia.

Labridæ. .

Labroides.

dimidiatus.

paradisæus

lacerta, Callzodon

lacrymatus, Abudefduf.

$$
\text { Tetraodon. }
$$

Iacteoguttatus, Holocentrus

Lactoria.

cornuta.

galeodon.

schlemmeri.

lacunosa, Atherina

Lamonema

$$
\text { rhodochir. }
$$

lævis, Holocentrus.

$$
\text { Spheroides. }
$$

lafa, Ambassis.

lambdurus, Colocopus

Lambertis.

atra. . . . . . . . . . .

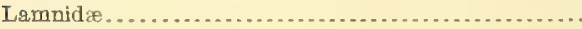

Lampridae
Page.

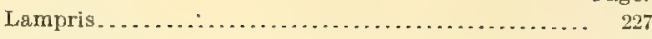
regia............................. 227

lamellifer, Cypsilurus ............................ $\quad 210$

lanceolatus, Pseudapocryptes . . . . . ............. 407

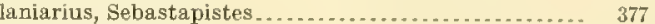

lao, IJalichøeres. . . . . . . . . . . . . . . . . . . .... 303

laotale, Sebastapistes. . . . . . . . . . ............... 376

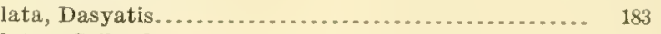

latax, Callyodon............................... 329

lateralis, Imia . . . . . . . . . . . . . . . . . . . . . . . . 240

laticanda, Myropterura...................... 193

laticaudus, Caranx..... 332

Lethrinus.......................... 270

laticeps, Chlamydes............................... 394

Hemiramphus.......................... $20 \%$

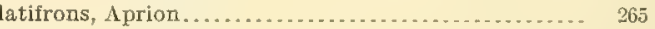

latirostris, Galeichthys. ............................ 191

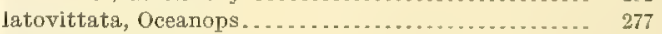

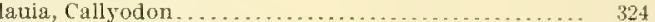

laysanius, Antennarius.................... 438

laysanus, Grammatonotus...................... 261

Gymnothorax....................... 200

lazulinus, Callyodon........................... 333

leclusei, Cymolutes. . . . . . . . . . . . . . . . . . . . . . . . . . . . . $\$ 312$

leihala, Echidna............................... 203

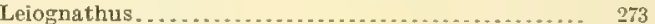

dussumieri.......................... 273

edentulus. . . . . . . . . . . . . . . . . . . . 273

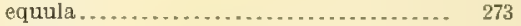

fasciatus....................... 273

obscurus................. 273

smithursti........................ 273

Letrus ................................... $\mathbf{2 3 6}$

maculatus........................... 236

paucidens. . . . . ....................... 236

Leiuranus. . .

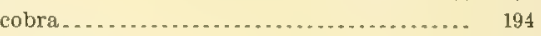

semicinctus............................... 194

leiuroides, Tylosurus........................... 206

lembus, Kyphosus............................... 271

Lemnisoma ............................. 228

thyrsitoides....................... 228

lentiginosum, Ostracion...................... 367

Lentipes concolor . . . . . . . . . . . . . . . . . . . . . . . 411

seminudus............................ 411

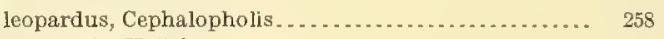

leparensis, Halichores....................... 303

Lepidopid

Lepidaplois . . . . . . . . . . . . . . . . . . . . . . . . 293

albotæniatus..................... 293

axillaris . . . . . . . . . . . 293

hirsutus . . . . . . . . . . . . . . . . . . . 293

modestus............................ 293

perditio . . . . . . ....................... 293

strophodes......................... 293

lepidus, Callyodon.............................. 319

lepomis, Julis . . . ............................... 304

leprosus, Antennarius......................... 438

leptacintha, Amia . . . . . . . . . . . . . . . . . . . . . . . 245

Leptecheneis. .

(nates................................ 411

Leptocephalus . . . . . . . . . . . . . . . . . . . . . . . . . . . . . . . 193

marginatus....................... 193 pardalis.............

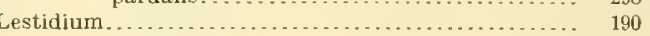

nudum. . . . . . . . . . . . . . . . . . . . . . . . ...... 190 

miniata

Iethrinus. alionuttuti. . . . . . . . . . . . . . . . . . amboinensis. aurolineatus. bonhamensis.

chrysostomus. erythracanthe

erythropterus

harak

hxmatopterus.

laticaudus.

leutjanus.

mahsena....

mithsenoi

nelulost:s.

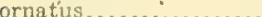

papuensis.

ramak.

waigionsis.

xanthopterus.

leuciscus, Myxus.

leucogaster, Abudefduí

leucogrammicus Anyperodon.

leucopareius, Hepatus.

leucopomus, Abudefduf.

leucostictus, Cryptocentrus

Gymnothorax.

leucurus, L ropterytus.

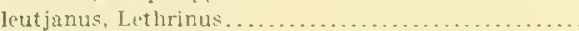

lili, Synchiroyus . . . . . . . . . . . . . . . . . . . . . . .

lima, IIolotrachys.

limbatus, Hemiramphus.

lineata, Scolopsis..

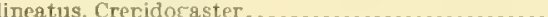

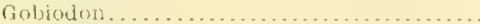

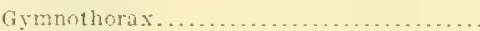

II

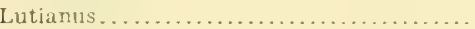

Phtheirichtlies . .............................

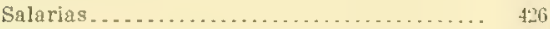

Siganus........................... $3 i 5$

lineolata, Archamia . . . . . . . . . . . . . . . . . . . . .

lineolatus, Chirtodon .................... 340

Petroscirtes. . . . . . . . . . . . . . . . . . . 4.40

Synchirni us...................... 41.;

lineopunctatus, Xanthichthys....................... 363

liorhynchus, Peristedion......................... 3\$1

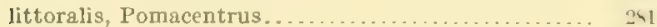

lituratus, $\Lambda$ canthurus........... 35

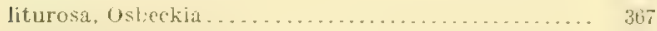

litus, finmnothorax........................ 198

lividus, Pomacentrus. . . . . . . . . . . . . . . . . . . . .

Liza. . . . . . . . . . . . . . . . . . . . . . . 217

compressa .......................... $21 \mathrm{~s}$

ceruleomaculata ........................ 217

melinopteria............................ 217

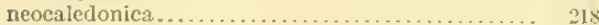

papillosa............................... 214

troscheli .................................

waigiensis ........................... 218

loaloa, $\Lambda$ gonostomus . ...................... 219

Lo.

vulpinus

lonchotus, Gobiichthys

longibartu, Cypsilurus. longidens, Caulolepis

longililis, Petroscirtes.............................. 431

longipes, IIologymnosus .......................... 304

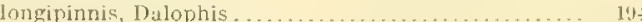

Valenciennea . . . . . . . . . . . ........... 352

longirostris, Euleptorhamphus.................. 20 s

Forcipiger........................ 326

Oxymonacanthus...................... 365

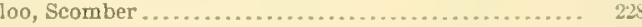

Lophiidx . . . .................................... 437

Lophiomus.

miacanthus....................... 437

naresi . . . . . . . . . . . . . . . . .

Iouti, Variola . . . . . . . . . . . . . . . . .

Ioriculus, Iolacanthus. ........................ 349

lucifer, Astronesthes................................ 190

lugubris, Caranx............................... 230

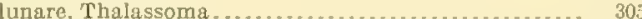

lunaris, Cæsio . ............................... 260

hundini, Decapterus. ................................ 229

Lunula, Chrtodon ............................. 340

lupus, Callyodon................................ 322

lurida, $\Delta$ riomma................................ 235

Iutescens, Thalassoma........................ 305

luteus, Callechelys . . ............................... 194

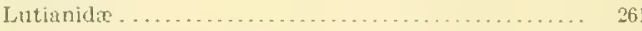

Lutianus...................................... 261

aleti............................ 265

argentimaculatus...................... 262

aureovittatus.......................... ght

bidens . . . . . . . . . . . . . . .

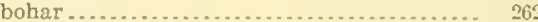

cæruleolineatus........................ 262

caudalis............................... 263

chrysotænia.......................... 264

ehrenbergi ............................ 264

erythropterus . . . . . . . . . . . . . . . . . . . . . 264

davipus............................ 264

Aavirnseus . .................................

fulvillamma ........................... 264

fulvus ............................... 263

fuscescens........................ 265

gibbus ................................. 262

goldiei .................................. 263

jolnni .............................. $\$ 64$

kasmira............................... 261

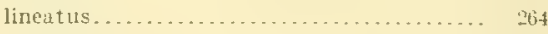

marginatus ..........................

marginipinnis........................... 263

monostigma ........................... 264

niger . . . . no . . . 260

olivaceus........................

parvidens.............................. 263

rivulatus................................ 262

roseis . . . . . . . . . . . . . . . . . . 262

rubens ................... 264

rufolineatus ....................... 263

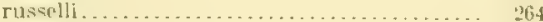

semicmetus . . . . . . . . . . . . .

sexfisciatus ..........................

unicolor ........................... ge.

vittit............................

waigiensis. ................................. 263

lutkenl, Myctophum . ............................ 189

Lycodapodidx................................... 435

Iymma, Treniura................................ 18.

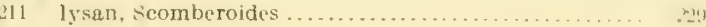

B. B. 1. $1905-1$ 
macgregori, Microdonophis..................... Page

macleayi, Callyodon.

Halichceres.

macloti, IIypoprionodon

macracanthum, Xystæma

macracanthus, Ambassis.

Macrias

amissus

macrocephala, Merinthe.

Moringua.

macrocephalus. Cnidoglanis

Epinephelus.

Uropterygius.

macrocheilos, Callyodon.

macrodon, Paramia.

macrolepidota, Ophiocara

macrolepidotus, Hypseleotris.

$$
\text { Novaculichthys: }
$$

Macropharyogodon

$$
\text { geofiroy }
$$$$
\text { meleagris }
$$

macrophthaimus, Scolopsis.

macropterus, Germo

Muranichthys.

Macrorhamphosidæ.

Macrorhemphosis ....

brevispinis................... 212

finschi ......................... 212

hawaijensis

macrosoma, Xystæma.

Macrouridæ.

Macrourus.

burragei.

ectenes.

gibber.

habenatus

holocentrus.

longicirrhus

obliquatus.

propinquus.

maculatus, Caracanthus

Epinephelus

Inimicus.

Paracanthistius . . .....................

maculifera, Amia.

maculipinnis, Gnatholepis.

maculosus, Zenarchopterus

Mænidæ.

magnificus, Epinephelus

Myrichthys.

mahsena, Lethrinus.

mahsenoides, Lethrinus

makua, Ranzania.

Malacanthidre

$$
\text { parvipinnis. }
$$

Malacocepbalus.

hawailensis ......................

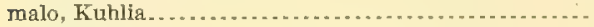

Malthopsis.

jordani..

manadensis, Anthias.

mancus, Platophrrs.

mandibularis, Caranx.

maoricus, Call sodon.

maou, Carcharias.

\begin{tabular}{c|}
194 \\
331 \\
303 \\
182 \\
272 \\
255 \\
414 \\
414 \\
374 \\
195 \\
191 \\
259 \\
206 \\
320 \\
252 \\
384 \\
385 \\
311 \\
298 \\
298 \\
298 \\
269 \\
228 \\
193 \\
212 \\
212 \\
212 \\
212 \\
212 \\
\hline
\end{tabular}

mappa, Tetraodon........................... 369

Маро......................................... 402

fuscus............................. 402

crassiceps............................ 403

Marcgravia.............................. 410

diemensis ........................ 416

grunniens............................. 416

marcusi, Salarias........................ 431

margaritaceus, Halichoeres................... 302

margaritatum, Myctophum . . . . . . . . . . . . . . . . . 189

margaritifera, Scolopsis ........................... 269

marginalis, Brotula .......................... 436

marginata, Kuhlia.......................... 255

marginatus, Caranx........................... 231

Congrogadus...................... 434

Hepatus . . . . . . . . . . . . . . . . . . . . . . . 354

Leptocephalus. ..................... 193

Lutianus......................... 263

Nemipterus...................... 265

Platyglossus. ....................... 299

marginipinnis, Discobatis . . . . . . . . . . . . . . . . . 183

Lutianus....................... 263

marianas, Holacanthus....................... 349

marmoratus, Alticus........................ 424

Apogonichthrs.................... 250

Cirrhitus....................... 278

Siganus........................ 359

Uropterygius...................... 206

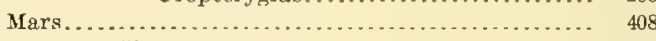

strigilliceps............................. 408

marshi, Etelis . . . . . . . . . . . . . . . . . . . . . . $26 .$.

mataafæ, Corythroichthys.................... 213

Matreocephalus .............................. 437

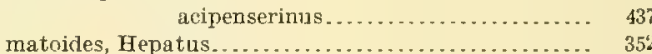

mauritiana, Anguilla....................... 192

Maurolicida................................. 189

medusophagus, Schedophilus. . ................... 236

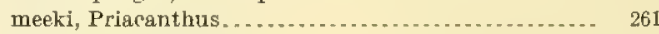

megachir, Epinephelus....................... 259

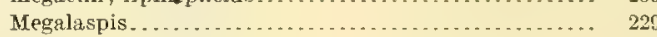

cordyla.................. 229

megalolepis, sphyræna........................... 219

Megalops...................................... 18

cyprinoides........................ 185

Megaprotodon............................. 336

trifascialis........................ 336

megastoma, Anguilla......................... 192

Melamphaes................................ 219

unicornis....................... 219

melampygus, Caranx........................ 230

melannotus, Chatodon....................... 341

melanotus, Paracirrhites......................... 278

Melanobranchus............................... 436

micronemus.................... 436

melanocepbalus, Monacanthus ................... 36.5

melanopterus, Carcharias ...................... 182

Gadomus....................... 436

Pomacentrus................... 281

melanostictus, $\Lambda$ seraggodes....................... 413

Melanotæniidæ............................... 216

melanurus, Anampses............................ 290

Dascyllus . . . . . . . . . . . . . . . . . . . . . . 290

Halichøeres....................... 303

Hemiramphus . . ...................... 207

melapterus, Hemigymnus...................... 294

melas, Abudefduf . .............................. 286

Pharopteryx.......................... 261 
I'age. | Page

meleagris, Gymnothorax.

Mobula japonica........................ 1 .

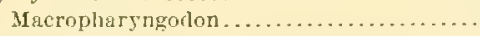

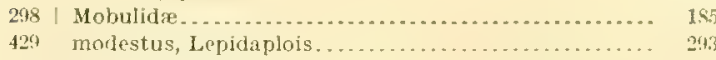

Salarias . . . . . . . . .

Melichthys

rarlulat.

melinoptera, Liza.

melanopus, $\Lambda$ mphiprion.

menesema, Amia

Merinthe.

bandanensis.

macrocephala.

merra, Fpinephelus.

$363 \mid$ moensi, Callyodon ............................... 317

$363 \mid \quad$ Lethrinus............................ 270

217 | Molidx........................................ 373

278 | moluccensis, Calotomis. ............................. 313

239 | Monacanthide . . . . . . . . . . . . . . . . . . . . . . . . . . 364

374 | Monacanthus................................... 365

374 chinensis $\ldots \ldots$

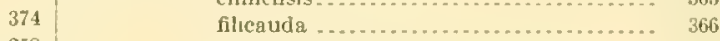

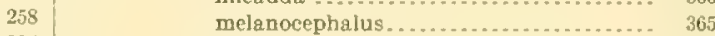

mertensij, Callyodon........................ 334

mertensi, Chrtodon.......................... 341

Thalassoma ........................ 307

metallicus, Abudéfduf . . . . . . . . . . . . ............ 289

Ietoromycter.

$$
\text { denticulatus. }
$$

metoposophron, Acanthurus.

miacanthus, Lophiomus.....

Microluglossus................
nigrostriolatus Microcanthus............................. 346

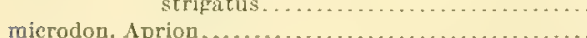

(

Fierasfer......................... 435

Microdonophis......

$$
\text { fow leri. }
$$

macgregori.

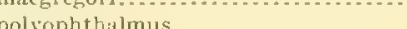

mierolepis, Antimora.

microlepidotus, Scomber...

inicronemus Melanobranchus.

Microphis. .

brachyurus $\ldots \ldots \ldots \ldots \ldots \ldots \ldots \ldots \ldots$
caudatus. $\ldots \ldots \ldots \ldots \ldots \ldots \ldots \ldots$

microphthalmus, Myripristis.

microptera, Evolantia......................... 208

micropus, Etrumeus.......................... 186

microrbinos, rallyodon ..................... 332

Microsicydium .......................... 411 elegans.

microstoma, Nematops.

microstomus, Holocentrus.

miliaris, Chætodon.

miniata, Eviota.

Lethrincllia . . . . . . . . . . .

miniatus, Callyodon ...................... 315

Cephalopholis...................... 258

Minous..................................

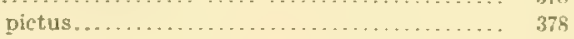

minuta, Gazza ............................. 273

minutits, Enneapterygius.

Mionorus..

$$
\text { gratrei }
$$

$$
\text { witikiki. }
$$

miojes, Ambussis

Miopsaras.

$$
\text { myops... }
$$

misolensis, Dalophis.

mitrigera, Malthopsis.

moana, Pseuduponeus.

Mobula.

draco.

nitens............................ 366

pricei................................... 366

spilosomus. ....................... 366

monoceros, Alutera.......................... 367

Heniochus ........................... 347

Monodactylus.............................. 236

argenteis......................... 237

monogramma, Scolopsis. . . . . . . . . . . . . . . . . . . 269

monostigma, Lutianus ........................... 264

Monotaxis euanus .............................. 271

grandoculis............................ 271

moresbyensw, Callyodon......................... 323

Caranx ...................... $\quad 332$

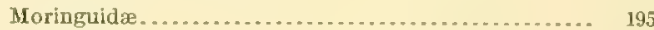

Moringua..................................... 195

hawailensis.......................... 195

javanica............................... 195

macrocephala. ....................... 195

mortoni, Pseudanthias........................... 260

moseleyi, Chirolophius......................... 437

Notacanthus........................ 206

muciler, Gymnothorax... . . . . . . . . . . . . 200

Mugil....................................... 217

argenteus............................. 217

broussoneti ............................. 217

caldwelli................................. 217

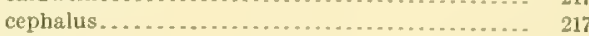

kandavensis............................. 217

kelaarti .................................... 217

perusi ................................. 217

planiceps.................................. 217

sundanensis ............................. 217

tongre............................... 217

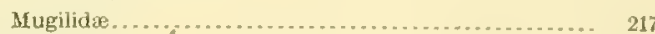

Mullidie. . . . . . . . . . . . . . . . . . . . . .

Mulloides . . . . . . . . . . . . . . . . . . . . . .

auriflamma......................... 276

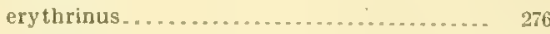

11 mmeus.............................. 277

pflugeri................................ 277

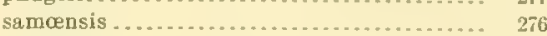

vanicolensis............................ 276

zeylonicus...........................

multicirrata, Brotula....................... 436

77 | multicolor, Coris................................. 303

247 | multifasciatus, Ephippus......................... 33.5

2491 Pseudupeneus, .................. 273

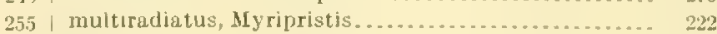

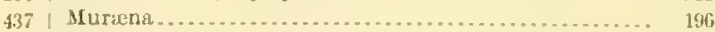

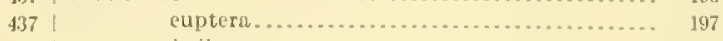

$194 \mid$ kailua................................. 196

438 pavonina.

274 | Murmesocidse............................. 19.3

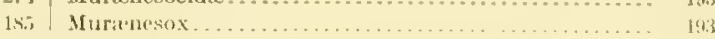

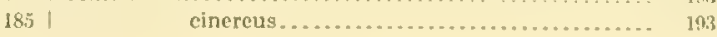




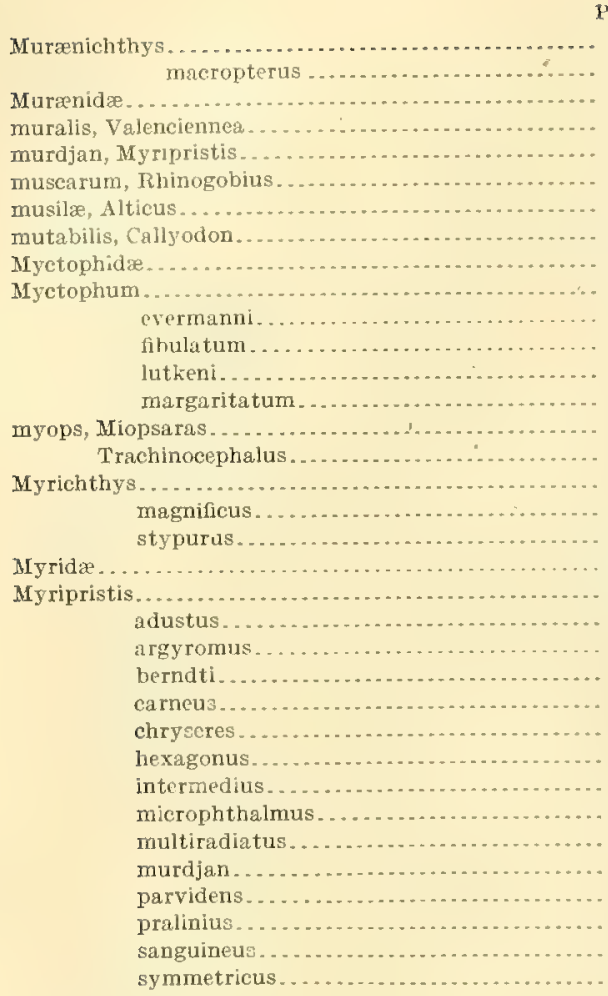

Myropterura

$$
\text { laticauda.. }
$$

mystacina, Waitea.

Myxus...

leuciscus.

Nannobrachium

$$
\text { nigrum. }
$$

nanum, Plectrogenium.

naresi, Cypsilurus.

$$
\text { Lophiomus. }
$$

narina,ri, Stoasodon.

nasus, Ostracion.

nasutus, Terapon...

natans, Parapegasus.

Naucrates.

$$
\text { ductor. }
$$

naucrates, Leptecheneis

nauticus, Chænomugil. -

navarchus, Holrcanthus

Nebrius.

$$
\text { concolor.. }
$$

nebulosa, Fchidng

nebulosus, Ialichores.

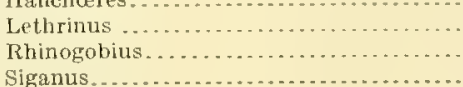

Nematobrotu

ranus.

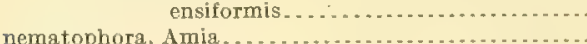

polygonifera. . . . . . . . . . .

nematophthalmus, Platycephalus.

Nematops...

microstoma

Page.

193

193

106

220

401

425

318

189

189

189

189

189

189

437

195

195

195

193

220

220

221

221

$2 \times 2$

22

221

220

220

222

220

222

221
Tage.

matoptera, Duymæria....................... 293

Nemichthyidæ................................ 193

Vernichthys ................................ 193

scolopaceus........................ 193

Nemipterus. . . . . . . . . . ................. 265

furcosus.......................... 265

marginatus........................ 265

ruber............................ 265

tæniopterus........................ 265

tolu........................... 20.5

waigiensis . . . . . . . . . . . . . . . . . . . 20.

neocaledonica, Liza.......................

neoguinaicus, Anampses. . . . . . . . . . . . . . . . . . .

neo-guinaicus, Congrellus........................ 193

Neopercis................................ 414

roseoviridis........................ 414

neophytus, Rhinogobius ................... 130

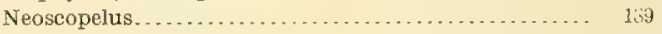

alcoki........................ 189

Neosudis ................................. 190

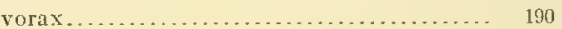

Nesiotes..................................... 293

purpurescens......................... 293

nesiotes, Carcharias........................ 182

Netuma spatula . . . . . . . . . . . . . . . . ......... 191

nexilis, Antennarius . . ......................... 438

nicobariensis, Holacanthus. . . . . . . . . ........... 349

niger, Antennarius . ........................... ${ }_{4} 438$

Balistes . . . . . . . . . . . . . . . . . . . . . . 362

Iniistius.............................. 312

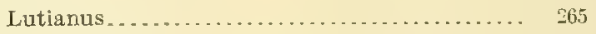

nigricans, Pomacentrus...................... $2 \$ 1$

Cantherines. . . . . . . . . . . . . . . . . . . ... 364

Hepatus......................... 351

Pharopteryx....................... 260

nigrifrons, Abudefduf......................... $2 \$ 60$

nigripinnis, Amia ........................... 241

nigropinnatus, Cheilinus.................... 310

nigropunctatus, Tetraodon ...................... $\quad 369$

nigrostriolatus, Microbuglossus................ 413

nigrum, Nannobrachium ................... 189

nimbarius, Zalarges............................... 189

nitens, Monacanthus. ....................... 366

niveilatus, Xyrichthys........................ 312

Notacanthidx. . . . . . . . . . . . . . . . . . . . . . 206

Notacanthus ............................... 206

moseleyi.......................... 206

notophthalmus, Halichores. . . . . ............... 301

Pomacentrus . 280

notopsis, Platyglossus.......................... $\quad 299$

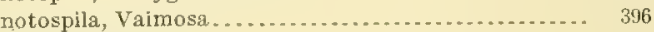

Novaculichthys ......................... 311

kallosomus................... 311

macrolepidotus.................. 311

troniurus.................... 311

moodi ......................... 311

novæ-caledoniæ, Sparus....................... 271

novæ-guineæ, Amia............................ 241

Caranx.......................... 232

Rhombatractus...................... 216

Scorpænopsis.................... 375

Sebastopsis....................... 375

novemfasciata, Amia......................... 242

nuchalis, Sebastapistes....................... 377

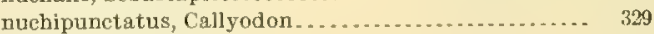

nudifrons, Diodon.............................. 373

nudum, Lestidium . . . . . . . . . . . . . . . . . . . .... 190

nummifer, Antennarius .......................... 438 
nuttingi, Gymnothorax.

$$
\text { Polyipnus. }
$$

rycteris, Balistes.

oahuensis, Ostracion......

$$
\text { Canthigaster. . }
$$

obesus, Trianodon......

obliquatus, Macrourus.

obliquus, Petroscirtes

oblongus, Caranx....

$$
\text { Spheroides. }
$$

obscura, Anguilla...

$$
\text { Echidna..... }
$$$$
\text { I.eiognathus. }
$$

obtusata, Sphyriena.

oltusiceps, Caranx.

oceanicus, Thinoscopclus

$$
\text { Spheroides: }
$$

Occamolis.

$$
\text { latovittata.. }
$$

ocellata, Pogonoperea.

ocellatum, IIemiscyllium.

$$
\text { Tetrabrachium. }
$$

ocellatus, Callyodon.

$$
\text { Pscudorhombus. }
$$

ocellaris, Awaous.

octotænia, Pseudocheilinus

Odontanthias.

$$
\text { fuscipinnis. . }
$$

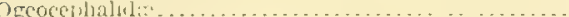

oire, Balistapus...

oligacanthus, Paracanthistius

oligolepis, Cypsilurus.

$$
\text { Gobius.... }
$$

oligostictus, Siganus.

olivaceus, IIepatus.

$$
\text { Lutianus. }
$$

onyx, Pomacentrus.

opercularis, Halichnercs.

$$
\text { Holocentrus. }
$$

Ophichthyidx

Ophiocara

$$
\begin{aligned}
& \text { aporos. ....... } \\
& \text { cantoris........ } \\
& \text { macrolepidota. } \\
& \text { porocephala... }
\end{aligned}
$$

ophthaimonemus, I'selaphias.

Opiopomus.

$$
\text { opiopomus }
$$

oplopomus. Oplopomus.

ophrvas, Tetraodon.

Opsanus..

dubius .

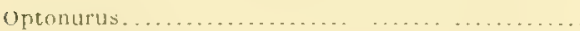

$$
\text { atherodon. }
$$

orbscularıs. .lmia.

$$
\text { PJatax }
$$

orcini Taractes..

Orectoobus.

barlialuy.

dasypogon.

orientalis, cephalacanthus.

P'ectorhynchus.

ornatissimus, Chetodon.

$$
\text { Hanchreres. }
$$

ornatum, Ostracion..

irnetiris. fontulus.
Piks:
Page.

ornatus, Lethrinus............................ 270

Osbeckia.....- 360

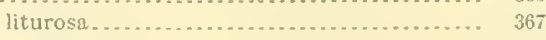

scripta .................. 360

Osopsaron . .................................. $\$ 14$ ineisum........................... 414

Ostichthys, ................................. 223 pillwaxi . ......................... 223

Ostraciida

Ostracion.................................... 367

lentiginosum . . .

nasus........................... 367

oahuensis.......................... 367

ornatum ....... 367

sebre............................ 367

tuberculatum........................ $\quad 367$

Osurus ....

schauinslandi............................ 414

otaheitensis, Anguilla.......................... 192

otaitensis, Platycephalus......................... 380

oualensis, Pempheris............................ ${ }_{236}$

ovalis, Chromis............................... 292

ovatus, Trachinotus.............................. 235

oviceps, Callyodon ............................. 321

oxycephalus, Cheilinus......................... 310

Cirrhitus...................... 278

Verreo............................. 293

Oxymonacanthus.............................. 365

Jongirostris................... 365

oxyrhynchus, Cheilinus........................ 310

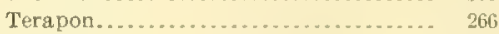

pachycentron, Epinephelus....................... $\quad 259$

Pachymetopon................................ 271

squamosum.................... 271

pacificus, Diplophos........................... 190

Gomphosus........................ $30 \pi$

Hemiramphus........................ 207

pallidus, Abudeiduf............................... 286

palpebratus, Anomalops.......................... 236

paluca, Callyodon................................ 319

pantherinus, Platophrys ....................... 412

pipilio, Pegasus........................... ... 215

prpilionaceus, Halichœres..................... 303

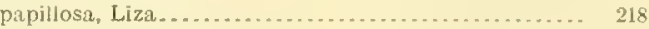

papta, Canthigaster.......................... 372

papuanus. $\Lambda$ mblygobius....................... 406

papuensıs, Amphiprion............................. 279

Balistapus........................ 363

Callyodon........................... 323

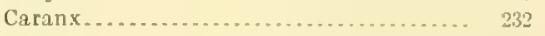

Corrica.............................. 186

Coris ............................... 303

Goblichthys... . . . . . . . . . . . . . . ... 407

Ichthyocampus. . . . . . ................. 215

Lethrinus...... . . . . . . . . . . . . . . . . $\quad 270$

Plectorhynchus...................... 268

Prinpis.............................. 255

Uranoscopus ......................... 414

I'aracanthustus. ......................

maculatus . ..................... 256

olugicantnu-:............. 256

Tatacirthtes, ................... 278

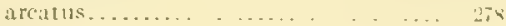

cinctus............................. 278

lorsteri.......................... 278

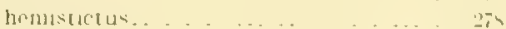

melinopus. . . . . . . . . . . . . 2.

polystictus....................... 278 
Taracirrhites punctatus

Page paradiscus, Labroides

Paragobiodon echinocephalus xanthosomus

Paralepidæe. prionurus

Parami

macrodon...

quinquelineata....

Parapegasus

$$
\text { truncata. }
$$

Parapercis.

matans............................

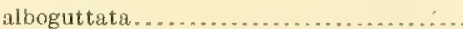

hexophthalma

tetracanthus.

xanthozoma.

parasitus, Caranx.

Pardachirus.

pavoninus.

pardalis, Leptojulis.

pardochir, Enneapterygius.

Parexocotus.

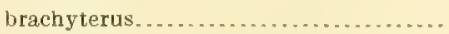

brevipinnis.

rostratus.

parvidens, Lutianus.

Myripristis.

parvipinnis, Jordanicus.

Malacanthus.

Sebastopsis.

paucidens, Leirus...

pauciradiatus, Cubiceps

paulus, Salarias.

pavo, Pomacentrus

pavonina, Muræna.

pavoninus, Inistius.

Pardachirus

Pegasidæ.

Pegasus. .

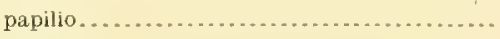

volitans.

pelagıcus, Amphioxides.

pelamis, Gymnosarda.

Pelecanichthys

crumenalis

pelewensis, Chitodon.

pellueidus, Aseraggodes.

Peloropsis.

$$
\text { xenops. }
$$

Pempheridæ

Pempheris oualensıs..............................

$$
\text { vanicolensis. }
$$

peniculligerus, Chrtodermis.

pentadactylus, Jemipteronotus . . . . . . . . . . . . . . . .

Pentapus. caninus.

vittatus.

pepo. Callyodon

Percophidid $x$.

percula, Amphiprion

perdıtio, Lepidaplois.

perideraion Amphiprion

Periophthaimodon.

australis

sch!osserı. periophthalmoides, IIypleurocheilus.

Yage.

......, 421

barbarus........................ 393

periophthalmus, Alticus. .................

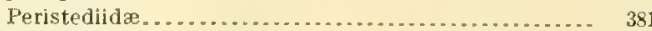

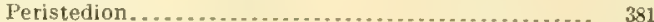

engyceros............................ 381

hians............................. 381

liorh ynchus . . . . . . . . . . . . . . . . . . 381

permutatus, Heniochus....................... 340

perspicillatus, Callyodon........................ 322

perusi, Mugil............................... 217

petellı, Gymnothorax.......................... 197

petımba, Fistularia . . . . . . ................. 211

Petroscirtes.................................... 431

atrodorsalis...................... 433

azureus............................ 432

elongatus.............. 433

filamentosus. . . . . . . . . . . . . . .... 431

germainı........................ 434

grammistes. .................... 432

lineolatus .......................... 433

longifilıs ... . . . . . . . . . . . . . .

obliquus........................... 434

rbynorhynchus...................... 432

semilineatus........................ 433

tæniatus. . ............................. 432

tapeinosoma..................... 432

xestus............................ 433

pflugeri, Mulloides.............................. 277

phaenna, Hetereleutris........................ 393

phalæna, Amblygobius............................ 405

Pharopteryx.... ............................. 260

melas............................ 261

nigricans.......................... 260

phekadopleura, Stethojulis....................... 297

phoreys, Carcharias........................... 182

Phtheirichthys................................ 411

lineatus......................... 411

pica, Plectorhynchus.......................... 267

pictus, Gymnothorax........................... 198

Gymnothorax......................... 200

Mınous .................................. 378

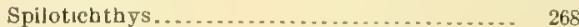

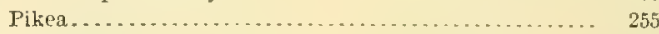

aurora.............................. 255

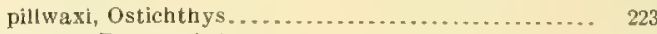

pinguis, Bascantchthys......................... 194

pinnatus, Platax............................... 336

pinnulatus, Decapterus.......................... 229

Trachelochismus . ..................... 434

pisang, Cæsio ........................... 260

plagiometopon, Abudefduf ....................... 286

planıceps, Mugı............................... 217

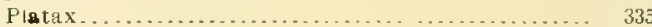

orbicularis.............................. 335

pinnatus........................... 336

teira..................................... 335

platessa, Caranx......................... $23 \overline{2}$

platodon, Callyodon.......................... 315

Platophrys............................. 412

chlorospilus......................... 412

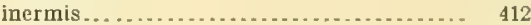

mancus............................ 412

pantherinus. ......................... 412

platophrys, Hoplichthys ...................... 380

Platycephalidx................................ 380

Platycephalus........... 380 
Platycephalus isacanthus.

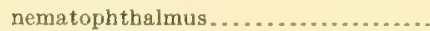

otuitensis.

punctatus.

quoyi.

serratus.

tentaculatus.

variolosus.

Platyglossus.

los-corallis.

hoveni.

marginatus.

notopsis...

Platyura, Belone.

plebeius, Polydactylus.

plebejus, Chætodon.

Plectorhynchus.

chætodonoides

diagramma.

giganteus .

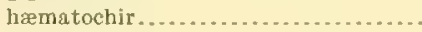

orientalis.

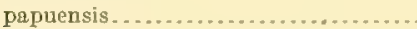

pica.

polytania.

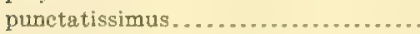
radja

Plectrogenium

nanum..

Plectropomus.

$$
\text { calcarifer. }
$$

Pleuronectidx

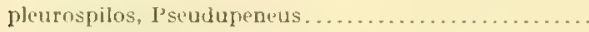

pleurostigma, Pseudupeneus.

pleurotania. (archarias

$$
\text { Microphis. }
$$

plicatellus, Ateleopus.

plicatilis, $A$ gonostomus.

Plotosidæ.

Plotosus anguillaris.

Pocilopsetta.

$$
\text { hawailensis. }
$$

poecilopterus, Cypsilurus.........................

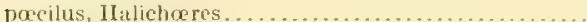

poeti, Systæma.

Pogonoperca.

$$
\text { ocellat } a \text {... }
$$

polyacanthus, Acanthochromis

Pseudogramma.

Polydactylus.

$$
\text { plebeius. }
$$

polygonilera, Nematoprora.

Polyipnus.

$$
\text { nuttingi.. }
$$

polyophthalmus, Gymnothorax.

$$
\text { Microdonophis. }
$$

Polymixilda

$$
\text { Polymixia....... }
$$

Polynemidx.

polymnus, Amphiprion. .

polystictus, Paracirrhites.

polytænia, Plectorhynchus.

polyuranodon, Gymnothorax.

polyzona, Echidna. rage.

389

380

$3 \$ 0$

380

380

380

380

$3 \times 0$

290

295

301

2349

$x y 4$

206

219

245

30

267

26 '

267

268

$26 \pi$

268

267

267

267

267

378

378

255

255

412

276

276

182

214

430

$21 \mathrm{~S}$

191

191

101

233

413

413

210

:

272

260

(ii)

292

277

215

219

219

194

190

190

199

219

219

219

219

278

278

267

200

203
Pomagentrida.

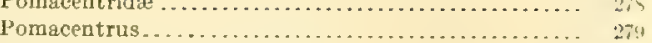

albofasciatus.................... 242

amboinensis ........................ 291

analis............................ 2

bankanensis...................... 241

bifasciatus. ......................

cyanomus. . . . . . . . .

devisi.............................. $24 t$

eclipticus...................... 26.

inornatus ...........................

jenkinsi........................ 24

littoralis........................

lividus . . . . . . . . . . . . . . . . . . . .

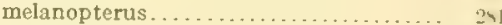

nigricans..........................

notophthalmus.................

onyx.............................

pavo ........................

prosopotrenia....................... 270

semifasciatus.....................

tæniurus. . . . . . . . . . . . . . . . . 279

trimaculatus................... 2 .

tripunctatus.......................

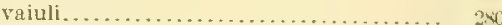

Pomadasis . . . . . . . . . . . . . . . . . . . . . . .

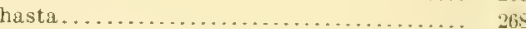

pondicerrianum, Rachycentron ................. $\quad 236$

Pontinus...............................

spilistius...........................

porocephala, Ophiocara..................... 34.

porphyreus, Pseudupeneus. .................

pralinius, Mfyripristis.....................

prasiognathus, Callyodon...................... 328

prasites, Eviota.............................. 35

praslin, IIolocentrus....................... 225

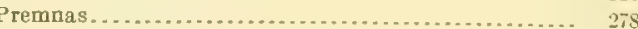

biaculeatus ...........................

preorbitalis, Pseudupeneus. . . . . . . . . . . . . . . . 270

pretiosus, Ruvettus. . . . . . . . . . . . . . . . . .

Priacanthide. . . . . . . . . . . . . . . . . . . . . .

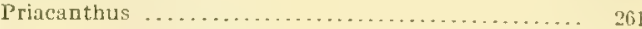

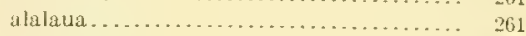

cruentutus........................... 261

hamruhr. . . . . . . . . . . . . . .

mecki........................ 261

pricei, Monacanthus. . . . . . . . . . . . . . . . . . . . .

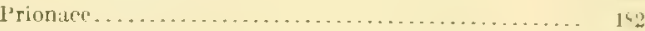

glauca...........................

prinnurus, Paraluteres....................... \}titi

Priopis.................................

agrammus ........................... 255

papuensis . . . . . . . . . . . . . . . . . . .

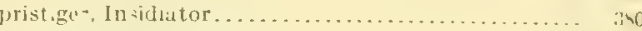

pristilepis, Dasyscopelus..................... 140

proboscidea, Aldrovandia..................... 191

prometheus, Prometbichthys .................... 228

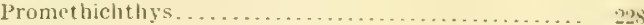

prometheus................

Promyllantor . . . . . . . . . . . . . . . . . . . 103

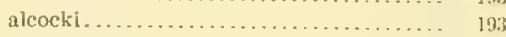

pronus, Callyodon ......................... 320

propinquus, Macrourus..................... 437

proridens, Chlorophthalmus................. In

prorigera, Chascanopsetta........................ 413

prosopotænia, Pomacentrus.................... 27 !

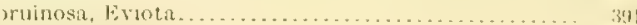

psalion, Echidna.............................. 
Page

psegma, Canthigaster

Pselaphias

ophthalmonemus.....................

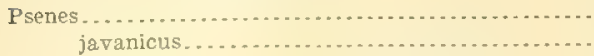

Psenidæe.

Pseudanthias

lrypselosomus

kelloggi.

mortoni

Pseudapocryptes

lanceolatus.

punctuiarum.

Pseudocheilinus .

"ranidus.

hexatænia

octotænia.

Pseudochromidæ.

Pseudochromis......

$$
\text { fuscus. }
$$

Pscudogobiolon.

citrinus.

verticalis.

Pseudogramma.

polyacanthus

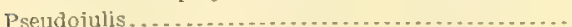

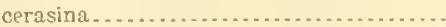

Pseudolabrus.

unilineatus . . . . . . . . . . . . . . . . . . .

Pseudorhombus.

$$
\begin{aligned}
& \text { guttulatus. } \\
& \text { ocellatus... }
\end{aligned}
$$

triocellatus.

Pseudupeneus.

$$
\text { atrocingulatus }
$$

barberinoides.

barberinus...

bifasciatus .

chryserydros

chrysonemus.

crassilabris.

cyclostomus.

filamentosus.

fraterculus.

indicus.

moana....................................

multifasciatus.

pleirospilos. .

pleurostigma.

porphyreus.

eorbitalis

saffordi - mor

semifasciatus.

treniatus...

Pterocresio.

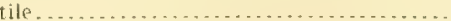

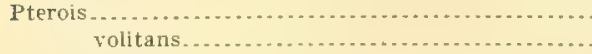

sphex.

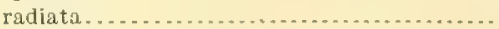

vittata.

Pteropbryne.

$$
\text { histrio. }
$$

pterophthalmus, Anampses.

Pteropsaridæ....

puellus, Siganus. .

pugnans, Sicyopterus.

pulchellus, Callyodon
Page

pulchellus, Cheilinus........................ 308

pulcherrima, Julis. ............................. 304

punetata, Drepane.......................... 335

punctatissimus, IIolocentrus....................... 224

Plectorhyncbus .................... 267

punctatofasciatus, Chætodon..................... 343

punctatum, Thalassoma........................ 306

Xystæma.......................... 272

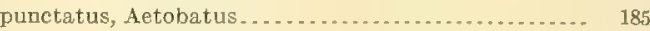

Paracirrhites........................ 278

Platycephalus........................ 380

Siganus . . . . . . . . . . . . . . . . . . . . 360

punctularum, Pseudapocryptes...................... 408

punctulat us, Cantherines....................... 364

puntangoides, Exyrias............................. 405

purpurea, Anchovia....................... 187

purpurescens, Chimæra........................ 185

Nesiotes....................... 293

Seriola ............................ 229

purpureum, Thalassoma......................

purpureus, Callyodon........................ $\quad 310$

puta, Terapon ................................. 266

pyriferus, Hepatus............................ 350

pyrrbostethus, Callyodon...................... 328

pyrrhurus, Callyodon........................ 314

quadrimaculatus, Chætodon ...................... 345

quæsita, Rbinamuræna........................... 196

Querimana............................... 218

crenilabis . . . . .

queruus, Epinephelus........................ 259

quindecimradiatus, Cypsilurus . . . . . . . . . ........ 210

quinquelineata, Paramia ........................ 252

quoyi, Callyodon............................... 322

IIemiramphus....................... 207

Platycephalus . . . . . . . . . . .

Rachycentridæ................................ 236

Rachycentron........................... 236

pondicerrianum................

radiata, Pterois............................. 379

radja, Plectorhynchus........................... 267

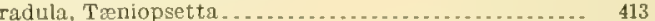

raflesi, Chetodon............................. 339

ramak, Lethrinus . ............................... 269

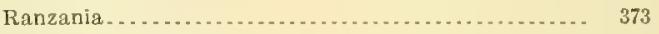

makua............................... 373

rectangulus, Balistapus........................ 363

regia, Lampris............................ 227

regularis, Caranx................................ 232

ramiger, Setarches............................ 377

remora, Echeneis............................... 411

Remorina.................................. 412

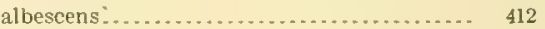

Remoropsis.................................. 412

brachyptera.................... -412

renardi, Stethojulis. . . ............................ 296

reticularis, Tetraodon... . . . . . . . . . . . . . . 369

reticulatus, Chætodon.............................. 341

Dascyllus........................ 290

retifera, Halieutæa............................... 439

Rhinamuræna..........................

eritima. . . .

quæsita ........................ 196

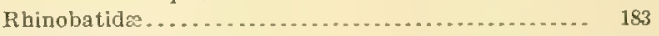

Rhinobatus ................................... 183

joram............................ 183

granulatus.......................... 183

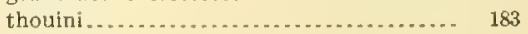

Rhinogobius......................... 400 
Rhinogobius circumspectus

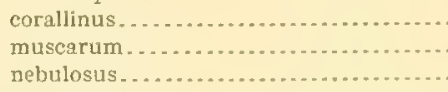

neophytus. . . . . . . . .

Rhinoscopelus. ... oceanicus............................

Rhizoiketicus... carolinensis...........................

rhodadenia, Cyclothone.

rhodocephalus, Gymnothorax

rhodochir, Læmonema.

Rhombiatructus.

$$
\begin{aligned}
& \text { Eoldiei ....... } \\
& \text { novaguinex. } \\
& \text { rubrostriatus }
\end{aligned}
$$

Thomberm, Zebrasoma.

Rhyacich thyidix.

Rhyacichthys. aspro. ............................

rhynorhynchus, Petroscirtes.

rivulatus, Gobiodon.

Lutianus. ....

Salarias.

Kanthichthys

Rooseveltia.

aloha..

brighami

rosea, Coris.

roseiceps, Callyodon

rosenbergł, Amphiprion.

Toseoviridis, Neopercis

roseum, Bembradium.

roseus, Cheilinus.

Cristiceps . .

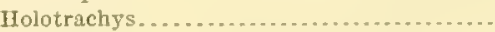

Lutianus. .

rostratum, Zebrasoma.

rostratus, Parexocotus.

$$
\text { Siganus. }
$$

rotundatus, Canthidermis

rubens, Lutianus.

ruber, Holocentrus.

$$
\text { Nemipterus. }
$$

ruberrimus, Callyodon.

Tubrofuscus, Antennarius.

rubrostriatus, Rhombatractus.

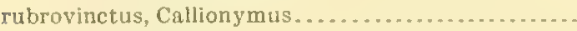

rufescens, Helicolenus.

rufolineatus, Lutianus

rupestris, Kublia..............

ruscosum, Centroseyllium

russelli, Lutianus......

Trachinotus

Ruvettus.

$$
\text { pretiosus.... }
$$

saffordi, Pseudupeneus.

sagitta, Vitreola.

Salarias.

atkinsoni.

airatus.

biseriatus.

bryani.

edenturus.

fasciatus.

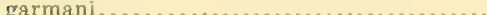

gilberti.

roesi.

Page:

400

400

401

400

189

190

202

436

216

216

216

216

355

$41, i$

415

432

409

262

429

363

265

265

265

303

322

279

414

380

310

420

223

262

356

208

360

363

264

225

265

316

438

216

415

378

263

255

183

264

23.5

228

$22 \mathrm{~s}^{\circ}$

275

393

426

428

431

427

430

429

427

429

431

4.31
Page.

...... 430

lineatus................................ 420

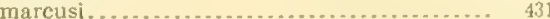

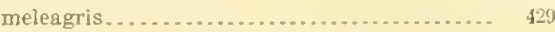

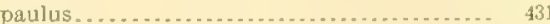

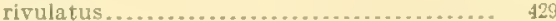

sertatus............................... 420

sindonis ............................... 427

zebra................................ 426

sqliens, 1 ticus. ................................. 421

Samariscus . ................ 413

corullinus.................... 413

sitmmara. Ilolocentrus............ . . . ..... ‥;

Samoan fishes known prior to 1902 , list........... 178 new species, list .................... 179

samoensis, Mulloides. .......................... 271 ,

sanctipetri, Scomberoides........................ 229

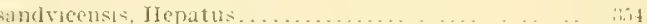

Kyphosus......................... 271

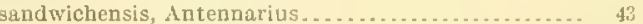

Calotomus........................ 313

Cantherines....................... 364

Eleotris......................... 383

Gomphosus ...................... 308

sangiensis, $A \mathrm{mia} . . . . . . . . . . . .24$

sanguineus, Myripristis ............................ 21

Verriculus . . . . . . . . . . . . . . . . . . . . . 293

Sarda ..................................... $22 \$$

chilensis ............................... 225

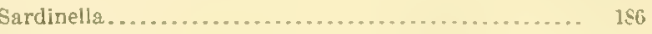

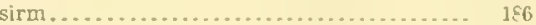

Saurida

gracilis............................... 189

grandisquamis......................... 189

tumbil. ............................... 189

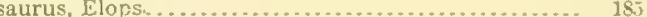

sausaulele, Dendrochirus. ... ....................... 378

Sauvagea................................... 420

caledonica . . . . . . . . . . . . . . . . . ............ 420

savayensis, Amia................................ 239

saxatilis, Abudefduf ............................ 28.

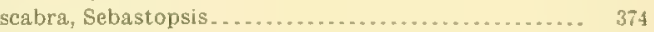

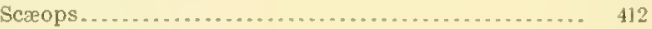

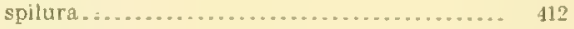

xenandrus........................... 412

scapularis, Halichceres. ... . . . . . . . . . . . . . . . . . . . . . . $\quad 300$

Scarichthyidæ ............................ 312

Scarichthys................................... 312

auritus........................... 312

cæruleopunctatus.................... 312

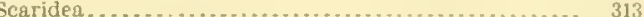

baha.............................. 313

aerosa . . . . .

zonarcha............................ 313

sceleratus, spherotdes.......................... $36 s$

schauinsłandı, Osurus............................. 414

Schedophilus ................................. 230

medusophagus..................... 230

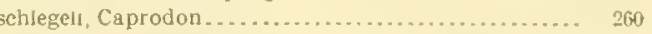

Erythrichthys....................... 266

schlemmerı Lactorı......................... \$3

schlosserı, Periophthalmodon.................... 394

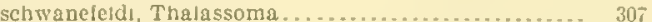

sciera, Dasyatis................................. 183

selaterı, Gobıomorphus.......................... $33_{4}$

scolopaceus, Nemichthys....................... 193

smonosis 


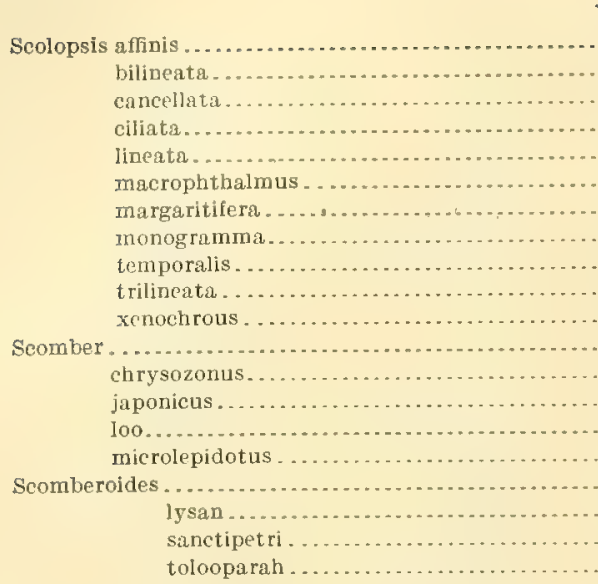

age 269 269
269 269 269

Scomberomorus.

Scombridx

$$
\text { commersoni }
$$

$$
\text { cooki... }
$$

Scorpænidæ.

Scorpænopsis.

altirostris
cacopsis...

cirrhosa.

gibbosa. -

nov $x$-guine:

zanzibarensis

S̄corpidæ.

scratchleyi, Anchovia.

scripta, Osbeckia...

sculptus, Microphis

Scuticaria.

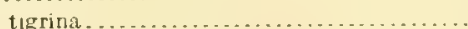

Scylliorbinidr

scythrops, Iolocentrus

sealei, Alticus

$$
\text { Corythroichthys. }
$$

seba, Alticus

$$
\text { Ostracion. }
$$

Sebastapistes.

ballieui $\ldots . . .6$.

coloratus.............................

coniorta.

corallicola .......................... 376

dentatus ......................... 376

galactacme ......................... 376

laniarıs....................... 377

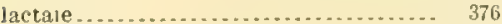

nuchalis...................... 377

strongus . . . . . . . . . . . . . . . . . . . 376

trıstıs . ............................. 377

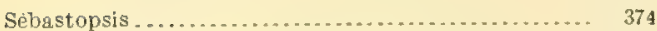

guamensıs........................... 374

kelloggt . . . . . . . . . . . . . . . . . . . . . 374

novæ-guineæ . . . .................... 375

parvipınnis...................... 374

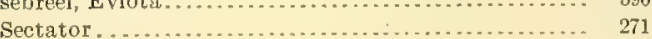

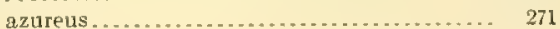

Page.

semeion, Chætodon ........................... 343

semicinctus, Leiuranus . ......................... 194

Amblygobius. . . . . . . . . ............ 405

Lutianus. .......................... 263

semicirculatus, Holacanthus. . .................... 349

semidiscus, Hologymnosus . .................... 304

semidoliatus, Zonogobius . . . . . . . . . . . . . . . . . . .... 397

semifasciatus, Pomacentrus................... 281

Pseudupeneus..................... 275

semilineatus, Petroscirtes . . . . . . . . . ............. 433

seminudus, Lentipes ........................ 411

semipunctatus, Asterropterix .................... 385

sentipellis, Traconurus . . . . . . . . . . . . . . . . . . . 437

sephen, II ypolophus. ............................. 155

septemfasciatus, Abudefduf . . . . ................. 285

Seriola ...................................... 229

purpurescens............................ $\quad 229$

sparna . . . . . . . ........................ 229

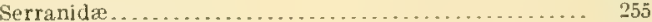

serrata, Fistularia ....................... 211

serratus, Platycephalus . . ............................ 380

Serrivomer ................................ 194

bcani ............................. 194

sertatus, Salarias . . . . . . . . . . . . . . . . . ............ 420

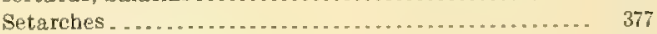

fidjiensis. . . . . . . . . . . . . . . . ....... 377

remiger. . . . . . .

setifer, Chætodon .............................. 338

sexfasciatus, Caranx....................... 231

Epinephelus........................ 259

Lutianus . . . . .................... 264

sexfilis, Polydactylus........................... 219

sexlineatus, Grammistes........................ 260

Terapon............................. 266

sexmaculatus, Cephalopholis . . . . . . . . . . . ........ 258

Sicyopterus ............................... 410

albotæniatus, .................... 410

pugnans. ......................... 410

stımpsoni ........................ 410

tænırus .......................... 410

tauæ............................... 410

sidat, Anguilla................................ 192

Siganidæ. . . . . . . . . . . . . ................. 359

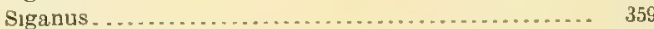

argenteus . . . .................... 360

canalicutatus............................ 360

concatenatus................. 359

corallinus . . . . . . . . . . . . . . . . . . ... 360

doliatus. . . . . . . . . . . . . . . . . . . . . . . . . . ... 359

fuscescens. ........................... 360

lineatus ............................ 359

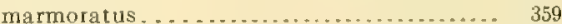

nebulosus . . . . . . . . . . . . . . . . . . 359

oligostictus . ............................... 360

puellus . . . . . . . . . . . . . . . . . . .... 359

punctatus . . . . .......................... 360

rostratus . . . . . . . . . . . . . . . . . . . 360

strolatus............................. 359

studer1 . . . . . . . . . . . . . . . . . . . . . . . . ... 360

vitianus.................................... 360

vermiculatus ......................... 359

signifer, Iracundus.............................. 374

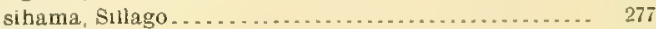

Sillagınıdæe........................... 27

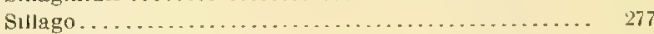

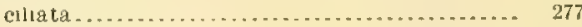

gractils................................... 277

insularis. .......................... 277 
Sillago sihama.

simplicornis, Calliurichthys

simus, Cypsilurus.

sindonis, Abudefduf

$$
\text { Salarias... }
$$

sinensis, Bostrychus

sirm, Sardinella.

smaragdus, Fviota.

smithursti, Leiognathus .

snodgrassi, Sphyræna....

snyderi, Amia.

$$
\text { Calotomus. }
$$

\section{Snyderidia.}

$$
\text { canina... }
$$

socialis, Epincphelus

solandri, Acanthoeylium

$$
\text { Canthigaster. }
$$$$
\text { Cypsilurus. }
$$

Soleichthys.

$$
\text { heterorhinos }
$$

Soleidx

Solenostomidit.

Solenostomus.

$$
\text { cyanopterus }
$$

solorensis, Cirrhilabrus.

$$
\text { Iralichoeres.. }
$$

sonnerati, Cephalopholis.

sordidus, Abudefduf

$$
\text { Blennius. }
$$

Lethrinus.

sorrah, Carcharias

South Sea islands, classified list.

Sparidæ...

sparna, Seriola.

Sparus.

nustralis . . . . . . . . . . . . . . . . . . . .

berda. . . . . . . . . . . . . . . . . . . 271

novatectedoniat......................

spatula, Netuma............................ 191

speciosus, Caranx............................... n?

speculiger, Cypsilurus........................... 209

speculum, Chætodon...................... 34.5

Sphagebranchus

flavicaudus ....................... 194

Spheroides

Dore:tlis..

hylselogencion

insularum.

lovis.

oblongus.

oceanicus.

sceleratus

sphex, Pternis.

sphinx, Amblygobius

Sphyrena.

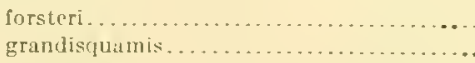

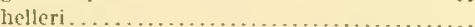

kenie.............................

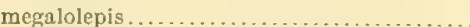

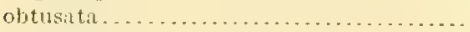

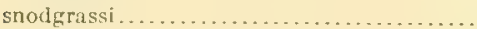

Sphyranidx

Sphyma..

(2)

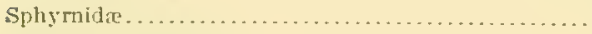

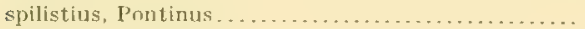

spilonota, Iracana.
Page:

spilonotus, Callyodon ......................... 325

spilosomus, Monacanthus......................... 366

Spilotichthys, ...

centurio................................ 26i

pictus .............................. 265

spilura, Scæops.............................. 412

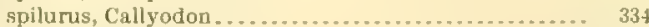

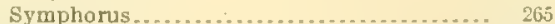

spinifer, IIolocentrus........................ 2.3

spiniger, Epinephelus............................. 259

spinosus, Dasyscopelus. ........................ 189

Insidiator ........................ 380

spinus, Callyodon ................................ 326

spongiceps, Catulus............................... 181

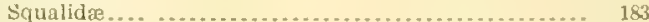

Squalus....................................... 183 mitsukurii.................. 183

squamiceps, Chrionema...................... 414

squamosum, Pachymetopon...................... 271

stamineus, Iwaous. .............................. 405

steindachneri, Antigonia....................... 335

Gymnothorax. . . . . . . . . . . . . . . . . 202

stelgis, Cyttomimus........................ 2.7

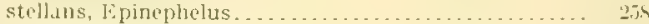

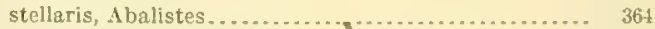

stellatus, Gymnothorax ............................ IFy

stellulatus, Dibranchus. .........................

Stemonidium................................. 194

hypomelas......................... 194

Sternoptychidæ........................... 190

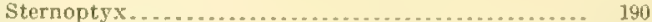

diaphana............................. 190

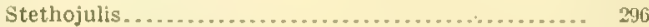

albovittata .................... 20. 20

axillaris. . . . . . . . . . . . . . .

bandanensis.......................... 297

casturi............................. 296

filholi .......... 295

fulvoventris ............................ 296

kalosoma........................... 295

phekadopleura........................ 297

renardi.............................. 290

strigiventer................... 296

trilineata . . . . . . . . . . . .

Stethopristis.................................. 227

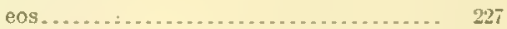

stevensoni, Vailima. ............................ 398

stimpsoni, Sicyopterus . . . . . . .................... 410

Stoasodon................................ 185

narinari......................... 185

Stolephorus................................. 180

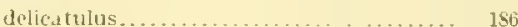

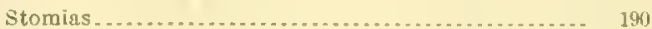

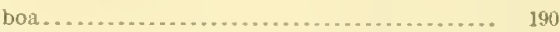

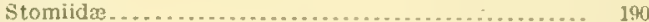

striatulus, Hymenocephalus. ................... 436

striatus, Alticus ....................

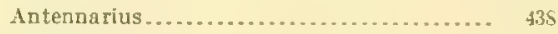

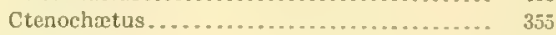

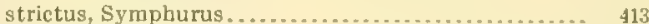

strigata, Valenciennea......................... 383

strigatus, Eoliscus............................... 212

Atypichthys....................... 237

Microcanthus......................... 346

strigilliceps, Mars.............................. $\$ 0 \$$

strigiventer, Stethojulis........................ 206

striolatus, Siganus................................. 359

stromateidx........................ 
strongius, Selastapistes

I'age

strongylocephalus, Callyodon

Strophidon

brummeri.

strophodes, Lepiclaplois

studeri, Signius.

stypurus, Myrichthys.

sulphureus, Uranoscopus.

summana, Epinephelus . . . . . . ........

sundanensis, Mugil.......................... 217

susumi, Chorististium . . . . . . . -

symmetricus, Myripristis . . . . . . . . . . . . . . .

Symphorus.

spilurts...................

Symphurus................................... 413

strictlos. . . . . . . . . . . . . . . . . . . . 413

undiatus........................ 413

Symphysanodon.

$$
\text { typus... }
$$

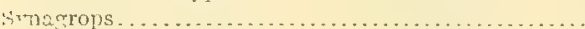

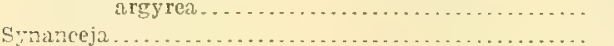

verruccs 2 . . . . .

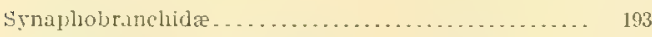

Synaphobranches. . . . . . . . . . . . . . . . . . . 193

brachysomus ................. 193

Synchiropus............................ 415

lili........................ 415

lineolatus....................... 415

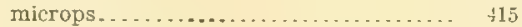

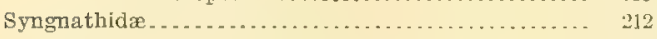

Synodontidx. . . . . . . . . . . . . . . . . ........ 188

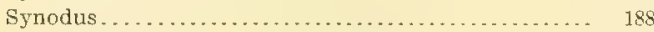

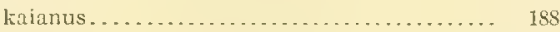

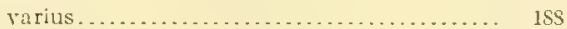

Tachysurus . . . .......................... 191

armiger............................ 191

græffi. . . . . . . . . . . . . . . . . . 191

Trenianotus

citrinellus..................... 3.5

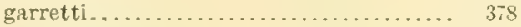

triacanthus......................... 318

tænianotus, Amblyapistus.

treniatus, Petroscirtes.

$$
\text { Pscudupeneus. }
$$

trenioides, Gympothorax. . .

Tæniopsetta . . . . . . . . . . . . . . . . . . . . . 413

radula....................... 413

trenioptera, Amia

treniopterus, Nemipterus..................... 265

¿†peneus.

Treniura...

atra...

teniura, Kuhlıa.

Pomacentrus...........

Sicyopterus . . . ............................ \$10 $\$$

tahmel, Kyphosus......................... 271

talofa, Gymnothorax....................... 201

tapeinosoma, Petroscirtes................... 432

Taractes. . . . . . . . . . . . . . . . . . . . . . . . . 235

orini............................ 235

taux, sicyopterus.

taupou, Abudefdul..

tauvina, Epinephelus.

teira, Platax.. l'age.

temporalis, Scolopsis............................. 269

tenebrosus, Gymnothorax ....................... 200

tentaculatus, Platycephalus..................... 380

Terapon .................................... 266

argenteus................................ 260

caudavittutus. . . . . . . . . . . . . . . . . . 260

chalybarus . .................................... 260

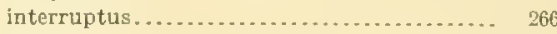

jarbua................................. 260

nasutus. ........................ 260

oxyrhynchus............................... 260

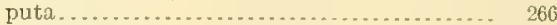

sexlineatus....................... 260

theraps. ....................... $\quad 266$

trima ulatus........................

unicolor . . . . . . . . . . . . . . . . . . . . . . . . . . 260

Tetrabrachium.......

ocellatum...................... 439

tetracanthus, Parapercis....................... 114

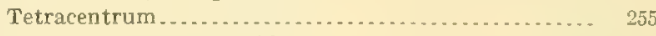

apogonoides........................ 255

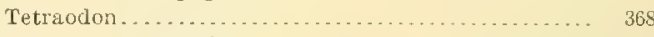

crostaticus..................... 368

g.ganteus. ....................... 371

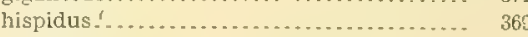

immaculitus....................... 370

lacrymatus........................ 371

mappa........................ 360

nigropunctatus ..................... 369

ophryas............................. 371

reticularis............................. 369

Tetraodontidæ.................................. 368

thalassinus, Alticus............................... 425

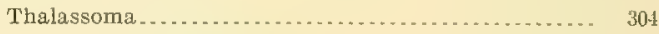

aneitense $\ldots \ldots \ldots \ldots \ldots \ldots \ldots \ldots \ldots . .30 \ldots \ldots$

bahlieui............................. 305

cyanogaster......................... 305

dorsalo................ 307

duperreyi ....................... $30 t$

fuscum . .... 306

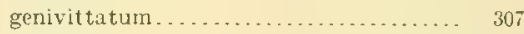

guntheri . . . . . . . . . . . . . . . . . . . . ... 305

janseni.......................... 307

lunare .............................. 305

lutescens. .................. 305

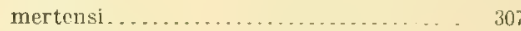

punctatum . ............ 300

purpureum................... 305

schwanefeldi.................... $33^{-}$

umbrostigma . . . . . . . . . . . . . . . . 300

thalassopterus, Gymnothorax ................... 201

Thalliurus. . . . .

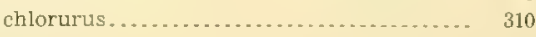

thazard, fuxis............................ 28

theraps, Terapon......................... 266

thompsoni, Caranx ........................ $\quad 230$

thouini, Rhinobatus . . . . . . . . . . . . . . . . . . . . . 183

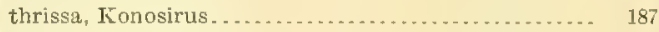

thynnoides, Axinurus. . . . . . . . . . . . . . . . . . . . . 358

thyrsitoides, Lemnisora........................... 228

thyrsoideus, Gymnothorax ....................... 198

tiere, Holocentrus........................ $2 z_{4}$

tiereoides, Ifolocen trus . . . . . . . . . . . . . . . . . . . . . 224

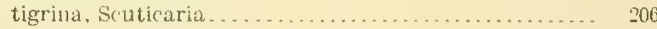

tigrinus, Galeoecrdo . . . . . . . . . . . . . . . . . . . $1 \$ 2$

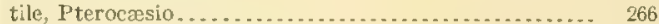

tolooparah, scomberoides. . . . . . . . . . . . . . . . . . . 229

tolu, Nemipterus............................. 265 
tonge, Mugl

Hage.

tonganus, Blennius...

torrentius, Microphis...

totoyensis, frobioides.

Toxotes...........

Toxotidx.

Trachelochismus

Trachinoceplualus.

pinnulatus.

$$
\text { myops. }
$$

Trachinotus

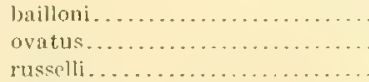

Trikehonurus.

$$
\text { sintipellis. }
$$

Trachurops crumenophthalma.

trachypoma, Corythroichthys.

Trachyrhamphus.

$$
\text { sp.... }
$$

tragula, Tpeneis . . . . . .

triacanthus, Tenianotus.

Tritenodon.

nljosus..............

triangulum, finnochentodon. .

trichrous, ( hit tolon.

tricolor. Imphiprion

$$
\text { Callyodon.... }
$$

trif́ascialis,

trifiscultus, Chrtodon . . . . . . . . . . . . . . . . . . .

trigonoliles, Dasyatis.

trilineata, scolnpisis.

$$
\text { Stethojulis. }
$$

trilobatus, Cheilinus

trimaculata, Amia...

trimaculatus, Daseyllus.

\section{Il alicheres}

\section{Pomacentrus.}

Trimma...

Terapon...

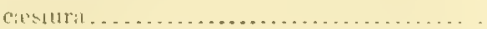

tripunctatus, P'omacentrus . .....................

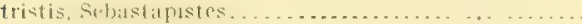

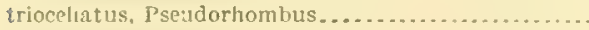

trinstegus, Ilepiatus.

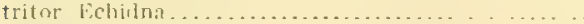

troscheli callyorlon.

b.17n

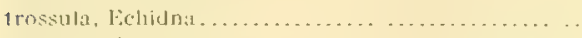

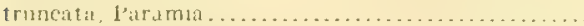

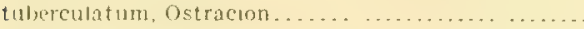

tuberosus, icanthurus.

tumbil, Saurida

tusitalie, Enrapterygus.

tutuiar, Drombus. . Tyoshrus.

$$
\text { Enneapterygus }
$$

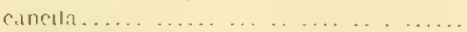

coromanilelicus.

giganteuc.

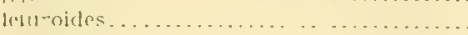

urvilici...

typus, symphysanodion

uarnak, Ilimantura.

usila, $A$ therina.
4319

1) 1 .

411

$2 \pi$

$2 \%$

$3 \%$

131

1.31

158

144

$23 ;$

23.3

23,
TH.0mil

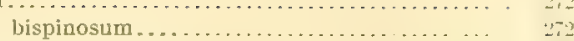

ulietensis, Chætodon .......................

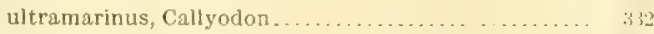

umbra, Ilepatus. .........................

umbratilis, Jordanicus.................... 43.5

umbrilatus, Hemipteronotus.................. 311

umbrinus, Chaunax........................... 437

umbrostigma, Thalassoma.................. 306

undatus, Symphurus....................... 41 ?

undulatus, Balistapus . ..................... $3 t_{i 3}$

Cheilinus. . . ....................... 309

Gomphosus. ..................... 307

Gymnothorax................... 2112

undulosus, Epinephelus.................. 25

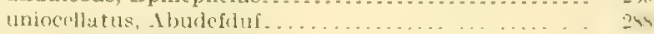

unicolor, Cypsilurus. . ........................ 200

Evelatichthys...................... 265

Lutianus. . . . . . . . . . . . . . . . . .

Terapon......................... 206

unicornis, Acanthuris . . . . . . . . . . . . .

Melamplap....................... 219

unifasciatus, Chrilımes....................... 309

Dascyllus ................... $\quad 250$

uniformis, Echidna ........................ 201

unilineatus, Pseudolabrus..................

unimaculatus, Chrtodon........................ 342

unipinna, Amphiprionichthys. . . . . ............. 380

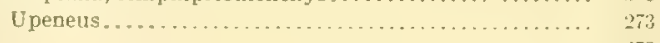

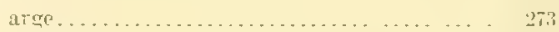

tæniopterus..................... 273

tragula....................... 273

vittatus........................

upolensis, Callyolon. . . . . . . . . . . . . . . . . . . $\quad 319$

Uranoscopidæ......................... 413

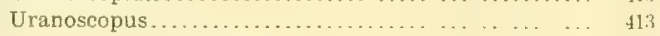

fuscomaculatus $\ldots \ldots \ldots \ldots \ldots \quad \ldots \ldots \quad t 14$

papuensis.................. $\$ 14$

sulphureus..... ........... . 113

urodelus, Cephalopholis............... . . . 2iv

urolampus, Diaphus.................. .... . I

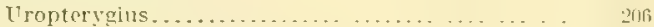

concolor................. 2ne

leucurus. ...................... 2111;

macrocephatus............... 206

marmoratus....................... 206

xanthopterus................. 206

urvillei, Tytosurus ........................ 20.

urvillii, Kuhlia................................ 25.

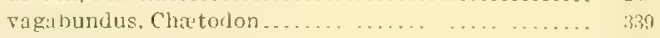

Vailima ........................................ 39

stevensoni........................

Faillanlı. Hypleurochilus... . .............. . 421

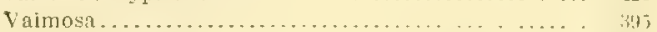

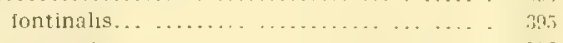

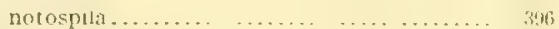

vaisganis, Glossngnbius... . . . . .... ... . 403

Zenarchopterus . ............ , . . .

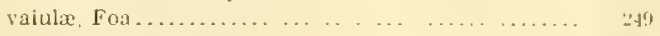

valulı Pomacentrus .... . . . . . . . . . . . . . 240

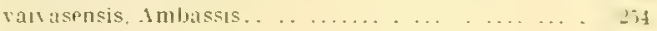

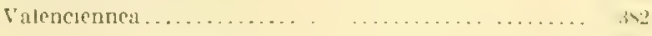

เongipunns. ...............

muralı................. . . . .

strigata... ............. . \$3

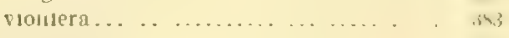

valentini, $\rfloor$ ulnstomus.................. . 211

vamicolensis, Hypseleotrıs . . . . . . . . . . . . . . . 


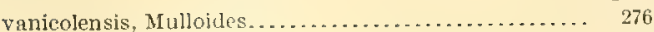
Pempheris - . .

vanicoris, IIarengula.

variegata, Coris.....

Variola.

Havimarginata louti.

variolosus, Alticus.

Platycephalus. . . . . . . . . . . . . . . . . . .

varius, Gomphosus

Heniochus a

Synodus.

veliferum. Zebrasoma.

venusta, Corıs

vermiculatus, Siganus .............................

verrens, Veternio

Verreo...

$$
\text { oxycephalus. }
$$

Verriculus.

sanguineus . . . . . . . . . . . . . . . . . . . . . . . .

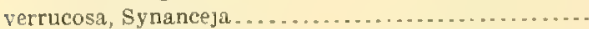

verrucosus, Balistapus.

vertıcalıs, Aldrovandia.

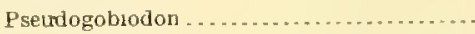

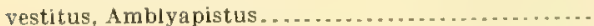

Veternio.

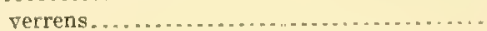

vidua, Balistes

villosus, Etmopterus.

violaceus, Holocentrus

violescens, Bowersia. .

violufera. Valenciennea

virescens, Aprion...

viridescens, Balistes

vitianus Siganus.

vittata, Pterois.

vittatus, Chellodactylus.

vitta, Lutianus.

vittatus, Upeneus

Vitreola

Vitrara.

$$
\text { clarescens... }
$$

vlamingı, canihurus

volitans Exocoetus.

Pegasus.

Pteroic.

vorax, Champsodon

$$
\text { Neosudis. }
$$

vulcanus. Emmydrichthys.

vulpes, Albuia.

$$
\text { Alopias }
$$

vulpinus Lo.

waialuze Gymnothorax

waigiensis, Atherina.

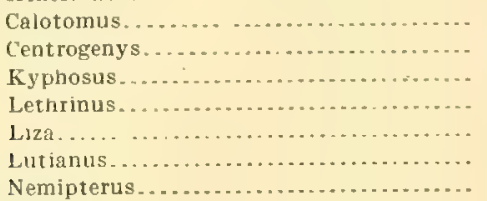

waikiki, Mionorus.

$$
\text { Nemipterus }
$$

Waitea .

\section{6}

187

303

250

257

257

257

424

380

307

$34 \overline{7}$

188

356

303

359

193

293

293

293

293

37

363

191

410

378

193

193

$3 \mathrm{~b} 1$

183

223

265

383

265

362

360

379

$27 \mathrm{~s}$

26

273

393

393

406

406

358

208

215

379

414

190

380

186

183

361

197

216

313

256

271

270

218

263

265

248

407

Page.

aitea mystacina........................ 407

waitei, Cory th roich thys....................... 212

woodi, Novaculichthys........................... 311

xantherythrus, Holocentrus. . . . . . . . . . ............ 224

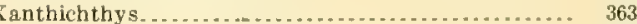

lineopunctatus..................... 363

rivulatus. . . . . . . .

anthopterus, Lethrinus . . . . . . . ............... 270

Uropterygius . ..................... 206

San hostomus, Gymnothorax..................... 198

xanthosomus, Paragobiodon . .................... 397

ranthozoma, Parapercis........................ 414

xanthurus, Chætodon . . . . . . . . . . . . . . ............ 339

xenandrus, Scæops............................. 412

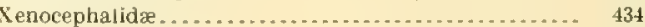

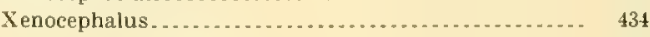

armatus......................... 434

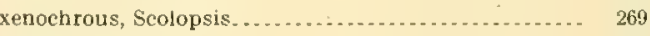

xenops, Peloropsis. . . . . . . . . . ................. 379

xestus, Petroscirtes. .............................. 433

Xiphias gladius................................. 229

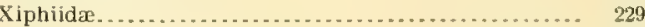

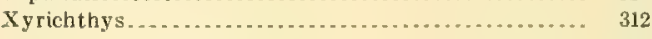

niveilatus. . . . . . .

Xystæma abbreviatum. ......................... 272

acinaces. . . . . .

argureum............................... 272

gigas............................... 272

macracanthum........................ 272

macrosoma........................ 272

poeti................................. 272

punctatum. ............................ 27

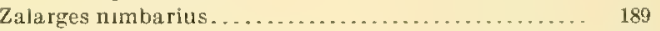

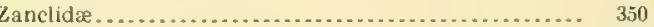

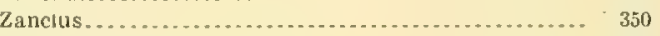

canescens. . . . . . . . . . . . . . . . . . . . 350

zanzibarensis, "Scorpænopsis....................... 376

zebra, Dendrochirus. . . . . . . . . . . . . . . . . . . . . . 378

Echidna............................... 203.

Salarias......................... 426

Zebrasoma................................... 355

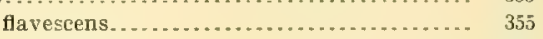

rostratum .......................... 356

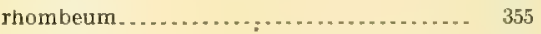

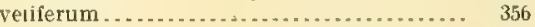

Zebrias....

dicholepis.............................. 413

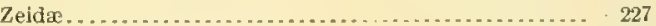

Zenarchopterus............................... 208

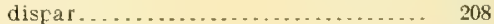

maculosus. . . . .

vaisiganis.....

zeylonicus, Mullowles........................... 277

zonarcha, scarndea............................ 313

zonata, Echudna............................ 203

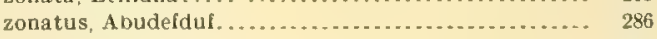

Callyodon . . . ............................ 325

Zonogobius................................ 397

semidoliatus.......................... 397

zonophæa, Echidna........................... 203

zonularis, Callyodon......................... 321

zonura, Evioti. ............................ 386

zosterophora, Amia.............................. 245

zygæna Sphyrna........................... 183 






\section{.}






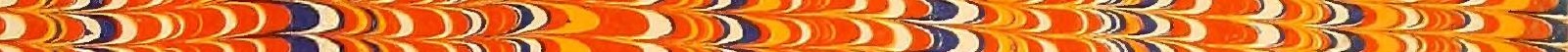

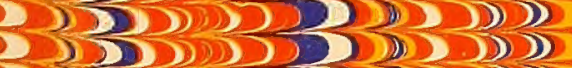

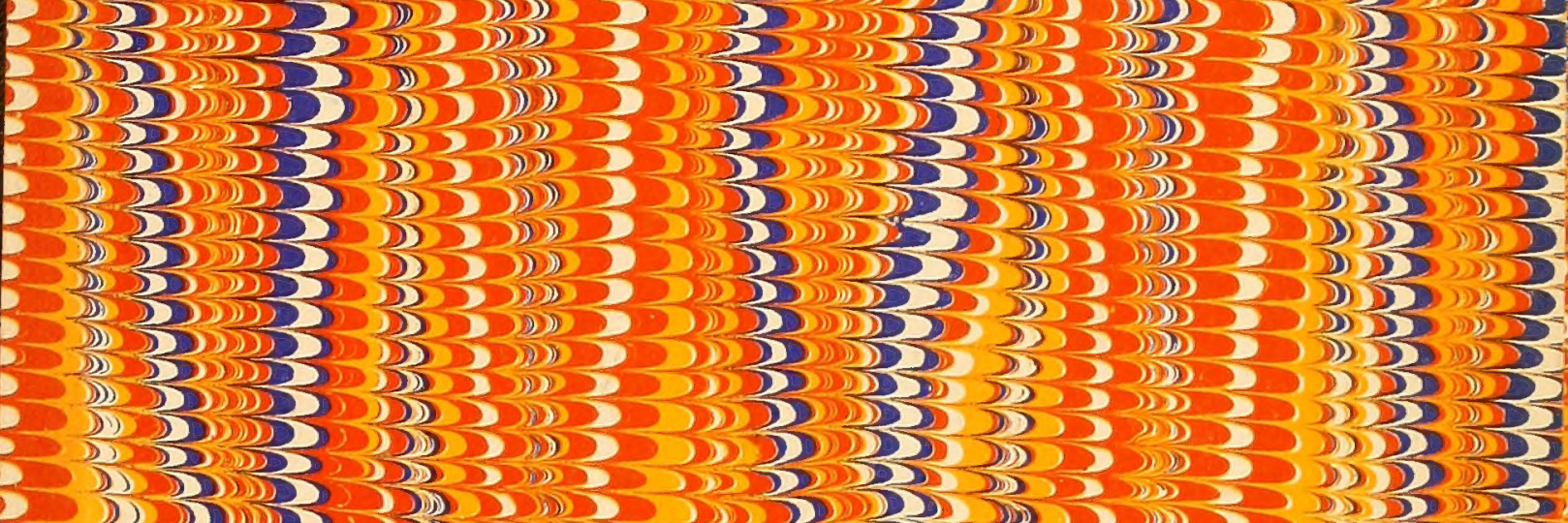

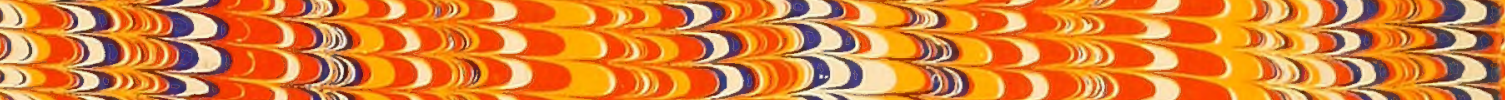

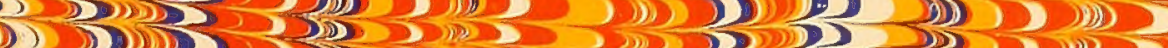
D) D) D 2

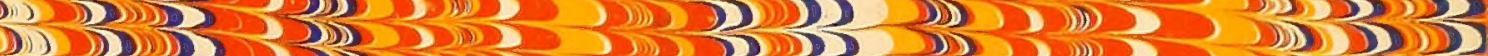

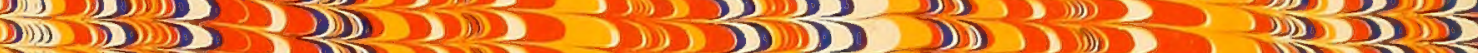

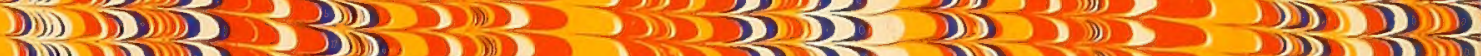

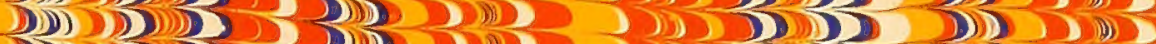

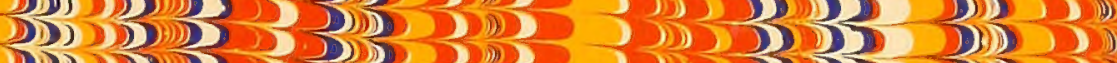

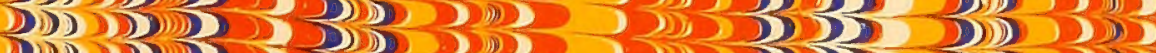

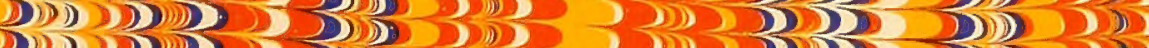

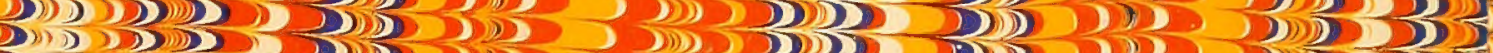

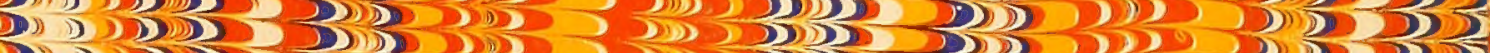
D) () () ()

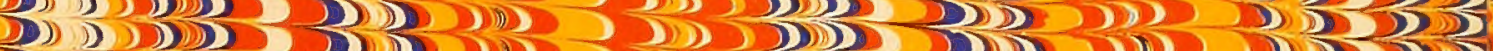

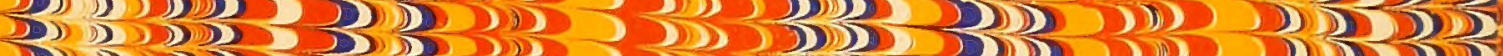

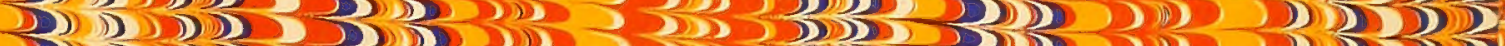
(D) D) D D D D) D) D D $>1$ (D) D D D D D D $D$ DSDDDDD D D

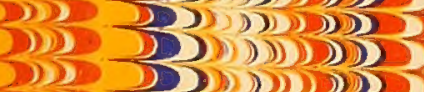

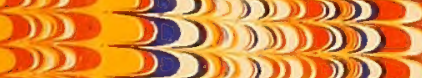

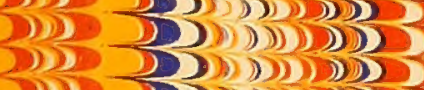
5312 SD)D DD S) $) 200$ DSDDD DDID $350 D 20 D$

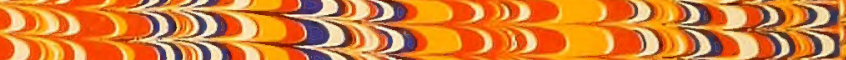

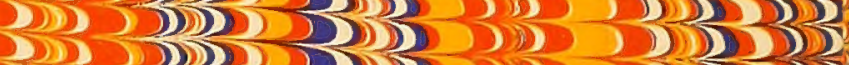
(D) DDD D D D D D

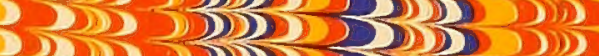

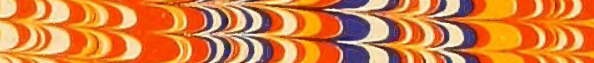

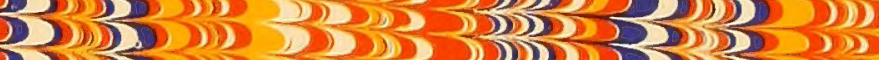

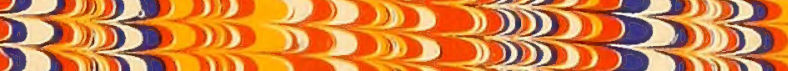

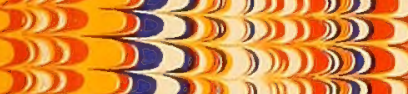

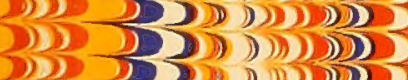

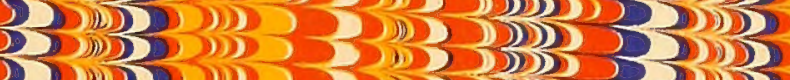
) $)$ 301020 (D) D DD) D) D) D) $2(2 D)(D) D D$

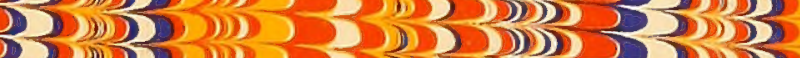
30202 )) $)(312$

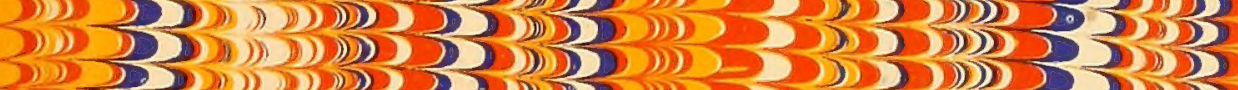

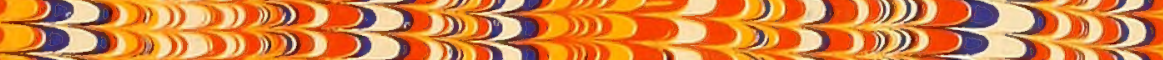

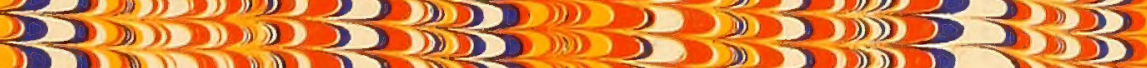

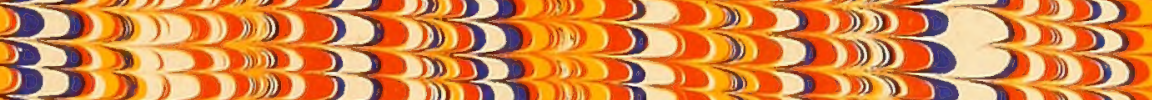

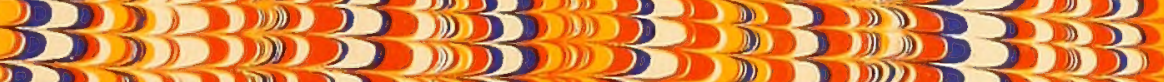

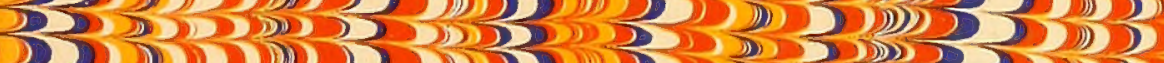

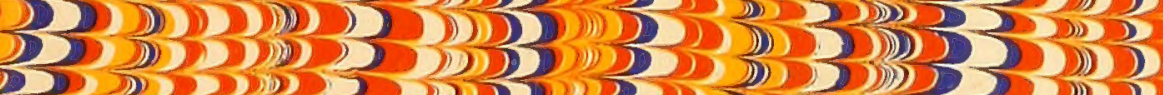

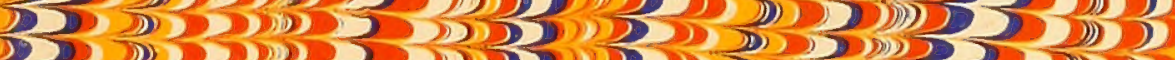
$3(2 D) D 2302$

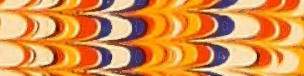

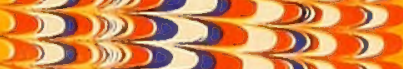

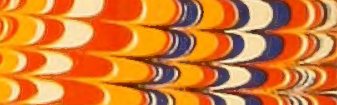

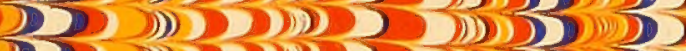

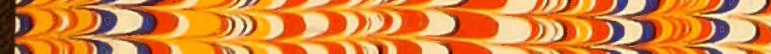

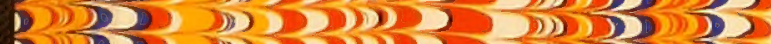

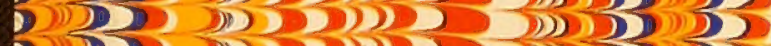

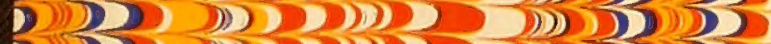

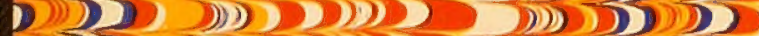

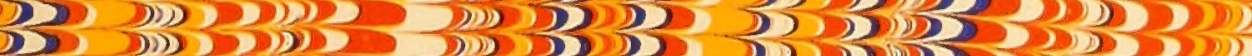

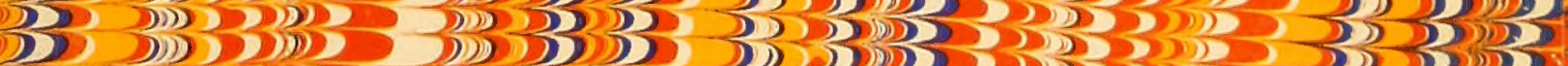

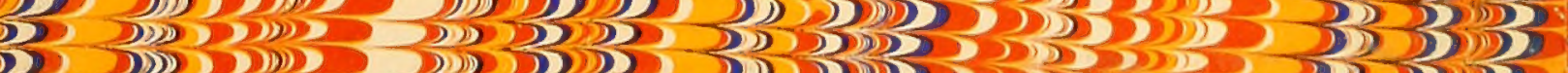

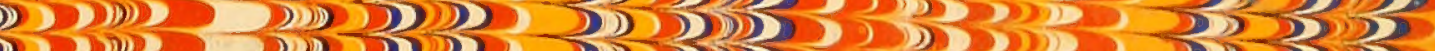




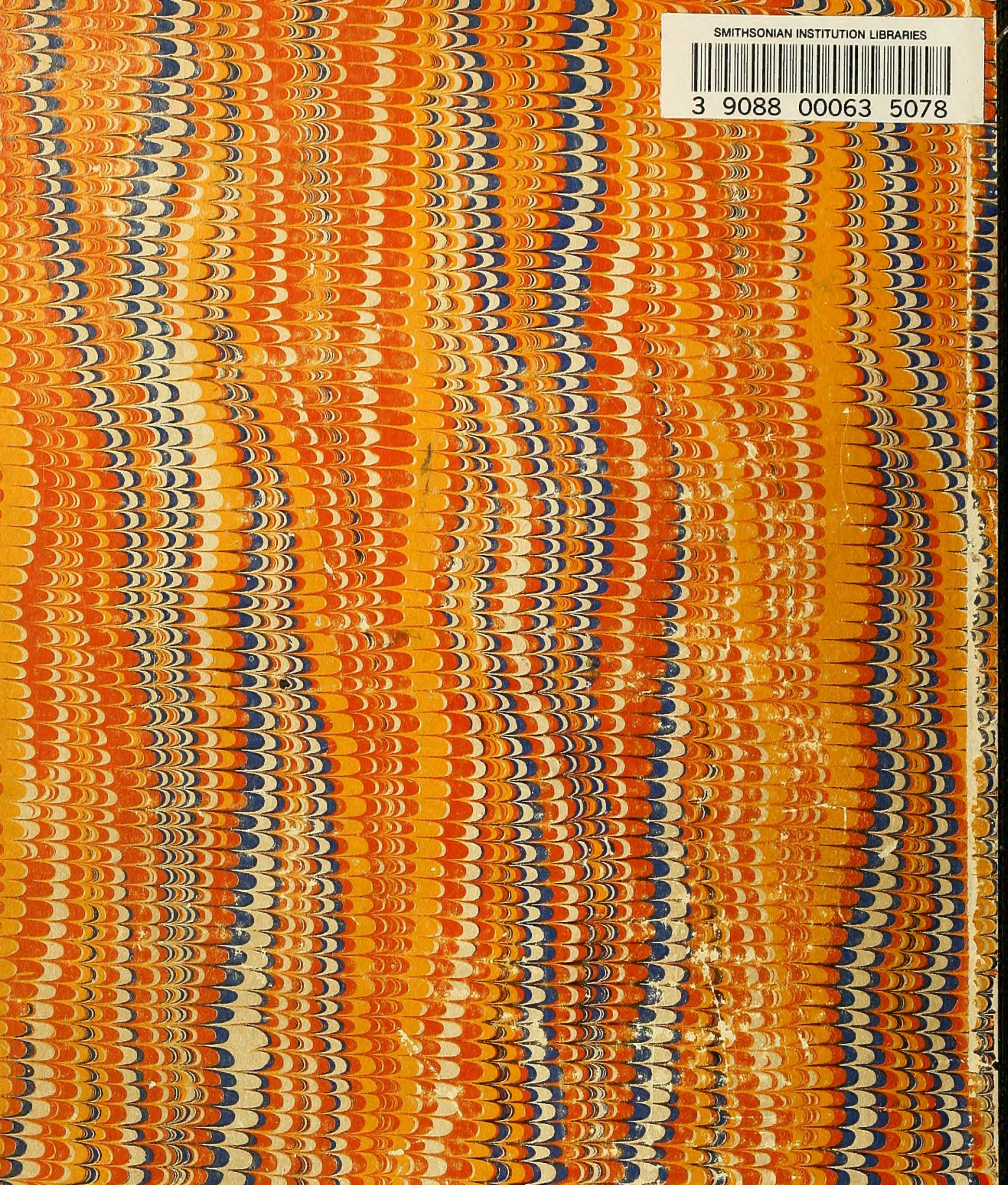

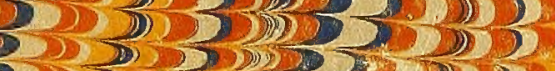

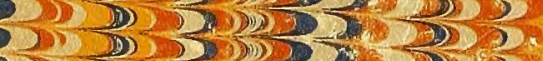

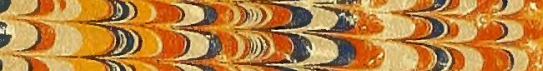

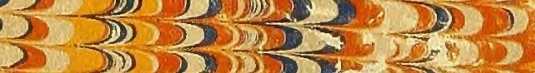
3

3) $325,35,3$

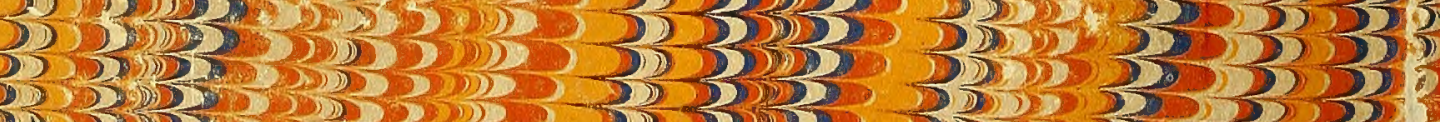
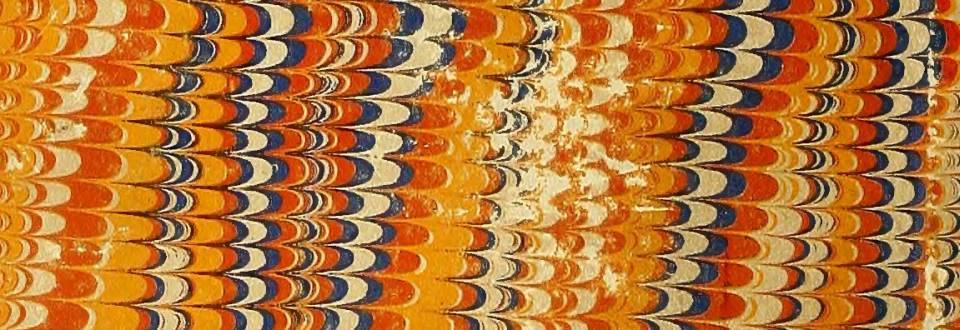

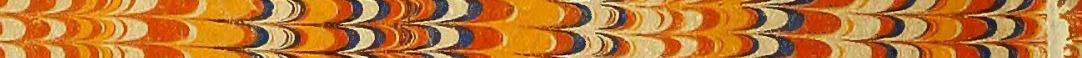

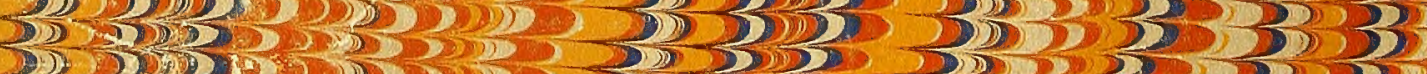

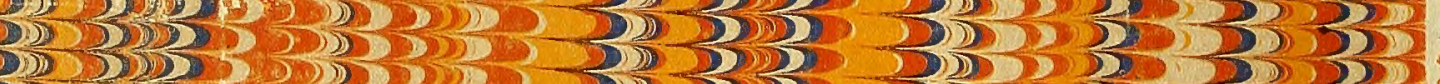

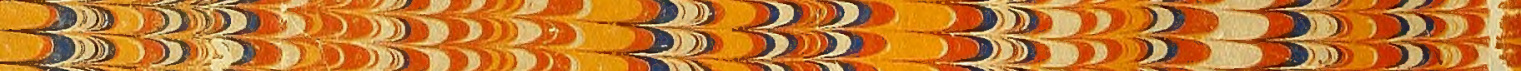

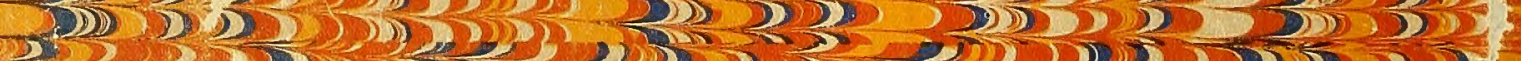

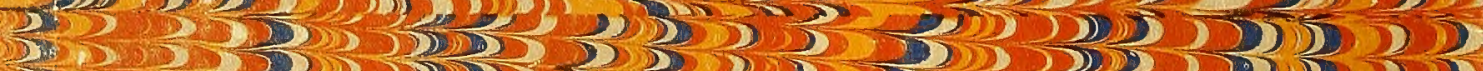

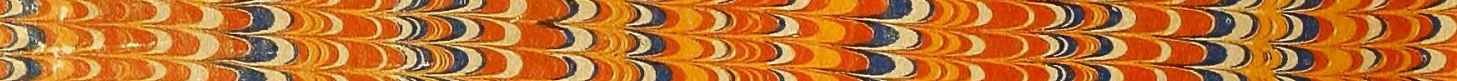

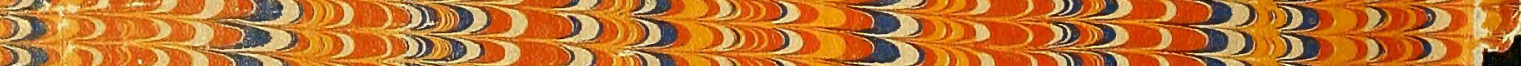

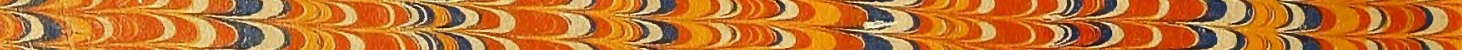

